University of Michigan Law School University of Michigan Law School Scholarship Repository

1959

\title{
Constitutional Uniformity and Equality in State Taxation
}

Wade J. Newhouse

Follow this and additional works at: http://repository.law.umich.edu/michigan_legal_studies

Part of the Constitutional Law Commons, State and Local Government Law Commons, Taxation-State and Local Commons, and the Tax Law Commons

\section{Recommended Citation}

Newhouse, Wade J. Constitutional Uniformity and Equality in State Taxation. Ann Arbor: University of Michigan Law School, 1959

This Book is brought to you for free and open access by the Law School History and Publications at University of Michigan Law School Scholarship Repository. It has been accepted for inclusion in Michigan Legal Studies Series by an authorized administrator of University of Michigan Law School Scholarship Repository. For more information, please contact mlaw.repository@umich.edu. 


\section{CONSTITUTIONAL UNIFORMITY AND EQUALITY IN STATE TAXATION}

PUBLISHED UNDER THE AUSPICES OF THE UNIVERSTTY OF MICHIGAN LAW SCHOOL (WHICH, HOWEVER, ASSUMES NO RESPONSIBILITY FOR THE VIEWS EXPRESSED) WITH THE AID OF FUNDS DERIVED FROM GIFTS TO THE UNIVERSITY OF MICHIGAN BY WILLIAM W. COOK 


\section{MICHIGAN LEGAL PUBLICATIONS}

The Conflict of Laws: A Comparative Study

Volume IV

ERnst Rabel

Water Resources and the Law

Legislative Research Center

Frontiers of Constitutional Liberty

PaUl G. KaUPer

Nonprofit Corporation Statutes

RALPH E. Boyer

Foreign Personal Representatives

Banks McDowell, JR.

Conference on Aims and Methods of Legal Research ed. Alfred F. Conard

International Law and the United Nations

1955 Summer Institute

Current Trends in State Legislation, 1955-1956 


\title{
GONSTITUTIONAL UNIFORMITY AND EQUALITY IN STATE TAXATION
}

\author{
by \\ Wade J. Newhouse, JR.
}

Foreword

by

PAUL G. KAUPER

Ann Arbor
UnIVERSity OF Michigan LaW School

1959 
COPYRIGHT, 1959

BY

THE UNIVERSITY OF MICHIGAN 


\section{Foreword}

QUESTION vital to the continuation of our federal
system is whether states will or can take care of the
demands made for governmental services in the areas where they are competent to act, or whether by failing to respond to this need, pressures will continue to be placed upon the federal government for increased intervention by way of financial assistance. It is hardly deniable that the states on the whole have access to economic resources and wealth which are adequate to support a tax structure yielding the revenues needed to finance their programs. The truth is, however, that, whatever the reason, the states in many instances are facing financial crises in attempting to meet budgetary demands. In a number of areas the federal government is already lending assistance financed by means of federal taxes derived from the same sources that lie within the competence of the states to reach. Perhaps one explanation is a more conservative political leadership in the states with respect to taxation and spending. Perhaps also citizens share the illusion that money which comes from the federal government does not dip into their pockets as much as local taxes do. But certainly also an important part of the picture is that states by their constitutional provisions have imposed limitations upon their taxing problems which often create very real barriers to effective financing of state programs. These limitations have usually had a long history and go back to an earlier time when the property tax was relied upon almost exclusively as a source of state revenue. They reflect a distrust and skepticism with respect to unlimited taxing power and the feeling that constitutional safeguards should be inserted to protect against abuse of the taxing authority. Prob- 
ably the foremost of these limitations imbedded in state constitutions is that one which requires uniformity and equality of taxation. A common result of these provisions is to hamstring the legislature in attempting to make the property tax system more flexible through exemptions, diversification of tax rates and classification of taxable property. Moreover, these provisions as judicially interpreted have often stood as barriers to the development of other kinds of taxes, notably the income tax, which are capable of yielding substantial revenues, which may temper the burden of the property tax and contribute to a more equitable and better balanced tax structure.

Professor Newhouse's work is a very valuable contribution to the study and understanding of the uniformity and equality limitations. This is the most complete and thorough treatment of these constitutional provisions that has appeared to date. Professor Newhouse has examined these provisions, state by state, has set forth their history, and analyzed the judicial interpretation placed upon them. He has done all this with painstaking and methodical thoroughness in order to determine the conceptual and practical significance of these limitations as they relate to each of the states and also to assess the total results on a comparative basis. The separate treatment of each of the states in the various divisions included in the author's treatment furnishes a series of monographs which in themselves constitute highly valuable analyses and commentaries. But the book also assumes a wider significance because of the conclusions drawn and the comparisons made on the basis of the separate state-by-state studies. The author's total treatment reveals an extraordinary intimacy with the large body of constitutional provisions and judicial decisions embraced in the study.

In order to facilitate the comparative study and thereby make the entire project more meaningful, the author has 
very carefully divided the uniformity provisions into nine different classes and has conducted the state studies by reference to the appropriate class in which a given state is found. Moreover, he has at the very outset, and the reader is well advised to note this carefully, defined his terms very accurately in order to furnish more useful tools of analysis in dealing with the problems of judicial interpretation. The overall study makes clear another conclusion which of course is evident in other fields of constitutional interpretation, namely, that courts, starting with the same or approximately the same language, reach widely divergent results based on the approach they make to these provisions. As the author points out, the judicial conception of basic economic policy and the need for flexibility in the tax structure may readily induce one court to adopt an interpretation which makes words meaningful in a sense quite different from the result reached by another state court which may be more literally or conceptually minded and reaches decisions without regard to present fiscal policy considerations.

The writer deals with the case materials in each state in a very critical way in order to see the underlying ideas that have been developed, the consistency and coherence in results reached, and the extent to which policy considerations have entered into these decisions. In turn, he draws upon the common fund of knowledge derived from a separate study of each of the states to make his illuminating comparative studies in a later chapter. As an illustration of the problems faced in regard to new types of taxes and the difficulties involved in fitting them into constitutional limitations premised on historical considerations, Professor Newhouse has devoted a chapter to the history of state income tax laws and the problems faced by the courts in adapting them to uniformity limitations. As Professor Newhouse points out, the later trend has been to find a basis for justifying income 
taxes notwithstanding an earlier view that an income tax was a tax on property and therefore had to meet the uniformity requirement. The chapter on the income tax is a good commentary on the need of revision of constitutional provisions in order to make them adequate to modern fiscal needs.

The author concludes in the end that while much can be achieved by liberal interpretation of these provisions to prevent their becoming unduly rigid as a limitation on legislative tax power, there is need for clarification of these constitutional provisions through the amendment process so as to define more precisely the objectives of these limitations, the exceptions to them and the particular taxes that may be authorized notwithstanding these restrictions. Certainly it has placed an almost intolerable burden upon the courts to accommodate these provisions to modern needs. They are faced with the choice either of adhering to judicially established conceptual interpretations that may severely circumscribe legislative discretion in devising a modern, equitable and adequate tax structure or of resorting to liberal interpretations founded on policy considerations which may have the effect of diluting the significance of these provisions to the point where they are no longer meaningful. There is much to be said for the idea of complete revision of these provisions in the interest of clarity and greater precision. Perhaps, indeed, the time has come to eliminate the separate uniformity provisions altogether and to rely instead upon the broad limitations of due process and equal protection to protect against arbitrary exercise of the tax power. Flexible and adequate taxation powers must be accorded state legislatures if the states are to preserve a substantial degree of self-reliance as opposed to looking for aid to the federal government with its virtually unlimited tax powers.

Professor Newhouse is to be congratulated on the thor- 
ough and patient research, careful and critical analysis, excellent organization and clarity of presentation which combine to make this volume a very useful sourcebook and commentary in dealing with the vital problems raised by these constitutional limitations. Here is a work that should prove to be of enduring value to lawyers, legislators and judges in dealing with the concrete problems arising under these limitations at the present time. It should also prove invaluable to students of public finance and to those who are concerned with the problems of constitutional revision.

PAUl G. KaUper 


\section{Preface}

$7 \mathrm{HE}$ method of approach and arrangement of materials are developed during the course of the

monograph. Therefore, it is not necessary to repeat them here. The purpose of the study is twofold. First, it should provide background material for constitutional revision. Second, it should aid counsel and court in deciding cases arising under existing constitutional limitations and state legislatures in drafting tax measures in such a way that pitfalls in existing limitations are avoided.

The greater part of this monograph was prepared during a two year period from June 1951 to 1953 , while I was a Research Assistant with the Legislative Research Center, University of Michigan Law School. It was completed during succeeding summers, and I have attempted to reflect all cases decided through the summer of 1956. It is a great pleasure for me to acknowledge my indebtedness to Professor William J. Pierce, Director of the Center, with whom I had day to day contact while writing the monograph, and to Professor Paul G. Kauper, who read the manuscript and gave helpful criticism. Of course, the views and conclusions expressed are those of the writer, who accepts full responsibility for any defects as may appear.

Wade J. Newhouse, Jr.

School of Law

University of Buffalo

Buffalo, New York 


\section{Analytical Table of Contents}

Foreword by PaUl G. KaUper ........... v v

Preface $\ldots \ldots \ldots \ldots \ldots \ldots \ldots \ldots \ldots \ldots \ldots \ldots \ldots$ ix

Chapter I. Introduction. ............... 1

Chapter II. A Comparison, Solely According to Phraseology, of the State Constitutional Provisions 9

A. The Nine Basic Types of Uniformity Clauses. . 9

B. Analysis of Each State's Uniformity Structure 11

1. States with Type I Clauses........... 11

2. States with Type II Clauses........... 15

3. States with Type III Clauses.......... 19

4. States with Type IV Clauses.......... 21

5. States with Type V Clauses........... 24

6. States with Type VI Clauses.......... 27

7. States with Type VII Clauses .......... 33

8. States with Type VIII Clauses......... 43

9. States with Type IX Clauses......... 47

10. States without Uniformity Clauses. . . . . 48

Chapter III. The Operative Effect of Each State's Uniformity Structure .................. 49

A. Analyses of States with Type I Clauses. . . . . 49

1. Arkansas .................... 49

a. The provisions; historical note..... 49

b. Meaning of the uniformity limitation... 50

(1) Property taxation.......... 54

(2) Income $\operatorname{tax} \ldots \ldots \ldots \ldots, \ldots 6$ 
2. Maine

a. The provisions; historical note...... 58

b. Meaning of the uniformity limitation... 59

(1) Property taxation........... 60

3. Tennessee $\ldots \ldots \ldots \ldots \ldots \ldots \ldots \ldots 65$

a. The provisions; historical note...... 65

b. Meaning of the uniformity limitation... 67

(1) Property taxation............ 68

(2) Nonproperty taxes........... 88

(3) Income tax .............. 91

B. Analyses of States with Type II Clauses. . . . . 94

1. Alabama .................... 94

a. The provisions; historical note...... 94

b. Meaning of the uniformity limitation... 96

(1) Property taxation. . . . . . . . . . 98

(2) Income tax.............. 103

2. California ................ 105

a. The provisions; historical note...... 105

b. Meaning of the uniformity limitation... 109

(1) Property taxation: prior to 1933 . 113

(2) Property taxation: 1933 to present. 114

3. Illinois . . . . . . . . . . . . . 116

a. The provisions; historical note..... 116

b. Meaning of the uniformity limitation... 118

(1) Property taxation............ 125

(a) Effective rates, generally.... 129

(b) Effective rates: ratio of valuation

(i) General Property Tax: Valuation of property by county officers for application of county rates. 
(ii) General Property Tax: Valuation by officers of one taxing authority with application of rate of another taxing authority with non-coterminous boundaries

(ii) (a) General Property Tax: Railroad property valued by state officers and apportioned to the counties for taxation

(ii) (b) General Property Tax: Valuation of capital stock of certain corporations by state officers used for local tax rates

(iii) The significance of the preceding cases

(c) Property taxation: conclusion. 165

4. Nebraska ................... 166

a. The provisions; historical note...... 166

b. Meaning of the uniformity limitation... 168

C. Analyses of States with Type III Clauses . . . . 172

1. Massachusetts ................. 172

a. The provisions; historical note...... 172

b. Meaning of the uniformity limitation... 173

(1) Property taxation........... 175

(2) Income $\operatorname{tax} \ldots \ldots \ldots . \ldots \ldots 180$

2. New Hampshire................ 181

a. The provisions; historical note...... 181 
b. Permissible taxes ("taxable objects") . . 182

c. Meaning of the uniformity limitation. . 187

(1) Property taxation: taxation of "estates"

(2) Property taxation: taxation of "other classes of property"......... 191

(3) Income $\operatorname{tax} \ldots \ldots \ldots . \ldots . \ldots 5$

D. Analyses of States with Type IV Clauses . . . . 197

1. Michigan . . . . . . . . . . . . . . . . . 197

a. The provisions; historical note...... 197

b. Application of the uniformity limitation. 198

(1) Distinction between ad valorem and specific taxes............. 200

c. Meaning of the uniformity limitation. . 212

2. New Jersey.................. 217

a. The provisions; historical note...... 217

b. Meaning of the uniformity limitation... 218

3. Ohio ................... 221

a. The provisions; historical note..... 221

b. Meaning of the uniformity limitation. . 224

(1) Property taxation: 1851 to $1929 \ldots 227$

(2) Property taxation: since 1929.... 228

4. Wisconsin ................... 234

a. The provisions; historical note ....... 234

b. Meaning of the uniformity limitation .. 235

(1) Property taxation............ 239

E. Analyses of States with Type V Clauses . . . . . 248

1. Mississippi ... . . . . . . . . . . . . 248

a. The provisions; historical note...... 248

b. Meaning of the uniformity limitation . . 249

2. Texas .................. 253

a. The provisions; historical note...... 253

b. Meaning of the uniformity limitation... 255 
3. West Virginia . . . . . . . . . . . . 260

a. The provisions; historical note..... 260

b. Meaning of the uniformity limitation... 262

(1) Property taxation......... 266

4. Wyoming $\ldots \ldots \ldots \ldots \ldots \ldots \ldots . \ldots 270$

F. Analyses of States with Type VI Clauses. . . . 273

1. Florida ................... 273

a. The provisions; historical note ...... 273

b. Meaning of the uniformity limitation... 275

(1) Property taxation.......... 278

2. Indiana .................. 281

a. The provisions; historical note...... 281

b. Meaning of the uniformity limitation... 282

(1) Property taxation: intangibles taxes 285

(a) Intangibles tax ........ 291

(b) Summary: property taxation. 303

(2) Income tax............. 304

3. Kansas ................... . 307

a. The provisions; historical note..... 307

b. Meaning of the uniformity limitation... 308

(1) Property taxation: generally..... 310

(2) Taxation of "intangibles" since 1924323

(3) Property taxation: summary..... 331

4. Nevada . . . . . . . . . . . . . . . . . . . . 333

5. South Carolina.................. 336

a. The provisions; historical note...... 336

b. Meaning of the uniformity limitation... 339

(1) Property taxation........... 340

6. Utah .................... 342

a. The provisions; historical note...... 342

b. Meaning of the uniformity limitation... 344

(1) Property taxation........... 345 
G. Analyses of States with Type VII Clauses.

1. Colorado

a. The provisions; historical note.

b. Meaning of the uniformity limitation... 350

(1) Property taxation........... 352

2. Delaware .................. 359

3. Georgia .................... 364

a. The provisions; historical note...... 364

b. Meaning of the uniformity limitation... 365

(1) Property taxation: 1868 to $1877 \ldots 367$

(2) Property taxation: 1877 to $1937 \ldots 372$

(3) Property taxation: since $1937 \ldots 375$

4. Idaho ................. 378

a. The provisions; historical note...... 378

b. Meaning of the uniformity limitation. . 379

(1) Property taxation.......... 381

5. Louisiana . . . . . . . . . . . . . . . . . 387

6. Minnesota ................... 391

a. The provisions; historical note...... 391

b. Meaning of the uniformity limitation... 395

(1) Taxation, generally: 1857 to 1906.395

(2) Taxation, generally: since $1906 \ldots 397$

(a) Income tax ........... 400

(b) Property taxation......... 403

7. Missouri .................. 416

a. Uniformity in taxation prior to $1945 \ldots 416$

(1) The provisions and meaning of the uniformity limitation: 1820 to 1875416

(2) The provisions and meaning of the uniformity limitation: 1875 to 1945418

(a) Property taxation........ 422

(b) Uniformity in taxation since 1945 
8. Montana

a. The provisions; historical note...... 428

b. Meaning of the uniformity limitation... 430

(1) Property taxation.

9. New Mexico.

440

a. The provisions; historical note.

b. Meaning of the uniformity limitation

442

(1) Property taxation.

10. Oklahoma

a. The provisions; historical note...... 447

b. Meaning of the uniformity limitation... 448

(1) Property taxation.

11. Oregon ................. 455

a. Uniformity in taxation: 1859 to $1917 \ldots 455$

b. Uniformity in taxation: since $1917 \ldots 457$

12. Pennsylvania

a. The provisions, method of analysis to be used

461

b. General property taxation

(1) Real property tax

(a) Taxation of "occupations".... 471

(2) Personal property taxation: intangibles

(a) The personal property tax (intangibles in the hands of individuals)

(b) The Corporate Loans Tax (intangibles in the hands of individuals)

(c) The Capital Stock and Franchise Taxes (intangibles in the hands of corporations)

(3) Personal property taxation: tangibles 514 (a) "Hard" coal tax.......... 514 
(b) Other tangible personal property taxes.......... 516

c. Transfer taxes............... 520

d. Corporation taxes.............. 520

e. "Business" taxes................. 524

f. Individual income taxes . . . . . . . . . 530

g. Inheritance $\operatorname{tax} \ldots \ldots \ldots \ldots \ldots \ldots 534$

h. A summary of the meaning of the uniformity limitation............. 536

(1) Property taxation.......... 537

13. Virginia

541

a. The provisions; historical note...... 541

b. Meaning of the uniformity limitation... 544

H. Analyses of States with Type VIII Clauses. . 545

1. Arizona .................... 545

a. The provisions; historical note...... 545

b. Meaning of the uniformity limitation... 546

2. Kentucky ................. 549

a. The provisions; historical note ...... 549

b. Meaning of the uniformity limitation... 551

(1) Property taxation........... 553

3. Maryland ................. 554

a. The provisions; historical note...... 554

b. Meaning of the uniformity limitation... 555

4. North Carolina .................. 558

a. The provisions; historical note...... 558

b. Meaning of the uniformity limitation... 559

5. North Dakota................... 562

a. The provisions; historical note..... 562

b. Meaning of the uniformity limitation. . . 564

6. South Dakota.................... 567

a. The provisions; historical note...... 567

b. Meaning of the uniformity limitation... 569 
7. Washington

a. The provisions; historical note...... 572

b. Meaning of the uniformity limitation... 574

(1) Property taxation........... 576

(2) Net income and gross income taxes 580

I. Analyses of States with Type IX Clauses .

591

1. Rhode Island. . . . . . . . . . . . . . . . 591

2. Vermont .................. 593

J. Analyses of States without Uniformity Clauses. 595

1. Connecticut ............... 595

2. Iowa ................... 596

3. New York.................. 599

Chapter IV. Uniformity and Equality in Taxation Required by the Federal Equal Protection Clause. . 601

Chapter V. A Comparative Analysis of the Uniformity Limitations.

A. Origin and Development............. 609

B. A Summary Comparison of Effective and Literal Limitations in Terms of Particular Rules of Uniformity.

643

1. A "Rule by Rule" Summary Analysis . . . . 644 a. Application ... . . . . . . . . . . . 644

b. The requirement of universality ...... 650

c. Uniformity and effective rates....... 655

d. Method of taxation. . . . . . . . . . . 668

2. A Summary Comparison of Effective Uniformity Limitations... . . . . . . . . . . 674

C. A Comparison of Results as to Particular Taxes 689

1. Judicial Precedent and the Income Tax. . . 690 
2. A Special Note on "Gross" Income Taxes and Corporate Franchise Taxes with a Base of Net Income............... 738

3. An Evaluation of the Property-Nonproperty Tax Dichotomy in Light of the Special Study of the Income $\operatorname{Tax} \ldots \ldots \ldots \ldots 741$

a. Some preliminary information....... 743

b. A classification according to results favorable to the imposition of an income tax. . 750

c. A classification relating the results concerning the income tax to types of uniformity clauses............. 755

d. Conclusions .............. 760

Chapter VI. Conclusion............... 767

Appendix-Constitutional Provisions........ 771

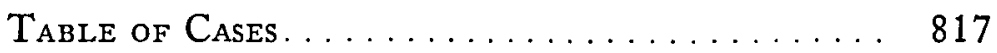




\section{Chapter I}

\section{Introduction}

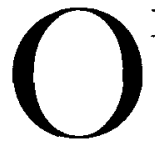

$\mathrm{N}$ February 8 th, 1955 , upon submitting to the Congress his recommendations concerning federal assistance to the states in the construction of school facilities, President Eisenhower stated:

These are the facts of the classroom shortage:

The latest information submitted by the States to the Office of Education indicates that there is a deficit of more than 300,000 classrooms, a legacy - in part - of the years of war and defense mobilization when construction had to be curtailed. In addition, to keep up with mounting enrollments, the Nation must build at least 50,000 new elementary and high school classrooms yearly. It must also replace the thousands of classrooms which became unsafe or otherwise unusable each year.

... [M] $]$ illions of children still attend schools which are unsafe or which permit learning only part-time or under conditions of serious overcrowding. To build satisfactory classrooms for all our children, the current rate of school buildings must be multiplied sharply and this increase must be sustained.

Fundamentally, the remedy lies with the State and their communities. ${ }^{1}$

There is a profound difference of opinion concerning the extent to which the federal government should participate in the education of the nation's children, but it is generally agreed that the task is a basic function of state and local government. Moreover, partisans from both sides of the aisle deplore further concentration of functions in Washington:

We talk about and we deplore incessantly the increasing centralization of power over our lives in Washington. But that

1101 Cong. Record 1047 (1955). Emphasis added. 
tidal drift toward the Capital will go on and on unless those necessary functions of government which don't have to be performed in Washington are performed, and properly performed, at the state and the local level.

The people will demand the services, and if they don't get them at home they will turn to Uncle Sam. And every dollar you send to Washington to pay for them will shrink before it gets back home.

... [T] he states are the dikes which we can build more strongly against the flood waters ever sweeping toward the District of Columbia. ${ }^{2}$

The problem of the public schools is simply a single example of the many general problems facing state and local government today. There is a crying demand for the states to solve the problem of highways, to create or maintain institutions for the aged and infirm, and to provide increased services for the mentally ill, to name only a few of the many and complex services expected of modern government. If the increasing demands for state services are to be met, state revenues obviously must increase, ${ }^{3}$ which means an added strain on already creaking state tax structures. As a result,

${ }^{2}$ From a speech by Gov. Adlai E. Stevenson, Democratic Presidential nominee in 1952, at the Illinois State Fair. The New York Times, August 15, 1952, p. 5, col. 3.

3 For example, a press release of Commerce Clearing House, dated January 24,1955 , indicated that many state legislatures in 1955 faced a problem of reducing state services or levying new and higher taxes. Most of the reporting states heard urgent demands from their governors or tax study groups for bolstering their hard-pressed state treasuries. New York was told "the day of reckoning has come," and that city tax authorizations must be made on a permanent, not temporary basis. A commission urged a 2 cent increase in the gasoline tax and a 3 cent increase in the diesel fuel tax. California had a bill pending to cancel scheduled reductions in gasoline and diesel fuel taxes. Massachusetts was informed that substantial new revenues must be found on a long-term basis. Vermonters received word that the state needed more money if it were to pay for increased services. West Virginia needed $\$ 7$ million, and its legislators were asked to produce that sum within the framework of present taxes. Idaho was asked for $\$ 8.5$ 
there will be demands for new sources of revenue, but in creating new tax structures the state legislatures must always operate within state constitutional limitations.

Probably the most important of the state constitutional limitations upon the taxing power is the requirement that taxation be "uniform and equal" to some degree. That limitation, which is the subject of this monograph, may have a profound effect on the choices available to a state legislature when it attempts to increase revenue yields. Therefore a comparative study of state constitutional uniformity limitations on taxation seems desirable for two reasons: (1) to determine the exact meaning of existing uniformity limitations in order to avoid unconstitutional exercises of the taxing power; and (2) to ascertain what uniformity limitations are desirable if existing ones are so strict as to preclude judicious exercise of the taxing power in the light of modern economic conditions.

The constitutions of forty-three (possibly forty-five) of the forty-eight states contain provisions which may be described as "uniformity clauses." Generalizing further about the uniformity limitation is a treacherous, though necessary, undertaking.

In the first place, there is a substantial and significant diversity in the phraseology of the several types of so-called "uniformity clauses." Moreover, much like the commerce clause and the equal protection clause in the federal Constitution, the language of these provisions is so general as to be meaningless without an extensive study of court decisions.

million. Maine proposed a 3 cent sales tax and/or a personal income tax. In New Hampshire the governor suggested new sources of revenue. These, he said, would not be a sales or income tax. A $1 \%$ income tax was proposed in the legislature. Utah reported that an automatic property tax increase for schools seemed "unavoidable." Washington was told its growing population forced tax raises. For the long pull, suggestions were for an income tax for which a constitutional amendment is required. 
This is not to say that the phraseology of the basic uniformity clauses is unimportant. The courts always purport to start from the words of the governing clause. Therefore, the states will be classified in this study on the basis of the phraseology of the basic uniformity clauses found in their respective constitutions. This approach will provide significant comparisons between the "literal" limitations and the court-made "effective" limitations.

A second reason for avoiding generalizations concerning the state uniformity clauses is that a considerable number of states have extremely complex uniformity structures. The basic uniformity clause is often supplemented by other constitutional provisions directed to some particular phase of the general limitation. Therefore, the entire "uniformity structure" of each state constitution, rather than the basic uniformity clause alone, must be analyzed.

The uniformity limitation has taken a definite form in each of the forty-eight states. In order to evaluate the limitation properly, one must remember that in comparing state constitutional limitations it can not be said that a "single" requirement of uniformity in taxation applies throughout all of the states, or throughout several of the states. Even if identical effective limitations were found in all states, there would still be forty-eight such limitations. Therefore when the constitutional provision is framed in the equivocal language common to the so-called uniformity clauses, it should come as no surprise that there may be several different interpretations of identically phrased provisions. The following comment, though made in another context, is quite appropriate here:

Indeed, in view of our constantly growing body of cases and statute law, it is believed that an increasingly fruitful type of legal research is that which concentrates on the law of a single jurisdiction. Not only does it provide a more pre- 
cise statement of legal doctrines of one state than can be derived from more general treatises, but it also furnishes a unique basis for generalizations as to rules which are applicable in all jurisdictions. After all, general statements about the American common-law, when in one sense there are in fact some forty-eight or more American common-law systems, are not uniformly helpful. ${ }^{4}$

Substitute "state constitutional law" for "common-law," and justification is had for the approach and method of this monograph, the main body of which will consist of individual studies of the law in each of the forty-eight jurisdictions.

\section{$* * * * * *$}

Confusion will be kept at a minimum if certain basic definitions are set forth and used throughout the monograph. In this way it is hoped that some apparent conflicts may be resolved, conflicts which stem from the fact that words describing the general limitation of uniformity are not always used with the same meaning. The particular rules of the general limitation may be classified and studied according to the following elements of a "tax." (1) The object of a tax, which is the thing taxed; for example, property, sales of goods, income, the privilege of engaging in a certain type of business. (2) The base of the tax, which is the unit of taxation; for example, the value of the property taxed, a unit of weight or measure, the income from a business taxed, the price of a thing sold. (3) The rate of taxation, which is the amount per unit. The rate is usually stated in percentages; for example, three per cent of net income, four mills per dollar of the value of property taxed. However, the rate may be stated as a flat rate, a certain sum per unit of taxation (e.g., two cents per bushel of grain taxed, or so many dollars

${ }^{4}$ Simes, Lewis M., Foreword to Fratcher, Perpetuities and Other Restraints, viii-ix (1954). 
for each additional store operated by a single management). If the rate is uniform for each unit taxed, it is proportional. If the rate increases as the tax base increases, it is progressive. (4) The method of taxation, which depends upon the combined base-rate structure. Thus, ad valorem refers to a combined base-rate structure of value-percentage rate. The method of taxation is primarily identified by the base used.

The application of particular rules of uniformity depends upon the nature of the tax. All taxes fall into a dichotomy of property taxes and nonproperty taxes. This study of the uniformity limitation demonstrates, without doubt, that a sharp distinction has been made between these two types of taxes, with a stricter uniformity limitation usually being applied to property taxes. The basis of this classification of taxes is the object of the tax. Property taxes have property as their object. All other taxes are denoted nonproperty taxes. However, a very few states have not employed this distinction. One may fundamentally disagree with any effort to distinguish between property and nonproperty taxes, and it appears quite clear that the dichotomy is the source of considerable confusion. Nevertheless, in order to understand the meaning of the uniformity limitation as it is applied in each of the several states, one must accept and work with the distinction. Defects in theory cannot obviate its existence.

\section{$* * * * *$}

For reasons which will be made clear by the state by state analysis, it will be helpful to break down the general uniformity limitation into particular rules of uniformity. The particular rules, which apply to property taxes, correspond to the elements of the tax.

Uniformity required of the object of property taxes. This particular rule concerns the exclusion from or inclusion within the object of a property tax. The basic question is: 
must all property within the territory of a taxing authority, except that expressly designated as exemptible by the constitution, be selected for the object of any property tax imposed by that authority? Conversely, is the exemption of classes of property from the property tax prohibited? If all property must be selected, and no property may be exempted, there is said to be a requirement of universality. The further question arises: is the universality requirement derived from the basic uniformity clause, or is the requirement found in phrases apart from the basic clause?

Uniformity required of the effective rate of a property tax. The effective rate of a property tax is the combined baserate structure. This combination is significant because property selected for property taxation may be classified for the application of different effective rates in either of two ways. First, all property may be assessed for taxation at the same ratio of valuation and different percentage rates applied to different classes of property. The ratio of valuation is the per cent of "actual" value at which property is entered on the tax rolls. Second, all property may be subject to the same percentage rate, but classified for the application of different ratios of valuation. ${ }^{5}$ Is an absolute uniformity required so that all property must be taxed at the same effective rate? Or, is there only a requirement of uniformity within classes, so that property may be classified for the application of either different ratios of valuation or different percentage rates?

The uniformity limitation is a territorial requirement. That is, rates imposed by the state must be uniform throughout the state, those by the county throughout the county, etc. There is no requirement that the rates of the different taxing authorities be correlated.

Double taxation is one aspect of the problem of uniformity

' Generally see Leland, The Classified Property Tax in the United Statea, Ch. II, especially at 52 (1928). 
in effective rates. If an item of property is either subject to two taxes by the same taxing authority, or subject to the same tax twice, it is apparent that the effective rate for that class of property will vary from the effective rates applicable to other property. If absolute uniformity is required, double taxation would obviously violate the requirement. The issue of double taxation becomes acute when representative intangible property is taxed. This raises the only really difficult question: just when is the "same property" being taxed twice? This question necessitates a consideration of the relationship between representative intangible property and the tangible property which it represents. For example, $\mathrm{X}$ farm is encumbered with a mortgage. Are the farm land and the mortgage to be considered, for purposes of uniformity in taxation, the "same" property? If so, the taxation of both (the farm as realty and the mortgage as intangible property) results in double taxation.

Uniformity required in the method of taxing property. Does the basic uniformity clause require that property be taxed only by the ad valorem method? Or, may specific property taxes be imposed?

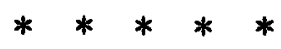

An understanding of these definitions and particular rules of uniformity will assist immeasurably in comparing the state constitutional uniformity and equality limitations. 


\section{Chapter II}

\section{A Comparison, Solely \\ According to Phraseology, of the State \\ Constitutional Provisions}

A. THE NINE BASIC TYPES OF UNIFORMITY CLAUSES

$\mathrm{N}$ examination of the constitutional provisions which
may be called basic uniformity clauses reveals nine
typical clauses. The distinguishing characteristics of the several types relate to the manner in which the words "uniform" and "equal" are used. First it will be helpful simply to set forth the several typical clauses and indicate those states having such provisions. Any doubtful classifications of particular states will be justified later in this chapter.

The first two types of uniformity clauses are identified by the use of the word "value" and obviously have a close kinship.

TyPe I: Property shall be taxed according to its value. Three states have substantially such a clause which serves as the primary uniformity provision. They are Arkansas, Maine, and Tennessee.

Type II: Property shall be taxed in proportion to its value.

Four states have substantially such a constitutional provision. They are Alabama, California, Illinois, and Nebraska. The third typical clause is closely related to Types I and II.

TYPE III: The legislature may impose proportional and reasonable assessments, rates, and taxes upon all persons and estates within the state. 
Only two states, Massachusetts and New Hampshire, have such a basic uniformity clause.

The next three typical clauses are closely related because of the manner in which they use the words "equal" and "uniform."

Type IV: There shall be a uniform rule of taxation. Four states have substantially such a constitutional provision which serves as a basic provision. They are Michigan, New Jersey, Ohio, and Wisconsin.

Type V: Taxation shall be equal and uniform. The four states having a Type V basic clause are Mississippi, Texas, West Virginia, and Wyoming.

TYPe VI: The legislature shall provide by law for a uniform and equal rate of assessment and taxation.

Six states have substantially such a constitutional provision serving as the basic uniformity provision. They are Florida, Indiana, Kansas, Nevada, South Carolina, and Utah.

There are two typical clauses, Types VII and VIII, which are framed in terms of "uniformity within classes."

TYPE VII: Taxes shall be uniform upon the same class of subjects.

Thirteen states have this type of provision as a basic uniformity clause. They are Colorado, Delaware, Georgia, Idaho, Louisiana, Minnesota, Missouri, Montana, New Mexico, Oklahoma, Oregon, Pennsylvania, and Virginia.

Type VIII: Taxes shall be uniform upon the same class of property.

Seven states have this type of basic uniformity clause. They are Arizona, Kentucky, Maryland, North Carolina, North Dakota, South Dakota, and Washington.

Rhode Island and Vermont have no provision which 
might be called a uniformity clause other than a provision similar to the following:

Type IX: There shall be a fair distribution of the expense of government.

Three states, Connecticut, Iowa, and New York, have no uniformity clause whatsoever.

\section{B. ANALYSIS OF EACH STATE'S UNIFORMITY STRUCTURE}

One purpose of this preliminary analysis is to justify the inclusion of each state within a particular group and to note any variations from the typical clauses. Another purpose is to describe the supplementary provisions which deal with particular problems of uniformity. In this way the uniformity structure of each state can be seen as an integrated whole. Within each group of states, after a discussion of the basic uniformity clauses, the following supplementary provisions will be described: (1) provisions concerned with the degree of uniformity required of the object of a property tax; (2) provisions concerned with the method of property taxation; (3) provisions concerned with the uniformity required of the effective rates of property taxes; (4) provisions expressly providing for different types of taxes.

No attempt will be made in this preliminary analysis to comment on historical trends. Each of the state studies in Chapter III contains an historical note, and a comparative summary of the historical growth of the uniformity clauses is included in Chapter V. The entire uniformity structure of each state is reproduced in the Appendix.

\section{States with Type I Clauses}

Three states-Arkansas, Maine, and Tennessee-make up the group having a basic uniformity clause of Type I: 
"Property shall be taxed according to its value." The Maine uniformity clause, found in Art. IX, $\S 8$, of the 1819 Constitution, must be paraphrased somewhat in order to classify it as a Type I clause. The entire provision reads:

All taxes up on real [and personal] estate, assessed by authority of this state, shall be apportioned and assessed equally, according to the just value thereof; [but the legislature shall have power to levy a tax upon intangible personal property at such rate as it deems wise and equitable without regard to the rate applied to other classes of property.]

The phrase "and personal," modifying estate, was added by amendment in 1875 . The proviso concerning the taxation of intangibles was added by amendment in 1913 .

Arkansas and Tennessee fall more naturally into this group. In addition, their uniformity structures are much more elaborate than Maine's. The basic uniformity clause in each instance is similar to the following:

All property [subject to taxation] shall be taxed according to its value, that value to be ascertained in such manner as the legislature shall direct. . . .

The Arkansas Constitution of 1874, Art. XVI, $\S 5$, includes the phrase "subject to taxation" and adds this clause: "making the same equal and uniform throughout the state." This last clause seems to refer to "value," so that the Arkansas Constitution does not contain a Type $V$ uniformity clause: viz., "Taxation shall be equal and uniform." In the Arkansas provision the words "equal and uniform" are clearly subordinated to the "ad valorem" clause.

The Tennessee Constitution of 1870, Art. II, §28, omits the phrase "subject to taxation," and adds a clause reading "so that taxes shall be equal and uniform throughout the state." This additional clause places Tennessee in a unique 
position. It is substantially identical to the Type $\mathrm{V}$ clause, which reads: "Taxation shall be equal and uniform." However, it is suggested that the words "so that" subordinate this clause, making it a supplementary provision, with the result that the "ad valorem" clause is the basic uniformity provision in the Tennessee Constitution. ${ }^{1}$ The words "so that" imply that equality and uniformity in taxation follow from taxing property "according to its value."

Method of taxing property. None of the constitutions of these states have provisions other than the basic uniformity clause which are concerned with the method of taxing property. This is to be expected since the basic uniformity clause itself is phrased in terms of ad valorem taxation of property.

Object, property taxation. Both the Arkansas ${ }^{2}$ and Tennessee ${ }^{3}$ constitutions require the exemption of specified property. The phrase in the Arkansas uniformity clause which reads "All property subject to taxation" must be reconciled with Art. XVI, §6, which states that "All laws exempting property from taxation other than as provided in this Constitution shall be void." Article II, $\$ 28$ of the Tennessee Constitution provides that "All property, real, personal or mixed, shall be taxed but" that certain enumerated classes of property shall be exempted. This provision is in addition to the following words of the basic uniformity clause: "All property shall be taxed according to its value. . . Thus, both Arkansas and Tennessee have constitutional provisions which point to a likely requirement of universality.

1 Compare the Ohio clause, infra, classified as Type IV. The basic clause in the Ohio Constitution reads: "Land and improvements thereon shall be taxed by a uniform rule according to value." The words emphasize "uniform rule" rather than "according to value."

2 Ark. Const. Art. XVI, $\S 5$ (1874) and Amendments Nos. 12 and 22. In addition, Amendment No. 27 contains a permissive exemption.

8 Tenn. Const. Art. I, $\S \S 28,30$ (1870). 
Effective rates, property taxation. As pointed out previously, the Maine "uniformity clause" has been amended so that the "rate" - note the singular-on intangible personal property need not be correlated with the "rate" applied to other classes of property. In both Arkansas and Tennessee the basic "uniformity clause" is supplemented by a special provision which concerns uniformity in the effective rates of property taxes. In the constitutions of both of these states ${ }^{4}$ the basic uniformity clause is followed in the same provision by this clause:

No one species of property from which a tax may be collected, shall be taxed higher than any other species of property of the same value. ...

Other taxes. In the constitutions of both Arkansas ${ }^{5}$ and Tennessee ${ }^{6}$ the supplementary clause as to effective rates is coupled with a proviso which states that certain enumerated occupations and "privileges" generally are to be taxed in "such manner" as the legislature might deem proper. In addition, Art. II, $\$ 28$ of the Tennessee Constitution provides:

The legislature shall have power to levy a tax upon incomes derived from stocks and bonds that are not taxed ad valorem.

${ }^{4}$ Ark. Const. Art. XVI, §5 (1874); Tenn. Const. Art. II, §28 (1870). In addition the Tennessee Constitution has a special provision concerning the uniformity required of the rate applicable to a particular class of property. Article II, $\$ 28$ provides: "The portion of a Merchant's Capital used in the purchase of Merchandise sold by him to non-residents and sent beyond the State, shall not be taxed at a higher rate than the ad valorem tax on property."

${ }^{5}$ Ark. Const. Art. XVI, §5 (1874): ". . . provided the General Assembly shall have power from time to time to tax hawkers, peddlers, ferries, exhibitions and privileges, in such manner as may be deemed proper."

${ }^{8}$ Tenn. Const. Art. II, $\$ 28$ (1870): "But the Legislature shall have power to tax Merchants, Peddlers, and privileges, in such manner as they may from time to time direct." 
Miscellaneous. The Tennessee Constitution ${ }^{7}$ has a uniformity clause directed solely to local taxes. The Arkansas Constitution ${ }^{8}$ contains a unique provision, which is in effect a uniformity clause limiting local "special assessments."

\section{States with Type II Clauses}

Four states-Alabama, California, Illinois, and Nebraska -constitute the group having basic uniformity clauses phrased substantially like the Type II clause: "Property shall be taxed in proportion to its value." However, there is some diversity in phraseology. The clauses in Alabama and California most closely resemble each other and the typical clause. Article XI, $\$ 211$ of the Alabama Constitution of 1901 provides that:

All taxes levied on property in this state shall be assessed in exact proportion to the value of such property. . . .

Article XIII, $\S 1$ of the California Constitution of 1879 provides that:

All property in the State except as otherwise in this Constitution provided, not exempt under the laws of the United States, shall be taxed in proportion to its value. . . .

However, the effectiveness of this uniformity clause has been severely limited since 1933, when Art. XIII, §14, fit was amended to increase the power of the legislature in respect to the taxation of personal property. ${ }^{\boldsymbol{9}}$

7 Tenn. Const. Art. II, $\$ 29$ (1870), providing as to county and town taxes that: "all property shall be taxed according to its value, upon the principles established in regard to State taxation."

${ }^{8}$ Ark. Const. Art. XIX, $\$ 27$ (1874): “. . . such [special] assessments shall be ad valorem and uniform."

${ }^{9}$ Paragraph 4 of Art. XIII, $\$ 14$ reads:

The Legislature shall have the power to provide for the assessment, levy and collection of taxes upon all forms of tangible personal property, 
The Illinois and Nebraska basic uniformity clauses vary somewhat from the phraseology of the typical clause, yet they may reasonably be classified in this group. Article IX, $\S 1$ of the Illinois Constitution of 1870 reads:

The general assembly shall provide such revenue as may be needful by levying a tax, by valuation, so that every person and corporation shall pay a tax in proportion to the value of his, her or its property. . . .

The Nebraska Constitution of 1875 was amended in 1920 so that Art. VII, $\S 1$ now reads:

. . . taxes shall be levied by valuation uniformly and proportionately upon all tangible property and franchises, and taxes uniform as to class may be levied by valuation upon all other property.

Before 1920 the Nebraska uniformity clause was identical with the present Illinois provision except that the words "and franchises" appeared after the word "property." However, as in the California Constitution, the amendment limited the application of the basic uniformity clause to "tangible property and franchises," and provided a more liberal uniformity limitation for the taxation of "all other

all notes, debentures, shares of capital stock, bonds, solvent credits, deeds of trust, mortgages, and any legal or equitable interest therein, not exempt from taxation under the provisions of this Constitution, in such manner, and at such rates, as may be provided by law, and in pursuance of the exercise of such power the Legislature . . . may classify any and all kinds of personal property for the purposes of assessment and taxation in a manner and at a rate or rates in proportion to value different from any other property in this State subject to taxation and may exempt entirely from taxation any or all forms, types or classes of personal property.

Article XIII, $\S 1$ contains, in addition to the basic uniformity clause set forth in the text, a definition of "property" by enumeration so that it definitely includes intangibles. This is, of course, superseded by the amendment to Art. XIII, $\$ 14$ providing for separate treatment of personal property. 
property." The Nebraska uniformity clause obviously deviates substantially from the norm for this group. However, it falls more naturally under the Type II clause than any other, and its phraseology is not so different as to warrant a separate classification.

Method of taxing property. There are no provisions in the constitutions of these states, other than the basic uniformity clauses, which deal with the method to be used in taxing property. As under Type $I$, this is not unexpected, since the uniformity clause is framed in terms of ad valorem taxation of property.

Object, property taxation. Apart from the basic uniformity clauses, the following provisions are relevant in determining the uniformity required of the object of property taxes. The Alabama Constitution ${ }^{10}$ contains a provision requiring the exemption of specified property. The Illinois Constitution ${ }^{11}$ contains a provision which permits the exemption of specified property. The California Constitution ${ }^{12}$ contains both permissive and mandatory exemption provisions. In addition, the provision ${ }^{13}$ concerning uniformity in the taxation of personal property expressly provides that the legislature may exempt classes of personal property from taxation. The Nebraska Constitution ${ }^{14}$ contains both permissive and mandatory exemption provisions. In addition, exemption of property other than that specified is expressly prohibited. ${ }^{15}$

Effective rates, property taxation. Provisions other than the basic uniformity clauses which concern uniformity in

${ }^{10}$ Ala. Const. Art. IV, $\$ 91$ (1901).

11 Ill. Const. Art. IX, $\$ 3(1870)$.

12 Cal. Const. Art. XIII, $\S 1$ (1879), and numerous provisions providing for the exemption of certain classes of property. See the discussion of the California limitation in Chapter III, infra.

13 Art. XIII, §14, \4 supra note 9.

${ }^{14}$ Neb. Const. Art. VIII, $\$ 2$ (1875).

15 Ibid. 
effective rates are found in both the Alabama and California constitutions. Art. XI, $\$ 217$ of the Alabama Constitution requires that the property of corporations and individuals "shall forever be taxed at the same rate." Article XIII, §14 of the California Constitution provides that personal property shall not be taxed at a greater rate than realty. ${ }^{16}$ In addition, both the Alabama ${ }^{17}$ and the California ${ }^{18}$ constitutions have provisions designed to prohibit the "double taxation" of certain representative property.

Other taxes. The Illinois and Nebraska constitutions have general provisions providing for taxes other than property taxes. The Illinois basic uniformity clause is followed by a proviso stating that certain enumerated occupations and "privileges" may be taxed uniformly as to classes. ${ }^{19}$ The Nebraska Constitution simply provides in Art. VII, $\$ 1$ that "Taxes, other than property taxes, may be authorized by law." In the Alabama ${ }^{20}$ and California ${ }^{21}$ constitutions there

${ }^{16}$ The provision reads:

. . . no tax burden shall be imposed upon any personal property either tangible or intangible which shall exceed the tax burden on real property in the same taxing jurisdiction in proportion to the actual value of such property.

17 Ala. Const. Art. XI, $\$ 211$ (1901).

${ }^{18}$ Cal. Const. Art. XIII, $\$ 1$ (1879).

19 Ill. Const. Art. IX, $\$ 1$ (1870):

.. . but the general assembly shall have power to tax peddlers, auctioneers, brokers, hawkers, merchants, commission merchants, showmen, jugglers, innkeepers, grocery keepers, liquor dealers, toll bridges, ferries, insurance, telegraph and express interests or business, vendors of patents, and persons or corporations owning or using franchises and privileges, in such manner as it shall from time to time direct by general law, uniform as to the class upon which it operates.

20 Ala. Const. Art. XIII, $\$ \S 229,232$ (1901) (corporate franchise tax); Amdt. XXIII (inheritance tax); Art. XXII (net income tax).

21 Cal. Const. Art. XIII, $\$ 11$ (1879) (income tax, "in such manner as shall be prescribed by law"); Art. XIII, $\$ 14$ 4/5 (insurance companies, gross premiums tax); Art. XIII, $\$ 16$ (bank franchise tax measured by net 
are numerous provisions authorizing particular taxes, including income taxes.

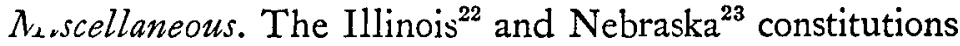
have uniformity clauses designed especially for local taxes.

\section{States with Type III Clauses}

Two states-Massachusetts ${ }^{24}$ and New Hampshire ${ }^{25}$ have as their basic uniformity clause a provision which reads substantially as follows:

The legislature may impose proportional and reasonable assessments, rates and taxes, upon all the inhabitants of, and persons resident, and estates lying within the state.

In addition, both of these state constitutions have provisions in their respective Bills of Rights which are pertinent to the uniformity limitations. Part I, Art. X of the Massachusetts Constitution reads:

Each individual of the society has a right to be protected by it in the enjoyment of his life, liberty and property, ac-

income, in lieu of all other taxes except upon realty; corporate franchise taxes, generally, "by any method not prohibited by this Constitution.").

22 Ill. Const. Art. IX, $\S \S 9,10$ (1870):

$[\S 9]$... [municipal taxes] shall be uniform in respect to persons and property, within the jurisdiction of the body imposing the same. ... [§10] The general assembly . . . shall require that all the taxable property within the limits of municipal corporations shall be taxed for the payment of debts contracted under authority of law, such taxes to be uniform in respect to persons and property, within the jurisdiction of the body imposing the same.

${ }^{23}$ Neb. Const. Art. VIII, §6 (1875):

... such [municipal] taxes shall be uniform in respect to persons and property within the jurisdiction of the body imposing the same.

24 Mass. Const. Pt. II, Ch. I, Art. IV (1780).

${ }^{25}$ N. H. Const. Pt. II, Art. 5 (1784). 
cording to standing laws. He is obliged, consequently, to contribute his share to the expense of this protection. . . .

Part I, Art. 12 of the New Hampshire Constitution is substantially identical to the Massachusetts provision.

The basic uniformity clause of the New Hampshire Constitution must be reconciled with Art. 6 of Part II, which was amended in $1903^{27}$ to read:

The public charges of government, or any part thereof, may be raised by taxation upon polls, estates, and other classes of property, including franchises and property when passing by will or inheritance. . . .

The provision is not too clear as to its purpose, but it will be shown in Chapter III that it has the effect of modifying the uniformity limitation as it theretofore had existed in New Hampshire.

The constitutions of both of these states have been amended to provide that special treatment may be given to forest lands, ${ }^{28}$ and to this extent a special class of property is established.

Other taxes. The uniformity clause in the Massachusetts Constitution is followed immediately by a clause reading:

[Power is given to the legislature] also to impose and levy, reasonable duties and excises, upon any produce, goods, wares, merchandise, and commodities, whatsoever, brought into, produced, manufactured, or being within the [state].

Also, the Massachusetts Constitution was amended in 1951 by the addition of Art. XLIV which provides for the taxation

${ }^{26}$ Note that in the constitutions of Rhode Island and Vermont a provision such as this stands as the basic uniformity clause. See the discussion of states with Type IX clauses, infra.

${ }^{27}$ Art. 6 was theretofore a provision relating to the periods required for the recurrent valuation of property.

${ }^{28}$ Mass. Const. Art. XLI, added in 1912; N. H. Const. Pt. II, Art. 5 as amended in 1942 . 
of income. It is further provided that property, the income of which is taxed, may be exempted from the "imposition of proportional and reasonable" taxes as presently authorized by the constitution.

\section{States with Type IV Clauses}

Four states-Michigan, New Jersey, Ohio, and Wisconsin - constitute the group having some form of a Type IV uniformity clause: "A uniform rule of taxation." There are marked differences in the scope and phraseology of their respective clauses. The more general clause is found in Art. VIII, $\S 1$ of the Wisconsin Constitution of 1848 , which reads:

The rule of taxation shall be uniform. . . .

The Michigan uniformity clause is quite similar to the Wisconsin provision but is limited in its operation by a unique exception. Article $\mathrm{X}, \S 3$ of the Michigan Constitution of 1908 reads:

The legislature shall provide by law a uniform rule of taxation, except on property paying specific taxes. . . .

In addition, Art. $\mathrm{X}, \S 4$ of the Michigan Constitution provides that:

The legislature may impose by law specific taxes, which shall be uniform upon the classes upon which they operate.

The New Jersey uniformity clause is expressly limited in its application to the taxation of property. Article VIII, $\S 1, \pi 1$ of the New Jersey Constitution of 1947 provides that:

Property shall be assessed for taxation . . . by uniform rules.

The uniformity clause in the Ohio Constitution is even more limited on its face than the other uniformity clauses in this 
group. Article XII, $\S 2$, of the Ohio Constitution of 1851 was amended in $1929^{28}$ to read as follows:

Land and improvements thereon shall be taxed by uniform rules according to value.

Object, property taxation. Both the Michigan and Wisconsin basic uniformity clauses are combined with supplementary clauses which, in effect, state that taxes shall be levied on such property as the legislature shall prescribe-intimating a freedom of selection, and possibly a freedom of exemption of property. The New Jersey Constitution, Art. VIII, $\S 1, \llbracket 2$, provides that "Exemptions from taxation may be granted only by general law." A rather ambiguous provision appears in the Ohio Constitution. Article XII, $\$ 2$ contains the following clause:

... and without limiting the general power, subject to the provisions of Art. I of this constitution, to determine the subjects and methods of taxation or exemptions therefrom, general laws may be passed to exempt [specified real property].

In addition, Art. II, $\S 36$ of the Ohio Constitution provides that forest lands may be exempted "in whole or in part."

Effective rates, property taxation. Article VIII, §1, $\llbracket 1$, of the New Jersey Constitution of 1947, which contains the basic uniformity clause, also contains the following pertinent provision:

All real property assessed and taxed locally or by the state for allotment and payment to taxing districts shall be assessed according to the same standard of value; and such real property shall be taxed at the general tax rate of the taxing

${ }^{29}$ Prior to 1929 Art. XII, $\$ 2$ read:

Laws shall be passed, taxing by a uniform rule, all moneys, credits, investments in bonds, stocks, joint stock companies, or otherwise, and also all real and personal property, according to its true value in money. . . . 
district in which the property is situated, for the use of such taxing district.

There are two minor provisions in the Ohio Constitution which deal with effective rates. Article II, §36, provides for the exemption of forest lands "in whole or in part," and Art. XIII, §4, provides that corporate property "shall forever be subject to taxation, the same as the property of individuals." Article $X, \S 7$, of the Michigan Constitution governs the ratio of valuation. It reads: "All assessment hereafter authorized shall be on property at its cash value."

Other taxes. Both the constitutions of Michigan and Wisconsin have general provisions authorizing "other" taxes, with separate uniformity provisions therefor. Article X, $\$ 4$ of the Michigan Constitution provides that:

The legislature may by law impose specific taxes, which shall be uniform upon the same classes upon which they uperate.

Article VIII, $\S 1$ of the Wisconsin Constitution was amended in 1908 by the addition of the following sentence:

Taxes may also be imposed on incomes, privileges and occupations, which taxes may be graduated and progressive, and reasonable exemptions may be provided.

In the Ohio Constitution there are both general and specific provisions for "other" taxes. Article XII, sections 7 and 8 , provide for an inheritance tax and for the taxation of incomes. Article XII, $\S 10$ is a general provision reading:

Laws may be passed providing for excise and franchise taxes and for the imposition of taxes upon the production of coal, oil, gas and other minerals.

All of these provisions were added to the Ohio Constitution in 1912. 


\section{States with Type V Clauses}

Four states-Mississippi, Texas, West Virginia, and Wyoming-have a Type V uniformity clause: "[All] taxation shall be equal and uniform." The Wyoming clause Art. I, $\$ 28$, is in the Bill of Rights of the Wyoming Constitution of 1890, and includes the word "all." The uniformity clauses found in the other three state constitutions omit the word "all" (Miss. Const. 1890, Art. IV, \$112; Tex. Const. 1876, Art. VIII, §1; W. Va. Const. 1872, Art. X, \$1). ${ }^{30}$ The Mississippi and West Virginia provisions have the additional phrase "throughout the state."

Each of these four states has at least one additional provision which could serve as a basic uniformity clause. Mississippi, Texas, and West Virginia have a "proportionality clause" substantially identical to the Type II provision, viz., "[All] property shall be taxed in proportion to its value." In each instance this clause appears in the same provision containing the basic uniformity clause. The Mississippi clause omits the word "all."

The fourth state-Wyoming-has an additional provision which is somewhat similar to the Type IV clause, viz., "A uniform rule of taxation." Article XV, $\$ 11$ of that constitution reads:

All property .. . shall be uniformly assessed for taxation, and the legislature shall prescribe such regulations as shall secure a just valuation for taxation of all property. ${ }^{31}$

30 The West Virginia basic uniformity clause remains in this form. However, fundamental changes have been made as to its effectiveness by amendments in 1932 which state certain exceptions thereto. See the discussion under "effective rates."

31 This final clause as to a "just valuation for taxation of all property" is substantially the same as that clause which supplements the basic uniformity clause of all states except one having a Type VI clause: "The legislature shall provide by law for a uniform and equal rate of assessment and taxation." 
The Mississippi Constitution has a third provision which could serve as a basic uniformity clause. In Art. IV, §112which contains the two provisions already referred to-the following clause is found:

Property shall be assessed for taxes under general laws, and by uniform rules, according to (its true) value. ${ }^{32}$

Object, property taxation. In both the Mississippi and West Virginia constitutions there are few significant provisions, other than the uniformity clause along with the supplementary clause already referred to, which concern the uniformity required of the object of property taxes. In the Mississippi Constitution the only provisions are sections 182 and 192, which permit industrial exemptions under certain conditions. The West Virginia Constitution provides for both mandatory and permissive exemptions of property in Art. X, $\S 1$. And in Art. VI, $\S 53$, it is provided that forest lands may be defined and classified, and may be "exempted from all taxation or be taxed in such manner . . . as the legislature may" provide.

The Texas and Wyoming constitutions are more definite on this issue. In the Texas Constitution, Art. VIII, $\S 1$ requires certain exemptions, ${ }^{33}$ and Art. VIII, $\$ 2$ permits certain other exemptions. Article VIII, $\$ 2$ concludes:

.. . all laws exempting property from taxation other than the property above mentioned shall be null and void.

In Wyoming a contrary approach is found. Art. XV, $\S 12$, which requires the exemption of certain property, with this direction concludes: "and such other property as the legisla-

32 Note the similarity of this provision to the basic clause in the New Jersey Constitution, discussed with other Type IV states, supra.

${ }^{33}$ In addition there are numerous provisions in the Texas Constitution providing for the mandatory exemptions of specific property. See the discussion in Chapter III, section E, supra. 
ture may by general law provide [shall be exempt from taxation]."

Effective rates, property taxation. Only the Mississippi and West Virginia Constitutions have provisions other than the basic uniformity clauses which concern the uniformity required of effective rates. A minor provision in the Mississippi Constitution, $\$ 181$, provides that corporate property "shall be taxed in the same way and to the same extent as" individual property, with certain exemptions. The effect of the basic uniformity clause ${ }^{34}$ in the West Virginia Constitution was radically altered by an amendment in 1932. The basic clause remained the same. However, this proviso was added: "subject to the exceptions in this section contained." In effect, the exceptions which follow divide all property into five classes and set an aggregate maximum rate for all taxes assessed upon any class. The significant point is that different amounts were set up as the maximum rate for each of the classes.

Other taxes. In the Wyoming Constitution the only provision concerning other taxes is Art. $\mathrm{XV}, \S 3$ which provides for a gross products tax on mines, etc., in lieu of taxes on "the lands." The West Virginia and Texas Constitutions have both general and specific provisions referring to other taxes. Article $\mathrm{X}, \S 1$ of the West Virginia Constitution contains the following clause:

The legislature shall have authority to tax privileges, franchises, and incomes of persons and corporations and to classify and graduate the tax on all incomes according to the

${ }^{34}$ The following clause also accompanies the basic uniformity clause in Art. X, $\S 1$ of the West Virginia Constitution:

No one species of property from which a tax may be collected shall be taxed higher than any other species of property of equal value. . . . Of course, this sweeping limitation must be read in the light of the 1932 amendments set forth in the text. 
amount thereof and to exempt from taxation, incomes below a minimum to be fixed from time to time.

Article VIII, $\$ 1$ of the Texas Constitution contains the following clause, which is placed immediately after the basic uniformity clause:

The legislature may impose a poll tax. It may also impose occupation taxes, both upon natural persons and upon corporations, other than municipal, doing any business in this State. It may also tax incomes of both natural persons and corporations other than municipal, except that persons engaged in mechanical and agricultural pursuits shall never be required to pay an occupation tax. . ..$^{35}$

Article VIII, $\$ 2$ contains a second basic uniformity clause which is applicable to "occupation taxes." It provides that such taxes shall be "equal and uniform upon the same class of subjects within the limits of the authority levying the tax. ..."

Miscellaneous. West Virginia is the only state in this group which has a uniformity clause ${ }^{36}$ applicable solely to local taxes.

\section{States with Type VI Clauses}

Six states-Florida, Indiana, Kansas, Nevada, South Carolina, and Utah-have a Type VI basic uniformity clause. In each of these states, except Indiana, the effectiveness of that clause has been substantially limited by subsequent amendments which leave the basic clause unchanged

${ }^{35}$ Art. VIII, $\$ 17$ contains a provision similar to the Illinois provision discussed supra. It provides that "The specification of the objects and subjects of taxation shall not deprive the Legislature of the power" to tax other objects and subjects "consistent with the principles of taxation fixed in this Constitution."

${ }^{36}$ Art. X, $\S 9$ ". . . such [local] taxes shall be uniform, with respect to persons and property within the jurisdiction of the authority imposing the same." 
while providing for special treatment of intangible property. Each state has a uniformity clause reading substantially as follows:

The legislature shall provide [by law] for a uniform and equal rate of [assessment and] taxation, [and shall prescribe such regulations as shall secure a just valuation (for taxation) of all property]. . . .

The basic clause is followed immediately by a provision excepting property of described characteristics which may be exempted by law.

There are three significant variations on the basic clause. The uniformity clause in the Florida Constitution of 1885, Art. IX, $\S 1$, omits the words "assessment and," thus reading "a uniform and equal rate of taxation." clause in the Kansas Constitution of 1859, Art. XI, $\$ 1$, does not have the "just valuation" clause. ${ }^{38}$ The third significant variation, one of addition rather than omission, is in the uniformity clause of the Utah Constitution of 1896, Art. XIII, $\S 3$. That clause reads as follows:

The Legislature shall provide by law a uniform and equal rate of assessment and taxation on all [tangible] property in the State, according to its value in money, and shall prescribe by law such regulations as shall secure a just valuation for taxation of such property, so that every person and corporation shall pay a tax in proportion to the value of his, her or its property. ...

The italicized words are those found only in the Utah uniformity clause. The word "tangible," modifying "property," as well as a provision for special treatment of intangible property, was added by amendment in 1930 .

The uniformity clauses in the remaining three states of

37 In addition, the Florida provision omits the words "by law" and "for taxation."

38 In addition, the Kansas provision omits the words "by law." 
this group are identical with the typical clause (Ind. Const. 1851 , Art. X, $\$ 1$; Nev. Const. 1864, Art. X, $\S 1$; S. C. Const. 1895 , Art. X, §1). With the exception of the Utah provision, all of the uniformity clauses in this group are followed in the same provision by the "exceptions" clause which permits certain exemptions of property.

South Carolina and Utah have additional provisions in their constitutions which could serve as basic uniformity clauses if they stood alone. Article I, $\S 6$ of the South Carolina Constitution provides that:

All property subject to taxation shall be taxed in proportion to its value.

And Art. XIII, §2 of the Utah Constitution provides:

All [tangible] property in the state, not exempt under the laws of the United States, or under this constitution, shall be taxed in proportion to its value.

These provisions, of course, are Type II clauses.

Intangible property, special treatment. In all of these states, except Indiana, the constitution has been amended by the addition of a provision removing the taxation of intangible personal property from the scope of the uniformity clause. There is considerable variation among these amendments. The Kansas and Utah provisions are similar. In Kansas a 1924 amendment takes the form of a proviso inserted in Art. XI, $\$ 1$, immediately after the uniformity clause, so that the section now reads:

The legislature shall provide for a uniform and equal rate of assessment and taxation, except that mineral products, money, mortgages, notes and other evidence of debt may be classified and taxed uniformly as to class as the legislature shall provide.

In the Utah Constitution a 1930 amendment altered the 
words of the basic uniformity clause itself-it refers now to "tangible" property, and a just valuation of "such" property. In addition, the following sentence was added to the same provision, Art. XIII, §3:

Intangible property may be exempted from taxation as property or it may be taxed in such manner and to such extent as the Legislature may provide.

However, a maximum rate of five mills is provided therefor.

In the South Carolina Constitution the uniformity provision, Art. X, $\S 1$, was amended in 1932 by the addition of a new paragraph which states that the legislature may provide for the assessment of "intangible personal property" "at its true value in money" for purposes of state and local taxation. A low maximum "total" rate is provided and any tax on such property other than pursuant to this amendment is prohibited.

Florida provides for a more limited separate treatment of intangible property. By an amendment in 1924, an “exception" was made to the uniformity clause, Art. IX, $\S 1$, so that the legislature may now provide for "special rate or rates on intangible property," with a maximum rate of two mills. The rate was raised to five mills by an amendment in 1944 . Such special rate or rates are exclusive of all other state and local taxes. The 1944 amendment also added a proviso to the effect that a recordation tax of two mills might be imposed in lieu of all other intangible assessment on certain secured obligations. ${ }^{30}$

${ }^{39}$ In 1940 Art. IX, $\$ 2$ of the Florida Constitution was amended to provide that no levy of ad valorem taxes on property other than intangible property is to be made by the state. Thus, the overall structure presents this picture: intangible property is to be taxed only by the state, and such taxation is governed as to uniformity by the proviso to Art. IX, $\S 1$. Tangible property, real and persunal, is to be taxed only at the local level. 
The most limited special treatment for intangible property is found in Nevada. In 1942 the exemption clause in Art. X, $\S 1$, which also contains the uniformity clause, was amended to require the exemption of intangible property. ${ }^{40}$

Object, property taxation. The Indiana and Kansas Constitutions have no provisions other than the uniformity clauses which deal with uniformity of the object in property taxes. In Florida Art. IX, sections 1 and 2 provide that the state shall tax intangible property and the local units shall tax tangible property. Article IX, $\$ 13$ provides for a motor vehicle license tax "in lieu" of taxation of motor vehicles for personal property taxation. Article XVI, $\S 16$, provides that corporate property shall be subject to tax unless used for certain enumerated purposes. There are provisions for both mandatory ${ }^{41}$ and permissible ${ }^{42}$ exemption of property. In Nevada the only supplementary provision dealing with uniformity in the object of property taxes is Art. VIII, §2, which provides that corporate property shall be subject to taxation the same as property of individuals. In South Carolina, Art. X, $\S 4$ of the constitution requires certain exemptions, and Art. VIII, $\S 8$ permits industrial exemptions. Article XIII, $\$ 2$ of the Utah Constitution contains both mandatory and permissive exemptions.

Effective rates, property taxation. In addition to the numerous provisions already discussed, in Nevada and South Carolina there are certain other clauses concerning uni-

40 The provisions read:

- . . shares of stock (except shares of stock in banking corporations), bonds, mortgages, notes, bank deposits, book accounts and credits, and securities and choses in action of like character are deemed to represent interest in property already assessed and taxed, either in Nevada or elsewhere, and shall be exempt.

${ }^{41}$ Art. IX, $\S \S 9,11$; Art. X, 7 .

42 Art. IX, §1. 
formity in effective rates. Article VIII, $\$ 2$ of the Nevada Constitution provides that corporate property "shall be subject to taxation the same as property of individuals." Article III, $\$ 29$ of the South Carolina Constitution provides that "all taxes upon property, real and personal, shall be laid upon the actual value of the property taxed. . . ."

"Other" taxes. With the exception of Nevada, all of the states in this group have provisions concerning "other" taxes. In Florida, Indiana, and Kansas there are only special provisions. The Florida Constitution expressly prohibits the taxation of inheritances and income in Art. IX, $\S 11$. This is a unique provision. Indiana, in Art. $X, \S 8$, provides that a tax upon incomes may be imposed, "from whatever sources derived, at such rates, in such manner, and with such exemptions as may be prescribed by law." The Kansas Constitution, Art. XI, §2, also provides for a tax on incomes, which may be graduated and progressive. Article XI, $\S 10$ grants the power to levy "special taxes, for road and highway purposes, on motor vehicle and on motor fuels." South Carolina has a general provision in its section containing the uniformity clause, Art. IX, $\S 1$, which provides that a "graduated tax on incomes" and "a graduated licence on occupations and business" may be imposed. The Utah Constitution, Art. XIII, §3, provides for the taxation of incomes, which tax "shall be" graduated. A general provision in Art. XIII, $\S 12$ reads:

Nothing in this Constitution shall be construed to prevent the Legislature from providing for a stamp tax, or a tax based on income, occupation, licenses or franchises.

Miscellaneous. Both the Florida ${ }^{43}$ and the South Caro-

43 Article IX, $\$ 5$ provides that the legislature may authorize local taxes, "and all property shall be taxed upon the principles established for State taxation." 
lina ${ }^{44}$ constitutions contain uniformity clauses applicable only to local taxes.

\section{States with Type VII Clauses}

Thirteen states-Colorado, Delaware, Georgia, Idaho, Louisiana, Minnesota, Missouri, Montana, New Mexico, Oklahoma, Oregon, Pennsylvania, and Virginia-constitute the group having a Type VII basic uniformity clause. There are variations in the precise phraseology, on the basis of which five subgroups may be established.

Three states (Minn. Const. 1857, Art. IX, §1, as amended 1906; N.M. Const. 1911, Art. VIII, §1, as amended 1914; Okla. Const. 1907, Art. X, §5) have a clause which simply provides as follows:

Taxes shall be uniform upon the same class of subjects.

There is a variation in the New Mexico provision, which reads: ". . . taxes shall be equal and uniform upon the subjects of taxation of the same class." This is the only provision in this group which varies from the basic words identifying this type clause, viz., "uniform upon the same class of subjects." The variations described below concern additional phrases attached to the basic words.

Two states (Mo. Const. 1945, Art. X, §3; Mont. Const. 1889, Art. XII, §11) have a basic clause which contains a "territorial" phrase and reads as follows:

Taxes shall be uniform upon the same class of subjects within the territorial limits of the authority of levying the tax.

Four states (Del. Const. 1897, Art. 8, §1; La. Const. 1921, Art. X, \$1; Pa. Const. 1874, Art. 9, §1; Va. Const.

${ }^{44}$ Art. VIII, §6; Art. X, §5. Local taxes shall be "uniform with respect to persons and property within the jurisdiction of the body imposing the same." 
1902, Art. 13, \$168) have clauses identical with the second variation above, except that the clauses read " $A l l$ taxes. ... ."Two states (Ga. Const. 1945, Art. VII, $\$ 1, \llbracket 3$; Ore. Const. 1859, Art. I, §32) have clauses identical with the second variation above, except that the clauses read "All taxation. . . ." Two states (Colo. Const. 1876, Art. X, §3; Idaho Const. 1890, Art. VII, \$5) not only have the word "All" modifying "taxes," but also add a clause as to "just valuation" which is similar to the clause which commonly modifies the Type VI basic clause. Thus, the uniformity clause found in those two states reads:

All taxes shall be uniform upon the same class of subjects within the territorial limits of the authority levying the tax, and shall be levied and collected under general laws, which shall prescribe such regulations as shall secure a just valuation for taxation of all property, real and personal.

Additional uniformity clauses. Similar to the development found in practically every other group, there are several states in Group VII which have clauses in addition to the basic uniformity clause capable of serving as a basic clause if they stood alone. Four states in this group-Montana, Oregon, Idaho, and New Mexico-have such a supplementary uniformity clause. The Montana Constitution contains a Type VI clause combined with the "just valuation" clause, such as is found attached to the basic clause in Colorado and Idaho. Article XII, $\S 1$ of the Montana Constitution of 1889 reads:

... [T] he legislative assembly . . . shall levy a uniform rate of assessment and taxation, and shall prescribe such regulations as shall secure a just valuation for taxation of all property, except that specially provided for in this article.

This provision is substantially identical to the basic Type III clause. 
The constitution of Oregon also contains a provision similar to the Type VI clause, but it varies by substituting the word "rules" for "rate," so that Art. IX, $\S 1$, reads:

The Legislative Assembly shall . . . provide by law uniform rules of assessment and taxation. All taxes shall be levied and collected under general laws operating uniformly throughout the State.

However, the provision is of general nature and could serve as a basic clause in the absence of other provisions. As a matter of fact, the clause resembles the Type IV provision in the use of the word "rules."

Idaho has a separate provision which is practically identical to the provision of the Illinois Constitution, classified as Type II. Article VII, $\$ 2$ of the Idaho Constitution reads:

The legislature shall provide such revenue as may be needful, by levying a tax by valuation, so that every person or corporation shall pay a tax in proportion to the value of his, her, or its property, except as in this article hereinafter otherwise provided.

New Mexico also has a provision which might be classified as Type II, although it is limited in application, and-as contrasted to the other "supplementary" clauses found in this group of states-the New Mexico provision is coupled with and precedes the basic clause. Article VIII, $\$ 1$ reads:

Taxes levied upon tangible property shall be in proportion to the value thereof, and taxes shall be equal and uniform upon the subjects of taxation of the same class.

Elaboration of the basic clauses as to classes of property. Five of these thirteen states-Georgia, Idaho, Missouri, Oklahoma, and Virginia-have provisions which permit the classification of property or "subjects." The Georgia and Missouri provisions are similar in this respect, both establish- 
ing in the constitution the permissible degree of classification of property. The Georgia Constitution of 1945, Art. VII, $\S 1, \llbracket 3$, which also contains the basic uniformity clause, provides as follows:

Classes of subjects for taxation of property shall consist of tangible property and one or more classes of intangible personal property including money. The General Assembly shall have power to classify property including money for taxation, and to adopt different rates and different methods for different classes of such property.

In the Missouri Constitution of 1945, Art. X, $\S 4$ (A) provides for classification of property in the following manner:

All taxable property shall be classified for tax purposes as follows: class 1 , real property; class 2 , tangible personal property; class 3 , intangible personal property. The general assembly, by general law, may provide for further classification within classes 2 and 3 , based solely on the nature and characteristics of the property, and not on the nature, residence or business of the owner, or the amount owned. . . .

The Idaho, Oklahoma, and Virginia provisions are more general. The Idaho Constitution, Art. VII, $\$ 3$, provides:

The word "property" as herein used shall be defined and classified by law.

The Oklahoma Constitution, Art. X, $\$ 22$, takes a negative approach, providing:

Nothing in this Constitution shall be held or construed, to prevent the classification of property for purposes of taxation; and the valuation of different classes by different means or methods.

The Virginia provision which contains the basic clause, $\S 168$, simply adds the following: 
The general assembly may define and classify taxable subjects. ...

The sentence concludes with a reference to the power to classify property for purposes of subjecting it to either state or local taxes, but not both. It should also be pointed out that the Montana Constitution, Art. XII, §17,--in contrast to the permissive provision of the Idaho Constitution-defines property by providing:

The word property as used in this article is hereby declared to include moneys, credits, bonds, stocks, franchises and all matters and things (real, personal and mixed) capable of private ownership. ...

Structure of each state. Of course the above provisions take on additional meaning against a background of the entire uniformity structure of the state constitutions. The Colorado uniformity clause, in Art. X, $\S 3$, is accompanied by a proviso requiring a minimum personal property exemption. Also, Art. $\mathrm{X}$, sections 4 and 5 require the exemption of described classes of property. Article X, $\$ 6$ provides: "All laws exempting from taxation, property other than that hereinbefore mentioned, shall be void. . . ." A proviso in section 6 permits motor vehicles to be classified, and the levying of a "graduated annual specific ownership tax thereon," with the tax being "in lieu of all ad valorem taxes upon such property." Article X, $\S 17$ of the Colorado Constitution provides that "The general assembly may levy income taxes, either graduated or proportional . . . , and may, in the administration of an income tax law, provide for special classified or limited taxation or the exemption of tangible and intangible personal property."

There are few provisions in the Delaware Constitution other than the basic uniformity clause. The basic uniformity clause in Art. VIII, $\S 1$ is followed by this exemption proviso: 
"but the General Assembly may by general laws exempt from taxation such property as in the opinion of the General Assembly will best promote the public welfare." Article X, $\S 4$ provides for a special mandatory exemption of certain school property.

In Georgia the basic uniformity clause is accompanied by the provision which establishes certain limits within which property may be classified. The same section, Art. VII, $\$ 1$, $\llbracket 3$, deals further with the particular problems of method of property taxation and effective rates. It is provided that the general assembly may "adopt different rates and different methods for different classes of such property." In Art. VII, $\S 1, \Upsilon 4$, a very long provision sets forth permissive exemptions, and concludes: "All laws exempting property from taxation, other than the property herein enumerated, shall be void." A minor point is dealt with in Art. VII, $\S 2, \llbracket 4$, wherein it is provided that property of public utilities might be valued by different methods "but not at a greater basis of value or at a higher rate of taxation than other properties."

In Idaho the basic uniformity clause, as described above, is accompanied by the "just valuation" clause. The section, Art. VII, §5, concludes: "Provided, that the legislature may allow such exemptions from taxation from time to time as shall seem necessary and just. . . ." Article VII, $\S 4$ contains a mandatory exemption. The "supplementary" clause in the Idaho Constitution, which concerns "proportional" taxation of all property, in Art. VII, $\S 2$, is joined by a clause covering nonproperty taxes. The latter reads: "The legislature may also impose a license tax (both upon natural persons and upon corporations, other than municipal, doing business in this state). ..."This section concludes with a permissive exemption of improvements on land. Furthermore, Art. VII, $\S 3$, as already described, provides that "The word 'property" . . . shall be defined and classified by law." Idaho is the 
only state having a provision relating to double taxation generally, as contrasted to some particular problem thereof. A proviso in Art. VII, $\S 5$ reads: “. . . duplicate taxation of property for the same purpose during the same year, is hereby prohibited."

The Louisiana Constitution is the most detailed of the forty-eight states. This is the result of the numerous provisions dealing with particular taxes ${ }^{45}$-at times, in what amounts to a complete statutory form which is amended as frequently as statutes are amended. For each of the taxes, the degree of uniformity required is spelled out in the special provision. Article $\mathrm{X}, \S 4$ of the Louisiana Constitution is a general property exemption provision, listing a great many classes of property to be exempted. The section begins with the following words: "The following property, and no other, shall be exempt from taxation...."There are several other property exemption provisions. ${ }^{46}$ A provision in Art. $\mathrm{X}, \S 1$ governs the ratio of valuation to be used in taxing property, ${ }^{47}$ but the provision must be read along with Art. $\mathrm{X}, \S 12$, providing that "all real estate . . . shall be valued at actual cash value." Article $\mathrm{X}$, sections 1 and 21 provide for special treatment of forest lands and natural resources.

The Minnesota Constitutional uniformity structure consists primarily of the basic uniformity clause, to which there is attached a proviso reading: "but" certain enumerated classes of property "shall" be exempted. By subsequent

${ }^{45}$ Art. $X, \S 1$ (income tax) ; Art. X, $\S 7$ (inheritance tax) ; Art. X, $\S 8$ (license taxes generally); Art. X, $\S 9$ (taxation of banks); Art. VI, $\$ 22$ and Art. VI-A (statutory scheme for motor fuel and motor vehicle taxes).

${ }^{46}$ Art. X, $\S \S 4,9,22$; Art. VI, $\S 16.2$.

47 The provision reads:

The valuations and classification fixed for State purposes shall be the valuation and classification for local purposes; but the taxing authorities of the local subdivision may adopt a different percentage of such valuation for purposes of local taxation. 
amendment a "permissive" exemption of certain personal property was added. All the other Minnesota provisions relative to uniformity are provisions for particular taxes: Art. IX, $\S 1 \mathrm{~A}$, spells out the requirements for an occupation tax as to mining; Art. XVI, $\S 3$ provides that motor vehicles may be taxed on a more onerous basis than "other personal property," but that a tax pursuant thereto is to be in lieu of all others except local wheelage taxes; Art. XVIII, $\S 1$ provides for special treatment of forest lands; Art. XVIII, $\$ 3$ provides for a fuel tax; Art. XIX, $\$ 4$ establishes an in lieu aircraft tax.

As stated above, the Missouri Constitution supplements the basic uniformity clause in Art. X, $\S 3$ with Art. X, $\$ 4$, which spells out the particular requirements of uniformity to some degree. It reads:

(A) All taxable property shall be classified for tax purposes as follows: class 1, real property; class 2, tangible personal property; class 3 , intangible personal property. The general assembly, by general law, may provide for further classification within classes 2 and 3 , based solely on the nature and characteristics of the property, and not on the nature, residence or business of the owner, or the amount owned. . . . (B) Property in classes 1 and 2 and subclasses of class 2, shall be assessed for tax purposes at its value or such percentage of its value as may be fixed by law for each class and for each subclass of class 2. Property in class 3 and its subclasses shall be taxed only to the extent authorized and at the rate fixed by law for each class and subclass, and the tax shall be based on the annual yield and shall not exceed eight per cent thereof.

Moreover, in Art. X, $\S 6$, both mandatory and permissive exemption of named classes of property are provided for, the section concluding: "All laws exempting from taxation property other than the property enumerated in this article, shall be void." Article $\mathrm{X}, \S 7$ provides for special treatment 
of forest lands, and Art. X, $\S 5$ for the method of taxing railroads. A sentence of Art. X, $\S 4(\mathrm{~A})$, provides for other taxes in a negative way:

Nothing in this section shall prevent the taxing of franchises, privileges or incomes, or the levying of excise or motor vehicles license taxes, or any other taxes of the same or different types.

As stated above, the basic clause in Art. XII, $\$ 11$, of the Montana Constitution is supplemented by a clause of the "uniform rate" Type. Section 1 also contains a general provision as to license taxes: "The legislative assembly may also impose a license tax. . . A" Article XII, §1a permits the graduated and progressive taxation of income. Article XII, $\S 3$ provides for special treatment of mines and mining claims, and Art. XII, $\S 2$ contains both mandatory and permissive exemptions. Montana has a provision relating to a particular problem of double taxation. Art. XII, $\$ 17$, which defines "property," concludes:

.. . but this shall not be construed so as to authorize the taxations of the stocks of any company or corporation when the property of such company or corporation represented by such stocks is within the state and has been taxed.

The uniformity structure of the New Mexico Constitution is quite limited. It consists simply of the uniformity clause in Art. VIII, §1, mandatory exemptions in Art. VIII, §3, and a permissive exemption in Art. VIII, $\S 5$.

Oklahoma has a rather lengthy constitution, but the uniformity structure is not particularly complicated. Article X, $\$ 5$ contains the uniformity clause, and Art. X, $\$ 22$, as described above, refers to the classification for methods of valuation. Article X, $\S 6$ and Art XII-A provide for the exemption of described property, and Art. V, $\$ 50$ states: "The Legislature shall pass no law exempting any property within 
this State from taxation, except as otherwise provided in this Constitution." Concerning the problem of effective rate, Art. X, $\S 8$ reads: "All property which may be taxed ad valorem shall be assessed for taxation at its fair cash value. ..."Article X, $\S 12$ is a general provision referring to "other" taxes than property taxation by way of a lengthy enumeration of types of taxes.

Oregon has as its uniformity structure only the uniformity clause and the supplementary clause, described above, in Art. IX, $\S 1$, and Art. I, $\$ 32$, respectively.

The uniformity structure is also fairly simple in Pennsylvania. Article IX, $\S 1$ contains the uniformity clause, and a proviso reading: "but" the legislature may by general laws exempt from taxation certain named classes of property. Article IX, $\$ 2$ reads: "All laws exempting property from taxation, other than the property above enumerated shall be void."

Virginia has one of the more lengthy uniformity structures. Section 189 provides for the permissive exemption of industries, and Section 183 reads: "Unless otherwise provided in this Constitution, the following property and no other shall be exempt from taxation, State and local, including inheritance taxes. . . ." Section 171 provides that "No State property tax for State purposes shall be levied on real estate or tangible personal property, except the rolling stock of public service corporations. . . ." This provision is, of course, pertinent to the classification referred to above concerning classes for either state or local property taxes. Dealing with effective rates, section 169 provides that all assessments of tangible property shall be at "fair market value." A proviso to that section reads: "The general assembly may allow a lower rate of taxation to be imposed for a period of years by a city or town upon land added to its corporate limits, than is imposed on similar property within 
its limits at the time such land is added." Section 170 provides for a tax on incomes, a license tax upon business which cannot be reached by the ad valorem system, and state franchise taxes.

\section{States with Type VIII Clauses}

Seven states-Arizona, Kentucky, Maryland, North Carolina, North Dakota, South Dakota, and Washington-constitute the group having a basic uniformity clause of Type VIII: "Taxes shall be uniform upon the same class of property." There are variations in the precise phraseology of the basic clause, on the basis of which the seven states may be divided into sub-groups.

Five states (Ariz. Const. 1912, Art. IX, §1; Wash. Const. 1889, Art. XI, $\S 176$, as amended 1911; Ky. Const. 1891, $\$ 171$, as amended 1915 ; N.D. Const. 1829, Art. XI, \$176, as amended 1919; S.D. Const. 1889, Art. XI, §2, as amended 1918) have a clause providing as follows:

[All] taxes shall be uniform upon [the same class of property] [all property of the same class] [within the territorial limits of the authority levying the tax].

The Arizona, Washington, and North Dakota provisions use the phrase "the same class of property," but only Arizona and Washington include the word "all." The Kentucky and South Dakota provisions use the phrase "all property of the same class," and both omit the word "all" which modifies taxes. Except for South Dakota, all of the above states have the phrase concerning territorial limits. Other minor differences are: in Kentucky the phrase "all property of the same class" is modified by the phrase "subject to taxation"; and in North Dakota the word "property" is modified by the phrase "including franchises." The provision in the North Carolina Constitution of 1868, Art. V, $\S 3$, as amended in 
1935 may be differentiated from the above group, although there is little real substantial difference. It reads:

Taxes on property shall be uniform as to each class of property taxed.

The provision in the Maryland Constitution of 1867, Art. $\mathrm{XV}$, Bill of Rights, as amended in 1915, may be legitimately included in this group despite considerable difference in phraseology. It reads:

[A]1l taxes [state and county] . . shall be uniform as to land within the taxing district, and uniform within the class or subclass of improvements on land and personal property which the respective taxing powers may have directed to be subject to the tax levy.

Additional uniformity clauses. Two states have supplementary clauses of some other basic type. Section 174 of the Kentucky Constitution provides that:

All property . . . shall be taxed in proportion to its value, unless exempted by this Constitution. . . .

This corresponds, of course, to the Type II clause. In the South Dakota Constitution, Art. VI, $§ 17$ reads as follows:

... all taxation shall be equal and uniform.

However, it should be pointed out that in each of the above instances, these "supplementary" clauses are found in the constitutions as originally drafted, while the basic clauses have reached their present status by way of subsequent amendments. This explains any apparent conflict.

Elaboration of the basic clauses as to classes of property permitted. In both Maryland and Washington there are provisions which establish certain minimum classes of property. In each of these two states, the effect of such provisions is to establish real property as a minimum class, with personal property being subject to further classification. In Maryland 
the basic uniformity clause itself, Art. XV of the Bill of Rights, is framed in terms of minimum classes of property. "Land" is established as a single class, with "improvements" and "personal property" subject to being "sub-classified." Article VII, $\$ 1$ of the Washington Constitution, which contains the basic uniformity clause, also states that "All real estate shall constitute one class." A proviso adds that "the legislature may tax mines and mineral resources and lands devoted to reforestation by either a yield tax or an ad valorem tax at such rate as it may fix, or by both." In addition, the Washington Constitution defines "property." Article VII, §1 states: "The word 'property' as used herein shall mean and include everything, whether tangible or intangible, subject to ownership."

Structure of each state. Of course, the above provisions of each state take on additional meaning against a background of the entire uniformity structure. In Arizona, in addition to the basic uniformity clause in Art. IX, $\S 1$, there is a provision (Art. IX, §2) setting forth both mandatory and permissive exemptions of property. That section concludes: "All property in the state not exempt . . . under this constitution, or not exempt by law under the provisions of this section shall be subject to taxation. . . A Article IX, $\S 11, \mathbb{}\{2$, which was added in 1940, imposes a motor vehicle license tax "in lieu of all ad valorem property taxes on any vehicle subject to such license tax."

Kentucky has a number of provisions in addition to the basic uniformity clause, as amended, which is in $\$ 171$. The same section authorizes the classification of property to be subject to local taxation, the provision reading: "The General Assembly shall have power to divide property into classes and to determine what class or classes of property shall be subject to local taxation." This provision was added at the time of the amendment of the basic uniformity clause. 
Section 174 remains in its original form, and contains the second "uniformity clause." In addition, it has a provision dealing expressly with a particular problem of rates, providing that "all corporate property shall pay the same rate of taxation paid by individual property." Section 170 remains in its original form and contains mandatory exemptions. It concludes: "and all laws exempting . . . property from taxation other than the property above mentioned shall be void." Section 3, still in its original form, provides that "no property shall be exempt from taxation except as provided in this Constitution." Section 172 provides that "All property, not exempted from taxation by this Constitution, shall be assessed for taxation at its fair cash value, established at the price it would bring at a fair voluntary sale."

There are no relevant provisions in the Maryland Constitution, other than the uniformity clause which defines to some degree the minimum classes of property, as described above.

In North Carolina the uniformity clause, Art. V, $\S 3$, is accompanied by a provision, Art. V, $\S 5$, which sets forth both mandatory and permissive exemptions.

In North Dakota the only relevant provisions are in the same section which contains the basic uniformity clause, Art. $\mathrm{XI}, \S 176$. There are certain mandatory exemptions. Since the amendment of 1911 adding the present basic uniformity clause, the section has been further amended in 1919 to add a provision which states that "the legislature may by law exempt any or all classes of personal property from taxation." "Improvements" are to be considered personal property.

In South Dakota the section containing the basic uniformity clause, Art. XI, $\$ 2$, also contains a clause which affirms a freedom of selection for the legislature. It reads: "The legislature is empowered to divide all property includ- 
ing moneys and credits as well as physical property into classes and to determine what class or classes of property shall be subject to taxation and what property, if any, shall not be subject to taxation." However, there remain some provisions which appeared in the constitution as originally drafted. Article VI, $\$ 17$ contains the second uniformity clause, and Art. XI, $\$ 4$ provides that "The legislature shall provide for taxing all moneys, etc.," and also for the taxing of property employed in banking, "so that all property employed in banking shall always be subject to a taxation equal to that imposed on the property of individuals." Article XI, sections 5 and 6, contain mandatory exemptions, and Art. $\mathrm{XI}, \S 7$, still in the original form, provides that "All laws exempting property from taxation other than that enumerated in sections 5 and 6 of this article, shall be void."

In Washington the section which contains the basic uniformity clause and establishes certain classes of property, Art. VII, $\S 1$, also sets forth both mandatory and permissive exemptions.

\section{States with Type IX Clauses}

Rhode Island and Vermont constitute the group of states having a Type IX basic uniformity clause: "There shall be a fair distribution of the expense of government." These two states are often listed with those states categorized as having no uniformity provisions at all. However, in each of these states there is a single provision which serves the purpose of a basic uniformity clause. The Rhode Island Constitution of 1843, Art. I, $\$ 2$, reads:

All laws . . . should be made for the good of the whole; and the burdens of the state ought to be fairly distributed among its citizens.

The Vermont Constitution of 1793, Ch. I, Art. 9 reads:

. . every member of society hath a right to be protected 
in the enjoyment of life, liberty, and property, and therefore is bound to contribute his proportion toward the expense of that protection. ...

There are no other provisions in either of these two states which deal with particular problems of uniformity.

\section{States Without Uniformity Clauses}

Three states-Connecticut, Iowa, and New York-have no constitutional provisions which might be called basic uniformity clauses. Any general limitation upon taxes of some degree of uniformity is found in the "equal protection" clauses-or the equivalent of such clauses-of those states (Conn. Const. 1818, Art. I, $\S 1$; Iowa Const. 1857, Art. I, \$; N.Y. Const. 1938 [1894], Art. I, \$11).

In addition, in Iowa and New York there are provisions dealing with particular uniformity problems. Both states have clauses preventing discrimination in certain cases. In the Iowa constitution, Art. VIII, $\$ 2$, provides that "The property of all corporations for pecuniary profit, shall be subject to taxation, the same as that of individuals." In New York, Art. XVI, $\$ 4$ prohibits discrimination as to rates and method of taxation as between corporations established under United States laws and corporations under New York laws engaged in similar businesses. In addition, New York also has a provision relating the taxation of intangibles, Art. XVI, $\S 3$, which reads:

. . Intangible personal property shall not be taxed ad valorem nor shall any excise tax be levied solely because of the ownership or possession thereof, except that the income therefrom may be taken into consideration in computing any excise tax measured by income generally. . . .

New York also has a provision concerning exemptions. Article XVI, $\$ 1$ provides that "exemptions from taxation may be granted only by general laws." 


\title{
Chapter III
}

\section{The Operative Effect of Each State's Uniformity Structure}

\author{
A. ANALYSES OF STATES WITH TYPE I CLAUSES
}

\section{Arkansas}

\section{a. The provisions; historical note}

HE present constitution of Arkansas came into
force in 1874 , and the uniformity clause is found in
Art. XVI, $\S 5$, which reads:

All property subject to taxation shall be taxed according to its value, that value to be ascertained in such manner as the General Assembly shall direct, making the same equal and uniform throughout the State. No one species of property from which a tax may be collected shall be taxed higher than another species of property of equal value, provided the General Assembly shall have power from time to time to tax hawkers, peddlers, ferries, exhibitions and privileges in such manner as may be deemed proper. . . .

The basic uniformity clause is italicized. The omitted part of Art. XVI, $\S 5$, requires the exemption from taxation of property used for public, religious, educational, and charitable purposes. ${ }^{1}$ Several amendments to the constitution have pro-

1 Arkansas was admitted into the Union in 1836 . In its original constitution the uniformity clause was in $\$ 2$ of the Revenue Article [unnumbered]. Section 2 was substantially identical to Art. XVI, $\$ 5$ of the present constitution of 1874 , with only minor differences of punctuation. In the clause concerning "other" taxes, the occupation of "merchants" was included, but "ferries" and "exhibitions" were not. In the succeeding constitution of 1861 the only change of substance was the insertion of the word "true" to modify "value," so that the provision read "All property 
vided for additional property exemptions. ${ }^{2}$ Article XVI, $\S 6$, stipulates that

All laws exempting property from taxation other than as provided in this Constitution shall be void.

\section{b. Meaning of the uniformity limitation}

There has been relatively little controversy concerning the meaning of the uniformity limitation embodied in the Arkansas constitution. For purposes of uniformity in taxation, taxes are either property taxes or excise taxes. The term excise taxes is used to designate all taxes which are not property taxes. It is clear that both the uniformity clause in Art. XVI, $\$ 5$ and the supplementary provision refer-

subject to taxation shall be taxed according to its true value." In the next constitution of 1864 the word "true" was omitted.

The fourth constitution was dated 1868 and the uniformity clause was substantially changed. The revenue article was Art. X, and $\S 2$ thereof provided:

Laws shall be passed taxing by a uniform rule all money credit, investments in bonds, joint-stock companies, or otherwise; and also all real and personal property according to its true value in money; but [certain enumerated classes of property, public, religious, etc.] shall never be taxed. . . . Personal property shall be appraised in such manner as may be provided by law at its true value in money, but the general assembly may exempt from taxation personal property to the value of five hundred dollars to each taxpayer.

In addition, Section 3 of that article provided:

The general assembly shall provide by law, for taxing the notes and bills discounted or purchased, moneys loaned, and all other property, effects or dues of every description, without deduction, of all banks now existing, or hereafter created, and of all bankers, so that all property employed in banking, shall always bear a burden of taxation equal to that imposed on other property of individuals.

The present constitution was adopted in 1874 , and the uniformity provision reverted to its prior phraseology.

2 Amendment No. 12 (added in 1926) and Amendment No. 27 (added in 1938) provide for industrial exemptions; Amendment No. 22 (added in 1936) provides for a homestead exemption. 
ring to "species of property" apply only to property taxes. ${ }^{3}$ Nonproperty taxes, on the other hand, must be uniform within classes. This requirement is alternately derived either from Art. II, $\S 3^{4}$ and $\S 18^{5}$ of the Arkansas Constitution, or the equal protection clause of the fourteenth amendment to the federal Constitution. ${ }^{6}$ The objects selected for excise taxes and the exemptions therefrom need only be reasonable classes, ${ }^{7}$ and classifications may

${ }^{3}$ See, for example, Sims v. Ahrens, 167 Ark. 557, 271 S.W. 720 (1925) and Stanley v. Gates, 179 Ark. 886, 19 S.W.2d 1000 (1929), discussed under "Income Tax," infra. Nor does Art. XVI, $\$ 6$, concerning the exemption of property, limit nonproperty taxes. See Ward v. Bailey, 198 Ark. 27, 127 S.W.2d 272 (1939) upholding a statutory provision which was construed to exempt income from certain refunding bonds from the state income tax. Fulkerson v. Refunding Board, 201 Ark. 957, 147 S.W.2d 980 (1941) followed the Ward case.

4 Section 3 reads: "The equality of all persons before the law is recognized, and shall ever remain inviolate. . . ."

5 Section 18 reads:

The General Assembly shall not grant to any citizen or class of citizens privileges or immunities which upon the same terms shall not equally belong to all citizens.

${ }^{6}$ See, for example, Stanley v. Gates, supra note 3 at 900.

${ }^{7}$ See, for example, Fort Smith v. Scruggs, 70 Ark. 549, 69 S.W. 679 (1902) in which an act authorizing cities to require residents thereof to pay a tax for the privilege of keeping and using a vehicle within the city was held not to be an unreasonable discrimination in favor of those who dwelled outside of the city and used a vehicle therein. In Ex Parte Byles, 93 Ark. 612,126 S.W. $94(1910)$ a license tax on peddlers of enumerated articles was upheld, the court stating, at p. 618: "Treating this statute as one imposing a tax on privileges or occupations, it is valid, as the Legislature has the power to select certain occupations and tax them, without taxing others, and to classify the peddling of certain articles as an occupation and tax it." In Standard Oil Co. v. Brodie, 153 Ark. 114, 123-124, 239 S.W. 753 (1922) a fuel tax, construed as a tax upon the privilege of using the highways, was upheld, even though it did not reach vehicles propelled by steam, electricity, or gasoline purchased out of the state. In State v. Handlin, 100 Ark. 175, 139 S.W. 1112 (1911) an amendment to the inheritance tax, providing in effect that the excess of $\$ 50,000$ of estates subject to the tax was to be exempt, was upheld. See also, Wiseman v. Phillips, 191 Ark. 
be made for the application of different rates. ${ }^{8}$ The court has held that a progressively graduated rate is a reasonable classification. ${ }^{9}$ Because of the stricter uniformity limitation applicable to property taxes, it is always crucial to determine the nature of a particular tax. The Arkansas court has held that a net income $\operatorname{tax},{ }^{10}$ an inheritance $\operatorname{tax}{ }^{11}$ a tax on the privilege of severing timber from the soil, ${ }^{12}$ and a corporate franchise tax with a base of capital stock ${ }^{13}$ are not property taxes. ${ }^{14}$

63, 84 S.W.2d 91 (1935) and Hardin v. Vestal, 204 Ark. 492, 162 S.W.2d 923 (1942), upholding certain exemptions under the sales tax.

${ }^{8} \mathrm{See}$, for example, Stanley v. Gates, supra note 3, in which separate rate schedules for corporations and individuals under the income tax were held to be valid. However, in Waters-Pierce Oil Co. v. Hot Springs, 85 Ark. 509, 109 S.W. 293 (1908), the Arkansas court held that a local ordinance which imposed an annual tax upon coal oil wagons of $\$ 50$, while imposing an annual tax of $\$ 10$ on other vehicles, was void because it arbitrarily discriminated against all owners of vehicles used for delivering coal oil. The court relied upon Art. II, $\S 18$ of the Arkansas Constitution as the pertinent constitutional limitation.

${ }^{9}$ See Stanley v. Gates, supra note 3, discussed in the text under "Income tax."

${ }^{10}$ See the discussion in the text at notes 21-29, infra.

11 State v. Handlin, supra note 7 at 179: ". . . it may now be regarded as settled law that inheritance taxes are not laid upon property, but upon the privilege or right of succession to it; or, in other words, it is in the nature of excise tax, and not subject to the same tests with respect to equality and uniformity as taxes levied upon property."

12 Floyd v. Miller Lbr. Co., 160 Ark. 17, 254 S.W. 450 (1923).

${ }^{13}$ St. Louis Southwestern R. Co. v. State, 106 Ark. 321, 152 S.W. 110 (1913). The base of the tax was the proportion of the outstanding capital stock of the corporation, represented by property owned and used in business transacted within the state.

${ }^{14}$ But see the dissenting opinion in Wiseman v. Phillips, supra note 7 at 76-78, in which the sales tax was held by the majority to be an excise tax and valid. The dissent not only vigorously disagreed with the view concerning the nature of the income, inheritance, and severance taxes, but would as well have held the sales tax to be a tax upon property. The dissent, therefore, would have held the tax to be invalid as not conforming to the uniformity clause in Art. XVI, $\$ 5$ which limits property taxation. In the 
The uniformity limitation in taxation has not been the most serious obstacle to the validity of nonproperty taxes in Arkansas. The court has given a very restrictive interpretation to that part of Art. XVI, $\S 5$, which reads:

.. provided the General Assembly shall have power from time to time to tax hawkers, peddlers, ferries, exhibitions and privileges in such manner as may be deemed proper. . . .

Contrary to the interpretation given similar provisions in other state constitutions, the Arkansas court ${ }^{15}$ has consistently relied upon the maxim expresio unius est exclusio alterius to rule that the $\operatorname{state}^{16}$ can not tax those "occupations" or "privileges" of "common right." The occupations and privileges enumerated in Art. XVI, $\S 5$ are characterized as not being of "common right," and by their enumeration the state is prevented from taxing those which are of "common right."

A unique situation exists in Arkansas concerning uniformity and "special assessments." In all other states it is held that the basic uniformity clause is not applicable to special assessments. However, Art. XIX, $\$ 27$ of the Arkansas Constitution imposes a special limitation upon special assessments, requiring that "such assessments shall be ad valorem and uniform." In addition, there are cases suggesting that the court has ruled that the uniformity clause in Art. $\mathrm{XVI}, \S 5$ is applicable to special assessments. ${ }^{17}$ For the purposes of this monograph it is sufficient merely to refer to this

view of Chief Justice Johnson the former opinions as to the nature of the named taxes were "novations."

15 See, for example, the discussion of this problem in the several opinions in Floyd v. Miller Lbr. Co., supra note 12.

16 This limitation is not imposed upon the local taxing authorities. Sims v. Ahrens, supra note 3 at 563-564.

17 See, for example, Monticello v. Banks, 48 Ark. 251, 2 S.W. 852 (1886); Davis v. Gaines, 48 Ark. 370, 3 S.W. 184 (1886); Martin v. 
unusual situation which is primarily based on the unique uniformity provision for special assessments.

\section{(1) Property taxation}

The few cases which have ruled on uniformity and property taxation definitely establish a limitation of the strictest degree, as might be expected in light of the manner in which the property tax uniformity rules are spelled out in Art. XVI, §5. A requirement of universality governs both the selection of property for taxation and the exemption of property other than that specified in the constitution as exemptible. This requirement is said to be derived from the uniformity clause as well as from the clause in Art. XVI, §6, which expressly prohibits exemptions. ${ }^{18}$

Reynolds, 125 Ark. 163, 188 S.W. 4 (1916). Contra: Caton v. Western Clay Drainage Dist., 87 Ark. 8, 112 S.W. 145 (1908); Bensberg v. Parker, 95 S.W.2d 892 (1936).

${ }^{18}$ See Little Rock \& Ft. S. R. Co. v. Worthen, 46 Ark. 312 (1885). In that case the issue involved the validity of a statute which provided that the schedules furnished by railroad companies, upon which the value of their property for taxation purposes was figured, were not to include "embankments, tunnels, cuts, ties, trestles or bridges." The court stated that if the legislature meant to relieve any portion of the property belonging to railroad corporations from the duty of contributing to the property tax, then it had undertaken to do something which was quite beyond its power. It was said (at p. 327) that:

The theory of our constitution is that the common burden shall be borne by common contributions. All property is to be taxed according to its value. "All" does not mean all the legislature may designate, or all except such as the legislature may exempt. If this were so the whole burden of taxation might be thrown upon land, or upon any one species of property. . . . The legislature cannot discriminate between different classes of property in the imposition of taxes. The only discretion with which it is invested, is in the ascertainment of values, so as to make the same equal and uniform throughout the state. [Emphasis added.]

The italicized sentence makes it clear that the Arkansas court finds the words of the basic uniformity clause sufficient to require universality in taxation of property, quite apart from the specific provision in Art. XVI, $\$ 6$ prohibiting the exemption of property. 
Absolute uniformity is required in the effective rate applied to that property actually taxed. ${ }^{19}$ Note, however, that the requirement of absolute uniformity in both percentage rate and ratio of valuation is spelled out in Art. XVI, $\S 5$ in phrases which supplement the uniformity clause. The percentage rate requirement is spelled out in the clause referring to "species of property." The ratio of valuation requirement is spelled out in the following words, found in the uniformity clause itself: "making the same [i.e., value] equal and uniform throughout the state." There is no judicial precedent concerning the effect of these additional words on the meaning of the basic uniformity clause itself. That is, there is no indication that the words "according to value," standing alone, would necessarily require absolute uniformity in effective rates.

Property may be classified for the purpose of using different methods in determining the value of the several classes. ${ }^{20}$

${ }^{19}$ See Ex parte Fort Smith \& Van Buren Bridge Co., 62 Ark. 461, 36 S.W. 1060 (1896), holding that all property subject to a property tax must be taxed on the same percentage of its actual value. The court emphasized both the clause directcd to making value "equal and uniform" and the second sentence of Art. XVI, $\$ 5$. However, the ratio of valuation does not have to be $100 \%$ of the actual value. Any per cent may be used, so long as absolute uniformity prevails. State ex rel. Nelson v. Meek, 127 Ark. 349, 353-354, 192 S.W. 202 (1917), and cases there cited.

It is usually held that the requirement of uniformity in effective rates is "territorial"- that a comparison between ratios of valuation used by separate taxing authorities imposing separate tax burdens, such as the state and County $X$, is irrelevant. While this applies as to the final effective rate in Arkansas, the peculiar wording of Art. XVI, $\S 5$ is the basis for a rule that the ratio of valuation must be the same for the several taxing authorities in Arkansas. Hays v. Missouri Pac. Ry. Co., 159 Ark. 101, 250 S.W. 879 (1923). The basis of this rule is the following clause in Art. XVI, §5: "making the same [that is, value] equal and uniform throughout the State." Of course, the percentage rate may vary from district to district so that the effective rate of any taxing authority is not limited by this rule.

${ }^{20}$ See, for example, St. Louis, I.M. \& S.R. Co. v. Worthen, 52 Ark. 529,135 S.W. 254 (1889). 
It is important for comparative purposes to emphasize this because any indication found in the annotations or digests of cases to the effect that "property may be classified for purposes of taxation" stems from the language found in the cases ruling on this particular point. Taken out of context, the language quoted in the annotations is misleading. But there is no confusion in the actual decisions of the Arkansas court. Any statements concerning the classification of property were made solely in relation to classification for the method of determining the value of property.

There is no question, of course, that the ad valorem method must be used in taxing property, because the basic uniformity clause is phrased in terms of this particular rule of uniformity. There have been no judicial decisions on this point.

\section{(2) Income tax}

Two leading cases, Sims v. Ahren ${ }^{21}$ and Stanley v. Gates, ${ }^{22}$ establish the validity of an income tax under the Arkansas Constitution. The first Arkansas income tax was passed in 1923. It purported to be a gross income tax, reaching income from all sources. ${ }^{23}$ The tax was held invalid by a five judge court in the Sims case. The opinion is long and somewhat confusing. However, the basis of the opinion on rehearing, agreed to by three of the judges, was (1) that the tax was not a property tax but an excise tax, and (2) that the tax, as an excise tax, was invalid for two reasons. First, the tax was a violation of the commerce clause of the federal Constitu-

21 Supra note 3.

22 Stupra note 3.

${ }^{23}$ General Acts 1923, No. 345, p. 282; the statute is set forth, in part, in Sims v. Ahrens, supra note 3, at 560-561. The tax had a flat rate of

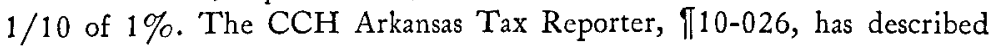
the tax as substantially a net income tax. 
tion. ${ }^{24}$ Second, the tax was a violation of the requirement that excise taxes be uniform within classes. It was said that a gross income tax operating upon all persons and all corporations alike was discriminatory. ${ }^{25}$ However, the three judge majority agreed upon this statement: "[I]t is within the discretion of the Legislature to pass a properly classified net income tax law."26

Taking a hint from the dictum in the Sims case, the legislature passed the Income Tax Act of 1929, ${ }^{27}$ which imposed a net income tax. The rates for individual income were progressively graduated, but a flat rate was applicable to corporate income. The tax was upheld in the Stanley case, the court ruling that the tax was a nonproperty tax, and that the distinction made between individual and corporate rates, the progressive individual rates, and the minimum personal exemptions were all reasonable classifications. Three justices dissented, the court now being composed of seven members. However, there was no disagreement concerning the nature of an income tax, the dissenting justices disagreeing only as

24 Supra note 3 at 573-574.

${ }^{25} \mathrm{ld}$. at 584 . The majority view was: "It is absolutely essential to uniformity that the income only should be taxed. . . . For the reason that the relation between the amount of capital and of profits varies widely, a tax on gross profits would nccessarily operate in a discriminatory manner and be arbitrary."

${ }^{26}$ Id. at 580, 599. Emphasis added.

27 General Acts 1929, No. 118, p. 573. Section 3 of the Act imposed the tax, section $3(\mathrm{a})$ reading:

A tax is hereby imposed upon and with respect to the entire income of every resident, individual, trust or estate, which tax shall be levied ... annually upon such entire net income as herein computed, at the following rates. ...

Section 3(b) read:

Every corporation organized under the laws of this State shall pay annually an income tax with respect to carrying on or doing business equivalent to two (2\%) per cent of the entire net income of such corporation as defined herein. . . . 
to the reasonableness of certain classifications found in the Act. ${ }^{28}$ The Sims and Stanley cases resolved any doubts concerning the validity of an income tax under both the uniformity limitation ${ }^{29}$ and the restrictive interpretation given the provision in Art. XVI, $\$ 5$ concerning the permissible coverage of nonproperty taxes.

\section{Maine}

\section{a. The provisions; historical note}

Maine has had but one constitution, dated 1819. The only provision pertinent to uniformity in taxation is Art. IX, §8, as amended, which provides:

All taxes upon real [and personal] estate, assessed by authority of this state, shall be apportioned and assessed equally, according to the just value thereof [but the legislature shall have power to levy a tax upon intangible personal property at such rate as it deems wise and equitable without regard to the rate applied to other classes of property]. ${ }^{1}$

${ }^{28}$ Supra note 3 at 906-907. Among other classifications objected to was the fact that a partnership was taxed at the higher schedule of rates for individual, while a corporation doing the same business was taxed at the lower flat $2 \%$ rate.

${ }^{29}$ See Ward v. Bailey, supra note 3, and Fulkerson v. Refunding Board, supra note 3. Also see Baker v. Hill, 180 Ark. 387, 21 S.W. 2d 867 (1929) holding the income tax to be a nonproperty tax insofar as the "maximum rate limitation" upon property taxation was concerned. The cases discussed in the text and the rationale therein on the nature of an income tax were relied upon.

1 The word "apportioned" in Art. IX, $\$ 8$ refers to the apportionment of the state property tax in a lump sum in quotas among the towns in proportion to the valuation of property within the towns. Contrary to the usual practice, the state of Maine levies a certain sum of money upon each town, to be collected by the town at will and paid over, rather than levying a rate per $\$ 100$ upon all property in the jurisdiction. For problems raised under the requirement of uniformity in "apportionment," see, for example, Sandy 
The phrase "and personal" was added in 1875 by amendment. The clause in brackets concerning the taxation of intangible personal property was added in 1913 by amendment.

\section{b. Meaning of the uniformity limitation}

It is clear, as expected under this type of basic uniformity clause, that Art. IX, $\S 8$ applies only to property taxes. ${ }^{2}$ Nonproperty taxes are required to be uniform within classes. The source of this limitation has never been clearly stated. The cases simply make the assertion that a tax, if a nonproperty tax, is not limited by Art. IX, $\S 8$ and that the tax is constitutional if all in a class are treated alike. There are only a small number of cases concerning the uniformity required of nonproperty taxes. ${ }^{3}$ In State v. Hamlin ${ }^{4}$ the court ruled that a collateral inheritance tax which had a flat rate was upon the privilege of receiving property, not upon the property itself.

River Plantation v. Lewis, 109 Me. 472, 84 Atl. 995 (1912); Hamilton v. Portland State Pier Site District, 120 Me. 15, 21-22, 112 Atl. 836 (1921).

${ }^{2}$ For example, State v. Hamlin, 86 Me. 495, 30 Atl. 76 (1894); In re Opinion of the Justices, 133 Me. 525, 178 Atl. 621 (1935) ; State v. Western Union Telegraph Co., 73 Me. 518 (1882); State v. Maine Cent. R. Co., 74 Me. 376 (1883); In re Opinion of the Justices, 123 Me. 573, 121 Atl. 902 (1923).

${ }^{3}$ In addition to the cases discussed in the text, see: State v. Western Union Tel. Co., supra note 2, holding selective corporation franchise taxes (with bases computed by reference to all property owned by the corporation except realty) to be excise taxes, and therefore not subject to the uniformity clause, Art. IX, §8; In re Opinion of the Justices, 123 Me. 573, 121 Atl. 902 (1923), ruling that a "reasonable tax or charge per gallon upon" motor fuels would be an excise tax.

In a more recent case, State v. F. H. Vahlsing, Inc., 147 Me. 417, 88 Atl. 2d 144 (1952), the court upheld the Maine Potato Tax Law, R.S. 1944 , c. $14, \S \S 206-217$, against the contention that it violated the property tax uniformity limitation because it was not levied ad valorem. The court ruled that the tax, which imposes a rate of $1 \phi$ a barrel on all potatoes raised in the state, except such as are retained by the grower to be used for home consumption and for seed purposes, was an excise tax. The revenue is used to publicize Maine potatoes.

${ }^{4}$ Supra note 2. 
The present Maine Inheritance $\operatorname{Tax}^{5}$ has a classified object with different graduated rate schedules applicable to each class. The validity of the graduated rates has not been litigated before the Maine Supreme Judicial Court.

Although there is no income tax in Maine, in 1935 the court rendered an advisory opinion ${ }^{6}$ in which it ruled that a net income tax would not be a direct tax upon property, and therefore would not be subject to the uniformity clause in Art. IX, §8. The court stated that the proposed tax was a "proposal . . . to tax the privilege of receiving income."” Several particular issues were passed on. The court stated that to tax income from intangible personal property at a higher rate than the rate upon income derived from other sources would be an invalid discrimination. However, income from real property might be exempted. Of most significance was the statement that the tax might be enacted with either a graduated rate or a single fixed rate.

\section{(1) Property taxation}

The uniformity clause in the Maine Constitution has been interpreted to require a strict degree of uniformity. ${ }^{8}$ Absolute uniformity is required of the effective rate applicable to all

5 Maine Rev. Stat. 1944, c. 142, as amended.

${ }^{6}$ Opinion of the Justiccs, 133 Me. 525, 178 Atl. 621 (1935).

${ }^{7} I d$. at 528 .

8 On its face the scope of the uniformity provision was broadened by the 1875 amendment adding the phrase "and personal" to make the clause now read: "All taxes upon real and personal estate. . . " However, there is some doubt whether before 1875 uniformity was required only as to taxation of real property. The court in an 1873 opinion stated:

Though this section applies specially to real estate, yet the very idea of taxation implied an equal apportionment and assessment upon all property, real and personal, "according to its just value." It cannot for a moment be admitted that the constitution authorizes an unequa] apportionment and assessment upon real and personal estate, without any reference to its "just value."

Brewer Brick Co. v. Brewer, 62 Me. 62, 73, 16 Am. Rep. 395 (1873). 
property taxed by any taxing jurisdiction;" thus, "double taxation" is prohibited. ${ }^{10}$ The 1913 Amendment to Art. IX, Sec. 8 apparently makes an exception to this requirement. That amendment provides that intangible personal property may be taxed at a "rate" without regard to the "rate" appli-

${ }^{9}$ In In re Opinion of the Justices, $97 \mathrm{Me} .595,55 \mathrm{Atl} .827$ (1903) it was said that, in levying a state tax, the legislature would be prohibited by Art. IX, $\S 8$ of the constitution from fixing a higher rate of taxation upon rural lands than the rate upon urban lands. Quoting Art. IX, $\S 8$, the court said (p. 597): "This command of the Constitution is absolute and comprehensive. . . The only permissible variation of the amount of the tax is that resulting from the difference in value. The rate must be the same everywhere. Locality can be considercd only so far as it affects value." And in In re Opinion of the Justices, $123 \mathrm{Me}$. 573, $121 \mathrm{Atl} .902$ (1923), when asked whether the legislature had the right to levy a reasonable tax per gallon upon all motor fuel, the court stated (p. 577): "The answer to this question depends upon the nature of the contemplated tax. If a property tax, it obviously offends the Constitution of Maine, Art. IX, §8. . . . To single out any particular species of property . . . and impose a property tax upon it uncqual in comparison with the tax upon other commoditics as to value would be void."

Other than advisory opinions the cases have concerned the proposition that absolute uniformity is required of the ratio of valuation used within any one taxing district, but that this ratio need not be $100 \%$ of the "actual" value. Spcar v. Bath, 125 Mc. 27, 130 Atl. 507 (1925); Cumberland County Power \& Light Co. v. Hiram, 125 Me. 138, 131 Atl. 594 (1926). Also sce the recent case, Sears, Roebuck \& Co. v. Inhabitants of City of Presque Isle, 150 Mc. 181, 107 Atl. 2d 475 (1954).

${ }^{10}$ It is clear that the court holds the view that to tax a part of the property located in a taxing district twice, while the remainder is taxed only once, would be a violation of the uniformity clause, Art. IX, §8. Dyar v. Farmington Village Corp., $70 \mathrm{Me}$ 515, 522-523 (1878). In Wheeler v. County Commissioners, 88 Me. 174, 180 (1895) it was said that for a taxing authority to tax the rcal estate of a corporation to the corporation and to tax the shares of the corporation to the holder thereof when the real estate already taxed was taken into account, to some extent, in fixing the value of the shares "resulted in double taxation . . . contrary to the spirit and policy of the law." Art. IX, $\$ 8$ was quoted, but it was noted that the statutory scheme provided for a deduction of the value of the real estate. In Stevens v. Dixfield \& Peru Bridge Co., 115 Me. 402, 99 Atl. 94 (1916) such a case of "double taxation" was held to violate the uniformity clause. 
cable to "other classes of property." In fact, practically no use has been made of this exception and intangible personal property is, purportedly, still subject to the General Property Tax. ${ }^{11}$ Thus, the court has had no occasion to interpret the scope of this exception. On its face the amendment appears to authorize only a separate rate applicable to all intangible personal property.

In addition to the requirement of absolute uniformity in effective rates, property may be taxed only by the ad valorem method. ${ }^{12}$ In contrast, there is no rule of universality either for the selection or exemption of property. ${ }^{13}$ The court has said:

This provision [Art. IX, \$8, before the 1913 amendment] simply requires that any tax which shall be lawfully imposed upon any kind or class of real or personal property shall be

11 The only cxception is that shares of stock in domestic trust companies and national banking institutions are taxed separately at a fixed rate. Maine Rev. Stat. 1944 , c. $14, \S \S 156-158$ A.

12 There is no case directed specifically to this problem. However, note the implication in the statement in In re Opinion of the Justices, $123 \mathrm{Me}$. $573,577,121$ Atl. 902 (1923) to the effect that "To single out any particular species of property ... and impose a property tax upon it unequal in comparison with the tax upon other commodities as to value would be void." [Emphasis added.]

13 There are very few cases on this point. In In re Opinion of Justices, 102 Me. 527, 66 Atl. 726 (1907) the court stated that an excise (gross receipts) tax on railroads which was to be in lieu of state and local taxes upon their property was not forbidden by any constitutional provision. In Portland v. Portland Water Co., 67 Me. 135 (1877) the court held that the city's exemption of the property of the water company for a term of years was not a violation of the uniformity provision, Art. IX, §8. However, in that case the court relied to a considerable degree on a contract between the city and the company under which water was to be furnished without charge to the city. While stating the general principle concerning the power to exempt, the court distinguished former cases by stating that this situation "partakes the character of a contract."

In Brewer Brick Co. v. Brewer, supra note 8, the court affirmed the general power of exemption, but held an exemption by the city of certain 
apportioned and assessed upon all such property equally. . . It does not require the legislature to impose taxes upon all the real and personal property within the State of whatever kind and to whatever use applied. The legislature may, nevertheless, determine what kinds and classes of property shall be taxed and what kinds and classes shall be exempt from taxation. It has exercised this power of exemption frequently and continually, without question, since the adoption of the Constitution. . . It is now too late to question the power. ${ }^{14}$

classes of manufacturing institutions within the city to be invalid. One alternative reason given was that the exemption violated Art. IX, $\S 8$ in that the exemption was not "statewide." See the discussion on that limitation in the text.

And in Dyar v. Farmington Village Corp., supra note 10, the court held that the attempt to create a territorial corporation made up of a part of a town and to impose a tax upon the realty therein, when the "territorial corporation" remained a part of the town for all other tax purposes, was invalid. One reason given was that this was an invalid exemption contrary to Art. IX, §8 (pp. 522-523).

The court asserted:

... [I]n this state ... a tax cannot be constitutionally imposed upon a portion only of the real estate of a town, leaving the remainder exempt. So held in Brewer Brick Company v. Brewer. ... . In that case the portion to be exempted was specified, while in this the portion to be taxed is specified. But this difference is unimportant. . . . The result is the same. One portion is taxed and the other is exempt. Or, to speak with entire exactness, one portion has an additional tax placed upon it from which the remainder is cxempt. And it is this result-this inequality of taxation-that renders the proceeding unconstitutional.

It is questionable whether the Brewer case supports the statement made. However, the Dyar case clearly rules upon the point, so that we may conclude that realty may not be exempted solely on the basis of location. The statement that no realty may be exempted is broader than the holding and does not necessarily represent the law in light of the opinion (Opinion of the Justices, supra) ruling upon the validity of the exemption of railroad property. Of course, in that case there was an "in lieu" excise tax. However, realty classified as public property and property of benevolent institutions, for example, are in fact exempted. See Maine Rev. Stat. 1944, c. 81, $\$ 6$.

${ }^{14}$ In re Opinion of the Justices, 102 Me. 527, 66 Atl. 726 (1907). 
This is not a surprising result in view of the fact that there are no provisions in the Maine Constitution for either the mandatory or permissive exemption of certain classes of property which are almost universally exempted to some degree in the forty-eight states-for example, public property, educational property, and the like. ${ }^{15}$

However, the court has ruled that the exemption of property must be on a statewide basis. ${ }^{16} \mathrm{~A}$ species of property cannot be exempted in one jurisdiction and taxed in another. The rationale of the court for this proposition was as follows:

The legislature may determine the amount of taxation and select the objects. They may exempt by general and uniform laws certain descriptions of property from taxation.

To have uniformity of taxation, the imposition of, and the exemption from taxation, must be by one and the same authority - that of the legislature. It is for the legislature to determine upon what subject matter taxation shall be imposed; upon land, upon loans, upon stock, etc.; but the subject matter once fixed, the rule is general, and applied to all property within its provisions. . . . It cannot be pretended that it would be constitutional to impose a tax on a church in A., and to exempt one of the same character in B. ... But if it be conceded that each town has the right to tax part and exempt part of the property located therein, whatever its character, uniformity in relation to the subject matter, as well as to the ratio of taxation, is at an end.

15 See Maine Rev. Stat. 1944, c. $81, \S 6$.

16 Brewer Brick Co. v. Brewer, 62 Me. 62, 16 Am. Rep. 395 (1873). The issue concerned the validity of a state statute providing that manufacturing establishments were to be excmpt for a term of years from property taxation, provided the towns and cities in which the same were located gave their consent to such exemption. Besides finding an improper delegation of power, the court ruled that such an exemption would violate the uniformity provision, Art. IX, $\S 8$, in that the nature of the exemption could vary from town to town. 
If, of the innumerable varieties of manufacture, different towns exempt different, or the same species of manufacture, the utter want of uniformity is obvious. ${ }^{17}$

This position is in contrast to the rule of uniformity required of effective rates. There need be no correlation of the effective rates imposed by the state and the several local taxing jurisdictions, because absolute uniformity is required only of the rate applied to all property taxed by any single taxing jurisdiction, state or local. ${ }^{18}$

\section{Tennessee}

\section{a. The provisions; historical note}

The principal provision concerning uniformity of taxation in the present Tennessee Constitution of 1870 is Art. II, \$28. Section 28 contains the basic uniformity clause and other pertinent limitations. The section reads (with indentation and emphasis supplied):

All property, real, personal or mixed, shall be taxed, but the Legislature may except such as may be held by the State, by counties, cities or towns, and used exclusively for public or corporation purposes, and such as may be held and used for purposes purely religious, charitable, scientific, literary or educational, and shall except one thousand dollars' worth of personal property in the hands of each taxpayer, and the direct product of the soil in the hands of the producer and his immediate vendee.

All property shall be taxed according to its value, that value to be ascertained in such manner as the Legislature shall direct, so that taxes shall be equal and uniform throughout the State. No one species of property from which a tax may be collected shall be taxed higher than any other species of property of the same value.

17 Id. at 74.

${ }^{18}$ See the cases cited in note 9 , supro. 
But the legislature shall have power to tax Merchants, Peddlers, and privileges, in such manner as they may from time to time direct. The portion of a Merchant's Capital used in the purchase of Merchandise sold by him to nonresidents and sent beyond the State, shall not be taxed at a rate higher than the ad valorem tax on property.

The Legislature shall have power to levy a tax upon incomes derived from stocks and bonds that are not taxed ad valorem. ....

Two other provisions should be considered. Article II, $\$ 29^{2}$ makes the principles of uniformity found in Art. II, $\$ 28$ expressly applicable to local taxes. Article II, $\S 30^{3}$ provides for the exemption of domestic produce and manufactured articles. Tennessee has had substantially this same uniformity structure for the greatest part of its history. However, a novel uniformity clause based on quantity rather than quality, and sometimes referred to as the first "real" uniformity clause, ${ }^{4}$ was introduced in the original Tennessee Constitution, dated $1796 .{ }^{5}$

1 The omitted part of Art. II, $\$ 28$ concerns a poll tax.

2 The provision reads:

The General Assembly shall have power to authorize the several counties and incorporated towns of this State, to impose taxes for county and corporation purposes respectively, in such manner as shall be prescribed by law; and all property shall be taxed according to its value, upon the principles established in regard to State taxation. . . .

3 The provision reads:

No article manufactured of the produce of this State shall be taxed otherwise than to pay inspection fees.

4 Matthews, "The Function of Constitutional Provisions Requiring Uniformity in Taxation," 38 Ky. L. J. 31, 41 (1949). Cf. Chapter V, Part A, infra.

5 The original Tennessee Constitution, Art. I, \$26, contained the following provision:

All lands liable to taxation in this state, held by deed, grant, or entry, shall be taxed equal and uniform, in such manner that no one hundred 


\section{b. Meaning of the uniformity limitation ${ }^{6}$}

In Tennessee taxes may be classified for the purpose of applying Art. II, $\$ 28$ as property, nonproperty, and income taxes. The uniformity limitations in Art. II, $\$ 28$ apply only to the taxation of property. Nonproperty taxes and taxes upon income are limited only to that degree of uniformity required by either Art. XI, $\S 8$ of the Tennessee Constitution-the equivalent of an "equal protection" clause-or the equal protection clause of the fourteenth amendment to the United States Constitution. " The court at one time ruled that "special assessments" as well as "taxes" upon property were limited

acres shall be taxed higher than another, except town-lots, which shall not be taxed higher than two hundred acres of land each; no freeman shall be taxed higher than one hundred acres, and no slave higher than two hundred acres on each poll.

Article I, $\S 27$ of the constitution of 1796 was identical to the present Art. II, $\$ 30$, supra note 3 , providing for a special exemption.

In the Tennessee Constitution of 1834 the uniformity provision was found in Art. II, $\$ 28$ and the rule of uniformity was changed to one of value. The basic uniformity clause and supplementary clause as to "rates" were identical with those appearing in present Art. II, \$28. However, the first sentence varied significantly from the first sentence of the present Art. II, $\$ 28$. That section provided:

All lands liable to taxation, held by deed, grant, or entry, town-lots, bank-stock, slaves between the ages of twelve and fifty years, and such other property as the legislature may from time to time deem expedient, shall be taxable.

Article II, $\$ 30$ of the 1834 constitution carried over Art. I, $\$ 27$ of the 1796 constitution, and was therefore identical with the present Art. II, $\$ 30$. Article II, $\$ 29$ of the 1834 constitution was new, and substantially the same as the present Art. II, §29, supra note 2, which applies the principles of uniformity to local taxes.

${ }^{6}$ One of the very few articles dealing with the uniformity problem generally is Parker, "Tax Problems Presented by the Tennessee Constitution," 4 Vand. L. Rev. 116 (1950), in which the writer analyzes the uniformity limitation under the Tennessee Constitution.

${ }^{7}$ See, for example, Shields v. Williams, 159 Tenn. 349, 366-367, 19 S.W. $2 \mathrm{~d} 261$ (1929) and the cases discussed in notes 60-62, infra. 
by the uniformity provision in Art. II, $\$ 28 .^{8}$ This interpretation has since been overruled. ${ }^{9}$

\section{(1) Property taxation}

Uniformity in selection and exemption. The Tennessee Supreme Court has consistently interpreted Art. II, \$28, to require the strictest degree of universality in the taxation of property. Therefore, except for property designated as exemptible in Art. II, $\$ \$ 28$ and 30 of the constitution, it is said that no property may be exempted from taxation, and a taxing authority may not select for taxation less than all property within its territorial jurisdiction. ${ }^{10}$ However, the apparent strictness of this rule was notably limited in the 1929 Shields case, discussed below, in which the court, in fact, sanctioned the "exemption" of representative intangible personal property, although in theory the strict rule was not even partially abandoned.

With certain exceptions of no consequence to the present discussion, the cases concerning universality, which were decided before the 1929 Shields case, fall into five groups. First, in several cases the court held that Art. II, $\$ 28$ was violated by certain statutes purporting to exempt a part or all of the property in newly incorporated territory from city taxation for a period of years. ${ }^{11}$ The only cases decided since

8 The leading case was Taylor McBean \& Co. v. Chandler, 56 Tenn. 349 (1872).

${ }^{9}$ Arnold v. Knoxville, 115 Tenn. 195, 90 S.W. 469 (1905). See Parker, supra note 6 at 120-121.

${ }^{10}$ See the cases cited in notes 11-13,19, and 23, infra.

11 See Jones v. Memphis, 101 Tenn. 188, 47 S.W. 138 (1898). Also see Allen v. Board of Mayor and Aldermen of Smithville, 140 Tenn. 418, 205 S.W. 124 (1917), in which the court held an entire act void because of the proviso reading: "that not more than one acre of any lands included in said boundary and used for farming purposes shall be taxable under this act. . . ." The purpose of the act was to grant a charter to the municipality.

A clear statement of the limitation is found in the dictum of Railway 


\section{9 which concern either the "exemption" or "selection"} of property from taxation are affirmations of this principle. ${ }^{12}$ Second, there are those cases in which the court has held that the uniformity provision, Art. II, $\$ 28$, was violated by certain statutes which "selected" only real estate for taxation, with the result that all personalty within the taxing jurisdictions was not subject to the taxes. Such omissions were held to be unconstitutional "exemptions." 13

The third group of cases embodies correlative propositions.

Company v. Wilson County, 89 Tenn. 597, 609 (1891), in which the court, after first finding that there was no statutory power in the county to exempt railroad property from taxation, said, after quoting Art. II, §28:

This constitutional mandate that all property (except that mentioned therein for exemption) shall be taxed, prohibits even-the Legislature from granting any other excmption whatever, no matter what the consideration; and if it attempts to do so, the effort is unavailing and void for want of legislative power. [The constitution declares what property] shall be taxed, and what may and what shall be exempt from taxation.

12 American Bemberg Corp. v. City of Elizabethton, 180 Tenn. 373, 175 S.W. 2d 535 (1943); Bell v. Town of Pulaski, 182 Tenn. 136, 184 S.W. 2d 384 (1944); Corp. of Sevierville v. King, 182 Tenn. 143, 184 S.W. $2 \mathrm{~d} 381$ (1944). In the latter two cases, as in the Allen case, supra note 11 , the land to be exempt was farm land.

13 A leading case is Reelfoot Lake Levee Dist. v. Dawson, 97 Tenn. 151, 36 S.W. 1041 (1896), in which the court clearly explained the proposition. The court stated that Section 28 is mandatory in at least two points, one of which is that all property, of whatever kind, except for exemptions in the constitution, shall be taxed. And it held that the act in question "utterly" ignored this requirement in that "it expressly limits taxes therein provided for to land alone, and thereby exempts all personalty, and without as well as that within the exceptions mentioned in the fundamental law. ..." (pp. 161-162). Also see Taylor McBean \& Co. v. Chandler, 56 Tenn. 349, $24 \mathrm{Am}$. Rep. 308 (1872). Both of these cases arose over the validity of what were held to be "special assessments," not "taxes." In those early cases such "special assessments" were held to be limited by Art. II, §28, and therefore invalid for the reasons mentioned. As stated above, at note 9 , this interpretation of the application of the uniformity provision was later reversed. However, the cases are still valid as to the meaning of the uniformity limitation. 
On the one hand, the court has held that the same taxing authority, without violating Art. II, §28, may tax both the "capital stock" of a corporation as property of that corporation and the shares of the same corporation as personal property of the shareholder. ${ }^{14}$ The court reasoned that the two items were separate and distinct items of taxable property, and that to tax both was not such "double taxation" as is prohibited by the uniformity limitation. In addition, the court has stated, as dictum, that the same proposition held true for the taxation of both land and the mortgages thereon. ${ }^{15} \mathrm{~A}$ similar statement has been made concerning the taxation of property bought on credit as property of the buyer and the debt on the same as property of the seller. ${ }^{16}$ It should be pointed out, however, that in the "capital stock" cases the court was referring to the taxation of the "capital stock" as invested in the corporate tangible property. Thus, the court was not in fact approving the taxation at the same time of both corporate intangible assets and the corporate shares. ${ }^{17}$

14 Memphis v. Ensley, 65 Tenn. 553, 32 Am. Rep. 532 (1873); Street Railroad v. Morrow, 87 Tenn. 406, 11 S.W. 348 (1889); and see Memphis v. Memphis City Bank, 91 Tenn. 574, 195 S.W. 1045 (1892); Memphis v. Home Insurance Company, 91 Tenn. 558, 19 S.W. 1042 (1892).

${ }^{15}$ Dunn v. Dunn, 99 Tenn, 598, 607, 42 S.W. 259 (1897), in which the issue was the priority of a tax lien. The court stated that land and the mortgagee's interest therein are separate and distinct things, for while the land is taxed in the hands of the mortgagor, and to its full value, the mortgagee is taxed upon his notes and the mortgage which he holds to secure them. Thus, for tax purposes, they were treated as separate and distinct properties. Also see Street Railroad v. Morrow, supra note 14 at 419-420.

${ }^{16}$ Street Railroad v. Morrow, supra note 14 at 419-20.

17 See, for example, Memphis v. Ensley, supra note 14. The Court said (at p. 554) that the Company had "all their capital stock invested in Gas Works Manufactory and other appurtenances necessary to the production and supply of gas. This property has been regularly assessed for taxes, and the same was paid. A tax, however, has been assessed on the shares of stock 
On the other hand, in subsequent cases the court held that, while both corporate shares and "capital stock" may be taxed without violating Art. II, $\S 28$, the provision does not require the taxation of both. ${ }^{18}$ The court characterized the taxation

owned by the shareholders at their market value as part of the personal property of said shareholders. . ." (Emphasis added.) It was claimed that this was an unconstitutional "double taxation" (but with no constitutional citation) on the ground that the tax on the capital stock "as invested is a tax on the shares. . . ." (Emphasis added.) In concluding that the tax on the shares was valid, the court stated at p. 562: "The shareholders are liable to be taxed for their stock as owners of other property [than the capital stock], regardless of the fact that the capital stock invested in the property of the company has been taxed. . .." (Emphasis added.) Also see Street Railroad v. Morrow, supra note 14, in which it was stated (at p. 419): "The tax in the case now being considered is laid upon the property of the corporation, and the capital stock in the hands of the corporation is, by express direction of the lawmaker, omitted from assessment." See Tenn. Public Acts of 1887, Ch. $2, \S 8$.

18 Union \& Planters' Bank v. Memphis, 101 Tenn. 154, 46 S.W. 557 (1898), in which the court pointed to the provision in Art. II, \$28 stating that the valuation of property is to be determined in such manner as the legislature might direct, and stated (pp. 159-160):

The Legislature in its wisdom has provided for the assessment of stock to the shareholder, and has determined that no tax shall be assessed upon the capital of the corporation. It was clearly within the power of the Legislature to prescribe this method of taxing bank stock, and, until the system is changed, no ad valorem tax can be collected from the corporation on the capital stock. (Emphasis added.)

Also in Tennessee Fertilizer Co. v. McFall, 128 Tenn. 645, 163 S.W. 806 (1913), the court stated (at p. 660):

It is within the power of the legislature to assess corporations upon their corporate property and capital stock excluding the shares of stock, or it is within the power of the legislature to assess shares of stock in lieu of corporate property and capital stock. . . Either mode of assessment is valid, and neither can be regarded as unlawfully exempting corporate property from taxation. The two plans are merely different methods of assessment of corporate property. [Emphasis added.]

Also see Carroll v. Alsup, 107 Tenn. 257, 64 S.W. 193 (1901); Sloan v. Columbia, 144 Tenn. 197, 232 S.W. 663 (1920). But see the earlier case of Chattanooga v. Nashville, C. \& St. L. R. Co., 75 Tenn. 561 (1881). 
of only one item (e.g., "capital stock") at its full value as simply a "method of assessing" such property. It is significant to note that in these later cases the court was referring to the intangible assets of the corporations when it referred to "capital stock." A change had been made in the General Property Tax by this time so that most corporations were taxed on their intangible assets (that is, their "capital stock"), the value of which was stated to be the value of corporate shares minus the value of tangible property taxed as other property. The shares of such corporations were not taxed to the holders thereof. On the contrary, when the first proposition above was stated-that it was permissible to tax both "capital stock" and shares-it appears that shares were taxed, but that no provision was made for taxing the total intangible assets (that is, the "capital stock") of corporations.

The fourth group of cases concerns the "exemption" of both governmental and private bonds from the general property tax. These cases are of particular importance because they concern positive efforts to "exempt" a class of intangible property from taxation. The court first held that two statutes, interpreted as providing for the exemption of state bonds from both state and local property taxation, violated the uniformity provision, Art. II, $\S 28$, because they were, in fact, "exemptions" of property not designated as exemptible by the constitution. ${ }^{19}$ However, a few years later,

${ }^{19}$ In State Nat. Bank v. Memphis, 116 Tenn. 641, 94 S.W. 606 (1906) a statute (Gen. Rev. Act. 1903, c. $258, \S 25$ ) which provided that the assessable value of shares of stock in banks was to be the actual cash value of such stock less the value of realty and tangible personalty belonging to the bank, and less the value of state bonds owned for not less than six months, was construed to create, in effect, an exemption of state bonds. The court held the clause void, because (p. 653) "It violates the clause of the constitution that 'all property ... shall be taxed,' and the clause that 'taxation shall be equal and uniform throughout the State." 'In Keith v. Funding Board of Tennessee, 127 Tenn. 441, 155 S.W. 142 (1912) a statute expressly providing that the "principal and interest" of state bonds were not to 
in Foster v. Roberts, the court overruled those prior cases ${ }^{20}$ and held that the "exemption" of the principal and interest from state bonds from state and local taxation was not an "exemption" of property as contemplated by Art. II, \$28, but was an "act of sovereignty" by which the state simply provided for its credit. ${ }^{21}$ It was agreed that if the statutory provision was construed to be an "exemption" of property, the decisions of the overruled cases would have been correct. ${ }^{22}$ The precise nature of the Foster case rationale was emphasized by a 1924 decision, Cumberland University v. Golladay, ${ }^{23}$ in which the court ruled that the "Foster case

be taxed by either the state or local governmental units was held to violate Art. II, $\$ 28$ of the constitution because it was an "exemption" of property not designated as exemptible in the constitution.

20142 Tenn. 350, 219 S.W. 729 (1919). As stated by the court (p. 351 ), the power of the legislature to authorize the issuance of "nontaxable bonds of the state" was "again brought in question" by the challenge of the validity of Tenn. Laws 1919 , c. 114, which provided that "neither the principal nor intcrest of said [state] bonds shall be taxed" by state or local units of government. It was recognized that a similar statute was held unconstitutional in the Keith case, supra note 19. The court expressly overruled that case, and it mentioned (at p. 356) State Nat. Bank v. Memphis as only "correctly" holding that there was no implied exemption of state bonds from taxation. However, in fact the court found an implied statutory "exemption," so that this case must be taken as overruling both the Keith case and the State Nat. Bank case.

21 The court (p. 354) relied on the dissenting opinions in the Keith case, which had concluded that the constitutional inhibition against exemptions from taxation was not intended to control the state with reference to its own credits as a means of floating its obligations at lower rates of interest. Thus, the legislature might, in the exercise of its "inherent sovereign power," contract that bonds issued by the state should be free from the burden of taxation.

22 Foster v. Roberts, supra note 20 at 353 , saying that an examination of the Keith case "clearly discloses that the correctncss of the positions taken therein depends entirely upon whether the consideration of the question is undertaken as one of taxation exemption of property forbidden by the Constitution, or whether it is to be viewed as an act of sovereignty."

23152 Tenn. 82, 274 S.W. 536 (1924). Tenn. Laws 1925, c. 77, §1 
rule" did not extend to the exemption of the principal and interest from private bonds from taxation. The rationale of the earlier cases was relied on in this opinion to support a decision that Art. II, $\$ 28$ was violated by a statute providing for the exemption of bonds of educational institutions from state and local taxation.

Fifth, in State ex rel. Hauk v. American Trust Co.," ${ }^{24}$ the court held that the "in lieu" provision of a "mortgage registry" tax was unconstitutional. The tax had been imposed "in lieu of all other taxes." "The tax itself was considered a nonproperty tax and therefore valid, but the "in lieu" provision violated Art. II, $\$ 28$, because it amounted to an exemption. "[T] he legislature is without power to exempt from taxation any property except as specified in [the Constitution]."26 Thus, the court established the following general rule. A privilege tax imposed indirectly upon a class of property not designated by the constitution as exemptible, could not constitutionally be imposed "in lieu" of the general

was substantially identical to the provisions which had been contested in the cases discussed in the text, and provided that such bonds "should not be taxed." The court clearly treated the provision as an "exemption" (p. 85 ) and relied upon Art. II, $\$ 28$, to hold the statute invalid, stating that Section 28 provides that "all property" shall be taxed, and (at p. 86) that "The legislature is without power to grant tax exemptions to individuals or institutions contrary to the express mandate of the constitution. . . . Bonds, when issued and sold by a literary institution, after passing into hands of an individual, are beyond the tax-exempt class of property enumerated" in Section 28.

24141 Tenn. 243, 208 S.W. 611 (1918).

25 Tenn. Laws 1917, c. 70: “. . . prior to the recording by the Registrars of the several counties of the State of any mortgage, or deed of trust ... there shall be levied and paid, in lieu of all other taxes, a state tax of $15 \phi$ on each $\$ 100$ or portion thereof, of the amount of the indebtedness so secured . . provided that this tax shall not apply to loans under $\$ 1,000$."

${ }^{26}$ Supra note 24 at 246 . The court stated that it "must conclude that it was the intention to exempt registered mortgages and deeds of trust from ad valorem taxation." 
property tax upon that class of property because such an "in lieu" provision would, in fact, be an "exemption" of such property.

To 1929, then, the meaning of the rule of universality had developed rather clearly. It prohibited both the positive exemption of classes of property, and the "negative" exemption of classes of property by way of a failure to select such classes for taxation. Neither could an "in lieu" nonproperty tax be substituted for the general property tax on a class of property not designated as exemptible by the constitution. However, the effect of the strict rule had been modified in two instances. First, the court had held that, while the constitution did not forbid the simultaneous taxation of both corporate stock in the hands of the individual and the capital stock of the corporation, nevertheless there was no requirement that both must be taxed. Second, the exemption of state bonds had been construed not to be an "exemption," and consequently not governed by the strict rule of universality. ${ }^{27}$ Of course, this second "exemption" really proved the rule of universality, because, if Art. II, $\$ 28$, was not to be violated, it was necessary to construe the statutory relief of state bonds from property taxation as not being an "exemption" of property. The evasive nature of this rationale was emphasized when the court subsequently held that private bonds could not be "relieved" of taxation as that would be an unconstitutional "exemption."

27 In Foster v. Roberts, supra note 20, the court took a possible alternative position when it stated (at p. 357): "Further, we are of the opinion that the bonds of the State do not constitute property within the meaning of that term, as used in the taxation clause of the Constitution," but that such are instrumentalities of the government which it could not be contended that the legislature is mandatorily required to tax, or which because of constitutional language cannot be exempted. However, this position was not pursued at length, and does not appear in the later cases concerning the "exemption" of representative intangible property. 
At this point it will be helpful to describe the pertinent parts of the general property tax act as it appeared before being changed by the legislature in 1929. This will be of considerable aid in determining the implication of those changes which were upheld by the court in the 1929 Shields case, discussed below. In 1929 the general property tax act was located in Chapter 602 of the Public Acts of 1907. Section 1 of that Act, the general provision, read:

... all property-real, personal, and mixed-shall be assessed for taxation for state . . . [and local] purposes, except such as is declared exempt in the next section.

The next section was obviously a paraphrase of the first sentence of Art. II, $\$ 28$ of the constitution. Section 2 of Chapter 602 set forth certain exemptions, stating “. . . all property herein enumerated and none other shall be exempt from taxation." The enumerated property coincided with that property designated as exemptible by the constitution. Section 8 of Chapter 602 implemented the general section by providing for the classifications under which "all personal property of every kind" was to be assessed. The section clearly covered all intangible property, except certain stocks in corporations the capital stock of which was taxed by Tennessee. $^{28}$

Section 24 of Chapter 602 provided that shares of stock in banking institutions and certain miscellaneous corporations were to be assessed as personal property to the holders thereof, the tax to be in lieu of any taxation of the corporate capital stock. The value of such shares was to be the actual cash value minus the value of realty and tangible personalty owned by such corporations which was taxed as other property. Sections 21,22 , and 26 of Chapter 602 provided for the

${ }^{28}$ See note 30, infra, for the original and amended versions of this section. 
taxation of intangible property in the hands of corporations other than the banking institutions and miscellaneous corporations mentioned in Section 24. Thus, the capital stock of substantially all domestic and foreign corporations doing business in Tennessee was taxed, with its value being the actual cash value of the shares in such corporations less the value of realty and tangible personalty owned by such corporations, which was to be taxed as other property.

In 1929 the Tennessee legislature passed Chapter 86 of the Public Acts of 1929. The obvious purpose was to implement the unique provision in Art. II, $\$ 28$, which reads: "The legislature shall have power to levy a tax upon incomes derived from stocks and bonds that are not taxed ad valorem." (Emphasis added.) The Act did two things. First, sections 1 through 6 imposed a tax of $5 \%$ on the "incomes derived by way of dividends from stocks or by way of interest on bonds. . . ."29 There were certain exclusions and exemptions, and the term "bonds" was defined very broadly, in Section 4 of the Act, so that it included all "obligations . . . evidenced by an instrument whereby the obligor is bound to pay interest to the obligee. . . ."

Second, section 7 of the Act amended the General Property Tax Act of 1907 , so that the ad valorem tax would, in fact, fail to tax all intangible personal property in the hands of individuals, other than money on hand or on deposit and bank shares. This was done in the following manner. The general section of the General Property Tax Act, purporting to subject "all property" to taxation, was left unchanged. However, Section 8 of Chapter 602 of the Acts of 1907, which provided the classification under which all personal property was to be assessed, was amended to provide only for the assessment of tangible personal property and money

${ }^{29}$ The income tax and its particular provisions are discussed infra. 
on hand or on deposit. ${ }^{30}$ Section 24 of Chapter 602, providing for the taxation of bank shares to the holders thereof, was left unchanged.

The validity of Chapter $86^{31}$ of the Public Acts of 1929known as the "Hall Income Tax Act"-was immediately

${ }^{30}$ Section 8 of the Act, as amended, read as follows, with the italicized words being those deleted by the 1929 amendment, and the words in CAPITALS being those added by the 1929 amendment.

.. . all personal property of every kind shall be assessed under the following classification:

Class 1. [Household goods and similar property.]

Class 2. [Farming tools and similar property.]

Class 3. [Livestock.]

Class 4. [Watercraft.]

Class 5. The amount of income derived from United States bonds and all other stocks and bonds not taxed ad valorem.

Class 6. All bonds except United States bonds and all shares of stock as herein after provided in section 22 [and section 21 by interpretation, see Sloan v. City of Columbia, 144 Tenn. 197 (1920)] of this Act.

Class [5] 7. Notes, duebills, choses in action, accounts, mortgages, or any other evidence of indebtedness, and money on hand or on deposit, or invested in any manner in this State or elsewhere not otherwise assessed IN THIS STATE.

Class [6] 8. All other TANGIBLE personal property not hereinbefore designated. ...

The deletion of the phrase "of every kind," modifying "personal property" in the first sentence, and the addition of the word "tangible" to modify "personal property" in the catch-all clause, now class 6, emphasize the effect of this amendment.

${ }^{31}$ Chapter 86 was amended three days after its enactment by Chapter 116 of the Public Acts of 1929. The changes made were irrelevant for the present discussion. An exemption from the income tax was amended and Section 3 of chapter 116 read in part: "the General Assessment Act of 1907 is amended so as to provide that stocks and bonds upon whose income an income tax is imposed shall not be assessed for State, county or municipal taxation." Of course the General Assessment Act had already been amended so as to "fail to tax" most intangible property, and it was not conditioned on the imposition of the income tax. It appears that this rather questionable provision, constitutionally, was intended to relate to certain back ad valorem taxes for the years immediately preceding 1929. See Trotter, "The Tennes- 
challenged, and both features of the Act-the Income Tax and the amendment of the General Property Tax Act-were upheld in Shields v. Williams. ${ }^{32}$ The uppermost issue facing the court, as the opinion makes clear, was the validity of the income tax. The validity of the "release" of certain intangible property from taxation was subordinate to and a part of that issue. Consequently, this was the crucial constitutional issue which the framers of the constitution had in mind when, in Art. II, §28, they "authorized" the legislature to levy a tax "upon incomes derived from stocks and bonds that are not taxed ad valorem."

The court rejected the contention of the complainants that the income tax provision in Art. II, $\$ 28$ referred to the income from "stocks and bonds which could not be taxed ad valorem," namely, the income from federal obligations and stocks in certain railroad corporations, the shares of which were exempted by charter provisions from taxation. ${ }^{34}$ In the court's opinion:

The clause . . . was not designed to authorize an attempt to tax incomes from stocks and bonds not taxable but to au-

see Income Tax Law of 1929," 8 Tenn. L. Rev. 106, 118-123 (1930). The provision was not referred to at all in a case contesting the constitutionality of the Income Tax Law.

32159 Tenn. 349, 19 S.W. 2d 261 (1929). There were four distinct issues dealt with by the court, only the first of which is of interest to the immediate discussion: first, the validity of the amendment to the general assessment law and the consequent "repeal" of the general property tax in respect to a substantial part of intangible property; second, the general validity of the income tax, which raised the issue of its nature; third, the validity under uniformity restrictions applicable to the income tax of the exemptions therefrom; and, fourth, certain issues concerning the constitutional limitation on legislative procedure. The validity of the income tax, as such, will be dealt with infra.

${ }^{33}$ Supra note 32 at 356.

34 Supra note 32 at 357. 
thorize a tax upon incomes derived from stocks and bonds that were (lawfully) not taxed ad valorem. ${ }^{35}$

Therefore the basic problem was one of identifying the "stocks and bonds" which might be "lawfully not taxed ad valorem." The importance of the word "lawfully" was emphasized by the complainants' contention that the 1929 Act's "omission" of intangible property classified as "stocks and bonds" from the ad valorem General Property Tax was a transgression of "the constitutional mandate that all property should be taxed and that authority for the income tax [could not] be drawn from such legislative dereliction." ${ }^{36}$

The court agreed that "a contumacious failure or refusal to levy a tax on property, taxation of which the Constitution required," could not create a class of property lawfully "not taxed ad valorem." ${ }^{37}$ Therefore, it was necessary for the court to determine the validity of that part of the 1929 Act which removed from the scope of the general property tax that property producing income which was taxed by the income tax imposed by the same 1929 act. Upon the validity of this amendment of the General Property Tax Act rested the ultimate validity of the income tax itself.

The court's decision upholding this "repeal [by the 1929 Act ] of the ad valorem tax on property described as" stocks and bonds was supported by a rationale encompassed by the following brief statement:

Section 28 ordains that all property be taxed and enjoins uniformity and equality in taxation but it does not exact double taxation. ${ }^{38}$

After reviewing the cases in which it had faced the issue of

35 Supra note 32 at 359 , emphasis supplied.

${ }^{30}$ Supra note 32 at 357.

37 Supra note 32 at 360 .

38 lbid., emphasis supplied. 
"double taxation" in relation to the taxation of both corporate shares and corporate capital stock, the court asserted:

Notwithstanding our Constitution requires that "all property, real, personal or mixed, shall be taxed" and notwithstanding it has been held for years that the capital stock of a corporation and the shares of stock of a corporation were distinct items of property, it has likewise been held for years that the Constitution did not require the assessment of both capital stock and shares of stock. ${ }^{39}$

The court then extended this rationale to justify a ruling that the constitution did not require the taxation of both "bonds," as defined in the 1929 Act, and the property which they represented. Remember that the term "bonds" was broadly defined as including all interest bearing obligations. The court's statement warrants quoting at length.

The principle of these cases [concerning the "double taxation" of corporate shares and capital stock] seems ample warrant for the legislative repeal of taxes hitherto levied on the instruments described as bonds in chapter 86 of the Acts of 1929. Such instruments merely call for money. They have no intrinsic value. The money upon which such bonds are based is assessed under other provisions of chapter 602 of the Acts of 1907. The substance does not escape, only the symbol is freed.

The owner of a bond is entitled, besides interest, to receive the money called for when his bond matures. Meanwhile, the money coming to him is being taxed.

The owner of a share of stock in a corporation whose cor-

${ }^{39}$ Supra note 32 at 362 , emphasis supplied. The court reviewed the cases discussed supra, notes 15 through 18 . It should be pointed out that the court did not recognize the distinction that in the cases holding taxation of both "capital stock" and shares valid, the term "capital stock" was not used to refer to the intangible assets of a corporation but was used to refer to the capital stock as invested in tangible property, while in the later cases the term "capital stock" was used to refer to the taxation of the intangible assets of a corporation. 
porate property is assessed is entitled, besides dividends, to his part of the corporate property when the corporation is wound up. Meanwhile, the corporate property coming to him is being taxed.

The essence of the corporation tax cases cited is that taxation of the basic property justifies release from taxation of the ultimate right to receive such property. The repeal of the ad valorem tax on property described as bonds by chapter 86 of the Acts of 1929 may be securely rested on the doctrine implicit in these cases, as well as the release from ad valorem taxation of stock in corporations located and taxed elsewhere. ${ }^{40}$

In making its decision the court found it necessary to distinguish the Hauk case in which the court had held that the in lieu provision of a nonproperty tax on the privilege of recording mortgages was invalid. As the distinguishing factor the court suggested that the prior opinion "involved the assumption that mortgages must be assessed as other property. ... ."11 Thus, the only thing in the Shields case contrary to the rationale of the Hauk case was the rejection of that assumption. However, the rationale of the Hauk case was rendered ineffectual in so far as representative intangible property is concerned. ${ }^{42}$

The court did, in fact, overrule the Cumberland University case, in which it was held that the "exemption" of the

${ }^{40}$ Supra note 32 at 363-364, emphasis added. It is interesting to note that the court relied upon a Washington case (State ex rel. Wolfe v. Parmenter, 50 Wash. 164, 96 Pac. 1047 (1908)) as supporting authority for this analysis. See the discussion of Washington's uniformity limitation in Chapter III, Part H, infra.

${ }^{41}$ Supra note 32 at 365 . The Hauk case is discussed supra at note 24.

42 Therefore it is not correct to say that "No attempt was made either to distinguish the holding [in the Hauk case] or to overrule it. Nevertheless the 'double taxation' approach does reject the Hauk holding entirely, for the court permits the legislature to exempt all intangibles which may be fitted into that concept. Nothing in the opinion indicates that they have to be taxed in some other manner; in fact, stocks and bonds which pay no income 
principal and interest of bonds of educational institutions was a violation of Art. II, $\S 28$. That case and its antecedents concerning the exemption of state bonds from taxation were not mentioned in the opinion. ${ }^{43}$ Nevertheless, it must be recognized that the Shields case can not be entirely reconciled with all prior decisions. In extending by analogy the rationale found in the "double taxation" cases the court of necessity reversed another line of cases which did not just assume, as did the Hauk case, that a class of representative intangibles had to be taxed, but actually held that private bonds, strictly speaking, could not be "released" from taxation.

In summary, one may conclude that a rule of universality is clearly found in Art. II, $\$ 28$ of the Tennessee Constitution, but that the strictness of the rule has been avoided in the case of representative intangible personal property by use of a rationale which considers all property taxed when the "basic property" is taxed. ${ }^{44}$ The court has followed this raare not taxed at all [under the Income Tax]." Parker, supra note 6 at 133. To the contrary, the "double taxation" approach as described in the text avoids the Hauk holding. The court still accepts the rule of the Hauk case to the effect that an indirect non-property tax may not be substituted for a direct ad valorem property tax. However, with the "double taxation" rationale this rule becomes irrelevant for limiting the exemption of representative intangible property.

43 Nor is the Cumberland University case mentioned in the article by Parker, supra note 5, in his rather thorough analysis of the Shields case. The Cumberland University case is discussed supra at note 23 .

44 It is interesting to note that the court never used the word "exemption" in Shields v. Williams, supra note 32 . It always spoke in terms of a failure to select, e.g.: the 1929 act amended the General Assessment Act so as "to omit from taxation" certain items (p. 353); the taxpayer, states the court, contends that "in omitting such securities from ad valorem taxation" etc. (p. 357); "The principle of these [double taxation] cases seems ample warrant for the legislative repeal of taxes hitherto levied on the instruments described as bonds. ..." (p. 363); the essence of the corporate double taxation cases cited "is that taxation of the basic property justifies release from taxation of the ultimate right to receive such property. The 
tionale even though it has also actually held that both the representative property and the property represented thereby may be taxed by the same taxing authority without running afoul of the uniformity requirement of Art. II, $\$ 28$.

This summary demonstrates one difficulty in the Shields case rationale. In its conclusion in that case the court pointed out that the money upon which "bonds" are based is "assessed under other provisions" of the general property tax (i.e., as personal property to the holder), that corporate property of domestic corporations is also taxed under the general property tax, and that the doctrine of the cases supports the "release from ad valorem taxation of stock in corporations located and taxed elsewhere." An important question to be asked is this: does the court mean that representative property may be "released" from taxation only when the basic property is actually taxed somewhere? Certainly there was no proof offered that the property of all foreign corporations concerned was "taxed elsewhere." In addition, the "double taxation" cases were equating the taxation of corporate shares to the holder and corporate capital stock to the corporation. In very few states are corporations taxed upon their "capital stock," i.e. the value of their assets above the value of their tangible assets. In addition, what of "bonds," i.e. obligations calling for interest, which "call for money" beyond the taxable jurisdiction of Tennessee? Certainly, in many states money on hand or deposit may well be exempt from taxation.

These questions are not raised in an effort to find some way by which the exemption of representative intangible property in Tennessee may be challenged, because it does not seem likely that such an attack would be successful. But

repeal of the ad valorem tax on properties described as bonds . . . as well as the release from ad valorem taxation of stock in corporations located and taxed elsewhere. ..." (p. 364). 
the questions do point out the obstacles to a flexible tax structure which are raised by a strict uniformity provision, and they also demonstrate the doctrinal difficulty a court runs into when it seems determined to approve an attempt to avoid the alleged harshness of a strict rule of uniformity which forbids both the total exemption of intangible property and the imposition of a lower rate upon such property. ${ }^{4 \check{ }}$

At times the court has relied solely upon the words of the first sentence of Art. II, $\S 28$ ("All property shall be taxed") to reach its conclusion that Section 28 declares what property "shall be taxed, and what may and what shall be exempt from taxation." ${ }^{46}$ However, in other opinions ${ }^{47}$ it is

${ }^{45}$ Compare the following comment:

It can readily be seen that with enactment of the Hall income tax in 1929, and its subsequent approval by the State Supreme Court in Shields v. Williams, the critics of the uniformity rule obtained most of the reforms they had sought by means of constitutional amendment. . . .

... [W] ith respect to intangibles, Tennessee is accomplishing under the income tax practically everything that is accomplished in other states by means of low rate property taxes. However, there are two exceptions, which may be rather important.

The first exception is in connection with securities that temporarily yield no income. . . . There is no tax on income, because there is no income; neither is there any property tax since stocks and bonds have been exempted outright from ad valorem taxes. . . .

The second exception refers to the treatment of money and bank deposits. . . . [T] hese items are still technically subject to taxation under the general property tax rates.

White, "Revision of the Taxation Uniformity Clause in the [Tennessee] Constitution," 1 Papers on Const. Revision 79, 84-86 (Univ. of Tenn., 1947).

${ }^{46}$ For example, Memphis v. Memphis City Bank, supra note 14 at 588 , in which it was pointed out that the contrary was true under the constitution of 1834 (see note 5, supra); Railway Co. v. Wilson County, supra note 11 at 608; Cumberland Univ. v. Golladay, supra note 23 at 86.

${ }^{47}$ For example, Bell v. Town of Pulaski, supra note 12; Allen v. Board of Mayor \& Aldermen of Smithville, supra note 11; Jones v. Memphis, 
also clear that the court has ignored this express requirement of universality and found that exemption of property not designated as exemptible in the constitution would violate that part of Section 28 which "provides for uniformity in taxation."

Other rules. There is little, if any, controversy concerning the other particular rules of uniformity governing the taxation of property in Tennessee. Property may be taxed only by the ad valorem method; thus, specific property taxation is forbidden. ${ }^{48}$ This is, of course, expected in view of the express words of the basic uniformity clause of this type. The Tennessee uniformity provision is unique in this respect in that it seems to spell out "equality and uniformity" as a condition resulting from taxation of property according to its value: "All property shall be taxed according to its value, ... so that taxes shall be equal and uniform throughout the state."

Absolute uniformity is required in effective rates, both of the percentage rate ${ }^{49}$ and the ratio of valuation. ${ }^{50}$ This re-

supra note 11. In State Nat. Bank v. Memphis, supra note 19 at 653 the court relied on both the express requirement of universality and a general requirement of "uniformity" when it held an exemption violated "the clause of the constitution that 'all property . . . shall be taxed,' and the clause that 'taxation shall be equal and uniform throughout the State." "

${ }^{48}$ Reelfoot Lake Levee Dist. v. Dawson, supra note 13; Phillips v. Lewis, 3 Tenn. Cas. 230 (1877); Taylor McBean \& Co. v. Chandler, supra note 13.

${ }^{49}$ See Jones v. Memphis, supra note 11 at 191 , in which it was concluded that to "exempt" newly incorporated territory from taxation for certain current purposes for a period of years would be to impose "a different rate of taxation upon the old and new territory within the same" taxing jurisdiction. Also see American Bemberg Corp. v. City of Elizabethton, supra note 12 .

${ }^{60}$ Carroll v. Alsup, supra note 18 ; McCord v. Nashville, C. \& St. L. Ry., 187 Tenn. 277, 213 S.W. 2d 196 (1948). However, absolute uniformity is not required in the "method" of assessment. That is, as long as the same standard is achieved in each case- "actual cash value"-different classes of 
quirement is spelled out in the supplementary clause of Section 28 which provides that "No one species of property from which a tax may be collected, shall be taxed higher than any other species of property of the same value." However, as with the other particular rules of uniformity, the court has tended to refer to Art. II, $\S 28$ 's requirement "of uniformity and equality" as the source of the limitation, so that the spelling out of this particular rule does not stand for the proposition that the basic clause would not require it.

The requirement in Tennessee concerning the ratio of valuation differs from the usual position. The Tennessee Supreme Court has held ${ }^{51}$ that "actual cash value"-that is, a ratio of $100 \%$-is the only ratio of valuation which satisfies

property may be valued by different methods. For example, see City of Knoxville v. Ft. Sanders Hospital, 148 Tenn. 699, 257 S.W. 408 (1923), pointing to the provision in Art. II, $\$ 28$ stating that the value of property is to be ascertained in such manner as the legislature shall direct.

51 Carroll v. Alsup, supra note 18 , is the leading case. It was there stated (at p. 283):

There are ... two fundamental principles to be taken as guides in assessing property under our Constitution and laws: (1) That all property shall be assessed at its actual cash value; and (2) that taxes shall be equal and uniform. The latter proposition flows naturally and inevitably as a corollary to the former, for, when all property is assessed at its actual cash value, then all taxes become equal and uniform. However difficult it may be to arrive at the first result, it is imperatively demanded by the Constitution and laws, and the second unavoidably and from necessity follows it. . . .

And, at 292 the court said:

The actual cash value is the only practicable basis upon which taxes can be made equal and uniform, and this is clearly the constitutional requirement. . . . [Emphasis by the court.]

The latest case is McCord v. Nashville, C. \& St. L. Ry., supra note 50. This doctrine is severely criticized in Parker, supra note 6 at 121-125, in which the author points out that the federal courts have held to the contrary under the federal equal protection clause, and, indeed, an early federal decision construed the Tennessee constitutional provision to the contrary: Taylor v. Louisville \& N. R. Co., 88 F. 350 (6th Cir., 1898). 
the constitutional requirement of "equal and uniform" taxes. It is interesting to note, however, that in the pertinent cases $^{52}$ it was alleged that the other property in the taxing jurisdiction was valued at varying ratios for different classes of property. It was the position of the court that such a pattern demonstrated the "impracticability of adopting any other than the actual cash value as" the ratio of valuation to be used. It was suggested that the only practical remedy in such cases was to seek to have the ratio of valuation for all property raised to $100 \% .^{53}$ The court rejected any suggestion that it declare the entire tax void because of an illegal use of varying ratios of valuation. However, one writer suggests that in later opinions, the court has in effect, stymied any effort to seek the remedy suggested. ${ }^{54}$ Thus, the court has condemned a de facto classification of property for effective rates as being illegal, but leaves the situation in fact unchanged. As a final point, the court has ruled that the requirement of uniformity in taxation of property is "territorial." "55

\section{(2) Nonproperty taxes}

The first important issue in determining the validity of any given tax is to determine its nature. In contrast to the strict uniformity limitation applicable to property taxes, nonproperty $\operatorname{taxes}^{56}$ need only be uniform within classes. The

52 Carroll v. Alsup, supra note 18 at 291; McCord v. Nashville, C. \& St. L. Ry., supra note 50 at 291-292.

53 Carroll v. Alsup, supra note 18 at 292.

54 Parker, supra note 5 at 124-125.

${ }^{55}$ Nashville, C. \& St. L. Ry. v. Marshall County, 161 Tenn. 236, 246247, 30 S.W. 2d 268 (1929).

56 'The terms alternately used to designate nonproperty taxes are "excise" and "privilege," the same being synonymous for purpose of uniformity. Bank of Commerce \& Trust Co. v. Senter, 149 Tenn. 569, 260 S.W. 144 (1923) ; Foster \& Creighton Co. v. Graham, 154. Tenn. 412, 421, 285 S.W. 570 (1925). 
limitation is alternately derived from the equal protection clause of the fourteenth amendment to the federal Constitution and the equivalent of an equal protection clause in the Tennessee Constitution. ${ }^{57}$ The state limitation has been equated to that derived from the federal equal protection clause. $^{58}$ The object selected for a nonproperty tax and exemptions therefrom need only be reasonable classes. ${ }^{59}$ The

57 Both Art. I, $\S 8$ and Art. XI, $\$ 8$ are generally cited.

58 See, for example, Marion County River Transp. Co. v. Stokes, 173 Tenn. 347, 350, 117 S.W. 2d 740 (1938).

59 See, for example, Shields v. Williams, supra note 32 (in respect to a tax on income from intangibles, the court held the following classifications were valid: the exemption of (1) income from commercial paper maturing in six months or less (2) income of eleemosynary and similar institutions); State v. Alston, 94 Tenn. 674, 30 S.W. 750 (1895) (collateral inheritance tax; the court held that the distinction made between collateral and direct kindred was a reasonable classification, and that the minimum exemption was a reasonable classification on the basis of "ability to pay."); Sterchi Bros. Stores, Inc. v. Wallace, 168 Tenn. 299, 77 S.W. 2d 807 (1934) (miscellaneous license tax imposed on sellers of electrical appliances and exempting merchants whose stock was not more than $\$ 5,000$, of which electrical appliances constituted not more than $10 \%$, held not to be an arbitrary classification). Also see Ogilvie v. Hailey, 141 Tenn. 392, 210 S.W. 645 (1918) (local vchicle tax which selected only autos used for pleasure, to the exclusion of autos used for business purposes, was held a valid classification); Foster \& Creighton Co. v. Graham, supra note 56 (fuel use tax which selected the privilege of using gasoline as the object of the tax, to the exclusion of the use of all other petroleum products, held not to be an arbitrary classification). In Bank of Commerce \& Trust Co. v. Senter, supra note 56 (corporate Excise Tax, with a base of net income) and Camden Fire Ins. Ass'n v. Haston, 153 Tenn. 675, 284 S.W. 905 (1925) (annual corporate report tax with a base of capital stock) the court held that it was not arbitrary to select corporations as the object of a tax, even though partnerships and individuals engaging in business were not included. Compare Corn v. Fort, 170 Tenn. 377, 95 S.W. 2d 620 (1935), in which the court held that it was arbitrary to select partnerships as the object of a privilege tax with a base of invested capital, when individuals engaging in similar business were excluded. The tax was upheld as to corporations, but that part of the statute reaching partnerships was held invalid, the court saying it could find no reasonable distinction between the partnership and the individual engaging in competing businesses. 
object of a nonproperty tax may be further classified for the purpose of applying different rates to the different classes. ${ }^{60}$ The Tennessee court has not had an occasion to pass upon the validity of a progressively graduated rate. It has ruled that the following taxes of comparative interest were not property taxes: an inheritance tax; ${ }^{61}$ a mortgage recording $\operatorname{tax} ;^{62}$ a realty transfer $\operatorname{tax} ;^{63}$ a fuel use $\operatorname{tax} ;^{64}$ and both a corporate

${ }^{60}$ See, for example, Marion County River Transp. Co. v. Stokes, supra note 58, upholding a miscellaneous license tax classifying ferries so that a higher rate was applied to those competing with state toll bridges. Also see Camden Fire Ins. Ass'n v. Haston, supra note 59, in which the court upheld as reasonable the use of a flat rate increasing according to brackets based on increasing amounts of capital stock of corporations subject to the annual corporate report tax. But in Royal Crown Bottling Co. of Knoxville v. Stokes, 177 Tenn. 117, 146 S.W. 2d 838 (1941) the court held that the distinction made under a miscellaneous license tax between distributors of liquid carbonic acid gas and distributors of solid carbonic acid gas was an arbitrary classification and therefore a violation of Art. I, $\S 8$ and Art. XI, $\$ 8$ of the Tennessee Constitution and the federal equal protection clause. Distributors of the liquid gas were taxed at the rate of five cents a pound, while distributors of the solid gas were taxed at the rate of two cents a pound.

${ }^{61}$ State v. Alston, supra note 59 , in which it was held that the tax was upon the right or privilege of acquiring property by succession.

${ }^{62}$ State ex rel. Hauk v. American Trust Co., supra note 24. The tax was held invalid for other reasons, see notes 26 and 27 supra. It was said that the act might have been held valid as a tax upon the privilege of registration.

${ }^{63}$ State ex rel. Stewart v. Louisville \& N. R. Co., 139 Tenn. 406, 201 S.W. 738 (1918).

${ }^{64}$ Foster \& Creighton Co. v. Graham, supra note 56. It was contended that a tax on the use of a particular commodity is a tax on the property itself, which would have subjected the tax in question to the property tax uniformity limitation. The court rejected this contention, using a classification of "direct" and "indirect" taxes, direct taxes being "imposed directly on property according to its value," while indirect taxes are "upon some right or privilege." The court refused to follow the rule suggested by the taxpayer, distinguishing Dawson v. Kentucky Distilleries \& Warchouse Co., 255 U.S. 288,41 S. Ct. $272(1920)$, and rejecting the reasoning in Thompson v. McLeod, 112 Miss. 383, 73 So. 193 (1916). Those cases are discussed respectively in Chapter III, Parts $\mathrm{H}$ and E, infra. Also see Humphries v. Carter, 172 Tenn. 392, 112 S.W. 2 d 833 (1937). 
franchise tax with a base of capital stock ${ }^{65}$ and a corporate franchise tax with a base of net income. ${ }^{86}$ In an early case it was held that a tax could not be levied solely on the "privilege of ownership," but that such a tax was upon the property itself. ${ }^{67}$

The Tennessee court has not restrictively interpreted the "other taxes" clause ${ }^{68}$ in Art. II, \$28. Briefly, the court has held that a "privilege is whatever the legislature chooses to declare to be a privilege, and to tax as such." ${ }^{69}$ Furthermore, the court has stated that the "other taxes" clause is not a grant of power but simply an attempt to emphasize the nonapplicability of the uniformity provision in Art. II, $\$ 28$ to nonproperty taxes. ${ }^{70}$ This view is to be contrasted to the result under a similar provision found in the Arkansas Constitution. ${ }^{71}$

\section{(3) Income tax}

The court has held ${ }^{72}$ that a general net income tax ${ }^{73}$ is prohibited by the Tennessee constitution. It should be emphasized

${ }^{65}$ Corn v. Fort, supra note 59.

${ }^{68}$ Bank of Commerce \& Trust Co. v. Senter, supra note 56 , and see the discussion under "Income Tax," infra.

${ }^{67}$ Phillips v. Lewis, supra note 48.

68 "... . but the legislature shall have power to tax Merchants, Peddlers and privileges, in such manner as they may from time to time direct."

${ }^{69}$ Hooten v. Carson, 186 Tenn. 282, 286, 209 S.W. 2d 273 (1948). See the thorough discussion of this problem by Parker, supra note 6 at 125 130.

${ }^{70}$ Camden Fire Ins. Ass'n v. Haston, supra note 59, in which the court stated (at p. 688):

This language [note 68, supra] would seem . . . to confer upon the legislature the power to tax merchants, peddlers, and privileges. Its true object, however, was to indicate with distinctness that the power to tax merchants, peddlers, and privileges was not to be understood as inhibited by the restriction as to the taxation of property.

71 Supra, Chapter III, Part A, text at notes 15-16.

72 Evans v. McCabe, 164 Tenn. 672, 52 S.W. 2d 159 (1932).

${ }^{73}$ In 1923 the court held that a corporate "excise" tax with a base of 
that this is the result of a unique provision in Art. II, $\$ 28$ of that constitution. There has been no determination by the court concerning the effect of the uniformity limitation on an income tax in Tennessee. In 1929 the legislature acted to implement that part of Art. II, §28, which reads:

The legislature shall have power to levy a tax upon incomes derived from stocks and bonds that are not taxed ad valorem.

As previously described, ${ }^{74}$ in 1929 the legislature amended the general property tax to exempt therefrom substantially all intangible property, except money on hand or deposit, and at the same time imposed a tax of $5 \%$ on the "income derived by way of dividends from stocks or by way of interest on bonds. ..." The term "bonds" was defined very broadly, so as to include all "obligations . . . evidenced by an instrument whereby the obligor is bound to pay interest to the obligee. . . ." There were several "exclusions" and "exemptions" from this limited income tax. The act provided that the following income should be "excluded" from the income tax: (1) income from governmental obligations; (2) income from stocks if, in effect, the "capital stock" of the issuing corporations was taxed or if such stocks were taxed to the holder thereof as personal property $;^{75}$ and (3) income in the hands of "educational, religious or other like institutions." In addition, the act provided for an exemption of "income derived from stocks and/or bonds having a value of $\$ 1,000$." The term "bond" was defined to exclude commercial paper maturing in six months or less. In other words, the net income was not an income tax. It had been contended that the tax was in fact a tax upon the net income and that a tax upon income was a property tax limited by Art. II, $\S 28$. The court held the tax to be a nonproperty tax upon the privilege of exercising the corporate franchise. Bank of Commerce \& Trust Co.v. Senter, supra note 58.

74 Supra note 30.

${ }^{75}$ See the description of the general property tax in this respect, supra, text at notes $28-30$. 
income from substantially all "notes, duebills, choses in action, (and) accounts" ${ }^{36}$ was subject to the tax.

As described above, ${ }^{77}$ in Shields v. Williams, ${ }^{78}$ the court held that the unique income tax provision in Art. II, $\$ 28$, referred to the taxation of the incomes derived from stocks and bonds "lawfully" not taxed ad valorem. After an extended analysis in which it reached the conclusion that the removal of substantially all intangible property from the scope of the general property tax was "lawful," the court passed on to consider the validity of the income tax itself.

The court ruled that it was not necessary to determine the nature of an income tax, i.e., whether property or excise tax, because Art. II, $\$ 28$, "ex vi termini, excludes the income tax from the scope of the equality and uniformity clause." Thus, the court concluded:

If the income tax sanctioned by section 28 of Article II be a property tax, it only reaches property not within the purview of the equality and uniformity clause, that is property not taxed according to value. The only equality and uniformity therefore required in this limited income taxation is such equality and uniformity as it demanded in all legislation by section 8 of Article I and section 8 of Article XI of the Tennessee Constitution and 14th Amendment to the Federal Constitution. That is to say, a reasonable classification of incomes to be taxed is permissible. ${ }^{80}$

Having determined that the more liberal uniformity requirement was applicable, rather than the strict limitation applicable to property taxation, the court readily held that the exemptions of the "income from so many stocks" and the

${ }^{76}$ Cf. White, supra note 45 at 85 . See the section of the general property tax providing for the classifications under which personal property was to be taxed prior to 1929 , supra note 30 , particularly class seven thereunder.

77 Supra, text at notes 31-40.

78159 Tenn. 349, 19 S.W. 2 d 261 (1929).

79 Id, at 366 .

${ }^{80}$ Id. at $366-367$. 
income of religious, educational and similar institutions were reasonable classifications. ${ }^{81}$ The court also held that the "only debatable classification," the "exclusion" of commercial papers maturing in six months or less, was valid. In doing so it repeated the shibboleth usually used by courts once it is determined that a classification is valid, namely, "that in revenue measures the Legislature has a wide range of discretion and ... the courts will not interfere if any good reason can be conceived to justify a classification." ${ }^{\prime 82}$

In 1931 the legislature enacted a General Net Income Tax Act, ${ }^{83}$ which reached income from all sources. In Evans v. $M c C a b e,{ }^{84}$ the court held that the tax was prohibited by Art. II, §28, of the constitution. The provision in Art. II, §28, concerning the taxation of income from stocks and bonds was interpreted to deny the legislature the power to tax income of other classes. ${ }^{85}$ Thus, the nature of an income tax is irrelevant under the Tennessee uniformity limitation, and Tennessee is limited to a tax on the income from intangibles because of its unique constitutional provision.

\section{B. ANALYSES OF STATES WITH TYPE II CLAUSES}

\section{Alabama}

a. The provisions; historical note

The original Alabama Constitution, dated 1819, contained only one provision concerning uniformity in taxation. Article VI, §8 provided that:

$81 \mathrm{Id}$. at 367 .

82 Id. at 367-368.

83 Public Acts 1931, c. 21.

84 Supra note 72.

${ }^{85}$ Id. at 680-682. This analysis is severely criticized by Parker, supra note 6 at 136-138. 
All lands liable to taxation in this State, shall be taxed in proportion to their value.

The next two constitutions of Alabama, dated $1868^{1}$ and $1875^{2}$ respectively, contained a uniformity clause enlarged in scope over the original clause, and joined by a new supplementary provision. The uniformity provisions in those two constitutions were substantially identical with the basic uniformity clause (Art. XI, §211) and supplementary provision (Art. XI, \$217) found in the present Alabama Constitution of $1901 .^{3}$ Section 211 provides that:

All taxes levied on property in this State shall be assessed in exact proportion to the value of such property. . . .

The supplementary clause, section 217 , reads:

The property of private corporations, associations and individuals of this State shall forever be taxed at the same rate; provided, this section shall not apply to institutions

${ }^{1}$ Article IX, $\S 1$ was identical with section 211 of the present 1901 constitution, and Art. XIII, $\S 4$ was substantially identical with section 217.

${ }^{2}$ Article X, $\S 1$ was identical with section 211 of the present 1901 constitution, and Art. X, $\$ 6$ was identical with section 217 except that in the proviso the words "or enterprises" appeared after the word "institutions."

${ }^{3}$ In view of the substantially identical phraseology of the uniformity provisions of the constitutions of 1868,1875, and 1901, it is permissible to use indiscriminately cases decided under the prior constitutions in describing the meaning of the present Alabama uniformity limitation. In citing the cases under the prior constitutions only the present section numbers will be used in order to avoid interpolations.

4 The omitted part of $\$ 211$ concerns "double taxation," and reads:

... but no tax shall be assessed upon any debt for rent or hire of real or personal property, while owned by the landlord or hirer during the current year of such rental or hire, if such real or personal property be assessed at its full value.

This proviso did not appear in the prior constitutions, and its purpose and history are referred to in note 20 , infra. 
devoted exclusively to religious, educational or charitable purposes.

The present 1901 constitution also contains other uniformity provisions which did not appear in the prior constitutions. Article IV, $\S 91$, requires the exemption of governmental and certain other limited classes of property from taxation. A corporate franchise tax is required by Art. XII, $\$ \$ 229$ and 232 . Amendment 23, added in 1931, spells out the extent to which an inheritance tax is permissible in Alabama. ${ }^{5}$ Amendment 25 , added in 1932, provides that the legislature shall have the power to impose a net income tax, and adds that "Income shall not be deemed property for purposes of ad valorem taxes." "

\section{b. Meaning of the uniformity limitation}

Although it should hardly need be stated that Art. XI, $\$ \$ 211$ and 217 apply only to property taxes, the rule continues to be restated in judicial opinions, ${ }^{7}$ and necessarily so because most Alabama taxes are challenged as violations of the basic uniformity provisions. The challenge continues to be made, although with a noticeable lack of success. The only uniformity required of nonproperty taxes is a uniformity

5 An inheritance or estate tax is allowed only to the extent that such a tax absorbs any deduction or credit allowed under a federal inheritance or estate tax. This amendment supersedes former section 219 of the Alabama Constitution which provided expressly that the legislature might impose an inheritance tax with a rate of not more than $2.5 \%$.

6 The necessity of this amendment authorizing an income tax and excepting it from the property tax uniformity and maximum rate limitations is discussed in the text at notes 27-33, infra.

${ }^{7}$ For example, Western Union Tel. Co. v. State Board of Assessment, 80 Ala. 273, 60 Am. Rep. 99 (1885), Lee v. State Tax Comm., 219 Ala. 513, 123 So. 6 (1929), Nachman v. State Tax Comm., 233 Ala. 628, 173 So. 25 (1937), and National Linen Service Corp. v. State Tax Comm., 237 Ala. 360,186 So. 478 (1939). But see the early case of Clark \& Murrell v. Port of Mobile, 67 Ala. 217 (1880). 
within classes. ${ }^{8}$ Thus, the object selected for a nonproperty tax and exemptions therefrom need only be reasonable classes, ${ }^{9}$ and an object may be further classified for the application of different rates. ${ }^{10}$ The Alabama court has not had an occasion to rule upon the validity of a clearly progressively graduated rate.

8 The source of this limitation in the Alabama Constitutions is not always clearly stated. However, it appears that the requirement alternately stems from Art. I, $\S 1$ and $\S 2$ of the Alabama Constitution, as well as from the federal equal protection clause of the fourteenth amendment. The language of the court in this respect is interesting to note. For example, a typical statement is found in Nachman v. State Tax Comm., supra note 7 at 635, in which a selective gross receipts tax was held not to be within the operation of sections 211 and 217: "The only limitation imposed upon the Legislature is that when it proceeds to impose a tax on occupations or privileges, it must be equal and uniform. The equality and uniformity consist in the imposition of the like tax upon all who engage in the vocation, or who may exercise the privilege taxed." Of course, when the court uses the term "equal and uniform" in respect to property taxation, it is not limited to "classes."

${ }^{9}$ See, for example, Frazier v. State Tax Comm., 234 Ala. 353, 175 So. 402 (1937) (sales tax; holding that the exemption of gross receipts received by manufacturers, compounders, processors, producers, miners, and quarries from sales to consumers in carload lots or in larger quantities, except as otherwise provided was not an arbitrary classification); Nachman v. State Tax Comm., supra note 7 at 635 (selective gross receipts tax, with a rate of $1.5 \%$ as an additional license tax on retailers and places of amusement; held, the object was a reasonable class: "The state may tax all [privileges and occupations], or it may select for taxation certain classes and leave the other untaxed."); Phoenix Carpet Co. v. State, 118 Ala. 143, 22 So. 627 (1897) (corporate franchise tax with a base of paid-up capital; held, corporations may be classified and less than all corporations selected for the tax).

${ }^{10}$ See, for example, American Bakeries Co. v. City of Huntsville, 232 Ala. 612, 168 So. 880 (1936) (miscellaneous local license tax with a flat rate for named occupations and business; held, the distinction made between itinerant sellers of bakery products $(\$ 300)$ and bakeries $(\$ 100)$ was not an arbitrary classification contrary to the federal equal protection clause and Art. I, $\$ 1$ of the Alabama Constitution, nor was a flat rate as opposed to a proportional rate applied to amount of business done arbitrary); Lee v. State Tax Comm., supra note 7 (securities recordation tax); Warrior Water Co. v. Long, 218 Ala. 125, 117 So. 656 (1928) (utilities gross receipts 
Since the uniformity required of property taxes is a strict limitation, an important issue in all cases is the determination of the nature of the tax. The court has held the following taxes of comparative interest to be nonproperty taxes: gross receipts taxes on selected businesses $;^{11}$ a corporate franchise tax with a base of paid-up capital stock $;^{12}$ recording taxes $;^{13}$ a general use tax $;^{14}$ and a selective severance tax. ${ }^{15}$ The court has held that a net income tax is a property tax, but a later decision casts considerable doubt on the reasoning of that case. $^{16}$

\section{(1) Property taxation}

The Alabama court has held that the uniformity structure tax; a classification between new public utilities being constructed for first year business, and one taking over an old and going public utility, where the first class paid a minimum tax of $\$ 100$ and the latter paid $2 \%$ of the gross receipts as did all other utilities, held valid); Goldsmith v. Huntsville, 120 Ala. 182, 24 So. 509 (1897) (local merchants gross receipts tax, with the rate being a flat rate graduated according to the value of gross amount of stock of merchandise on hand; held, a privilege tax and the classification for rates valid); Saks v. Birmingham, 120 Ala. 190, 24 So. 728 (1897) (similar tax to that in the Goldsmith case, supra; held, reasonable classification).

11 Western Union Tel. Co. v. State Board of Assessment, supra note 7; Capital City Water Co. v. Board of Revenue, 117 Ala. 303, 23 So. 970 (1897). Also see Goldsmith v. Huntsville, supra note 10.

12 Phoenix Carpet Co. v. State, supra note 9.

13 The leading case is State v. Alabama Fuel \& Iron Co., 188 Ala. 487, 66 So. 169 (1914) concerning a mortgage recording tax. Also see Lee v. State Tax Comm., supra note 7 concerning a foreign securities recording tax.

14 National Linen Service Corp. v. State Tax Comm., supra note 7, in which the court distinguished such a tax from a tax on the "mere use of property for purpose of ownership" of property.

${ }^{15}$ Republic Iron \& Steel Co. v. State, 204 Ala. 469, 86 So. 65 (1920), coal and iron ore mining taxes, holding that the fact the taxes were fixed at so much per ton on the mineral mined does not render the tax a direct tax on the mineral, rather the tax was held to be on the privilege of the business of mining.

${ }^{16}$ The income tax cases in Alabama are discussed in the text at notes 27-33, infra. 
of the Alabama Constitution, Art. XI, $\$ 211$ and $\$ 217$, does not contain a rule of universality. ${ }^{17}$ Classes of property may be exempted from the general property tax, the only limitation being that such exemptions constitute reasonable classes. "In lieu" provisions of nonproperty taxes, which

${ }^{17}$ Moog v. Randolph, 77 Ala. 597 (1884) in which it was ruled that the allowance of deductions of indebtedness from solvent credits in valuing the same for assessment was not a violation of the uniformity provisions. The court stated that those provisions do not prohibit exemptions from taxation. The ruling was necessary in order to determine the issue of a material variance in the General Revenue Act. In State v. Birmingham Southern R. Co., 182 Ala. 475, 62 So. 77 (1913), it was held that a statutory provision providing that taxable property was to be assessed at $60 \%$ of its fair cash value was not a violation of the uniformity provisions; the court supported its decision by use of a rationale which characterized this reduced ratio as being the equivalent of an exemption of property. In Pullman Car \& Mfg. Corp. of Alabama v. Hamilton, 229 Ala. 184, 155 So. 616 (1934), it was necessary to restate the general rule as to the exemption of property; the court (at pp. 186-187) reviewed the cases to that time. Also see the cases in notes 18 and 19, infra, and In re Opinion of the Justices, 234 Ala. 358, 175 So. 690 (1937); Opinion of the Justices, 249 Ala. 572, 32 S. 2d 297 (1947).

18 In State v. Alabama Fuel \& Iron Co., supra note 13, the court held that the exemption of mortgages, or debts secured thereby upon which a recording privilege tax had been paid from the ad valorem tax, while leaving subject to such tax other intangibles, listed in the statute as "all money lent, solvent credits, or credits of value" with certain exceptions, was a reasonable classification. Thus, Barnes v. Moragne, 145 Ala. 313, 41 So. 947 (1906) was overruled to the extent that dictum therein asserted that this class of "money, etc." could not be further classified.

In Board of Revenue v. Montgomery Gas-Light Co., 64 Ala. 269 (1879) the court indicated that if only "annual gains, profits or incomes" of individuals were subject to the general property tax, Art. XI, $\$ 217$ would be violated. Thus, the supplementary uniformity provision, providing for equal rates as between property owned by corporations and individuals, places a potential restriction upon classifications which may be made. But see State $v$. Board of Revenue \& Road Com'rs, 73 Ala. 65 (1882) concerning the same fact situation, but in which the court asserted that, although it would violate Art. XI, $\$ 217$, nevertheless "when the legislature, through a failure to levy, leaves a species of property free of taxation, by providing no machinery which can be adapted to the assessment, the courts of the country 
relieve property indirectly affected by such nonproperty taxes from property taxation, have been held to be nothing more than a valid exercise of the power to exempt property from taxation. ${ }^{10}$

Apart from the absence of a rule of universality, the strictest degree of uniformity is required. Absolute uniformity is required of the effective rate applicable to all property selected for the general property tax by a taxing jurisdiction. ${ }^{20}$ However, the ratio of valuation may be less than

are powerless to remedy the evil." Also see Pullman Car \& Mfg. Corp. of Alabama v. Hamilton, supra note 17 , in which the court considered the "inducement" exemption of industrial plants to be reasonable.

19 State v. Alabama Fuel \& Iron Co., supra note 13 (mortgage recording tax) and Lee v. State Tax Comm., supra note 7 (foreign corporate securities tax).

20 See, as to the percentage rate: Mobile v. Stonewall Ins. Co., 53 Ala. 570 (1876) in which the court held that a statute violated the uniformity clause because it required the taxation of corporate capital stock under the local general property tax at a lesser per cent than the general rate imposed. Also see Proctor v. State, 215 Ala. 6, 109 So. 105 (1926). See, as to ratio of valuation: State v. Birmingham Southern R. Co., supra note 17; State v. Alabama Power Co., 254 Ala. 327, 48 S. 2d 445 (1950). The Alabama Power Co. case is the leading case on the uniformity required of effective rates. See note 25 , infra, for further discussion. Also see the dissent in Lee v. State Tax Comm., supra note 7 , which would have held the securities recording tax, supra notes 13 and 19, a tax upon property and therefore a violation of the uniformity clause because the 2.5 mill rate was lower than the general property tax rate.

In some early cases the Alabama court ruled that it was not "double taxation" to tax both property and the mortgage thereon (Alabama Gold Life Ins. Co. v. Lott, 54 Ala. 499 (1876)), and both corporate shares and the tangible property of the issuing corporations (Jefferson County Sav. Bank v. Hewitt, 112 Ala. 546, 20 So. 926 (1896)). It may be pointed out that the basic uniformity clause in the 1901 constitution, Art. XI, \$211, was expanded to prohibit the taxation of one particular class of representative property and the property represented thereby. See note 4, supra. The purpose of this proviso is commented upon in a concurring opinion in Eliasberg Bros. Mercantile Co. v. Grimes, 204 Ala. 492, 500, 86 So. 56 (1920), the first income tax case. The concurring justice stated that the proviso was added to the uniformity clause in the 1901 constitution to counteract an 
$100 \%$ so long as an absolute uniformity purportedly prevails. ${ }^{21}$ The court has compared the use of a reduced ratio of valuation to a "partial exemption," which would be valid. ${ }^{22}$

The opinions have contained much loose language, however, so that-at least until 1950--there may have been some doubt as to the necessity of absolute uniformity in effective rates. The opinions ${ }^{23}$ have referred in a general way to the power of the legislature to classify property for purposes of taxation, and at times-for example, as in $M \circ \mathrm{g} \mathrm{v}$. Randolp $h^{24}$-seemed to relate the power of classification to effective rates. However, if there was any doubt raised by the dictum in these cases, it was settled by unequivocal lan-

unreported opinion, in which it was held that notes for the rent of land were taxable even though the land itself was already taxed.

21 State v. Birmingham Southern R. Co., supra note 17. The issue in that case concerned the validity of a statute providing that taxable property was to be assessed at $60 \%$ of its fair and reasonable cash value. The court held that Art. XI, $\$ 211$, the basic uniformity clause, was complied with as long as all property was assessed at the same ratio. It was said (at p. 481): "There is nothing expressed or implied in the language of this limitation which prohibits the Legislature from fixing as a basis for taxation any percentage of the actual value of property whether greater or less than 100 per cent thereof, provided only that such rule is applied without discrimination to all property of the same nature."

22 Id. at 480-481, 490.

${ }^{23}$ See the cases cited in notes 17 and 18, supra.

${ }^{24}$ Supra note 17. In commenting upon the validity of exemptions of property from taxation, the court stated (at p. 602):

These clauses have never been construed to exact the taxation of all property, of every description, in the State, at precisely the same rate of taxation, without regard to its peculiar nature, uses, or other characteristics.

This statement is contrary to the facts; see, for example, Mobile v. Stonewall Ins. Co., supra note 20. Also see State Bank v. Board of Revenue, 91 Ala. 217, 223, 8 So. 852 (1890) in which the court stated: "Nor is it necessary that we should express any opinion at this time, whether every species of property, if taxed at all, must necessarily be taxed at the same rate per centum." 
guage in State v. Alabama Power Co., ${ }^{25}$ to the effect that absolute uniformity is required of effective rates. Thus, the dictum is limited to the particular rule which was stated in those cases, namely, that the legislature may classify property for purposes of exemption - "total" exemption or "partial" exemption-if all taxable property is exempted to the same degree.

As expected under this type of basic uniformity provision, property must be taxed by the ad valorem method. The same "standard" of "value" must be used for all property taxed; the legislature may not fix an "arbitrary" value for any class of property. ${ }^{26} \mathrm{It}$ is interesting to note that there are no words of "uniformity and equality" in the Alabama Constitution.

${ }^{25}$ Supra note 20. The issue in the case concerned the power of the Department of Revenue to assess the property of plaintiff, a public utility, at a ratio of $60 \%$ while all other property in the state was systematically and intentionally assessed at a rate not in excess of $40 \%$. It was contended by the state that the plaintiff was not treated differently from other public utilities, thus all of a class were treated alike. It was insisted by the state that sections 211 and 217 must be tested by the rules applicable to the federal equal protection clause. The court rejected this argument, flatly stating (at p. 335): "This is not correct." The court rejected the argument that the cases dealing with exemption from property taxation in effect admitted the principle of classification. The court ruled that the legislature has the power to select certain species or classes of property for taxation, but that (at p. 338):

. . once a species or class of property is selected by the legislature for taxation then the constitutional provisions come into play and all property of such species or class that is taxed must be taxed uniformly or equally at the same rate regardless of its ownership. . . Once property is made taxable there is but one classification and that classification is property under the very language of the constitution. [Emphasis added.]

Of course, the discrimination in this respect must be an intentional and systematic discrimination. Hamilton v. Adkins, 250 Ala. 557, 35 S. 2d 183 (1948).

${ }^{28}$ Board for Assessment of Property of R. Cos. v. Alabama Cent. Ry., 59 Ala. 551 (1877). Also see State v. West Point Mfg. Co., 236 Ala. 467, 183 So. 449 (1938). 
However, the court quite often refers to the strict rules of property-tax uniformity as being required by the constitutional limitation of "uniformity and equality." The failure of the court to find a rule of universality in this limitation is not surprising since there are no provisions in the constitution expressly providing for the exemption of certain classes of property which are almost universally exempted.

\section{(2) Income tax}

In 1919 the Alabama legislature enacted a General Net Income Tax Act. ${ }^{27}$ The rate of the tax was graduated from $2 \%$ to $4 \%$. In Eliasberg Bros. Mercantile Co. v. Grimes ${ }^{28}$ the tax was challenged as a violation of Art. XI, $\$ 214$ of the Alabama Constitution which limits the maximum rate on property to an annual $.65 \%$. The court held that the tax was a violation of section 214 . Income was said to be embraced within the meaning of the word "property" as used in that particular constitutional limitation. There was no discussion of the validity of the tax under the uniformity provisions, Art. XI, $\$ \$ 211$ and 217 . However, the opinion was largely devoted to an evaluation of prior Alabama decisions that income was "property" within the meaning of that word as it was used in the uniformity provisions, sections 211 and 217 , of the present constitution and their historical antecedents. ${ }^{29}$

In 1933 the 25th amendment to the Alabama Constitution was adopted. That amendment removed the income tax from the scope of the uniformity and maximum rate limitations which apply to property taxes, and specifically provided for

27 Ala. Gen. Acts 1919, pp. 374-395.

28204 Ala. 492, 86 So. 56 (1920).

${ }^{29} \mathrm{Id}$. at 494-499. The court also concluded that the weight of authority from other jurisdictions was in concurrence with its decision. But $c f$. Chapter V, Part C, infra. 
the imposition of a progressively graduated net income tax with a classified object. ${ }^{30}$ Such a tax was thereafter imposed by the legislature, and in State v. Weil ${ }^{31}$ the court dealt with the issue of the power of the state to tax residents on income from out of state. In the course of its decision, it was necessary that the court comment upon the purpose of the 25 th amendment to the Alabama Constitution. ${ }^{32}$ In doing so, the court, although disclaiming any intent to "discredit" the Eliasberg opinion, in fact, tends to question the validity of the reasoning therein. ${ }^{33}$ While this is now immaterial insofar as the validity of an income tax in Alabama is concerned, it is nevertheless of some significance for comparative purposes.

${ }^{30}$ The amendment reads, in part:

The legislature shall have the power to levy and collect taxes for state purposes on net incomes from whatever source derived within this state ... and to designate and define the incomes to be taxed and to fix the rates of taxes provided that the rate shall not exceed 5 per cent nor 3 per cent on corporations. Income shall not be deemed property for purposes of ad valorem taxes.

Certain minimum personal exemptions and exemptions for dependents are required.

31232 Ala. 578, 168 So. 679 (1936).

32 Id. at 583 :

... it is reasonably clear that its dominating purpose is to remove net incomes, as a subject of taxation, from the influence of the decision of this court in Eliasberg Bros. Mercantile Co. v. Grimes . . . and sections ..211,214 ... of the Constitution, by taking this subject of taxation, by constitutional mandate, out of the property class, placing it in the class of privileges that are subject to excise taxation.

${ }^{33} I d$. at 582-583. But see State v. Ala. Power Co., supra note 20 at 340, discussed supra note 25 , in which the court drew upon the income tax amendment to support its view of the restrictiveness of the basic uniformity clause applicable to property taxation, saying: "The authors of the constitutional amendment recognized that an income tax was a direct tax the same as an ad valorem tax on property generally. ..." 


\section{California}

\section{a. The provisions; historical note}

The present California Constitution, dated 1879, has a complex structure of provisions requiring uniformity in taxation, and that structure reached its present status after numerous revisions. The basic uniformity clause is found in the first paragraph of Art. XIII, $\S 1$, which reads (with indentation supplied):

All property in the State [except as otherwise in this Constitution provided], not exempt under the laws of the United States, shall be taxed in proportion to its value, to be ascertained as provided by law, or as hereinafter provided.

The word "property," as used in this article and section, is hereby declared to include moneys, credits, bonds, stocks, dues, franchises, and all other matters and things, real, personal, and mixed, capable of private ownership; [provided, that a mortgage, deed of trust, contract, or other obligation by which a debt is secured when land is pledged as security for the payment thereof, together with the money represented by such debt, shall not be considered property subject to taxation]. ${ }^{1}$

The section contains a further proviso which requires the exemption of described classes of property (public property, growing crops, and certain educational property). An additional provision permits the deduction of certain debts from credits in some instances. ${ }^{2}$

There is a second uniformity provision in the California Constitution which vitally affects the scope of the uniformity

${ }^{1}$ The phrase in the first brackets was added by amendment in 1914 . The proviso in the second brackets was added by amendment in 1910 . These amendments did not represent a change in the general operation of the uniformity provision, and they are explained in notes 5 and 6 , infra.

2 The sentence reads: "The Legislature may provide, except in the case of credits secured by mortgage or trust deed, for a deduction from credits of debts due to bona fide residents of this State." 
clause in Art. XIII, $\S 1$. The following paragraphs were added to Art. XIII, §14, in 1933:

The Legislature shall have the power to provide for the assessment, levy and collection of taxes upon all forms of tangible personal property, all notes, debentures, shares of capital stock, bonds, solvent credits, deeds of trust, mortgages, and any legal or equitable interest therein, not exempt from taxation under the provisions of this Constitution, in such manner, and at such rates, as may be provided by law, and in pursuance of the exercise of such power the Legislature . . . may classify any and all kinds of personal property for the purposes of assessment and taxation in a manner and at a rate or rates in proportion to value different from any other property in this State subject to taxation and may exempt entirely from taxation any or all forms, types or classes of personal property. [Emphasis added.]

In addition, the following provisions are relevant. There are a substantial number of sections in the constitution, ${ }^{3}$ added since 1900 , which provide for either mandatory or permissive exemptions of special classes of property. There are several provisions concerning particular taxes. Article XIII, §11 provides that an income tax may be imposed. That section appeared in the constitution of 1879 in its original form. Since that time other sections have been added, and frequently amended, providing for other particular taxes. ${ }^{4}$

${ }^{3}$ Art. XIII, §1a (added 1914; college property, etc. generally); Art. XIII, §lb (1926; cemeteries); Art. XIII, §1c (1944; property used for religious, hospital, charitable purposes); Art. XIII, $\$ 11 / 4$ (1911, several subsequent amendments; veterans' exemption); Art. XIII, $\$ 11 / 2$ (1900; church property); Art. XIII, $\$ 11 / 2$ a (1920; property of orphanages); Art. XIII, $\S 13 / 4$ (1902; state, municipal and district bonds); Art. XIII, $\S 101 / 2$ (1904; personal property, $\$ 100$ to each householder); Art. XIII, $\$ 123 / 4$ (certain trees and vines); and Art. IX, $\$ \S 10-13$ and 15 (property of named educational institutions).

4 Article XIII, \$14, paragraphs 1-3 provide for the taxation of utilities and their property. Article XIII, $\$ 144 / 5$ contains a detailed provision for a gross premiums insurance companies tax, setting forth the base, rates, and 
The apparently overlapping uniformity clauses can be better understood after a brief historical survey of the uniformity provisions in past and present California constitutions. In the first constitution, dated 1849 , there was a single provision concerning uniformity of taxation. Article XI, $\$ 13$ provided, in part:

Taxation shall be equal and uniform throughout the state. All property in this State shall be taxed in proportion to its value, to be ascertained as directed by law. . . .

The kinship of that provision to the present Art. XIII, $\S 1$ is obvious. The "equal and uniform" clause has been deleted, and the "proportion to value" clause retained.

The next California Constitution was the present constitution of 1879. In its original form, the uniformity structure was only slightly expanded over that found in the constitution of 1849. There were three relevant provisions. Article XIII, $\S 1$ contained the basic uniformity clause and was phrased in substantially the same words used today. ${ }^{5}$ Article XIII, §4 provided for the manner in which enumerated representative intangible property (property security) was to be taxed, the clause being framed to avoid "double taxation." deductions. The tax is "in lieu" of all other taxes except upon realty. Article XIII, $\$ 16$ provides for a bank tax "according to or measured by their net income," to be "in lieu" of all other taxes except upon realty. Section 16 also contains the following general provision:

The Legislature may provide by law for the taxation of corporations, their franchises, or any other franchises, by any method not prohibited by this Constitution or the Constitution or laws of the United States.

"The addition of the phrase in the first sentence-"except as otherwise in this Constitution provided"-coincides with the practice of adding provisions to the constitution which provide for the exemption of special limited classes of property. It was not the basis of any change in the meaning of the uniformity clause. The addition of the provision concerning the "double taxation" of land securities is explained in note 6, infra.

- The pertinent part of section 4 read:

A mortgage, deed of trust, contract, or other obligation by which a 
The third provision was Art. XIII, $\S 11$, which provided that income taxes might be imposed "in such cases and amounts, and in such manner, as shall be prescribed by law.”

This remained the basic uniformity structure until the transition period of 1924-1933. In 1924 a section was added, Art. XIII, $\S 12 \mathrm{I} / 2$, which provided for the taxation of enumerated intangibles unrestricted by the limitations of the strict unformity requirement applicable to the taxation of all other property. ${ }^{7}$ The implementation of this provision failed, ${ }^{8}$ and 1933 marked the transition to a new effective

debt is secured, shall, for the purposes of assessment and taxation, be deemed and treated as an interest in the property affected thereby. Except as to railroad and other quasipublic corporations, in case of debt so secured, the value of the property affected by such mortgage, deed of trust, contract, or obligation, less the value of such security, shall be assessed and taxed to the owner of the property, and the value of such security shall be assessed and taxed to the owner thereof, in the county, city, or district, in which the property affected thereby is situated. . . .

In 1910 this section was repealed, and the problem was dealt with by the addition of the proviso to Art. XIII, $\S 1$, by which the security was thereafter not to be "considered property subject to taxation." For a discussion of the problem of "double taxation" prior to these provisions, see infra note 24 .

7 The pertinent part of Art. XIII, $\S 12 \mathrm{~L} / 2$ read:

The Legislature . . . shall have power to provide for the assessment, levy and collection of taxes upon all notes, debentures, shares of capital stock, bonds, solvent credits or mortgages, not exempt from taxation under the provisions of this Constitution, in a manner, at a rate or rates or in proportion to value different from any other property in this State subject to taxation; taxes imposed by any act of the Legislature adopted pursuant to the powers hereby conferred shall be in lieu of all other property taxes, State, county, municipal or district, upon such property . . . provided, that the rate or rates of taxation of such securities . . . shall not exceed those assessed or imposed upon other property in this State not exempt from taxation. ...

8 The implementing statute was held invalid in Arnold v. Hopkins, 203 Cal. 553, 265 Pac. 223 (1928) because it did not conform to certain requirements of the constitutional provision, Art. XIII, $\$ 121 / 2$. However, no issue of uniformity in taxation was raised. 
uniformity limitation. In 1933 the paragraphs quoted above were added to Art. XIII, §14. The amendment withdrew the taxation of personal property from the scope of the uniformity clause in Art. XIII, $\$ 1$ which would otherwise apply to the taxation of "all" property. "Thus, the basic uniformity clause in California has been subjected to a substantial modification although its words remain unchanged.

In summary, the history of the California uniformity structure falls into two periods. From 1849 to 1933 , under two constitutions, there was a single basic provision governing the taxation of "all" property, and, as will be shown, requiring the strictest degree of uniformity. From 1933 to the present time, there have been two basic provisions, one of which has relieved the taxation of personal property from the strict uniformity limitation.

\section{b. Meaning of the uniformity limitation}

Nonproperty taxes are not limited by the uniformity provision in Art. XIII, $\$ 1 .^{10}$ Such taxes are required only to be

"However, a "maximum rate" equality is ensured between personal property and realty. Article XIII, $\$ 14$ was amended in 1933 to include the following:

The total tax imposed on notes, debentures, shares of capital stock, bonds, solvent credits, deeds of trust, mortgages and any legal or equitable interest therein in pursuance of the provisions of this section shall not be at a rate in excess of four-tenths of 1 per cent of the actual value of such property and no tax burden shall be imposed upon any personal property either tangible or intangible which shall exceed the tax burden on real property in the same taxing jurisdiction in proportion to the actual value of such property.

This limitation emphasizes the dominating purpose of the amendment which was to permit "low-rate" taxation of intangible property.

${ }^{10}$ Under Art. XI, $\S 13$ of the 1849 constitution there was a tendency to apply the first sentence of that section- "Taxation shall be equal and uniform throughout the State"- to nonproperty taxes. However, all that was required of such taxes was uniformity within classes. For example, in Sacramento v. Crocker, 16 Cal. 119, 123 (1860) it was said that a rate 
uniform within classes. ${ }^{11}$ The source of the limitation is both Art. I, $\$ 11^{12}$ of the California Constitution and the federal equal protection clause. Thus, the objects selected for nonproperty taxes and exemptions therefrom need only be reasonable classes, ${ }^{13}$ and the objects may be further classified for

schedule (increasing flat rates for additional amounts of gross receipts) of a "business" tax was "uniform and equal, applying to all persons in the same category." [Emphasis added.] See note 20, infra.

11 See, for example In re Wilmerding's Estate, 117 Cal. 281, 49 Pac. 181 (1897) (inheritance tax); Kaiser Land \& Fruit Co. v. Curry, 155 Cal. 638, 103 Pac. 341 (1909) (corporate franchise tax with a base of capital stock); Douglas Aircraft Co. v. Johnson, 13 Cal. 2d 545, 90 P. 2d 572 (1939) (general use tax). Also see the summary of this problem in the recent case, Fox Bakersfield Theatre Corp. v. City of Bakersfield, 36 Cal. 2d 136, 222 P. 2d 879 (1950). While this is established beyond argument, it is still an important proposition since almost invariably a tax is challenged as a violation of the uniformity clause, Art. XIII, $\S 1$. The usual reason for this approach is to enable the taxpayer to challenge the tax as not being imposed "ad valorem," or as resulting in "double taxation." Of course, if the court establishes that the tax in question is not a property tax, then the "method" used is immaterial; see, for example, the Douglas case, supra. There is no "double taxation" as between different nonproperty taxes or as between a property tax and a nonproperty tax; see, for example, the Fox Bakersfield Theatre Corp. case, supra. The "double taxation" issue has been continually raised in California-invariably without success, which has not seemed to bother later complaining taxpayers.

${ }^{12}$ The section reads: "All laws of a general nature shall have a uniform operation." The same provision, with the same number, was found in the 1849 constitution. Article I, $\$ 21$ is also cited at times as the source of this limitation. That section provides: ". . . nor shall any citizen, or class of citizens, be granted privileges or immunities which, upon the same terms, shall not be granted to all citizens."

${ }^{13}$ See, for example: In re Wilmerding's Estate, supra note 11 (inheritance tax; holding that the selection of only collateral heirs was not an arbitrary classification, and that a minimum exemption of $\$ 500$ was a reasonable classification); Fox Bakersfield Theatre Corp. v. City of Bakersfield, supra note 11 (local license tax of $1 \phi$ per $10 \phi$ admission fee, applicable to places of amusement if admission fee charged, with certain exemptions of places where no fee charged and of charitable organization and the like where fee was charged; upholding tax against contention that the classification was improper because not all amusement businesses in city were in- 
application of different rates. ${ }^{14}$ The court has not ruled upon the validity of graduated rates. However, the present inheritance tax does have a graduated rate schedule.

Since the uniformity required of property taxes is a stricter limitation, the nature of a tax is always a crucial issue. The court has ruled upon the following taxes of comparative interest. It has held that an inheritance tax was a nonproperty tax, ${ }^{15}$ but that a so-called "probate fee" was a tax upon property and a violation of the uniformity clause in Art.

cluded); Roth Drugs v. Johnson, 13 Cal. App. 2d 720, 57 P. 2d 1022 (1936) (retail sales tax; holding the following to be reasonable classifications: the selection of retail sales as opposed to wholesale sales, and the exemption of sales of certain classes of things, such as food, as well as the exemption of certain sales which were subject to other privilege taxes). In Bacon Service Corp. v. Huss, 199 Cal. 21, 248 Pac. 235 (1926), followed in Ex parte Schmolke, 199 Cal. 42, 248 Pac. 244 (1926), the court held that the exemption from the state motor vehicle transportation license tax of those transporting their own property or employees, and those transporting no persons or property for hire, as well as those operating commercial vehicles within incorporated cities were not arbitrary classifications. However, in the Bacon Service Corp. case it was held that the exemption of sightseeing motor-buses carrying passengers for hire and operating outside of municipalities was an arbitrary classification and therefore invalid. See the following cases for further examples of arbitrary classifications: Bueneman v. City of Santa Barbara, 8 Cal. 2d 405, 65 P. 2d 884 (1937); Town of St. Helena v. Butterworth, 198 Cal. 230, 244 Pac. 357 (1926); Ex parte Richardson, 170 Cal. 68, 148 Pac. 213 (1915).

14 See, for example, Los Angeles v. Los Angeles Independent Gas Co., 152 Cal. 765, 93 Pac. 1006 (1908) (local utilities license tax; holding the flat rate of $\$ 100$ per period was not an unreasonable discrimination, as against the contention that to use a flat rate and disregard the amount of business done was discriminatory); Town of St. Helena v. Butterworth, supra note 13 (local license tax; upholding different rate schedules for those having and those not having fixed places of business in the city). Also see McAdams Oil Co. v. City of Los Angeles, 32 Cal. App. 2d 359, 89 P. 2d 729 (1939).

${ }^{15}$ In re Wilmerding's Estate, supra note 11, collateral inheritance tax, the court said (at p. 287): "This tax is not upon property, but upon the right of succession, [therefore] the constitutional provision that all property shall be taxed according to its value is inapplicable." 
XIII, $\S 1 .^{16} \mathrm{~A}$ local motor vehicle license tax was held to be a tax on the "mere ownership" of property, and therefore on the property itself and a violation of Art. XIII, $\S 1 ;{ }^{17}$ but a state vehicle license tax was held to be a nonproperty tax. ${ }^{18}$ The following taxes were held to be nonproperty taxes: a general use tax; ${ }^{19}$ a local selective severance tax; ${ }^{20}$ and a corporate franchise tax with a base of capital stock. ${ }^{21}$

${ }^{16}$ Fatio v. Pfister, 117 Cal. 83, 48 Pac. 1012 (1897); a fee, at the time of filing in proceedings for administration of estates of deceased persons, and in guardianship proceedings, amounting to $\$ 1$ per $\$ 1,000$ of appraised valuation in excess of $\$ 3,000$, was held to be a tax on the estates of decedents, infants, and incompetents, and not analogous to an inheritance tax.

17 Flynn v. San Francisco, 18 Cal. 2d 210, 115 P. 2d 3 (1941). The court placed considerable reliance on the exact words of the ordinance. It said that the tax "depend[s] entirely on the factor of ownership; no mention is made [in the ordinance] of use or opcration of the vehicles" with the exception as to motorcycles. "A tax levied by reason of ownership of property is a tax on property rather than an occupation tax," relying on Dawson v. Kentucky Distilleries \& Warehouse Co., 255 U.S. 288, 41 S. Ct. 272 (1920), and the discredited Thompson v. Kreutzer, 112 Miss. 165, 72 So. 891 (1916), infra Chapter III, Part E.

${ }^{18}$ Ingels v. Riley, 5 Cal. 2d 154, 53 P. 2d 939 (1936). Here the words of the statute explicitly provided for a tax on a particular "use," rather than "mere ownership." However, the amount of the tax was a per cent of the actual market value. The tax was held to be on the privilege of operating vehicles on the highways.

19 Douglas Aircraft Co. v. Johnson, supra note 11.

${ }^{20}$ McAdams Oil Co. v. City of Los Angeles, supra note 14.

${ }^{21}$ Kaiser Land \& Fruit Co. v. Curry, supra note 11, holding (at p. 653): "The charge is in no sense a tax upon the thing granted, as is the tax imposed under section 1 of article XIII. It is a mere license fee charged for the privilege, and is not a tax upon property at all, and the requirements of section 1 of article XIII of the constitution do not apply thereto." The court had earlier held that a corporate "franchise to be" was taxable property subject to the general property tax, but that such franchise might be taxed by either a property tax or an excise tax. See, for example, Bank of California v. San Francisco, 142 Cal. 276, 75 Pac. 832 (1904) and Spring Valley Water Works v. Schottler, 62 Cal. 69 (1882). Those cases concerned the property tax, and the issue was primarily raised by the listing of "franchises" in the definition of property found in Art. XIII, §1, supra. 


\section{(1) Property taxation: prior to 1933}

It was clear that under both Art. XI, $\S 13$ of the 1849 constitution and Art. XIII, $\$ 1^{22}$ of the present 1879 constitution the strictest degree of uniformity in the taxation of property was required. There was a rule of universality, exemption of any property other than that specifically designated as exemptible in the constitution being prohibited. ${ }^{23}$ Absolute uniformity was required of the effective rate applicable to all property taxed by any taxing authority. ${ }^{24}$

22 There seems to have been no significance in the deletion of the sentence "Taxation shall be equal and uniform" from the uniformity provision as it was carried over from Art. XI, $\$ 13$ of the 1849 constitution to Art. XIII, $\S 1$ of the 1879 constitution. The result as to property taxationstrict uniformity-was the same under both constitutions. In the application of the "equal and uniform" clause to nonproperty taxes under the 1849 constitution it was simply interpreted to mean uniformity within classes. Note 10, supra.

${ }^{23}$ See Crosby v. Lyon, 37 Cal. 242 (1869) (1849 constitution; relying on the sentence "taxation shall be equal and uniform" to prohibit exemptions of property) ; People v. Latham, 52 Cal. 598 (1878) (1849 constitution; the court clearly relied alternately upon the "equal and uniform" clause and the words "all property shall be taxed," emphasizing the word “all”); McKay v. San Francisco, 113 Cal. 392, 397, 45 Pac. 696 (1896); Chesebrough v. San Francisco, 153 Cal. 559, 96 Pac. 288 (1908).

${ }^{24}$ See for example, Fatjo v. Pfister, supra note 16, in which the court held that a "fee" amcunting to $\$ 1$ per $\$ 1,000$ of appraised valuation over $\$ 3,000$ of estates of deceased persons, infants, and incompetents, to be paid at the time of filing in a proceeding for the administration of such estates, was in fact a property tax upon such estates. The tax violated Art. XIII, §1 because it imposed "an extraordinary tax upon the property to which it applies, in addition to the equal and uniform tax to which alone all property in the state is liable." In other words, this was a clear example of "double taxation"-the taxing of the same property twice in the same taxing period by the same taxing authority, resulting in effective rates not being absolutely uniform.

There has been considerable controversy in California as to just what constitutes "double taxation" in the taxation of representative intangible property. In a line of cases the court has ruled that the taxation of shares to the shareholder and corporate property to the corporation constituted the taxation of the "same" property twice, resulting in unequal effective rates. 
Of course, only the ad valorem method might be used in taxing property. ${ }^{25}$

It appears that under the present constitution the rule of universality has been derived from the words " $A l l$ property shall be taxed," rather than from a principle based upon the phrase "in proportion to its value." However, under the 1849 provision a rule of universality was alternately attributed to the "equal and uniform" clause. ${ }^{26}$ It should be pointed out that the court has equated "uniformity and equality" to the requirement of "proportionality," as, for example, in the following statement: "Manifestly, under the prevailing circumstances, the exaction of the assessments in question was violative of the indispensable principle of equality and uniformity commensurate with taxation of property in proportion to its value'."27

\section{(2) Property taxation: 1933 to present}

The uniformity provision in Art. XIII, $\$ 14$, which was

However, this is said to be so only when the corporate property is within the taxing jurisdiction attempting to reach the stock and subject to the tax. Thus, it was held that the taxation of shares in corporations having no property in the state was not "double taxation." See the following cases which developed this doctrine: Pcople ex rel. Burke v. Badjam, 57 Cal. 594 (1881); San Francisco v. Fry, 63 Cal. 470 (1883); Germania Trust Co. v. San Francisco, 128 Cal. 589, 61 Pac. 178 (1900); Crocker v. Scott, 149 Cal. 575, 87 Pac. 102 (1906); Chesebrough v. San Francisco, supra note 23; Canfield v. Los Angeles, 157 Cal. 617, 108 Pac. 705 (1910) ; Bank of California, Nat. Ass'n v. Roberts, 173 Cal. 398, 160 Pac. 225 (1916). Also see San Francisco v. Anderson, 103 Cal. 69, 36 Pac. 1034 (1894) and McKay v. San Francisco, supra note 23.

On the absolute uniformity required in the ratio of valuation, see the statement in McClelland v. Board of Sup'rs, 30 Cal. 2d 124, 128-129, 180 P. 2 d 676 (1947).

$25 \mathrm{See}$, for example, the dictum in Roth Drugs v. Johnson, supra note 13 at 739 .

26 See the cases in note 23.

27 Flynn v. San Francisco, supra note 17 at 216 , emphasis added. 
added in 1933 and governs the taxation of personal property, limits to a substantial degree the effective operation of the uniformity provision in Art. XIII, $\S 1$, which remains unchanged in form. Because of Art. XIII, $\S 14$, the strict degree of uniformity required by Art. XIII, $\S 1$ is now limited to the taxation of real property. There has been no clear-cut line of decisions developing the meaning of the uniformity limitation which is derived from Art. XIII, $\$ 14$ and applicable to personal property taxation. ${ }^{28}$ However, on its face, it seems quite clear that Section 14 permits the taxation of all personal property-tangible as well as intangible - by specific as well as ad valorem taxes. There is no rule of universality for the taxation of personal property. And less than all taxable personal property may be selected for taxation, with that selected being subject to varying rates for different classes. ${ }^{20}$

In fact, under the existing California tax structure the following use has been made of the liberal Art. XIII, $\$ 14$. Intangible property, except solvent credits, is entirely ex-

28 But see Dawson v. County of Los Angeles, 15 Cal. 2d 77, 98 P. 2d 495 (1940), concerning the maximum rate limitation applicable to the taxation of intangibles which requires equality as between such rate or rates and the rate imposed on real property. See note 9 , supra.

${ }^{29}$ But see Flynn v. San Francisco, supra note 17, in which the court held that a local tax (as construed by the court) upon the "mere ownership" of vehicles was in fact upon the property (i.e., vehicles, personal property) and therefore a violation of Art. XIII, $\S 1$ because it imposed "double taxation." The cases relied upon by the court were decided under the present constitution before the 1933 amendment which clearly removes the requirement of an absolute uniformity of rates as to all property-real and personal-in a taxing jurisdiction. Therefore, the limitation as to "double taxation" in Art. XIII, $\$ 1$ should no longer be relevant to taxes imposed upon personal property. However, the court might well have struck down the tax as a violation of the proviso in the amendment of Art. XIII, $\$ 14$ which insures a "maximum rate" equality between real and personal property (see note 9 , supra). If the vehicle was subject to the general property tax, then the additional "property" tax would impose a greater rate than that imposed on real property in that taxing jurisdiction. 
empt. ${ }^{30}$ However, tangible personal property remains subject to the general property tax at the real property ad valorem rate, ${ }^{31}$ and apparently no tangible property not expressly described as exemptible by a special constitutional provision has been exempted under the new limitation applicable to personal property taxation. There has been one unusual result under the new uniformity provision found in Art. XIII, \$14. The court has held that the enumeration of classes of intangible property in that provision limits the legislature to the taxation of only such classes. ${ }^{32}$ Thus, intangible property not enumerated may not be taxed. For example, a liquor license was considered intangible property, but not taxable since not enumerated in the new Art. XIII, $\$ 14$.

\section{Illinois}

\section{a. The provisions; historical note}

The basic uniformity clause of the present Illinois Constitution, dated 1870 , is found in the first clause of Art. IX, $\$ 1$, which reads:

The general assembly shall provide [such revenue as may be needful by] levying a tax, by valuation, so that every person and corporation shall pay a tax in proportion to the value of his, her [or its] property . . . ; but the general assembly shall have power to tax peddlers, auctioneers, brokers, hawkers, merchants, commission merchants, showmen, jugglers, innkeepers, grocery keepers [liquor dealers,] toll bridges, ferries, [insurance, telegraph and express interests or business, vendors of patents, ] and persons [or corporations owning or] using franchises and privileges, in such manner

${ }^{30}$ Cal. Revenue and Taxation Code $\S \S 212,2153$. Solvent credits are subject to an "in lieu" tax of $1 / 10$ of $1 \%$.

${ }^{31}$ Cal. Revenue and Taxation Code $\$ \$ 106,201$.

${ }^{32}$ Roehm v. County of Orange, 32 Cal. 2d 280, 196 P. 2d 550 (1948). 
as it shall from time to time direct [by general law, uniform as to the class upon which it operates].

This provision is accompanied by Art. IX, $\$ 2$, which provides:

The specification of the objects and subjects of taxation shall not deprive the general assembly of the power to require other subjects or objects to be taxed in such manner as may be consistent with the principles of taxation fixed in this constitution.

A third provision, Art. IX, §3, states that enumerated classes of property "may be exempted from taxation." In addition, Art. IX, $\S 9^{3}$ and $\$ 10^{4}$ provide expressly for uniformity in local taxes.

1 The two prior constitutions of Illinois (dated 1818 and 1848) had basic uniformity clauses substantially identical to the uniformity clause of the present constitution. In the first constitution of 1818 there was a single provision relative to uniformity of taxation. Article VIII, $\$ 20$ read:

The mode of levying a tax shall be by valuation, so that every person shall pay a tax in proportion to the value of the property he or she has in his or her possession.

In the second constitution, dated 1848 , Art. IX, $\$ 2$ read as does the present Art. IX, $\S 1$ quoted in the text, but with the words in brackets not present. Article IX, $\S 6$ was identical with the present Art. IX, $\S 2$. Article IX, $\S 3$ was similar to the present exemption section, Article IX, $\$ 3$, but provided for the "permissible" exemption only of governmental, education, religious, and charitable property. Article IX, $\S 5$ of the 1848 constitution combined, in substantially the same terms, the present sections 9 and 10 of Art. IX.

${ }^{2}$ Article IX, $\$ 3$ reads:

The property of the state, counties, and other municipal corporations, both real and personal, and such other property as may be used exclusively for agricultural and horticultural societies, for school, religious, cemetery and charitable purposes, may be exempted from taxation; but such exemption shall be only by general law. ...

3 The section reads:

... but such [municipal] taxes shall be uniform in respect to persons and property, within the jurisdiction of the body imposing the same.

4 The section reads:

The general assembly ... shall require that all the taxable property 


\section{b. Meaning of the uniformity limitation ${ }^{5}$}

The court has ruled that the "proportionality clause" in Art. IX, $\$ 1$ applies only to property taxes. ${ }^{6}$ Nonproperty taxes are required only to be uniform within classes. ${ }^{7}$ The objects selected for nonproperty taxes and exemptions therefrom

within the limits of municipal corporations shall be taxed for the payment of debts contracted under authority of law, such taxes to be uniform in respect to persons and property, within the jurisdiction of the body imposing the same. ...

${ }^{5}$ One of the few articles dealing with the general uniformity problem of a state constitution is a Comment, "The Illinois Constitutional Requirement of Uniformity in Taxation," 33 Ill. L. Rev. 57 (1938). Also Cushman, "The Proposed Revision of Article IX of the Illinois Constitution," 1952 Univ. of Ill. Law Forum 226, is largely concerned with the requirement of uniformity under the Illinois Constitution. It is a more cursory treatment, but is a thorough presentation of the proposed amendment to Art. IX, §1 which would considerably alter the meaning of that provision. The proposal was rejected in the 1952 elections, but will again be voted on in the 1956 general elections. Senate Joint Resolution No. 16, Adopted June 24, 1955 [Ed.: Rejected, 1956]. Also see Report of the Illinois Revenue Laws Commission (Springfield, 1949), especially at 73-80, 201-220.

${ }^{6}$ See, for example, Kochersperger v. Drake, 167 IIl. 122, 47 N.E. 321 (1897) and the cases in notes 8 and 9, infra. This is particularly clear under the Illinois type of provision which contains a separate uniformity limitation applicable to nonproperty taxes. Of course, it remains necessary to state the proposition since the property tax limitation is more restrictive with the result that complaining taxpayers attempt to bring every tax within the operation of the proportionality clause in Art. IX, $\$ 1$.

7 The source of the limitation is alternately the second clause of Art. IX, $\$ 1$ and the "equal protection clause" of the fourteenth amendment to the United States Constitution. But see note 11, infra, pointing out that the limitations cannot be equated, and that the state provision tends to be more restrictive.

The provision in Art. IX, $\S 9$, supra note 3, could conceivably be construed to apply a strict limitation upon municipal nonproperty taxes. However, local nonproperty taxes are subject only to the uniformity within classes limitation derived from Art. IX, $\S 1$. Article IX, $\$ 9$ has been construed to limit municipal property taxes only. See, for example, Harder's Fireproof Storage \& Van Co. v. Chicago, 235 Ill. 58, 85 N.E. 245 (1908). 
need only be reasonable classes, ${ }^{8}$ and the objects may be

\section{${ }^{8}$ For example:}

Retailers' Occupational (Sales) Tax. Because of the interpretation given Art. IX, $\S 1$ concerning the types of nonproperty taxes permissible [see note 13, infra] the Illinois retail sales tax is framed as a tax upon the occupation of making retail sales. The first such tax was imposed in 1933 and held invalid in Winter v. Barrett, 352 11l. 441, 186 N.E. 113 (1933). Under that tax farmers selling their own produce at retail and retailers of motor fuel were exempted. The court ruled that the act purported to be on "one class," those engaged in making sales at retail, and it was therefore held that the exemptions were arbitrary classifications. Thus, the court gave a very strict interpretation as to what might constitute a minimum class. A second such tax was imposed in the same year, and the above exemptions were eliminated. That tax was upheld in Reif v. Barrett, 355 Ill. 104, 188 N.E. 889 (1934), and it was also held that the exemption of "isolated sales" was not an arbitrary classification.

Cigaretie taxation. For the same reason mentioned under the Retailers' Occupational $T_{a x}$ [and sce note 13, infra] the legislature in 1941 enacted a Cigarette Tax Act which imposed a tax upon the occupation of distributing cigarettes. By a 1943 amendment the word "distributors" was defined so as to, in fact, include "users" of cigarettes bought in other states. The amendment was held to violate Art. IX, $\$ 1$, 『2 in Johnson v. Daley, 403 I11. 338, 86 N.E. 2d 350 (1949) as being an arbitrary classification-the inclusion of those within a class which are not in fact within that class. So, in 1951 the legislature passed the Cigarette Use Tax Act which purported to impose a tax on the privilege of using cigarettes in Illinois, taxing all users irrespective of where the cigarettes were purchased. However, distributors who were required to collect the "use" tax and who were subject to the "distributors" tax [the rate is the same under both taxes], were allowed to offset this amount by an amount required to be paid under the "distributors" tax. Thus, we have the complementary use tax structure, but drafted as it was because of the interpretation concerning permissible types of taxes. In Johnson v. Halpin, 413 Ill. 257, 108 N.E. 2d 429 (1952), the court held that the tax was a privilege tax and not a violation of the uniformity limitation. It was said that "all users" were taxed, thus all in the same class were treated alike, since "The statute does not tax only those users who buy their cigarettes out of the State."

Also see the following cases for examples of classifications found to be reasonable: In re Speed's Estate, 216 Ill. 23, 74 N.E. 809 (1905), aff'd 203 U.S. 553 (inheritance tax; holding that the exemption of devises to domestic charitable corporations was reasonable) and similarly see People v. O'Donnell, 327 Ill. 474, 158 N.E. 727 (1927); People v. Tatge, 267 


\section{further classified for the purpose of applying different rates.} The Illinois court has not ruled upon the validity of gradu-

Ill. 634, 108 N.E. 748 (1915) (inheritance tax; a proviso excluding devises to step-children from any exemptions under the tax held to be reasonable); People v. Deep Rock Oil Corp., 343 Ill. 388, 175 N.E. 572 (1931) (motor fuel tax; holding the tax to be upon the privilege of operating motor vehicles on the highways, and finding the classification under the act not arbitrary even though kerosene and electricity were excluded as motor "fuel"; the case is often cited as a leading case on these issues); Routt v. Barrett, 396 Ill. 322, 71 N.E. 2d 660 (1947) (privilege tax levied under Horse Racing Act; holding the tax valid, and rejecting the contention that there was no just distinction between horse racing and harness racing, the latter not being included within the tax); City of Metropolis v. Gibbons, 334 I11. 431, 166 N.E. 115 (1929) (local ordinance licensing moving picture theaters; held, moving picture theaters may be taxed as a class).

In the following cases the court held certain classifications to be arbitrary: Ohio Oil Co. v. Wright, 386 Ill. 206, 53 N.E. 2d 966 (1944) (oil production tax; where producers were limited to those owning the product when taken from the ground, thus excluding nonowning producers, an arbitrary exclusion; and see the discussion in the text, infra); City of Chicago v. Ames, 365 Ill. 529, 7 N.E. 2d 294 (1937) (public utility tax imposed on the gross receipts from sales of water, gas, or electricity supplied for domestic or commercial consumption and not for resale, thus excluding in fact receipts from such services supplied for industrial use; held, the exclusion constituted an unreasonable distinction in the class of those furnishing such services).

${ }^{9}$ See, for example: Kochersperger v. Drake, supra note 6 (inheritance tax; held, the classification of beneficiaries into six classes according to relation to the deceased for purpose of applying a different proportional rate to the property devised to each was reasonable); Metropolis Theater Co. v. Chicago, 246 Ill. 20, 92 N.E. 597 (1910), aff'd, 228 U.S. 61 (local ordinance, classifying theaters into five classes according to the price of admissions, and imposing an annual license tax increasing for each class; held, a reasonable classification); Braun v. Chicago, 110 Ill. 186 (1884) (local license tax, brokers, classified according to nature of business done, e.g., bankers, with different flat rates for each sub-class; held, uniform as to all within the same classes). In the following cases local vehicle taxes were held valid, the court finding classification of vehicles according to passenger capacity, number of horses drawing, horsepower, etc. for purposes of different rates to be reasonable: Melton v. City of Paris, 333 Ill. 190, 164 N.E. 218 (1928); McGrath v. Chicago, 309 Ill. 515, 141 N.E. 299 (1924); Ayres v. Chicago, 239 Ill. 237, 87 N.E. 1073 (1909); Harder's Fireproof 
ated rates under the uniformity within classes limitation found in the second clause of Art. IX, $\$ 1 .^{10}$ In general the Illinois court has followed the usual approach of liberally interpreting the classification limitation; however, some fairly recent decisions ${ }^{11}$ indicate that the second clause of Art. IX, $\$ 1$ of the Illinois Constitution may be given a more restrictive interpretation than is given to the federal equal protection clause.

A potentially serious limitation upon the power of the Illinois legislature to impose nonproperty taxes stems from the enumeration of taxable objects in the second clause of Art. IX, $\$ 1 .{ }^{12}$ The court has held that only three types of taxes may be imposed in Illinois, 1) ad valorem property taxes, 2) occupation taxes, and 3) franchise or privilege taxes. ${ }^{13}$ Thus, nonproperty taxes are limited to "occupation" and "franchise or privilege" taxes. However, this "limitation" can mean much or nothing depending on meaning given the terms "occupation," "franchise," and "privilege." There is every indication that "this limitation to three types of non-

Storage \& Van Co. v. Chicago, supra note 7. In Mutual Tobacco Co. v. Halpin, 414 Ill. 226, 111 N.E. 2d 155 (1953), the court held that the flat rate per cigarette (or pack) under the cigarette distributor's tax was reasonable in answer to the contention that to tax without regard to the differing value of cigarettes resulted in a tax not uniform in burden.

${ }^{10}$ However, in Magoun v. Illinois Trust \& Savings Bank, 170 U.S. 283, 18 S. Ct. 594 (1897) the United States Supreme Court, in a leading case, held that the progressive graduated rates then in effect under the Illinois inheritance tax did not violate the equal protection clause of the U.S. Constitution. See Chapter IV, infra.

${ }^{11}$ See Winter v. Barrett (retailers occupation tax), and Chicago v. Ames (Public Utilities Gross Receipts Tax), note 8, supra.

${ }^{12} \mathrm{Cf}$. the same problem under the Arkansas and Tennessee Constitutions, supra Chapter III, Part A.

${ }^{13}$ Bachrach v. Nelson, 349 Ill. 579, 588-589, 182 N.E. 909 (1932) is usually cited for this proposition. See Comment, "The Illinois Constitutional Requirement of Uniformity in Taxation," 33 Ill. L. Rev. 57 at 60-61, 80-81 (1938); Cushman, supra note 5 at 237-238. 
property taxes is not so restrictive as might first appear because of the broad scope which [the Illinois] Supreme Court has given to privilege taxes."14

Of course, it is of crucial importance in most instances that a tax be removed from the operation of the "proportionality clause" in Art. IX, $\$ 1$ if the tax is to be upheld. Thus, the nature of any given tax is of considerable importance. For purposes of uniformity of taxation the court has held that an inheritance tax was not upon property but on the privilege of succession. ${ }^{15}$ However, it has also held that a statute fixing a graduated "fee" to be paid in making application for letters of administration of estates was in fact a tax upon the property involved and a violation of the proportionality clause which limits property taxes. ${ }^{16}$

Income tax. ${ }^{17}$ In 1932 the Illinois legislature passed an act which imposed a personal net income tax with a graduated rate. ${ }^{18}$ The tax was immediately challenged, and in Bachrach

14 Cushman, supra note 5 at 237-238. Nevertheless, as that same writer points out, "In spite of these holdings, much uncertainty still exists as to the power of the General Assembly to make a given transaction rather than an occupation or employment a privilege for the purpose of taxation." Ibid. In addition, he states that such doubts had prevented the imposition of a general complementary use tax. But see the action taken as to the cigarette use tax, supra note 8. In that case, Johnson v. Halpin, the court clearly takes a dim view of a restrictive interpretation of the type of provision found in Art. IX, $\S 1$ and refers to the Arkansas restrictive interpretation as "a vague doctrine of tax immunity of natural or common rights."

${ }^{15}$ Kochersperger v. Drake, supra note 6, a leading state case on this issue.

${ }^{16}$ Cook County v. Fairbank, 222 Ill. 578, 78 N.E. 895 (1906), discussed under "property taxation," infra. Also see the taxes considered in the cases found in notes 8 and 9, supra.

17 See Comment, "Is Any Desirable Type of General Income Tax Constitutional in Illinois?" 35 Ill. L. Rev. 730 (1941) ; Note, "The Constitutionality of the Illinois Income Tax Law of 1932," 1 Univ, of Chi. L. Rev. 124 (1933) ; Barnett, "An Income Tax Law in Illinois," 27 Ill. L. Rev. $119(1932)$.

18 Ill. Laws 1931-32, First Spec. Sess., p. 91. 
v. Nelson ${ }^{19}$ the Illinois Supreme Court held that it violated the proportionality clause in Art. IX, $\$ 1$. Income was ruled to be property within the meaning of that clause, and the tax under consideration was said to be upon income, therefore upon property. ${ }^{20}$ Having brought the tax within the operation of the property tax uniformity clause, the court held that the graduated rate feature violated "the constitutional provision that all taxes must be levied on property according to valuation." ${ }^{21}$

Since it was decided that income itself was property, the court did not have to determine whether a tax upon income from property is a tax upon that property from which it was derived. However, the court did make a statement approving that doctrine, ${ }^{22}$ and in a subsequent case concerning the oil production tax, the court relied upon that proposition as being "decided" in the Bachrach case. It was in fact so held in the later case. ${ }^{23}$ Therefore, it would appear that taxation of income derived from property, even at a flat rate equal to that imposed on all other property, is subject to some constitutional doubt in Illinois. ${ }^{24}$

Oil Production Tax (Severance tax). In 1941 the Illinois legislature enacted the Oil Production Tax Act. ${ }^{25}$ Section 2

19349 I11. 579,182 N.E. 909 (1932).

$20 \mathrm{Id}$. at 591-595.

21 Id. at 595-596.

22 Id. at 595. In an earlier case, Young v. Illinois Athletic Club, 310 Ill. 75, 141 N.E. 369 (1923) the court had ruled that an income tax was not a tax upon the property from which that income was derived. However, the case concerned the liability for payment of the income tax upon rentals when by the terms of the lease the lessee covenanted to pay as additional rent all taxes levied upon the real estate, any interest of the lessor under the lease, or any tax the lessor was required to pay by reason of interest in the real estate.

${ }^{23}$ See discussion below.

24 But see Comment, 35 Ill. L. Rev., supra note 18 at 736.

25 Ill. Laws 1941, p. 1068. 
of that act purported to impose a tax "upon each person engaged in the business of producing oil in" Illinois. The tax was to be computed at a rate of $3 \%$ of the value of the oil produced. Among the definitions, found in section 1, was the following: " 'Producer' or 'person engaged in the business of producing oil' means any person owning oil or having a royalty interest therein at the time it is taken in this State, whether taken by him or some other person in his behalf." The entire tax was held unconstitutional in Ohio Oil Co. v. Wright. ${ }^{20}$ In brief, the court found that the tax was in part a property tax and in part an occupation tax. This classification was made because

a different situation [was] presented as to an oil company owning an interest in lands on which it [had] a right to drill wells and produce oil, and does by its operations produce oil, and that of an owner of land who [had] executed a lease or deed authorizing an oil company to go upon his land and explore for and procure oil. . . . ${ }^{27}$

As for the "mere" royalty owner-brought by statutory definition within the meaning of the term "producer"-the court held that the tax was in reality upon the royalties, that mineral royalties were rent, and as such, income. ${ }^{28}$ The court ruled that a tax upon the income derived from property was in reality a tax upon the property itself. Therefore, the tax under consideration was upon the property producing the

26386 Ill. 206, 53 N.E. 2d 966 (1944). See note 28, infra, as to relevancy of Friedrich v. Wright, 386 Ill. 229, 53 N.E. 2 d 974 (1944).

27 Id. at 211.

28 In the Ohio Oil Co. case there were no royalty owners parties to the case; however, the court dealt with every aspect of the tax, and in the companion case, Friedrich v. Wright, supra note 26 , the taxpayers were royalty owners. The court simply referred to the Ohio Oil Co. case as decisive. It was also held that to define arbitrarily as producers those who were not "in fact" producers, would be an unreasonable classification and violative of the second paragraph of Art. IX, §1. See note 8, supra. 
royalty (the mineral rights as real estate).$^{29}$ Therefore, the tax as to royalty owners was held to be a violation of the proportionality clause in Art. IX, $\S 1$, which governs the taxation of property. ${ }^{30}$

However, as to the company operating the lease and doing the actual production work, it was said that an occupation, or nonproperty tax might be properly levied. But the tax in question was held to violate the second clause in Art. IX, $\S 1$, which requires nonproperty taxes to be uniform within classes. ${ }^{31}$ This was so because "many persons properly in the business of producing oil were excluded." A producer who did not own or have a royalty interest in the oil at the time it was taken from the ground was "excluded from" the operation of the tax.

\section{(1) Property taxation}

Property taxes must conform to that degree of uniformity required by the proportionality clause in Art. IX, $\S 1$. Generally speaking, Illinois is known as having a constitutional limitation which requires the strictest degree of uniformity in the taxation of property. The reservation in section 2 of Art. IX ("The specification of the objects and subjects of taxation shall not deprive the general assembly" etc.) does not create exceptions to the proportionality clause, but refers only to nonproperty taxes. ${ }^{32}$ To the contrary, the court has ruled

29 Ohio Oil Co. v. Wright, supra note 26 at 212-214.

30 The court was not clear concerning the precise manner in which the tax violated the property uniformity clause. Probably the basis of this conclusion was that "double taxation" would have resulted. See the discussion under "property taxation," infra. Cf. People ex rel. Smith v. Cocn, 415 III. 73, 112 N.E. 2 d 119 (1953). However, some statements indicated the basis of the tax's invalidity was the ad valorem method requirement. There was no "valuation" by state officers.

31 Ohio Oil Co. v. Wright, supra note 26 at 218-222.

32 See, for example, Bachrach v. Nelson, supra note 13 at 587-588 (holding an income tax a property tax, and subject to the proportionality 
that the degree of uniformity required of property taxes is affected by the second clause of Art. IX, $\S 1$ :

... but the general assembly shall have power to tax peddlers, auctioneers, brokers, hawkers, merchants, commission merchants, showmen, jugglers, innkeepers, grocery keepers, liquor dealers, toll bridges, ferries, insurance, telegraph and express interests or business, vendors of patents, and persons or corporations owning or using franchises and privileges, in such manner as it shall from time to time direct by general law, uniform as to the class upon which it operates.

This rather unusual interpretation given the second clause of Art. IX, $\S 1$ has been the basis in recent years for making an exception to the strict property tax uniformity requirement. This development is discussed in detail under the subject of "effective rates."

Of course, under this type of basic uniformity clause property must be taxed by the ad valorem method. Specific property taxes violate Art. IX, $\S 1 .^{33}$ There is a strict rule of universality which forbids both the omission of taxable property from the general property tax ${ }^{34}$ and the positive exemp-

clause) ; People's Loan \& Homestead Ass'n v. Keith, 153 Ill. 609, 623-624, 39 N.E. 1072 (1894) (Section 2 not intended to permit exemptions of property not enumerated in section 3 of Art. IX). See note 35, infra.

${ }^{33}$ People v. Cook County, 221 Ill. 493, 77 N.E. 914 (1906), holding that a statute was unconstitutional which provided for a specific amount per acre of land to be paid on land from which certain obnoxious weeds were removed by the county. The court held that the statute imposed a "tax," not at "special assessment," and was therefore a violation of Art. IX, $\$ 1$ because it was not levied with regard to the value of such property. But see the early case, Rhinehart v. Schuyler, 7 Ill. 473 (2 Gilman) (1845), discussed in note 39 , infra.

${ }^{34}$ A statutory failure to select all taxable property in the taxing jurisdiction invalidates the entire tax, Primm v. Belleville, 59 Ill. 142 (1871); Crane v. West Chicago Park Com'rs, 153 Ill. 348, 38 N.E. 943 (1894). In both of those cases a purported "special assessment" was held to be, in fact, a "tax." Therefore the selection of realty to the exclusion of person- 
tion of such property. ${ }^{35}$ The universality limitation has been derived both from the proportionality clause in Art. IX, $\S 1$, and the enumeration of exemptible classes of property in Art. IX, §3. Section 3 creates an exception to the rule of uni-

alty violated the rule of uniformity in Art. IX, $\$ 1$. In the Primm case the provision in question was Art. IX, $\$ \S 2,5$ of the 1848 constitution. See note 1, supra. However, the court has also held that the failure of a ministerial officer to carry out the statutory mandate to list all taxable property will not invalidate a tax. Dunham v. Chicago, 55 Ill. 357 (1870) (under the 1848 constitution, see note 1, supra) ; Spencer and Gardner v. People, 68 Ill. 510 (1873) ; People v. Lots In Ashley, 122 Ill. 297, 13 N.E. 556 (1887); People v. Missouri Pac. R. Co., 301 Ill. 541, 134 N.E. 314 (1922), distinguishing People v. Noyes, 295 Ill. 355, 129 N.E. 151 (1920); and see the cases in note 49, infra; but see People ex rel. Wangelin v. Wiggins Ferry Co., 357 Ill. 173, 191 N.E. 296 (1934), note 48, infra.

${ }^{35}$ See the leading case of People's Loan \& Homestead Ass'n v. Keith, supra note 32 , in which the court held a statute unconstitutional which provided that the stock and notes of building and loan associations should not be subject to taxation. The statute was construed to be an exemption statute, and the court said (at p. 618): "Under section 1 of article 9 of the constitution ... it is plain that the burdens of taxation were intended to be cast equally upon all the property of the State, of every description." $\mathrm{Had}$ it not been for Art. IX, $\$ 3$, listing exemptible property, the legislature would have no power in any case to enact laws exempting property from taxation. It was said that the enumeration of exemptible property in Art. IX, $\S 3$ is also "a clear limitation upon the power of the legislature to exempt any other property." Thus, the statute violated both sections of Art. IX. Relied on in In re St. Louis Loan \& Investment Co., 194 I11. 609, 62 N.E. 810 (1902), holding invalid a statute providing that capital stock and shares on which loans had been procured were not to be taxed.

Also see People v. National Box Co., 248 Ill. 141, 93 N.E. 778 (1910), in which the court had to construe a statute providing for the assessment of the capital stock of certain corporations by state officers. The court ruled that, if the statute were construed to imply that the capital stock of all other corporations was exempt, it would violate the proportionality clause, Art. IX, §1. Therefore, it was held that local assessors had to assess the capital stock of corporations not listed for state valuation. The same result was reached in Consolidated Coal Co. v. Miller, 236 Ill. 149, 86 N.E. 205 (1908); and see Oak Ridge Cemetery Corp. v. Tax Comm'n, 299 Ill. 430, 132 N.E. 553 (1921). In People v. First Congregational Church, 232 IIl. 158, 83 N.E. 536 (1907) held that a statute exempting parsonages 
formity established by section 1 . And the enumeration of exemptible property in section 3 is said to preclude the exemption of any other property. ${ }^{36}$ The rule of universality may not be avoided by use of an "in lieu" nonproperty tax. ${ }^{37}$

violated Art. IX, $\S \S 1$ and 3 because parsonages was a broader class of property than the class described as "exclusively religious" in section 3. Also see People ex rel. Lloyd v. University of Illinois, 357 Ill. 369, 192 N.E. 243 (1934), based on: People ex rel. Olmstead v. University of Illinois, 328 I11. 377, 159 N.E. 811 (1928); People v. Deutsche Gemeinde, 249 Ill. 132, 94 N.E. 162 (1911); Supreme Lodge M.A.F.O. v. Board of Review, 223 Ill. 54, 79 N.E. 23 (1906).

${ }^{36}$ See the cases in note 35 , supra.

${ }^{37}$ See Report of the [Illinois] Revenue Laws Commission 201-219 (Springfield, 1949) and the cases there analyzed in discussing the question: "Would it be constitutional to repeal the provisions of the Revenue Act relating to the assessment and taxation of the capital stock of domestic corporations and substitute in lieu thereof a supplemental franchise tax on both domestic and foreign corporations measured by net income from business carried on in this State?"

In the other states having a rule of universality the courts have agreed with the proposition stated in the text. (But see Oklahoma, infra text at notes 9-21, Chapter III, Part G.) Any apparent exception to the rule in Illinois has its roots in a decision sustaining the Illinois Central gross receipts tax imposed in lieu of all state and local taxes. See Illinois Central R. Co. v. McLean, 17 Ill. 291 (1855). This arrangement was a part of the original charter of the railroad. Priv. Laws, 1851 , p. 61, $\S 18,20$; I1l. Ann. Stat., c. $120, \S \S 373-374$. The court has consistently viewed this arrangement as a contract, subject to all the protection of the state and federal constitutional limitations concerning the impairment of the obligations of contract. See, for example, Illinois Central R. Co. v. Emmerson, 299 Ill. 328,132 N.E. 471 (1921). At the time this arrangement was originally entered into, there was no provision in the governing constitution of 1848 which prohibited the commutation of taxes. The present constitution of 1870 (Art. X, §6) does prohibit the commutation of state taxes. However, in a special section (11l. Const. 1870, Separate Sections: $\S 1$ ) the constitution also sanctions the continuance of the special Illinois Central gross receipts tax with its in lieu features.

Apart from the contract aspect of this anomalous arrangement, the McLean case, supra, and other later cases, in upholding the tax relied to some extent on the second clause of Art. IX, §1, finding authority therein for the legislature to impose an in lieu tax for taxes on property owned by those enumerated. The loose language of the McLean case was picked up and 


\section{(a) Effective rates, generally}

The Illinois legislature has made no attempt to impose a systematic classified property tax. The Illinois general property $\operatorname{tax}^{38}$ has remained basically unchanged since shortly after the admission of Illinois to the Union. ${ }^{39}$ All property is

elaborated on in the Porter case, infra note 87 , discussed in relation to effective rates. See the text at notes 86-115, infra. As suggested in the text, the only issue in the Porter case concerned the power of the legislature to classify property for the purpose of using different methods of valuation. See text to note 92 , infra. Nevertheless, the unwarranted dictum has been the source for controversy concerning exemptions as well as the more important controversy concerning classification of property for effective rates, as discussed in the text. See, e.g., note 100, infra. However, other than the Illinois Central Railroad gross receipts tax cases, only one case has actually had an in lieu tax issue involved for decision. In Raymond v. Hartford Fire Ins. Co., 196 Ill. 329, 63 N.E. 745 (1902), the court was faced with determining the validity of a $2 \%$ tax on the gross premiums of foreign insurance companies (other than life), the tax to be in lieu of all other taxes other than taxes on the real estate of such companies. The court, on the basis of the McLean decision, supra, and the dictum in the cases cited in notes $87-91$, infra, did indicate that the in lieu provision would have been valid insofar as it was in lieu of state taxes. Authority for this proposition was found in the second clause of Art. IX, $\$ 1$. Because of this authorization the commutation clause (Art. IX, §6) was said to be no obstacle. However, the tax was declared to be unconstitutional as a violation of the uniformity clauses limiting local taxes, Art. IX, $\S \S 9,10$. See notes 3 and 4, supra. Those local uniformity clauses were said to prohibit taxes in lieu of local property taxes because they were not coupled with the second clause of Art. IX, $\$ 1$.

On the basis of an extensive analysis of the above and other opinions the writer in the Report, supra, concludes that such an in lieu tax would not now be constitutional. No distinction was made as to state taxes on property because there was, in fact, no state rate at the time. Thus, practically, the problem concerned only relief from local property tax rates. However, the author calls attention to the controversy caused by broad unwarranted dictum found in the cases concerning the method used to value property, notes 87-91, infra. The controversy stems from the peculiar construction given the second clause of Art. IX, $\S 1$.

${ }^{38}$ At present this is the Revenue Act of 1939 as amended, Ill. Ann. Stat. c. $120, \S \S 482-811$.

${ }^{39}$ However, until 1839 the Illinois property tax was both a selective tax and a specific tax. Land was the principal item taxed, but a few items of 
subject to the tax, unless specifically exempted, and is to be extended on the tax rolls at its "fair cash value." The same percentage rate is applied to all property taxed by any taxing district. This is the statutory scheme-the facade. The factual picture has long been quite different from that set forth in the statutes. At times a single ratio of valuation of less than $100 \%$ is applied in a roughly uniform manner throughout a taxing district. However, especially since the early part of this century, the assessors of several local units (counties in

personal property were also subject to taxation. See Report, supra note 37 at 1 (1949), and the preface to the Revenue Act of 1939 by the Illinois Tax Commission, reprinted, 11l. Stat. Ann., c. 120, p. 186. Also see Jensen, Property Taxation in the United States 45-47 (1931) for a historical account of early taxation in Illinois.

By the Act of Feb. 18, 1823 all lands were to be divided into three classes: "first quality," "second quality" and "third quality" respectively. Property was to be declared by the owner as to which class it belonged. The classes were arbitrarily valued at four, three, and two dollars per acre respectively. A tax of $1 / 2$ of 1 per cent was imposed and town lots were exempt. In Rhinehart v. Schuyler, supra note 33, that tax was upheld against the contention it violated the proportionality clause in the first constitution of 1818 . See note 1, supra. Two judges dissented, believing that property was exempted and that the tax was specific. The case was an action of ejectment brought in 1845 to recover possession of a plot of land bought at a tax sale for taxes due under the prior tax act. One defense was that the revenue act, under which the land in question was assessed and subsequently sold for taxes, was unconstitutional and void because the tax was specific and not ad valorem. The majority anticipated its conclusion when it stated the very practical situation which it faced (at p. 496-497): "The most solemn acts of the legislature, long acquiesced in, have been denounced as unconstitutional. Titles to valuable estates, acquired under them, are questioned; and the whole tax laws of the State, from the very commencement of its government down to the year 1829, are declared to have been passed without authority, and against the express provisions of the constitution." Stressing the practical difficulties which would have been faced in those earlier years in attempting to value all property in the state, the majority concluded that the system used was the "best system, and the only mode by which uniformity of taxation can be secured." The Rhinehart decision has been since ignored. The decision is not hard to understand when seen against its factual background. In addition, at the time it was made, the present general property-tax system had been introduced. 
particular) have enforced a de facto classified general property tax. Property has been classified by the local assessor, and the several classes extended on the tax rolls at varying ratios of valuation. The result is a de facto classified effective rate. ${ }^{\mathbf{4 0}}$

Since there has been no statutory scheme for a classified property tax, the court has had few occasions to pass upon the requirement of uniformity in percentage rates. However, it is quite clear that the Illinois court interprets the proportionality clause of Art. IX, $\S 1$ as requiring absolute uniformity in the percentage rate ${ }^{41}$ applied to all property taxed by any single taxing authority. ${ }^{42}$

${ }^{40}$ See, for example, Cushman, supra note 5 at 235-236; Report, supra note 37 at $30 \mathrm{ff}$. (1949).

41 Bachrach v. Nelson, supra note 20 (holding an income tax to be on the income as property, and the graduated rate feature to be a violation of the proportionality clause); Cook County v. Fairbank, supra note 16 (graduated probate fee held to be in fact upon the property of the estate, thus the graduated rate would violate the proportionality clause). In addition, "double taxation" would violate the requirement of absolute uniformity in rates. Thus, in the Cook County case the additional fee would have been an invalid "double taxation" of the property involved which was also taxed under the general property tax. See Friedrich v. Wright, supra note 26, following Ohio Oil Co. v. Wright, supra note 26, and holding that an attempt to tax royalty owners under the oil production tax (see notes 25-30, supra) was in fact upon the royalty received. It was further held that to tax the income from land (royalty is rent, rent is income, so reasoned the court) was to tax the land itself in violation of the proportionality clause. The opinion was not too clear, but apparently the court conceived of this as an example of the prohibited "double taxation." At the time there was no state property tax, and the oil production tax was a state tax. Therefore it would have been irrelevant to add this burden on land taxed to the burden imposed by local units because to have "double taxation" the two taxes must be by the same taxing authorities. Board of Highway Com'rs v. Bloomington, 253 111. 164, 97 N.E. 280 (1912). The court has held that the taxation by the same taxing authority of corporate tangible property to the corporation and taxation of shares in the corporation to the holders thereof was not "double taxation." Danville Banking \& Trust Co. v. Parks, 88 Ill. 170 (1878); Illinois Nat. Bank v. Kinsella, 201 Ill. 31, 66 N.E. 338 (1903).

42 Since the limitation is "territorial," a comparison of rates between 


\section{(b) Effective rates: ratio of valuation}

The de facto classification system introduced by local assessors is conceded by some writers to be a realistic adjustment to the facts of economic life. ${ }^{43}$ Indeed, there are those who feel that the system is not likely to be upset by the court even though found to be illegal. ${ }^{44}$ Nevertheless, such a system is not above constitutional standards. Since the Illinois Supreme Court has ruled that universality and absolute uniformity in percentage rates are required, one would expect the rationale supporting such rules to support a further rule requiring absolute uniformity in the effective rate applicable to all property taxed by any single taxing authority, thus requiring absolute uniformity in ratio of valuation as well as percentage rate. If either the percentage rate or the ratio of valuation may vary for classes of property, it becomes obvious that there is little sense in requiring the other factor of the effective rate to be the same for all property taxed..$^{\mathbf{4 5}}$

property taxes imposed by different taxing authorities is irrelevant. Anderson v. City of Park Ridge, 396 Ill. 235, 72 N.E. 2d 210 (1947). Also see People ex rel. O'Connell v. Chicago \& W.I.R. Co., 256 Ill. 388, 100 N.E. 35 (1912).

${ }^{43}$ For example, Cushman, supra note 5 at 236: "Using this de facto classified property tax, Mr. Clark [the County Assessor of Cook County], has ... done as good a job as any assessor in the state with an unworkable personal property tax system." See the Report, supra note 37 at 37-38 (1949), pointing out that the equitable result depends upon the assessor: “. .. [T] he state does have an extra-legal system of administrative classification. This system . . o operates in a most discriminatory and inequitable manner. In Downstate counties, especially, it is haphazard, arbitrary, and grossly lacking in uniformity. A few years ago the Assessor of Cook County attempted to improve personal property assessment in that county by setting up an administrative system of classification of certain types of personal property." After describing that system, the writer concludes: "Although the system of classification used in Cook County is without legal authority, it represents a sincere effort to improve personal property tax assessments."

44 Cushman, supra note 5 at 236.

45 See the general discussion on this problem in Chapter I, supra. 
It will be helpful to make a summary statement of the detailed analysis to follow. Until approximately 1935 one could conclude that a rule of absolute uniformity applied to effective rates and that the rule was derived from the proportionality clause in Art. IX, $\S 1$. Broad language is found in some opinions which, when taken out of context of actual decision and attendant facts, might support a conclusion that only uniformity within classes is required of the ratio of valuation-at least, for certain classes of property. ${ }^{46}$ However, this was never actually decided by the court. Indeed, the court was never really faced with any contention that classification for such purposes was permissible. In those cases the opinions of which contain language susceptible of being interpreted as approval of classification for such purpose appears, the court was in reality faced only with this question: could property be classified for the purpose of using different methods of valuation, the aim purportedly being to ascertain the full value of all classes of property? In other cases the court consistently paid lip service to the rule of strict uniformity. However, it is not unusual to find in those cases in which the court pronounced most vigorously the rule of absolute uniformity in ratio of valuation, that the court also placed an obstacle in the way of the rule's enforcement. That obstacle took the form of procedural requirements and available remedies. Thus, until about 1935 , the court held firm to the rule of absolute uniformity with no announced exceptions. In fact, it was long obvious that the rule was an ineffective constitutional limitation, being honored more in the breach than in the observance. ${ }^{47}$

During the period from 1935 to 1946 the court decided certain cases of considerable significance which appear to reverse, to some extent, the prior interpretation of Art. IX,

40 See the cases discussed in notes 87-92, infra.

${ }^{47}$ See note 40 , supra. 
$\S 1$ as it limits property taxation. It appears now that at least some property may be classified for the purpose of applying different ratios of valuation, thereby achieving a classified effective rate. In part this results from the unusual interpretation given to the second clause of Art. IX, $\S 1$.

The cases which bear upon this problem may be placed into three significant groups. First, there are those cases which concern the taxation of property, in general, by the general property tax, with such property being valued by local authorities for application of the local rates. Second, there are those cases concerning the taxation of railroad property by the general property tax, with such property being valued by state officers and apportioned to the counties through which the railroads run for application of the local property tax rate. Third, there are those cases concerning the taxation of the capital stock of corporations at the general property tax rate by the "Capital Stock Tax," with such capital stock being valued by state officers and entered on the tax rolls at that value for the county tax rate. A different approach has been taken by the Illinois court in each of these three groups of cases in approving-tacitly or expresslyclassification of property for the purpose of applying different ratios of valuation.

(i) General Property Tax: Valuation of property by county officers for application of county rates. In the cases concerning this situation it could safely be said, until 1935, that the Illinois Supreme Court in its decisions (purportedly), as well as in its words, adhered to the view that the proportionality clause of Art. IX, $\S 1$ required absolute uniformity in the ratio of valuation used by any taxing jurisdiction. Thus, if a ratio of valuation other than "fair cash value" ( $100 \%$ ratio, as required by statute) was actually used by county assessors in valuing property for entry upon the tax rolls, then that ratio had to be applied to all property 
alike. ${ }^{48}$ The opinions of the court, although at times not too precisely formulated, never deviated from this view.

${ }^{48} \mathrm{See}$, for example, the following cases in which the taxpayer alleged that a ratio of valuation was applied generally to all property in the county, and that the ratio was lower than that used for taxpayer's property. In People ex rel. Wangelin v. Gillespie, 358 Ill. 40, 192 N.E. 664 (1934), the court stated as the rule: if an assessor intentionally rejects a statutory provision and generally assesses property for taxation at substantially less than true or market value, then all property in the same district must be assessed on the same ratio. However, this "rule" was reduced to dictum because the decision actually turned on the proposition that there had been a "fraudulent" overvaluation of taxpayer's property above its "actual" value. In People ex rel. Wangelin v. St. Louis Bridge Co., 357 Ill. 245, 191 N.E. 300 (1934), the court found that, notwithstanding the statutory requirement of actual value, evidence showed that the taxing authorities in the county, in disregard of the statute, assessed property generally, both real and personal, at from $37 \%$ to $40 \%$ of actual value. Relying on Art. IX, $\S 1$, the court held that a ratio of not to exceed $40 \%$ of fair cash market value, as adopted by the county, must be applied to the property of the taxpayer. People ex rel. Wangelin v. Wiggins Ferry Co., supra note 34, is a leading case, in which the evidence showed that the customary ratio of valuation used by the board of the county was about $40 \%$. In one of the clearest statements of the meaning of Art. IX, $\S 1$, the court said (at p. 180):

[It is the intent of Art. IX, $\S 1$ ] that one class of property within the municipality should not be assessed at one value while the same class of property similarly situated, in the same community, should be assessed at a grossly higher value. Uniformity in taxation by this method is thwarted. The command of the constitution is equality and uniformity of taxation. ... The assessment of all property, regardless of whether it is owned by an individual or corporation, must, therefore, be made at its proportional value. This rule applies not only to the fair cash market value of the property, but where a factor has been adopted by a taxing body or taxing officials by which property is listed for taxation purposes below its market value, the same factor must be applied equally to other property in order to secure uniformity of taxation. [Emphasis added.]

The very significant statement was then made (at p. 181), that "The duty to assess the full valuation cannot be supreme unless applied to all tax-payers alike, and where it is impossible to secure both the standard of full value and the uniformity and equality required by section $I$. . . the command of the constitution must be adopted as fundamental law [Emphasis added]." Cited for this proposition were the Stuckart and Bureau County cases, infra 
However, it is clear that the enunciation of this rule in a number of cases was so hedged by remedial limitations that the result was a "rule" having no real relationship to the facts supposedly governed by that "rule." This was particularly clear in a series of cases decided from 1932 to 1934 which resulted from the so-called "tax strike" which occurred in Cook County and elsewhere in 1932. In these cases the taxpayers alleged that substantially different ratios of valuation were applied to different classes of property as established by the county assessors, and that some personal property was entirely omitted from the tax rolls, with the result that property extended on the rolls at the higher ratios of valuation bore a disproportionate part of the tax burden. ${ }^{49}$

notes 93 and 72, respectively. It was held that the court below erred in not sustaining an objection of the taxpayer in an action for delinquent taxes, because the taxpayer had paid a tax computed on the basis of $40 \%$ of the actual cash value of its property and a collection of a greater amount was not justified by the record. It may be noted that the court found that there was no failure to exhaust statutory remedies. Thus, we have a case in which the court actually extended relief where the "illegal" action was wholly that of ministerial officers. Cf. notes 34, supra, and 52, infra. Also sce the following cases: People v. Keokuk \& Hamilton Bridge Co., 287 Ill. 246, 122 N.E. 467 (1919); People ex rel. Miller v. Chicago B. \& Q. R. Co., 300 Ill. 399, 133 N.E. 325 (1921); and People ex rel. Carr v. Stewart, 315 Ill. 25, 145 N.E. 600 (1924). However, in the two early cases, Spencer and Gardner v. People, supra note 34, and People v. Lots in Ashley, supra note 34 , the court stated as a rule that the mere omission by ministerial officers of taxable property from the roles, or the assessment at less than the statutory requirement of $100 \%$ ratio, would not affect the validity of the tax imposed on other property in the county, and that the court had no power to "revise" an assessment in the absence of "fraud," that "mere error" was not sufficient. Also see, for example, the cases in note 49, infra, in which the taxpayer alleged that a ratio of valuation was systematically applied to another class of property, and that the ratio used was lower than that applied to a class of property to which taxpayer's belonged.

$49 \mathrm{~A}$ leading case is Bistor v. McDonough, 348 Ill. 624, 181 N.F. 417 (1932), in which it was sought to enjoin the collector of Cook County from seeking recovery of a judgment for general taxes levied on plaintiffs' property for 1929. It was alleged (1) that the officers had intentionally and 
The taxpayers either requested injunctions against collection of the alleged excessive amount of taxes due, or described the situation as a defense against the alleged excessive amount due in an action for delinquent taxes.

The court continued its verbal adherence to the rule of absolute uniformity, stating that such factual situations as alleged were violations of both the proportionality clause and the statutory requirement of "fair cash value." However, the court, after stating its position concerning the "illegality" of such de facto classification systems, proceeded to dismiss the

fraudulently failed to asscss some personal property and had under-assessed other personal property, all in violation of Art. IX, $\$ 1$, because realty was compelled to bear a disproportionate burden of taxation, and (2) that plaintiffs were willing to pay a tax on a uniform ratio of valuation for all property. After characterizing plaintiffs' position as being a claim of discrimination in favor of personal property with the result that the levy was void to that extent, the court (p. 629) gave lip service to the rule of absolute uniformity. It said that Art. IX, $\S 1$ requires one person not to be compelled to pay a greater proportion of taxes according to the value of his property than another, that uniformity of taxation implies uniformity of burden, and that this equality cannot exist without uniformity in the basis of assessment as well as the rate of taxation. It was further said (p. 632) that when it is impossible to secure both the standard of "true value" and the uniformity and equality required by Art. IX, $\S 1$, the latter is preferred as achieving the ultimate purpose of the law, and therefore plaintiffs had a right to have the assessments of their rcalty be equal and uniform "with all other property." However, the court asserted, one must exhaust remedies at law before a court of equity will interfere, and in this case plaintiffs had failed to avail themselves of legal remedies. It was said (p. 634) that plaintiffs had not asked the Board of Review to revise the assessments upon realty. The rule of Spencer and Gardncr v. Pcople, supra notes 34, 48 was repeated, namely, that neither omission to assess nor undervaluation of one kind or class of property will invalidate assessments upon other property in the same jurisdiction. Other cases were: Koester v. McDonough, 351 Ill. 492, 184 N.E. 826 (1933); People ex rel. Koester v. Board of Review of Cook County, 351 I1l. 301, 184 N.E. 325 (1933); and People ex rel. McDonough v. Cesar, 349 IIl. 372, 182 N.E. 448 (1932). For a similar result see the earlier case of First Nat. Bank v. Holmes, 246 Ill. 362, 92 N.E. 893 (1910). 
contentions of the taxpayers. The basis for this result was the rule that neither the ministerial omission of taxable property from the tax rolls nor the ministerial undervaluation of one kind or class of property will invalidate the assessments upon other property in the same jurisdiction. ${ }^{50}$ The only remedy the taxpayer has is mandamus, requiring the taxing officers to perform their duty properly.

In 1935 the court, although using language which might be construed as following the orthodox rule, in fact enforced a de facto classification system. In People ex rel. McDonough v. $S c h m u h l^{51}$ the action was for judgment against and sale of certain realty for the delinquent general property tax due in 1928 to Cook County. The taxpayer paid part of the tax and objected to the balance on two grounds. First, it was alleged that the Board of Review of Cook County had valued the premises in question at more than two and one-half times the "fair cash value." Second, it was alleged that the Board of Review of Cook County intentionally applied a ratio of valuation of $37 \%$ to realty in the county at large and a ratio of $20 \%$ to realty in the "loop" district of Chicago in violation of Art. IX, $\$ 1$.

Interestingly, the court used language which seems to support the orthodox rule and cited other cases which do support that rule. ${ }^{52}$ However, at the same time, the court stated that the pleadings admitted that the allegations showed such a disparity and discrimination "between the fair cash value of appellant's property and the valuation for taxation placed on

${ }^{50}$ But see the results in People ex rel. Wangelin v. Wiggins Ferry Co., supra notes $34,48$.

51 359 Ill. 446, 194 N.E. 731 (1935).

52 Id. at 449: "No tax-payer can be required to pay a greater proportion of the taxes, according to the value of his property, than any other taxpayer," citing the Bureau County case, infro note 72 . The assessments of taxing authorities "must be at the same proportionate value." 
other property of the same class as to entitle him [the taxpayer] to relief." "\$s The court concluded:

Appellant was entitled to have property assessed upon the same basis of valuation as other property. It is admitted that other property was assessed at $37 \%$ of its actual value. Appellant's property should have been assessed on that basis. ${ }^{54}$

Therefore, it was held that the judgment below for the county collector was reversed, and the cause was remanded with directions to enter a judgment for such amount as resulted from the application of the $37 \%$ factor to the value placed upon appellant's real estate for the year 1928.

Since the court stated that the allegations were admitted by the pleadings, the "facts" were as follows: realty in the "loop" was debased to $20 \%$; realty in the county at large was debased to $37 \%$; the property of the taxpayer was in the county at large, and overvalued to two and one-half times its actual value. The court ordered its final valuation reduced to $37 \%$ - the ratio used for the "class" of property to which taxpayer's property belonged, the "class" being characterized by location. The actual result of the decision makes meaningful the statement of the court first quoted above, in which the phrase "other property of the same class" is used. This language implicitly changes the phrase in the second quote to read "other property of the same class was assessed at $37 \%$." Thus we find the enforcement of a de facto classification system. ${ }^{55}$

In two cases decided since 1935, People ex rel. Toman v. Olympia Fields Country Club ${ }^{56}$ and People v. Southwestern

${ }^{53}$ Id. at 450 . Emphasis added.

${ }^{64}$ lbid. Emphasis added.

${ }^{55}$ Cf. the result in People ex rel. Schlaeger v. Allyn, 393 Ill. 154, 65 N.E. 2d 392 (1946), infra note 68, in which the court by its inaction actually enforced a de facto classification system.

${ }^{56} 374$ Ill. 101, 28 N.E. 2d 109 (1940). 


\section{Bell Tel. Co., ${ }^{57}$ the court has used language which clearly} implies that property may be classified for the purpose of applying different ratios of valuation without violating Art. IX, $\S 1 .^{58}$ However, the facts in those cases were such that no such variation was proved. Consequently, the actual decision of the court in either case was not contrary to a rule of absolute uniformity, and the language in question was reduced to dictum. It is significant that in the Southwestern Bell case, in which the strongest language concerning permissible classification was used, there was a dissent ${ }^{59}$ which pointed to the implication of the language used by the majority and re-

87377 Ill. 303 , 36 N.E. 2 d 362 (1941).

58 For example, in the Olympia Fields Country Club case, supra note 56, the issue was whether taxpayer's property was "fraudulently" overvalued, and whether it was proper to compare the value placed on property of a similar kind, similarly situated. However, the court made the broad statement (at p. 103):

Section I of article 9 . . requires that taxation shall be by general law uniform as to the class upon which it shall operate. The court adheres to the doctrine that this provision of the constitution means uniformity as applied to a class. No prohibition against classification of property and taxpayers into different classes can be read into the constitution.

In the Southwestern Bell case, supra note 57 , it was alleged that varying ratios were used as between realty and personalty. However, the court found that the percentage alleged was actually used only to lower or raise the value of some particular items of property in order to achieve an accurate valuation. Nevertheless, the court said (at p. 306):

This court has always recognized that all laws relating to taxation and the enforcement thereof by taxing bodies are subject to the requirements of equality and uniformity of taxation. We have construed the command for uniformity to mean that taxation must be uniform as to the class upon which it operates and that the uniformity demanded applies to property of like kind and character and similarly situated.

59 Two judges dissented in the Southwestern Bell case on the ground that they agreed with the taxpayer's interpretation of the facts. Murphy dissented for that reason and for the reason that the language seemed to imply that Art. IX, $\$ 1$ does not require uniformity in debasing valuations as between various classes of property. 
jected such words if they were taken to mean that property could be classified for effective rates.

However, at substantially the same time that the two above decisions were made, the court decided two other cases, Tuttle v. Bell ${ }^{00}$ and People ex rel. Toman v. Pickard, ${ }^{61}$ which clearly condemn any classification system for effective rates. ${ }^{62}$ In both of these cases taxpayers alleged the existence of a de facto classification system for applying different ratios of valuation. In the Tuttle case the court condemned the system as illegal but gave no injunctive relief as requested, falling back upon the rule that improper action by ministerial officers was not a ground for reduction of the value of taxpayer's property. ${ }^{63}$ But, as in the earlier cases, the court used some of its strongest and most unequivocal language in declaring such a factual situation "illegal," while at the same time doing nothing about it. ${ }^{64}$ In the Pickard case the court also squarely restated the rule of absolute uniformity, saying:

This court has held many times that [where assessors extend taxes on a percentage of fair cash value] such factor should be uniformly applied as to all property within the same jurisdiction. ${ }^{65}$

60377 I11. 510,37 N.E. $2 d 180$ (1941).

${ }^{61} 377$ Ill. 610,37 N.E. 2d 330 (1941).

${ }^{62}$ Also see People ex rel. Tedrick v. Allied Oil Corp. of Illinois, 388 Ill. 219, 67 N.E. 2d 859 (1944); People ex rel. Tennyson v. Texas Co., 406 Ill. 120, 92 N.E. 2d 142 (1950).

63 Tuttle v. Bell, supra note 60 at 514.

${ }^{64} I d$. at 513 , saying:

The constitutional provision [Art. IX, §1] precludes the taxing officials from adopting a method of valuing property whereby there is a discrimination in favor of or against any class of property. . . . This rule applies not only to the fair cash value of the property, but where an equaling factor has been adopted by a taxing body or taxing officials by which property is listed for taxation purposes below its fair cash value, the same equaling factor must be applied equally to other property in order to secure uniformity of taxes.

65 People ex rel. Toman v. Pickard, supra note 61 at 614. 
However, there was no necessity to pass upon the legality of the alleged classification system because the court found that no disparity in ratio of valuation was proved.

(ii) General Property Tax: Valuation by officers of one taxing authority with application of rate of another taxing authority with noncoterminous boundaries. For some years prior to 1945 the statutory scheme for determining the final value of property to which the percentage rates of the several taxing authorities might be applied was as follows: ${ }^{08}$ The state tax rate was to be applied by the county clerks to the property in their respective counties upon the valuation produced by the equalization and assessment of property by the State Tax Commission (at one time designated the Board of Equalization). All other tax rates (counties and other local units) were to be applied to the valuation produced by the equalization and assessment of property by the county officers, except for that property originally assessed by the State Tax Commission for which the valuation of the state officers was to be used. This latter property consisted of railroad property and the capital stock of some corporations. ${ }^{67}$

This system presented the following problems as to uniformity of taxation. Suppose special tax district $\mathrm{X}$ overlapped counties $A$ and $B$. In county $A$ an assessment ratio of $40 \%$ was used for all property taxed. In county $B$ an assessment ratio of $80 \%$ was used for all property taxed. Therefore, when the percentage rate of district $\mathrm{X}$ is applied to two items

${ }^{66}$ Ill. Laws 1939 , p. $886, \S 163$; Ill. Ann. Stat. c. $120, \$ 644$.

${ }^{67}$ Under the revenue act the capital stock of all domestic corporations, "except companies and associations organized for purely manufacturing and mercantile purpases, or for either of such purposes, or for the mining and sale of coal, or for printing, or for the publishing of newspapers, or for the improving and breeding of stock, or for banking, or for building and loan purposes," is assessed by the State Department of Revenue. The "exceptions" are assessed by local officers. Ill. Laws 1939, p. 886, \$21; Ill. Ann. Stat. c. $120, \S 502$. 
of property of equal value but located in different counties, the property in $\mathrm{B}$ county will pay twice the amount to district $\mathrm{X}$ that the property in A county pays. Obviously a disparity based upon geographical location exists in the effective rate and tax burden of district X. When the court was faced with just such a situation in People ex rel. Schlaeger v. Allyn ${ }^{68}$ it figuratively threw up its hands, condemned the situation as a violation of uniformity in taxation, but felt that it was a situation beyond its power to correct, ${ }^{69}$ and, in fact, by failure to grant any remedy actually enforced a classified property $\operatorname{tax}$.

A second problem raised by the above system was as follows: The State Board has determined the average debasement figure used by the several counties of the state. This figure is either greater or smaller than the assessment ratio used in county $\mathrm{A}$. Thus, an item of property valued centrally by the State Board and having a situs in county $A$ will pay a

68393 Ill. 154, 65 N.E. 2 d 392 (1946). In that case the taxpayer objected to the taxes of three special taxing districts (village, park, and school) having coterminous boundaries. These districts overlapped Lake and Cook Counties. The rates of the special districts were certified to the respective county clerks, to be extended upon the value of property as valued by the respective county officers. Taxpayer alleged that property in Cook County, in which taxpayer's property was located, was valued at an assessment ratio of $75 \%$, while property in the adjoining Lake County was valued at a ratio of only $21 \%$. Since the special district rates were extended on the county valuations it was obvious that taxpayer's property located in Cook County was carrying a greater proportionate tax burden of the special taxing districts than property of equal value in Lake County.

${ }^{69}$ Id. at 161 . The court said that the taxpayer made no suggestion as to how uniformity might be maintained in such a situation, and that if taxpayer was correct, it would necessitate all property in the state being valued alike before absolute uniformity in such situations could exist.

In such situations, as long as the assessment and levy of taxes is based upon the judgment of the assessing officers in each separate county, absolute uniformity cannot be achicved. This matter is one exclusively for the legislature, and the relief, if any, in the several counties must come from the legislature and not from the courts. 
larger or smaller amount of tax than an item of property of identical value in county $A$ but valued locally. A disparity in the effective rate and tax burden of county $A$ would seem to exist, with classification now being based on the identity of the assessor. ${ }^{70}$ In Illinois, railroad property and the capital stock of some corporations are valued by the State Board in the manner described above. The uniformity problem resulting from this arrangement has been dealt with by the court in distinctly different ways depending upon whether the property involved was railroad property or capital stock.

(ii) (a) General Property Tax: Railroad property valued by state officers and apportioned to the counties for taxation. In 1867, in two of the earlier uniformity cases, ${ }^{71}$ Bureau County v. Chicago B. E' Q. Ry. Co ${ }^{72}$ and Chicago $\mathcal{E}^{2} N . W$. $R y$. Co. v. Boone County, ${ }^{73}$ the court held that absolute uniformity should prevail in the assessment ratio used by any one taxing district, and that railroad property should be assessed for a county tax rate at no greater ratio of its "true" value than the assessment ratio used for other property in the county. This view was adhered to some years later, in the

70 The situation becomes more complicated when it is not assumed-as it is in the text-that there is a single ratio used in a county. That is, when there exists a de facto classification system within a county.

In 1945 the legislature attempted to deal with the inequities arising from this use of two equalized values. It provided that all taxes are to be extended by the respective county clerks upon the property in their counties upon the valuation produced by the equalization and assessment of property by the State officers. Ill. Laws 1945, p. 1212, 1 ; Ill. Ann. Stat. c. 120, $\$ 644$. Generally, see Report, supra note at 37 at $54 \mathrm{ff}$.; Allen, "Full-Value Assessment Program in Illinois," 31 Bull. Nat. Tax Assn. 116 (1946); Weil, "Property Tax Equalization in Illinois," 6 Nat. Tax J. 157 (1953).

71 These decisions were made under the uniformity provision of the prior 1848 constitution, but are relevant in view of the similarity of those uniformity provisions to the present constitutional provisions. See note 1, supra.

7244 I11. 229 (1867).

7344 Ill. 240 (1867). 
1870 's, in two cases ${ }^{74}$ decided shortly after the present constitution of 1870 came into force.

However, in 1887, in Illinois $\mathcal{E}$ St. L. Railroad E Coal Co. v. Stookey, ${ }^{75}$ the court refused to give relief although the taxpayer alleged that the township tax rate was applied to railroad property located therein on the basis of a $100 \%$ assessment ratio (as made by the state officers), while the same rate was applied to all other property in the township on the basis of a $33 \%$ assessment ratio (as made by local officers). The court did not view the result as constitutional. However, it took the position noted above, ${ }^{76}$ namely, that illegal action by local ministerial officers (the statutory requirement was full value) would not invalidate a tax. Implicitly the opinion suggested that the proper remedy of the taxpayer was to correct the valuations made locally. As for the Bureau County and Boone County cases, the court simply brushed them aside with the statement that it would not consider the question whether the constitutional uniformity provision was properly applied in those cases because that provision had no application in the case at hand.

So the matter stood until 1934. Then in People ex rel. McDonough v. Grand Trunk Western R. Co. ${ }^{77}$ the court stated that the rule governing the ratio of valuation for any taxing district was one of absolute uniformity, and that the taxation of the taxpayer-railroad's property had to be on that basis. The taxpayer was defending in an action for delinquent taxes. Its defense was that a part of the taxes alleged to be due had been paid, and that its property had been

74 Chicago \& A. R. Co. v. Livingston County, 68 Ill. 458 (1873) and Law v. People, 87 Ill. 385 (1877).

75122 Ill. 358,13 N.E. 516 (1887).

76 See note 49, supra.

77357 Ill. 493, 192 N.E. 645 (1934). See People ex rel. McDonough v. Illinois Cent. R. Co., 355 I11. 605, 190 N.E. 82 (1934) for similar facts and similar conclusion. 
placed on the tax rolls at $60 \%$ of its actual value, while other property throughout the taxing district (Cook county) was assessed at only $37 \%$ of actual value. The court held that this was a good defense, based on Art. IX, $\S 1$, and said:

The record conclusively shows that the taxing authorities of Cook county adopted an arbitrary factor of [37\%] of the fair cash or true value on which property was assessed for taxation purposes for the year 1930. The same factor of $37 \%$ must be applied impartially and equally to all property in Cook County in order to observe the constitutional guaranty of equality and uniformity of taxation. ${ }^{78}$

This ruling was, in fact, clearly reversed in the leading case of Mobile E' Ohio R. Co. v. State Tax Comm., ${ }^{79}$ although the opinion of that case did not refer to Grand Trunk at all. In an effort to achieve an equality within local taxing districts as between railroad property and all other property in such districts, the State Tax Commission in 1938 certified the property of railroads, apportioned on a mileage basis, to counties at the different assessment ratios which were found to be representative of the respective counties. ${ }^{80}$ In the Mobile

${ }^{78} I d$. at 498. Emphasis added.

79374 Ill. 75, 28 N.E. 2d 100 (1940). In the Union Electric case, infra note 99, the court expressly overruled the Grand Trunk Western case, supra note 77 , insofar as inconsistent with the doctrine expressed in the Mobile \& Ohio Railroad case.

${ }^{80}$ Prior to 1938 the Commission had certified the value of railroad property at an average debasement ratio, computed on a statewide basis. Thus, one ratio was used for all railroad property throughout the state. On investigation the Commission concluded that the tax of such property by local rates would result in inequality of tax burden as between that railroad property and property valued locally in counties in which the ratio used varied (greater or smaller) from the average figure. Of course, the method proposed in 1938 did not solve the problem completely, for the Commission had found that there generally existed within the counties a disparity between the assessment ratios used for rural and urban property, so that the local ratio used by the Commission was an average of the several ratios appearing in the respective counties. 
E Ohio case, the court held that this method violated the uniformity provisions of the constitution. ${ }^{81}$ It was conceded by all, stated the court, that Art. IX, $\$ \S 1,9$ and 10 "require that taxation on all persons and property shall be uniform within the taxing district levying the same." ${ }^{32}$ However, it was also asserted that the only constitutional issue concerned whether or not the state itself was a taxing district. The Attorney General, in attempting to avoid a decision that the method used by the Commission was illegal, had argued ${ }^{83}$ that the state was no longer a taxing district because there had been no statewide general property tax levy since 1932 . The court rejected this argument, pointing out that the statute provided for an annual determination, by designated officials, of the rate for the state tax, and that the determination by the officials that "no rate" was needed was no less a decision regarding a state tax than a determination that a "positive" rate would be needed. Thus, the court concluded that the only way of attaining the principle of uniformity for a statewide tax was by the application of a single uniform assessment ratio to all railroad property in the state.

By this line of argument the court completely avoided the real issue. The tax involved was not a state tax, and the state was not "the taxing district levying" the tax. Thus, since uniformity is required "within the taxing district levying the $[\operatorname{tax}]$," it was irrelevant whether uniformity would have been maintained within any other taxing district, e.g., the state. The fact that the property was valued by state officers cannot obscure the fact that this valuation was to serve two tax rates, one state and one local. The same consideration

81 The method was held to violate the Railroad Assessment Act of 1939, as well, which stated that railroad property was to be debased to the statewide average.

82 Mobile \& Ohio R. Co. v. State Tax Comm., supra note 79 at 82. Emphasis added.

${ }^{83} I d$. at 86. 
which led the court to conclude that a single ratio figure was necessary to attain uniformity throughout the state would demand the conclusion that a single ratio figure should have been used throughout the county in question. ${ }^{\mathbf{8 4}}$

\section{In the final analysis, the Mobile $\mathcal{E}^{2}$ Ohio case is a clear}

84 After this analysis of the Illinois uniformity limitation was written the Illinois Supreme Court decided Department of Revenue v. Warren Petroleum Corp., 2 Ill. 2d 483, 119 N.E. 2d 215 (1954). The Private Car Line Companies Tax Act (Ill. Ann. Stat. c. $120, \$ \S 372.1$ et seq.) provides for the assessment and taxation of the "operating personal property" of all private car line companies operating in Illinois. The rolling stock of domestic corporations is assessed by state offcers and certified to the county wherein the company has its principal place of business. This part of the act presents the same problem faced in the Mobile \& Ohio R. case, discussed in the text. However, the rolling stock of foreign corporations is not only assessed at an average debased ratio, but in addition it is then taxed at an "average rate of taxation" computed by the state officers and based on the rates used by all the counties in the state. In the Warren Petroleum case, the taxpayer contended (p. 218) that the tax discriminated against it as a foreign corporation in favor of domestic corporations of like character, "and therefore violate[d] the State and Federal constitutions." This contention was based upon the use of the "average rate of taxation" for the taxpayer's property, and the appropriate local rate for the property of domestic car line companies. The only issue discussed by the court was the validity of the act under the federal equal protection clause. It was held that there was no arbitrary discrimination, and, consequently, the equal protection clause was not violated. No one will quarrel with that conclusion. However, the court completely ignored any problems raised by Art. IX, $\$ 1$ of the Illinois Constitution. A "case note" in 1954 IIl. L. F. 525, 526 n. 10 indicates that the state constitutional issue was raised in the briefs, but that the treatment by the Supreme Court might have resulted from the rule that the constitutional issue must be timely raised or it will be waived.

In any case, if the tax on the rolling stock of foreign private car companies is considered a local property tax, the problem of Mobile \& Ohio R. is compounded-not only is a different assessment ratio used, but a different percentage rate is also used. On the other hand, if the tax is considered essentially a state tax rate, possibly no problem of uniformity in effective rates is raised. The same ratio of valuation and percentage rate is applied to all property taxed by the state- namely, the rolling stock of foreign car companies. But this runs head on into the universality requirement, which will not permit a taxing jurisdiction to select less than all taxable property for 
example of the court's talking in terms of absolute uniformity but in fact enforcing a limited classification system which will impose a different effective tax rate upon railroad property from the effective rate imposed upon other property within the same taxing jurisdiction. Mobile E Ohio was followed in a number of cases decided shortly thereafter. ${ }^{85}$

(ii) (b) General Property Tax: Valuation of capital stock of certain corporations by state officers used for local tax rates. Numerous cases have concerned the validity of the general property tax as it is applied to the capital stock of corporations. ${ }^{88}$ It is these cases which have quite often contained "classification language," and are often cited as authority for propositions beyond their actual scope. There are five early cases, decided between 1875 and 1904, which may be considered and disposed of as one. They are: Porter v.

taxation. See notes 34-37, supra. Indeed, if the tax is considered a state rate, what of the rationale suggested by the court in Mobile \& Ohio R., namely, that there is a state rate of "zero"? That would mean not only that the universality rule would be violated, but there would no longer be an absolute uniformity in effective rates because a different percentage rate would be applied to rolling stock of foreign corporations from that applied to all other property subject to the state rate. One may surmise that the court was not unhappy that the state constitutional issue did not have to be considered in Warren Petroleum.

${ }^{85}$ People ex rel. Hempen v. Baltimore \& O. R. Co., 379 Ill. 543, 42 N.E. 2 d 69 (1941) ; People ex rel. Ross v. Chicago M. St. P. \& P. R. Co., 381 Ill. 58, 44 N.E. 2d 566 (1942); People ex rel. Toman v. Chicago Union Station Co., 383 Ill. 153, 48 N.E. 2d 524 (1943). In the last case the court spelled out the rule that Art. IX, $\$ 1$ does not permit the valuation of one piece of property at certain ratios and other property in the same taxing district at substantially different ratios. It thereupon proceeded to ignore the fact that the state was not really the taxing district concerned.

86 The nature of this tax is aptly described in the following statement, Report, supra note 37 at 173 (1949):

Because of the frequent misunderstanding of the nature of the capital stock tax in Illinois an explanation of its meaning and operation is needed. Although the statutes and courts employ the term "capital stock," the tax is not a levy on capital stock as that phrase is generally employed. The tax 
Rockford, R.I. E' St. L. R. Co., ${ }^{87}$ Coal Run Coal Co. v. Finlen, ${ }^{88}$ Ottawa Gaslight $\mathcal{E}$ Coke Co. v. Downey, ${ }^{80}$ Sterling Gas Co. v. Higby, ${ }^{90}$ and $H u b$ v. Hanberg. ${ }^{91}$ In all of these cases there is much talk about "classification" of corporate property for purposes of taxation and of the power so to classify pursuant to the second clause of Art. IX, $\$ 1$, which reads:

. . . but the general assembly shall have power to tax peddlers, auctioneers, brokers, hawkers, merchants, commission merchants, showmen, jugglers, innkeepers, grocery keepers, liquor dealers, toll bridges, ferries, insurance, telegraph and express interests or business, vendors of patents, and persons or corporations owning or using franchises and privileges, in such manner as it shall from time to time direct by general law, uniform as to the class upon which it operates.

Indeed, in the important Union Electric Power Co. case, discussed below, these cases are relied on as establishing this proposition. However, it is submitted that the only issue in these cases, and really the only thing discussed despite some rather equivocal language, concerned the power of the legislature to classify property for the purpose of using different

is a property tax on those corporations chartered by the State of Illinois which is intended to tax, as property, the intangible values of corporations in the form of goodwill, franchise, or capitalized excess earning power and the like. The capital stock tax also needs to be distinguished from the annual franchise tax which is sometimes called a capital stock tax. . .

The capital stock tax is frequently defined as a tax on the corporate excess. In this sense it means that the full economic value of the corporation is taxable as property and that the excess of the entire economic value over the tangible property assessments is the amount that is to be assessed and taxed as capital stock.

\footnotetext{
8776 Ill. 561 (1875).

${ }^{88} 124$ III. 666,17 N.E. $11(1888)$.

89127 Ill. 201, 20 N.E. 20 (1889).

${ }^{90} 134$ Ill. 557,25 N.E. 660 (1890).

91211 Ill. 43, 71 N.E. 826 (1904).
} 
methods of valuation, ${ }^{82}$ but with the same end always in mind-the determination of the "actual" value of property.

The next case of interest is People's Gaslight E' Coke Co. v. Stuckart, ${ }^{03}$ in which the court avowedly followed a rule of absolute uniformity "within a taxing district." The opinion is not too clear, but the case may be reduced for present purposes to the following: Plaintiff's "home office" was in Cook County. The county assessor entered the value of plaintiff's capital stock (as centrally determined) upon the tax rolls and extended upon this centrally made valuation the total amount of rates which had been certified (state, Cook County, and any special taxing districts having jurisdiction over plaintiff). Plaintiff filed a bill against the Treasurer of Cook County to enjoin the collection of all of the tax in excess of a stated amount "upon the ground that the assessment was fraudulent, excessive and not uniform with the assessment of other property throughout the State." ther charged "that personal property in the State was assessed by the local assessors at not exceeding fifty per cent and real estate at not exceeding sixty per cent of its fair cash value." ${ }^{\text {"as }}$ Plaintiff also contended that the state board had not followed its own rules in assessing capital stock but had arbitrarily used several different methods.

The court apparently found that the particular assessment of plaintiff's capital stock was made in an arbitrary manner. It noted that the assessment of real property throughout the state "did not exceed" $55 \%$ of actual value, "and the evidence in regard to personal property tends to show an assessment no higher."96 The court concluded that, if assess-

${ }^{82}$ Admittedly, the court did seem to rely on the second clause of Art. IX, $\$ 1$ in reaching this conclusion.

${ }^{93} 286$ Ill. 164, 121 N.E. 629 (1919).

${ }^{94} \mathrm{Id}$. at 165 . Emphasis added.

${ }^{95} \mathrm{Id}$. at 167-168.

${ }^{0 B} \mathrm{Id}$. at $178-179$. 
ment of plaintiff's capital stock had been made on a similar ratio, the amount of tax would have been less than the amount above which plaintiff sought to enjoin collection. Therefore, it was held that the plaintiff was entitled to the decree. In explaining the applicability of Art. IX, $\S 1$, the court said that, while the mandate of the proportionality clause is directed to the legislature and concerns the laws which may be passed imposing taxes, nevertheless

. . . no power exists or should exist in any corporate authority to go counter to this command of the fundamental law. ... [A]nd where assessors have disregarded the in junction of the law and made an assessment of property far below its real cash value, their misconduct must also follow the principle of uniformity and their assessments of all persons must be at the same proportional value. ${ }^{97}$

The court also said, in the course of determining that a court of equity could exercise jurisdiction:

An assessment is . . . at too high a rate, even though less than the actual value, when the property is assessed at a greater proportion of its actual value than is used at the same time in the assessment of all other property. ${ }^{98}$

This opinion is more notable for what it did not, rather than for what it did establish. Somewhat like the later railroad property cases, the court was concerned with the state-

${ }^{97} I d$. at 173 . But see the cases in which the court has held that action of ministerial officers may not alone invalidate the tax on property assessed at a higher ratio of valuation, note 49 , supra.

${ }^{98} I d$. at 176 . Emphasis added. The court had said that a court of equity will exercise its jurisdiction to enjoin the collection of a tax where the property has been fraudulently assessed at too high a rate. The county officials argued that this would not apply here since taxpayer's property was not assessed at too high a rate since it was assessed at less than full value. The court replied that this involves the assumption that an assessment can be too high only when the assessed value exceeds full value, and then made the statement quoted in the text. 
wide assessment ratio, but in this case with the maximum rather than the average ratio. The plaintiff based its contention on the ratio applied to other property "throughout the state." No statement was made concerning the ratio used in Cook County. Was it the same as the statewide maximum ratio, or was it a lower percentage? Nor was any distinction made concerning the fact that the total tax extended against plaintiff's capital stock was an aggregate tax rate. Thus, for that portion of the tax representing a state rate extended by the county officer some statewide equality was relevant. But for that portion of the tax representing only the Cook County rate a countywide equality was all that was relevant. Thus, the opinion leaves much to be desired insofar as the problems of uniformity are concerned. Yet, it is clear that the court was thinking in terms of an absolute uniformity of effective tax rate used by any single taxing jurisdiction, regardless of the difficult questions which were left unanswered. The really important question one might raise about the case is whether it lends support to the railroad property cases which were concerned with achieving a uniformity throughout the state as to the ratio of valuation applied, disregarding the fact that the statewide uniformity is of no consequence in comparing tax burdens within a taxing jurisdiction on the local level.

In any event, in 1946 the Illinois Supreme Court made a deliberate and substantial inroad in the uniformity limitation applicable to the ratio of valuation used in taxing property. In People ex rel. Prindable v. Union Electric Power Co. ${ }^{99}$ the court ruled that, in determining the value of property for the application of the percentage tax rate of a single taxing authority, at least some property may be classified for the purpose of applying different ratios of valuation. This deviation from a rule of absolute uniformity in effective rates is

${ }^{89} 392$ Ill. 271, 64 N.E. 2d 534 (1946). 
based on an interpretation of Art. IX, $\S 1$, which modifies the import of the proportionality clause by placing emphasis on the second clause of that section.

Action in the Union Electric Power case was initiated by the collector of St. Clair County to recover unpaid taxes extended against the capital stock of the company. In its answer the company contended that Art. IX, $\S 1$ had been violated because the county tax was extended on $54 \%$ of the value of its capital stock as valued by the state board, while the tax was extended on $35 \%$ of the value of property in the county, assessed by local assessors. That is, the state board used an assessment ratio of $54 \%$, and the local assessors in St. Clair County used an assessment ratio of $35 \%$. The company contended that the proportionality clause required a comparison of the ultimate tax burden borne by its capital stock with that burden borne by the realty, personalty, and the capital stock located in the county and assessed locally.

First, the court reviewed the five early cases, referred to above, ${ }^{100}$ which were concerned with the meaning of the uniformity clause and its relation to the capital stock tax. The court concluded that those opinions established the power of the legislature to classify property belonging to the enumerated subjects in the second clause of Art. IX, $\S 1$ and, by general law, provide for their assessment in a different manner and at a different ratio of valuation from that applicable to other property located in the same taxing jurisdiction. This power to classify was said to be derived from the second clause of Art. IX, $\S 1$. It is submitted that this is not an accurate statement of the purpose of those early cases. ${ }^{101}$ It is

${ }^{100}$ See notes 87-91, supra. The court placed particular emphasis on the opinion in Porter v. Rockford, R. I. \& St. L. R. Co., supra note 87, as first establishing this proposition which it was asserted was consistently followed in the cases following. Cf. note 37 , stipra.

101 See text to notes 90-99, supra. Indeed, in People ex rel. Prindable v. Union Electric Power Co., supra note 99 at 277-278, the court quoted from 
true that in the opinions of those cases the court relied on the second clause of Art. IX, $\S 1$, and that in each opinion the court spoke at great length of the power of the legislature to classify certain property. Nevertheless, the fact remains that the issue in each of those cases concerned only the power to provide for different methods of valuing different classes of property (capital stock). The only decision in any of the cases was simply that classification of property was permissible for such a purpose. ${ }^{102}$

Nevertheless, in the Union Electric case, the court concluded that the reviewed cases supported the validity of such a classification as the facts showed in Union Electric. The court also concluded that the Mobile E Ohio R. Co. case ${ }^{103}$ supported this view. Then the court expressly overruled the Grand Trunk Western R. Co. case ${ }^{104}$ insofar as it held to the contrary of the Mobile $\mathcal{E}$ Ohio R. Co. case. The court significantly stated that the parties in the Grand Trunk Western

Coal Run Coal Co. v. Finlen, supra note 88 , at some length. The quotation clearly indicates the precise nature of the issue in those early cases:

We see nothing in the constitution which prohibits the legislature from providing one method for determining the value of the capital stock, including the franchise, of a railroad company, another method for a mining corporation, and still another for manufacturing corporations. We see no clause in the constitution which prohibits the legislature from placing certain specified corporations in one class, and providing a uniform method of assessment for that class, and placing certain other specified corporations in another class, and providing a uniform manner of assessment for that class. [Emphasis added.]

${ }^{102}$ In People ex rel. Prindable v. Union Elec. Power Co., supra note 99, the court at 284-285 dismisses the Stuckart case, supra notes 93-98, with the statement that nothing in the case "holds that property valued under the first clause of section I of article IX must be assessed in the same way as property coming within a class fixed by law under the second clause of section 1, or that the same debasing factor should be used in each of them." [Emphasis added.] This is hardly a fair description of the Stuckart opinion.

103 Supra note 79.

104 Supra note 77. 
$R$. Co. case failed to discuss the relation of the second clause of Art. IX, $\S 1$ to this problem. ${ }^{105}$

Following this review of what it considered to be the pertinent cases, the court reached several conclusions which are worth quoting at some length. As to the issue at hand, the court stated:

It is our conclusion that section 1 of article IX of the constitution permits the General Assembly to establish classes among certain enumerated types of property mentioned in said section; that among such classes is the property of corporations who own or use franchises and privileges; that such a general law has been enacted authorizing the taxing of the

105 People ex rel. Prindable v. Union Elec. Power Co., supra note 102. The court said at 285-286:

We have examined the record and briefs in that case, from which it appears the point was not raised that railroads, under the law then existing, could be classified under a general law uniform in effect, and assessed in a different manner and by different officers than those referred to in the first clause of section 1 of article IX, and not a single case establishing this well settled principle was cited by either party. Consequently the opinion does not point out that there is a distinction between property assessed and valued under the first clause of section 1 , and that valued in accordance with general laws enacted in pursuance of the second clause. . . .

If the statement in the Grand Trunk Railroad Co. case is taken to mean the valuation of capital stock by the Department of Revenue must conform to value fixed by a local assessor on a corporation subject to his jurisdiction, then this statement is erroneous, and not in accord with the law. We have never previously so held, nor has it been so applied since, and to the extent that the statement may be so understood it is hereby overruled.

Thus, while it has been shown, text to notes 79-84, supra, that the court in the Mobile \& Ohio R. case did not rely on the second clause of Art. IX, $\S 1$, but simply relied on the rationale that the state was the taxing jurisdiction of concern and that railroad property was uniformly assessed at the same ratio within that district, we now have the court shifting the basis for the Mobile \& Ohio R. decision to the second clause of Art. IX, $\$ 1$, thereby placing railroads in that category of corporations exercising or using franchises or privileges. 
value of the capital stock and franchises of the appellant company, which law is general in its nature and character, and creates a class within the permissive power granted by the last clause of section 1 of article IX; that there is no requirement that the valuation of such property be uniform with property not subject to assessment by the Tax Commission; and that but for aught appearing in the pleading or proof the same uniform method of valuation has been pursued throughout the State of Illinois, within the classification applying to appellant. ${ }^{106}$

Recalling the precise facts in issue, it is clear that the court is here ruling that property belonging to subjects enumerated in the second clause of Art. IX, $\$ 1$ may be classified and different ratios of valuation applied to each class. This is made particularly clear by a statement in which the court said absolute uniformity in the ratio of valuation was required for property "assessed and valued" under the first clause of Art. IX, $\$ 1 .{ }^{107}$

A very interesting and informative point made in the opinion concerns an "inequality of tax burden" which the court felt would be established if the local assessment ratio were applied in such a factual situation as before the court. The court stated:

${ }^{100}$ People ex rel. Prindable v. Union Elec. Power Co., supra note 102 at 287-288. Emphasis added.

${ }^{107} \mathrm{Id}$. at 286:

The general principle of uniformity applies to both clauses of section 1 but does not of necessity apply to them in combination. In other words, as to all property assessed and valued under the first clause the ratio must be uniform, whether actual value or debased value is taken. The same principle of uniformity applies to valuations fixed under the last clause of section 1, but the difference between the two is that the General Assembly may as to certain subjects create, by general law, classes of taxpayers, and in such cases the uniformity required must conform to all coming within that class, but need not be uniform in method or amount of assessment with the other classes, or with property coming under the first clause of section 1 of article IX. [Emphasis added.] 
The evidence shows the debasing factors in the several counties range from 20 per cent to 75 per cent, and therefore to place the debased value of 21 per cent of fair market value to a utility in Lake County and 75 per cent in the adjoining county of Cook would indicate a gross and damaging lack of uniformity. The value of the property assessed by the Department of Revenue is created by the privilege of incorporation granted by the State. The utmost inequality in tax burden would be created within the classes subject to valuation by the Department if the debasement figure of the several counties were applied. All real and tangible property is subject to the local debasement figure, and the benefit of such rate obtains. The value created by the State is subject to the valuation of its agents, and this we believe is fair in principle and lawful in operation. ${ }^{108}$

This passage demonstrates the failure of the court to differentiate clearly the several burdens of taxation-the same confusion that appeared in the railroad property cases discussed above. ${ }^{109}$ First, it must be remembered that no "burden of taxation" can exist without the application of a percentage rate. It is the effective rate which determines the "burden of taxation." Second, there are two distinct taxing authorities involved in each of these cases, and consequently two "taxes"- the county general property tax rate, and the state general property tax rate. This distinction is essential to any significant comparison of tax burdens. The third, the valuation of certain property by state officers, serves two distinct purposes. That value serves as the base for both the county and the state taxes. Fourth, it is important to remember that when this case and the railroad-property cases were decided the following system was used: the state tax rate was extended by the county clerks on the equalized value of all property in their respective counties. All other taxes (i.e.,

${ }^{108} I d$. at 287 . Emphasis added.

${ }^{109}$ Supra, text to notes 79-84. 
the local taxes) were extended by the county clerks on the value of property which was assessed by local officers at the assessed value determined by such officers, and on the value of property which was assessed by state officers at the assessed value determined by such state officers.

Thus, an inequality of tax burden would exist as to two species of property of equal value located in counties using different local assessment ratios (the situation described in the passage from the Union Electric case) only if the following qualification is added. There would be an inequality of tax burden in such a fact situation if the tax imposing the burden was the state tax rate. On the other hand, if the county tax rate is being considered (and that was the tax under consideration in Union Electric) a comparison of the tax burden resting on two species of property of equal value located in different counties is meaningless for purposes of uniformity in taxation, because the property located in county A is not subject to any tax burden imposed by county $\mathrm{B}$, and vice versa. Thus, the ratio figure used by the State Department of Revenue is significant when comparing the tax burden imposed by any one county only when the property to which that state determined ratio is applied is compared to other property taxed by the same county.

As can be seen, the passage from Union Electric concerning "inequality of tax burden" seems completely to disregard the point that the taxpayer should have made. The tax rate applied and burden thereby imposed which the Union Electric Company objected to was the St. Clair County tax burden. Thus, the assessment ratio applied to capital stock with a situs outside of St. Clair County was completely irrelevant because such other capital stock was not-indeed, could not have been-subject to the St. Clair tax rate. This serves to point out that it is uniformity within a taxing district which 
is relevant. ${ }^{110}$ The court mistakenly spoke in terms of the state being the taxing district in the Union Electric case when in fact it was the county rate and, therefore, the county as a taxing district which was pertinent. ${ }^{111}$

In any case, if the court were really only concerned with finding a uniformity within classes of property, then it would have been sufficient if the same assessment ratio had been used as to all capital stock of a class and located within St. Clair County, disregarding completely the ratio or ratios used as to capital stock in the other counties of the state. Of course, the "general law" requirement referred to in the Union Electric case may have caused some trouble in this respect, as will be pointed out. ${ }^{112}$

Regardless of how fallacious the court's view of "equality of tax burden" may appear, we may summarize its interpretation of Art. IX, $\S 1$ as follows: ${ }^{113}$ While the "general principle of uniformity" applies to both clauses of Art. IX, $\S 1$, it does not of necessity apply to them "in combination."

110 For example, Anderson v. City of Park Ridge, supra note 42.

111 Of course, there would have been a statewide inequality of tax burden if local factors were used and a state rate were applied thereto. However, the concern of the court for a statewide equality of burden, at the expense of an inequality of burden for local rates, was really of no consequence at that time, because since 1932 there has been no state property tax rate applied. Thus, even if the rate "zero" is considered the state tax rate because of a determination by officials that "no rate was necessary" ( $c f$. the rationale of the court in the Mobile \& Ohio R. case, supra text at note 82), there could in fact be no state tax "burden," consequently no inequality in burden, even though different species of property of identical value were debased to different values for the application of the rate "zero."

112 Infra, text to note 115 .

${ }^{113}$ In the Union Electric case, supra note 99, the court does not refer to an opinion of the Attorney General, Op. Atty. Gen., 1935, No. 782, p. 121, which reaches the same conclusion and uses the language of substantially the same cases. However, the Attorney General fails to mention the Grand Trunk Western R. Co. case, supra note 77. See Comment, 33 I11. L. Rev., supra note 5 at 77-78. 
Property belonging to the enumerated subjects in the second clause of Art. IX, $\$ 1$ may be "classified under a general law, uniform in effect," with the ratio of valuation applicable to such a class of property needing to be uniform only within that class. The preceding propositions were necessary to the decision. As dictum the court added that the ratio of valuation for property "assessed and valued" under the first clause of Art. IX, §1. must be absolutely uniform, whether the actual or a debased value is used.

(iii) The significance of the preceding cases. Several important questions remain to be answered in order to determine the significance of the preceding groups of cases. First, consider the Union Electric case (capital stock) and the Mobile ES Ohio R. case (railroad property). Three important questions are: (1) What is the limit as to that property which may be classified? (2) For what purposes may these classes of property be further classified? (3) What is the effect of the "general law" limitation?

As for the first question, it may be noted that the precise words of the Union Electric case were limited to this: "among such classes [of property which may be classified by general law] is the property of corporations who own or use franchises and privileges." However, the implication of the Union Electric case is that any property belonging to those "subjects" enumerated in the second clause of Art. IX, $\S 1$ may be classified by "general law." Thus, it would seem that the basis of permissible classification is "ownership" of property, with this identifying characteristic being limited to the following:

. . . peddlers, auctioneers, brokers, hawkers, merchants, commission merchants, showmen, jugglers, innkeepers, grocery keepers, liquor dealers, toll bridges, ferries, insurance, telegraph and express interests or business, vendors of 
patents, and persons or corporations owning or using franchises and privileges. ...

Nor is there anything in the Union Electric opinion which would limit power to classify property to certain types or kinds of property belonging to the enumerated subjects. On the face of the reasoning it would seem that any kind of property could be classified as long as it belonged to one of the enumerated subjects.

On this point the Union Electric case (as to capital stock) and the Mobile $\mathcal{E}$ Ohio $R$. case (as to railroad property) may be merged, because in the Union Electric case the court stated that the two opinions were supported by the same reasoning. ${ }^{114}$ Of course, it is true that the only classifications of property actually ruled upon have been the capital stock of corporations centrally assessed and the property of railroads. Moreover, the opinion in the Union Electric case rests both decisions upon the fact that the property belonged to "corporations owning or using franchises or privileges."

Nevertheless-if the court is to be taken as really meaning what it said-the reasoning of the Union Electric opinion leads one inevitably to the theory that any property belonging to, for example, "jugglers" may be classified by a general law for purposes which will be discussed shortly. One may safely say that this assertion demonstrates by its mere statement the questionable nature of the interpretation given the second clause of Art. IX, $\S 1$ by the court in the Union Electric opinion. ${ }^{115}$

114 While it was not definitely clear in the Mobile \& Ohio R. case, supra note 79, that the second clause of Art. IX, $\S 1$ was the basis for the decision, nevertheless the result approved in each of the cases is as follows: a uniformity within a class throughout the state as a taxing district, with the class being established by a general law.

115 Query, just how far would the rationale of the Union Electric opinion, supra note 99, be extended when Art. IX, $\$ 2$ is taken into consideration? 
The second question (the "purposes" for which classification is permissible) is quite important. The cases discussed are concerned solely with the classification of property for the purpose of applying different ratios of valuation to different classes of property. There is not even the slightest hint in the cases above discussed that the court is suggesting that classification is permissible for any other purpose. Indeed, the court has most unequivocally ruled against classification of any property either for the purpose of exemption ${ }^{116}$ or application of different percentage rates. ${ }^{117}$ We may conclude, then, that the court has used this novel interpretation of the second clause of Art. IX, $\S 1$ to rationalize its support of the de facto classification system which has been established throughout the state of Illinois.

This position is inconsistent with the fundamental principles which underlie the ruling that Art. IX, $\S 1$ prohibits the classification of property for the purposes of applying different percentage rates. To allow classification of property for application of different ratios of valuation results in just as effective a classified property tax as allowing property to be classified for percentage rates. It is the effective rate that is significant, and to classify for either the ratio of valuation or the percentage rates results in the tax burden being equal only as among classes of property.

The third question (the effect of the "general law" requirement) points up an important limitation upon the classification concept built around the second clause of Art. IX, $\S 1$. In the Union Electric case the court emphasized that there was a uniformity within the class of property under consideration-namely, capital stock assessed by the State Board throughout the state. The court further emphasized

116 Supra notes 34-37. Note that three of the cases in note 35 were discussions concerning the exemption of capital stock.

117 Supra note 39. 
that the statute providing for such a central assessment was not "special." Thus it is indicated that one limitation on this power of classification derived from the second clause of Art. IX, $\S 1$ is that classes cannot be limited to a local taxing district, but must be "general." Electric opinion coincides with the concern of the court in the Mobile E Ohio $R$. case (railroad property). The emphasis there was on the state as a taxing jurisdiction. As already pointed out, this confused the issue as to the taxing jurisdiction actually in controversy. However, the result is consistent with this "general law" limitation.

This consideration of the significance of the "railroad property cases" and the "capital stock cases" must be correlated to the analysis of the first group of cases consideredthose in which all property in question was assessed locally, and in which there was evidence of a local de facto classification system. In examining those cases it was seen that since 1935 the court has in several cases either (1) talked in terms of classification, while not actually sanctioning any such system, or (2) actually enforced a de facto classification system, while not necessarily abandoning in its opinion the rule of absolute uniformity theretofore developed.

That analysis must be balanced against the dictum in the Union Electric case, stated by the court while expanding the concept of the relation of the second clause of Art. IX, $\$ 1$ to the entire provision. It was there indicated that property assessed under the first clause must conform to a rule of absolute uniformity. ${ }^{119}$ Perhaps the only safe conclusion which may be drawn at this point is that the court will not in fact upset these local de facto systems, although they may be a

118 No attempt will be made in this study to analyze the scope of the "general law" limitation. Cf. 2 Sutherland, Statutes and Statutory Construction (3rd ed., by Horack, 1943), \$\$2101-2125.

110 See note 107 , supra. 
violation of the doctrine developed in the past as to the meaning of Art. IX, $\S 1 .{ }^{120}$ As the recognition of such a system becomes more and more commonplace, the court unwittingly slips into language implying that only a limitation of uniformity within classes is required in applying different ratios of valuation within a single taxing district. ${ }^{121}$

\section{(c) Property taxation: conclusion}

We may conclude that the existence of a statewide practice of illegal classification (some may wish to call it "extralegal") has been the lever by which the court's position indicating that the purpose of the proportionality clause in Art. IX, $\S 1$, is to achieve an absolute uniformity in tax burden has been so altered as to undermine this fundamental tenet. Writers can undoubtedly point to the difficult practical situation with which a court is faced in coping with this widespread use of de facto classification systems. It may be suggested that a court is ill-equipped to reëstablish the equilibrium of a system of absolute uniformity when the matter of proof is so difficult and it is faced with such a large-scale de facto classification system.

This does not alter the fact, however, that the court in sanctioning and rationalizing these situations has taken a path which may logically lead to making completely unrealistic its ruling that absolute uniformity is required for percentage rates and exemptions. Of course, it remains to be seen how far the rationale of the Union Electric opinion will be carried. Nevertheless, on the basis of what the court said as well as what the court did in that case, it must now either approve other classifications or reject the rationale presented

120 Cf. Cushman, supra note 5 at 236.

121 Cf. the dissent in People v. Southwestern Bell Tel. Co., supra notes 57,58 . 
in support of the Union Electric and Mobile E Ohio $R$. decisions.

Once again it is illustrated how the rule of absolute uniformity in property taxation leads substantially to a breakdown of the property tax system if enforcement is strictly attempted; and the result is more often than not a series of locally enforced de facto classification systems which apply different ratios of valuation and thereby achieve a classified effective rate while leaving as a façade a single proportional percentage rate applicable to all property alike. When such systems are challenged, as here, they are often upheld, but with the result that one is often faced with a developing hodgepodge of conflicting interpretations of an already confusing constitutional limitation. De facto classification systems are no substitute for de jure classification systems which are derived from statutory language and subject to a more certain constitutional limitation against arbitrary action by local assessors.

\section{Nebraska}

\section{a. The provisions; historical note}

The first Nebraska Constitution, dated 1867, contained no provisions concerning uniformity of taxation. The second and present Nebraska Constitution came into force in 1875 . In its original form it contained both a basic uniformity clause, Art. IX, $\S 1,{ }^{1}$ and a provision, Art. IX, $\S 3$, requiring the ex-

\section{${ }^{1}$ Article IX, §1 read:}

The legislature shall provide such revenue as may be needful, by levying a tax by valuation, so that every person and corporation shall pay a tax in proportion to the value of his, her, or its property and franchises, the value to be ascertained in such manner as the legislature shall direct; and it shall have the power to tax peddlers, auctioneers, brokers, hawkers, commission-merchants, showmen, jugglers, inn-keepers, liquor-dealers, 
emption of certain classes of property and permitting the exemption of others.

In 1920 the uniformity structure of the 1875 constitution was amended by the substitution of Art. VIII, $\S 1$, for Art. IX, $\$ 1$, and Art. VIII, §2, for Art. IX, \$3. The phraseology of the basic uniformity clause was changed, but in substance the clause remained the same except for a proviso removing the taxation of intangible property from the scope of the strict uniformity clause. The provision, Art. VIII, §1, was again amended in 1952 to permit special treatment of motor vehicles. Section 1 now reads:

The necessary revenue of the state and its governmental subdivisions shall be raised by taxation in such manner as the Legislature may direct. Taxes shall be levied by valuation uniformly and proportionately upon all tangible property[,] and franchises, except that the Legislature may provide for a different method of taxing motor vehicles. . . . Taxes uniform as to class may be levied by valuation upon all other property. Taxes, other than property taxes, may be authorized by law. . ...2

The only real changes accomplished by the 1920 amendment were the addition of the proviso: "taxes uniform as to

toll-bridges, ferries, insurance, telegraph, and express interests or business, vendors of patents, in such manner as it shall direct by general law, uniform as to the class upon which it operates.

2 The exception concerning motor vehicles also provides for the diversion of the revenue derived from the taxation of the same. Moreover, in 1954 a new section was added to Art. VIII which prohibits a state property tax if either an income tax or a general sales tax is adopted. Art. VIII, $\$ 1 A$. Prior to 1952 , Art. VIII, $\$ 1$ read:

The necessary revenue of the state and its governmental subdivisions shall be raised by taxation in such manner as the Legislature may direct; but taxes shall be levicd by valuation uniformly and proportionately upon all tangible property and franchises, and taxes uniform as to class may be levied by valuation upon all other property. Taxes, other than property taxes, may be authorized by law. . . . 
class may be levied by valuation upon all other [i.e., intangible] property," and the simplification of the provision concerning nonproperty taxes. The only change of importance in the exemption provision, for purposes of uniformity, was the addition of the following sentence: "No property shall be exempt from taxation except as provided in this section." The only other provision in the Nebraska Constitution concerning uniformity of taxation is Art. VIII, $\S 6$, which provides that "[municipal] taxes shall be uniform in respect to persons and property within the jurisdiction of the body imposing the same."

\section{b. Meaning of the uniformity limitation ${ }^{4}$}

Nonproperty taxes are required only to be uniform within classes. ${ }^{5}$ The objects selected for nonproperty taxes and exemptions therefrom need only be reasonable classes, ${ }^{6}$

${ }^{3}$ For the text of the present Art. VIII, $\$ 2$ see Appendix A, infra.

"See Nutting, "Taxation in Nebraska," 19 Neb. L. Bull. 7 at 10, 21-26 (1940).

${ }^{5}$ See the cases in notes 6 and 7 , infra. The source of the limitation is restricted by the 1920 amendment of Art. XIII, $\S 1$ to the equivalent of an equal protection clause in the Nebraska Constitution, Art. I, §1. The deletion of the express "uniformity within classes" limitation applicable to taxes "other than property taxes" resulted in no substantive change. The court has used some careless language in a few nonproperty tax cases, which might leave the impression that such taxes are governed by the "proportionality" clause in Art. VIII, \$1. See, for example, Continental Ins. Co. v. Smrha, 131 Neb. 791 at 796, 270 N.W. 122 (1936), and Thorin v. Burke, 146 Neb. 94 at 102, 18 N.W. 2d 664 (1945). The enumeration in the first uniformity provision in the 1875 constitution of taxable objects of nonproperty taxes did not result in a restriction on the possible scope of nonproperty taxes. It was held that the enumeration was not exclusive. Sec Nutting, supra note 4 at 25.

' For example, in the following cases classifications were found to be reasonable: Richter v. City of Lincoln, 136 Neb. 289, 289 N.W. 593 (1939) (local "public service" tax, per cent of gross receipts; not invalid although including taxicabs but excluding trucks carrying freight); Nebraska Tel. Co. v. Lincoln, 82 Neb. 59, 117 N.W. 284 (1908) (holding 
and such objects may be further classified for the purpose of applying different rates. ${ }^{7}$ A progressively graduated rate schedule is a reasonable classification. ${ }^{8}$ The distinction between nonproperty and property taxes assumes a great deal of importance because of the more strict uniformity limitation applicable to property taxes. Of interest for comparative purposes is the decision of the Nebraska court that an inheritance tax is not upon property but upon the privilege of succession. ${ }^{9}$

Property Taxation. Before 1920, the former Art. IX, $\$ 1$ was interpreted to require universality, ${ }^{10}$ absolute uniformity

that a gross earnings occupation tax on telephone businesses was a valid class) ; Rosenbloom v. State, 64 Neb. 342, 89 N.W. 1053 (1902) (license tax, peddlers, a valid class for selection); and see Magneau v. Fremont, 30 Neb. 843, 74 N.W. 280 (1890) (a local system of various occupation taxes with flat rate for each tax).

See the following cases for examples of classifications found to be arbitrary: Thorin v. Burke, supra note 5 ( $\operatorname{tax}$ on oleo, with such imitation butter containing domestic oil being exempt; held unreasonable and void, not considering the distinction made between oleo and butter; apparently treated as an excise tax); Continental Ins. Co. v. Smrha, supra note 5 (2\% tax on gross premiums of fire insurance companies, but only on premiums from policies upon property within the corporate limits of all incorporated $\mathrm{mu}$ nicipalities; revenue apportioned to municipalities for fire fighting units; held, arbitrary classification); Lincoln v. Lincoln Gas \& Elec. Light Co., 100 Neb. 182, 158 N.W. 964 (1916) (local tax on manufacture and sale of gas and electric current; several public service corporations engaged in furnishing light, heat, and power to people of a city; fact that one furnishes such services by electric current conveyed by wire and others by gas conveyed by underground mains did not furnish sufficient basis for classification to justify occupation tax on one, not on the other).

${ }^{7}$ State ex rel. Slabaugh v. Vinsonhaler, 74 Neb. 675, 105 N.W. 472 (1905). The court upheld an inheritance tax, with a classified rate schedule. The classes were based on the degree of relationship of the heir or devisee, and upon the amount received from the estate. Thus, there was a graduated rate within the subclasses.

${ }^{8}$ See note 7 , supra.

${ }^{\theta}$ See note 7 , supra.

${ }^{10}$ See, for example, State v. Poynter, 59 Neb. 417, 81 N.W. 431 
in the effective rate applicable to all property taxed by a taxing jurisdiction, ${ }^{11}$ and the use of the ad valorem method in the taxation of property. ${ }^{12}$ The only change brought about by the introduction in 1920 of the new Art. VIII, $\S 1$ is that intangible property may now be taxed at a different effective rate or rates from the rate applicable to tangible property. ${ }^{\mathbf{1 3}}$

(1899); State v. Walsh, 31 Neb. 469, 48 N.W. 263 (1891); Clother v. Maher, 15 Neb. 1, 16 N.W. 902 (1883). See Nutting, supra note 5 at 11. However, the court has ruled that neither the failure of the legislator to select a class of property (In re Laub, 104 Neb. 402, 177 N.W. 749 (1920) (failure to provide method of valuing life insurance policies) nor the omission by the assessor of taxable property from the tax rolls (State $\mathbf{v}$. Fleming, 70 Neb. 523, 524, 97 N.W. 1063 (1903)) will invalidate the levy on other property in the taxing jurisdiction.

11 While absolute uniformity is required in effective rate, less than a $100 \%$ ratio of valuation may be used if all property in the taxing jurisdiction is debased to the same percentage. State v. Osborn, $60 \mathrm{Neb} .415,83$ N.W. 357 (1900); State v. Savage, 65 Neb. 714, 91 N.W. 716 (1902); Beadle v. Sanders, 104 Neb. 427, 177 N.W. 789 (1920); Chicago, R.I. \& P.R. Co. v. State, 111 Neb. 362, 197 N.W. 114 (1923). Concerning percentage rate, see High School Dist. No. 137 v. Lancaster, 60 Neb. 147, 82 N.W. 380 (1900). A provision for a reduction in the assessed valuation of only a particular class of land (i.e., that used for growing timber and fruit trees) violated this rule. Union Pac. Ry. Co. v. Saunders, 7 Neb. 228 (1878). Providing an arbitrary method for the valuation of a class of property would violate this rule, because the ratio of actual value would not necessarily be uniform. Western Union Tel. Co. v. Omaha, 73 Neb. 527, 103 N.W. 84 (1905); Homan v. Board of Equalization, Boone County, 141 Neb. 400, 3 N.W. 2d 650 (1942).

12 McCann v. Merriam, 11 Neb. 241, 9 N.W. 96 (1881), followed in Covell \& Ransome v. Young, 11 Neb. 510, 9 N.W. 694 (1881), holding road tax imposed with a specific rate (so many dollars per acre of land) to be a violation of the uniformity clause. A similar tax had been upheld under the 1865 constitution which contained no uniformity provision. Burlington \& M. R. R. Co. v. Lancaster, 4 Neb. 293 (1876). Also see State v. MacFarland, 104 Neb. 42, 175 N.W. 663 (1919).

13 However, the court has held that the taxation of state bank shares at a higher rate than national bank shares is an arbitrary discrimination. State Bank v. Endres, 109 Neb. 753, 192 N.W. 322 (1923). The court has subsequently held that, if the shares in banks are taxed at a different rate from that applicable to shares of other corporations, there would be an 
However, all intangible property must still be taxed, and taxed by the ad valorem method. ${ }^{14}$ Since 1952 , motor vehicles may be taxed as property at a different rate and by specific methods, although that class of property still is subject to the rule of universality. ${ }^{15}$ For comparative purposes, it is sufficient to note that under this type of uniformity clause-whether in the precise phraseology of either the 1875 or the 1920 provision-it was necessary to write in an express exception thereto if any class of property, such as in-

arbitrary classification. State ex rel. Spillman v. Ord State Bank, 117 Neb. 189, 220 N.W. 265 (1928), and see Omaha Nat. Bank v. Heintze, 159 Neb. 520,67 N.W. $2 d 753$ (1954). At the present time intangibles are divided into two classes (Class $A$ : cash, savings accounts, and bank deposits; Class B: all other intangibles) with Class $A$ taxed at a $21 / 2$ mill rate and Class $B$ at a 4 mill rate. Neb. Rev. Stat. $\S \S 77-702,77-703$.

14 That intangibles must still be taxed, see International Harvester Co. v. County of Douglas, 146 Neb. 555, 20 N.W. 2d 620 (1945), saying, as to the purpose of the 1920 amendment (at pp. 562-563): "A reading of the proceedings of the 1920 Constitutional Convention clearly indicates that the framers of these amendments, by the use of the term 'other property,' had reference to and meant to include therein intangible property; that it was their purpose so to draft the constitutional provisions that all property in the state would be subject to taxation and be taxed. . . . To make certain that intangibles were not to be exempt they placed the provision in section 2 [prohibiting the exemption of property]." However, note that certain financial institutions pay an earnings tax in lieu of intangibles taxes. In Sommerville v. Board of Com'rs of Douglas County, 116 Neb. 282, 216 N.W. 815 (1927) the court, when faced with a gross premiums tax on insurance companies "in lieu of all other taxes upon intangible property," avoided making a decision whether this was in fact an exemption of property contrary to the uniformity clause. Thus, there may be some question as to the validity of an "in lieu" tax in Nebraska.

${ }^{15}$ See the amendment to Art. VIII, $\S 1$, supra at note 2 . There has been no interpretation of this amendment by the court. But see Boyd Motor Co. v. Box Butte County, 159 Neb. 514, 67 N.W. 2d 774 (1954). The Attorney General, in an opinion dated Feb. 26, 1953, stated that under the amendment motor vehicles might be taxed by any method, including a partial deferment of taxes or a small token payment for the year 1953, but that some assessment for the year had to be made. $\mathrm{CCH}$ Neb. Tax Reporter \24-507. 
tangibles, was to be treated differently. Thus, the problem of avoiding the harshness of the strict uniformity requirement was solved in Nebraska by leaving the basic uniformity clause in its original form and writing in express exceptions thereto, rather than by adopting a more liberal basic clause.

\section{ANALYSES OF STATES WITH TYPE III CLAUSES}

\section{Massachusetts}

\section{a. The provisions; historical note}

Massachusetts has had but one constitution, and it came into force in 1780. A basic uniformity clause was included in that constitution in its original form, and has remained unchanged. Part II, Ch. I, $\S 1$, Art. IV reads (with numbers added):

And further, full power and authority are hereby given and granted to the said general court. ... [1] to impose and levy proportional and reasonable assessments, rates and taxes, upon all the inhabitants of, and persons resident, and estates lying, within the said commonwealth; [2] and also to impose and levy, reasonable duties and excises, upon any produce, goods, wares, merchandize, and commodities, whatsoever, brought into, produced, manufactured, or being within the same. . . .

Other relevant provisions are two of the many amendments which have been added to the Massachusetts Constitution. ${ }^{1}$

${ }^{1}$ One might also consider the general provision in the Bill of Rights (Art. X of Part I) which provides: "Each individual of the society . . . is obliged ... to contribute his share to the expense of" government. This provision has not played an important part in Massachusetts insofar as uniformity of taxation is concerned. However, similar provisions have served as the basic uniformity clause in a few other states. See Part $J$ of this chapter. 
They deal with particular problems of uniformity in taxation. Amendment No. 44, added in 1915, provides that the legislature may impose an income tax within certain limits. ${ }^{2}$ Amendment No. 41 of 1912 provides for special treatment of "wild or forest lands" for purposes of property taxation.

\section{b. Meaning of the uniformity limitation}

For purposes of uniformity in taxation in Massachusetts, taxes are either property taxes or "excises" (nonproperty taxes). ${ }^{3}$ Property taxes are limited by the first uniformity clause in Art. IV and must therefore be "proportional and reasonable." Nonproperty taxes are limited by the second uniformity clause and must be "reasonable," which in effect means only uniform within classes. ${ }^{4}$ Thus, the objects se-

2 For the text of the amendment, see Appendix A, infra.

${ }^{3}$ For cxample, in White Dental Mfg. Co. v. Comm., 212 Mass. 35, 37, 98 N.E. 1056 (1912) the court said: "Under our Constitution, which has been the organic law of this Commonwealth since 1780 , taxes are of two kinds, property taxes and excises. The first of these must be both proportional and reasonable. The latter need not be proportional, but only reasonable." At an earlier date, the habit of the court was to refer to property taxes as "taxes," and nonproperty taxes as "excises." See, for example, Oliver v. Washington Mills, 11 Allen (Mass.) 268, 274-275 (1865).

4 See, for example, Portland Bank v. Apthorp, 12 Mass. 252 (1815) and the cases in notes 5 and 6 , infra. It is interesting to note that the catch-all phrase in Art. IV used by the court in dealing with nonproperty taxes is: "reasonable... excises upon any ... commodities. . ." The word "commodities" has been interpreted to include all taxable privileges. Thus, the problem arises as to what "commodities," i.e., privileges, are taxable. Similar to the situation described in Arkansas, Part A of this chapter, supra, Massachusetts follows the doctrine that certain occupations or privileges are enjoyed as a matter of "common right" and are not subject to taxation. Thus, the court has held that unincorporated businesses, partnerships, and associations could not be subjected to a tax comparable to that applicable to corporations (an excise for the privilege of doing business). In re Opinion of the Justices, 266 Mass. 590, 165 N.E. 904 (1929); Gleason v. McKay, 134 Mass. $419(1880)$. Also see the decision in O'Keefe v. Somerville, 190 Mass. 110, 76 N.E. 457 (1906). 
lected for "excises" and any exemptions therefrom must constitute reasonable classes; ${ }^{5}$ such objects may be further classified for the purpose of applying different rates. ${ }^{6}$ The court has ruled that a progressively graduated rate is a reasonable classification. ${ }^{7}$

The decisions of the court concerning the nature of several taxes are of comparative interest. The court has held that an income tax was a tax upon property. ${ }^{8}$ However, it has held that a corporate franchise tax with a base of net income was an "excise," and the same result was reached as to a selective corporate franchise tax with a base of capital stock. ${ }^{10}$ In one of the leading cases on the matter, the court ruled that an inheritance tax was not a property tax. ${ }^{11}$ There has been some confusion concerning taxes upon the privilege of transferring or registering certain intangibles. On the one hand a stock

5 See, for example, Portland Bank v. Apthorp, supra note 4 (franchise tax, financial companies, per cent of capital stock); White Dental Mfg. Co. v. Comm., supra note 3 (corporate franchise; capital stock); In re Opinion of the Justices, 196 Mass. 603, 85 N.E. 545 (1907) (stock transfer tax); Connecticut Mutual Life Ins. Co. v. Comm., 133 Mass. 161 (1882) (insurance companies).

6 See, for example, Minot v. Winthrop, 162 Mass. 113, 38 N.E. 512 (1894) (inheritance tax; classification according to relation to the deceased, higher rates applicable to collaterals and strangers).

7 In In re Opinion of the Justices, 266 Mass. 583, 587, 165 N.E. 900 (1929), the court ruled that graduated rates for an income tax would not be proportional and therefore would violate the proportionality clause because an income tax was a property tax. The court cited Pratt v. Dean, 246 Mass. 300, 140 N.E. $924(1923)$ as holding that the graduated rates imposed by the inheritance tax, an excise tax, were valid. An examination of the case indicates that the rates were not challenged, but simply applied.

${ }^{8}$ Infra, at notes 26-29.

${ }^{\circ}$ See Alpha Portland Cement Co. v. Comm., 244 Mass. 530, 139 N.E. 158 (1923).

${ }^{10}$ See Farr Alpaca Co. v. Comm., 212 Mass. 156, 98 N.E. 1078 (1912) (public utilities); Portland Bank v. Apthorp, supra note 4 (financial institutions).

11 Minot v. Winthrop, supra note 6. 
transfer tax was upheld in principle as an "excise,"12 and a realty conveyance tax was imposed in 1952 but has not yet been challenged. To the contrary, a mortgage bond registration tax, which was to be "in lieu" of any property taxation of the bonds indirectly affected, was held invalid because it was a property tax and violated the uniformity clause applicable to property taxes. ${ }^{13}$ However, it must be pointed out that the stock transfer tax had no such "in lieu" or exemption feature (neither does the realty conveyance tax). The coupling of a purported excise tax with an "in lieu" feature will apparently result in an adverse decision. ${ }^{14}$ Moreover, the court has stated that the mere right to own and to hold intangible property cannot be made the subject of an excise $\operatorname{tax}^{15}$

\section{(1) Property taxation}

The requirement that property taxes be "proportional and reasonable" does not prevent "some exemptions founded upon compelling reasons ... but extreme care must be exercised to see that they never go to such length as actually to impair the force of" the constitutional principle of proportional taxation of property. ${ }^{16}$ Exemptions of property must

12 In re Opinion of the Justices, 196 Mass. 603, 85 N.E. 545 (1907). No cases have arisen under the actual tax, in effect since 1914 .

13 Perkins v. Westwood, 226 Mass. 268, 115 N.E. 411 (1917). See notes 22 and 25, infra, concerning the property tax limitation.

${ }^{14}$ See the text at notes 21 and 22 , infra.

${ }^{15}$ In re Opinion of the Justices, 195 Mass. 607, 84 N.E. 499 (1907). This was in answer to the question whether it was within the power of the legislature to enact a law which would exempt classes of enumerated intangibles from all other taxation, and impose thereon, either as a property tax or an excise, a uniform tax of 3 mills on each dollar of fair cash valuation thereof. The intangibles were money on hand and on deposit, other debts due, public stocks and securities, stocks and bonds of corporations.

${ }^{16}$ In re Opinion of the Justices, 324 Mass. 724, 85 N.E. $2 \mathrm{~d} 222$. The court summarized the whole problem of exemptions and reviewed the situation to that date. It ruled that proposed legislation which would have ex- 
fall into "classes which cannot fairly be said to offend against the ... requirement," derived from the principle of proportional taxation, that

\section{. . . all property within the Commonwealth which is owned}

empted newly constructed residential buildings from local real estate taxation for a period of five years after construction would violate the proportionality clause, Ch. I, §I, Art. IV, and Art. X of the Bill of Rights. Also see: Day v. Lawrence, 167 Mass. 371, 45 N.E. 751 (1897) (exemption of household furniture not exceeding one thousand dollars in value held valid, the court saying (at p. 373): "Such exemptions have long existed, and it is too late to question the power of the Legislature to make them."); In re Opinion of the Justices, 261 Mass. 523, 159 N.E. 55 (1928) (exemption of bonds issued by a private transportation company upheld and justified on the basis that such bonds were in effect state issued and exemptible as "public property"; there was dictum indicating that the exemption might have been justified as being an avoidance of "double taxation" since another tax was levied on the property of the transportation corporation; however the failure to exempt the bonds of other transportation corporations would have been an arbitrary classification); Board of Assessors of City of Quincey v. Cunningham Foundation, 305 Mass. 411, 26 N.E. 2d 335 (1940) (exemption of property of charitable corporations upheld); Assessors of Boston v. Metropolitan Life Ins. Co., 320 Mass. 559, 70 N.E. 2d 806 (1947) (justifying the exemption of the personal property of a foreign insurance corporation from the local property tax, on the basis that a state excise tax with a base of "net value of all policies in force" was imposed on foreign insurance corporations and therefore the exemption was granted simply to avoid "double taxation"; no mention was made of the fact that the state excise tax had a reciprocal feature, exempting those corporations whose home state exempted Massachusetts insurance corporations, and that the foreign corporation involved was a New York corporation, and further that the New York excise tax in effect exempted Massachusetts corporations) ; Assessors of West Springfield v. Eastern States Exposition, 326 Mass. 167, 93 N.E. 2d 462 (1950) (exemption of all property owned by "agricultural societies" no matter to what use the property was put, held valid); Newhall v. Assessors of Brookline, 329 Mass. 100, 106 N.E. 2d 432 (1952) (reaffirming the validity of the exemption of a minimum amount of household furniture, the amount having been increased from $\$ 1,000$ to $\$ 5,000$, and reviewing the Day case, supra and others). Also see Massachusetts General Hospital v. Belmont, 233 Mass. 190, 124 N.E. 21 (1919), 238 Mass. 396, 131 N.E. 72 (1921) ; Boston Fish Market Corp. v. Boston, 224 Mass. 31, 112 N.E. 616 (1916). 
and held in such a way that it ought to be available by its owner to increase his ability and enlarge his duty to assist in defraying the expenses of the government, must be included in the property upon which assessments are made. ${ }^{\mathbf{1 7}}$

\section{The permissible "classes" are: ${ }^{18}$ (1) Exemptions of public} property and quasi-public property, including property used for charitable, religious, educational purposes, etc. This type of exemption is said to tend "in some measure directly or

${ }^{17}$ In re Opinion of the Justices, 324 Mass. 724, 730-731 (1949), discussed in note 16, supra. The court clearly stated the relation of property exemptions to "proportionality" when it preceded its conclusion that "some" exemptions might be made with the following statement (at p. 729):

It seems plain that a tax assessed upon most property at the current rate but upon other property at a lower rate, or in this instance (as to buildings) at no rate at all, is not "proportional" to property owned. . . . There would no longer be a uniform ratio between the value of property owned and the taxes upon it. [Emphasis added.]

However, the court then recognized the difficulty in such a situation where there are no classes of property expressly described as exemptible by the constitution when it stated (at p. 730):

Just how exemptions are to be reconciled with the requirement of "proportional and reasonable assessments, rates, and taxes, upon all the inhabitants of, and persons resident, and estates lying, within the said commonwealth" ... contained in c. $1, \S 1$, art. 4 , of the Constitution is a problem of some difficulty which cannot be said to have been fully solved. Probably the solution lies in recognizing that the Constitution states general principles not all of which can be applied with absolute literal exactness.

It was admitted that "some" exemptions might be made if they did not "actually impair" the constitutional principle, although this was admittedly not consistent in theory.

${ }^{18} \mathrm{Id}$. at 731-732. The court plainly recognized the crudeness of its attempted classification of exemptions "long in existence," when it stated (at p. 733): "The foregoing classification may not be wholly accurate or satisfactory. In a few instances it might not stand too close scrutiny. There may even be some possible doubt of the validity of some of the exemptions." As to some exemptions, the sanction of "long usage" weighs heavily. See, for example, Day v. Lawrence, supra note 16, and Newhall v. Assessors of Brookline, supra note 16. 
indirectly to relieve public burdens." (2) Exemptions, the underlying purpose of which is to "prevent or mitigate double taxation." (3) "Hardship" exemptions, closely limited in amounts. (4) Exemptions of "certain articles of personal use," e.g., wearing apparel, cash on hand, tools, household goods, and the like, justified on the basis of hardship, need for a minimum of necessities free of tax burden, freedom from minute inquiry into personal matters, and administrative difficulties.

Thus, Massachusetts stands somewhere between those states prohibiting all exemptions of property and those states in which such exemptions need only consist of reasonable classes. However, even in those states having a requirement of universality, the first class of exemptions is usually allowed. The last three classes of exemptions constitute the important exceptions to the rule of proportional taxation. The class of exemptions which may be made to "avoid double taxation" is of greatest interest because of the meaning the court has given to "double taxation" for this purpose. On the basis of this rationale it has sanctioned the exemption of property indirectly burdened by an excise tax-for example, the exemption of shares of stock because of a corporate franchise tax, and the exemption of motor vehicles indirectly burdened by the motor vehicle registration nonproperty tax.

However, when the exemption to avoid "double taxation" is made in the form of an "in lieu" provision written into a purported excise tax, the court evidently does not view the exemption too favorably. For example, in Perkins v. Westwood, ${ }^{20}$ a statute which imposed a 3 mill "registration" tax

${ }^{19} \mathrm{ld}$. at 731 . The court gives as examples: exemption of property of certain corporations, of property the income of which is taxable, of shares in certain business organizations, and motor vehicles subject to the excise tax.

20226 Mass. 268, 115 N.E. 411 (1917). 
for mortgage bonds, and provided that such bonds were to be exempt from property taxation for one year upon payment of the "fee," was held to violate the principle of proportional property taxation. The court held that this was not a valid example of an exemption to avoid double taxation. ${ }^{21}$ The tax was characterized as a property tax, and as such it violated the rule requiring uniformity of rates.

It is clear that the strictest form of uniformity prevails as to the other particular rules of uniformity. Absolute uniformity is required in the effective rate applicable to all property taxed by any taxing jurisdiction, regardless of whether the variance in effective rates is the result of different percentage rates, ${ }^{22}$ "unequal methods of valuation,"23 or a

21 It was the opinion of the court (id. at p. 274) that even though an entire exemption might be made of the described bonds, so as to avoid double taxation, nevertheless it would not follow that a "conditional exemption" operative only on payment of an arbitrary fixed percentage which was not "proportional" would be permissible. Prior to this case a similar objection had been raised to a three mill intangibles tax imposed on enumerated intangibles. In In re Opinion of the Justices, 195 Mass. 607 (1907), supra note 15, it was ruled that the tax could not be upheld as a property tax because its rate was not uniform with the rate on other property, that the tax could not be upheld as an excise tax because the mere right to own and to hold property could not be made the subject of an excise tax, and finally, that the tax could not be upheld under the exemption power, because the power to exempt the whole does not authorize a partial exemption conditional upon the property exempted paying an arbitrary percentage which was not proportional. Followed in principle in In re Opinion of the Justices, 220 Mass. 613, 624, 108 N.E. 570 (1915).

${ }^{22}$ For example, Oliver v. Washington Mills, supra note 3; In re Opinion of the Justices, 195 Mass. 607 (1907), supra note 15; In re Opinion of the Justices, 208 Mass. 616, 94 N.E. 1043 (1911) ; Perkins v. Westwood, supra note 20; In re Opinion of the Justices, 266 Mass. 583 (1929), supra note 7. And see the discussions in Northampton v. Hampshire, 145 Mass. 108, 13 N.E. 388 (1887); Connecticut Mutual Life Ins. Co. v. Comm., supra note 5 .

${ }^{23}$ For example, Cheshire v. Berkshire, 118 Mass. 386 (1875); In re Opinion of the Justices, 220 Mass. 613 (1915), supra note 21. 
"partial exemption."." In addition, property may be taxed only by the ad valorem method. ${ }^{25}$

\section{(2) Income tax}

The Massachusetts decisions that an income tax is a property tax are perhaps the leading state court decisions which have taken this position. In a 1915 advisory opinion, ${ }^{26}$ the court said that a tax upon the income from property would be in effect a tax upon the property itself. Therefore, such a tax would be a property tax subject to the proportionality limitation which requires absolute uniformity in effective rates. No ruling was made concerning income derived from salaries, wages, and the like.

To overcome this ruling by the court, Amendment No. $44^{27}$ was added to the Massachusetts Constitution in 1915. That amendment expressly authorizes a "tax on income" in the "manner provided." Income derived from different classes of property may be taxed at different rates, and income not derived from property may be taxed at a lower rate than income derived from property. Exemptions from the tax may be made, and property, the income of which is taxed, may be exempted from all property taxation.

The Massachusetts legislature subsequently enacted an income tax. But in one opinion concerning that tax, the court has stated that it was a property tax, and since Amendment 44 does not authorize graduated rates, such a rate schedule would violate the proportionality clause requiring absolute uniformity. ${ }^{28}$ It was said that the only exception made to the

24 See note 21 , supra.

25 See, for example, the discussions in Portland Bank v. Apthorp, supro note 4, and Connecticut Mutual Life Ins. Co. v. Comm., supra note 5.

${ }^{26}$ In re Opinion of the Justices, 220 Mass. 613 (1915), supra note 22. $C f$. the earlier case of Wilcox v. Middlesex, 103 Mass. 544 (1870).

27 For the text of the amendment, see the Appendix, infra.

${ }^{28}$ In re Opinion of the Justices, 266 Mass. 583 (1929), supra note 7. 
rule of proportionality by the amendment was to permit classification according to sources of income. ${ }^{29}$

\section{New Hampshire}

\section{a. The provisions; historical note}

The first and only constitution of New Hampshire came into force in 1784. Three provisions of that constitution concern uniformity of taxation. The basic uniformity clause, Art. 5 of $\mathrm{Pt}$. II, provides that the legislature may

levy proportional and reasonable assessments, rates, and taxes, upon all the inhabitants of, and residents within, the said state; and upon all estates within the same. . . .

In 1942, that provision was amended by the addition of a sentence providing for special treatment of forest lands. ${ }^{1}$ A companion clause is found in Art. 12 of Pt. I (the Bill of Rights). It provides that:

Every member of the community has a right to be protected by it, in the enjoyment of his life, liberty, and property; he is therefore bound to contribute his share in the expense of such protection. ${ }^{2}$

${ }^{29}$ For permissible classifications, see Tax Comm'r v. Putnam, 227 Mass. 522, 116 N.E. 904 (1917) (rate levied upon gains from sales of intangible personal property at $3 \%$, with the rate upon the dividends from stock and interest on bonds and notes being $6 \%$; upheld as a classification of two sources of income not belonging to the same "class"); In re Opinion of the Justices, 270 Mass. 593, 170 N.E. 800 (1930) (minimum exemptions, upheld as reasonable classifications).

1 The sentence reads: "For the purpose of encouraging conservation of the forest resources of the state, the general court may provide for special assessments, rates, and taxes on growing wood and timber." [Emphasis added.]

2 In New Hampshire the court has tended to rely on both Art. 12 of Pt. I and Art. 5 of Pt. II in developing the uniformity limitation. For example, in a leading case the court said: ". . . immunity from disproportional 
The third important provision is found in Art. 6 of Pt. II which was amended in 1903 by the addition of a new clause which definitely enlarged the scope of the taxing power in New Hampshire and contained important implications for the meaning of the uniformity limitation. Article 6, as amended, reads:

The public charges of government, or any part thereof, may be raised by taxation upon polls, estates, and other classes of property, including franchises and property when passing by will or inheritance. . . .

In New Hampshire the uniformity in taxation limitation is closely intertwined with the problem of taxable objects, that is, types of permissible taxes. As a result, one cannot intelligently deal with the problem of uniformity without first discussing the problem of taxable objects, concerning which New Hampshire has reached a unique result.

\section{b. Permissible taxes ("taxable objects")}

1784 to 1903. Under the original New Hampshire Constitution it was firmly established that only the taxation of "polls and estates" was permissible. Thus, nonproperty taxes (alternately designated "excise" or "occupation" taxes), excluding poll taxes, were not permitted. "The court did not find it necessary to elaborate upon the word "estates." The characterization of a tax was obviously of crucial importance.

taxation [is] expressly reserved in our bill of rights, and the power of proportional taxation only [is] granted the legislature by the constitution. ..." Curry v. Spencer, 61 N.H. 624, 631, 60 Am. Rep. 337 (1882).

3 The omitted part of Art. 6 provides for mandatory periodic valuations of property. Prior to 1903 the provision was of no importance to the uniformity limitation, since it dealt only with the periodic valuation requirement. The original Art. 6 read: "And while the public charges of government, or any part thereof, shall be assessed on polls and estates in the manner that has heretofore been practiced. ..."

${ }^{4}$ See the cases in notes 5 and 6, infra. 
Two legislative experimentations failed when a tax upon the gross receipts of express companies at a fixed percentage was held to be an excise tax and therefore invalid, ${ }^{5}$ and the inheritance tax was held to be upon the privilege of receiving property, not upon the property itself. ${ }^{6}$

The cases demonstrate the alternate reasons which supported this interpretation. In the gross receipts tax case the court emphasized that there was a failure to mention taxes other than those upon "polls and estates" in Arts. 5 and 6 of Pt. II. In addition, it was reasoned that Art. 5 was copied substantially from the Massachusetts uniformity provision, and that the framers omitted the clause found therein which expressly provided for "excises." On the other hand, in the inheritance tax case the court primarily relied upon the rationale that nonproperty taxes would be invalidated by the requirement of "proportionality" of taxation. Therefore, whether the tax was on property or on a privilege was immaterial, "for the same principle of equality and due proportion applies to every species of tax alike." 8

1903 to the present. The 1903 amendment of Art. 6 of Pt. II did not permit the imposition of nonproperty taxes-that is, "excise" or "occupation" taxes. Property and polls are still the measure of the tax power. However, because of the new clause in Art. 6 there are now two general classes of taxes upon property. There may be taxes upon "estates," and there may be taxes upon "other classes of property." This dual classification is the obvious result of the phraseology introduced by the new Art. 6:

The public charges of government . . may be raised by taxation upon polls, estates, and other classes of property,

State v. United States \& Canada Express Co., 60 N.H. 219 (1880).

${ }^{6}$ Curry v. Spencer, supra note 2.

7 State v. United States \& Canada Express Co., supra note 5 at 239.

${ }^{8}$ Curry v. Spencer, supra note 2 at 631. 
including franchises and property when passing by will or inheritance. ...

Conner v. State ${ }^{9}$ is the leading case developing the significance of this dual classification of permissible taxes. In that case the issue concerned the validity of a tax upon income from intangibles. A crucial question was whether Art. 6, as amended, enlarged the legislative power. The court reasoned that prior to 1903 under Art. 5 the legislature could tax "estates," which was, in effect, the taxation of the ownership, possession, or enjoyment of property. Also, it was well established that all property-real and personal, tangible and intangible-could be taxed as "estates." Therefore, the new reference to "other classes of property" than "estates" must have reference to some element other than the ownership, possession, or enjoyment of property as the factor determining the taxability of property under the new grant of authority. Thus, in the court's language, the "incidence" of a tax of the new type is to be characterized by some factor other than mere ownership, possession, or en joyment. As an example, the court referred to the named class of property which passes by "will or inheritance." That property is taxed annually because of ownership. Yet such property might now be subject to an inheritance tax because of the fact that the "estate" has passed from the ancestor to heir. Without further elucidating the test, the court merely passed on the validity of the tax under consideration and ruled that the receipt of income was a sufficient factor or event to validate a tax on the income from intangibles.

This determinant--something other than mere ownership, possession, or enjoyment of property-was identified more precisely in a subsequent advisory opinion. The pertinent

982 N.H. 126, 127-128, 130 Atl. 357 (1925). 
questions before the court in that opinion ${ }^{10}$ concerned the validity of both a general sales tax and a timber severance tax. In considering whether the taxes could be sustained as taxes other than upon "estates," the court cautioned that the power granted by the amended Art. 6 still had its limitations. To interpret the 1903 amendment as giving the legislature the power to impose "any kind of tax known" would be, in the view of the court, erroneous,

... since the power given still relates to property taxation only; yet the amendment ... contains a grant of a broad and general power. Authority is thereby given to lay various kinds of ad valorem taxes upon property, incident upon some characteristic event, which may fairly be considered to reasonably delimit a class of property, so that selection cannot be rejected as arbitrary if the event itself affords some rational basis for the imposition of a tax. ${ }^{11}$

Thus, property may now be taxed once by the general property tax, which is characterized as an "estates" tax. But the same property may also now be classified by some "characteristic event" and taxed again as property "if the event itself affords some rational basis for the imposition of a tax."

${ }^{10}$ In re Opinion of the Justices, 84 N.H. 559, 574-577, 149 Atl. 321 (1930).

11 Id. at p. 576, cmphasis supplied. The court made the following interesting obscrvation in rejecting the notion that any and all excise taxes were now permissible (at p. 576):

It is immaterial whether such taxes are called excises or something else. In the sense that they are dynamic rather than static, that their incidence is dependent upon the happening of an event rather than upon the mere existence of property, they may properly enough be classed as excises. In the features of being laid upon property and ad valorem, they are like estate taxes.

Thus if such taxes are properly called excises this does not prove that all kinds of excises are permitted. The limitation of Art. 6 is fixed by its language, asserted the court, not by "classifications by economists." 
Other cases support the rationale of these two leading opinions. $^{12}$

Therefore a unique situation is found in New Hampshire. Only "property" taxes may be imposed. However, the apparent rigidity of such a limitation is avoided by the use of a second category of "property" taxes which in its practical effect permits the imposition of most, but not quite all, of the taxes characterized as nonproperty or excise taxes in the other forty-seven jurisdictions. For example, before 1903 an inheritance tax was said to be a privilege tax and therefore prohibited. ${ }^{13}$ But after the 1903 amendment to Art. 6 the court noted that such a tax was expressly permitted by Art. 6 . And the tax was held to be a tax upon a distinct class of property characterized by the passing of such property by will or intestacy. ${ }^{14}$ Similar rulings and counterrulings are found concerning selective or general franchise taxes. ${ }^{15}$ Also approved as being taxes upon classes of property characterized

12 See, for example: Thompson v. Kidder, 74 N.H. 89, 65 Atl. 392 (1906) (inheritance tax); Williams v. State, 81 N.H. 341, 125 Atl. 661 (1924) (inheritance tax); In re Opinion of the Justices, 82 N.H. 561, 138 Atl. 284 (1927) (general occupation tax; income tax; corporate franchise tax); Havens v. Atty. Gen., 91 N.H. 115, 14 A. 2 d 636 (1940) (tobacco products sales tax); Opinion of the Justices, 94 N.H. 506, 52 A. 2 d 294 (1947) (sale of soft drinks); Opinion of the Justices, 95 N.H. 537, 64 A. 2d 320 (1949) (gross income tax).

${ }^{13}$ Curry v. Spencer, supra note 2.

14 Thompson v. Kidder, supra note 12.

15 State v. United States \& Canada Express Co., supra note 5, holding that a $\operatorname{tax}$ on the gross receipts of express companics was a privilege tax; In re Opinion of the Justices, 82 N.H. 561 (1927), supra note 12, ruling that both the franchise "to be" a corporation and the franchise "to do" corporate business might be taxed as classes of property under Art. 6; In re Opinion of the Justices, 84 N.H. 559 (1930), supra note 10, ruling that a tax on the franchise of public utilities would be valid. But see Opinion of the Justices, 95 N.H. 543, 64 A. 2d 324 (1949), in which the court said that a proposed amendment to the public utilitics franchise tax, which would have changed the base-rate to $1 / 4$ of 1 mill for each kilowatt hour of electricity produced, would have converted the tax from one upon a class 
by an "event" are a timber severance tax, ${ }^{16}$ general and selective sales taxes, ${ }^{17}$ and a tax upon income. ${ }^{18}$ Disapproved was an "occupation" tax on businesses and occupations in general. ${ }^{19}$

The rigidity of this second category of "property" taxes has been avoided in some cases by characterizing the revenue producer as a "toll" or "charge," and not a "tax." For example, the "fuel tax" was so characterized. ${ }^{20}$ Nevertheless, this unique situation must be kept in mind when making a comparative study, because the designation of a tax-for example, an income tax or an inheritance tax-as a "property" tax in New Hampshire is the sine qua non of its existence. The exact opposite will more than likely be the case in other jurisdictions. There the struggle will be to characterize a tax, such as an income tax, as a nonproperty tax.

\section{c. Meaning of the uniformity limitation}

Prior to 1903 , the uniformity limitation ${ }^{21}$ was said to apply to "all species of taxes," but, as pointed out above, only the

of property to one upon a privilege disconnected with any class of property. Thercfore, the tax would have been an "excise" tax of the type still not permitted in New Hampshire.

${ }^{16}$ In re Opinion of the Justices, 84 N.H. 559, 574-575 (1930), supro note 10 .

${ }^{17} \mathrm{Id}$. at 575-577, approving the principle of a general retail sales tax. See Havens v. Atty. Gen., supra note 12, upholding a tobacco products sales tax; and Opinion of the Justices, 94 N.H. 506 (1947), supra note 12 , approving a selective sales tax on bottled soft drinks.

18 See the text at notes 45-51, infra.

${ }^{19}$ In re Opinion of the Justices, 82 N.H. 561 (1927), supra note 12. Also see Opinion of the Justices, 95 N.H. 555, 65 A. 2d 876 (1949) ruling that a proposed assessment of one cent a bushel on all commercial apples grown in the state to promote the sale and use of apples would be an excise tax and not permitted.

${ }^{20}$ See note 44 , infra.

21 This refers to the requirement found alternately in Art. 5 of Pt. II and Art. 12 of Pt. I. See note 2, supra. 
taxation of estates and polls was permissible. A further distinction was made to the effect that correlation of the uniformity in taxes on estates and taxes on polls was impossible because of fundamental differences in the two types of taxes. ${ }^{22}$ Thus, the ground was laid for the development of the similar rule after 1903. Subsequent to 1903 and the establishment of the power of the legislature to tax property by either of two types of "property" taxes, the court held that the rule of uniformity derived from Art. 5 of Pt. II and Art. 12 of Pt. I was still applicable to "all" taxes, including taxes upon "other classes of property" as well as taxes upon "estates." However, there was no requirement that there be a correlation of uniformity as between a tax upon "estates" and taxes upon "other classes of property," nor as among the several taxes upon "other classes of property." ${ }^{23}$ The court relied upon the rationale which supported the ruling that no correlation of uniformity was necessary between a "poll" tax and an "estate" tax-namely, that there are fundamental differences in the types of taxes.

For comparative purposes it will be helpful to consider the meaning of the uniformity limitation separately as to the two basic types of taxes: taxes upon "estates" and taxes upon "other classes of property." These two categories conform roughly, but only roughly, to the property and nonproperty tax dichotomy.

\section{(1) Property taxation: taxation of "estates"}

The uniformity limitation applicable to the taxation of "estates" was unchanged by the 1903 amendment to Art. 6 which broadened the scope of the taxing power in New Hampshire. Therefore, cases dated either before or after

22 See Amoskeag Mfg. Co. v. Manchester, 70 N.H. 336, 46 Atl. 470 (1900).

${ }^{23}$ See the cases in note 40 , infra. 
1903 may be cited indiscriminately in developing this limitation. For the purpose of taxing property as "estates" all property constitutes a single class, but there is no requirement of universality, either as to selection or exemption. It is within the power of the legislature either to select less than all property for taxation on the basis of "mere ownership, possession or enjoyment," or, by general law, to provide for the exemption of classes of property. ${ }^{24}$ Property may be classified for the purpose of exemption on the basis of use, purpose, or inherent characteristics. The New Hampshire court has continuously reiterated that, while an inequality of taxes is forbidden, this does not include the inequality which is admittedly caused by taxing some property and not taxing other. ${ }^{25}$

However, the power to exempt property is hedged by another limitation in addition to reasonable classifications. Exemptions must be supported by what is called "just reasons," a test which is met when the public welfare is benefited. ${ }^{20}$ This additional limitation of "just reasons" appears to be, however, more illusory than real. For example, as stated in a recent advisory opinion, ${ }^{27}$ which approved the exemption

${ }^{24}$ In In re Opinion of the Justices, 77 N.H. 611, 93 Atl. 311 (1915) the court ruled that the legislature could either select for, or exempt from taxation as "estates" the following intangible property: bonds, notes, interest bearing credits, and corporate stock. In In re Opinion of the Justices, 84 N.H. 559 (1930), supra note 10, the court ruled that standing timber could be exempt from taxation as "estates." Also see Brewster v. Hough, 10 N.H. 138 (1839); Canaan v. Enfield Village Fire District, 74 N.H. 517, 70 Atl. 250 (1908); Eyers Woolen Co. v. Town of Gilsum, 84 N.H. 1, 146 Atl. 511 (1929); State v. Berlin Street Ry., 84 N.H. 313, 150 Atl. 14 (1930); and Opinion of the Justices, 95 N.H. 548, 65 A. 2d 700 (1949).

${ }^{25}$ Opinion of the Justices, 95 N.H. 548, 550 (1949), supra note 24. ${ }^{26}$ Id. at 551, citing Rosenblum v. Griffin, 89 N.H. 314, 321, 197 Atl. 701 (1938).

27 ld. at 550 . 
by general law of certain privately owned airports from property taxation, ${ }^{28}$ the legislature has a wide discretion in the selective process of classifying property for exemption and determining the existence of "just reasons" therefor. But it appears that any attempt to grant quantitative minimum exemptions will stand a substantial chance of running afoul the "just reason" limitation. ${ }^{29}$

Once property is selected for taxation as "estates" there may be no further classification. Absolute uniformity must prevail as to the effective rate applicable to all property taxed by a single taxing jurisdiction. This applies to both the ratio of valuation ${ }^{30}$ and the percentage rate. ${ }^{31}$ When ruling that the taxation of standing timber at $75 \%$ of its full value would violate the rule of proportionality if other property was taxed at full value, ${ }^{32}$ the court said:

A change in either factor, the rate or the valuation, affects the product, which is the tax, in the same way; and in order

28 The requirement that exemptions be by general laws has been a much greater obstacle. See, for example, the discussion in Eyers Woolen Co. v. Town of Gilsum, supra note 24.

29 See note 39 , infra.

${ }^{30}$ In re Opinion of the Justices, 76 N.H. 609, 85 Atl. 757 (1913); French v. Lyme, 77 N.H. 63, 86 Atl. 823 (1913); Bow v. Farrand, 77 N.H. 451, 92 Atl. 926 (1915); In re Opinion of the Justices, 76 N.H. 588, 78 Atl. 31 (1911) ; Rollins v. City of Dover, 93 N.H. 448, 44 A. 2 d 113 (1945). And see the recent case, Bemis Bro. Bag Co. v. Claremont, 98 N.H. 446, 451, 102 A. 2d 512 (1953), in which the court held that the assessment of plaintiff's stock in trade at its full market value and real estate and other such property at varying percentages lower than its market value was a "violation of the constitutional requirements of proportionality and equality."

31 State v. United States \& Canada Express Co., supra note 5; Curry v. Spencer, supra note 2; In re Opinion of the Justices, 76 N.H. 588, supra note 30. In re Opinion of the Justices, 77 N.H. 611 (1915), supra note 24.

32 But see the 1942 amendment to Art. 5, in note 1, supra, which permits special treatment for forest lands, interpreted in In re Opinion of the Justices, 114 A. 2d 327 (1955). 
that the tax may be equal and proportional, all property must be valued alike and taxed at the same rate. ${ }^{33}$

As would be expected, the taxation of "estates" must be by the ad valorem method..$^{34}$ Specific taxation of "estates" is prohibited.

\section{(2) Property taxation: taxation of "other classes of property"}

Taxes upon "other classes of property," imposed pursuant to the authority of Art. 6, as amended, are limited by the proportionality clause in Art. $5,{ }^{35}$ but as stated above there need be no "correlation" of uniformity among such taxes. The objects of such taxes must be reasonable classes of property, classified according to some characteristic event. ${ }^{36}$

${ }^{33}$ In re Opinion of the Justices, 76 N.H. 609, 611 (1913), supra note 30. And see the excellent discussion of the concept of effective rates in Brock v. Town of Farmington, 98 N.H. 275, 98 A. 2d 162 (1953).

${ }^{34} \mathrm{See}$, for example, Opinion of the Justices, 4 N.H. 565 (1828), supra note 30; State v. United States \& Canada Express Co., supra note 5. And see In re Opinion of the Justices, 76 N.H. 588, 591 (1911), supra note 30.

${ }^{35}$ They are also limited by Art. 12 of Pt. I. See notes 2 and 21, supra.

${ }^{36} \mathrm{See}$, for example, Thompson v. Kidder, supra note 12 (inheritance tax: property passing by will or inheritance; under a collateral inheritance tax, the selection of only that property passing to collateral heirs was upheld); Conner v. State, supra note 9 (intangibles income tax; the selection of only the income from intangibles of individuals thus excluding corporate income was upheld) ; In re Opinion of the Justices, 82 N.H. 561, 564-566 (1927), supra note 12 (franchises are valid classes of property; but if franchises "to do" are taxed, since such franchises are granted to other than corporations, franchises exercised by other than corporations must be taxed); In re Opinion of the Justices, 84 N.H. 559, 564-570 (1930), supra note 10 (tax on franchise of gas and electric utilities, valid classification based on use of property in described business; may exclude other franchises exercised); id. at 571-573 (tax on earned income; would be an invalid discrimination to exclude corporate earned income, distinguishing exclusion of income of corporations under intangibles income tax); id. at 574-575 (selection of standing timber; tax imposed on same when severed, a distinctive class), and see the discussion of the yield tax, imposed upon the stump- 
In later decisions the court has tended to permit a greater legislative discretion in determining what is to constitute a reasonable class of property. ${ }^{37}$ As in the taxation of "estates," exemptions may be made from the class of property selected to be the object of a tax, but such exemptions must also conform to the "just reasons" test. ${ }^{38}$ In this respect, in an advisory opinion the court has ruled that any quantitative minimum exemptions are justified only on the basis that the holders are too poor to pay and that the public welfare is benefited by the exemption; and the court apparently will require such minimum exemptions to be a small amount. ${ }^{30}$

age value of growing wood and timber, in Brock v. Town of Farmington, supra note 33; In re Opinion of the Justices, 84 N.H. 559, 575-577 (1930), supra note 10 (retail sales tax; a valid class of property is that passing from seller to buyer); Havens v. Atty. Gen., supra note 12 (tobacco products sales tax; in a divided opinion, tobacco products sold were upheld as a distinctive class which was not too narrow); Opinion of the Justices, 94 N.H. 506 (1947), supra note 12 (sales tax on bottled soft drinks; valid class).

${ }^{37}$ For example, although in the Havens case, supra note 36 , there was a vigorous dissent directed against a selective sales tax (tobacco products) as being too narrow, in a subsequent advisory opinion, 94 N.H. 506, supra note 36 , a selective sales tax on bottled soft drinks was approved without any dissent. Also note the small class of incomes approved as the object of a tax in the Conner case, supra note 36 . But see the recent advisory opinion in which the court ruled that the legislature could not constitutionally impose a tax upon the sale of cigarettes at the rate of $20 \%$ of their value while imposing a tax upon the sale of other tobacco products at $15 \%$ of the value. In re Opinion of the Justices, 113 Atl. $2 \mathrm{~d} 119$ (1955). The court distinguished a prior 1951 advisory opinion, 97 N.H. 546, 81 A. 2d 853 (1951), in which it had ruled that cigarettes were a distinctive class of property and might be selected as a class by themselves for the purposes of taxation.

${ }^{38}$ See, for example, In re Opinion of the Justices, 82 N.H. 561, 566574 (1927), supra note 12.

${ }^{38}$ See, for example, In re Opinion of the Justices, 84 N.H. 559, 571573 (1930), supra note 10 , in which the court felt that a proposed minimum exemption of $\$ 3,500$ for the head of a family, plus $\$ 400$ for each dependent, appeared to be in excess of what was permissible. The same was said for the exemption of the income of persons earning under $\$ 2,000$. Such 
Insofar as proportionality is required of the objects of taxes on "other classes of property," the requirement is hardly more stringent than the usual uniformity within classes required of nonproperty taxes in other states. However, the uniformity required of rates and methods of taxation marks the divergence of the New Hampshire limitation from the usual requirement imposed on nonproperty taxes. As in the taxation of property as "estates," an absolute uniformity is required of the rate to be imposed by any particular tax on "other classes of property." While the rates need not be correlated as between or among the several such taxes, nevertheless once a class of property is selected as the object of a tax, then the same rate must apply to the entire class. ${ }^{40}$ Thus, the classification for varying rates according to relationship to the deceased as found in an inheritance tax was held to be "disproportional," invalid for the same reason. ${ }^{42}$

an excessive exemption was compared to a graduated rate, which was said to be prohibited (see note 42 , infra) because "A tax levy cannot be sustained here upon any theory that the richer one is the higher his tax rate should be. . . . It is only upon the narrow ground [that the exempted party is too poor to pay] . . . that any substantial quantitative exemption to the individual can be sustained." The court scaled down the amounts it had previously ruled as "fair" in In re Opinion of the Justices, 82 N.H. 561,570 , supra note 12.

${ }^{40}$ For example, Opinion of the Justices, 81 N.H. 552, 120 Atl. 629 (1923); Williams v. State, supra note 12; Foster v. Farrand, 81 N.H. 448, 128 Atl. 683 (1925); In re Opinion of the Justices, 84 N.H. 559, 571 573 (1930), supra note 10; Opinion of the Justices, 95 N.H. 537 (1949), supra note 12; Brock v. Town of Farmington, supra note 33. Also see the recent advisory opinion in which the court indicated that the legislature could change the rate for the tax upon incomes (interest and dividend) from the average rate of taxation levied upon other property throughout the state to a rate of $2 \frac{1}{2} \%$. In re Opinion of the Justices, 112 Atl. $2 \mathrm{~d} 44$ (1955).

41 Foster v. Farrand, supra note 39, reversing In re Opinion of the Justices, 76 N.H. 597, 79 Atl. 490 (1911).

42 Williams v. State, 81 N.H. 552 (1924), supra note 12; In re Opinion 
The limitation that particularly emphasizes the fact that the second principal category of permissible taxes is considered to consist of taxes upon property is the requirement that such taxes be imposed by the ad valorem method, which would invalidate the use of a specific base-rate structure. ${ }^{43}$ It is this limitation which would severely limit the New Hampshire legislature in providing for a flexible over-all tax structure if the limitation were strictly applied. However, that result is avoided by calling some revenue producers "charges" or "tolls" rather than taxes, with the result that they are not subject to either the proportionality limitation or the prohibition against the imposition of "excises." For example, that was the result when the validity of the fuel tax, with a specific base-rate structure, was challenged. ${ }^{44}$ Thus, while this requirement will invalidate in some instances some of the taxes commonly used in most other states, this is not a of the Justices, 81 N.H. 552 (1923), supra note 40 . See note 39, supra. In a recent advisory opinion, Opinion of the Justices, 113 A. 2d 547 (1955), the court ruled that a proposed tax of 10 per cent of the federal income tax paid by every individual resident of the state would be a graduated tax and therefore unconstitutional. As the court stated, (at p. 548):

We recognize that the rate proposed is a flat or uniform rate of ten per cent. Such a rate applied directly to income would produce a tax permitted by the Constitution. But the proposal is to apply it to amounts which are different percentages of the net incomes of the various taxpayers, graduated according to the size of their incomes. It follows that a tax produced by superimposing a flat rate upon the products of graduated rates will be a graduated tax.

${ }^{43}$ Sce, for example, Opinion of the Justices, 95 N.H. 555 (1949), supra note 19 , ruling against a proposed assessment of one cent a bushel on all commercial apples grown in the state to promote the sale and use of apples. See Opinion of the Justices, 95 N.H. 543 (1949), supra note 15, disapproving a proposed amendment to the utilities franchise tax, which would have changed the base-rate to mills per kilowatt hour of electricity produced.

44 In re Opinion of the Justices, 81 N.H. 552, 554-555 (1923), supra note 40 . The tax was imposed upon motor vehicles fuels sold in the state at a rate of two cents per gallon. The court stated that this was the ground upon which the state regulation system for automobiles was sustained. 
foregone conclusion. Moreover, the tax structure in New Hampshire does not substantially deviate from the usual state structure regardless of the name given the revenue producers-_"taxes" or "tolls" or "charges."

\section{(3) Income tax}

The New Hampshire decisions concerning the nature and validity of an income tax must be carefully distinguished when used for comparative purposes because of the unique situation in New Hampshire. The first relevant decision was an advisory opinion ${ }^{45}$ in which the court ruled that income from intangibles (interest or dividends from bonds, notes, interest bearing credits, and corporate stock) could be taxed at the same rate as that levied upon all other property in the taxing district; ${ }^{40}$ in other words, that income could be taxed by the "estates" tax. In a vigorous dissent Justice Peaslee contended that the tax under consideration would be in reality an income tax, and that an income tax is an excise tax and, therefore, not permissible under the New Hampshire Constitution.

Subsequently, the legislature imposed the intangibles income tax in its original form, and in Conner v. State ${ }^{47}$ the tax was upheld. However, the basis of the decision shifted from that relied on in the advisory opinion. The tax as enacted imposed a single rate upon all such income, but a rate different from that applicable under the general property tax. The court held that the tax was valid under the amended Art. 6

${ }^{45}$ In re Opinion of the Justices, 77 N.H. 611 (1915), supra note 24.

46 The court at the same time said that the intangible producing property itself might be exempted from taxation as "estates." Prior to this opinion the court had ruled that both the intangible property and the income produced thereby could be taxed by the general property tax without being "double taxation" contrary to the rule of proportionality. In re Opinion of the Justices, 76 N.H. 588 (1911), supra note 30.

${ }^{47}$ Supra note 9. 
as a tax upon "other classes of property." relation between the income tax rate and the rate of either the general property tax or any other taxes was not necessary. The prior advisory opinion was distinguished on the following basis: the decisions in no way conflicted, the prior advisory opinion related only to the taxation of income as "estates," which is permissible. That opinion did not rule out the separate classification of income to be taxed as "other classes of property." It is particularly interesting to note that Justice Peaslee wrote the opinion in the Conner case, and thereby rejected his dissent in the prior advisory opinion insofar as it assumed that there was no constitutional warrant for the imposition of an income tax. Thus he rejected his prior contention that an income tax is necessarily an excise or nonproperty tax. But this later decision by Justice Peaslee must be always considered in light of the unique situation in New Hampshire, in which a second category of "property" taxes is substantially similar to the nonproperty or excise taxes of other states.

In subsequent advisory opinions the court has cautioned that all income taxed must be taxed at the same rate, ${ }^{49}$ and that any minimum exemptions must be limited in amount to what the justices considered "fair." It has also ruled" ${ }^{51}$ that while less than all income might be selected for such a tax, nevertheless to tax the earned income of individuals only, excluding earned income of corporations, would be an invalid discrimination. However, the only income tax ever actually

48 The characteristic event on which the classification of the income was based was said to be the receipt of income.

${ }^{49}$ In re Opinion of the Justices, 82 N.H. 561, 566-574 (1927), supra note 12. Also see Opinion of the Justices, 95 N.H. 537 (1949), supra note 12 , ruling the same as to a tax upon "gross income."

50 See note 39 , supra. 10.

61 Opinion of the Justices, 84 N.H. 559, $571-573$ (1930), supra note 
imposed in New Hampshire is the present intangibles income tax.

\section{ANALYSES OF STATES WITH TYPE IV CLAUSES}

\section{Michigan}

\section{a. The provisions; historical note}

In the first Michigan Constitution, dated 1835, there were no provisions dealing with problems of uniformity in taxation. Michigan has had two subsequent constitutions, dated 1850 and 1908, respectively, but the uniformity structure has remained substantially unchanged since 1850 . In the present Michigan Constitution of 1908 there are two principal provisions concerning uniformity of taxation. Article X, $\$ 3$, contains the basic uniformity clause comparable to that found in other constitutions, and it reads:

The legislature shall provide by law a uniform rule of taxation, except on property paying specific taxes, and taxes shall be levied on such property as shall be prescribed by law. ... ${ }^{1}$

1 The second clause of Art. X, $\S 3$, which is omitted, deals, in combination with Art. X, $\S 5$, with a special problem. The two sections provide for an exception to the rule of uniformity for ad valorem taxation insofar as property of corporations and property used for public utility purposes is concerned. This property may be centrally assessed and taxed at a separate average rate. For text of the provisions, see Appendix A, infra.

In the 1850 constitution Art. XIV, $\S 11$ was identical with the first clause of the present Art. $X, \S 3$, except that the words "by law" preceding "a uniform rule" did not appear. In $1900 \mathrm{Art}$. XIV, $\$ 11$ was amended by the addition of a second clause substantially similar to the present second clause of Art. X, $\S 3$. Art. XIV, $\S 10$, infra note 2, was amended by the addition of a provision substantially similar to the present Art. $X, \S 5$. Thus, the special treatment of the property mentioned in the first paragraph of this note dates from 1900 . 
The other principal provision, Art. X, $\S 4$, contains a separate uniformity clause for the second category of taxes in Michigan. Section 4 reads:

The legislature may by law impose specific taxes, which shall be uniform upon the classes upon which they operate. ${ }^{2}$ A minor provision for our purposes, Art. $\mathrm{X}, \S 7,{ }^{3}$ provides that "All assessments hereafter authorized shall be on property at its cash value."

\section{b. Application of the uniformity limitation}

For purposes of uniformity of taxation in Michigan, taxes are grouped into two categories: ad valorem and specific." The applicable rule of uniformity depends upon the nature of the tax. Broadly stated, ad valorem taxes are limited by Art. X, §3, while specific taxes are limited by Art. X, $\$ 4 .^{5}$ The statement of this general principle leaves the most important question unanswered. What is the basis of the distinction between ad valorem and specific taxes? Since the "uniformity clause" of Art. $X, \S 3$ is a more strict requirement than the "uniformity clause" of Art. X, $\$ 4$, it becomes of crucial importance to be able clearly to designate a given tax as either ad valorem or specific.

In the other states, the constitutions of which have any form of uniformity clause, the applicable rules of uniformity

${ }^{2}$ This provision did not appear in the 1850 constitution. However, Art. XIV, $\S 10$ of that constitution did provide expressly for certain specific taxes: “... The legislature may provide for the collection of specific taxes from banking, railroad, plank-road, and other corporations hereafter created."

${ }^{3}$ Art. XIV, $\S 12$ of the 1850 constitution.

${ }^{4}$ This division is derived from the key words in the uniformity clause of Art. X, §3: "a uniform rule of taxation, except on property paying specific taxes." The term "ad valorem" is not actually used in the constitution.

${ }^{5}$ For example, Shapero v. State Department of Revenue, 322 Mich. 124, 140-141, 33 N.W. 2d 729 (1948). Also see the cases discussed in notes $50,52-54$ infra. 
are determined by the basic distinction made between property taxes as contrasted to nonproperty taxes. ${ }^{6}$ Thus, the characterization of taxes for purposes of uniformity in taxation ordinarily depends on the object of the tax-namely, whether the object is property or otherwise. Having determined that the nature of a given tax is property or nonproperty, one particular question which arises in all other states is whether or not property must be taxed ad valorem in order to satisfy the requirement of the "uniformity clause" which limits property taxation. More often than not, the answer is yes. Thus, the application of the "uniformity clause" is determined by the object of the tax (i.e., whether property or nonproperty), while the method used to tax property (i.e., ad valorem or specific) is determined by the applicable rules of uniformity.

This orthodox approach has not been followed in Michigan. Rather the basic classification of taxes in Michigan, for the purpose of determining applicable rules of uniformity, is that of ad valorem and specific taxes. Each category is governed by a different uniformity limitation. Moreover, the term "specific" is used in two distinct ways. First, it is used to denote all taxes which may be described as nonproperty taxes; second, to denote property taxes which have a base other than "according to the value" of the property taxed." Thus, the applicable rules of uniformity in Michigan are determined by both the object and the base of taxes. Regardless of the method used in imposing a nonproperty tax, such a tax is a "specific" tax for purposes of uniformity in Michigan

${ }^{6}$ Perhaps New Hampshire might be added as another exception. See Part $\mathrm{C}$ of this chapter, supra. But note the basic similarity of the classification in that state to the distinction which is usually made, even though only taxes upon property are permitted.

7 This is clearly demonstrated by the opinion in Union Trust Co. v. Wayne Probate Judge, 125 Mich. 487, 84 N.W. 1101 (1901). See notes 17 through 22 , infra and text thereto. 
constitutional law. However, if a tax has property as its object, then the nature of the tax is determined by the base used, i.e., the method used for taxing the property. Thus, for property taxes, in Michigan, the method used to tax property (i.e., ad valorem or specific) determines the applicable rules of uniformity-which is the reverse of the situation found in the other states.

\section{(1) Distinction between ad valorem and specific taxes}

The most important problem, for the purposes of this monograph, concerns the test which is used to distinguish between a specific property tax and an ad valorem property tax. ${ }^{8}$ This issue has never been resolved to the extent that a clearly identified and easily applied rule is available. It will be helpful to review the relevant cases at some length before reaching any general conclusion as to this test. The first such case is Pingree v. Auditor General. ${ }^{9}$ The issue in that case concerned the validity of "An act to provide for the assess-

8 This distinction is valid regardless of some rather ambiguous language in some recent specific nonproperty tax cases, in which the court appears to oppose the term "specific taxes" to all "property taxcs." For example, see Banner Laundering Co. v. State Board of Tax Admin., 297 Mich. 419, 427-428, 429, 298 N.W. 73 (1941) (general use tax), and Smith Co. v. Fitzgerald, 270 Mich. 659, 672-673, 259 N.W. 352 (1935) (chain store tax). However, in the same paragraphs of these same opinions there is language which apparently refers to "property paying specific taxes." These statements must be taken in context. In the above cases the allegations were simply that the taxes under consideration were "property taxes" within Art. $\mathrm{X}, \S 3$ limitation. The court in ruling on this issue falls into the approach of courts in other jurisdictions wherein the general distinction for the applicability of the uniformity limitations is between property and nonproperty taxes. This possible confusion in the language of the specific nonproperty tax cases serves to emphasize the uniqueness of the Michigan situation as to the applicability of its uniformity limitations.

${ }^{9} 120$ Mich. 95, 78 N.W. 1025 (1899). The decision was made under Art. XIV, $\S 11$ of the 1850 constitution, which was identical to the present Art. $X, \S 3$ in so far as the basic uniformity clause is concerned. See supro note 1 . 
ment and taxation of telegraph and telephone lines within the State of Michigan." ${ }^{10}$ As viewed by the court, the substance of that act required certain state officers to assess telegraph and telephone lines at their true cash value, and to levy a tax upon that assessment at a rate equal to the average state and local rates levied throughout the state during the previous year. ${ }^{11}$ The tax was to be in lieu of all other taxes.

In rendering the opinion of the court, ${ }^{12}$ after quoting at length from leading writers concerning the definitions of specific and ad valorem, Justice Hooker referred to certain statutes in force at the time the constitution of 1850 was adopted. He asserted that these statutes, as well as the definitions by the writers quoted by him, were indicative of the meaning of the term "specific taxes" as used in the constitutional provisions. ${ }^{13}$ Of those statutes in force at the time the constitution of 1850 was adopted, Judge Hooker used certain taxes relating to banks, and to railroad, canal, and turnpike companies as the basis for the following significant statement:

It will be noticed that they were not based upon the actual value of the real and personal property in possession of the companies at the time, but upon the amount of capital that had been previously invested in their business. The interposi-

${ }^{10}$ Mich. Laws 1881, Act No. 168.

11 Id. at 96.

12 The court consisted of five judges at the time this case was decided. Hooker, J. gave the opinion of the court which was concurred in by all other judges. This is mentioned because separate concurring opinions were written by Montgomery (concurred in by all except Hooker) and Grant. It is from these two concurring opinions that many of the quotations are taken when this case is used as authority for the distinction between specific and ad valorem taxes. However, it is the opinion of Hooker that is decisive, and it is in that opinion that the rationale is most clearly stated.

${ }^{19} I d$. at $97-100$. The provisions were Art. XIV, $\$ \$ 10$ and 11 of the 1850 constitution. See supra note 1 . 
tion of no assessing officer was required to value the property. ${ }^{14}$

Justice Hooker described the procedure used under those taxes in the following manner: "Reports were made by the companies, and the state treasurer was to determine the amount of the tax after making a deduction from the amount of capital stock equal in amount to such real and personal property of the banks as was locally assessed and taxed." Therefore, the opinion concluded:

In view of these laws, some of which continued in force after the adoption of the Constitution, we are satisfied that the convention understood the meaning of the term "specific taxes," and used it in no other than the common and wellsettled sense of the term, which they understood to imply $a$ tax which was made specific in rate and arbitrary in its standards, requiring no assessment beyond a mathematical computation. ${ }^{15}$

In further explanation of the term "specific taxes," Justice Hooker quoted Cooley's treatise on taxation as follows:

... As regards all such [specific] taxes, the law by which they are laid is of itself a complete apportionment. Ministerial officers have nothing to do but to list the subjects of taxation; . . . ascertain the number, weight, measurement, etc., when taxation depends upon it; and collect the sum which the law has definitely fixed. . . . (Cooley, Taxation [2d ed.], 238)..$^{16}$

Having held that the tax was for these reasons an ad valorem property tax, Judge Hooker went on to rule that the tax violated the "uniformity clause" applicable to such taxes.

The next relevant case is Union Trust Co. v. Wayne Pro-

14 Id. at 100-101. Emphasis supplied.

${ }^{15} \mathrm{Id}$. at 101 . Emphasis supplied.

16 Ibid. 
bate Judge. ${ }^{17}$ The issue in that case concerned the validity of the Inheritance Tax Act of $1899 .{ }^{18}$ Justice Hooker also wrote this opinion. The details of the tax were not discussed in the opinion. However, it is clear from the opinion that the court had closely scrutinized the base of this tax. The act provided that the tax was to be at a specified rate "upon the clear market value of such property" transferred by methods described in the act. ${ }^{10}$ Section 11 of the act is most significant. It provided that:

The judge of probate ... shall ... appoint a competent person as appraiser to $f(x$ the fair market value at the time of the transfer thereof, of property of persons whose estate shall be subject to the payment of any tax imposed by this act. . . . Provided, however, That when such estate, income or interest shall be of such a nature that its fair and clear market value cannot be ascertained at such time, it shall be appraised in like manner at the time when such value first became ascertainable. . . .

Section 12 of the act provided for the proceedings by appraisers, and these officials were clearly to exercise judgment in determining the "clear market value" of the property concerned. They were empowered to take evidence in reaching a conclusion as to the "market value." Thus, it is clear that the determination of the value, used as a base for this tax, was more than a mere "mathematical computation"the term used by Judge Hooker in the Pingree case.

As in the Pingree case, the court had to determine the nature of the inheritance tax in order to determine the validity of the tax under the Michigan uniformity limitations. The court stated that if the tax was upon property then it was

17 Supra note 7.

18 Mich. Laws 1899, Act No. 188. That act is the basis for the inheritance tax in force today, although it has been frequently amended.

${ }^{10} \mathrm{Id} . \S \S 1$ and 2. 
contrary to the uniformity clause applicable to ad valorem taxation, unless it could be called a specific tax upon property and therefore within the exception to the rule of uniformity. ${ }^{20}$ However, the court seemed to be of the opinion that the tax, if upon property, was clearly ad valorem. This is understandable in view of the base of the tax as described above. Justice Hooker stated:

The conclusion that this statute imposes an ad valorem tax upon property can only be avoided by saying that it is not a tax upon the property, and that, therefore, the ad valorem feature, which, so far as assessment upon the value is concerned, is certainly present, is wanting, because it is not an assessment upon the value of the property taxed. In short, the claim of the respondent is that this is a tax upon a privilege, viz., the privilege of succession. . . . ${ }^{21}$

Justice Hooker also quoted approvingly from the concurring opinions in the Pingree case to the effect that " $\mathrm{A}$ tax based upon the assessed cash value of the property is not a specific tax."

The court went on to hold that the inheritance tax was upon a privilege, and, therefore, was not an "ad valorem" tax-that is, the term ad valorem for purposes of uniformity is limited solely to ad valorem property taxation. The use of value (assessed value) as a base for privileges taxed was held not to change the nature of a specific nonproperty tax. In this respect the Pingree case was said to have "involved a tax upon property, and the discussion of the subject therein was limited to specific taxes upon property, although other specific taxes-such as taxes upon occupations and privilegeswere recognized."22

The next case of interest, although it offers little enlight-

${ }^{20}$ Union Trust Co. v. Wayne Probate Judge, supra note 7 at 490.

${ }^{21} I d$. at 491 . Emphasis by the court.

${ }^{22}$ Id. at 492-493. 
enment for our problem, is Union Trust Co. v. Detroit. ${ }^{23}$ The issue in that case concerned the validity under the uniformity provisions of the Michigan Constitution of the exemption provisions of the mortgage tax. ${ }^{24}$ The statute provided in section 2 that:

A tax of $50 \phi$ for each $\$ 100.00$ and each remaining major fraction thereof of the principal debt or obligation which is ... secured by a mortgage upon real property situated within this State . . . is hereby imposed on each such mortgage. ...

In holding that the act was valid, the court simply assumed that the tax was a specific property tax without any discussion of the question. ${ }^{25}$ However, it is pertinent to point out that the base of the mortgage tax was the "face value"-that is, the value of the debt secured by the mortgages subject to the tax. In addition, the mortgages (as property) were apparently the object of the tax. On the face of the statute, no attempt was made to impose the tax upon a "privilege of recording." The value of the debt secured-which could be determined by a mere examination of records-was thus taken as the "arbitrary" value to be used as the base of the tax. One might say that the tax, therefore, required no assessment "beyond a mathematical computation"-the term used by Justice Hooker in the Pingree case.

The next two relevant cases are Shivel v. Kent County Treasurer $^{26}$ and Shapero v. State Department of Revenue. ${ }^{27}$ These cases concerned the validity of the intangibles tax imposed in $1939 .{ }^{28}$ Section 2 of the act read:

23170 Mich. 692, 137 N.W. 122 (1912).

24 P.A. 1911 , No. 91.

${ }^{25}$ Union Trust Co. v. Detroit, supra note 23.

26295 Mich. 10, 294 N.W. 78 (1940).

27 Supra note 5.

${ }^{28}$ Mich. Laws 1939, Act No. 301; Mich. Stat. Ann. $\$ \$ 7.556(1)$ et seq. 
[T] here is hereby levied upon each resident or nonresident owner of intangible personal property not hereinafter exempted having a situs within this state ... an annual specific tax on each item of such property owned by him. . . . ${ }^{29}$

The following provisions of the act will be helpful in characterizing, according to its base, the nature of this tax for purposes of uniformity of taxation. Section 2 of the act provided a base of "income" for income producing intangible personal property, with a rate of $6 \% .^{30} \mathrm{~A}$ base of "face, par or contributed value" was provided for non-income producing intangible personal property, with a rate of $1 / 10$ of $1 \%$. Contributed value is defined by section 2 of the act as "the average per share [of corporate stock or other evidence of corporate ownership having no par or face value] contribution to capital, surplus and other funds in consideration of which all of the then outstanding shares of stock of the same class of such corporation shall have been issued." The term "face value" is defined by $\S 1(j)$ as "the amount appearing on the face of the instrument or other written record evidencing the intangible personal property. . . ." Under section 4 the owner is required to make an annual return showing the "face, par or contribution value of each item of such property." The owner must also show the income, if any,

29 The title of the act originally read: "An Act to provide for the imposition and the collection of a specific tax upon the ownership of intangible personal property. . . ." In 1945 the title was amended, so that it now reads: "specific tax upon the privilege of ownership of intangible personal property. ..." Section 2, as quoted in the text, was amended by the insertion of the italicized phrase: "annual specific tax on the privilege of ownership of each item of such property. . . ." [Mich. Laws 1945, Act No. 165] See infra note 39, commenting on the lack of any legal operative effect being derived from the amendment.

${ }^{30} \mathrm{But}$, in any case, a minimum tax of $1 / 10$ of $1 \%$ of the "face, par or contributed value" was required. 
from each item of property. Pursuant to section 5, the Department of Revenue may examine the records of any corporation to determine contributed value, if that value is omitted by the taxpayer in his return.

The intangibles tax was first challenged in the Shivel case. ${ }^{31}$ The taxpayer contended (1) that the tax was an ad valorem tax, and as such failed to conform to the uniformity clause of Art. X, $\S 3$; (2) that the tax was without an assessment of property at cash value as required by Art. X, $\$ 7$; (3) that a specific tax, under the constitution, could not be imposed upon intangible personal property; and (4) if the tax was specific it was a violation of Art. X, $\$ 4$, the uniformity provision limiting specific taxes. The court first held that the tax was a specific tax, and therefore not within the scope of the uniformity limitation in Art. X, $\S 3 .^{32}$ The court then held that the tax was uniform within classes, as required by Art. X, $\S 4 .^{33}$ While the Shivel case is a leading case on this problem, there was no discussion of the base of the tax in order to demonstrate why the tax was not ad valorem. Of course, if the court had ruled that the tax was a specific privilege tax, this would not have been necessary. However, it appears clear from the language of the opinion that the tax was considered a specific property tax-and this is confirmed by the Shapero case. The sole discussion in the Shivel case opinion concerning the nature of the tax was as follows:

The tax is specific, being levied directly by legislative enactment upon ownership of designated personal property and cannot be held arbitrary, discriminatory or inequitable, and the rule of uniformity required by the Constitution, art. 10, $\S 3$, in case of ad valorem tax, has no applicability.

In C.F. Smith Co. v. Fitzgerald, 270 Mich. 659, 672, we

31 Shivel v. Kent County Treasurer, supra note 26 at 14.

$32 I d$. at 16.

${ }^{83}$ Id. at 17. 
held: "The rule of uniformity does not extend to property paying specific taxes. . . . ."34

In addition to this brief statement, the court quoted with approval Cooley on Taxation, which reads:

A specific tax is one which imposes a specific sum by the head or number, or by some standard of weight or measurement, and which requires no assessment beyond a listing and classification of the subject to be taxed. . . . ${ }^{35}$

In the Shapero case the intangibles tax was challenged as to its validity insofar as shares of stock were taxed thereby when those shares were in Michigan corporations, the tangible property of which was taxed under the ad valorem general property tax. ${ }^{36}$ The case resulted in a split decision, with a vigorous three-judge dissent. However, there appeared to be no disagreement either by the majority or the dissenting judges from the proposition that the tax was a specific property tax. The majority of five, in a very brief opinion, held that to impose a specific property tax and an ad valorem property tax upon the same property was not a violation of Art. X, $\S 3$, because specific taxes are not limited thereby. The majority simply cited and quoted the Shivel case as holding the intangibles tax to be a specific tax. It was said, ". . . this rule of uniformity [in Art. $\mathrm{X}, \S 3$ ] has no application to property paying specific taxes under the plain language of the constitutional provision. ${ }^{\gg 37}$

Thus, it appears certain that the court did hold that the intangibles tax was a specific property tax. However, there was no discussion or enlightenment as to why, beyond the state-

${ }^{34} I d$. at 16 , emphasis supplied.

${ }^{35} I d$. at 17-18, emphasis supplied. 1 Cooley, Taxation, $\$ 52$, p. 143 (4th ed.; Callaghan \& Co.).

${ }^{36}$ Shapero v. State Dept. of Revenue, supra note 5 at 127 (from the dissenting opinion).

${ }^{37} I d$. at 140-142, emphasis supplied. 
ment that the tax was specific, "being levied directly by legislative enactment," and the quotation from Cooley which described specific taxes by pointing to the lack of an "assessment beyond a listing and classification of the subject to be taxed."

Nevertheless, it is permissible to examine more minutely the base of the tax, and thus have some idea as to the elements which were responsible for its being characterized as a specific base. There are two alternative bases: income for income-producing property, and "face, par or contributed value" for non-income-producing property. Somewhat like the mortgage tax, described above, the base of the intangibles $\operatorname{tax}$ is not necessarily the "actual cash value," or "market value." 38 The value is determined by a fixed-i.e., "certain" -formula which leaves no room for exercise of judgment by the person computing the value. The value might be found simply by a look at the face of a written instrument. However, in the case of "contributed value," there is a computation to be made: "the average per share contribution to capital, surplus and other funds in consideration of which all of

${ }^{38} \mathrm{Cf}$. the thought behind the statements by Grant, C.J., in his concurring opinion to Pingree v. Auditor General, supra notes 9 and 12. He said (at p. 108, 109):

Our Constitution authorizes only two kinds of taxes, -one, specific, imposed without regard to value of the thing taxed; the other, general, based upon assessed cash value, and requiring uniformity. . . .

A tax based upon the assessed cash value of the property assessed is not a specific tax. It is an ad valorem tax and any enactment by a legislature that it is a specific tax does not make it so; . . . The fact that, in imposing a specific tax, the value of the thing taxed is taken into consideration in determining the amount of it, does not change the nature of the tax. A tax upon the capital stock of a corporation, paid or unpaid, or upon its bonds issued or money borrowed, is just as much a specific tax as is so much per article upon the thing produced. The real value of the capital stock is not its par value. [Emphasis supplied.] 
the then outstanding shares of stock of the same class of such corporation shall have been issued." But, as contrasted to the method used under the inheritance tax, described above, this computation may surely be termed a mere "mathematical computation"- the term used by Justice Hooker in the Pingree case.

However, it would not be denied that it might be permissible to use "face, par or contributed value" of corporate stock as conclusive evidence of the "actual cash value" (usually equated to "fair market value") of such stock for purposes of taxation by an ad valorem property tax. The use of this formula to determine the base ("actual cash value") would probably be held reasonable. However, the use of such a formula does not necessarily indicate an intent to tax by the ad valorem method-that is, levy the tax on the "actual cash value" of property. And it is not improbable that "face, par or contributed value" will not be the "market value" of intangibles.

In any case, the use of "income" and "par, face, or contributed value" of intangibles as the base of a property tax does not require the exercise of judgment by a ministerial officer in order to determine the "value" of the property taxed. These bases, when used in the intangibles tax, were evidently considered by the Michigan Supreme Court in the Shivel and Shapero cases to be specific-not ad valorem. ${ }^{39}$

In Pingree v. Auditor General (concerning the tax on

39 The Shivel and Shapcro cases concerned the nature and validity of the intangibles tax before the 1945 amendment which added the phrases, in the title and operative section of the act, concerning the "privilege of" ownership of intangibles. See supra note 29. There has been no decision by the court whether this amendment changed the nature of the tax for purposes of uniformity of taxation, so that it is now a specific privilege tax. However, in two subsequent "territorial jurisdiction" cases, the Michigan Supreme Court has indicated that the insertion of these phrases did not effect a change in the nature of the tax. Goodenough v. Department of 
telephone and telegraph poles) and Union Trust Co. v. Wayne Probate Judge (concerning the inheritance tax) the court stressed the point that under both of the taxes the exercise of judgment by some ministerial officer was necessary in order to reach a conclusion as to the value of the property concerned. This element was not present in either the mortgage tax or the intangibles tax. Therefore, in light of the above analysis, it is not unreasonable to conclude that (1) when this element (exercise of judgment ${ }^{40}$ by a ministerial officer) is present in a tax, and (2) if property is the object of the tax, then, and only then, the tax may be considered ad valorem in Michigan for purposes of uniformity of taxation.

Having reached a conclusion as to the test used to distinguish between ad valorem and specific taxes in Michigan for purposes of uniformity, it might be helpful before discussing the content of the uniformity limitation to summarize the decisions of the court concerning the nature of some taxes of comparative interest. The following taxes have been held to be specific privilege taxes: inheritance tax ${ }^{41}$ motor vehicle tax ${ }^{42}$ corporate franchise tax, with a base of capital stock ; $^{\mathbf{4 3}}$

Revenue, 328 Mich. 56, 43 N.W. 2d 235 (1950); same opinion on rehearing, 328 Mich. 502, 44 N.W. 2d 161; and Cleveland-Cliffs Iron Co. v. Department of Revenue, 329 Mich. 225, 45 N.W. $2 d 46$ (1950).

40 There must be more than mere action by a ministerial officer. There must be an action which requires an exercise of judgment, not a "mere mathematical computation."

41 Union Trust Co. v. Wayne Probate Judge, supra note 7, discussed in the text. See also In re Estate of Fish, 219 Mich. 369, 189 N.W. 177 (1922).

42 Jasnowski v. Board of Assessors of Detroit, 191 Mich. 287, 157 N.W. 891 (1916).

43 Union Steam Pump Sales Co. v. DeLand, 216 Mich. 261, 185 N.W. 353 (1921). The tax had a base of capital stock, and it was held to be a tax upon the privilege "to do," rather than the privilege "to be." This latter distinction was necessary because of a "diversion limitation" in Art. $\mathrm{X}, \S 1$ of the constitution. 
general use $\operatorname{tax} ;^{44}$ and others. ${ }^{45}$ The following taxes have been held to be specific property taxes: intangibles tax; ${ }^{46}$ and mortgage recording tax. ${ }^{47}$ There has been no decision concerning the taxation of income in Michigan. ${ }^{48}$

\section{c. Meaning of the uniformity limitation}

\section{Ad valorem (property) taxes. The court has ruled that} there is no requirement of universality in the "uniformity clause" of Art. X, $\$ 3$ which limits ad valorem taxes; there-

44 Banner Laundering Co. v. State Board of Tax Admin., supra note 8.

${ }^{45}$ For example: a fuel tax, Lake Shore Coach Lines v. Sec. of State, 327 Mich. 146, 41 N.W. 2d 503 (1950); chain store tax, Smith Co. v. Fitzgerald, supra note 8; and in Miller v. Michigan State Apple Commission, 296 Mich. 248, 296 N.W. 245 (1941) it was held that a tax of one cent per bushel, or two cents per hundredweight imposed "upon all apples" grown during the year was a specific privilege tax upon "the privilege of putting Michigan-grown apples on the market." See also Kull v. Michigan State Apple Commission, 296 Mich. 262, 296 N.W. 250 (1941).

${ }^{40}$ Shivel v. Kent County Treasurer, supra note 26 , and Shapero v. State Department of Revenue, supra note 5, discussed in the text.

${ }^{47}$ Union Trust Co. v. Detroit, supra note 23, discussed in the text.

48 Nor is there any real indication found in opinions of the court relating to other taxes. The only relevant statement by the court occurred in the Shivel case, supra note 26 , in which the court upheld the intangibles tax. With no discussion the court concluded its opinion with the following observation (at Pp. 18-19):

After submission of this case we called upon counsel to consider and file briefs on the following questions: . . .

3. Does the act in some respects tax income and is it, therefore, an income tax contrary to the rejection of such a tax by vote of the people in $1922,1924,1934$, and 1936 ? . . .

7. Does the provision ... of the act, which provides: "The tax on income producing intangible personal property shall be six per cent of the income," impose a tax on income? . . .

The questions have been briefed and we now make the following holdings with respect thereto: . . .

Questions 3 and 7. The income basis for measuring the tax does not constitute it an income tax.

As stated in Young v. Illinois Athletic Club, 310 Ill. 75, 81 (141 N.E. 369, 30 A.L.R. 985): "An income tax is an assessment upon the income 
fore, reasonable classes of property may be exempted from taxation..$^{49}$ As the preceding analysis has made clear, the uniformity clause of Art. X, $\S 3$ does not limit the method by which property may be taxed. Rather the method used (ad valorem or specific) determines the applicability of Art. X, $\S 3$. Therefore, the uniformity clause in that constitutional provision applies solely to the effective rate applicable to property actually selected for ad valorem taxation. Absolute uniformity is required of the effective rate applicable to property actually taxed ad valorem by a taxing jurisdiction. ${ }^{\text {Bo }}$

of the person and not upon any particular property from which that income is derived." . . .

Question 3 in the quotation refers to the fact that constitutional amendments authorizing an income tax in Michigan have been submitted to the electorate on the four dates mentioned and have been defeated each time. See State of Michigan, Official Directory, pp. 57-59 (1937).

Three opinions of the Attorney General have dealt with this question. Two opinions seem to cancel out one another. Op. Atty. Gen., 1923-1924, p. 162 and 1931-1932, p. 171. Both are simply bare conclusions concerning the nature and validity of an income tax in Michigan. Neither makes any attempt to support its conclusion by legal analysis. A third opinion, by a third attorney general, concludes that a "graduated net income tax is constitutional" in Michigan. Op. Atty. Gen., 1933-1934, pp. 261-268. This opinion makes some effort to support its conclusion by an analysis of pertinent material. It is primarily an analysis of the opinions of other state courts on the problem.

49 See People ex rel. St. Mary's Falls Ship Canal Co. v. Auditor General, 7 Mich. 84, 90-91, 96-97 (1859); Auditor General v. MacKinnon Boiler \& Machine Co., 199 Mich. 489, 490, 165 N.W. 771 (1917); and Lucking v. People, 320 Mich. 495, 31 N.W. 2d 707 (1948). Also see Union Trust Co. v. Detroit, supra note 23 at 697, and Jasnowski v. Board of Assessors, supra note 42 at 291 , in which the exemption of certain property was tied in with "in lieu" specific taxes. While the court has simply ruled that the rule of uniformity has no relation to the exemption of property from taxation, it might well have used the actual phraseology of Art. X, $\$ 3$ to buttress this conclusion. See the following significant words: “. . . and taxes shall be levied on such property as shall be prescribed by law. . . ."

${ }^{50}$ See, for example, Pingee v. Auditor General, supra note 9 at 102, discussed in the text, supra notes 9 through 16. The tax under consideration 
Specific taxes (property and nonproperty). Specific taxes, whether property or nonproperty, are limited only by the uniformity clause in Art. X, $\S 4$ which requires a uniformity within classes. This limitation has been equated to the federal equal protection clause. ${ }^{51}$ Thus, the objects of such taxes need only be reasonable classes, and exemptions therefrom may be made. ${ }^{62}$ The objects may be further classified for purposes of applying different rates, ${ }^{53}$ and it has been ruled that pro-

in that case would have applied, in lieu of all other taxes, an average of the state and local property tax rates upon an assessment of the property of telephone and telegraph companies. It was held that the tax was in fact an ad valorem tax, and that it violated the uniformity clause requiring absolute uniformity in effective rates because the rate would have been different in amount from that imposed upon all other property subject to a state ad valorem tax. Also see the cases holding that the taxation of corporate property to the corporation and the shares thereof to the shareholder by the same ad valorem property tax is "double taxation" and a violation of the requirement of absolute uniformity in effective rates: Bacon v. Board of State Tax Comm'rs, 126 Mich. 22, 85 N.W. 307 (1901); Stroh v. Detroit, 131 Mich. 109, 90 N.W. 1029 (1902); Thrall v. Guiney, 141 Mich. 392, 104 N.W. 646 (1905); Detroit v. Kresge, 200 Mich. 668, 167 N.W. 39 (1918); and Voorhies v. Walker, 227 Mich. 291, 198 N.W. 994 (1924). See First Nat. Bank v. Common Council of Detroit, 253 Mich. 89, 234 N.W. 151 (1931), discussed infra note 55. However, the court has ruled that the taxation by the same tax of both a mortgage and the land mortgaged is not "double taxation," that is, in such cases the "same" property is not being taxed: Attorney General v. Sanilac, 71 Mich. 16, 38 N.W. 639 (1888) ; Marquette v. Michigan Iron \& Land Co., 132 Mich. 130, 92 N.W. 934; and Stumpf v. Storz, 156 Mich. 228, 120 N.W. 618 (1909). Also see Thoman v. City of Lansing, 315 Mich. 566, 24 N.W. 2d 213 (1946) and Ontonagon v. Gogebic, 74 Mich. 721, 42 N.W. 170 (1889).

${ }^{61}$ Shivel v. Kent County Treasurer, supra note 26.

52 Banner Laundering Co. v. State Board of Tax Administration, supro note 8 (upholding the numerous exemptions from the general use tax as reasonable classes); Smith Co. v. Fitzgerald, supra note 8 (chain store tax; exemption of gasoline filling stations held to be reasonable); and see Miller v. Michigan State Apple Commission, supra note 45 (tax imposed on apples grown, a privilege tax; held the selection of growers of apples out of all engaged in agricultural pursuits is reasonable).

${ }^{63}$ In Shivel v. Kent County Treasurer, supra note 26, the court held that 
gressively graduated rates constitute a reasonable classification based on quantity. ${ }^{54}$ However, here one should be very careful in making generalizations. It might well be that the court would be more strict in examining classifications under specific property taxes; for example, classification of property according to quantity for purpose of applying a graduated rate under a specific property tax might well be required to conform to a stricter test than that applied to the graduated rates under specific privilege taxes concerning which the actual decisions have been made.

Also, the court has held that there is no constitutional inhibition against the same taxing authority taxing the same property by both an ad valorem property tax and a specific property tax. "Any prohibition against "double taxation" is

the classification of intangibles into income producing and non-income producing, and the imposition of a different rate on each class, was reasonable. Also see: Lake Shore Coach Lines v. Sec. of State, supra note 45 (motor fuel tax; classification for rates thereunder valid, the rates were four cents per gallon for diesel motor fuel used in vehicles operated under municipal franchise, and five cents per gallon for all other users of diesel motor fuel); Union Steam Pump Sales Co. v. Sec. of State, supra note 43 (corporate franchise tax, with a base of capital stock; holding that Art. X, $\S 4$ was not violated because of the fact that a provision fixed a maximum and minimum in the amount of the tax to be paid; the court stated that "the difference upon which the classification shall be based ... need not be great or conspicuous.") ; Jasnowski v. Board of Assessors, supra note 42 (motor vehicle tax; holding that difference in ownership of vehicles created a reasonable distinction and support for a classification under which individual owners paid a different rate schedule than that paid by manufacturers). Also see the cases in note 54 , infra.

${ }^{54}$ Union Trust Co. v. Wayne Probate Judge, supra note 7 (inheritance tax; the graduated rates were held to be a reasonable classification, primarily relying on the federal case Magoun v. Illinois Trust and Savings Bank, 170 U.S. 283, 18 S. Ct. 594 (1897)) and Smith Co. v. Fitzgerald, supra note 8 (chain store tax; graduated rates held reasonable).

${ }^{55}$ Shapero v. State Dept. of Revenue, supra note 5 (intangibles tax). There was a dissent of three judges, relying on the prior case First Nat. Bank v. Common Council of Detroit, supra note 50 at 94-96. However, in that early case (ruling as to the taxation of credits belonging to a bank 
derived from the uniformity clause in Art. X, $\S 3$ which applies only to ad valorem taxation. Thus, the court, besides ruling that specific property taxes do not have to conform internally to the uniformity clause in Art. $X, \S 3$ has also ruled that there is no limitation derived from Art. $\mathrm{X}, \S 3$ which applies to the external relation between a specific property tax and ad valorem property taxation. This result is reached because "double taxation" is but a shorthand way of describing the absolute uniformity required of the effective rate imposed by ad valorem taxation. ${ }^{56}$ While the court has had no occasion to actually make a decision on the precise issue, it would seem equally clear that Art. X, $\$ 3$ and any prohibition therein against "double taxation," has no relation to two specific property taxes imposed on the same property. ${ }^{57}$

secured by liens upon real property upon which a specific tax, the mortgage tax, had been paid, and the failure to allow a deduction of those credits from the shares of capital stock in banks which were to be taxed under the general property tax) there was no discussion of the fact that the cases relied on therein (see the cases supra note 50) concerned taxation by the same ad valorem tax. In any case, on this point the Shapero case makes a clear-cut ruling.

56 See the cases cited in supra note 50. Also see the discussion in Chapter I, supra.

57 The reason for stressing this rather obvious conclusion is to correct any erroneous impressions that might be drawn from Op. Atty. Gen., 19411942 , p. 262. An opinion was there given that oil royalties were not subject to the intangibles tax. The opinion rested on interpretation of that $\operatorname{tax}$ statute. However, in support of his interpretation that the intangibles tax was not intended to include royalties upon oil produced in Michigan and subject to the Michigan "severance" tax, the Attorney General asserted (at p. 263):

The rule of uniformity applies to specific taxes by the express language of the Constitution. [Art. X, $\$ 4$ had just been quoted.] The rule forbids double taxation. In the present instance, two different specific tax statutes are imposed upon the same objects.

The opinion then cites the Stroh case, supra note 50, and quotes therefrom to the effect that the constitution requires a uniform rule of taxation which forbids double taxation. Unfortunately the opinion appears to be inaccurate. 


\section{New Jersey}

\section{a. The provisions; historical note}

The first constitution of New Jersey, adopted in 1776, had no provisions concerning uniformity in taxation-indeed, no provision concerning taxation at all; neither did the second New Jersey Constitution adopted in 1844. However, the 1844 constitution was amended in 1875 by the addition of section VII (12) to Art. IV (the general legislative article). Subsection 12 read:

Property shall be assessed for taxes under general laws, and by uniform rules, according to its true value.

In 1947 the present constitution of New Jersey was adopted. In the new constitution only slight changes were made insofar as taxation is concerned. The former uniformity provision is now found in Art. VIII, $\S 1(1)$ in a somewhat altered form, but with substantially the same basic phraseology:

Property shall be assessed for taxation under general laws and by uniform rules. All real property assessed and taxed locally or by the State for allotment and payment to taxing districts shall be assessed according to the same standard of value; and such real property shall be taxed at the general tax rate of the taxing district in which the property is situated, for the use of such taxing district.

\section{A new provision, appearing as Art. VIII, §1(2), provides}

In the first place, the Stroh case was decided under Art. X, $\$ 3$ concerning the taxation twice of the same property by the same ad valorem property tax. The Attorney General refers to Art. X, \$4-which does govern specific property taxes-but which does not "forbid double taxation," for indeed property may be classified for different rates under specific property taxes. See, supra note 52. Moreover, while the First Nat. Bank case, supra note 55, was referred to, nevertheless even that case related only to the use of an ad valorem and a specific property tax, and not to two specific property taxes. 
that "Exemption from taxation may be granted only by general laws. ...."

\section{b. Meaning of the uniformity limitation}

Since the present New Jersey Constitution was adopted as late as 1947, there has been little opportunity for development of any comprehensive meaning of the new uniformity provision. However, this new provision is sufficiently similar to the prior provision which governed from 1875 to 1947 , that a brief statement of the meaning of the prior uniformity limitation will give a key to the significance of the changes made in the phraseology of the new uniformity clause.

1875 to $1947 .^{2}$ Under the prior constitutional provision the courts ruled that the requirement that "Property shall be assessed for taxes . . . by uniform rules, according to its true value" did not contain a rule of universality. Therefore, property could be classified for exemptions from taxation. In the exemption cases the court developed the rule that classification had to be of property according to its characteristics or the use to which it is put, and not according to the status of the owner or the mere incidence of location of the property. ${ }^{3}$ This result is not unexpected in view of the fact that

1 The omitted part of Art. VIII, $\S 1(2)$ deals with the status of certain exemptions which were granted before the constitution came into effect. With certain exceptions, "Exemptions from taxation may be altered or repealed." Art. VIII, $\S 1(3)$ deals expressly with the excmption of property belonging to veterans.

2 Primary reliance for this summary statement is placed on a monograph prepared for The Governor's Committee on Preparatory Research for the New Jersey Constitutional Convention (May, 1947), written by A. K. Neeld and entitled "Taxation-The Tax Clause."

${ }^{3}$ For example, an attempt to create an exemption of property to the amount of $\$ 500$ belonging to persons enrolled as active members of any fire company was held to be arkitrary. Tippett v. McGrath, 70 N.J.L. 110,56 Atl. 134 (1903). The same result was reached as to an attempt to exempt improvements on real property within a period of five years. Koch v. Essex 
no constitutional provision provided for the exemption of property usually exempted to some degree, such as public property, charitable property, and the like. Moreover, at times the court stressed the fact that the word "all" did not modify the word property in the uniformity clause.

The most interesting ruling under the old uniformity provision was that it did not require absolute uniformity in effective rates applicable to property taxed by any one taxing authority. ${ }^{4}$ Property could be classified for the purpose of applying different percentage rates by the same taxing authority. ${ }^{5}$ But it seems that an absolute uniformity of "true value" was required by the express words of the uniformity clause, ${ }^{6}$ so that classification could not legally be made for

County Board of Taxation, 97 N.J.L. 61, 116 Atl. 328 (1922). Also see Alpha Rho Alumni Ass'n v. New Brunswick, 126 N.J.L. 233, 18 A. 2d 68 (1941) ; State v. Mercer County Board of Taxation, 118 N.J.L. 408, 193 Atl. 555 (1937).

${ }^{4}$ A leading case establishing this is State Board of Assessors v. Central R. Co., 48 N.J.L. 146, 4 Atl. 578 (1886), in which there was a dissent on this point although unanimous agreement that the uniformity provision contained no rule of universality. Subsequent opinions developing this point are: Central R. Co. of New Jersey v. State Board of Assessors, 75 N.J.L. 120, 67 At1. 672 (1907); Central R. Co. of New Jersey v. State Board of Assessors, 75 N.J.L. 771, 69 Atl. 239 (1908). Broadly speaking, railroad property was separately classified, and further classified into two groups, one of which was taxed at the same rate as other property and one of which was taxed at a special fixed percentage.

5 No general classified property tax has bcen attempted, nor has there been a classification of intangibles for a low rate. However, at present intangibles are exempt entirely. Classifications consisted of special treatment for smaller classes of property such as, for example, bank stock and some railroad property. See Neeld, supra note 2 at 9 . Despite some comments to the contrary, it appears clear that the legislature had the power to impose a general classified property tax under the prior uniformity clause, and that any lack of "reform" in the tax structure in the form of a classified system was "due, not to necessity, but to choice or inertia." From a report of 1919 Commission to Investigate Tax Laws, quoted in Neeld, supra note 2 at 24. Also generally on this question, see Neeld, supra note 2 at 23-27.

${ }^{6}$ Neeld, supra note 2 at 7-8, states that the New Jersey courts have ruled 
the purpose of using different ratios of valuation. ${ }^{7}$ Of course, this should not affect the possibility of a classified property tax, since classification for either percentage rate or ratio of valuation achieves the same purpose.

As expected, the uniformity provision was limited in its application to property taxes. Nonproperty taxes were required only to be uniform within classes, and an inheritance tax (having a classified object and a graduated rate schedule) was upheld as a nonproperty tax. ${ }^{8}$ There is no precedent regarding an income tax. ${ }^{9}$

1947 to the present. There seems to have been very little change of substance in the uniformity provision as it was carried over into the new 1947 constitution. First, an express provision was added requiring exemptions of property to be by "general law." While a great deal of controversy appears to have existed concerning the manner in which exemptions had been theretofore made, and while this problem is undoubtedly of considerable importance to the peoples concerned, nevertheless it is a minor item for purposes of this study. Indeed, the only important change for purposes of this study was the elimination of the requirement that prop-

that assessment at "true value" prevails over any requirement of uniformity in ratio, and that the remedy in cases where it can be shown that other property is assessed at a ratio of less than $100 \%$ is an application to increase all assessments below true value, citing Royal Mfg. Co. v. Board of Equalization of Taxes, 78 N.J.L. 337, 74 Atl. 525 (1909), aff'g 76 N.J.L. 402, 70 Atl. 978 (1908). Also see Baldwin Construction Co. v. Essex County Board of Tax., 16 N.J. 329, 108 A. 2d 598 (1954).

${ }^{7}$ However, it appears that in the absence of a legal classification for application of different percentage rates local assessing officers have enforced de facto classification systems based on different ratios of valuation. See, for example, the complaints recorded in Neeld, supra note 2 at 16 . Also see the discussion in the dissenting opinion by Vanderbilt, C. J., in Baldwin Construction Co. v. Essex County Bd. of Tax., supra note 6 at 610-612.

${ }^{8}$ For example, Eastwood v. Russell, 81 N.J.L. 672, 81 Atl. 108 (1911).

${ }^{9}$ See Neeld, supra note 2 at 35-38. 
erty be assessed "according to its true value." In place of this requirement, it appears that all real property must now be assessed "according to the same standard of value," and that an absolute uniformity must prevail as to the effective rate applicable to all realty within a taxing jurisdiction.

There have been no judicial decisions concerning these changes. However, the omission of the phrase "according to value" as a modifier of "property" possibly opens the way for the specific taxation of personal property. Moreover, the requirement concerning the rate applicable to real property apparently restricts to a degree the legislature's freedom of classification, since there had been no ruling before 1947 that realty could not be further classified by the legislature under its power to classify property for purposes of taxation. However, the uniformity limitation remains in substance practically the same under the new 1947 constitution as it was from 1875 to 1947 under the amended 1844 constitution.

\section{Ohio}

\section{a. The provisions; historical note}

The first constitution of Ohio, adopted in 1802, had no provision concerning uniformity in taxation. The second, and present, constitution of Ohio was adopted in 1851 and originally contained an elaborate uniformity clause in Art. XII, $\$ 2$, which read:

Laws shall be passed, taxing by a uniform rule, all moneys, credits, investments in bonds, stocks, joint stock companies, or otherwise; and also all real and personal property, according to its true value in money; but burying grounds, public schoolhouses, houses used exclusively for public worship, institutions of purely public character, and public property used exclusively for any public purpose, and personal property, to an amount not exceeding in value $\$ 200$, 
for each individual, may, by general laws, be exempted from taxation. ... . $^{1}$

This basic uniformity provision was supplemented by two provisions dealing with special problems of uniformity which were probably covered implicitly by the general clause. Those provisions were intended to ensure an equality in tax burden as between property of individuals and "all property employed in banking" (Art. XII, §3) and corporate property (Art. XII, §4).

In 1929 a substantial change was made in the scope of the basic uniformity clause. Article XII, $\$ 2$ was amended, and now reads:

Land and improvements thereon shall be taxed by a uniform rule according to value. All bonds [of a specific character, being types of state and local issues] shall be exempt from taxation, and without limiting the general power, subject to the provisions of article I of this constitution, to determine the subjects and methods of taxation or exemptions

${ }^{1}$ Art. XII, §2 was amended several times before 1929, but not in such a manner as to alter substantially the effective uniformity limitation. In 1905 a proviso was added, following the words "according to its true value in money," which provided for the exemption of certain bonds of state and local governmental units. This was altered in details in 1912 and 1918. Also in 1912 the minimum exemption of personal property was raised to $\$ 500$, and the phrase "institutions of purely public character" in the exemption clause was changed to "institutions used exclusively for charitable purposes."

In 1918 a more important change for the purposes of this study was made. Following the exemption clause a provision was added sanctioning exemptions designed to avoid "double taxation" in the taxation of both realty and mortgages thereon. The provision read:

-. . laws may be passed to provide against the double taxation that results from the taxation of both the real estate and the mortgage or the debt secured thereby, or other lien upon it. . . .

This amendment followed a ruling that the taxation of both an item of property and a mortgage thereon was not prohibited by the uniformity clause. 
therefrom, general laws may be passed to exempt burying grounds, public school houses, houses used exclusively for any public purpose. . . .

At the time of the 1929 amendment to Art. XII, §2, Art. XII, $\$ 3$ concerning the taxation of banking property was repealed.

The significant changes in the uniformity provision found in Art. XII, $\$ 2$ were, first, the restriction of the operation of the unifromity clause to "land and improvements thereon," and, second, the alteration of the exemption clause which had theretofore modified the uniformity clause. The reference to the exemption of $\$ 200$ worth of personal was deleted, and this curious clause was added: "without limiting the general power, subject to the provisions of article I of this constitution, to determine the subjects and methods of taxation or exemptions therefrom." The exemption clause remained permissive, however, as contrasted to mandatory.

Prior to this establishment of a new effective uniformity limitation in 1929, three important provisions had been added in 1912. Inheritance and income taxes were expressly provided for in Art. XII, $\$ 7,{ }^{3}$ and Art. XII, $\$ 8,{ }^{4}$ respec-

2 The section was further amended in 1929 by the addition of a maximum rate limitation provision which preceded the uniformity clause.

3 Section 7 reads:

Laws may be passed providing for the taxation of the right to receive, or to succeed to, estates, and such taxation may be uniform or it may be so graduated as to tax at a higher rate the right to receive, or to succeed to, estates of larger value than to estates of smaller value. Such tax may also be levied at different rates upon collateral and direct inheritances, and a portion of each estate not exceeding twenty thousand dollars may be exempt from such taxation.

4 Section 8 reads:

Laws may be passed providing for the taxation of incomes, and such taxation may be either uniform or graduated, and may be applied to such incomes as may be designated by law; but a part of each annual income not exceeding three thousand dollars may be exempt from such taxation. 
tively, and the uniformity limitation applicable thereto was spelled out. Art. XII, $\S 10$, was phrased so as to refer expressly to the power of the legislature to impose nonproperty taxes in general. ${ }^{5}$ To summarize, the present uniformity structure consists primarily of Art. XII, $\S 2$, as amended in 1929, which contains the basic uniformity clause, and Art. XII, $\S \S 7,8$, and 10 , which concern particular taxes. ${ }^{6}$

\section{b. Meaning of the uniformity limitation}

The Ohio uniformity clause, both in its original and amended form, is obviously directed to the taxation of property, so that nonproperty taxes are limited only by a requirement of uniformity within classes. ${ }^{7}$ That limitation is derived from the equivalent of an equal protection clause found in the state constitution. ${ }^{8}$ However, before 1912 there was considerable controversy concerning the strictness of the uniformity limitation applicable to nonproperty taxes. This

\section{${ }^{5}$ Section 10 reads:}

Laws may be passed providing for excise and franchise taxes and for the imposition of taxes upon the production of coal, oil, gas and other minerals.

${ }^{6}$ Art. XII, $\S 4$, concerning an equality of tax burden between corporate and individual property, also remains. In addition, an exception to the uniformity required of property taxation was made in 1912 by the addition of Art. II, $\$ 36$ providing that forestry lands "may be exempted, in whole or in part from taxation. . . ."

7 See, for example, Southern Gum Co. v. Laylin, 66 Ohio St. 578, 64 N.E. 564 (1902) (corporate franchise tax with a base of capital stock); Saviers v. Smith, 101 Ohio St. 132, 128 N.E. 269 (1920) (motor vehicle tax); State ex rel. Walls v. Wallace, 138 Ohio St. 410, 35 N.E. 2 d 167 (1941) (motor vehicle tax). Also see the inheritance tax cases, discussed in the text.

${ }^{8}$ Art. I, $\S 2$, which for this problem has substantially the same meaning as the federal equal protection clause. See State ex rel. Struble v. Davis, 132 Ohio St. 555, 9 N.E. 2d 684 (1937), in which the court ruled upon the present limitation on the taxation of personal property. See infra note 21 . 
controversy centered on an inheritance tax. The first such attempted tax was struck down in State ex rel. Schwartz v. Ferris. ${ }^{9}$ The statute purported to impose a graduated rate on the whole amount when the estate received was valued at more than $\$ 20,000$. Estates received which were valued at not more than $\$ 20,000$ were entirely exempt. Thus, the recipient of $\$ 20,001$ would be subject to a tax on the entire amount, while the recipient of $\$ 20,000$ would not be subject to any tax whatsoever. The court held that the tax was a nonproperty tax imposed on the "right and privilege to receive."10 However, the court also ruled that the tax was not uniform within classes on two counts. ${ }^{11}$ First, it was said that graduated rates violated the uniformity within classes requirement. Second, the exemption of $\$ 20,000$ went only to those estates received which were valued at that amount or less, and consequently was arbitrary. The unfortunate thing about the decision was the court's attempt to limit nonproperty taxes by the "spirit" of the uniformity clause in Art. XII, §2. Thus it was asserted that an exemption of more than $\$ 200$ (the amount expressly allowed in Art. XII, $\$ 2$ for personal property) would not be allowed, and that "The exemption must be equally for all, and the rate per cent must be the same on all estates."12

The strictness of the Ferris opinion was departed from to a considerable degree in subsequent opinions. In Hagerty v. State $e^{13}$ the court ruled that a collateral inheritance tax was

953 Ohio St. 314,41 N.E. 529 (1895).

${ }^{10} \mathrm{Id}$. at $325-336$, rejecting the dictum of prior cases insofar as they intimated that property was the only proper object of taxes.

11 Id. at 336-341.

12 Id. at 338 .

1355 Ohio St. 613, 45 N.E. 1046 (1896). The tax under consideration had a single proportional rate and a general exemption of $\$ 200$. Thus, to a degree, it conformed to the Ferris opinion, although it was limited to collateral heirs. 
valid. In State ex rel. Taylor v. Guilbert ${ }^{14}$ the court in effect overruled the dictum in the Ferris case and held that a $\$ 3,000$ minimum exemption was valid. By 1912 , the only doubtful issue which was left concerned the validity of a graduated rate schedule.

The amendments which now expressly provide for inheritance and income taxes-Art. XII, $\$ \$ 7$ and 8-leave no doubt that graduated rates may be imposed..$^{15}$ Furthermore, it appears unlikely that the ruling of the early $F$ erris case, to the effect that graduated rates were arbitrary, would be carried over to other taxes. Thus today the uniformity limitation applicable to nonproperty taxes in Ohio is substantially the same as that in other states, except that the uniformity applicable to inheritance and income taxes is no longer derived from a general limitation. The provision which expressly sanctions an income tax renders moot any discussion of the nature of such a tax. Moreover, the express provision was not preceded by any opinions concerning the nature of such a tax which are of interest for comparative purposes. ${ }^{16}$

1470 Ohio St. 229, 71 N.E. 636 (1904). Also see Humphreys v. State, 70 Ohio St. 67,70 N.E. 957 (1904).

15 Some question has arisen in construing Art. XII, $\S 7$ because of the following words: "a portion of each estate not exceeding twenty thousand dollars may be exempt from such taxation." In Harvard College v. State, 106 Ohio St. 303, 140 N.E. 189 (1922) the court held that this proviso only set a maximum exemption for the classes of estates received and taxed, and that it did not prohibit "total" exemption, that is, a class selected on a reasonable basis (in that case educational institutions) might be wholly exempt. It had been argued (and two dissenting judges agreed) that while before Art. XII, $\S 7$ it was true that valid classes could be entirely excluded from inheritance tax, section 7 altered this. Also sec Sherman v. Tax Comm. of Ohio, 125 Ohio St. 367, 181 N.E. 539 (1932).

${ }^{16}$ Since Art. XII, $\S 8$ was adopted no state income tax has been enacted. However, several cities in Ohio have imposed income taxes which were upheld in Angell v. City of Toledo, 153 Ohio St. 179, 91 N.E. 2d 250 (1950). The only issue in that case, however, concerned the power of local units to impose such a tax. In reaching an affirmative answer the court did 


\section{(1) Property taxation: 1851 to 1929}

There was no doubt concerning the content of the uniformity limitation in its original and more elaborate form. It is clear that there was a requirement of universality which prohibited any exemptions of property other than those classes enumerated in the second clause of the original Art. $\mathrm{XII}, \S 2$; that property had to be taxed by the ad valorem method; and that all property taxed within a taxing jurisdiction had to be taxed at the same effective rate. ${ }^{17}$ Thus, the strictest degree of uniformity in the taxation of property was required.

In one of the earliest cases interpreting this uniformity provision, Exchange Bank v. Hines, ${ }^{18}$ the court went to great lengths in order to locate precisely the source of each of the rules of uniformity in the original Art. XII, \$2. The court took note of the fact that the universality and the ad valorem method requirements were spelled out in words apart from the "uniform rule" clause. ${ }^{19}$ However, it is important for the offer some gratuitous statements, such as (at 182): "While an income tax may be regarded as in the nature of an excise tax, the Constitution of Ohio differentiatcs an excise tax from an income tax." Reference was then made to Art. XII, $\S 8$ (income tax) and $\$ 10$ (excise and franchise taxes). Also see the recent cases, Clark v. City of Cincinnati, 163 Ohio St. 532, 127 N.E. 2d 363 (1955), and Youngstown Sheet \& Tube Co. v. City of Youngstown, 108 N.E. 2d 571 (Court of Appeals of Ohio, 1951).

17 See, for example, Exchange Bank v. Hines, 3 Ohio St. 1 (1853); Zanesville v. Richards, 5 Ohio St. 589 (1855); State v. Jones, 51 Ohio St. 492, 37 N.E. 945 (1894) (pointing out, however, that the requirement did not necessarily demand the same method of determining the value of every species of property without regard to classification); and see the more recent case, State v. Hess, 113 Ohio St. 52, 148 N.E. 347 (1925). In Treasurer v. Bank, 47 Ohio St. 503, 25 N.E. 697 (1890) the court pointed out that Art. XII, $\$ 2$ was, in effect, broad enough to cover the special limitations spelled out in Art. XII, $\S 4$.

183 Ohio St. 1 (1853).

${ }^{19} \mathrm{Id}$. at 13: "The language of the constitution is comprehensive and explicit in the requirement, that all property of every description, excepting only that which falls within the specified exemptions, should be taxed." 
purpose of interpreting the uniformity provision as amended in 1929 to note the court's assertion that the phrase 'uniform rule" contains within it a requirement of universality. The oft-quoted passage is:

What is meant by the words "taxing by a uniform rule?" And to what is the rule applied by the constitution? No language in the constitution, perhaps, is more important than this; and to accomplish the beneficial purposes intended, it is essential that they should be truly interpreted, and correctly applied. "Taxing" is required to be "by a uniform rule;" that is, by one and the same unvarying standard. Taxing by a uniform rule requires uniformity, not only in the rate of taxation, but also uniformity in the mode of assessment upon the taxable valuation. Uniformity in taxing implies equality in the burden of taxation; and this equality of burden cannot exist without uniformity in the mode of assessment, as well as in the rate of taxation. But this is not all. The uniformity must be co-extensive with the territory to which it applies. If a state tax, it must be uniform over all the State; if a county, town, or city tax, it must be uniform throughout the extent of the territory to which it is applicable. But the uniformity in the rule required by the constitution does not stop here. It must be extended to all property subject to taxation, so that all property may be taxed alike, equally - which is taxing by a uniform rule. ${ }^{20}$

A classic statement of the meaning of a strict uniformity clause, this passage is often quoted by other state courts when they restrictively interpret a uniformity provision.

\section{(2) Property taxation: since 1929}

Property other than "land and improvements." By its terms, the amended uniformity clause in Art. XII, \$2 applies only to the taxation of "land and improvements thereon." Therefore, other property-in effect, personal property-

$20 I d$. at 15 , italics by the court. 
may be taxed without regard to the "uniform rule" requirement. ${ }^{21}$ The court has held that taxes imposed upon personal property need only be uniform within classes. ${ }^{22}$ This limitation is derived from the state and federal equal protection clauses. This means that personal property may be classified for the purpose of applying the different effective rates to the several classes, ${ }^{23}$ and there is no longer a prohibition against

21 The leading case is State ex rel. Struble v. Davis, supra note 8, in which the court reviewed the history of the uniformity provisions in the Ohio Constitutions. It pointed out that before the present 1851 constitution there was no limitation upon the taxation of property except that classifications be reasonable, and that by the amendment of 1929 the power of the legislature over the taxation of personal property was restored substantially to the status which existed under the provisions of the first constitution of 1802 . In the Struble case the state equal protection clause, Art. I, $\$ 2$, was equated to the fourteenth amendment of the federal Constitution. Also see the cases infra notes 23-25.

22 Since real property is subject to a stricter uniformity limitation, this obviously gives rise to a very important "factual" determination: is a particular item of property to be classified as personal or real property for purposes of taxation. Sce, for example, Zangerle v. Republic Steel Corp., 144 Ohio St. 529, 60 N.E. 2 d 170 (1945) ; Zangerle v. Standard Oil Co., 144 Ohio St. 506, 60 N.E. 2d 52 (1945); Standard Oil Co. v. Zangerle, 144 Ohio St. 523, 60 N.E. 2d 59 (1945); and Roseville Pottery v. Board of Revision of Muskingum County, 149 Ohio St. 89, 77 N.E. 2d 608 (1948). Generally, see Holden, "Classification of Property as Real or Personal for Ohio Property Taxes: An Appraisal," 11 Ohio State L. J. 153 (1950). Also see Reed v. Board of Revision of Fairfield County, 152 Ohio St. 207, 88 N.E. 2d 701 (1949).

${ }^{23}$ See Reed v. Board of Revision, supra note 22, holding that the legislature is not prohibited from classifying personalty as realty and taxing such personalty at the higher real property tax rates, if such personalty constitutes a reasonable class. The first classified property tax law imposed under the 1929 amendment was upheld in State ex rel. Lampson v. Cook, 44 Ohio App. 501, 185 N.E. 212 (1932). Ohio has utilized the 1929 amendment in this way: intangible personal property is classified, with the several classes (except "income producing" intangibles) being taxed at different millages on their value. Income producing intangibles have been taxed at a per cent of their yield (see note 25 infra). Tangible personalty has been classified for purpose of applying different ratios of valuation, with the same per- 
the exemption of personal property. ${ }^{24}$ In addition, it would appear that personal property may be taxed by either the specific or the ad valorem method. ${ }^{25}$

"Land and improvements thereon." Under the amended uniformity clause in Art. XII, $\$ 2$ there appears to be no question but that the strictest degree of uniformity is required in the taxation of "land and improvements thereon" insofar as effective rates and the method of taxation are concerned. No change has been made in that respect. However, there has been some controversy whether any realty, other than that specified in Art. XII, $\$ 2$, may be exempted. Does a requirement of "universality" still govern the taxation of "land and improvements thereon?"

Until 1950 one could have answered affirmatively. In a line of decisions dated from 1944 to 1950, the Supreme Court of Ohio clearly ruled that the requirement in Art. XII, §2, as amended, "Land and improvements thereon shall be taxed by a uniform rule according to value," prohibited the exemption of any realty, other than that designated as exemptible by Art. XII, $\S 2 .^{26}$

centage rate applicable to all such tangible personalty. Thus, both systems of classification have been used in Ohio.

24 State ex rel. Struble v. Davis, supra note 8 (statute upheld exempting property of interurban railroad companies, other than real estate used for railroad purposes, from taxes during specified periods). Also see State ex rel. Williams v. Glander, 148 Ohio St. 188, 74 N.E. 2 d 82 (1947); State ex rel. Hostetter v. Hunt, 132 Ohio St. 568, 9 N.E. 2d 676 (1937).

${ }^{25}$ See Bennett v. Evatt, 145 Ohio St. 587, 62 N.E. 2d 345 (1945), in which the court clearly intimated in the several opinions that specific taxes upon personal property are not necessarily prohibited.

${ }^{26}$ Columbus Metropolitan Housing Authority v. Thatcher, 140 Ohio St. 38, 42 N.E. $2 d 437$ (1942). A provision of the property tax act provided that "public property used for a public purpose" should be exempt, and a provision of the code providing for the housing authority stated that all property of the same should "be deemed public property for public use." The court construed the provisions in light of Art. XII, $\$ 2$ of the constitution to mean: "public property used exclusively for public purposes." It was 
However, in 1950 and 1951 a series of cases were decided which indicate that the above interpretation has been reversed in an unusual manner. ${ }^{27}$ Article IV, $\$ 2$, of the Ohio Constitusaid that the legislature did not "intend" to declare such property to be of the class exemptible since it was clearly not within the constitutional class established in Art. XII, §2. The court made some rather questionable statements which might imply, when taken out of context of the decision, that realty might now be exempted. In Dayton Metropolitan Housing Authority v. Evatt, 143 Ohio St. 10, 53 N.E. 2d 896 (1944) a similar factual situation as that in the Columbus case, supra, involving the same statutes was dealt with. The court construed the exemption statute to intend "exclusive" use, and thus conform to the constitution. The same result was reached as in the Columbus case, but without use of any such questionable language. In Federal Public Housing Auth. v. Guckenberger, 143 Ohio St. 251, 55 N.E. 2d 265 (1944) only the tax statute providing for the exemption of "public property" was involved and the court stated that the entire exemption statute was based on Art. XII, $\S 2$ of the constitution which authorizes the exemption of only such property as is used "exclusively" for such purpose, and construed the statute as not exempting the property in question, since otherwise it would have been unconstitutional. In Youngstown Metropolitan Housing Auth. v. Evatt, 143 Ohio St. 268, 55 N.E. 2d 122 (1944) the same statutory structure involved in the Columbus and Dayton cases was again in question, and the court now left no doubt as to its view of Art. XII, §2, viz., that only such real property as is described in Art. XII, $\$ 2$ may be exempted from taxation. And see, with similar factual situations, Hospital Service Ass'n of Toledo v. Evatt, 144 Ohio St. 179, 57 N.E. 2d 928 (1944) ; Zangerle v. City of Cleveland, Division of Municipal Transp., 145 Ohio St. 347, 61 N.E. 2d 720 (1945); and New Orphans' Asylum Etc. v. Board of Tax Appeals, 150 Ohio St. 219, 80 N.E. $2 \mathrm{~d} 761$ (1948). In each of the preceding cases the court had to determine whether a given item of real property, not falling within the classes enumerated in Art. XII, $\$ 2$ as cxcmptible, was exempt, and in each case construed the statute involved as having no intent to exempt the property in question, because to interpret otherwise would render the statutes unconstitutional.

${ }^{27}$ It is interesting to note that this reversal was preceded by an article vigorously propounding the view that the amended Art. XII, \$2 no longer prohibits the exemption of realty, and that the rationale of that argument is the same as that accepted by the two new judges. See Caren, "Constitutional Limitations on the Exemption of Real Property from Taxation," 11 Ohio State L. J. 207 (1950). Evidently this view was held by many rocal proponents. 
tion requires that at least all but one of the judges of the Supreme Court of that state concur before a law may be declared unconstitutional. Subsequent to the 1944-1950 line of decisions, and prior to the 1950-1951 line of decisions, two new judges took their seats on the bench, and thus changed the composition of the seven-man court.

After this new alignment the court was faced with determining the constitutionality of a statute which left no doubt that it intended to exempt property admittedly not within the classes described in Art. XII, $\$ 2 .{ }^{28}$ Five members of the court were of the opinion that such a statute violated the uniformity clause, but the two new members took a contrary view. They were of the opinion that Art. XII, §2

${ }^{28}$ In re University of Cincinnati, 153 Ohio St. 142, 91 N.E. 2 d 502 (1950) concerned the validity of a statute (not involved in any of the cases cited in note 26 supra) which purported to exempt certain school property. A majority of five judges were of the opinion the statute was unconstitutional because the power of the legislature to exempt real property from taxation was, in their view, limited to that property enumerated in Art. XII, $\$ 2$ of the constitution. All agreed that the statute purported to exempt property not so enumerated. However, two judges were of the opposing view as to the nature of the constitutional limitation. Therefore, although the majority was of the opinion that the statute involved was unconstitutional, more than one member of the court not concurring, the statute was held constitutional. Art. IV,$\S 2$. Then in In re Application for Exemption, 155 Ohio St. 590, 99 N.E. 2d 761 (1951) the court had to determine the validity of the "housing authority property" exemption statute, supra note 26 , now amended to read that such property was to be considered public property used "exclusively" for a public purpose within the meaning of Art. XII, §2, and that it should be exempt from taxation. For the same reason governing the case of In re University of Cincinnati, supra, the statute was held to be constitutional. One of the two minority judges in the Cincinnati case was not sitting in this case, being represented by a lower-court judge who agreed with the opinion of the majority that Art. XII, $\$ 2$ would prohibit such an exemption and that the statute was unconstitutional. However, a "re"-reversal was prevented because Judge Zimmerman disagreed with the interpretation of "exclusive" in Art. XII, §2, contending that the housing authority property was within the class designated as exemptible in Art. 
contained no restriction on the power of the legislature to exempt realty, and that consequently the exemption of realty was permissible, limited only by a requirement of reasonable classes (Art. I, §2). It was the view of the two-judge minority that the "uniform rule" requirement applies only to effective rates, and that the source of the universality limitation in the original uniformity provision was express language now removed. ${ }^{29}$ Therefore, in the view of the minority, the statute was not unconstitutional.

More than one judge (two in fact) not concurring in the view that the statute was unconstitutional, the exemption had to be upheld. Thus, we have a reversal of the former interpretation of the meaning of the "uniform rule" clause, and

XII, §2. Judge Zimmerman had so dissented in the earlier cases, though agreeing with the view as to the prohibition of other exemptions of realty. Thus, two judges disagreed as to the unconstitutionality of the statute, but for different reasons, and it was upheld.

The result of these cases had been foreshadowed in City of Cleveland $\mathbf{v}$. Board of Tax Appeals, 153 Ohio St. 97, 91 N.E. $2 d 480$ (1950), in which the two new judges had an opportunity to express their view on the nature of the amended uniformity clause. However, the majority interpreted the statute involved as not exempting the property in question, since they would have otherwise found it unconstitutional. In other words, in the Cleveland case the majority was not faced with deciding the constitutional issue because there was room for interpreting the statute to avoid it.

${ }^{29}$ It appears to this writer that the majority of the court stands on firmer ground in reaching its decision. It is true that the word "all" does not modify "land and improvements thereon" in the amended uniformity clause. However, regardless of one's predilections on what type of limitation would be preferable, it seems clear that the majority is correct when they point to the interpretation of the original clause to the effect that the words "uniform rule" contain a rule of universality apart from the separate words in the original provision spelling out that all property should be taxed. See supra note 20, quoting from Exchange Bank v. Hines, supra note 17. It also seems clear to this writer that a careful reading of State ex rel. Struble v. Davis, supra note 8 , relied upon by the "minority" view, reveals that the opinion in that case referred only to the new freedom of the legislature to exempt personal property, leaving unchanged the prior requirement of universality concerning real property. See note 21 supra. 
the view of a minority of two is now the law in Ohio. "For the time being, at least, the question of the authority of the general assembly to grant tax exemptions [of realty] is settled. . . ."31

\section{Wisconsin}

\section{a. The provisions; historical note}

The state of Wisconsin has had but a single constitution, that of 1848. The only provision of that constitution which concerns uniformity of taxation is Art. VIII, $\S 1$, which originally read:

The rule of taxation shall be uniform, and taxes shall be levied upon such property as the Legislature shall prescribe.

There have been three amendments to this provision, none of which has altered the basic rule of uniformity derived from the provision as it originally stood. In 1908, a second sentence

30 That is, a view of the two-judge minority when combined with the view of a majority of the state legislature, particularly as to the statute involved in In re Application for Exemption, note 28 supra. The legislature had amended the statute there involved so that there would be no doubt that its purpose was to do what a majority of the court had said that it could not do. Of course, we do not know whether one should attribute to the legislative "intent," if such a thing ever exists, a view that it could exempt any real property, or a view that the housing property was in fact such property as described in Art. XII, $\S 2$. The words of the statute might suggest the latter.

${ }^{31}$ Caren, supra note 27 at 213 , emphasis added. The quoted statement was made by that writer after the majority had ruled that exemptions of realty were prohibited. It would not take a substantial change in the court's personnel to emphasize the significance of the words: "For the time being. . . " Query: On a newly constituted court, all seven of whom believed that a proper interpretation of Art. XII, $\S 2$, as amended, would prohibit the exemption of realty, would and should the court feel compelled to follow the view of a minority of two which was established as law by the unusual constitutional provision concerning the invalidation of statutes? 
was added which expressly permits taxes on "incomes, privileges and occupations" and provides for the degree of uniformity required of such taxes. In 1927, an exception was made to the rule of uniformity applicable to property taxes, so that special treatment of forest and mineral lands is now permissible. A 1941 amendment concerned the method of collecting local property taxes. ${ }^{1}$ The basic uniformity provision, Art. VIII, $\S 1$, now reads:

The rule of taxation shall be uniform but the legislature may empower cities, villages or towns to collect and return taxes on real estate located therein by optional methods. Taxes shall be levied upon such property with such classification as to forests and minerals including or separate or severed from the land, as the legislature shall prescribe. Taxes may also be imposed on incomes, privileges and occupations, which taxes may be graduated and progressive, and reasonable exemptions may be provided.

\section{b. Meaning of the uniformity limitation}

Even before the 1908 amendment which added the provision spelling out the uniformity required of taxes other than property taxation, it was clear that the uniformity clause in Art. VIII, $\$ 1$ had been interpreted to limit only property taxes. ${ }^{2}$ Nonproperty taxes were required only to be uniform

1 The installment payment of real estate taxes was made possible by this amendment. Wisconsin Annotations 1614, 1616 (3d ed., 1950) (Wisconsin Constitution: History).

2 The leading case is Nunnemacher v. State, 129 Wis. 190, 204-220, 108 N.W. 627 (1906) (holding an inheritance tax valid as a privilege tax). Also see the following cases decided at the same term: State v. Chicago \& N.W. R. Co., 128 Wis. 449, 108 N.W. 594 (1906) and Chicago \& N.W. R. Co. v. State, 128 Wis. 553, 108 N.W. 557 (1906), discussed infra, under "Property taxation." In these three cases the confusion that might have resulted from rather ambiguous language of prior decisions (see, for example, State v. Whitcom, 122 Wis. 110,99 N.W. 468 (1904), in which a peddlers' license tax was held to violate the federal and state equal protection clauses, but Art. VIII, $\$ 1$ was also cited) was dispelled, but not without 
within the classes to which they applied. ${ }^{3}$ Therefore, the objects of nonproperty taxes and exemptions therefrom had to be only reasonable classes. ${ }^{4}$ An exemption from an inheritance tax which would have exempted estates if the estate of the deceased did not exceed $\$ 10,000$ was held to be arbitrary. ${ }^{5}$

dissenting opinions. For example, in the Nunnemacher case, supra, two of the six judges dissented on this point. The majority in that decision pointed out that in any case Art. VIII, $\$ 1$ if applicable to nonproperty taxes would mean nothing more than the federal equal protection clause. In other words, if it be insisted that all taxes should be "uniform," then the limitation had a "dual" meaning depending upon the type of tax involved, property or nonproperty.

${ }^{3}$ The sources of this limitation are the state (Art. I, $\$ 1$ ) and federal (14th Amend.) equal protection clauses. See supra note 2. The two provisions are generally equated.

4 For example: Nunnemacher v. State, supra note 2 (inheritance tax; minimum exemptions valid); State v. Frear, 148 Wis. 456, 134 N.W. 673 (1912) (income tax; allowance of certain exemptions to individuals and denial of same to partnerships, held not arbitrary); Welch v. Henry, 223 Wis. 319,271 N.W. 68 (1937) (emergency tax on "Certain 1933 Dividends"; the object of the tax was certain dividends not subject to the 1933 net income tax; held, a valid class was selected). Also see the following cases in which exemptions were found to be reasonable: State ex rel. Transp. Ass'n v. Zimmerman, 181 Wis. 552, 196 N.W. 848 (1923); State ex rel. Atwood v. Johnson, 170 Wis. 218, 175 N.W. 589 (1919); State ex rel. Bernhard Stearn \& Sons v. Bodden, 165 Wis. 75, 160 N.W. 1077 (1917). For a reasonable class selected for the object of a privilege tax, see Nash Sales v. City of Milwaukee, 198 Wis. 281, 224 N.W. 126 (1929). In In re Will of Le Feber, 223 Wis. 393, 271 N.W. 95 (1937) an arbitrary classification was found.

${ }^{5}$ Black v. State, 113 Wis. 205, 89 N.W. 522 (1902). The court pointed out (at p. 221):

... under this provision the $\$ 10,000$ limitation or exemption is based on the size of the whole property devised or granted, and not upon the amount received by each individual legatee or grantec. Thus it results that one collateral relative, receiving a legacy of $\$ 2,000$ from one testator, whose estate amounts to but $\$ 9,500$, pays no tax, while another collateral relative in the same degree, receiving a legacy of $\$ 2,000$ from another testator whose estate amounts to $\$ 10,500$ is obliged to pay a tax. Here is unlawful discrimination, pure and simple. No rational distinction or difference can be drawn between the two legatees simply because the estates 
The objects of such nonproperty taxes may be further classified for the purpose of applying different rates, ${ }^{6}$ and graduated rates have been held to be a reasonable scheme of classification. ${ }^{7}$

For comparative purposes it is interesting to note that in Wisconsin an inheritance $\operatorname{tax}^{8}$ and a selective public utilities gross-earnings $\operatorname{tax}^{9}$ have been considered nonproperty taxes. ${ }^{10}$

from which their legacies come are of slightly different size. They are both within the same class, surrounded by the same conditions, and receiving the same benefits.

${ }^{6}$ For example: Nunnemacher v. State, supra note 2 (inheritance tax; five classes were established based upon relation to the deceased; for each class there was a different graduated rate schedule; held to be reasonable classes); State v. Frear, supra note 4 (income tax; different schedule of rates applicable to income of corporations from that applied to income of individuals, upheld as reasonable).

${ }^{7}$ Nunnemacher v. State, supra note 2 at $221-223$, relying to a great degree on Knowlton v. Moore, 178 U.S. 41, 20 S. Ct. 747 (1899) and Magoun v. Illinois Trust and Savings Bank, 170 U.S. 283, 18 S. Ct. 594 (1898). The court first stated, "If this question were an original one it would seem serious." However, noting that the United States Supreme Court had held that such graduated rates do not violate the federal equal protection clause, the court concluded that:

... as the general equality guaranties of our own constitution are substantially the equivalent of the equal protection of the laws guaranteed by the XIVth Amendment, we are content to follow the decisions of the United States supreme court, and hold that the progressive feature does not violate the constitution.

Also see In re Will of Harnishfeger, 208 Wis. 317, 242 N.W. 153 (1933). However, the court in Schuster \& Co. v. Henry, 218 Wis. 506, 261 N.W. 20 (1935) held that a statute imposing a graduated rate on the gross income of chain stores was void as arbitrary and violative of the state and federal equal protection clauses, following Stewart Dry Goods Co. v. Lewis, 294 U.S. 550, 55 S. Ct. 525 (1934) in which the United States Supreme Court held that a Kentucky chain store tax with a graduated rate feature applied to gross income as a base violated the federal equal protection clause.

${ }^{8}$ Nunnemacher v. State, supra note 2.

${ }^{9}$ State v. Chicago \& N.W. R. Co., supra note 2, discussed infra, "Property taxation." See infra notes 26 and 27.

${ }^{10}$ Also see State ex rel. Bernhard Stearn \& Sons v. Bodden, supra note 4, 
There have been Wisconsin decisions concerning the nature of an income tax for purposes of uniformity of taxation. However, those decisions ${ }^{11}$ are not particularly useful for this monograph because they were made after the amendment to Art. VIII, $\$ 1$ which now expressly permits income taxes, and, in addition, the decisions were based on the words of the constitutional amendment. ${ }^{12}$

holding a "Grain Handlers Tax" to be an occupation or privilege tax and not a tax upon the grain handled. In State ex rel. Froedtert v. Tax Comm. of Wisconsin, 221 Wis. 225, 267 N.W. 52 (1936) the court held that a "Privilege Dividend Tax" was in fact a privilege tax on the "transfer" of such dividends. No question of uniformity was raised, the issue being primarily one of territorial jurisdiction (due process). However, the court discussed at some length the scope of the word "privilege" as used in Art. VIII, $\S 1$, concluding that it was broad enough to cover any species of tax except property or capitation taxes.

11 The leading case is State v. Frear, supra note 4. For a description of the Wisconsin tax, see Ford, Taxation of Intangibles in Michigan (1939), Univ. of Mich., Michigan Governmental Studies No. 2.

12 In Welch v. Henry, supra note 4, it was indicated that a tax on gross income, as opposed to net income, might be characterized as a tax upon property. The tax there involved was a tax imposed on "certain 1935 dividends." In brief, the legislature made certain dividends not subject to the 1933 net income tax the object of an emergency relief tax. The rate scale was not the same as that applied under the 1933 net income tax. In the Welch case one contention was that the tax was a tax upon property. The court ruled that it was a tax upon the net income from a particular kind of property and therefore within the constitutional description of income taxes and not a tax upon the property from which the income is derived. The rather questionable statement was then made:

This is, of course, true only if the tax be upon the net income. A tax upon the gross income of particular kinds of property or particular taxpayers or a particular business is doubtless within the condemnation of [the Steward and Schuster cases, supra note 7, chain store tax] . . and constitutes in effect a tax upon the property itself.

Query. In the cases cited, the objectionable feature was the application of a graduated rates schedule to gross receipts. The ruling was that such was arbitrary classification. The decisions did not rest on any notion that such taxes were "property taxes." Also see State v. Chicago \& N.W. R. Co., supro 


\section{(1) Property taxation}

The extent to which Art. VIII, $\S 1$, limits the power of the legislature to tax property has been the subject of extended controversy in the Wisconsin cases. Conflicting views are found in a line of cases beginning in 1855. However, these conflicting decisions and dicta were either reconciled or rejected by the court in 1906 and a definitive meaning of the uniformity clause, Art. VIII, $\S 1$, was then set forth. In view of these 1906 cases which purported to set at rest any controversy theretofore existing, it will suffice for our purposes simply to record the points of disagreement without any extended critical analysis of the particular decisions.

The first of these decisions was Milwankee $\mathcal{E}$ M.R. Co.v. Waukesha County, ${ }^{13}$ decided in 1855. This case concerned the validity of a statute which required railroad companies to pay annually a tax of $1 \%$ of their gross earnings, the tax to be in lieu of "all other taxes" on the company and its property. The local authorities of the jurisdiction in which the plaintiff company was located had deemed the act to be unconstitutional, and had levied the local property-tax rate upon plaintiff company's property. Plaintiff company brought an action seeking to restrain collection of the local propertytax rate. There was a demurrer, alleging the act to be unconstitutional, and the demurrer was overruled. On appeal note 2 , infra notes 26 and 27 , ruling that a tax upon the gross receipts of railroads was a privilege tax, not a property tax.

139 Wis. 431 (1855). This decision is recorded only as a footnote by the Reporter to Knowlton v. Rock County, 9 Wis. 410 (1859). There was no written opinion for the decision, and only the decision and opinion of the circuit court judge is set forth in the footnote. Evidently Judge Smith of the court in 1855 was assigned to write the opinion, but it was never recorded and no record remained even in Judge Smith's records. Also on the court at that time were Judges Cole and Whiton. Only Judge Cole remained on the bench when the Knowlton decision was made in 1859 , and he relies in that case on what was his view of the rationale for the Milwaukee \& M.R. Co. case. 
to the Supreme Court, the judgment was affirmed. Thus the tax statute and its "in lieu" provision were upheld. The precise rationale supporting the Supreme Court's ruling is not known because the opinion was not reported. ${ }^{14}$ However, it is clear that the Circuit Court upheld the tax statute as a "partial" exemption, thus seemingly taking the view that the tax on gross receipts was on the property itself. ${ }^{15}$ The Supreme Court was at that time composed of three justices.

In 1859, the Supreme Court passed upon the validity of a statute ${ }^{16}$ which provided that "rural" property within the city limits of the city in question was not to be subject to an annual city tax exceeding one half that levied on other land in the city. In Knowlton v. Rock County ${ }^{17}$ the statute was held unconstitutional because it violated the uniformity clause in Art. VIII, §1. A two-judge majority ruled that absolute uniformity in rates was required by section 1 , and rejected the contention that the legislature might classify property for different rates which were to be uniform within classes. In addition, the majority rejected any theory which viewed "partial" exemptions as permissible. Partial exemptions were equated with classified rates. It was admitted that there was no requirement of universality, but the court held that once property was selected it must be taxed entirely and at the same rate applied to other property within the territory. ${ }^{18}$ Judge Cole, in a dissent, would have followed

${ }^{14}$ See note 13. There is some question whether the particular tax structure was viewed as a privilege tax combined with an "in lieu" feature exempting property from property taxation, or whether the tax was viewed as a valid attempt at "partial" exemption of property. Cf. the view of the lower court, text to note 15 , infra.

${ }^{15}$ Milwaukee \& M.R. Co. v. Waukesha, supra note 13.

${ }^{16}$ The statute involved was a "local" law, setting forth the Charter of the city in question.

17 Supra note 13.

${ }^{18}$ Also see Slauson v. Racine, 13 Wis. 398 (1861) for a similar holding. A proviso in a tax statute provided, in substance, that "rural" lands in Racine 
what he considered the doctrine of the Milwaukee $\mathcal{E}^{2} M . R$. Co. case, namely, that the legislature had the power to classify property for purposes of different rates. He seemed to consider the railroad gross-receipts tax which was ruled on in the prior case to be a property tax with a base of gross earnings. Thus, in effect, he rejected the view that the ad valorem method was required in taxing property. Of the three justices on the bench for the Knowlton case, only Judge Cole was serving when the Milwaukee $\mathcal{E}$ M.R. Co. case was decided.

Subsequently, in State ex rel. Attorney General v. Winnebago Lake EO Fox River Plank Road Co., ${ }^{19}$ dated 1860, the same two-judge majority approved the Knowlton case and considered and overruled the Milwaukee $\mathcal{E}$ M.R. Co. case. The same gross-receipts tax considered in the Milwaukee $E$ M.R. Co. case was in question, and it was held unconstitutional on the ground that it was a property tax with a rate different from that applicable to other property. Apparently the majority gave no serious consideration to the possibility that the tax might be an "in lieu" excise tax. It was said that the object of Art. VIII, §1 was to "secure equality as between different kinds of taxable property. ... A And this can only be attained by a uniform rate." However, the power to exempt property was again reaffirmed, and again Judge Cole dissented, still adhering to the view that the Milwankee $\mathcal{E}$ M.R. Co. case correctly interpreted the uniformity clause as sanctioning classification for either rates, exemptions, or partial exemptions.

The same railroad gross receipts tax was again considered were to be taxed at a different and lesser rate than other land. The proviso was held unconstitutional and the entire statute was consequently held inoperative. The decision rested simply on a citation of the Knowlton case, supra note 13.

1911 Wis. 35 (1860). This was an action to compel the payment of the gross receipts tax by defendant railroad company. 
in Kneeland v. Milwaukee, ${ }^{20}$ decided in 1862 . In that case the plaintiff sued to restrain the issuing of tax deeds for land sold for taxes due under the local property-tax rate for certain prior years. During those years the "in lieu" provision of the railroad gross-earnings tax had been followed and the local authorities had not assessed railroad property. One contention of plaintiff was that such an omission invalidated the property tax. The court was of the opinion that if the railroad tax was held unconstitutional then the entire state and local general property tax for the years in question was unconstitutional because property was omitted by "other than error of judgment." A prior decision was relied on for this proposition. ${ }^{21}$ On rehearing-after first having defended its position assumed in the Winnebago case, namely, that the railroad tax was unconstitutional-the court overruled the Winnebago case and followed the Milrwaukee E M.R. Co. case, citing the dual reason of "stare decisis" and the "practical results" of a contrary opinion. It must be admitted that the court seemed most impressed with the result which a decision invalidating the entire state and local general property taxes for the prior years would have brought aboutapparently, a chaos in governmental matters.

In 1881 the court, in Wisconsin Central R. Co. v. Taylor, ${ }^{22}$ reviewed the above cases. The statute before the court exempted the property of the Wisconsin Central Railroad Company for a period of ten years (extended by amendment for three additional years). Thus, the only issue properly raised concerned the power of the legislature to exempt property. However, in holding that the statute was constitutional, the majority "approved" the Milwaukee $\mathcal{E}^{\circ}$ $M . R$. Co. case of 1855 , saying that anything inconsistent

2015 Wis. 454 (1862).

21 Weeks v. Milwaukee, 10 Wis. 242 (1860).

2252 Wis. 37,8 N.W. 833 (1881). 
therewith was overruled. Furthermore, language was used indicating that the power to classify property for both rates and exemptions existed. ${ }^{23}$ Of course, there was no need for this language. The only issue raised concerned the exemption of a "part of a class," i.e., an unreasonable classification. The majority never faced the real issue of whether the exemption of the property of a single railroad company was the exemption of a reasonable class of property. ${ }^{24}$ In effect, the purpose of the majority opinion appeared to be to reaffirm the 1855 Milwaukee $\mathcal{F}$ M.R. Co. case on its merits rather than on the lone principle of stare decisis.

Thus the situation stood until 1906. None of the cases decided after 1881 and before 1906 contributed to a solution of the problem. ${ }^{25}$ In 1903, the Wisconsin legislature changed

${ }^{23}$ In making an extensive comparative study of the uniformity clauses existing in other state constitutions at that time, the court placed an emphasis on the absence of the word "equal" (i.e., "equal and uniform") in the Wisconsin provision, as a basis for its conclusion that an absolute uniformity was not required by the Wisconsin uniformity clause.

${ }^{24}$ In Chicago \& N.W. R. Co. v. State, supra note 2 at 643 , this decision was described as follows: "There [in the Wisconsin Central case] . . a very small subclass of real estate, a class so small as to be confined to one owner, was deemed sufficiently different from realty generally to warrant the legislature in exempting it from taxation. It is not likely, as we have before indicated, that this court will soon go further on that line than it did in that case."

25 The following cases contain discussions of the uniformity limitation but contributed nothing new: Wisconsin Cent. R. Co. v. Lincoln, 57 Wis. 137, 15 N.W. 121 (1883) (re different assessment times for personalty and realty); State ex rel. Holt Co. v. Bellew, 86 Wis. 189, 56 N.W. 782 (1893) (essentially a question of "situs," not of uniformity); State ex rel. Milwaukee St. R. Co. v. Anderson, 90 Wis. 550, 63 N.W. 746 (1895) (re method of selection of assessors, language of uniformity irrelevant); and Lund v. Chippewa, 93 Wis. 640, 67 N.W. 927 (1896) (re the territorial nature of the uniformity limitation). Also see State ex rel. Barabou v. Sauk, 70 Wis. 485,36 N.W. 396 (1888) and Battles v. Doll, 113 Wis. 357,89 N.W. 187 (1902). For the importance of Kingsley v. Merrill, 122 Wis. 185, 99 N.W. 1044 (1904) see infra notes 31 and 32. 
the method of taxing railroad companies. It abandoned the method which had required a payment of a percent of gross earnings, to be "in lieu of other taxes" imposed on the companies and their property; and by Chapter 315, Laws of 1903 , the property of railroads was to be thereafter taxed by the ad valorem method, with the rate applicable thereto being the statewide state-local average ad valorem rate. In two cases decided in 1906 the court felt compelled to pass upon the nature and validity of both the prior system of taxing railroads and their property and the system inaugurated in 1903. In State v. Chicago E⿱ $N . W . R$. Co., ${ }^{26}$ the court ruled that the "gross earnings" tax was not a property tax (the distinction between "direct" and "indirect" taxes on property was relied upon) but was a "privilege tax" with an "in lieu" feature which simply provided for the exemption of certain property from the general property tax. ${ }^{27}$

The more important case for our purposes was Chicago $\mathcal{E}^{2}$ N.W.R.Co. v. State, ${ }^{28}$ in which an action was brought to enjoin collection of taxes levied upon the property of plaintiff railroad company for the year 1904 pursuant to the new tax law embodied in the 1903 statute. ${ }^{29}$ The new method of ad valorem taxation of railroad property raised anew the fundamental problem of the precise meaning of the uniformity

${ }^{26}$ Supra note 2 . This was an action to recover the penalty for noncompliance with the law relating to the payment to the state of a per cent of defendants' gross earnings, due to the state for 1903.

27 Id. at 484-495.

${ }^{28}$ Supra note 2.

${ }^{29}$ Note how the court framed the issue: The action was "to test the validity of the law changing the method of requiring railway companies in [the] state to share with other property owners therein the burden of its government from the indirect way to the ad valorem method." [Emphasis added.] Id. at 559. There was a challenge both as to the validity of the law itself, generally, and the procedure thereunder to determine certain values. Of course, the opinion writer anticipated his conclusion in so framing the question to be answered. 
clause in Art. VIII, $\S 1$. The lower court had ruled that under the uniformity clause the legislature might properly classify property for the purpose of applying different rates, and that the application of a different rate to railroad property from the rate applicable to other property in the state was an example of the exercise of this power.

The Supreme Court first reviewed the cases discussed above, and concluded ${ }^{30}$ that they could all be "reconciled" with an "accurate" interpretation of the uniformity clause. The court summed up the content of the uniformity limitation as follows: (1) There is no requirement of universality, thus exemptions of reasonable classes of property are permissible ${ }^{31}$ however, there can be no "partial" exemption. (2) Absolute uniformity must prevail in the effective rate applicable to all property taxed by any taxing district. ${ }^{32}$ Thus property selected for taxation must be taxed at the same rate. On this point, of course, the court faced the difficult problem of reconciling the prior cases. However, it asserted that this view was never departed from in the decisions, although some language might appear to the contrary. (3) The requirement of absolute uniformity in effective rates does not extend to

${ }^{30} I d$. at $604,614$.

${ }^{31}$ Also see the following cases on exemptions of property: Lawrence University v. Outagamie, 150 Wis. 244, 136 N.W. 619 (1912) (finding an exemption arbitrary, and saying that the "rule of uniformity would be violated" by arbitrary classifications for the exemption of property); Milwaukee E.R. \& L. Co. v. Tax Comm., 207 Wis. 523, 242 N.W. 312 (1932). In the earlier case of Kingsley v. Merrill, supra note 25 at 194-198, the court had held that the taxation of "debts due from solvent debtors," and exemption of "debts due from others" was not a violation of Art. VIII, $\S 1$. It was held that there was a reasonable distinction between "good" and "bad" debts.

${ }^{32}$ In Kingsley v. Merrill, supra note 25 at 198-201, the court held that notes and mortgages are "property" and that the taxation of credits is not such double taxation as would violate the uniformity clause, Art. VIII, $\$ 1$. 
the "mechanics" of valuation or assessment. (4) Property taxed must be taxed ad valorem. ${ }^{33}$

Having ruled that an absolute uniformity of rates was required the court faced some difficulty in upholding the average rate feature of the railroad property ad valorem tax. Such property was not subject to the local rate where it might be physically located, nor was it subject to the state general property-tax rate-rather it was taxed at an average of these rates. Those challenging the validity of the tax naturally fell back on a determination by the Michigan court only a few years before, in Pingree v. Auditor General, ${ }^{34}$ that such a tax was in essence a state tax and therefore a violation of the Michigan uniformity clause, which was the same type as the Wisconsin provision. The Pingree case was distinguished by the court on the basis of the characterization by the Michigan court of the nature of such a tax. ${ }^{35}$ The Wisconsin court held that the tax in question was of a "multi-nature," that is, that there was a conformity with the requirement of absolute uni-

${ }^{33}$ This limitation is not necessarily derived from the requirement of a "uniform rule." In Chicago \& N.W. R. Co. v. State, supra note 2, the limitation was said to be implied from the words as they appeared in the original Art. VIII, $\S 1$ : "and taxes shall be levied upon such property as the legislature shall prescribe" (the so-called "second clause" of the original provision). The court stated (at p. 607):

... when the second clause was added [in the constitutional convention], it impliedly prescribed value as the basis since . . . "the rule of property taxation is that the property is the basis of taxation. It ... rests solely upon value. . .."

The idea of taxation on a value basis being necessarily embodied in the second clause of sec. 1, all that was necessary to the first [clause] was the idea of uniformity.

This was stated in reference to the omission of the word "equal" from the phraseology of the basic uniformity clause.

${ }^{34} 120$ Mich. 95, 78 N.W. 1025 (1899). See the Michigan discussion, in this chapter at notes 10-16, supra.

${ }^{85}$ Chicago \& N.W. R. Co. v. State, supra note 2 at 649-652, 667-669. 
formity in rates because the average rate feature was a reasonable compliance with the uniformity limitation which requires "uniformity of burden, not necessarily uniformity of methods of imposing burdens." There was a reasonable compliance because a tax burden was assessed on railroad property which was substantially equal to that imposed upon all other property in the state. ${ }^{36}$

Judge Cassoday ${ }^{37}$ concurred in the result of the majority opinion (holding the new average-rate method of taxing railroad property valid) only because in his opinion "under the uniformity clause of the constitution the legislature has power to classify property for the purposes of taxation and then to impose different rates of taxation upon the different classes of property." 38

Thus, after some confusion concerning the meaning of the uniformity limitation which governs the taxation of property in Wisconsin, one may conclude that absolute uniformity

${ }^{36} I d$. at 671, 675-676. Compare Minneapolis, St. P. \& S.S.M.R. Co. v. Douglas, 159 Wis. 408,150 N.W. 422 (1914). An ore and merchandise dock, which was a necessary part of the terminal facilities of a railroad, was taxed by local authorities at a higher rate than the balance of the railroad's property under the ad valorem tax law. This was held to be a violation of the constitutional rule of uniformity.

In addition, the court held in Chicago \& N.W. R. Co. v. State, supro note 2 , that the procedure under the law in question was not invalid, that the uniformity clause does not prohibit classification for methods of assessment. Different methods were to be used by the assessors to determine the value of the railroad property.

37 Judge Cassoday was the only member of the court at the time of the Chicago \& N.W. R. Co. case, supra notes 2, 35, who had been on the bench when the Wisconsin Central R. Co. v. Taylor case, supra note 22, was decided in 1881 . His opinion was more fully set forth in State v. Chicago \& N.W. R. Co., supra note 2 at 519-552.

${ }^{38}$ Chicago \& N.W. R. Co. v. State, supra note 2 at 677-678. It was his opinion that the majority could not reach their decision without a departure from the rule set forth in the Knowlton case, supra notes 13,17, although that case was purportedly followed. 
is required of effective rates, ${ }^{39}$ but that exemption of classes of property may be made.

\section{E. ANALYSES OF STATES WITH TYPE V CLAUSES}

\section{Mississippi}

\section{a. The provisions; historical note}

The state of Mississippi has had four constitutions. In the constitutions of 1817 and 1832 there were no provisions which expressly dealt with uniformity of taxation. In the constitution of 1869 , two provisions concerning the uniformity limitation were introduced in Art. XII, $\$ \S 13$ and 20. In the present constitution of 1890 , those uniformity provisions of 1869 were carried over substantially, without any change in phraseology, but with some elaboration. The basic uniformity clause is now found in Art. IV, $\$ 112$ of the 1890 constitution, and reads as follows:

Taxation shall be uniform and equal throughout the state. Property shall be taxed in proportion to its value. . . .

39 The latest statement by the court concerning this requirement is found in State ex rel. Baker Mfg. Co. v. City of Evansville, 261 Wis. 599, 53 N.W. 2d 795 (1952). The court stated (p. 609):

As we heard the city's oral argument and read its brief we gained the impression that it contends that there is uniformity of taxation if one fraction of true value is applied to all real property, although some other fraction thereof may be used in the case of personalty,- that the requirement of uniformity is satisfied so long as there is uniformity within the class. We do not consider this to be the law. In our view the command of Sec. 1, Art. VIII of the Wisconsin constitution requires uniformity of taxation, according to value, of real and personal property without distinction. . . . [W] Wen once the true value is arrived at, each dollar's worth of one sort of property is liable for exactly the same tax as a dollar's worth of any other sort of property, and to assess real property at a different fraction of the value than personalty is error. 
Property shall be assessed for taxes under general laws, and by uniform rules, according to its true value. . . .

In addition, Art. VII, $\$ 181$ provides:

The property of all private corporations for pecuniary gain shall be taxed in the same way and to the same extent as the property of individuals. ....

The present constitution has also introduced the practice of providing for industrial exemptions for a limited period in order to "encourage" the establishment of such industries."

\section{b. Meaning of the uniformity limitation}

\section{The court has consistently ruled that the requirement that}

1 The first omission indicated in the text concerns a "per capita" tax upon certain destructive domestic animals, thus establishing an exception to the "proportionality" requirement. The second omission provides that the legislature may provide for special modes of "valuation and assessment" for property "not situated wholly in one county," with a proviso that all such property shall be assessed at its "true value."

Art. XII, $\S 20$ of the 1869 constitution was identical with the first two sentences of the present Section 112, except that the word "All" modified the word "property" in the second sentence, and the second sentence contained the additional phrase "to be ascertained as directed by law." The 1869 provision was limited to those two sentences.

2 The omission contains the following proviso:

.. . but the legislature may provide for the taxation of banks and banking capital, by taxing the shares according to the value thereof (augmented by the accumulations, surplus, and unpaid dividends), exclusive of real estate, which shall be taxed as other real estate. . . . And domestic insurance companies shall not be required to pay a greater tax in the aggregate than is required to be paid by foreign insurance companies doing business in this state, except to the extent of the excess of their ad valorem tax over the privilege tax imposed upon such foreign companies; and the legislature may impose privilege taxes on building and loan associations in lieu of all other taxes except on their real estate.

Art. XII, $\S 13$ of the 1869 constitution contained only the following brief requirement: "The property of all corporations for pecuniary profits shall be subject to taxation, the same as that of individuals."

${ }^{3}$ Art. VII, $\S 182$ and $\S 192$. 
"Taxation shall be uniform and equal throughout the state" applies only to the taxation of property, and that nonproperty taxes need only be uniform within classes. ${ }^{4}$ Thus, the objects of nonproperty taxes and the exemptions therefrom need only be reasonable classes. ${ }^{5}$ The objects of such taxes may be further classified for the purpose of applying different rates. ${ }^{\circ}$ A schedule of graduated rates has been held a reasonable classification. $^{\text {? }}$

Since the uniformity limitation applicable to property taxes is more stringent, it is apparent that the characterization of a tax is extremely important. In a series of cases often cited in other jurisdictions, the Mississippi court has ruled that certain taxes were really taxes upon the "privilege of ownership" of certain property and therefore on the property itself, and consequently the taxes were held to violate the stricter property-tax uniformity limitation. In the first such case, Thompson v. Kreutzer, ${ }^{8}$ decided in 1916, the court considered the validity of a statute which purported to impose "an annual privilege tax, or occupation fee" of twenty cents per acre upon "each person, association of persons, or business firms and corporations pursuing the business of buying, owning or holding more than one thousand acres of

${ }^{4}$ See, for example, Coca Cola Co. v. Skillman, 91 Miss. 677, 44 So. 985 (1908). While the source of this limitation has not been made entirely clear, it appears to be solely the federal equal protection clause, although a number of the older cases refer at times to section 112 of the Mississippi Constitution and at other times to the due process provision of the state constitution, Art. III, $\$ 14$.

5 See State ex rel. Knox v. Gulf, M. \& N.R. Co., 138 Miss. 70, 104 So. 689 (1925) (exemptions from the net income tax); Notgrass Drug Co. v. State, 175 Miss. 358,165 So. 884 (1936) (business and occupation tax, in substance a sales tax, numerous classifications in the object); Clarksdale Ins. Agency v. Cole, 87 Miss. 637, 40 So. 228 (1906); Johnson v. Long Furniture Co., 113 Miss. 373, 74 So. 283 (1917).

${ }^{6}$ State ex rel. Knox v. Gulf, M. \& N.R. Co., supra note 5.

${ }^{7}$ Id.

${ }^{8} 112$ Miss. 165, 72 So. 891 (1916). 
timber land or lands in this state." It held that the tax was in fact upon property and, not being "in proportion to its value," violative of the property-tax uniformity limitation. In an oft-quoted statement, the court said: ". . . a tax on the right of ownership of a thing is necessarily a tax on the thing itself."

During the same term, in Thompson v. McLeod, ${ }^{10}$ the court considered "an annual privilege tax or occupation fee upon all persons, associations of persons, or business firms and corporations, pursuing the business of extracting turpentine from standing trees." This tax was also held to be, in fact, a tax upon the property involved and violative of Art. IV, $\$ 112 .{ }^{11}$ The reasoning was essentially the same as that found in the Kreutzer case. Subsequently, in Barnes v. Jones ${ }^{12}$ the court passed on the validity of a tax upon the rights of residents of Mississippi to own shares of capital stock of nonresident corporations, stock companies, associations, or trust companies organized and conducting business for profit, such tax amounting to one half of one per cent of the value of such shares. It ruled that the tax was, in fact, a tax upon the property involved and a violation of the property-tax uniformity clause.

The broad implication often drawn from these cases has been limited by the Mississippi court in subsequent opinions, so that the cases are now restricted to their particular facts.

${ }^{9} \mathrm{ld}$. at 167 .

${ }^{10} 112$ Miss. 383, 73 So. 193 (1916).

${ }^{11} I d$. at 391,392 . The invalidity of the tax stemmed from the fact it resulted in "double taxation" of the property involved. The court reasoned that to tax the standing pine trees with an ad valorem tax, and at the same time "exact tribute from the owner as a condition precedent to his right to lay hands upon the trees" would result in "double taxation upon the tree itself," which would be contrary to the uniformity clause. Two justices dissented, asserting that the tax was a tax upon the privilege of engaging in the "business of extracting crude turpentine."

12139 Miss. 675, 103 So. 773 (1925). 
Not infrequently the cases have been distinguished. For example, in 1925 in State ex rel. Knox v. Gulf, M. E N.R. Co., ${ }^{13}$ the court held that a net income tax was not a tax upon property; in 1942 in Stone v. General Contract Purchase Corp., ${ }^{14}$ the court held that a "Finance Companies" tax with a base consisting of the amount of indebtedness secured by tangible property in the state was a privilege tax; and in 1945 in Gulf Refining Co. v. Stone, ${ }^{15}$ the court held that an oil severance or production tax was not upon the oil severed but upon an occupation. The court has also ruled that the Mississippi inheritance tax was not a tax upon property. ${ }^{16}$

Property taxation. The court has ruled that the uniformity provision of the Mississippi Constitution, Art. IV, §112, does not require universality. ${ }^{17}$ As stated by the court:

Section 112 does not require all property to be taxed. It commits to the legislature the duty of designating and classifying property for taxation and all property not within the classes selected will be exempt from taxation. It does not deprive the legislature of the power which it has been accustomed to exercise from the inception of the state government to exempt from taxation property of a particular class embraced within a general class that is subjected to taxation. ${ }^{18}$

${ }^{13}$ Supra note 5. This position reaffirmed the stand taken in the earlier case of Hattiesburg Grocery Co. v. Robertson, 126 Miss. 34, 88 So. 4 (1921). In the Robertson case the tax did not have a graduated rate. Thus, the Knox case is more important because it restated the position of the court on the nature of an income tax, and also ruled that graduated rates were permissible.

14193 Miss. 301, 7 S. 2d 806 (1942).

15197 Miss. 713, 21 S. 2d 19 (1945).

16 Enochs v. State, 133 Miss. 107, 97 So. 534 (1923).

17 See, for example, Mississippi Power \& Light Co. v. Love, 201 Miss. 676, 27 S. 2 d 850 (1946); Jackson v. Mississippi Fire Ins. Co., 132 Miss. 415, 95 So. 845 (1923), followed in Miller v. Lamar Life Ins. Co., 158 Miss. 753, 131 So. 282 (1930). Also see City of Jackson v. Edwards House, 145 Miss. 135, 110 So. 231 (1926); Brennan v. Mississippi Home Ins. Co., 70 Miss. 531, 13 So. 228 (1893).

18 Jackson v. Mississippi Fire Ins. Co., supra note 17 at 419. 
It is said that there are only two limitations on the exemption of property. Such exemptions must be based upon "some principle of public policy that can support a presumption that the public interest will be subserved by the exemption granted," and the class of property must constitute a reasonable classification. ${ }^{\mathbf{1 9}}$

However, the court has interpreted section 112 to require an absolute uniformity in the effective rate applicable to all property taxed by a single taxing jurisdiction, saying: "In order that the equality of taxation contemplated by this section may exist . . . there must be no discrimination in rates between different species of property. All property must be taxed at the same rate on its true value. ${ }^{20}$ In addition, as might be expected in view of the additional words found in the Mississippi uniformity clause, taxation of property must be ad valorem. ${ }^{21}$

\section{Texas}

\section{a. The provisions; historical note}

The present constitution of Texas, which became effective in 1876, contains two basic uniformity provisions, both found in Art. VIII. Section 1 of Art. VIII provides, in part:

Taxation shall be equal and uniform. All property in this State, whether owned by natural persons or corporations,

${ }^{19}$ Mississippi Power \& Light Co. v. Love, supra note 17 at 690.

${ }^{20}$ Chicago, R.I. \& P.R. Co. v. Robertson, 122 Miss. 417, 422, 84 So. $499(1920)$. And section 112 is said to require "uniformity" in assessed value over "true" value in situations where both are impossible. For discussion of the uniformity required under the uniformity clause in the 1869 constitution, see Vicksburg Bank v. Worrell, 67 Miss. 47, 7 So. 219 (1889); Hawkins v. Mangum, 78 Miss. 97, 28 So. 872 (1906); Adams v. Miss. State Bank, 75 Miss. 701, 23 So. 395 (1898); and Dams v. Bank of Oxford, 78 Miss. 532, 29 So. 402 (1900).

${ }^{21}$ For example, Chicago, R.I. \& P.R. Co. v. Robertson, supra note 20. 
other than municipal, shall be taxed in proportion to its value. . . .

Section 1 further provides for particular types of taxes, including the taxation of income, ${ }^{1}$ and contains a proviso requiring the exemption from taxation of $\$ 250$ of household furniture belonging to each family. The uniformity structures in the prior constitutions of Texas were limited substantially to the above provisions. ${ }^{2}$ The second uniformity clause in the present constitution is specifically concerned with "occupation taxes." Section 2 of Art. VIII provides:

All occupation taxes shall be equal and uniform upon the same class of subjects within the limits of the authority levying the tax. ... ${ }^{3}$

1 The provision reads:

... The Legislature may impose a poll tax. It may also impose occupation taxes, both upon natural persons and upon corporations, other than municipal, doing business in this State. It may also tax incomes of both natural persons and corporations other than municipal, except that persons engaged in mechanical and agricultural pursuits shall never be required to pay an occupation tax. ...

2 The first constitution of the State of Texas, dated 1845, contained a provision, Art. VII, $\S 27$, substantially identical to Art. VIII, $\S 1$ of the present constitution with the important difference being that the following italicized clause was present: "All property in this State shall be taxed in proportion to its value . . ; except such property as two-thirds of both houses of the legislature may think proper to exempt from taxation." Compare the proviso of the present Art. VIII, $\$ 2$, described in the text. The constitution of 1845 also contained a provision, Art. VII, $\$ 28$, which was identical to the present proviso in Art. VIII, $\$ 1$ exempting household furniture from property taxation. In the subsequent constitution of 1866 Art. VII, $\S \S 27$ and 28 were identical to Art. VII, $\S \S 27$ and 28 of the 1845 constitution. In the constitution of 1868 there was a single provision, Art. XII, $\S 19$, identical to Art. VII, $\S 27$ of the 1845 constitution. The next constitution was the present one of 1876 .

${ }^{8}$ In Art. VIII, $\$ 17$ the constitution provides:

The specification of the objects and subjects of taxation shall not deprive the Legislature of the power to require other subjects or objects to be taxed in such manner as may be consistent with the principles of taxation fixed in this Constitution. 
The second clause of this provision requires the exemption from taxation of designated classes of property and concludes with the proviso that "all laws exempting property from taxation other than the property above mentioned shall be null and void." Another provision of interest is Art. VIII, $\$ 20$, providing that property shall never be assessed for ad valorem taxes at a greater value than its "fair cash market value."

\section{b. Meaning of the uniformity limitation}

In Texas taxes are classified for purposes of uniformity as either property taxes or nonproperty taxes. Because of the use of the term "occupation" taxes in Art. VIII, §2, the Texas courts have generally referred to most of the "nonproperty" taxes as "occupation" taxes," although the term has a more narrow significance in most other states. In any case, it is clear that "nonproperty" taxes are limited only by that degree of uniformity required by Art. VIII, \$2-a uniformity within classes. ${ }^{\circ}$ Texas has had a substantial number of cases

4 The designated classes of property are "public" and "quasi-public." Other provisions of the constitution provide for the exemption of special classes of property. See Art. XI, §9; Art. VIII, §§1b, 19; Art. VII, §6a.

${ }^{5}$ For purposes other than uniformity it may become of some importance in Texas to distinguish between those nonproperty taxes designated "occupation" taxes and those held not to be occupation taxes. For example, municipalities are exempt from certain "occupation" taxes. This was held not to include a fuel use tax. Sec State v. City of El Paso, 135 Tex. 359, 143 S.W. 2d 366 (1940), in which this problem is developed.

${ }^{6}$ See, for example, the leading case, Texas Co. v. Stephens, 100 Tex. 628, 103 S.W. 481 (1907). The court has oftentimes equated the uniformity limitation in Art. VIII, $\$ 2$ with the federal equal protection clause. See, for example, Dallas Gas Co. v. State (Tex. Civ. App.), 261 S.W. 1063,1069 (1924); Hurt v. Cooper, 130 Tex. 433, 441, 110 S.W. 2d 896 (1937). Under the prior constitutions of Texas there was no uniformity provision directed expressly to nonproperty taxes, and the broad uniformity clause identical to that now found in Art. VIII, $\S 1$ could have possibly been interpreted to apply to all taxation. However, as expected, the 
applying this limitation and determining its meaning for "nonproperty" taxes. The court has permitted the legislature a wide discretion as illustrated in its opinions ruling that the objects of nonproperty taxes and exemptions or exclusions therefrom need only be reasonable classes, ${ }^{7}$ and that subclassifications may be made within the larger class constituting the object of a given tax for the purpose of applying different rates to different subclasses. ${ }^{8}$ The court has ap-

court ruled that nonproperty taxes need only be uniform within classes. While some of the older cases implied that the requirement that "taxation shall be equal and uniform" limited nonproperty taxes, they also read in the phrase "within classes." For a review of the situation under prior constitutions, see Dallas Gas Co. v. State, supra.

' $\mathrm{See}$, for example, the leading case, Texas Co. v. Stephens, supra note 6 , in which the court upheld an occupation tax upon the persons engaged in the wholesaling of oil. In the same case, the court upheld another section of the statute which imposed a tax on the gross receipts of pipeline companies engaged in conveying oil. Also see: Hurt v. Cooper, supra note 6 (chain store tax, upholding both the object of the tax as a class, and exemptions therefrom) ; State v. Southwestern Gas \& Elec. Co., 145 Tex. 24, 193 S.W. 2d 675 (1946) (chain store tax, exemption of certain utilities owning and operating stores selling gas and electric appliances in towns of 3,000 population or less upheld); Lockhart v. American Mutual Life Ins. Co. (Tex. Civ. App.), 194 S.W. 2d 285 (1946) (insurance companies, gross premiums tax, exemption of fraternal benefit societies upheld); San Jacinto Nat. Bank v. Sheppard, (Tex. Civ. App.) 125 S.W. 2d 715 (1938) (inheritance tax, exemption of a minimum amount for religious organizations if the devise was to be used within the state). See Pullman Palace Car Co. v. State, 64 Tex. 274, 53 Am. Rep. 758 (1885) for one of the few cases finding a classification to be arbitrary.

${ }^{8}$ For example, Texas Co. v. Stephens, supra note 6 (gross receipts tax, different businesses classified for different rates); Dallas Gas Co. v. State, supra note 6 (gross receipts tax, utilities, rate varied according to population of town in which utility operated); Hurt v. Cooper, supra note 6 (chain store tax, rates graduated according to number of stores operated); Garr, Scott \& Co. v. Shannon, 52 Tex. 634, 115 S.W. 361 (1909) (corporation franchise tax); State v. Hogg, 123 Tex. 568, 72 S.W. 2d 593 (1934) (inheritance tax, classification for different rates according to relationship to deceased). 
proved the principle of progressively graduated rates as a reasonable classification. ${ }^{\circ}$

Of comparative interest are the decisions that the following are nonproperty taxes: gross receipt taxes, ${ }^{10}$ severance and production taxes ${ }^{11}$ (which play an important part in the Texas tax structure), and an inheritance tax. ${ }^{12}$ Texas has never imposed an income tax; however, such a tax is expressly provided for in Art. VIII, $\S 1$, thus removing any doubt as to the validity of such a tax in Texas. ${ }^{13}$

Property taxation. The court has ruled that a requirement of universality governs the taxation of property in Texas. This limitation is spelled out in Art. VIII, $\S 1$, which provides that "All property . . . shall be taxed in proportion

${ }^{9}$ See the cases in footnote 8 , supra.

10 Texas Co. v. Stephens, supra note 6; Lockhart v. American Mutual Life Ins. Co., supra note 7 (insurance companies, gross premiums tax).

11 Producers' Oil Co. v. Stephens, 44 Tex. Civ. App. 327, 99 S.W. 157 (1906).

12 State v. Hogg, supra note 8.

13 In an opinion by the Texas Attorney General, dated October 17, 1932, it was concluded that the Texas legislature might constitutionally impose an income tax with graduated rates. (Summarized in the Texas CCH Tax Reporter, $110-000$.) Of course, in favor of this conclusion concerning graduated rates are the inheritance tax case and the chain store tax case, supra note 8 . However, the result might not be quite so clear as is suggested in the opinion of the attorney general. Which uniformity requirement limits income taxation? The context of Art. VIII, $\$ 1$ could indicate one of several results. For example, is the taxation of income the taxation of property specially provided for in Art. VIII, $\S 1$, and thus still limited by the stricter property tax uniformity limitation requiring absolute uniformity in rates? Or, is the provision in Art. VIII, $\$ 1$ relative to taxation of income indicative of an intent to emphasize that taxation of income is not to be considered taxation of property, and thus would be limited only by the uniformity within classes clause found in Art. VIII, \$2? Or, is it possible to conclude that the income tax clause indicates that the income tax in Texas is to be sui generis, leaving open the problem then as to which of the two uniformity limitations is applicable? These questions are the type which perhaps make the conclusion in the opinion of the attorney general a bit optimistic. 
to its value." However, the court has expressed the view that the requirement would be derived in any case from the following words in section 1: "Taxation shall be equal and uniform."14 The several classes of property designated as exemptible by the Texas constitution constitute the only exception to the above limitation, and the universality limitation is further buttressed by the proviso in Art. VIII, §2, which stipulates that only that property listed may be exempted. ${ }^{15}$ In developing the meaning of the property tax limitation, the court has ruled that a breach of uniformity caused by an omission of taxable property from the tax rolls or by a failure to provide means to assess and tax such property does not invalidate the tax as a whole. The only redress for the taxpayer whose property is listed and taxed would appear to be a remedy requiring the tax official to list the omitted property. ${ }^{16}$

14 For example, Austin v. Austin Gas Light \& Coal Co., 69 Tex. 180, 7 S.W. 200 (1887). In that case the municipality in question had attempted to contract that the company would be free from all taxes for a period of twenty-five years. Saying that the power to commute taxes is but an incident of the power to exempt, the court held that the purported exemption was unconstitutional. This case arose under a prior constitution, containing, however, a uniformity clause identical to that now found in Art. VIII, §1. See supra note 2 . At that time the legislature was expressly given the general power to exempt property. However, the court held that (1) the city had not been delegated that power, and (2) therefore such an exemption was a violation of the uniformity clause in the absence of an express exception thereto.

${ }^{15}$ For example, see City of Abilene v. State, (Tex. Civ. App.) $113 \mathrm{~S} . \mathrm{W}$. $2 d 631$ (1937), indicating that any power that might exist concerning the exemption of property, independent of constitutional authorization, is expressly prohibited by the last clause of Art. VII, $\$ 2$. The most recent decision is Dickison v. Woodmen of the World Life Ins. Soc., 280 S.W. $2 d$ 315 (1955), in which the court held that a statute was "inoperative" insofar as it attempted to exempt the property of fraternal benefit societies from taxation.

${ }^{10}$ See City of Wichita Falls v. J. J. \& M. Taxman Refining Co., (Tex. Civ. App.) 74 S.W. 2 d 524 (1934). The plaintiff taxpayer brought an 


\section{The court has interpreted the "equal and uniform" clause} as requiring an absolute uniformity in the effective rate applicable to all property taxed by a taxing jurisdiction. ${ }^{1 \tau}$ However, it is pertinent to note that, in fact, intangible property is more often than not omitted from the tax rolls by local assessors. The requirement of uniformity in effective rate has been expressly related to the ratio of valuation used by the assessors. ${ }^{18}$ However, this requirement does not pro-

action to recover taxes already paid, and alleged-and the facts showedthat large amounts of intangibles were not rendered for assessment. It was therefore contended that the whole assessment was void. The court held that the tax was not void as to the levy on plaintiff's real property simply because a great deal of property was omitted from the tax rolls. Also see City of Arlington v. Cannon, 271 S.W. $2 \mathrm{~d} 414$ (1954). Compare the treatment by the court if some property is taxed at a lesser effective rate because of a lower ratio of valuation being used. In such a situation the court will enjoin the collection of the tax on the property at a greater rate than that called for by the lowest ratio found to have been used. Note 18, infra. Query, is not the omission situation a case of the lowest ratio used being "zero?"

17 See the cases in note 18 , infra.

18 See Lively v. Missouri K. \& T. R. Co. of Texas, 102 Tex. 545, 120 S.W. 852 (1909). Plaintiff's intangible property was placed on the rolls at its true value, but tangible property was assessed for taxation at $662 / 3 \%$ of its fair market value. It was held that the valuation of plaintiff's property at full value for purposes of this levy was a violation of the uniformity clause in Art. VIII, $\S 1$. The court pointed out that it had an alternative in remedies available; it could either (1) increase the valuation of other property to full value, or (2) reduce plaintiff's property to conform to the general standard. The latter was chosen as the "practicable" and proper remedy. Also see Houston v. Baker, (Tex. Civ. App.) 178 S.W. 820 (1915) (holding the "Houston Plan" contrary to the uniformity clause; land was taxed at $70 \%$ of its full value; improvements at $25 \%$; tangible personalty at $50 \%$; and intangibles were deliberately omitted). The interesting point of the Baker case is the discussion of the remedy available. The court pointed out that generally in such a situation the court will restrain the collection of taxes from property at a higher ratio of value than that applied to other classes of property. However, the court wondered if this would not be disastrous to the city in this case because, while three classes were valued at $25 \%, 50 \%$, and $70 \%$ of full value, the lowest ratio was in effect "zero" as to the intangible omitted. The court sidestepped the dilemma, finding 
hibit the use of different methods of valuation for different classes of property. ${ }^{19}$ Finally, specific property taxation is prohibited, both expressly and by implication from the "equal and uniform" clause. ${ }^{20}$

\section{West Virginia}

\section{a. The provisions; historical note}

The present constitution of West Virginia became effective in 1872. Its basic uniformity structure is found in Art. X,

the question not necessary for decision here, for it could simply enjoin the discriminatory valuation and not interfere thereby with the taxing discretion of the local officers who were thereafter free to revalue the property at any ratio which was uniform. This remedy was available because the tax had not yet been levied. Other cases are: Garza Land \& Cattle Co. v. Redwine Independent School Dist., (Tex. Civ. App.) 282 S.W. 905 (1926); Willis v. State, (Tex. Civ. App.) 142 S.W. 2d 385 (1940) (finding an arbitrary method was used in fixing the value of acreage land for tax purposes). The latest decisions illustrating the problems dealt with in the Lively case, supra, and Houston v. Baker, supra, are: City of Arlington v. Cannon, supra note 16, and Aycock v. Travis County, 255 S.W. 2d 910 (1953).

${ }^{19}$ See the leading case, Missouri K. \& T. R. Co. of Texas v. Shannon, 100 Tex. 379, 100 S.W. 138 (1907), upholding the intangibles act which provided for a different method of assessing intangibles of certain named corporations. In effect, central assessment for such property was provided, with the state board apportioning proper amounts to local tax units. The court ignored the reality of the situation here, for it was known that local units failed to assess other intangible property, thus making the ultimate effect of the act in question to be the taxation of the named intangibles, while all other intangible property remained untaxed. Followed in Druesdow v. Baker, (Tex. Com. App.) 229 S.W. 493 (1921). In Texas Pipe Line Co. v. Anderson, (Tex. Civ. App.) 100 S.W. 2d 754 (1937), the aforementioned act was held not to be unconstitutional even though in actual practice it was the only law providing the means for taxing intangibles, and local authorities did not in fact tax intangibles of corporations or persons not within the act.

20 There are no cases holding specifically on this point; however, it is an obvious conclusion from Art. VIII, $\S 1$ in which the requirement is spelled out. 
$\S 1$, which was substantially modified by amendment in 1932 . The phraseology of the uniformity clause itself remains unchanged, but by the amendment a significant proviso was added which radically changed the meaning of the effective limitation. Article X, $\S 1$ reads, in part, as follows (with that part added by the 1932 amendment italicized):

Subject to the exceptions in this section contained, taxation shall be equal and uniform throughout the State, and all property, both real and personal, shall be taxed in proportion to its value to be ascertained as directed by law. No one species of property from which a tax may be collected shall be taxed higher than any other species of property of equal value; except that the aggregate of taxes assessed in any one year upon personal property employed exclusively in agriculture, including horticulture and grazing, products of agriculture as above defined, including live stock, while owned by the producer, and money, notes, bonds, bills and accounts receivable, stocks and other similar intangible personal property shall not exceed fifty cents on each one hundred dollars of value thereon and upon all property owned, used and occupied by the owner thereof exclusively for residential purposes and upon farms occupied and cultivated by their owners on bona fide tenants one dollar; and upon all other property situated outside of municipalities, one dollar and fifty cents; and upon all other such property situated within municipalities, two dollars; . . . but property used for educational, literary, scientific, religious or charitable purposes, all cemeteries, public property, and personal property, including live stock, employed exclusively in agriculture as above defined and the products of agriculture as defined while owned by the producers may by law be exempted from taxation; household goods to the value of two hundred dollars shall be exempted from taxation. ${ }^{1}$

1 The indicated omission provides that the maximum rates on the classes of property may be increased by the voters, but with a limit of a $50 \%$ increase over the maximum rates listed in Art. X, $\S 1$. The prior and original constitution of West Virginia, dated 1863, contained a provision in Art. VIII, $\S 1$ substantially identical to Art. X, $\S 1$ of the constitution of 1872 as 
By its operation this amendment changed the uniformity requirement in West Virginia from a strict absolute uniformity to a liberal uniformity within classes.

Article X, $\S 1$, also contains a second uniformity clause expressly directed to nonproperty taxes-or, at least, some nonproperty taxes. Before the 1932 amendment the following clause was found immediately after that part of Art. X, $\S 1$, quoted above:

The Legislature shall have power to tax, by uniform and equal laws, all privileges and franchises of persons and corporations.

In 1932 this was amended to read:

The legislature shall have authority to tax privileges, franchises, and incomes of persons and corporations and to classify and graduate the tax on all incomes according to the amount thereof and to exempt from taxation, incomes below a minimum to be fixed from time to time. . . .

\section{b. Meaning of the uniformity limitation ${ }^{2}$}

Unfortunately, the language of the West Virginia decisions dealing with problems of uniformity is at times confusing and even misleading. However, concentration on the rules actually necessary for the several decisions concerning the uniformity problem avoids those errors into which one might fall by relying on some generalities repeated throughout the decisions.

it originally appeared, with the exception that the class of permissible exemptions did not include "cemeteries." By an amendment in 1946, a new provision was added to the West Virginia Constitution (Art. VI, §53) which authorizes special treatment for "forest lands," both for exemption and method of taxation, including the imposition of a severance tax. These uniformity provisions are not applicable to local taxes. The latter are governed by Art. X, $\S 9$, which reads: “. . . but such [local] taxes shall be uniform, with respect to persons and property within the jurisdiction of the authority imposing the same."

2 Generally, see Michie's West Va. Juris., Taxation, $\$ 17$. 
Both before and after the 1932 amendment to Art. X, §1, it is quite clear that nonproperty taxes have been required only to be uniform within classes. The clause in the original section 1 providing that privileges and franchises were to be taxed "by uniform and equal laws" was, in effect, held to mean "uniform and equal within classes." The omission of this clause in the amended version of Art. X, $\$ 1$ has had no significance, the same uniformity within classes limitation still being applicable to nonproperty taxes. ${ }^{4}$ Thus, the objects of such taxes need only be reasonable classes, ${ }^{5}$ and subclassifications may be made within the general classes for purpose of applying different rates. ${ }^{6}$ In view of the stricter uniformity limitation applicable to property taxes, the characterization

${ }^{3}$ See, for example, Hope Natural Gas Co. v. Hall, 102 W. Va. 272, 135 S.E. 582 (1926) (Gross Sales Tax Law of 1921, in effect, a general occupation tax with base of gross income); State v. Azel Meadows Realty Co., 108 W. Va. 118, 150 S.E. 378 (1929) and Blue Jacket Consol. Copper Co. v. Scherr, 50 W. Va. 533, 40 S.E. 514 (1901) (corporate franchise tax, base of capital stock).

4 Laing v. Fox, 115 W. Va. 272, 175 S.E. 354 (1934) (business and occupation tax, base of gross income). The contention was made that since the amended Art. X, $\$ 1$ authorized the legislature to classify income taxes it impliedly rejected the power to classify privileges and franchises. The court summarily rejected this argument.

5 Hope Natural Gas Co. v. Hall, supra note 3 (exemption of $\$ 10,000$, and reasonableness of the object); Laing v. Fox, supra note 4 (exemption of farmers from business and occupation tax). Also see Central Trust Co. v. State Tax Com'r, 116 W. Va. 37, 178 S.E. 520 (1935) (inheritance tax, exemptions).

${ }^{6}$ See Arslain v. Alderson, 126 W. Va. 880, 30 S.E. 2d 553 (1944); Blue Jacket Consol. Copper Co. v. Scherr, supra note 3 (corporate franchise tax, different rates for foreign and domestic corporations upheld); Central Trust Co. v. State Tax Com'r, supra note 5 (inheritance tax); State v. Azel Meadows Realty Co., supra note 3. There have been no West Virginia cases concerning the validity of a graduated rate. But see Eureka Pipe Line Co. v. Hallahan, 87 W. Va. 396, 105 S.E. 506 (1920). In respect to the chain store tax, see the leading federal case under the federal equal protection clause, Fox v. Standard Oil Co. of New Jersey, 294 U.S. 7, 55 S. Ct. 333 (1934). 
of a tax as either property or nonproperty is of crucial importance. $^{7}$

Income tax. The cases give no indication as to what would have been the result had Art. X, $\S 1$ not been amended so as to provide expressly for an income tax. Probably the closest precedent concerned the Gross Sales Tax Law enacted in 1921, which was, in effect, a general business and occupation tax with a base of gross income. ${ }^{8}$ However, the validity of such a tax furnishes little basis for assuming that the traditional net income tax would have been characterized as a nonproperty tax, thus avoiding the strictness of the property tax uniformity limitation. In any case, the drafters of the amended Art. X, $\$ 1$ forestalled any controversy when they spelled out the scope of a permissible income tax-including a graduated rate and at least minimum exemptions.

However, despite this permissive provision, the West Virginia legislature has imposed a net income tax for only a brief period: 1935 to $1943 .^{\circ}$ In two cases the court was concerned with the interpretation of the net income tax statute, and in each case some dictum is found concerning the uniformity requirement. Indeed, the language used in Dickinson v. James ${ }^{10}$ might well lead one to believe that but for the

${ }^{7}$ The court has held an inheritance tax to be a nonproperty tax. See Central Trust Co. v. State Tax Com'r, supra note 5.

${ }^{8}$ The Gross Sales Tax Law of 1921 was upheld in Hope Natural Gas Co. v. Hall, supra note 3. It is the predecessor of the present West Virginia business and occupation tax, upheld in Laing v. Fox, supra note 4.

${ }^{9}$ Imposed by W. Va. Laws 1935, c. 89. Repealed by W. Va. Laws 1943, c. 96.

${ }^{10} 120$ W. Va. 222, 197 S.E. 633 (1938), in which the court said (at 224):

It will be noted . . that the tax is controlled by the provision in [Art. $X, \S 1]$ that "Subject to the exceptions uniform throughout the State.

. . "The exceptions are those with respect to classification of property, certain exemptions, and the power to classify and graduate the tax on all incomes according to the amount thereof. They are limited to those specified in the constitution, and but for the exceptions so noted do not 
exceptions concerning graduated rates and minimum exemptions an income tax is governed by the "equal and uniform" clause which limits property taxes. This line of reasoning, if followed, would prevent the exemption of reasonable classes of income. However, dictum in a later case, Christopher v. James, ${ }^{11}$ would indicate that income taxes need only be uniform within classes to the same extent that nonproperty taxes

infringe upon [Art. X, §1] before the so-called Tax Limitation Amendment, adopted in 1932. . . [A]nd it seems clear that once $a$ tax is imposed, under whatever classification it falls, it must be applied with equality and uniformity to all persons and corporations subject thereto. [Emphasis added.]

The issue in the Dickinson case concerned the date as to which profits or losses on property purchased was to be considered in computing annual gross income. The statute was construed so that the tax was limited to actual profits or gains realized in the tax year for which the taxpayer made his returns. This was said to be the meaning of income as required by Art. X, $\S 1$, the court, at 226 , concluding:

... any construction which requires him [the taxpayer] to do more [than pay a tax on his actual income realized during the tax year as the basis of the tax] results in injustice to him, and violates the principles of equality and uniformity in taxation, as well as the elementary rule of fair play. It is obvious that, if through the use of an arbitrary date for the ascertainment of profits, a taxpayer is made to pay on income he has not actually received, there is no equality or uniformity of payment when compared with the taxpayer who pays only on his actual income. . . . [Emphasis added.]

11122 W. Va. 665, 12 S.E. 2d 813 (1940), in which the issue concerned the deduction from gross income of certain other taxes paid by the taxpayer. The court in reaching a conclusion as to the meaning of the statute stated (at p. 670):

The taxpayer also draws into consideration the constitutional requirement of "equal and uniform" taxation. ... Art. X, $\$ 1$. That provision means merely that as to classes of property, businesses or incomes there shall be uniformity of taxation. "A tax upon all business of the same class, which is uniform as to that kind of business, is not unconstitutional." Charleston \& S. Bridge Co. v. County Court, 41 W. Va. 658. . . .

But as to the misuse of the quotation from the Charleston Bridge Co. case, see the discussion under property taxation, text at notes 12-18, infra. 
are required to be. Nevertheless, it is not at all certain, in view of the equivocal language of these opinions, just what the West Virginia court would decide as to the nature of an income tax and the validity of exemptions other than the minimum exemptions expressly provided for in Art. $\mathrm{X}, \$ 1$.

\section{(1) Property taxation}

Prior to the 1932 amendment of Art. X, $\S 1$, it was clear that the strictest uniformity limitation governed property taxes in West Virginia-at least, in theory. The requirement was based upon the first part of Art. X, $\S 1$, which was interpreted to require universality, ${ }^{12}$ absolute uniformity in effective rates, ${ }^{13}$ and the use of the ad valorem method. ${ }^{14}$ The property tax uniformity clause of Art. X, $\$ 1$, did not, however, limit local taxes, but a similar uniformity requirement for such taxes was derived from Art. X, $\$ 9 .^{15}$

12 Chesapeake \& O. R. Co. v. Miller, 19 W. Va. 408 (1882), holding that the legislature was prevented from passing a law exempting the property of a railroad from taxation. The court (at pp. $435 \mathrm{ff}$.) emphasized the sentence in Art. X, $\S 1$ which provided that "All property" shall be taxed in proportion to its value, underlining the word "all." There was no indication that this requirement of universality would not stand in the absence of this supplementary provision to the "uniform and equal" clause. Also see State v. McDowell Lodge, 96 W. Va. 611, 123 S.E. 561 (1924).

13 The problem was never squarely faced, but see Harvey Coal \& Coke Co. v. Tax Com'r, 59 W. Va. 605, 53 S.E. 928 (1906) and State v. Graybeal, 60 W. Va. 357, 55 S.E. 398 (1906), both concerned with "double taxation" and representative property. In the Graybeal case, the issue was one of statutory interpretation, and the court interpreted the general propertytax act so that a bank might deduct the value of its realty in ascertaining the taxable value of its capital stock, the court reasoning that this was necessary in order to void an unconstitutional "double taxation." Also see West Penn Power Co. v. Board of Revicw \& Equalization, 112 W. Va. 442, 164 S.E. 862 (1932), discussed infra note 18.

14 There are no cases on this point, but the requirement is so obvious and certain that this is not unexpected.

${ }^{15}$ Powell v. Parkersburg, 28 W. Va. 698 (1886); Duuglas v. Harrisville, 9 W. Va. 162, 27 Am. Rep. 548 (1876). See note 1, supra. 
However, this strict limitation did not prohibit the classification of property for the purpose of using different methods of valuation for the different classes, since the purpose of such classification was to ascertain more precisely the "true" value of all classes of property. ${ }^{16}$ It was in the leading case on this point that careless language was used which has often been quoted and reported in annotations and digests in a misleading manner. ${ }^{17}$ Nevertheless, the opinions and their holdings bear out the above analysis, despite the fact that broad misleading language was often used during the course of an opinion. Before 1932, property could not be classified for other than the purpose of mechanics of valuation. However, it is true that, despite the theoretical requirement of the strictest uniformity, the West Virginia court has shown, and still does show, a marked reluctance for examining valuations of property in order to determine whether or not the particular property was assessed at precisely the same ratio as property of the same class. ${ }^{18}$

${ }^{16}$ Charleston \& S. Bridge Co. v. Kanawha County Court, 41 W. Va. 658,24 S.E. 1002 (1896), upholding a special mode of assessment for toll bridges and ferries.

${ }^{17}$ Charleston \& S. Bridge Co. v. Kanawha County Court, supra note 16. In the syllabus by the court it was stated that "A tax upon all business of the same class, which is uniform as to that kind of business, is not unconstitutional." However, only the property tax was under consideration, and all relevant classification related only to mode of assessment. Nevertheless, the statement is often repeated out of context, and other cases could leave the impression that property could be classified for rates prior to 1932. An example of an unwarranted citation of the Charleston \& S. Bridge Co. case is found in note 11, supra, from Christopher v. James. Also compare In re Charleston Federal Sav. \& Loan Ass'n, 126 W. Va. 506, 512, 30 S.E. 2d 513 (1944), and In re National Bank of West Virginia at Wheeling, 73 S.E. $2 \mathrm{~d}$ 655, 660-661 (1952).

${ }^{18}$ For example, a recent case is In re Charleston Fed. Savings \& Loan Ass'n, supra note 17, discussed infra notes $21-23$, and distinguishing West Penn Power Co. v. Board, supra note 13, decided before the 1932 amendment of Art. X, $\S 1$. In the West Penn Power case it was clear that taxpayer's realty was assessed at a greater ratio of true value than other realty in the 
With the amendment of Art. X, $\S 1$ in 1932, a significant change was made in the meaning of the property tax effective uniformity limitation. The phraseology of the basic uniformity clause governing the taxation of property remained unchanged. However, a proviso was added which in fact changed the nature of the effective uniformity limitation. The uniformity clause was made "subject to the exceptions in this section contained." The new "exception" clause divided all property into the following four classes. Class 1 : Property employed exclusively in agriculture; and money, notes, bonds, bills and accounts receivable, stocks and "other similar intangible personal property." Class 2: Residential property used for such purposes by the owner. Class 3 : All property, other than that in Classes 1 and 2, situated outside municipalities. Class 4: All property, other than that in Classes 1 and 2, situated within municipalities. ${ }^{19} \mathrm{~A}$ different annual maximum aggregate rate was established for each class of property. The importance of this new proviso for our purposes is not as a "maximum rate limitation" clause, but as a clause which in fact provides for a classification of property for different rates. The requirement of universality remains intact, ${ }^{20}$ but insofar as effective rates are concerned, there

same taxing district. The court invalidated the assessment. It seems clear in light of the case of In re Charleston Fed. Sav. \& Loan Ass'n, supra at 519521 , that a very "clear" case of discrimination must be proven.

${ }^{19}$ It is obvious that Class 1 consists of two unrelated classes, agricultural property and intangibles, grouped together simply for the purpose of limiting the tax rate upon such property the lowest maximum rate. It is interesting to note the basis of the classifications: Two Classes (1a and 2) are established on the basis of the personal use of such property. One class (1b) is established on the basis of the nature of the property. Two classes ( 3 and 4) are established on the basis of the location of such property.

${ }^{20}$ Central Realty Co. v. Martin, 126 W. Va. 915, 30 S.E. 2d 720 (1944), overruling Prichard v. Kanawha County Court, 109 W. Va. 479, 155 S.E. 542 (1930). Also see In re Hancock County Fed. Savings \& Loan Ass'n, 125 W. Va. 426, 25 S.E. 2d 543 (1943). 
now need only be a uniformity within classes. Of course, the constitution defines the classes, leaving the legislature no discretion on this matter.

A leading case concerning the classification of property for rates is In re Tax Assessments Charleston Fed. Sav. E' Loan Ass'n, ${ }^{21}$ decided in 1944. The taxpayer contended that other property of the same class belonging to it (intangibles, Class 1, supra) was assessed at approximately $70 \%$ of its true value, but taxpayer's property was assessed at its full true value. It was contended that this was a violation of the uniformity clause, Art. X, $\S 1$. It was shown that certain bonds were assessed at less than $100 \%$ of their face value, that certain agricultural property belonging to Class 1 was assessed at less than $100 \%$ of its purchase value, but that plaintiff's securities were valued at $100 \%$ of their face value. The court held that Art. X, $\S 1$ was not violated. It concluded that the above method of assessment was only an attempt to get at the "true" value for all property, and that plaintiff's securities were undoubtedly worth $100 \%$ of their face value, but that this was not necessarily true as to all property. Thus, the situation described by plaintiff was characterized as being nothing more than a rough way of subclassifying property belonging to a "minimum" constitutional class for the purpose of mechanics of valuation, and in the end all property was to be levied on at the same ratio of "true" value. Therefore, it was held that the evidence was insufficient to establish a case of discrimination which would justify the application of the uniformity provision. The court's view of the difficulties of the general problem was apparent in this statement:

While our State Constitution requires uniformity and equality in taxation, no one has ever believed that either

${ }^{21}$ Supra note 17. For similar cases, see: Bankers Pocahontas Coal Co. v. McDowell County Court, 135 W. Va. 174, 62 S.E. 2d 801 (1950); In re National Bank of West Virginia at Wheeling, supra note 17. 
could be attained as a practical matter. The constitutional provision is a statement of an ideal, and is implemented by numerous statutes, all seeking to put into practice such ideal so far as humanly possible. But do all we can, and attempt as rigidly as we may to enforce such statutes, we will fall short of attaining equality, uniformity and justice in levying taxes. ${ }^{22}$

Thus, the court, in effect, threw up its hands insofar as the enforcement of absolute uniformity is concerned, even within a subclass of property. ${ }^{23}$ In other words, in West Virginia the requirement of uniformity of rates even within constitutionally established classes is pretty much of a façade, since more often than not the real story of the property-tax rates is to be found in a de facto classification system established by the assessors.

\section{Wyoming}

Wyoming has had but a single constitution, that of 1890 , and the uniformity provisions found therein have remained unchanged. The basic uniformity clause is not found in the revenue article (Art. XV), but in the Bill of Rights. Article I, $\S 28$, reads: “. . . All taxation shall be equal and uni-

\section{${ }^{22}$ Supra note 17 at 515 .}

23 The court further indicated the freedom allowed the assessor when it described the plan in question as follows (at p. 517):

We do not have a case where the true and actual value was ascertained and a discount allowed from that value; but rather a case where the discount was allowed, particularly as to intangibles, in an effort to reach the true value. The more or less arbitrary allowance of the discount as to notes and accounts may have been an erroneous exercise of the duties of the assessor. We think it was. Some plan which would take into account the difference between the secured notes and unsecured notes and accounts could, and should be devised; but mere error of judgment as to the plan adopted is not sufficient to establish discrimination, where the plan, though imperfect is adopted in a good faith effort to secure fair and equitable assessment, and equality and uniformity in taxation. 
form." In addition, the following provisions in the revenue article are pertinent. Article XI, $\S 11$, in the absence of Art. I, $\$ 28$, would probably have served as the basic uniformity clause for property taxation. Section 11 reads:

All property, except as in this constitution otherwise provided, shall be uniformly assessed for taxation, and the legislature shall prescribe such regulations as shall secure a just valuation for taxation of all property, real and personal.

Article XV, $\$ 12$ provides that designated classes of "public" and "quasi-public" property

shall be exempt from taxation, and such other property as the legislature may by general law provide.

Article I, $\S 34$ of the Bill of Rights is also important. It reads: "All laws of a general nature shall have a uniform operation."

Meaning of the uniformity limitation. The uniformity clause in Art. I, $\S 28$ is framed in the most general terms, i.e., "all taxation," and it is not adjacent to the property tax provisions. However, the Wyoming court has generally taken the position that this uniformity clause limits only property taxes, and that, in any case, even if construed to apply to nonproperty taxes it would require only a uniformity within classes. ${ }^{1}$ Thus, regardless of the source of the limitation, non-

1 The very few cases in Wyoming concerning uniformity in nonproperty taxes have generally arisen from a challenge of the object (exemption or sclection) of a particular tax. See Ludwig v. Harston, 65 Wyo. 134, 197 P. 2d 252 (1948) (oleo tax, object held to be a valid class as defined); Unemployment Compensation Comm. v. Renner, 59 Wyo. 437, 143 P. 2d 181 (1943) (upheld exemption of farmers from the unemployment tax; general class in question was "employers"); Continental Supply Co. v. People, 54 Wyo. 185, 188 P. 2d 488 (1939) (use tax, upheld different treatment between retailers maintaining place of business within the state and "peddlers"; the latter class was not subject for the tax); Public Service Comm. v. Grimshaw, 49 Wyo. 158, 53 P. 2d 1 (1935) (motor vehicle tax, several exemptions upheld, e.g., motor vehicles of farmers). Also see 
property taxes (generally designated "excise" taxes in Wyoming) are only subject to the usual uniformity within classes limitation. It is always of some importance to determine the nature of a particular tax, since property taxes are subject to a stricter limitation. ${ }^{2}$

Property taxes are limited by the general uniformity clause of Art. I, $\$ 28$, and by the clause in Art. XV, $\$ 11$. It has been established that there is no requirement of universality. ${ }^{3}$ This result is based upon the express words in Art. XV, $\S 12$, which are said to state an exception to the rule of uniformity otherwise stemming from Art. I, $\$ 28$ and Art. XV, \$11.

State v. Willingham, 9 Wyo. 290, 62 Pac. 797 (1900). In the Ludwig and Renner cases the court maintained the alternative proposition as to the applicability and meaning of Art. I, $\$ 28$. In the Grimshaw case only Art. I, $\$ 34$ (uniform operation of laws) was cited, along with the federal equal protection clause. There have been no cases concerning the validity of classification for rates. Note, for example, that the inheritance tax has its object classified for varying flat proportional rates, with certain minimum exemptions.

2 No cases have arisen concerning the inheritance tax, and Wyoming has never had any form of an income tax. The tax structure of Wyoming has remained relatively simple. The sales tax, fuel tax, and general property tax are the primary sources of revenue. Article 15, $\$ 3$ of the Wyoming Constitution provides specifically for a gross products tax as to mining claims. In Miller v. Buck Creek Oil Co., 38 Wyo. 505, 269 Pac. 43 (1928) the court held that this was a property tax rather than a license, privilege, or occupation tax. The issue, however, did not relate to uniformity of taxation but concerned the problem of who was to pay the tax, lessor or lessee.

${ }^{3}$ State v. Snyder, 29 Wyo. 199, 212 Pac. 771 (1922), upholding an exemption of $\$ 2,000$ of property belonging to certain veterans and their relatives. Also see Harkin v. Board of Com'rs of Niobrara County, 30 Wyo. 455, 222 Pac. 35 (1923).

${ }^{4}$ State v. Snyder, supra note 3 at 221-224. The court stressed the following phrase in Art. XV, $\S 11$ : "except as in this constitution otherwise provided." On this point of interpretation concerning the reading of all the provisions in the light of the others, the court distinguished State ex rel. Chamberlain v. Daniel, 17 Wash. 111, 49 Pac. 243 (1897), in which a different result was reached in a similar situation. That case and its rather strained construction is discussed infra, $\mathrm{Part} \mathrm{H}$ of this chapter. 
Thus, the uniformity provisions apply only to that property selected for taxation, but as to such property an absolute uniformity in effective rates is required. ${ }^{5}$ However, classification of property for the use of different modes of assessment is not prohibited if the purpose is to assess all property at the same ratio of actual value. ${ }^{6}$

\section{F. ANALYSES OF STATES WITH TYPE VI CLAUSES}

\section{Florida}

\section{a. The provisions; historical note}

The uniformity clause of the present Florida Constitution (dated 1885) is found in Art. IX, §1, as amended in 1924. The 1924 amendment left the basic uniformity clause unchanged in phraseology, but added a proviso which made an important change in the effective limitation. ${ }^{1}$ Article IX, $\S 1$ reads as follows, with that material added by the 1924 amendment in italics:

The Legislature shall provide for a uniform and equal rate of taxation, except that it may provide for special rate or rates

${ }^{5}$ See Bunten v. Rock Springs Grazing Ass'n, 29 Wyo. 461, 215 Pac. 244 (1923). The use of a higher ratio of valuation for taxpayer's property than was used on other property was held to violate the requirement of Art. $15, \S 11$. That section was expressly relied on rather than the general uniformity clause in Art. I, §28. The court (at p. 489) stressed the constitutional requirement that all taxable property should be assessed uniformly, so as to bear a just proportion of burdens of taxation.

${ }^{6}$ Kelley v. Rhoads, 7 Wyo. 237, 51 Pac. 593 (1897), upholding the use of a different mode of valuation for transient grazing sheep, taxable under the personal property tax. It was asserted (at p. 265) that the uniformity limitation was met when the same rate and basis of valuation was used for all taxable property.

${ }^{1}$ Compare the same approach which was found in West Virginia, Part E of this chapter, supra. 
on intangible property, but such special rate or rates shall not exceed two mills on the dollar of the assessed valuation of such intangible property. . . . The special rate or rates, or the taxes collected therefrom, may be apportioned by the legislature, and shall be exclusive of all other state, county, district, and Municipal taxes; and shall prescribe such regulations as shall secure a just valuation of all property, both real and personal, excepting such property as may be exemptied by law for municipal, education, literary, scientific, religious or charitable purposes. ${ }^{2}$

Other provisions of some importance are: the section added in 1930 which provides for special treatment of motor vehicles for purposes of property taxation; ${ }^{3}$ the several sections providing for the special exemption of designated property; ${ }^{4}$

2 The indicated omission within the italicized portion is a 1944 amendment which added the following proviso for the alternate treatment of some intangible property:

- . . provided, that as to any obligations secured by mortgage, deed or transfer, or other lien, the Legislature may prescribe an intangible tax of not more than two mills on the dollar, which shall be payable at the time such mortgage, deed of trust or other lien is presented for recordation, said tax to be in lieu of all other intangible assessments on such obligations.

In addition, this 1944 amendment lowered the maximum rate on intangibles to two mills. In the original 1924 amendment a five-mill maximum rate had been provided for.

Florida has had several prior constitutions. The original Florida constitution became effective in 1838 and had the following uniformity clause:

The General Assembly shall devise and adopt a system of revenue, having regard to an equal and uniform mode of taxation, to be general throughout the State.

An identical provision was found in the subsequent constitutions of 1861 and 1865 , except that in the 1865 version the phrase "to be general" was omitted. The next succeeding constitution of Florida was dated 1868. Article XII, $\S 1$ therein was phrased identically to Art. IX, $\S 1$ of the present constitution of 1885 as quoted in the text.

${ }^{3}$ Art. IX, §13. For the text, see the appendix, infra. There is to be a single license tax in lieu of all ad valorem taxes assessed against the motor vehicles as personal property.

4 Article IX, $\$ 11$, added in 1924 , requires the exemption from taxation 
the section added in 1924 which prohibits taxes upon inheritances or upon incomes $;{ }^{5}$ and the section added in 1940 which forbids a state tax upon any property except intangible property. ${ }^{6}$ In addition, Art. IX, $\$ 5$ deals expressly with the uniformity required of local property taxes. ${ }^{7}$

\section{b. Meaning of the uniformity limitation}

The court has repeatedly stated that nonproperty taxes are not limited in any way by the uniformity clause found in Art. IX, $\S 1$, and that such taxes are only required to be uniform within classes. ${ }^{8}$ Thus, the Florida legislature is free to select

"to the head of the family residing in [Florida] household goods and personal effect to the value of Five Hundred (\$500.00) Dollars"; Art. X, $\$ 7$ provides for a homestead exemption of $\$ 5,000$; and Art. IX, $\$ 9$ provides for a minimum excmption to certain disabled persons. In addition, there is a provision which relatcs to the last clause of Art. IX, $\S 1$ as quoted in the text. Article XVI, $\$ 16$ provides:

The property of all corporations, except the property of a corporation which shall construct a ship or barge canal across the peninsula of Florida, if the Legislature should so enact, whether heretofore or hereafter incorporated shall be subject to taxation unless such property be held and used exclusively for religious, scientific, municipal, educational, literary or charitable purposes.

${ }^{5}$ Article IX, $\S 11$, added in 1924 . In 1930, that section was amended to provide that the legislature might impose an estate tax to take advantage of the provision in the federal estate tax for deductions allowed for state inheritance or estate taxes paid. See the Appendix, infra, for text.

${ }^{\circ}$ Article IX, §2: “. . . after December 31st, AD 1940, no levy of ad valorem taxes upon real or personal property except intangible property, shall be made for any State purpose whatsoever. . . ."

${ }^{7}$ Section 5 provides that the legislature may authorize local taxes, "and all property shall be taxed upon the principles established for State taxation."

${ }^{8}$ For example, Jackson v. Neff, 64 Fla. 326, 60 So. 350 (1912); Shiep Co. v. Amos, 100 Fla. 863 , 130 So. 699 (1930); Gaulden v. Kirk, 47 S. $2 \mathrm{~d} 567$ (1950). The source of this limitation is both the state equal protection clause in Sec. 1 of the Bill of Rights of the Florida Constitution, and the federal equal protection clause. At times only the federal clause is referred to. See, for example, State ex rel. Chavers v. Lee, 122 Fla. 638, 163 So. 92 (1935) (chain store tax). 
classes for the objects of nonproperty taxes and to provide for exemptions therefrom so long as such classifications are reasonable ${ }^{9}$ and, of course, different rates may be applied to the different classes. ${ }^{10}$ The principle of graduated rates has been approved, although the Florida court did find that a rather unusual form of graduated rate embodied in the chain store tax was an arbitrary classification. ${ }^{11}$ In any case, under

${ }^{-}$See, for example, Gaulden v. Kirk, supra note 8 (sales tax, which in Florida includes rentals and admissions; exemption of rental of two family apartment buildings justified on a de minimus basis; exemption of rental to guests staying in same hotel or apartment for period longer than six months justified as a reasonable classification); Peninsular Industrial Ins. Co. v. State, 61 Fla. 376,55 So. 398 (1911) (tax of $2 \%$ of the gross receipts of premiums received by companies or associations engaged in business of sick and funeral beneficial insurance in the state; selection held valid and not unreasonably discriminatory). Also see Jacksonville Gas Co. v. Lee, 110 Fla. 61, 148 So. 188 (1933).

${ }^{10}$ See, for example, Florida Sugar Distributors v. Wood, $135 \mathrm{Fla} .126$, 184 So. 641 (1938) (different treatment under separate taxes for wholesalers and retailers held valid); Jackson v. Neff, supra note 8 (licenses tax for motor vehicles; higher rates for commercial vehicles; held a valid classification).

11 The second Florida chain store tax was imposed in 1935, and its validity was considered in State ex rel. Lane Drug Stores v. Simpson, 122 Fla. 582, 166 So. 227 (1935), cert. den. 299 U.S. 543, and State ex rel. Chavers v. Lee, supra note 8 , cert. den. 299 U.S. 542. The tax provided for two separate sets of rates. First, there was the usual type of graduated rate found in the chain store taxes, a flat sum increasing in amount according to number of stores operated. This rate schedule was upheld in the Lane Drug Stores Case as a reasonable classification. The second rate schedule was an additional excise tax. The base was gross receipts and the rate was a proportional rate increasing as the number of stores in the chain increased. This rate schedule was held invalid because the classification was found to be arbitrary.

The first Florida chain store tax, imposed in 1931, was struck down in a leading United States Supreme Court Case, Liggett Co. v. Lee, 288 U.S. $517,53 \mathrm{~S}$. Ct. 481 (1933), as a violation of the federal equal protection clause. The objectionable feature of that tax was the rate schedule which imposed a higher rate on stores according to their geographic location. The higher rates were imposed upon stores in counties with the greater population. See Chapter IV, infra. 
the Florida Constitution as it now stands, questions concerning the validity of graduated rates are not likely to be raised because of the prohibition against either an income or inheritance tax.

An important issue in all cases is whether the tax in question is to be characterized as a property or nonproperty tax. Thus, in Sheip Co. v. Amos ${ }^{12}$ the court upheld a motor fuel storage tax because it was characterized as being upon the privilege of storing the fuel, not upon the fuel itself. The taxpayer challenging the tax argued that the tax was upon the "mere right to acquire and possess" the property and therefore upon the property itself. If this position had been sustained, the tax would have run afoul of the uniformity clause in Art. IX, $\$ 1$. A similar problem was faced in Floyd Fruit Co. v. Florida Citrus Comm., ${ }^{13}$ in which a "borderline" tax was involved and its validity depended upon its being characterized as a nonproperty tax. The tax, which was sustained, was imposed on citrus fruit, and the revenue went into an advertising fund for the promotion of such fruit. ${ }^{14}$ There have been no decisions in Florida concerning the nature of either an income or an inheritance tax insofar as uniformity of taxation is concerned, nor are there likely to be any, since those taxes are now expressly prohibited. ${ }^{15}$

12 Supra note 8. The court distinguished the Mississippi cases concerning a tax on the "use" and "ownership" of property. See Part E of this chapter, supra.

13128 Fla. 565, 175 So. 248 (1937). As the court stated (at p. 571): "It is a tax upon the privilege of handling fruit, of selling fruit, of delivering fruit for shipping or delivering fruit for canning or processing into by-products. The tax is not levied upon the right of ownership or production, or of possession." In this way Thompson v. McLeod, 112 Miss. 383, 73 So. 193 (1916) was distinguished. See the reference in note 12, supra. ${ }^{14}$ Compare the similar Michigan tax for advertisement of Michigan grown apples, referred to in Part D of this chapter, supra.

15 The several cases concerning income taxes dealt with local taxes which were challenged on the ground that they were "income" taxes prohibited by Art. IX, $\S 11$. Thus, in City of Lakeland v. Amos, 106 Fla. 873, 143 


\section{(1) Property taxation}

First, the uniformity provision in Art. IX, $\S 1$, has been interpreted as requiring universality. In establishing this limitation the court has relied upon that part of Art. IX, $\$ 1$, which reads: "a just valuation of all property" (emphasis by the court), although some support apparently is drawn from the words of the uniformity clause itself. ${ }^{16}$ It should be noted, however, that before the proviso concerning special treatment for intangibles was written into Art. IX, $\$ 1$, the actual practice in Florida was to fail to assess intangibles, although such property was within the terms of the general property-tax act. ${ }^{17}$

So. 744 (1932), the court held that a tax on the "gross receipts" of corporations receiving payment for electricity, etc., was not a "tax on income" but merely a "license" or "excise" tax. Also see Bentley-Gray Dry Goods Co. v. Tampa, 137 Fla. 641, 188 So. 758 (1939) for a similar decision. But in State ex rel. McKay v. Keller, 140 Fla. 346, 191 So. 542 (1939), the court held that a local tax with a base of gross income, when applied to attorneys, was in fact a tax "upon income" and therefore prohibited. Upholding the state intangibles tax on this point, see Owens v. Fosdick, 153 Fla. 17, 13 S. 2d 700 (1943).

${ }^{16}$ State ex rel. Burbridge v. St. John, $143 \mathrm{Fla} .544,550,197$ So. 131 (1940). In that case the court ruled that property owned and controlled by a housing authority was not exempt under Art. XVI, $\$ 16$ of the constitution referring to property held and used exclusively for a "municipal purpose." Since such property was not designated as exemptible by the constitution, it would be unconstitutional to exempt it because the legislature cannot add to the classes of property designated as exemptible by the constitution. See Op. Atty. Gen., Oct. 14, 1947, in which serious doubt is raised as to the validity of Fla. Laws 1947 , c. 24045 , which would classify aircraft as motor vehicles and thus exempt aircraft from all ad valorem property taxation.

${ }_{17}$ See Op. Atty. Gen., Nov. 13, 1930, in which it is stated, after a description of the de jure situation, that in fact tax assessors for years ignored putting on the rolls and would not put thereon intangible property, and therefore in actual practice such property was not assessed. Indeed, in recognition of this de facto classification system, the legislature in 1929 expressly failed to require the listing of intangibles for taxation in enacting the compulsory tax return law. 
Second, the "cardinal principles of equality and uniformity in taxation" can not be met unless there is an absolute uniformity in the effective rate ${ }^{18}$ applicable to all property taxed by any one taxing authority. ${ }^{19}$ The court has realized that the rationale underlying the requirement of absolute uniformity is that all taxpayers should share a proportionate effective tax burden, and that this is achieved regardless of whether the assessment is at full value as long as the same percentage rate and ratio of valuation is applied to all property taxed by any one taxing authority. ${ }^{20}$

Of course, the above analysis is subject to the exception made by the 1924 amendment of Art. IX, $\$ 1$, concerning

${ }^{18}$ Camp Phosphate Co. v. Allen, 77 Fla. 341, 365, 81 So. 503 (1919). In that case, the court found that thcre was a deliberate systematic undervaluation of certain classes of realty, and an arbitrary valuation of other classes which resulted in different ratios of the full value being used as to the several classes of realty. Such a system was held to violate Art. IX, §1. The court pointed out that a mere error of judgment would not violate the principle. There must be established a deliberate systematic violation of the uniformity requirement. Other cases finding that the same ratio of valuation was not used for all property within the territory of the taxing authority, and therefore finding a violation of the principles of uniformity are: Coombes v. City of Coral Gables, 124 Fla. 374, 168 So. 524 (1936); Louisville \& N.R. Co. v. Amos, 98 Fla. 350, 123 So. 745 (1929). Also see Klemn v. Davenport, 100 Fla. 627, 129 So. 904 (1930); Colonial Investment Co. v. Nolan, $100 \mathrm{Fla} .134,131$ So. 178 (1930). Porter v. First Nat. Bank, 96 Fla. 740,119 So. 130 (1928) is discussed in note 22, infra.

19 That the uniformity required is only a "territorial" uniformity, see: Town of Palm Beach v. City of West Palm Beach, 55 S. 2d 566 (1951); Howey Co. v. Williams, 142 Fla. 415, 195 So. 181 (1940); State v. City of Miami, 103 Fla. 54, 137 So. 261 (1931).

20 Thus, in Camp Phosphate Co. v. Allen, supra note 18 at 349-352, the court concluded that although the statute required all property to be assessed at $100 \%$ of true cash value, it was sufficient if all property taxed by the taxing authority was assessed on the basis of $50 \%$ of cash value, for this would not defeat the purpose of the constitutional requirement of uniformity. The adoption of $100 \%$ ratio would not make a difference as to the ultimate effective burden. 
intangible property. The 1924 amendment left the basic uniformity structure unchanged in phraseology, but the added proviso now permits the classification of intangible property for the purpose of applying different effective rates, with a maximum rate stipulated. ${ }^{21}$ But note that this intangible property proviso is permissive-thus, if the legislature does not choose to exercise this express power to classify intangibles for rates lower than the rate applicable to all other property, then such intangible property must be assessed under the general property tax. This is so because the 1924 proviso does not alter the universality requirement. Only the strictness of the uniformity limitation as it applies to property tax rates is affected. ${ }^{22}$

Since 1940 another amendment has changed the uniformity picture to some degree. By that amendment, Art. IX, $\$ 2$ now forbids the state taxation of any property other than intangible property. Thus, the state is limited to an intangible property tax which must only be uniform within classes, although all intangibles must be reached.

The court has ruled that Art. IX, §5, which governs local property taxes, imposes the same effective uniformity limitation that Art. IX, $\S 1$ imposed upon state taxation of prop-

${ }^{21}$ At the present time intangible personal property is to be assessed at its full cash value. Cash, bank deposits, and the like, are taxed at $1 / 20$ of one mill. Obligations for the payment of money are taxed at two mills. This is not a recurring tax. All other intangible personal property is taxed at one mill. Fla. Rev. Stat. $\$ 199.11$ (1941).

22 Porter v. First Nat. Bank, supra note 18, rehearing den. 96 Fla. 740. The court stated that the amendment obviously operates as an exception to the organic general rule of uniformity and equality in the rate of taxation. However, the amendment is neither self-executing nor mandatory, but merely confers upon the legislature permissive authority to provide for special rate of taxation for intangible property. "Therefore, until the Legislature does duly provide for special tax rate or rates on intangible property, the organic general rule of uniformity and equality in the rate of taxation of all property, real and personal, including intangible property, remains in force." 
erty. ${ }^{23}$ The only extent to which this requirement is altered by the 1924 amendment is that intangibles will now be exempt from local taxation if subject to a special state rate.

In summary, the present situation in Florida is this: The state property tax is limited to intangible property, all of which must be taxed, no exemptions being allowed. However, classification of such property is allowed for the purpose of applying different rates. The local general property tax is still governed by the strictest of uniformity requirements, but that tax is now limited in scope to tangible property.

\section{Indiana}

\section{a. The provisions; historical note}

The uniformity structure of the Indiana Constitution of 1851 , now in force, is quite simple. Prior to 1932 the constitution contained but a single provision pertinent to the problem of uniformity in taxation. That was Art. X, $\S 1$, providing:

The General Assembly shall provide, by law, for a uniform and equal rate of assessment and taxation, and shall prescribe such regulations as shall secure a just valuation for taxation of all property, both real and personal, excepting such only for municipal, educational, literary, scientific, religious, or charitable purposes, as may be specially exempted by law.

In 1932 a new section, Art. X, $\S 8$, was added to the constitution. It provides for an income tax and reads:

The general assembly may levy and collect a tax upon income, from whatever source derived, at such rates, in such manner, and with such exemptions as may be prescribed by law.

${ }^{23}$ Merrell v. St. Petersburg, 64 Fla. 367, 60 So. 349 (1912). 
Indiana has had only one other constitution, that of 1816. In that constitution there was no provision expressly concerning uniformity in taxation.

\section{b. Meaning of the uniformity limitation}

As the Indiana court has stated: "It is well settled that Article 10, Section 1, which provides for uniform and equal rate of assessment and taxation, and forbids exempting property except for specific purposes, applies only to property taxes under a general levy."1 In imposing nonproperty taxes the legislature is governed only by the requirement that such taxes be uniform within classes. ${ }^{2}$ The objects of nonproperty taxes and exemptions therefrom need only be reasonable classes. ${ }^{3}$ Further classifications may be made for the applica-

1 Miles v. Dept. of Treasury, 209 Ind. 172, 177, 193 N.E. 855 (1935), (gross income tax) and cases there cited, as well as cases discussed in notes 3 through 5, infra. Also see the very important case, Lutz v. Arnold, 208 Ind. 480, 193 N.E. 840 (1935), concerning intangibles taxes, discussed infra.

2 See the cases in notes 3 through 5 , infra. The source of this limitation is Art. I, $\$ 23$ of the Indiana Constitution, an equivalent of the federal equal protection clause. The court has said: "The requirements of Section 23 of Article 1 of the Indiana Constitution are substantially the same as the requirements of the 14th Amendment of the Federal Constitution. . . ." Kelly v. Finney, 207 Ind. 557, 579, 194 N.E. 157 (1935). But see note 8, infra.

3 See, for example, Crittenberger v. State Savings \& Trust Co., 189 Ind. 411, 127 N.E. 552 (1920) (holding exemptions to charitics under the inheritance tax to be valid); Gafill v. Bracken, 195 Ind. 551, 145 N.E. 312 (1925) (object of gasoline tax a valid class, selection of use of gasoline for propelling vehicles on highways of the state); Kersey v. Terre Haute, 161 Ind. 471, 68 N.E. 1027 (1903) (the object of a municipal vehicle tax which excluded electric street cars and automobiles was upheld); Kelly v. Finney, supra note 2 (motor vehicles for hire tax of 1933, Ind. Laws 1933, c. 153, upholding the distinction made between trucks for hire and those not used for hire, selecting the former; and upholding the exemption of vehicles used in transportation of school children, those carrying the mail, etc.) ; Richmond Baking Co. v. Dept. of Treasury, 215 Ind. 110, 18 N.E. 2d 778 (1939) and Eavey Co. v. Dept. of Treasury, 216 Ind. 25 5, 24 
tion of different rates, ${ }^{4}$ and the court has approved the principle of graduated rates. ${ }^{5}$ However, the validity of the Indiana chain store $\operatorname{tax}^{6}$ was challenged in Midwestern Pe-

N.E. 2d 268 (1939) (motor vehicle weight tax, Ind. Laws 1937, c. 255, superseding the tax referred to in the Kelly case, again upholding the object and certain exemptions therefrom). See Henderson v. London \& Lancashire Ins. Co., 135 Ind. 23, 34 N.E. 565 (1893) for one of the few cases finding a classification arbitrary.

4 For example, Miles v. Dept. of Treasury, supra note 1 (finding that the segregation of income according to its source and the application of a different rate to the several classes was valid; the gross income tax, discussed separately, infra); Crittenberger v. State Savings \& Trust Co., supra note 3 (stating that classifications for different rates might be made under the inheritance tax according to the relationship to the deceased); Barber Grocery Co. v. Fleming, 229 Ind. 140, 96 N.E. 2d 108 (1915) (classification of vehicles according to carrying capacity, held reasonable; motor vehicle tax), followed in Eavey Co. v. Dept. of Treasury, supra note 3.

${ }^{5}$ For example, in Crittenberger v. State Savings \& Trust Co., supra note 3, the court, at 422-423, stated: "An inheritance tax law providing for an increased rate of taxation upon inheritances as the amount of the inheritances increased does not violate the constitutional provisions as to uniformity and equality." This was dictum, however, since the rate schedule was not in use. Also see Terre Haute v. Kersey, 159 Ind. 300, 64 N.E. 469 (1902); Baldwin v. State, 194 Ind. 303, 141 N.E. 343 (1924).

6 The tax was imposed by the Indiana Legislature in 1929. Ind. Laws 1929, c. 207; Ind. Stat. Ann. $\S \S 42.301-42.313$. Section 5 thereof provided that:

Every person, firm, corporation, association or co-partnership opening, establishing, operating or maintaining one or more stores or mercantile establishments, within this state, under the same general management, supervision or ownership, shall pay the license fees hereinafter prescribed for the privilege of opening, establishing, operating or maintaining such store or mercantile establishments.

The prescribed license fee was to be paid annually, and was graduated as follows: 1 st store, $\$ 3 ; 2 \mathrm{~d}$ to 5 th store, inclusive, $\$ 10$ each; 6th to 10 th store, $\$ 20$ each; 11 th to 20 th store, $\$ 30$ each; 21 st and succeeding stores, $\$ 150$ each. This tax was immediately challenged in a federal court as being a violation of the federal equal protection clause. In a leading chain store tax case the United States Supreme Court upheld the tax. State Board of Tax Commissioners of Indiana v. Jackson, 283 U.S. 527, 51 S. Ct. 540 (1931), discussed in Chapter IV, infra. 
troleum Corp. v. State Board of Tax Com'rs, ${ }^{7}$ and the court indicated that it had some difficulty in justifying the graduated rate schedule insofar as all lines of business were concerned. The issue was resolved by simply holding that the chain store tax law could be upheld as an exercise of the police power intended to prevent monopolies and combinations in restraint of trade, rather than as a strict revenue measure. ${ }^{8}$ One might question whether this evasive approach would be necessary today in order to uphold the tax..$^{9}$ One can easily conclude, as did the court at an earlier date, that in imposing nonproperty taxes the legislative power is "un-

${ }^{7} 206$ Ind. 688, 187 N.E. 882 (1934). Plaintiff first contended that "filling stations" were not "stores" within the meaning of the act, and that the tax was therefore not applicable to its business. The court rejected the plaintiff's argument on this issue of statutory construction and then considered the second contention that the tax was unconstitutional as a violation of the equal protection clause of the Indiana Constitution, Art. 1, §23.

8 The court, id. at 691-692, took note of the fact that the Jackson case, supra note 6 , was conclusive as to the federal equal protection clause, but pointed out that it was not controlling, though strongly persuasive authority, as to the meaning of the state equal protection clause. It was felt to be desirable that there should be no conflict between state and federal decisions upon the subject. The court further noted that the Supreme Court of the United States upheld the act as a revenue measure, being of the opinion that substantial and significant difference exists between the business and operation of chain stores and that of a single store, and that these differences were sufficient to sustain the legislative classification for revenue purposes. However, the Indiana court, at 694 , stated that:

It cannot be doubted that the differences in practices and advantages between the operation of a single and a chain of stores may vary with the lines of merchandise handled. That the question of the constitutionality of the act as a revenue measure prevents many difficulties is evidenced by the division of opinion among the learned Justices in the Jackson case.

And the court then, at 694-704, shifted to the proposition that the act could be upheld as a regulatory measure, and that "the graduation of license fees upward is justified, since the larger the chain the greater is the threatened damage."

${ }^{9}$ For example, the division among the United States Supreme Court Justices on this question is no longer in evidence. See Chapter IV, infra. 
trammeled, except that invidious discrimination will not be permitted."10

The judicial development of the meaning of the uniformity limitation in Indiana aptly demonstrates the importance of determining the nature of a given tax when property taxes are subject to a stricter uniformity limitation. The Indiana court has ruled that an inheritance tax is a nonproperty $\operatorname{tax}^{11}$ and in a more controversial area the same result was reached as to the Indiana gross income tax. ${ }^{12}$ But the most important decision on this problem dealt with the nature of the Indiana intangibles taxes.

\section{(1) Property taxation; intangibles taxes}

There has been no controversy or unusual development concerning some of the particular rules of uniformity limit-

${ }^{10}$ Gafill v. Bracken, supra note 3 at 559, and cases there cited. Of course, just when is a discrimination "invidious?" This is nothing more than saying in a different fashion that such discriminations must not be "arbitrary." The words are not much help; one must inevitably turn to the specific examples to determine what a particular court at a particular time considers "arbitrary." However, it would seem clear that a heavy burden is placed upon one attempting to show that a classification found in nonproperty tax is arbitrary. Certainly the presumption of validity is deeply entrenched here. As the court in a leading case has said:

As to classification, it may be said that the rule is that, while the state is not at liberty to resort to a classification that is palpably arbitrary, any classification is valid, provided it rests upon some ground of difference having a fair and substantial relation to the object of the legislation, so that all persons similarly circumstanced shall be treated alike. And it is generally admitted and conceded that absolute equality in taxation can never be attained and that that system is best which comes the nearest to it. All that is required to make valid any classification that the legislature may adopt is that it shall be based upon a rational ground--some difference that bears a just relation to the purpose to be served as limited by state and federal Constitutions. Lutz v. Arnold, supra note 1 at 498-499.

${ }^{11}$ Crittenberger v. State Savings Trust Co., supra note 3.

12 Miles v. Dept. of Treasury, supra note 1. That case is discussed separately, infra notes 52-62. 
ing property taxes. Thus, it is settled that there must be an absolute uniformity in effective rate, "co-extensive with the territory to which the tax applies."13 This means that the same ratio of valuation and same percentage rate must be applied to all property taxed by any one taxing authority of the state. ${ }^{14}$ However, it has also been settled by the court that this requirement of strict uniformity in effective rates does not apply to the method of ascertaining the value of the property that is to be taxed. Thus, property may be classified for the purpose of using different methods to value the different classes. ${ }^{15}$ The opinions in these latter cases reveal the diffi-

${ }^{13}$ Bright v. McCullough, 27 Ind. 223, 230 (1866), in which the court rejected the contention that if the uniformity clause of Art. $X, \S 1$ applied to local taxes, then such rates had to be the same in all counties and townships in the state. To the contrary, the provision was construed to mean:

... that the rate of assessment and taxation must be uniform and equal throughout the locality in which the tax is levied. If the levy is for state purposes, then the rate must be uniform and equal in all parts of the State; and if the levy be for county purposes, the rate must be uniform and equal throughout the county in which the levy is made; and so in townships, when the levy is for township or road purposes. . . . [The object of this provision was] to devise a system for the assessment and levy of taxes that would distribute these burdens, among those liable to them, upon principles of uniformity, equality, and justice. To this end the primary principle adopted is that taxes shall be assessed on the property liable thereto, according to its just value, and by a uniform and equal rate.

However, the tax with which the court was concerned in the Bright case was struck down for reasons stated in note 16 , infra.

${ }^{14}$ For example, Johnson v. Board of Park Com'rs of Ft. Wayne, 202 Ind. 282, 174 N.E. 91 (1930); Ehle v. State, 191 Ind. 502, 133 N.E. 748 (1922); Forrey v. Board of Com'rs of Madison County, 189 Ind. 257, 126 N.E. 673 (1920); Wright v. House, 199 Ind. 247, 121 N.E. 433 (1918). And see Cleveland \& St. L. Ry. Co. v. Backus, 133 Ind. 513, 33 N.E. 421 (1892).

${ }^{15}$ Cleveland \& St. L. Ry. Co. v. Backus, supra note 14, upholding the method by which railroad assets and miles of track were assessed centrally and then pro-rated among the several counties on the basis of mileage. As the court pointed out, at 535-536, the statute under consideration was 
culty faced when the goal is to ascertain the same ratio of value, e.g., the "true" value, of all property to be taxed. Goals such as absolute uniformity, "just valuation," and the like are always sought but seldom attained. Nevertheless, absolute uniformity in effective rate is required, and "theoretically" the requirement is adhered to by the tax laws. Also, it is certain that specific taxation of property is forbidden so that only an ad valorem property tax may be levied. ${ }^{16}$

valid since all property was to be assessed at its true cash value and the rates were the same within the respective taxing districts. As for the second part of the uniformity clause ("shall prescribe such regulations as shall secure a just valuation"), it was said that this left to the General Assembly the problem of prescribing the mode by which valuation of all property was to be ascertained, with a single limitation that it be a "just" valuation. The provision for the fixing of value of railroad property by a state board, while other property was assessed by local boards was, in fact, an attempt to provide for valuation by those best qualified, thus achieving a "just" valuation.

In Johnson v. Johnson, 173 Ind. 76, 89 N.E. 590 (1909) the court found the method of assessing banking property to be valid, saying (at $\mathrm{p}$. 92): "Perfect equality of assessment is practically impossible, nor does the Constitution require uniformity in the methods or rules of assessment or valuation, but it does require a just valuation of all property, so that the burdens may be distributed with uniformity. . . . It does require a rate that is uniform and equal." This case concerned the right of the taxpayer, an unincorporated private banking business, to deduct its deposits from all taxable property owned by it, except real estate, rather than to deduct the same only from its "credit proper." The statute was construed to permit the former, and held not to violate the uniformity clause even though individuals were permitted only to deduct indebtedness from "credits proper." It was said (at p. 90): "The spirit of the taxing laws is not the taxation of apparent values; disassociated from all else, nor the taxation of all property at its gross value, but by securing a just valuation upon principles of uniformity, equality and justice." The case well illustrates the difficulties faced when attempting to assess all the property, tangible and representative, once at its full value. For cther cases on this problem, see Clark v. Vandalia R. Co., 172 Ind. 409, 86 N.E. 851 (1909); Smith v. Stephens, 173 Ind. 564, 91 N.E. 167 (1910).

${ }^{16}$ Bright v. McCullough, supra note 13 , in which the court struck down a township tax of "one cent on each acre of taxable land ... for road purposes for the year 1863." It was admitted by township authorities 
There remains the very unusual development concerning the requirement-or lack of requirement-of universality. The court has quite explicitly stated the proposition that " $[t]$ he exemption of any property necessarily produces inequality, and confers rights on some which are not granted to others, and thereby increases the burdens which they must bear." ${ }^{17}$ Any direct attempts to exempt property other than the classes of property specially designated as exemptible by the constitution, and any methods of assessments judicially determined to be, in fact, "exemptions," have all been held by the court to be violations of the uniformity provision, Art. $\mathrm{X}, \S 1 .{ }^{18}$ However, the court has made an important distinction between the "selection" and the "exemption" of property. The former process, it has been held, is not limited by the uniformity requirement. The significance of this distinction is demonstrated by the judicial development concerning the intangibles taxes.

The first hint of this development occurred in 1898 in

that under Art. X, $\$ 1$ taxes levied exclusively for state purposes "must be ad valorem, and not specific; that they must be levied of a given per cent on the appraised value of the property subject to taxation, and not as a specific tax on designated articles of personal property or on real estate, at a fixed amount, without regard to value." However, it was contended that this rule did not prohibit specific local property taxes. Finding that all property taxation was governed by the limitation, the court struck down the tax since it was specific and therefore was neither upon a "just valuation" nor could the rates be uniform upon the property taxed. Also see Conter v. Commercial Bank, 209 Ind. 510, 199 N.E. 567 (1936); and Johnson v. Board of Park Com'rs of Ft. Wayne, supra note 14.

17 Johnson v. Johnson, supra note 15 at 93. However, the court sanctioned "deductions" when the purpose was to avoid double taxation by the taxation of both tangible property and representative property.

18 See Stark v. Kreyling, 207 Ind. 128, 188 N.E. 680 (1934); State ex rel. Lewis v. Smith, 158 Ind. 543, 63 N.E. 25 (1902); State ex rel. Morgan v. Working Men's Bldg., Loan Fund \& Savings Ass'n, 152 Ind. 278 (1899); State ex rel. Tieman v. Indianapolis, 69 Ind. 375, 35 Am. Rep. 223 (1879). 
State Board of Tax Com'rs v. Holliday. ${ }^{19}$ In that case, suit was brought to enjoin the listing and valuing of life insurance policies for the general property tax. The taxpayer alleged that the State Board of Tax Commissioners was attempting to cause all assessors in the state to assess and value for taxation all such policies. The cardinal question to be decided was said to be whether life insurance policies were legally subject to taxation in Indiana. Such property had in fact never been taxed theretofore. Nor was there any statutory provision authorizing by name the taxation of life insurance policies. On the part of the state it was argued that the policies were "personal property" within the general section of the general property tax which required the taxation of "personal property," and that, indeed, Art. X, $\$ 1$, required the assessment of such policies as personal property.

There was no question on the part of anyone concerned that the legislature had the power to include such policies within the general class of personal property for purposes of taxation. The questions for decision were as follows: (1) whether the legislature had in fact done so; and (2) if it had not, whether it was constitutionally required to do so. On the first issue, that of statutory interpretation, the court decided that the legislature had not intended to include life insurance policies in the general category of "personal property." Thus, the actual "holding" of the case was that the action of the State Board in providing for the assessment of the policies was without authority of law, and void.

19150 Ind. 216,49 N.E. 14 (1897).

${ }^{20} \mathrm{Ibid}$. The explanation of the court's construction on this point was that such policies by their nature demanded special provisions for their valuation, and no such regulations or provisions had been made by the legislature. The court warned, however, that this interpretation of the general term "personal property," so as not to include insurance policies because of the absence of special provisions for valuation, must be strictly confined to the case before it. 
As for the constitutional requirement, the court had this to say:

It may be conceded that it was a duty devolved on the legislature by the constitutional provision ... to provide for the taxation of all property, both real and personal, except such only for municipal, educational, literary, scientific, religious, or charitable purposes as it might especially exempt by law. ... [However] the constitutional provision ... is not self-executing, but requires appropriate legislation to carry it into effect. ${ }^{21}$

Nevertheless, said the court, no provision had yet been made for the taxation of life insurance policies, and without such legislation they could not be taxed. "It is . . . a legislative power to select the subjects for taxation," and Art. X, $\S 1$ is a limitation upon the exercise of that inherent legislative power. Nevertheless, " $[\mathrm{w}]$ here the legislature has not exercised this power, no other department of the State government can supply the omission; and where no such regulation has been prescribed by law as to any particular species of property, then such property cannot be taxed." ${ }^{22}$

The preceding analysis was all that was actually necessary for the decision. However, the court went on to assume that the tax law was constitutional, even though it failed to

21 Id. at 228-229, emphasis added. It may be noted that the Holliday case was a 3-2 decision. The dissent asserted that the legislature had intended to select all property including insurance policies; and in any case, if there was doubt the act should be construed so as to include the policies because "under our constitution, . . . the legislature must do, what it has in fact done, that is, select as the subjects of taxation all property both real and personal, save that only which the constitution itself, for reasons of public policy, provides may be exempt." Id. at 241. Indeed, the dissent claimed, that "It is conceded that the constitution requires that all property within the jurisdiction of the State should be taxed. . . . It is further conceded that it was the solemn duty of the legislature to obey this mandate of the constitution, in respect to this as all other property." Id. at 259-260, emphasis added.

22 Id. at 220. 
provide for the assessment of a class of personal property not designated as exemptible by the constitution, and therefore failed to carry out the constitutional mandate in full. ${ }^{23}$ In order better to evaluate the selection-exemption dichotomy subsequently developed by the court, a doctrine based in part upon the Holliday case, it will be helpful to state as precisely as possible what the court in the Holliday case did not decide, as well as what it did decide.

The true import of the case seems to be as follows: The constitution (Art. $\mathrm{X}, \S 1$ ) does require the legislature to tax all property. However, if the legislature fails to provide legislation which reaches all property, no tax can be levied upon that property which is not within the terms of the legislation. Apparently, although this was dictum, such legislation which reaches less than all taxable property and which otherwise conforms to the uniformity limitation will stand as constitutional. But this does not suggest that the failure on the part of the legislature to select some taxable property was an exercise of de jure legislative power. To the contrary, the court clearly viewed such action as a violation of Art. $X$, $\$ 1$ - that is, no more than the exercise of de facto power. ${ }^{\mathbf{2 4}}$

\section{(a) Intangibles tax}

This, then, was the judicial development on the meaning of the uniformity limitation until 1933, at which time the Indiana General Assembly, by several companion acts, in fact segregated intangible property from all other property and provided a separate means for taxing such intangibles. Intangible property in general was dealt with by one act, ${ }^{25}$ section 2 of which provided that:

... every person residing in and/or domiciled in this state,

23 Id, at 229.

24 Compare the position of the dissent, note 21 , supra.

25 Ind. Laws 1933, c. 81; Ind. Stat. Ann. \$\$64-901-64-940. 
shall pay a tax to the State of Indiana at the rate and in the manner provided in this act, for the right to exercise any one or more of the following privileges:

(a) Signing, executing and issuing intangibles;

(b) Selling, assigning, transferring, renewing, removing, consigning, mailing, shipping, trading in and enforcing intangibles.

(c) Receiving the income, increase, issues and profits of intangibles.

(d) Having and possessing the right to transmit the same by will and of making gifts thereof and therefrom and of having the right to allow such property to pass to other persons by descent under the intestate laws of the state of Indiana.

(e) For the right to have such intangibles separately classified for taxes levied, assessed and collected on account thereof and/or measured thereby.

The rate imposed on intangibles in general was $25 \phi$ on each hundred dollars "of the actual value of" such intangibles.

A second act ${ }^{26}$ dealt with bank and trust company shares and deposits, and surplus and undivided profits of savings banks. The tax was described by section 2 as follows:

. . a all of the shares of the capital stock of every bank having a capital stock, and of every trust company, and the surplus and undivided profits of every savings bank, and all of the property of and all deposits in every bank and trust company, except as herein otherwise provided, shall be assessed for taxation and taxed in the manner and at the rate and value prescribed in this act and not otherwise.

The rate was the same as that applicable to intangibles in general. ${ }^{27}$

${ }^{26}$ Ind. Laws 1933, c. 83 ; Ind. Stat. Ann. $\$ \$ 64-801-64-821$.

${ }^{27}$ Section 4, providing for the rate, also contains language susceptible of being construed as indicating that the tax is upon the shares as such. It provides that such shares and deposits "shall be assessed to the respective owners of such shares of stock and to the respective owners of such deposits, 
A third act $^{28}$ dealt with the shares of building and loan associations. After stating in section 2 that "every association and its property shall be assessed and taxed in the manner and at the rate prescribed in this act, and not otherwise," it was provided in section 4 that:

In addition to the tax upon its real estate and tangible personal property [that is, under the general property tax], there shall be levied and imposed upon each such association for the privilege of exercising its franchise and transacting its business, an annual excise tax which shall be assessed and computed and paid at the time, in the manner and at the rate prescribed in this act.

The rate was again $25 \%$ on each hundred dollars of the value of shares and each hundred dollars of surplus, deducting from the capital stock and surplus the amount of the value of all tangible property subject to taxation.

The several acts also purported to relieve these intangibles from all other taxes except estate, inheritance, and gross income taxes. Thus, section 31 of the act, concerning intangibles in general, provides:

The tax hereby imposed shall be in lieu of all other taxes except estate and/or inheritance and gross income taxes, ... . imposed upon intangibles or against the owners or holders thereof by virtue of the provisions of any law of this state enacted prior to the passage of this act. No tax except gross income, inheritance and estate taxes shall be imposed upon any intangibles in account of which a tax is imposed by the provisions of this act by virtue of the provisions of any other law of this state enacted prior to the passage of this act. ${ }^{29}$

in the township, town or city wherein such bank or trust company is located, and such shares of stock and such deposits shall be taxed at the rate of" 25 per year upon each $\$ 100.00$ value.

28 Ind. Laws 1933 , c. 82 ; Ind. Stat. Ann. $\$ \$ 64-822-64-835$.

29 Ind. Laws 1933, c. $81, \S 31$. Section 16 of c. 83 , concerning the taxation of bank shares, is substantially the same as the quoted provision. Section 
In 1935, soon after their enactment, these companion acts were held to be constitutional in Lutz v. Arnold ${ }^{30}$ by a majority of three of the five judges. The majority ${ }^{31}$ decided that the tax was a nonproperty $\operatorname{tax}^{32}$ and therefore not subject to the uniformity limitation in Art. $\mathrm{X}, \S 1 .^{33}$ In addition, it

9 of c. 82 , concerning the taxation of shares of building and loan associations, provides:

The excise taxes imposed by the terms of this act shall be in lieu of all other taxes on mortgages, notes, contracts for sale of real estate, and the shares of capital stock and surplus of each such association, and no association and no owner of shares of capital stock therein shall be liable for any other tax on such shares of stock and surplus except estate and inheritance and gross income taxes.

\section{${ }^{30}$ Supra note 1.}

${ }^{31}$ Ibid. There was a majority opinion written by Judge Hughes, concurred in by one other judge. A separate concurring opinion was written by Chief Judge Treanor. There was a single dissenting opinion by Judge Roll, concurred in by one other judge.

${ }^{32} \mathrm{Id}$. at 500 . The court upheld the several acts as parts of a single integrated intangibles tax law, saying: "Chapters 81,82 , and 83 must be construed together as parts of one body of law and as together expressing the legislative will. These three chapters were enacted by the same legislature and approved on the same day." Several actions below, all secking declaratory judgments declaring the taxes unconstitutional and injunctions to prevent their enforcement, were consolidated for this opinion. The court began its opinion by saying that these three causes "relate to chapters 81,82 , and 83 of the Acts of 1933 , being the intangible tax law. . . . The greater part of all questions presented in the different causes are the same." However, throughout the opinion the judges refer solely to the chapter imposing the tax on intangible property in general.

${ }^{33}$ Id. The court held that the intangibles tax conformed to the uniformity required of nonproperty taxes, i.e., a uniformity within classes. The plaintiffs had contended that the classification in the act reaching intangibles in general was invalid because financial institutions were not reached. Dismissing this argument, the court pointed out that the three chapters must be read together so that the situation complained of was nonexistent. When it was pointed out that certain intangibles, such as judgments for the payment of compensation under the workmen's compensation laws, and like judgments as to alimony, were not included within the scope of the act, the court replied: "It was the evident purpose of the legislature in making 
was ruled that the in lieu provisions did not amount to "exemptions" of property but were simply illustrations of the power of "selection" vested in the legislature. Therefore those provisions were not violations of Art. X, $\S 1$, which prohibits the exemption of property. Each of these two propositions will be examined separately.

The tax under consideration aptly illustrates how very important it is to characterize a tax for the purpose of determining the applicable uniformity limitation. If the intangibles tax was to be upheld, then clearly it had to fall outside the scope of operation of the strict property-tax uniformity limitation in Art. $\mathrm{X}, \S 1$. The majority opinion started with the proposition that if the tax was "an excise tax it must [have been] so because the tax [was] imposed against the person because of privileges enjoyed and not against the property of the taxpayer." 34 And the majority pointed out that the clear intention of the legislature was to impose a nonproperty tax. While not conclusive, such legislative intent was nevertheless to be given some weight. As evidence of such intent on the part of the legislature the court referred to that act concerning intangibles in general, the language of which indicated that the tax was for the "right to exercise any one or more of" the enumerated privileges. ${ }^{35}$ The majority concluded that the tax was imposed upon the exer-

this classification to base it on grounds of sound public policy and classification on this ground is permitted." See note 10, supra, for the general statement found in this opinion concerning the power of the legislature to classify.

$34 I d$. at 489 . In stating the general nature of an excise, or nonproperty tax, the court said (at p. 489):

An excise tax has been defined to be a tax imposed upon the performance of an act, the engaging in an occupation, or the enjoyment of a privilege, and that every form of tax not imposed directly upon property must constitute an excise if it is a valid tax of any description.

85 See text to note 25 , supra. Also see note 32 , supra. 
cise of the enumerated acts. ${ }^{36}$ Some indication of the attitude of the majority on the immediate problem is found in its approval of the following statement:

In deciding upon the validity of a tax with reference to these [constitutional] requirements, no microscopic examination as to the purely economic or theoretical nature of the tax should be indulged in for the purpose of placing it in a category which would invalidate the tax. ${ }^{37}$

\section{In addition, the court referred to the history of the adoption}

${ }^{38}$ Lutz v. Arnold, supra note 1 at 491. The majority opinion framed its conclusion in these words:

The tax is not payable unless the privileges as set out are exercised and the exercising of the privileges is made the occasion for the tax. The tax imposed may be said to be an excise upon the particular privilege or privileges enumerated in doing certain things. There is a distinct difference between the mere ownership of property and the performance of certain acts of business. And the act in question, ... relates alone to the performance and doing of certain acts, and unless done there is no tax. The tax is therefore imposed upon the doing of the things described.

One might well view the assertion that "the tax is not payable unless the privileges as set out are exercised" is a bit misleading. This conclusion of the court is so only because of the broadest possible description of privileges which seem to describe just about every possible incident of ownership. The method of the payment of the tax on intangibles in general is interesting in this respect. Payment is made by attaching a stamp to the intangible. Ind. Laws 1933 , c. $81, \S \S 9,10$; Ind. Stat. Ann. $\S \S 64-909,64-910$. On all current intangibles the payment is made annually. Thus, one might pay a tax annually on the "exercising" of the privilege of "the right to have such intangibles separately classified for taxes levied, assessed and collected on account thereof and/or measured thereby." Somehow, this does appear to put a bit of a strain on the orthodox conception of "exercising a privilege." Perhaps this is some sort of a "bootstrap" privilege. The court also rejected the contention that the act in question taxed the right to exercise the incidents of ownership, and the right to devote the property to the only uses to which it was adapted, rather than taxing the exercise of any privilege. The court's answer to this was that the same could be said of other privilege taxes, such as, for example, the gasoline use tax. $I d$. at 494 .

${ }^{37}$ Id. at 493 . The court quoted this passage from Nicol v. Ames, 173 U.S. 509,19 S. Ct. 522 (1898). 
of the tax, which it asserted was a matter of common knowledge. This, of course, was a reference to the fact that intangibles were escaping from taxation, and the alleged need for a low rate tax on intangibles to encourage compliance with the tax. ${ }^{38}$

Having thus established the validity of the intangibles tax as a tax, there remained what the court considered to be the more difficult question. This concerned the validity of the "in lieu" provisions. Were they in effect "exemptions" of property from property taxation and therefore violations of Art. $\mathrm{X}, \S 1$ ? $^{39}$ The contention of the taxpayers, as restated in the majority opinion, was that the intangible property, which the legislature attempted to relieve from property taxation by use of the "in lieu" provisions, had theretofore been and was still covered by the Indiana general property tax law. Therefore, it was argued, the "in lieu" provisions were merely attempts to exempt such intangible property from the general property tax, and were therefore unconstitutional because the described intangible property was not within any class of property named in Art. X, $\S 1$ as being exemptible from the general property tax. ${ }^{40}$

This argument was rejected by the majority, which found that the "in lieu" provisions were constitutional. The reasons are more articulately stated in the concurring opinion by

${ }^{38}$ Id. at 506. Cf. Ind. CCH Tax Reporter (25-001.

${ }^{39}$ Id. It was upon this point that the dissent concentrated its fire. The dissent doubted whether the tax could be properly designated an excise tax, but did not belabor the issue since from the dissent's viewpoint the tax was invalid regardless of its nature. See notes 48,49 and 50 , infra. The concurring opinion by Judge Treanor also concerned itself with this problem of the in lieu provisions. He stated, id. at 512 , that at the time the decision was rendered he was in doubt as to the nature of the tax, "But after more mature consideration [he was] convinced that they [were] excise taxes." Judge Treanor voted with the majority at the time of decision, but delayed filing an opinion.

40 1d. at 502. 
Treanor, C. J., than in the majority opinion..$^{41}$ It was asserted that the taxpayers' contention that the several "in lieu" provisions violated Art. X, $\S 1$, of the Indiana Constitution posed the problem:

... whether the inhibition against tax exemptions encompasses and destroys the sovereign power of the General Assembly to select and classify the subjects of taxation.

It is elementary that the General Assembly's power to select subjects of taxation is unlimited, except insofar as such power is restricted by some provision of the Constitution; and Art. X contains no provision which expressly requires the General Assembly to select all classes of real and personal property of the state as subjects of taxation. ${ }^{42}$

Having thus framed the issue, Judge Treanor asserted that the taxpayers' conclusion that Art. X of the constitution requires the General Assembly to subject "all real and personal property to a property tax" could be reached only by drawing such an inference from those limitations in Art. X, $\S 1$, concerning uniformity of taxation and the permissible exemption of certain classes of property.

The majority decided that such an inference could not be justifiably drawn and that the Indiana Constitution contains no universality limitation, at least, insofar as the process of "selection" is concerned. Both the majority and concurring opinions relied to some degree on the Holliday case. According to Judge Treanor, in the Holliday case the court held that the legislature did not intend to make life insurance policies subjects of taxation and that this was a valid exercise of the plenary power of selection resting in the

${ }^{41} \mathrm{Id}$. The discussion of the majority on this question is at 502-507. The same thesis was used as that which is found in the opinion by Judge Treanor, but it is stated much less convincingly.

42 Id. at 513 . Judge Treanor did point out that the court had recognized the definitely restrictive force of the prohibition against exemptions in Art. $\mathrm{X}, \S 1$, citing Stark v. Kreyling, supra note 18 . See cases there cited. 
legislature. Certainly the first part of that proposition was "held" in the Holliday case but, as pointed out above, the Holliday case characterized the failure to select such policies as a violation of Art. X, $\S 1$. Nevertheless, accepting Judge Treanor's proposition, the taxpayer-plaintiffs in the Lutz case made the distinction that the Holliday rule was not applicable because insurance policies had never been selected as subjects of taxation, while intangible property generally was formerly taxed and would now be relieved of such taxation by the provisions in controversy. Judge Treanor answered:

If the foregoing distinctions have legal significance it is because (1) the General Assembly has no power to withdraw from the subjects of taxation any class of property which has once been subject to taxation; and (2) any such withdrawal constitutes an exemption. ${ }^{43}$

Dealing first with the issue whether "withdrawal constitutes an exemption," Judge Treanor relied on the brief supporting the validity of the "in lieu" provisions to make the following distinction between "exemption" and "selection."

An exemption takes property which is in the taxable class and removes it from taxation upon some designated ground of ownership or use. . . Exemption as permitted by section 1 of article 10 of the Constitution is a discrimination within a taxable class on the basis of municipal, educational, literary, scientific, religious or charitable purpose. Selection, on the contrary, is the determination of the taxable class, and unless impressed with such arbitrary methods of classification as violate the equal privileges and immunities provision of the Constitution, it is valid. ${ }^{44}$

43 Id. at 515 .

44 Id. at 516. To demonstrate this distinction the opinion pointed out that an educational institution may own real estate, tangible personal property, and intangible personal property for the purposes of education. Assume that the legislature selects all of these classes of property for taxation. They are thereby taxable unless exempted, which the legislature may do pursuant 
Thus, he reasoned, the exemptions contemplated in section 1 are exemptions of property on the basis of use alone, and not on the basis of the nature or character of the property. In the opinion of Judge Treanor, section 1 presupposes that the particular items of property which are exempted belong to a class of property which has been subjected to taxation by the General Assembly in an exercise of its power to select the objects of taxation.

Treating the question of the power of the legislature to "withdraw" as one aspect of its power to "select,"45 Judge Treanor concluded that the General Assembly had the power to withdraw intangibles from the general class of taxable property because the limiting provisions of Art. X, $\S 1$, left unimpaired the plenary, inherent legislative power to select the objects of taxation. ${ }^{46}$ This, then, is the meaning of Art. X, $\S 1$ : the restrictive provisions therein are directed

to Art. X, $\S 1$. However, having selected all classes for taxation, the legislature cannot exempt a manufacturing establishment which possesses all three classes. On the other hand, the legislature may withdraw intangible personal property from taxation, and as a result thereof both the educational institution and the manufacturing establishment will be relieved from paying taxes on such tangible personal property, but not on the principle of exemption, rather because the same is not in the taxable class.

45 Id., the opinion stated the issue as follows (at p. 517):

Consequently, we come back to the question of the power of the General Assembly to classify property for the purpose of selecting subjects for taxation. And more particularly, to the question of whether the provisions of $\S 1$, Art. $X$, deprive the General Assembly of the power to reclassify personal property into tangibles and intangibles for the purpose of withdrawing intangibles from the classes of property subject to a property tax.

${ }^{46}$ Id. at 517 . Judge Treanor admitted that the actual holding of the court on the facts in the Holliday case was not determinative of the question of power to "withdraw." However, he asserted that the "principles announced and the reasoning therefrom appear to support the conclusion that the General Assembly had the power to withdraw intangibles from the general class of property taxables." But for actual import of the Holliday case, see supra, text at notes 19-24. 
to the mechanics of the taxing system and are not restrictions on the substantive power to select the subjects for taxation.

The requirement that the General Assembly "shall provide, by law, for a uniform and equal rate of assessment and taxation" cannot be the source of an implied restriction of the legislative power to select subjects of taxation; and the clause "prescribe such regulations as shall secure a just valuation of all property, both real and personal," cannot be said reasonably to constitute a constitutional mandate to the General Assembly to select all property, both real and personal, as subjects of taxation. It seems more reasonable to assume that it is a mandate to prescribe regulations to secure a just valuation for taxation of all property which is subject to taxation. And since $\S 1$, Art. $\mathrm{X}$ does not purport to select subjects for taxation it follows that the power of the General Assembly in that respect is full, unimpaired and continuing. ${ }^{47}$

The $L u t z$ case was not unanimous; two of the five judges recorded a vigorous dissent. ${ }^{48}$ The dissent was essentially based on two premises. First, the dissent seriously doubted whether the intangibles taxes could be designated nonprop-

47 Id. at 518-519, emphasis added. An interesting bit of dictum by Judge Treanor was added at this point. In his view of the constitutional limitation, the tax would be valid even if it were characterized as a property tax. The basis of this conclusion was that the word "rate," as used in Art. $\mathrm{X}, \S 1$, was intended to mean-and reasonably construed must mean"mode" or "rule" or "method," and not the percentage rate of tax; and, further, that the "equal and uniform rate" restriction does not prevent classification for the purpose of imposing different percentage rates. $\mathrm{He}$ would rule that intangibles could be treated as a separate class of personal property for the purpose of imposing a lower rate per centum than is imposed upon other personal property. This interpretation was, of course, not shared by the other justices. If this had been his reason for finding the tax valid, he would have stood alone. Also there might have been some basis for the rash conclusion in the Comment, "Indiana's Intangible Tax Law," 10 Ind. L.J. 450, 455 (1935).

48 Id. at $520-526$. 
erty taxes. If considered property taxes, then clearly there was violation of the uniformity clause, Art. $X, \S 1$, which requires absolute uniformity of rates, ${ }^{49}$ because the intangibles tax rates would vary from the rate applicable to property taxed under the general property tax.

Second, even assuming that the tax was a nonproperty tax, the dissent argued that the "in lieu" provisions amounted to exemptions of property in violation of Art. X, $\S 1$. The distinction made by the majority between "selection" and "exemption" was rejected with the observation that such an analysis "would have the effect of making the constitutional provision absolutely nugatory, and permitting the legislature to except from taxation not only property for the purposes set out in the Constitution but any other class of property which the legislature itself might deem it wise or expedient to exempt." ${ }^{.50}$ The dissent further reasoned that it was obvious from the words of the statute that the legislature did not intend to add the tax in question to the general property tax on intangibles, and therefore the "in lieu" provisions alone could not be struck down as severable, but the whole act had to fall.

$49 \mathrm{Id}$. at 523 . In support of this proposition citing Johnson v. Johnson, supra note 15. See notes 13,14 and 15 supra. Compare Judge Treanor's view on this, note 47 , supra.

${ }^{50} I d$. at 521-522. The dissent also rejected the majority interpretation of the Holliday case. They viewed that case in this manner:

. . . it was held in that case that, while the legislature might not expressly excmpt life insurance policies from taxation, since they are property, the failure of the legislature to provide machinery for levying and collecting a tax, had the practical effect of leaving them unburdened by a property tax.

Id. at 521 , emphasis added. In any case, the dissent here would not extend the rule laid down by the Holliday majority so as to permit the legislature to exempt any class of property which it might choose to exempt merely by repealing the law which provides machinery for levying an assessment upon such property. 


\section{(b) Summary: property taxation}

To summarize, the Indiana uniformity structure which limits property taxation is interpreted to require the strictest degree of uniformity for the purpose of effective rates and method. But, although exemptions of property are prohibited, this restriction is avoided to some degree by the interpretation that the power to "select" property for taxation is left unimpaired by the strict uniformity requirement. Thus, strictly speaking, a full requirement of "universality" is not found in Indiana. Furthermore, it is apparent that this doctrine concerning the power of "selection" developed from a rather questionable use of precedent, although the Lutz case does not purport to rest entirely on the earlier Holliday case.

Nevertheless, by holding first that the intangibles tax was a nonproperty tax, and then by holding that the power to select property for property taxation was not limited by the strict uniformity requirement, the Indiana court has in effect given constitutional sanction to a limited classified property-tax system in Indiana. ${ }^{51}$ This result demonstrates the crucial importance of determining the nature of a given tax, and of the need for precise analysis of the particular rules of the uniformity limitation. Whether or not this result was reached by the use of overly refined distinctions, it demonstrates that the strictness of the property-tax uniformity limitation has been avoided by some states when necessity seemed to demand in the tax structure a flexibility which the constitution would at first blush prohibit.

51 On this general problem, compare the Indiana tonnage tax which is "in lieu" of all other taxes, and the forest reserve tax which ensures a lower effective rate for forest lands by the placing of an arbitrary valuation of $\$ 1.00$ per acre on approved forest lands. Neither tax has been challenged as to its constitutionality. Tonnage tax: Ind. Stat. Ann. $\$ \S 64-741-64-748$; Forest tax: Ind. Stat. Ann. $\$ \S 32-301-32-319$, and 32-401-32-406. 


\section{(2) Income tax}

In 1933, the Indiana legislature enacted the Gross Income Tax Act, ${ }^{52}$ section 2 of which provided:

There is hereby imposed a tax, measured by the amount or volume of gross income, and in the amount to be determined by the application of rates on such gross income as hereinafter provided. Such tax shall be levied upon the entire gross income of all residents of the state of Indiana, and upon the gross income [derived within the state by nonresidents]. ... .53

Section 3 of the act divided gross income into two broad classes according to its source for the purpose of applying different rates to each class. ${ }^{54}$ Provision was also made for certain deductions and exemptions.

Shortly after its enactment, the act was challenged and upheld in Miles v. Department of Treasury. ${ }^{55}$ The first problem concerned the nature of the tax, since it was challenged as a violation of the property-tax uniformity limitation, Art. X, $\S 1$, in that the rates were not absolutely uniform. After a lengthy review of the split of opinion among other state courts on this issue, the court held that this tax was a nonproperty tax, saying:

. . . the tax in question is an excise, levied upon those domi-

52 Ind. Laws 1933 , c. 50 ; Ind. Stat. Ann. $\$ \$ 64-2601$ et seq.

53 Note the following changes in phrascology made by a 1937 amendment: "There is hereby imposed a tax upon the receipt of gross income. -. Such tax shall be levied upon the receipt of the entire gross income. - . Ind. Stat. Ann. \$64-2602. The italics indicate the added words.

54 The first class consisted of income from manufacturing, mining, producing oil or timber, agriculture, wholesaling, and jobbing of tangible commodities. The rate applied to the class of income was $1 / 4$ of $1 \%$. The second class of income consisted of income from all other sources, and the rate applied to this class was $1 \%$.

55 Supra note 1. Plaintiff brought an action to enjoin payment of public funds for the costs of printing and publication of the act on the grounds that the act was unconstitutional. 
ciled within the state or who derive income from sources within the state, upon the basis of the privilege of domicile or the privilege of transacting business within the state, and ... the burden [of the tax] may reasonably be measured by the amount of income. ${ }^{56}$

In reaching this conclusion the court approved the use of income as a base as an equitable means of spreading the burdens of government among those most able to pay. ${ }^{57}$ Also of interest was the court's rejection of the argument that a tax upon income is a tax upon property if the income is derived from property. ${ }^{58}$ Having determined that the tax was not a property tax, and therefore not subject to the stricter uniformity limitation, the court disposed of the second problem, the validity of the classifications embodied in the tax. Both the classification of income according to its sources for the purpose of rates and the various exemptions in the tax were found to be reasonable. ${ }^{59}$

However, one should be quite cautious in using this case for comparative purposes. The features of the Indiana tax set it apart from other state taxes characterized as income

$$
\begin{aligned}
& { }^{56} I d \text {. at } 177-188 \text {. See Chap. V, infra. } \\
& { }^{57} I d \text {. at } 187 \text {, saying: }
\end{aligned}
$$

It is universally recognized that the burdens of government cannot be distributed with exact justice upon all persons and property. It is also recognized that to distribute the burden of government per capita would work an injustice upon those who are least able to pay and least able to cope with social and economic problems, in favor of those better equipped to meet social and economic problems, and who, because of their more complex activities, receive more protection from and put more burden upon the instrumentalities of government. To distribute the burden with exact justice is impossible. The legislature has chosen to measure the share of each by his gross income. It cannot be said that that method is unreasonable.

Of course, this argument is the one usually used to justify progressive rates under an income tax. However, the Indiana tax had only proportional rates.

${ }^{58}$ ld. at 185.

59 Id. at 189-192. 
taxes. The Indiana tax is more in the nature of what is usually called a "gross receipts" tax. However, it can be distinguished from the usual gross-receipts tax in that it applies to all persons, whether in business or not, and includes all forms of earned and unearned income. ${ }^{60}$ The court in the Miles case recognized that a distinction might be drawn between this tax and the ordinary income tax-although belittling such a distinction-when it said:

While there may be a "theoretical distinction" or a "very slight" difference between a net income tax and an excise measured by income, it is difficult to find any practical distinction to be made between a gross income tax and an ordinary excise tax. It is a tax "on the recipient of the income, the tax being upon the right or ability to produce, create, receive, and enjoy, and not upon specific property."

Finally, an amendment to the Indiana Constitution now provides that a tax on income may be imposed in Indiana, thus removing any doubt as to the validity of such a tax. ${ }^{62}$ Thus, further refinements of the Miles case are unnecessary.

${ }^{60} \mathrm{Cf}$. $\mathrm{CCH}$ Ind. Tax Reporter $\llbracket 10-001$, quoting from the foreword to the 1946 Regulations to the tax.

${ }^{61}$ Miles v. Department of Treasury, supra note 1 at 184, emphasis added.

${ }^{62}$ In 1932 Art. X, $\S 8$ was added to the Indiana Constitution by amendment. It reads:

The general assembly may levy and collect a tax upon income, from whatever source derived, at such rates, in such manner, and with such exemptions as may be prescribed by law.

This amendment was not referred to in the Miles case, discussed in the text, even though in a case decided shortly before the Miles case in the same year the Supreme Court of Indiana had ruled regarding the necessary votes for an amendment to the constitution so that it would seem that the new Art. X, $\S 8$ was validly a part of the constitution. See In re Todd, 208 Ind. 168, 193 N.E. 865 (1935). Before that case it appears that the court had held that the constitution required a majority of votes of the voters voting at the election when an amendment was submitted to approve the proposed amendment before it could be valid. Thus, a simple majority voting for the amendment did not necessarily ensure its adoption. In the Todd case the 


\section{Kansas}

\section{a. The provisions; historical note}

The uniformity structure of the Kansas Constitution of 1859 is relatively simple. Article XI, $\S 1$ contains the basic uniformity clause and originally read:

The legislature shall provide for a uniform and equal rate of assessment and taxation; but all property used exclusively for state, county, municipal, literary, educational, scientific, religious, benevolent and charitable purposes, and personal property to the amount of at least two hundred dollars for each family, shall be exempted from taxation.

This basic uniformity clause and the accompanying "mandatory" exemption clause were supplemented by the original Art. XI, §2, which expressly required that banking property bear its just share of the tax burden. ${ }^{1}$

However, in 1924 a significant change was made in the uniformity structure by the addition to Art. XI, $\S 1$, of a clause providing for special treatment for "intangibles" and the resultant repeal of the original Art. XI, §2. Thus, since 1924 Art. XI, $\$ 1$ has read:

The legislature shall provide for a uniform and equal court reversed itself and held that a majority voting thereon was sufficient. Since the amendment proposing Art. $\mathrm{X}, \S 8$ received a majority of those voting thercon, but not a majority thereat, there was some doubt before the ruling in the Todd case as to whether Section 8 of Art. X was validly adopted. See Comment, "In re Todd and Constitutional Amendment," 10 Ind. L.J. 510 (1935).

1 That provision read:

The legislature shall provide for taxing the notes and bills discounted or purchased, moneys loaned, and other property, effects, or dues of every description, (without deduction) of all banks now existing, or hereafter to be created, and of all bankers; so that all property employed in banking shall always bear a burden of taxation equal to that imposed upon the property of individuals. 
rate of assessment and taxation, except that mineral products, money, mortgages, notes and other evidence of debt may be classified and taxed uniformly as to class as the legislature shall provide. ...

The exemption clause of the original Art. XI, $\$ 1$ remains unchanged, except that it is now a separate sentence.

The only other pertinent constitutional provisions are those dealing with special problems, all added since the basic change in 1924. For example, Art. XI, $\S 2$, added in 1932, expressly authorizes an income tax. ${ }^{2}$

\section{b. Meaning of the uniformity limitation}

As in a great many other states, the distinction between property and nonproperty taxes is of utmost importance for the purposes of the uniformity limitation. The uniformity clause found in Art. XI, $\$ 1$ does not limit nonproperty taxes, which are only required to be uniform within classes. ${ }^{3}$ Thus, the objects of nonproperty taxes need only be reasonable classes, ${ }^{4}$ and such objects may be further classified for the purpose of applying different rates to the subclasses. ${ }^{5}$ In

2 Article XI, §2 reads:

The state shall have power to levy and collect taxes on income from whatever source derived, which taxes may be graduated and progressive. Another provision, added to the constitution by amendment in 1928 is Art. XI, $\$ 10$ which reads:

The state shall have power to levy special taxes, for road and highway purposes, on motor vehicles and on motor fuels.

${ }^{3}$ A leading case is State ex rel. Arn v. Cline, $91 \mathrm{Kan}, 416,137 \mathrm{Pac} .932$ (1914), upholding an inheritance tax. See the cases in notes 4 through 6, infra.

${ }^{4}$ State ex rel. Arn v. Cline, supra note 3 (inheritance tax; exemptions therefrom reasonable classes); State ex rel. Arn v. State Comm. of Revenue \& Taxation, 163 Kan. 240, 181 P. 2d 532 (1947) (fuel tax, exemptions therefrom found reasonable). Also see State v. Wilson, $101 \mathrm{Kan} .789,168$ Pac. 679 (1917) (local trading stamp license tax, exemptions, upheld as valid classifications).

${ }^{5}$ See the cases in note 6 , infra. 
a leading case the court held that progressively graduated rates did not violate the uniformity within classes requirement. $^{6}$

The importance of characterizing a given tax as either property or nonproperty is best illustrated in Kansas by the decision that the mortgage recording tax of 1915 was a property tax and therefore unconstitutional because it violated the stricter property-tax uniformity limitation, ${ }^{7}$ whereas had the tax been held to be an "excise" or "nonproperty" tax it would have withstood the attack. Also of interest for comparative purposes is the decision of the Kansas court that an inheritance tax was a nonproperty tax..$^{8}$ The constitutional amendment of 1932, expressly authorizing the imposition of an income tax, rendered moot any controversy concerning the nature of an income tax for purposes of the Kansas uniformity limitation. ${ }^{9}$

${ }^{6}$ State ex rel. Arn v. Cline, supra note 3 . Also see the following cases in which local privilege taxes upon merchants were held to be excise taxes, and the rates reasonable classifications. The rates were graduated according to the average amount of stock, with the rate being a flat amount increasing within brackets of increasing amounts of stock. In re Martin, 62 Kan. 638, 64 Pac. 43 (1901); Newton v. Atchison, 31 Kan. 151, 1 Pac. 288 (1883).

7 Wheeler v. Weightman, $96 \mathrm{Kan}$. 50, 149 Pac. 977 (1915), discussed under Property Taxation, infra, text at notes 14-17, 25-29.

${ }^{8}$ State ex rel. Arn v. Cline, supra note 3. In State ex rel. Arn v. State Comm., supra note 4, the court held that Art. XI, $\$ 10$, added in 1928 (see note 2 , supra), was nothing more than a recognition of the legislative power existing before the section was adopted, and that probably its only purpose was to make that power express because of several challenges of such taxes. The classifications under the fuel tax were upheld, and the tax itself was held to be an excise tax. See the earlier case, State ex rel. Beck v. Board of Com'rs of Barton County, 142 Kan. 624, 51 P. 2d 33 (1935). Also, in City of Chanute v. State Comm. of Revenue \& Taxation, 156 Kan. 538, 134 P. $2 \mathrm{~d} 672$ (1943), the court held that the state sales tax was a nonproperty tax and, therefore, not limited by the provision of Art. XI, $\$ 1$ which requires the exemption of municipal property.

- But see Hartman v. State Comm. of Revenue \& Taxation, 164 Kan. 67, 


\section{(1) Property taxation: generally}

The 1924 amendment of Art. XI, §1, which incorporated an exception, changed in only a limited way the content of the basic uniformity clause. Therefore, the meaning of the basic uniformity clause as it developed before 1924 will be described first. The special treatment provided for in the 1924 amendment will then be analyzed to determine its effect on the general effective uniformity limitation.

Except for an anomaly in 1949, the Kansas court has unfailingly paid lip service to the formal rules derived from the property-tax uniformity limitation, although several cases have resulted in the "bending," if not the "breaking" of those rules. The court has held that Art. XI, §1 does not contain a rule of universality, saying:

While the constitution provides that certain property shall be exempt from taxation, it does not declare that other exemptions may not be made, but does provide that property subject to taxation shall be taxed at a uniform and equal rate. So it has been held that the enumerated exemptions must be made, but that more exemptions may be made by the legislature. ${ }^{10}$

187 P. 2 d 939 (1947), in which the court indicated that its past decisions might stand for the proposition that an income tax is not a property tax. However, in light of Art. Xl, $\$ 2$, a decision on the matter was not necessary.

${ }^{10}$ Gunkle v. Killingsworth, $118 \mathrm{Kan} .154,156,233 \mathrm{Pac} .803$ (1925), emphasis added, upholding the exemption of rural-credit shares of building and loan associations from the general property tax. Also see: City of Harper v. Fink, 148 Kan. 278, 80 P. 2d 1080 (1938); Ritchie v. Ahlstedt, 105 Kan. 739, 186 Pac. 131 (1919); State ex rel. Fatzer v. Board of Regents, 167 Kan. 587, 207 P. 2d 373 (1949); Sumner County v. Wellington, 66 Kan. 590, 72 Pac. 216 (1903). In the following cases exemptions were found to be violations of the uniformity provisions: Alpha Tau Omega v. Board of Com'rs of Douglas County, 136 Kan. 675, 18 P. 2d 573 (1933); Graham v. Chautauqua County, 31 Kan. 473, 2 Pac. 549 (1884); Hamilton v. Wilson, 61 Kan. 511, 59 Pac. 1069 (1900); Marion \& M. Ry. Co. v. Champlin, 37 Kan. 682, 16 Pac. 222 (1887). 
However, exemption of property other than that characterized as exemptible in Art. XI, §1 must not only meet a test of reasonable classification, but such exemptions must also be "in the public interest." The court has explained this in the following manner:

The imposition of taxes upon selected classes of property to the exclusion of others, and the exemption of selected classes to the exclusion of others, constitute invidious discriminations which destroy uniformity.

The exemption provision of the constitution is a qualification of the rule of uniformity and equality. . . .

... [E]xemptions must rest on the definite basis of promoting the public welfare in some peculiar and substantial way, and even they cannot be tolerated to the extent of building up large accumulations of favored property which would disturb general equality and uniformity. ${ }^{11}$

It may be noted that this dual test of reasonable classification plus "public interest" has in fact limited the Kansas legislature to the exemption of very little property other than that specifically enumerated in Art. XI, $\S 1 .^{12}$

A stricter rule governs the effective rates of property taxes. An absolute uniformity, whether in ratio of valuation or percentage rate, is required of the rate levied by any tax-

11 Wheeler v. Weightman, supra note 7 at 58, 59, 68 .

12 For example, a number of cases upholding exemptions concerned property which might well have been within the enumerated classes of exemptible property in Art. XI, $\$ 1$ except for a controversy over the meaning of the words "exclusively used for." As to municipal water works, see City of Harper v. Fink and Sumner County v. Wellington, supra note 10. But see the Gunkle case, supra note 10. 


\section{ing unit. ${ }^{13}$ Thus, in Wheeler v. Weightman, ${ }^{14}$ the 1915} mortgage recording tax was held to be a property tax and a violation of Art. XI, $\S 1$, one of the reasons being that the rate was not uniform as compared with the rate applied to all other property taxed by the state. Moreover, in that case the court found that the tax also violated the requirement that taxation of property must be by the ad valorem method. ${ }^{15}$

13 As to ratio of valuation, see Chicago B. \& Q. R. Co. v. Atchison County, 54 Kan. 781, 39 Pac. 1039 (1895). Railroad property had been assessed at $100 \%$ of full value, while the rest of the property in the county was assessed at only $25 \%$ of full value. The court held that this violated the uniformity clause, Art. XI, $\S 1$, and that the railroad was entitled to an injunction as to the illegal excess. As to percentage rate, see: Atchison T. \& S. F. Ry. Co. v. Howe, 32 Kan. 737, 5 Pac. 397 (1884); Midland Elevator Co. v. Stewart, 50 Kan. 378, 32 Pac. 33 (1893); In re Page, 60 Kan. 842, 58 Pac. 478 (1899). The court has ruled that a different method of valuation for different classes of property is not forbidden. First Nat. Bank v. Geary, 102 Kan. 334, 170 Pac. 33 (1918). Nor is the taxation of stock in a foreign corporation "double taxation" even though the corporation had considerable property located in the state which was subject to the general property tax. Hunt v. Allen, 82 Kan. 824, 109 Pac. 106 (1910).

$1496 \mathrm{Kan} .50,149$ Pac. 977 (1915). See note 16, infra.

${ }^{15} \mathrm{Id}$. at 77-78. Also see In re Page, supra note 13; State v. Cumiskey, 97 Kan. 343, 155 Pac. 47 (1916). One of the early and leading cases is Hines v. Leavenworth, 3 Kan. 186 (1864), in which the court held that certain assessments on realty were "special assessments" and therefore not within the scope of the uniformity limitation. Nevertheless, in an often quoted passage, the court interpreted the uniformity clause in these words (at p. 200):

It will be observed that the constitution does not in terms require that the property in the State should be taxed according to its value, but it must be apparent to every one that such was the intention of the constitution makers. Taxes cannot be levied by an equal and uniform rate except upon the value. If so much were levied upon each acre, lot, horse, cow, sheep, note, bond, etc., the rate might be uniform, but it would be very unequal. [Emphasis added.]

Apart from the general principle, one may well question whether the characterization made in the Wheeler case, and discussed in the text, would stand today. The court was there concerned with the fact that the tax rate was to be applied to the value of the obligation secured, and it ruled that 
In the Wheeler case the Kansas court made one of its strongest statements in support of the strict rules of uniformity derived from Art. XI, $\S 1$, of the constitution, ${ }^{16}$ even though the court conceded that such might well be the reason for an ineffective tax structure. ${ }^{17}$ The court could only apply the constitution, no matter what the consequences. However, the court has, at least on three other occasions, been faced with the problem of applying the constitution, no matter what the consequences. Those decisions are difficult, if not impossible, to reconcile with the rules of uniformity as developed above. A pair of cases arose in 1877, Francis v. Atchison T. E S.F.R. Co. ${ }^{18}$ and Ottawa v. Nelson. ${ }^{19}$

The Francis case concerned the validity of an act providing for the collection of the state general property tax rate on railroad property located in the unorganized counties of

there was an absence of the necessary valuation by taxing officials. However, after the intangibles amendment, discussed infra, which relieved intangibles from the uniformity-in-rate requirement but not from the ad valorem requirement, a similar tax was upheld in Citizens' Bank v. Tax Comm. of Kansas, 132 Kan. 5, 294 Pac. 940 (1931), and no question was raised as to the method of taxation. See text to note 53 , infra.

16 By Chapter 250 of the Laws of 1915 the legislature provided that before any rcal estate mortgage could be recorded there had to be paid a "registration fee" of fifteen cents on each one hundred dollars of the principal debt or obligation secured by such mortgage. The payment of the fee exempted the mortgages from all other taxes, and the failure to pay the fee meant that the mortgage could not be enforced. The court held that the rate and method used violated the uniformity clause, the tax being characterized as a property tax. The court also carefully scrutinized the in lieu feature, but did not pass upon it since it held that the tax was a property tax. Had the tax been held to be an excise tax, the court indicated that it had serious doubt as to the validity of the exemption proviso, suggesting that no public interest would be served. Id. at 68-69.

17 See the text at note 27 , infra.

1819 Kan. 303 (1877).

1919 Kan. 234 (1877). 
the state. The taxpayer (a railroad having property in such counties) challenged the validity of the tax. It was admitted that the machinery for all ordinary assessments was in the county organization, and consequently in unorganized counties the machinery was wanting and all property therein escaped taxation. This inadequacy was remedied only as to railroad property. State assessment was provided for such property. The taxpayer contended that this arrangement violated the rule that a tax to be valid must be levied upon all the property in the taxing district. The act was upheld, but with some doctrinal difficulty on the part of the court, which expressed its quandary in the following manner:

The question is a difficult one. A negative answer [i.e., that the act was constitutional] seems to conflict with the general idea of uniformity, which common justice as well as the general understanding of both legislatures and courts places as the foundation of all valid taxation. But an affirmative answer if carried to its logical result produces an effect so startling, and so fatal to all taxation from the commencement of our state history, as to compel the clearest conviction of its truth before it can be given. ${ }^{20}$

The court recognized that all would admit that taxation must be equal and uniform; nevertheless, "this general proposition has some limitations." The court then looked at the "facts," namely, since the admission of the state there had always been unorganized counties within the borders, and never had property therein been made subject to taxation for support of state government. The court questioned whether such a failure invalidated the state tax for all those years. Such a proposition and its implications (for example, its effect upon the validity of all titles which were founded upon tax proceedings during those years) were not to be ac-

${ }^{20}$ Francis v. Atchinson T. \& S.F.R. Co., supra note 18 at 308. 
cepted without a battle. So, the struggle ensued. ${ }^{21}$ After approaching its dilemma from several directions the court concluded that, indeed, "underlying all valid taxation rests the principle of uniformity. . . ." Nevertheless, the court felt it could not ignore reality, for

... in practical operation, a general rule or principle is often limited by some other general rule or principle, or by the facts and conditions under which its application is invoked. And sometimes it happens that a general rule is given its truest and most thorough enforcement by an apparent disregard in minor and temporary matters of its mandates. ${ }^{22}$

Applying this approach to the facts at hand, the court reasoned:

Thus it may be that uniformity in the burden of taxation, will be secured in the truest and best sense by not attempting to extend the machinery of taxation into unorganized counties where the expense of the machinery may exceed the proceeds of the tax; and this being so, the principle of uniformity is in no just sense overthrown or disregarded by leaving the property in those counties untaxed. In a limited sense, it may be said, that there is a disregard of the obligations of uniformity because there is no attempt to reach all property; but in a higher and better sense, it is clear that there is secured an equality and uniformity in the burden of taxation. The spirit is present, though the letter may be wanting. ${ }^{23}$

Having been touched by the spirit, the court eventually held

21 Id. Before proceeding, the court salved its judicial conscience by saying (at p. 309):

It is doubtless true, that results do not change rules, and that consequences may not be invoked to overthrow established principles, and that courts may not disregard plain constitutional requirements to save from the injurious effects of illegal legislative action. . . .

$22 I d$, at 314 . Emphasis added.

${ }^{23}$ Id. at 314-315. Emphasis added. 
the act in question to be valid, although not without some uneasiness.

The conclusions which we have reached are by no means entirely satisfactory to us. We hold the section to be constitutional and valid, not because it is clear to us that it is so, but because it is not clear to us that it is not. And the benefit of the doubt must be given to the law. ${ }^{24}$

The court at a later date, in 1915, when deciding Wheeler v. Weightman, ${ }^{25}$ made a lengthy review of the uniformity cases to that date. The Francis case was noted. However, "Little assistance in the elucidation of the constitution" was afforded by that decision..$^{26}$ Now, one might not be disposed to criticize the result of the Francis case, certainly not this writer. Indeed, some sympathy is felt. But what of "the facts and conditions under which [the mortgage tax's] application [was] invoked?" The opinion in the Wheeler case included the following answer:

It is a matter of common knowledge and regret that the effort to assess and tax real-estate mortgages on the ad valorem plan as a part of the general property of the state has been neither satisfactory nor successful. The method is reprobated as involving double taxation. To what extent this criticism is economically sound is not now material. The prejudice created by the double-taxation argument against the method is widespread and deepseated. It is certain that the method is productive of shameful tax evasion. . . . It is estimated that the holdings of securities of this character by residents of Kansas are four times the amount listed, but the resources of the tax collecting officials for uncovering such holdings appear to be substantially exhausted ... [ the high per cent of income taken by taxing such mortgages at the general property tax rate was referred to]. . . The

${ }^{24}$ Id. at 316. Emphasis added.

25 Supra note 14. See text at notes $14-17$, supra.

${ }^{28}$ Id. at 62. 
result is inequality greater than should result from the administration of a fair and just system. . . .

The struggle for tax reform in this state is an interesting story which need not be told here. It has long been recognized that the constitution provision [requiring uniformity] has outlived its usefulness, and, as outlived restraints usually do, now bars the pathway to the establishment of an equitable system of taxation adequate to the present economic needs of the state. ${ }^{27}$

However, the court was not sitting to express an "opinion regarding the soundness of the policy [behind the mortgage recording tax] because it has no legal concern with the wisdom or unwisdom of legislative policies. ${ }^{28}$ The court would not ignore "reality"- the tax was a property tax, ${ }^{29}$ and as

27 Id. at 51-52. Emphasis added.

${ }^{28} \mathrm{Id}$. at 74 . But note the following statement by the court, at p. 68 , made in reference to the exemption scheme of the mortgage tax:

. . . it is quite unlikely that any great reservoir of capital, whose movements are controlled by economic forces and conditions not merely national but international in character and extent, would be drained into local real-estate mortgage basins by tinkering with local tax laws. So say careful investigators and economists of high qualification and repute. But the legislature may be of a different opinion. It may entertain a belief that its acts will in some way find exemption from the natural laws governing the business world and will be attended by unusually propitious consequences. It may believe that by a simple exemption statute it can correct a crying evil of our system of taxation and at the same time solve for this state the problem of rural credits which is now engaging the earnest attention of statesmen and publicists throughout the United States, including those states which now have mortgage exemption and mortgage registration fee laws. Who has knowledge that the scheme is wholly chimerical?' [Emphasis added.]

29 The court saying, id. at 74 :

The method ... is the method of the property tax. The only marked difference between the statutes of the states referred to and the Kansas statute, barring matters of detail, is that in the latter the soothing term "registration fee" is used instead of the rude word "tax." The voice is the voice of crafty Jacob, but the hands are the hands of hairy Esau, and the court declines to be deceived by a name when it knows what every- 
such had to conform to the requirements of uniformity, which it did not. Here, again, "the spirit was present"though perhaps a spirit of a different sort-and certainly "the letter was wanting."

What purpose has been served by the preceding comparison? Certainly no attempt has been made to show that one decision was more "right" than the other. That would serve little purpose for this study. However, the two cases should illustrate the difficulties which are faced when a court attempts to apply the strict property-tax uniformity limitation. Of more importance, they should illustrate the selective process used by the court of one state. In one instance "the facts and conditions under which the uniformity clause's application was invoked" led to a struggle to uphold legislative action even at the risk of sacrificing "letter" for "spirit," in order that a practical effort might be made to provide, at least, a workable tax structure. Perhaps the "facts and conditions" in the Wheeler case did not warrant such an effort as was made in the Francis case. Perhaps the legislative action was too blatantly in violation of the uniformity requirement. Or perhaps the Wheeler case indicates that the Francis approach has been quietly shelved, and that the court will not engage in such a selective process; the constitution shall mean what the words say, not what the court says! Before reaching that conclusion, "let's look at the record" again.

In 1949, the court decided Associated Ry. Equipment Owners v. Wilson. ${ }^{30}$ One issue concerned the validity of the

one else knows, that the statute embodies a method now becoming common of taxing real-estate mortgages.

It appears that all taxes looked upon with disfavor by Justice Burch, the writer of the opinion, are "the hands of hairy Esau." See Stevenson v. Metzker, infra note 51, with appropriate comment in the dissenting opinion by Justice Harvey.

30167 Kan. 608, 208 P. 2 d 604 (1949). 
statutory provisions whereby private car companies are required to pay annually for each current year a sum, "in the nature of a tax," of two and one-half per cent upon the total gross earnings received from all sources by reason of the use or operation of their cars within the state of Kansas. The tax is in lieu of all other state taxes upon the property of such organizations. ${ }^{31}$ However, it is the "declared intention" of the legislature that the tax imposed "be not greater than the amount of tax such orgaizations would pay if their cars were taxed on an ad valorem basis. . . ." In order to accomplish this intent, further provisions are made for the filing of a complaint with the Commission of Revenue and Taxation concerning the correctness of the rate used or the amount of tax imposed. Upon the hearing of such a complaint, it becomes the duty of the Commission to raise or lower the rate specified in order to make the amount of tax due equivalent to such ad valorem tax. ${ }^{32}$ The court stated that the first question was "the constitutional validity of the act" ${ }^{33}$ under both the federal and state constitutions. The court provided some rather amazing reasons for finding that the tax did not violate the uniformity clause in Art. XI, $\$ 1$. The court's own words are:

It is safe to say the equal protection clause of the federal constitution and state constitutional provisions pertaining to equality and uniformity of taxation are substantially similar and that, in general, what violates one will contravene the other and vice versa. (51 Am. Jur., Taxation, §169.) At any rate no distinction is apparent with respect to any matter

${ }^{31} I d$. at 610 .

32 Kan. Gen. Stat. §79-911a, quoted id. at 616.

${ }^{33}$ Associated Ry. Equipment Owners v. Wilson, supra note 30 at 615. It is said, at 617, that "Appellants [taxpayer] . . . contend the entire act is invalid for the reason it contravenes the due process clause of the fourteenth amendment to the federal constitution and article 11 , section 1 , of our state constitution which require a uniform and equal rate of assessment and taxation except as to property not here involved." 
raised here and the two complaints will be considered together. $^{34}$

Having stated the guiding "principle," the court applied it to the facts. The court rejected the contention that the classification in question was based on "ownership" of property. On the contrary, the classification was said to be based on the "use or operation" of the equipment within the state. The court left no doubt as to the nature of the tax involved-it was a property tax, and the classification was of property.

In reality it is not a tax on the gross receipts accruing from the use and operation of the machinery. It is a tax on the property itself. The tax on the property is merely measured by a percentage of the gross earnings received from the use and operation of the property within the state. It is actually a lieu tax placed on the property in the absence of the physical property for assessment purposes. In order, however, that the tax should be equal and uniform the legislature stated it to be its intention ". . . that the tax herein imposed be not greater than the amount of tax such organization would pay if their cars were taxed on an ad valorem basis. ...."35

Furthermore, the court looked to the "reality" of the situation-reminiscent of the court's attitude in the Francis opinion-and pointed out that the rolling stock of these companies never came to rest within any particular county in the state so that it might be assessed. "Absent some method of this nature for taxing such property it could not be taxed at all." ${ }^{38}$

${ }^{84} I d$. at 617 , emphasis added. The quote in the text follows the quote set forth in note 33 , supra. In one place the court refers at the same time to the due process clause and the equal protection clause. Probably a slip of the pen. The due process clause is of no concern in a discussion of the equality issue.

${ }^{85} I d$. at 618 . Emphasis added.

${ }^{30}$ Ibid. 
To buttress its dubious general proposition the court noted that not only had the need for similar legislation been recognized, enacted, and upheld "in other states with substantially the same constitutional provisions" where it was subjected to the same contentions as those advanced here by the taxpayers, but that each of such contentions had been laid at rest in one or more of the decisions cited in the opinion. Unfortunately for the persuasiveness of the Associated opinion, some of the several decisions cited were decided with reference to state constitutions expressly sanctioning the classification of property for effective rates, ${ }^{37}$ while others were

37 Two cases concerned such a tax imposed by California. People v. Keith Ry. Equipment Co., 70 Cal. App. 2d 339, 161 P.2d 244 (1945), and Pullman Co. v. Richardson, 185 Cal. 484, 197 P. 346 (1922), id., 261 U.S. 330, 43 S. Ct. 366 (1922). As shown in the California study (Part B of this chapter, supra), the constitutional uniformity structure in that state was amended expressly to permit the classification of some property for purposes of taxation, and the type of tax under consideration was imposed after the amendment. In the Keith case a second issue concerned the federal equal protection clause, and in the Pullman Co. case, in fact, the only issues raised were federal questions: namely, whether the tax was a violation of the commerce clause, and whether the tax violated the territorial jurisdictional limitation derived from the federal due process clause. A third case concerned such a tax imposed by Minnesota. Almer Ry. Equipment Co. v. Commissioner of Taxation, 213 Minn. 62, 5 N.W. 2d 637 (1942). As the discussion of the Minnesota limitation shows (Part G of this chapter, infra), the type of tax in question is expressly provided for by a special constitutional provision, and an amendment in 1906 permits the classification of property for purposes of taxation. The Almer Ry. case also raised a federal question concerning the territorial limitation derived from the due process clause of the fourteenth amendment. A fourth case concerned a tax imposed by Missouri. Pacific Express Co. v. Seibert, 142 U.S. 339, 12 S. Ct. 250 (1891). The primary issues were federal questions: the commerce clause and the federal equal protection clause. However, the United States Supreme Court also ruled that the tax did not violate the state uniformity clause. This ruling departed from Missouri decisions (Part G of this chapter, infra) which had interpreted the then existing uniformity clause to require absolute uniformity. Interestingly enough, the United States Supreme Court equated the state limitation to the federal equal protection clause and indicated that 
United States Supreme Court opinions concerning the validity of state taxes under the commerce and equal protection clauses of the federal Constitution. ${ }^{38}$ Nevertheless, the court confidently summed up as follows:

All property within the classification of the statute is taxed equally and uniformly under the statute. This meets all constitutional requirements if the classification is a reasonable one for tax purposes. (People v. Keith Railway Equipment Co., supra. $)^{39}$

The Keith case, cited in the quotation (and the only case cited as authority for the conclusion), is one of the cases referred to above, and it was decided by a California intermediate appellate court which approved a classification under the California constitutional provisions which expressly

only arbitrary classification was prohibited; but there was not a single reference to Missouri decisions interpreting this state constitutional provision. In other words, the Seibert decision was no authority for sustaining such a tax under the then existing strict uniformity clause in the Missouri Constitution. The Missouri study indicates that the Kansas court could find no comfort for its Associated Ry. Equipment Owners decision by reference to Missouri taxes.

${ }^{38}$ Two cases, Cudahy Packing Co. v. Minn., 246 U.S. 450, 38 S. Ct. 373 (1917) and United States Express Company v. Minn., 223 U.S. 335, 32 S. Ct. 211 (1911), concerned the validity of a Minnesota tax under the federal commerce clause. One case, People v. Keith Ry. Equipment Co., supra note 37 , concerned the validity of a California tax under the federal equal protection clause, and one case, Pullman Co. v. Richardson, supro note 37 , concerned the validity of a California tax under both the federal commerce clause and due process clause (territorial jurisdiction). One case, Western Union Tel. Co. v. State of Indiana, 165 U.S. 304, 17 S. Ct. 345 (1897), concerned the validity of an Indiana tax under both the federal equal protection clause and due process clause (territorial jurisdiction).

${ }^{39} \mathrm{Id}$. at 618 . Emphasis added. The court further stated at 619:

The fact railroad property generally is not assessed at the same rate does not render the instant act invalid. The entire property of railroads is assessed in one manner while other property may be assessed in another manner and be valid. 
provide for the classification of certain property for purposes of taxation. ${ }^{10}$

One may well wonder just how much "assistance in the elucidation of the constitution" is afforded by the Associated Railway Equipment Owners case. The opinion leaves no doubt that the court found the tax to be a tax upon property. Some slight suggestion is made that one provision in the tax might have offered at least some support for reconciling the tax with the prior judicial development of the meaning of the uniformity limitation in Kansas. This, of course, refers to that provision stipulating that if some objection is raised by the taxpayer, the tax should not be greater than the amount of a tax which would be paid on the property involved if it were taxed at the general property tax rate. However, there was no real reliance on this approach, and the court never even partially developed its possibilities. Essentially, the court relied on the proposition that "All property within the classification of the statute is taxed equally and uniformly under the statute" and that nothing else is required by Art. XI, $\$ 1$. Also the court found that the base of the tax was "merely" gross earnings rather than "value." Further comment on the future influence of this anomalous case will be delayed until after a discussion of the constitutional changes made in 1924. Then the opinion by Justice Wedell in the 1949 Associated Railway Equipment Owners case can be evaluated along with the opinion by the same Justice Wedell in Hunt v. Eddy, a case decided in 1929 and of considerable importance in interpreting the 1924 "intangible amendment" to the uniformity clause in Art. XI, $\S 1$.

\section{(2) Taxation of "intangibles" since 1924}

The 1924 amendment to the uniformity clause in Art. XI, 40 See Part B of this chapter, supra. 
$\$ 1$, inserted the following proviso: "except that mineral products, money, mortgages, notes and other evidence of debt may be classified and taxed uniformly as to class as the legislature shall provide." Two problems are raised by this amendment. First, precisely what property is included within the scope of the proviso? "Mineral products" and "intangibles?" Or, does the enumeration of "money, mortgages, notes and other evidence of debt" indicate that there remain some intangibles beyond the effect of this liberalizing amendment? Second, to what degree has the strict uniformity requirement applicable to property taxation in general been liberalized in its application to the taxation of the enumerated classes of property?

In 1925, immediately after the amendment, the legislature made use of its new power in two ways. It passed a mortgage registration tax law $^{41}$ providing that real-estate mortgages could not be received and filed for record until the payment of a fee of 25 cents per $\$ 100$ of the principal debt was made. On payment of the fee, the mortgage and the note secured by it could not thereafter be otherwise taxed. The constitutionality of this tax was established in Citizens Bank v. Tax Comm. of Kansas, ${ }^{42}$ decided in 1931. It was contended that the law violated the constitutional requirement of uniform taxation of classes embodied in the 1924 proviso, in that the law discriminated against unrecorded real-estate mortgages, mortgages on personal property, and mortgages on land and personal property in other states held by residents of Kansas. This contention was rejected as "unsound," the court saying:

The plain reading of the amended statute is that mineral products may be classified by placing oil in one class, coal in

41 Kan. Laws, 1925, c. 274; Kan. Gen. Stat., c. 79, Art. 31.

42132 Kan. 5, 294 Pac. 940 (1931). The more important issue concerned the "money and credits" tax. See text at note 53 , infro. 
another, and lead and zinc in another; and so with other classifiable things, including mortgages. . . .

So mortgages may be classified for purpose of taxation if there is fair basis for classification. ${ }^{43}$

Thus, the segregation from the larger class of mortgages in general of recorded real-estate mortgages on realty located in Kansas was said to be a reasonable classification. This mortgage registration tax is still in force in Kansas, in substantially the same form. Moreover, other than the case already discussed, there has been no real controversy as to its constitutionality under the amended Art. XI, $\S 1$.

To the contrary, the companion measure enacted by the legislature in 1925 has been the source of the utmost confusion and controversy. This companion measure placed a low rate tax on "intangibles." The main controversy concerned whether all intangibles, including stock, were included in the tax, and secondly, if they were, whether this was permitted under the amended Art. XI, $\S 1$. In the companion measure, the legislature imposed an annual low rate tax on "money" and "credits," to be in lieu of all other taxes upon such property. ${ }^{44}$ The catalyst for the inevitable conflict was the decision of a federal district court in February, $1927 .^{45}$ That court held that it would be a violation of the controlling federal statute, section 5219, to apply the higher general property tax rate to shares of national bank stock if moneyed capital coming in competition with such bank shares were taxed at the lower "money and credits" rate. ${ }^{46}$

43 Id. at 8-9.

44 Kan. Laws 1925 , c. 277 , c. 278 . By Kan. Laws 1927 , c. 326 , the rate was raised from $2 \frac{1}{2}$ mills to 5 mills. The tax was repealed by Kan. Laws 1930 , c. 18 , and reenacted by Kan. Laws 1931 , c. 311 , c. 312 .

45 Central National Bank v. McFarland, 20 F. 2d 416 (1927).

${ }^{46}$ State taxation of national bank shares is a federal statutory problem because

National banks are not merely private moneyed institutions but agencies 


\section{Thus, shares of stock in national banks could only be taxed} at the lower rate.

A direct result of the above decision was the case of Voran v. Wright. ${ }^{47}$ The legislature had so defined "credits" to exclude shares of stock in either state or national banks. ${ }^{48} \mathrm{~A}$ stockholder in a state bank brought an action to compel the

of the United States created under its laws to promote its fiscal policies; and hence the banks, their property and their shares cannot be taxed under state authority except as Congress consents and then only in conformity with the restrictions attached to its consent.

First National Bank of Guthrie Center v. Anderson, 269 U.S. 341, 347, 46 S. Ct. 135 (1926), as quoted in First National Bank of Hartford v. City of Hartford, 273 U.S. 548, 550, 47 S. Ct. 462 (1927). Congress has provided for such taxation in the familiar "Section 5219," which is now embodied in 12 U.S.C.A. $\$ 548$. Generally on the problems involved in state taxation of national bank shares, see Woosley, State Taxation of Banks (1935). Also see Lutz, "The Evolution of Section 5219," Bul. N.T.A., XIII, 205-212; Ford, Taxation of Intangibles in Michigan, Univ. of Mich., Michigan Governmental Studies, No. 2 (1939), pp. 127-135.

47129 Kan. 1, 281 Pac. 938 (1929), rehearing, 129 Kan. 601, 284 Pac. 807 (1930).

${ }^{48} \mathrm{~K}$ an. Laws 1927 , c. 326, $\S 1$ of which read, in part:

The term "credits" shall mean and include notes, mortgages, foreign stocks, bonds, annuities, royalties, contracts, copyrights, claims secured by deeds and every liquidated claim and demand for money, shares of stock in building and loan associations, other than permanent stock, or other valuable thing, except notes or obligations secured by mortgages on real estate, which mortgages have been recorded in this state, and registration fee or tax paid thereon, and shares of stock upon which taxes are otherwise payable under the laws of this state: Provided, That nothing in this act shall be construed to apply to money or credits, as herein defined, belonging to persons, partnerships, associations or corporations, the taxation of which is otherwise provided for by law, or to any national banking association, or the stock thereof, or to moneyed capital in the hands of individual citizens of this state coming into competition with the business of national banks: Provided further, That bonds, notes or other evidences of indebtedness in the hands of individual citizens not employed or engaged in the banking, loan or investment business and representing merely personal investments, not made in competition with the business of national banks, shall not be deemed such moneyed capital. 
acceptance of a tender of an amount due for taxes on state bank shares computed at the "money and credits" rate instead of the higher general property tax rate. The decision, at least, is clear enough. The court held that state bank shares could only be taxed at the lower "money and credits" rate. In effect, the rationale was this: National bank shares could not be taxed at the higher rate, and to distinguish between items of property on the basis of "ownership" was not permissible. ${ }^{49}$ Thus, state bank shares had to be taxed at the same rate as that applicable to national bank shares. Otherwise, the "uniform within classes" requirement in the amended Art. XI, $\S 1$ would have been violated. There was no clear explanation of just how bank shares were to be taxed as "credits."

It was on this point that Justice Harvey dissented. $\mathrm{He}$ too agreed that national bank shares could only be taxed at the lower rate, and that to tax state bank shares at a higher rate would be discriminatory. However, it was his opinion that bank shares were not "evidence of debt" and therefore were not classifiable under the 1924 amendment to Art. XI, $\S 1$. Thus, since state bank shares could only be taxed at the lower rate, it would follow that all property in the state could only be taxed at the lower rate, otherwise the basic uniformity clause would be violated. In other words, only "money, notes, mortgages and other evidence of debt" are classifiable under the amended uniformity provision. If bank shares are not "evidence of debt," then they are a part of the mass of property which may be reached only by an absolutely uniform rate. If bank shares are taxable only at

40 Voran v. Wright, supra note 47 . Overruling to the extent that it might be contrary to the proposition in the text: Davis-Wellcome Mtg. Co. v. Haynes, 119 Kan. 1, 237 Pac. 918 (1925), in which a distinction between money and "credits" owned by domestic corporations and manufacturing merchants and the same money and "credits" owned by others was sustained. 
the lower rate, then all property could be taxed only to that extent. $^{\text {s0 }}$

This fundamental issue of uniformity, as posed by Justice Harvey in his Voran case dissent, was raised more clearly in Stevenson v. Metsker, ${ }^{51}$ decided in 1930. Here the plaintiff taxpayer was the owner of real estate, and he sought mandamus to compel the acceptance of a sum of money sufficient to discharge the taxes due on such real estate if computed at the "money and credits" tax rate rather than the higher general property tax. The basis of the taxpayer's claim was that state bank shares were taxable, since the Voran case, at the lower "money and credits" rate; that shares of bank stock were not property falling within any of the classes

50 Justice Harvey recognized the practical consequences of the view which he held. As he succinctly summed up, id. at 623:

... Under our present constitution and statutes, and giving force to the federal statute (Rev. Stat. 5219), as we must do, we cannot have a valid $\operatorname{tax}$. . . on any property in the state at a rate greater than that which can be lawfully made on the shares of stock of national banks. This, as we have heretofore seen, is measured by the rate provided by our statutes for the taxation of moneyed capital in the hands of individual citizens of the state which comes into competition with the business of national banks, none of which is taxed at more than the intangible tax rate of 50 cents per $\$ 100$ valuation. We all know, of course, that if no property in the state can be lawfully taxed at more than 50 cents per $\$ 100$ valuation, the functions, not only of the state but of every subdivision of it, supported in the main by our general-property tax, will be seriously impaired.

How can this situation be remedied? Broadly speaking, it may be done in any of three ways: By (1) changing the federal statute . . . ; (2) changing our constitution $(\$ 1$, art. 11), or our [tax] statutes ... ; or (3) raising the additional necessary funds by methods other than a direct tax on property. Which changes, or combination of them, should be used involves the consideration of questions of economics and statecraft. To determine what should be done comes within the functions of the executive and legislative branches of our government rather than the judicial.

51130 Kan. 251, 286 Pac. 673 (1930). 
mentioned in the amended Art. XI, $\S 1$ and, therefore, unless all property was taxed at the same rate as that applied to bank shares, the uniformity clause of Art. XI, $\$ 1$ would be violated. The majority, in denying the taxpayer's claim, never really held that bank shares were "evidence of debt," but, in effect, ruled that "in reality" the taxation of such shares was the taxation of the "assets" of the banks which were, in turn, made up of substantially the "credits" enumerated in the tax law. Therefore, it was not a violation of the general uniformity clause to tax such shares at a lower rate than other property, i.e., realty. Again Justice Harvey dissented, and for the same reasons. ${ }^{52}$ The position of the Voran and Stevenson cases was reaffirmed one year later in Citizens Bank v. Tax Comm. of Kansas, ${ }^{53}$ and Justice Harvey still dissented.

So the matter stood until 1939, although the "money and credits" tax had been repealed in 1930 and reenacted in 1931. Then in 1939, the legislature amended the definition of "money and credits" so as to leave no doubt that all types of shares of stock were to be taxed at the lower rate. Furthermore, such shares were defined in such a manner to be in-

52 Id. at 262-290. Justice Harvey emphasized the pressure under which the decision was made, and the undue speed, in his opinion, with which a decision was reached. He also noted that the Central National Bank case (supra note 45), the appointment, work, and report of a tax commission, and the decision in the Voran case (supra note 47), all brought about a special session of the legislature, which was in progress when the Stevenson action was brought and determined. "Opposing influential political and financial groups, apparently almost equal in legislative strength, were contending over pending legislative measures. It is no secret that this action was hurriedly brought and an early decision sought with the view of having the ruling of this court influence pending legislation. This accounts largely for the speed in the presentation and disposition of the case." In a detailed dissenting opinion, Justice Harvey meets the majority opinion point for point.

${ }^{53}$ Supra note 15. 
cluded within the term "notes and other evidence of debt." "ss Thus, the issue was squarely presented and faced in Hunt v. $E d d y,{ }^{55}$ decided in 1939. The court held that shares of stock in corporations were taxable at the "intangibles" rate, and that such shares of stock were "evidence of debt." The majority opinion of Justice Wedell stressed what was termed a "non-legalistic" interpretation of the meaning of the words in the amended Art. XI, $\S 1$ of the constitution. The court "readily concede[d] that according to the processes of refined judicial research an ordinary certificate of stock is not technically an 'evidence of debt,' but rather a certificate evidencing the ownership of unit of a corporate entity." But, discarding such a strictly technical and legalistic meaning of the "words," the court sought "the common understanding, the true intention, of the people at the time they adopted the constitutional provision." And "a majority of this court [was] not convinced beyond a reasonable doubt that the man on the street, the lay mind, did not regard a 'certificate evidencing shares of stock' as an 'evidence of debt.' "\$6 The majority also stressed the continual use of the term "intangibles" to characterize both the amendment to Art. XI, §1, and the "money and credits" tax. They were generally referred

54 The following italicized words were added to Kan. Gen. Stat. §793108:

The term "notes and other evidences of debt" shall include and mean certificates evidencing shares of stock otherwise taxable to the owner or holder. . . .

55150 Kan. 1, 90 P. 2 d 747 (1939). Plaintiff brought a mandamus proceeding to compel the county assessor to tax five shares of corporate common stock owned and listed for taxation by him at the intangible rate, rather than at the ad valorem rate applied by the defendant. Defendant contended that the amendment to the tax statute, bringing shares of stock within the meaning of "notes and other evidences of debt," was unconstitutional.

50 Id. at 10-11. To the extent that the prior decision, Ryan v. Tax Comm. of Kansas, 132 Kan. 1, 294 Pac. 938 (1931), might conflict with this ruling, the views expressed in the Hunt case were said to be controlling. 
to as the "intangibles amendment" and the "intangibles tax." ${ }^{37}$ Again Justice Harvey dissented, this time gaining an adherent (Justice Thiele) from the new members of the court. ${ }^{58}$

One thing seems to be certain after the Hunt case. The amendment to Art. XI, $\S 1$ regardless of its phraseology, is now in fact an "intangibles" amendment, and intangibles in general may be classified by the Kansas legislature under the amended uniformity provision. This brief survey of a really difficult problem hardly does justice to the complex way in which it developed. However, the summary treatment is justified since it delineates the problem to the extent necessary for this comparative study of uniformity clauses found among the several states. A more critical evaluation of the manner in which the court made this inclusive interpretation of the words of the amendment to Art. XI, $\S 1$ is entirely possible, and would undoubtedly be of considerable value. However, the limitations of space and strict relevancy rule out such an evaluation here.

\section{(3) Property taxation: summary}

In summary, it can be seen that the taxation of all property, except intangible property, is governed by a strict requirement of absolute uniformity in effective rates and the ad valorem method. However, only a "semi" requirement of universality is found. The requirement of "public interest" has in fact limited the power of the legislature to exempt property to substantially that property listed as exemptible in the constitution, Art. XI, §1. As for intangible property, only the strictness of the requirement of absolute

${ }^{67} I d$. at 6-10.

58 Justice Hoch concurred only in the result, preferring to rely solely on the rationale of the Voran and Stevenson cases, namely, that the taxation of shares was in effect the taxation of the assets. Id. at 14 . 
uniformity in effective rates has been relaxed. Such property may be classified for the purpose of applying different rates.

This leaves aside, of course, any possible change in the effective uniformity limitation which might be derived from the 1949 case, Associated Railway Equipment Owners v. Wilson. Has that decision in fact reversed the interpretation formerly given the basic uniformity clause in Art. XI, $\S 1$ so that property in general may now be classified for rates, and so that the general property tax may have a base of "income produced" rather than "value?" One is hardly warranted is reaching such a conclusion. In all probability the Associated case must simply stand as an anomaly. It does, however, raise some interesting questions. What happened to the dissenting justices in Hunt v. Eddy, decided in 1939, just ten years before Associated? Justice Harvey, who so vigorously fought the extensive interpretation given the "intangibles" amendment of Art. XI, $\S 1$ and so forcefully stated the strict uniformity limitation, was still on the bench when Associated was decided, but he did not participate in the opinion. Justice Thiele, who joined Justice Harvey in the Hunt dissent, was also still on the bench when Associated was decided. However, he registered no dissent in $A s-$ sociated, voting with the unanimous majority. Certainly the Associated case aptly illustrates the manner in which these very strict uniformity limitations have caused great difficulty for the courts, and how at times the limitation is simply ignored. Kansas stands as a state having a strict uniformity requirement for property, other than intangible property. However, that requirement has at times been relaxed on the basis of subjective value judgments made by the court, or a majority thereof. The Associated case offers little help in predicting when in the future the Kansas court will see fit to ignore the strict and inflexible degree of uniformity which it has said is required by the constitution. Perhaps it simply 
aids to the extent of indicating that at times such a relaxation is possible. ${ }^{\text {so }}$

\section{Nevada}

Nevada has had but a single constitution, that of 1864 . The uniformity clause is found in Art. X, $\$ 1$, which was amended in 1942 to provide for the mandatory exemption of representative intangible property. Section 1 now reads (with those words added in 1942 in italics):

The legislature shall provide by law for a uniform and equal rate of assessment and taxation, and shall prescribe such regulations as shall secure a just valuation for taxation of all property, real, personal and possessory, except mines and mining claims, when not patented, the proceeds alone of which shall be assessed and taxed . . . ; shares of stock (except shares of stock in banking corporations), bonds, mortgages, notes, bank deposits, book accounts and credits, and securities and choses in action of like character are deemed to represent interest in property already assessed and taxed, either in Nevada or elsewhere, and shall be exempt. No inheritance or estate tax shall ever be levied, and there shall also be excepted such property as may be exempted by law for municipal, educational, literary, scientific or other purposes. $^{1}$

${ }^{59} \mathrm{It}$ is not inappropriate to raise a query at this point concerning the validity of the grain handling tax. The tax is clearly correlated with the ad valorem property tax. The statute purports to levy an occupation tax, and is levied upon dealers at the rate of $1 / 2$ mill per bushel upon all grain received during the preceding calendar year whether or not such grain is owned by the dealer. Producers pay a tax at the rate of $1 / 2$ mill per bushel upon all grain over and above 1,000 bushels harvested in the state. The grain is thereafter exempted from property taxation. Kan. Gen. Stat. §§79-3901-79-3910.

1 The omitted part of Art. X, $\S 1$ deals with the manner in which patented mines and mining claims shall be taxed. Such patented property is to be assessed at not less than $\$ 500$, except where $\$ 100$ in labor has been actually performed on such property during the year, in addition to the tax 
The only other provision of interest is Art. VIII, §2, which provides that all property of corporations "shall be subject to taxation the same as property of individuals; provided, that the property of corporations formed for municipal, charitable, religious, or educational purposes may be exempted by law."

Nonproperty taxes, as contrasted to property taxes, are not limited by the uniformity clause in Art. X, $\S 1$ and are only required to be uniform within classes. ${ }^{2}$ There have been no cases in Nevada concerning the nature of certain controversial taxes, which is understandable in light of the limited scope of the Nevada tax structure. No income tax has ever been imposed, nor are there any express constitutional provisions concerning such a tax. An inheritance tax is now prohibited by the 1942 amendment to Art. X, $\$ 1$ and while Nevada did at one time have such a tax, it was repealed in 1925 and no questions appear to have been raised as to its validity. In the absence of such taxes as those mentioned, it is not surprising that the question of the validity of graduated rates has not been discussed. ${ }^{3}$

The taxation of property is governed by the strictest ef-

on net proceeds. This provision for special treatment of patented mines and mining claims was added by amendment in 1906.

2 A leading case is Ex parte Robinson, 12 Nev. 263, 28 Am. Rep. 794 (1877), in which the court held that a state license tax upon itinerant peddlers was valid. Also see: Ex parte Cohn, 13 Nev. 424 (1878) (a $2 \%$ tax on the gross premiums of foreign insurance companies was held to be valid and not within the uniformity clause limitation); Ex parte Dixon, 43 Nev. 196, 183 Pac. 642 (1919) (local occupation tax on attorneys, upheld as a nonproperty tax); Ex parte Iratacable, $55 \mathrm{Nev} .263,30$ P. 2d 284 (1934) (motor carrier tax, exemptions therefrom upheld as reasonable classes).

3 But see Ex parte Dixon, supra note 2, in which the court stated that it was not pointed out by those attacking the ordinance in just what way the tax was not uniform. But the court noted that the tax provided for a graduated rate of taxation, based upon the individual income of attorneys. The rate was a flat rate, increasing with brackets of increasing amounts of income. 
fective uniformity limitation. Article $X, \S 1$ is said to contain a requirement of universality; thus before the 1942 amendment intangible property had to be taxed since it was not generally a class characterized by the exemption proviso as exemptible. ${ }^{4}$ This requirement is said to stem from alternate sources. First, there could not be a "uniform and equal rate of assessment and taxation" if some property is taxed and other is not. Also the court has stressed the words requiring regulations for a just valuation of "all" property, with the exception of named classes of property which "may" be exempted. This requirement of universality has been restricted by the 1942 amendment which now expressly requires the exemption of representative intangibles on the theory that the taxation of such property is "double taxation." The court had ruled before the amendment that such property had to be taxed because there was no "double taxation."

As to that property actually taxed, there must be an absolute uniformity in the effective rate. ${ }^{5}$ This was ruled upon in State v. Eastabrook, ${ }^{6}$ which held that the tax on mines and mining claims expressly provided for in Art. X, $\$ 1$ was a property tax, and therefore the rate imposed on such property had to be correlated with the general property tax rate. The main difference made by the proviso in Art. X, $\S 1$ is to sanction a different base for the taxation of such property. Instead of "value" the "proceeds" from such property must be used as the base. While no cases have been decided on the

${ }^{4}$ State v. Carson City Savings Bank, 17 Nev. 146, 30 Pac. 703 (1882), in which the court held that intangibles were taxable property even though the property mortgaged was also taxed. Also see State v. Eastabrook, $3 \mathrm{Nev}$. 178 (1867); State v. Wells Fargo \& Co., 38 Nev. 505, 150 Pac. 836 (1915).

5 However, classification for use of different methods of valuation is permissible. Sawyer v. Dooley, 21 Nev. 391, 32 Pac. 437 (1893).

${ }^{6}$ Supra note 4. And see State v. Kruttschnitt, 4 Nev. 178 (1868). 
matter, it seems clear that the ad valorem method is required in the taxation of property. The proviso for mines and mining property states an exception to that requirement.

The sparseness of litigation and controversy concerning the uniformity limitation in Nevada is not unexpected in view of the fact that the tax structure of the state is relatively simple insofar as variety of taxes is concerned, and the further fact that Nevada stands last among the states in total amount of revenue collected.

\section{South Carolina}

\section{a. The provisions; historical note}

South Carolina, one of the original states of the Union, has had several constitutions, dated respectively 1778, $1790,1865,1868$, and the present constitution of 1895 . There has also been a steady expansion of the constitutional uniformity structure from nothing in the first constitution of 1778 to the long and redundant structure of the present constitution of 1895 .

The basic uniformity clause is currently found in Art. X, $\S 1$ and reads:

The General Assembly shall provide by law for a uniform and equal rate of assessment and taxation, and shall prescribe regulations to secure a just valuation for taxation of all property, real, personal and possessory, except mines and mining claims, the products of which alone shall be taxed; and also excepting such property as may be exempted by law for municipal educational, literary, scientific, religious or charitable purposes: . . . And provided, further, That the General Assembly may provide for a graduated tax on incomes, and for a graduated license on occupations and business.

In 1932 Art. X, $\S 1$ was amended by adding the following 
important proviso authorizing special treatment for intangibles:

Provided, Further That the General Assembly may provide by law for the assessment of all intangible personal property, including moneys, credits, bank deposits, corporate stocks, and bonds, at its true value for taxation for State, County, and municipal purposes or either thereof: Provided, that the total rate of taxation imposed thereon shall never exceed one-half of one per centum of the actual value of such intangible property; Provided, Further, that such intangible personal property shall not be subject to the three mill levy provided by $\S 10$, Art. 11 of this instrument or to any other general or special tax levy, except such as is especially provided by the General Assembly by the authority and within the limitations of this provision; nor shall such intangible personal property be considered a part of "taxable property," as such term is used in this instrument, of the State or any subdivision thereof.

Article $\mathrm{X}, \S 4$ requires the exemption of certain classes of property, and there are several other provisions dealing with special exemptions. ${ }^{1}$ In addition to the basic uniformity clause in Art. X, $\S 1$, there is a provision which in some other states has been the sole source of uniformity for property taxation in general. Article I, $\S 6$ of the Bill of Rights provides:

All property subject to taxation shall be taxed in proportion to its value.

Also of interest is Art. III, $\$ 29$, found in the Legislative Article. Section 29 requires that

All taxes upon property, real and personal, shall be laid

${ }^{1}$ For the text of Art. X, $\S 4$, see Appendix A, infra. Article VIII, $\S 8$ is a "manufactorics" exemption provision, stating that "[c] ities and towns may exempt from taxation . . . except for school purposes, manufactories established within their limits for five successive years from the time of the establishment of such manufactories. ..." 
upon the actual value of the property taxed, as the same shall be ascertained by an assessment made for the purpose of laying such a tax.

Rounding out the uniformity structure of the present constitution of 1895 are two sections dealing expressly with uniformity of local taxes. ${ }^{2}$

In contrast to the rather cluttered and verbose uniformity structure found in its present constitution, the first constitution of South Carolina, dated 1778, and its successor, dated 1790 , had no provisions expressly relating to uniformity of taxation. The first such provision appeared in the third constitution, that of 1865 . That constitution was in force only a few years, and it had a single provision, Art. I, §8, which was identical to the present Art. III, \$29.

In the next constitution, dated 1868 , which served over a quarter of a century, the uniformity structure was quite similar to that found in today's constitution. Article II, $\$ 33$ was a carry-over from the 1865 constitution, and identical to the present Art. III, §29. More important was Art. IX, §1, which was identical with Art. X, $\S 1$ of the present constitution as it appeared before 1932, and excepting the proviso for income and occupation taxes which was added with the 1895 constitution. In addition, the 1868 constitution added

${ }^{2}$ Article VIII, $\$ 6$ provides that cities and towns are to be vested with the power to

.. . assess and collect taxes for corporate purposes, said taxes to be uniform in respect to persons and property within the jurisdiction of the body composing the same; and all the property, except such as is exempt by law, within the limits of cities and towns shall be taxed for the payment of debts contracted under authority of law. License or privilege taxes imposed shall be graduated so as to secure a just imposition of such tax upon the classes subject thereto.

Article $\mathrm{X}, \S 5$ contains a provision substantially the same as the above for "counties, townships, school districts, cities, towns and villages," except that the last sentence as to license or privilege taxes does not appear. 
Art. I, §36, which was identical with the present Art. I, §6, with the qualification that it had an additional clause ${ }^{3}$ similar to that which today serves two states (Rhode Island and Vermont) as a basic uniformity provision.

\section{b. Meaning of the uniformity limitation}

Although the South Carolina Constitution is replete with uniformity provisions, one finds, as usual, that nonproperty taxes are not limited by the uniformity clause in Art. X, $\S 1$, and need only be uniform within classes. ${ }^{4}$ The objects and exemptions therefrom need only be reasonable classes, ${ }^{5}$ and further classification may be made for applying different rates. ${ }^{6}$ In an unusual constitutional provision, graduated rates are expressly permitted for either income or occupation and business taxes. $^{7}$

${ }^{3}$ Article I, $\$ 36$ contained the following sentence:

. . . Each individual of society has a right to be protected in the enjoyment of life, liberty, and property, according to standing laws. He should, therefore, contribute his share to the expense of his protection. . . .

4 A leading case is Gregg Dyeing Co. v. Query, 166 S.C. 117, 164 S.E. 588 (1932). Also sce: State v. Touchberry, 121 S.C. 5, 113 S.E. 345 (1922); Hay v. Leonard, 212 S.C. 81 , 46 S.E. 2 d 653 (1948). That this was not always so clearly accepted, see the dissenting opinion of McIver, J. in Charlotte, C. \& A. R. Co. v. Gibbes, 27 S.C. $385,402-403,4$ S.E. 49 (1887). The case refers to Art. IX, $\S 1$ of the 1868 constitution, which was identical to Art. $X, \S 1$ of the present constitution insofar as the basic uniformity clause was concerned.

${ }^{5}$ For example, of the numerous cases, see: State ex rel. Roddey v. Byrnes, 219 S.C. 485, 66 S.E. 2 d 33 (1951); Carolina Music Co. v. Query, 192 S.C. 308 , 6 S.E. $2 d 473$ (1939); State ex rel. Coney v. Hicklin, 168 S.C. 440, 167 S.E. 674 (1933).

${ }^{6}$ For example, of the numerous cases, see: Great Atlantic \& Pacific Tea Co. v. City of Spartanburg, 170 S.C. 262, 170 S.E. 273 (1932); Hill v. Abbeville, 59 S.C. 396, 38 S.E. 11 (1901); State v. Touchberry, supra note 4. For a classification found to be arbitrary, see Ex parte Bates, 127 S.C. 167,120 S.E. 717 (1923).

${ }^{7}$ See Alderman v. Wells, 85 S.C. 507,67 S.E. 781 (1910), in which the court recognized the authority of the legislature to impose an income 
As in other states having the strict uniformity limitation applicable to property taxes, important results flow from characterizing a tax as either a property or nonproperty tax. However, there have been few, if any, really difficult problems raised on this point in South Carolina. A graduated income tax is expressly sanctioned in Art. X, $\S 1$, and there was no controversy concerning such a tax even before this provision was written into the present 1895 constitution. $^{8}$ Nor has the South Carolina inheritance tax, ${ }^{8}$ which has graduated rates, ever been challenged on this point. In Gregg Dyeing Co. v. Query ${ }^{10}$ the fuel use tax was held to be a nonproperty tax and therefore not within the Art. X, $\S 1$ uniformity limitation, and the same result was reached as to a local probate fee with a graduated rate. ${ }^{11}$

\section{(1) Property taxation}

Not unexpectedly, there are very few cases in South Carolina concerning the content of the uniformity limitation. However, it is clear that there is a requirement of universality. ${ }^{12}$ The source of the limitation is usually attributed mainly to the clause in Art. $X, \S 1$, which states certain

tax with a graduated rate. However, while graduated rates for excise taxes are permitted, they are not required. Marshall v. South Carolina Tax Comm., 178 S.C. 57,182 S.E. 96 (1935).

${ }^{8}$ South Carolina at the present does have an income tax with a graduated rate. S.C. Code (1952), tit. 65, c. 5. South Carolina, as a colony, had a "faculty" tax, and during the period of the Civil War imposed a tax of $1 \%$ on the professional incomes and salaries over $\$ 500$, this latter tax being repealed after the war.

${ }^{9}$ S.C. Code (1952) §\$65-451-65-553.

${ }^{10}$ Supra note 4.

11 Anderson v. Page, 208 S.C. 146, 37 S.E. $2 d 289$ (1946).

12 For example, Ellerbe v. David, 193 S.C. 332, 8 S.E. 2d 518 (1940); Germania Sav. Bank v. Darlington, 50 S.C. 337, 27 S.E. 846 (1897); Strong v. City of Sumter, 185 S.C. 203, 193 S.E. 649 (1937); Wofford College Trustees v. City of Spartanburg, 201 S.C. 315,23 S.E. $2 d 9$ (1942). 
permissive exemptions. However, there is no indication that the result would necessarily be different even if there were only the general uniformity clause in Art. $\mathrm{X}, \S 1$. Nor is there any indication that the requirement in Art. I, $\$ 6$, that "All property subject to taxation shall be taxed in proportion to its value," would or would not be the source of this limitation.

As for that property selected for taxation, it must be taxed by the ad valorem method, ${ }^{13}$ and the effective rate applied by any one taxing authority must be absolutely uniform. ${ }^{14} \mathrm{Al}$ though it would seem that the ratio of valuation would have to be a uniform $100 \%$, since Art. III, $\$ 29$ requires that "All taxes upon property . . . shall be laid upon the actual value of the property taxed," in fact ratios of a much smaller per cent are actually used in the several taxing districts. ${ }^{15}$ The ad valorem requirement is usually attributed to Art. I, $\S 6$, the "proportionality" clause; however, there is no indication that such a requirement would not be derived from the basic uniformity clause itself.

Intangibles: taxation of, since 1932. The 1932 amendment to Art. X, $\S 1$ is authority for special treatment for intangible property. To date the legislature has made no effort to implement this proviso. Therefore intangibles are apparently still subject to the general property tax. ${ }^{16}$ Consequently, there has been no occasion on the part of South Carolina authorities to interpret the intangibles proviso. However, it would appear to be a reasonable conclusion that intangibles may be taxed only as a single class at the low

${ }^{13}$ State v. Cheraw \& D. R. Co., 54 S.C. 564, 32 S.E. 691 (1898). Also see State v. Railroad Corporations, 4 S.C. 376 (1873), decided under the 1868 constitution.

14 For example, Smith v. Robertson, 210 S.C. 99, 41 S.E. 2 d 631 (1947); Nettles v. Cantwell, 112 S.C. 24, 99 S.E. 765 (1919).

${ }^{15}$ See CCH S. Carolina Tax Reporter, $\lceil 70-501$ and $\llbracket 20-321$.

${ }^{16} I d$. at $\llbracket \llbracket 20-004,20-180$. 
rate. There is no relaxation of the ad valorem requirement, and it would not appear that intangibles could not be exempted unless falling within one of the classes of property designated as exemptible by the constitution. Indeed, it appears to this writer that a good case could be made for the proposition that intangibles could not be constitutionally subject to the general property-tax rate if that rate is higher than that provided for in the proviso, namely, one half of one per cent of the actual value of such property.

\section{Utah}

\section{a. The provisions; historical note}

The first and only constitution of Utah came into force in 1896. Two provisions constitute the essential parts of the uniformity structure: Art. XIII, §3, containing the basic uniformity clause, and Art. XIII, $\$ 2$, containing a supplementary proportionality clause. Both of these sections are rather lengthy, and have been the subject of several amendments. However, it is the 1920 amendments to both sections 2 and 3 of Art. XIII which are of considerable significance for the meaning of the effective uniformity limitation in Utah. The provisions will be examined in their present effective forms, and then their historical development will be noted. Article XIII, $\S 3$, containing the basic uniformity clause, reads as follows (with the paragraph notations added by this writer for convenience):

[đ1] The Legislature shall provide by law a uniform and equal rate of assessment and taxation on all tangible property in the State, according to its value in money, and shall prescribe by law such regulations as shall secure a just valuation for taxation of such property, so that every person and corporation shall pay a tax in proportion to the value of his, her, or its tangible property. ... 
[ $\llbracket 2]$ Intangible property may be exempted from taxation as property or it may be taxed in such manner and to such extent as the Legislature may provide. Provided that if intangible property be taxed as property the rate thereof shall not exceed five mills on each dollar of valuation. When exempt from taxation as property, the taxable income therefrom shall be taxed under any tax based on incomes, but when taxed by the State of Utah as property, the income therefrom shall not also be taxed.

[ $[3]$ The Legislature may provide for deductions, exemptions, and/or offsets on any tax based upon income. The personal income tax rates shall be graduated. . . .

The other important uniformity provision, Art. XIII, §2, reads in part:

All tangible property in the State, not exempt under the laws of the United States, or under this constitution, shall be taxed in proportion to its value, to be ascertained as provided by law. ...

The remainder of the section is concerned with the exemption of property, providing first that certain classes of property (the usual public and quasi-public classes) "shall be exempt from taxation." In addition, other special classes of property either "shall" or "may" be exempted." To be considered along with these two principal provisions is Art. XIII, §12, which provides:

Nothing in this Constitution shall be construed to prevent the Legislature from providing a stamp tax, or a tax based on income, occupation, licenses, or franchises.

In their original forms both sections 2 and 3 of Art. XIII were not limited to "tangible" property, but referred simply to "all property." Also, the second paragraph in Art. XIII,

${ }^{1}$ For the text of Art. XIII, §2, see the Appendix, infra. Article XIII, $\S 4$ provides for special treatment of mines or mining claims. 
\$3, providing for special treatment for intangible property, was not present. In addition, following the proportionality clause in Art. XIII, $\$ 2$, there was originally a definition of "property" which left no doubt that intangible property was to be within the scope of the basic uniformity provisions. The 1930 amendment made the following important changes, namely, it added the intangibles proviso, limited the other provisions to "tangible" property and, obviously, deleted the former definition of "property." Thus, an important exception to the general uniformity limitation was made in 1930 .

\section{b. Meaning of the uniformity limitation}

In view of the particular phraseology of the uniformity clause in the Utah Constitution, Art. XIII, §3, which adds the phrase "on all [tangible] property" to the words of uniformity, there should not be the shadow of a doubt that nonproperty taxes are not limited by this clause. However, the court has found it necessary to rule upon the question when nonproperty taxes were challenged as violating Art. XIII,

2 The word property was defined in the original Art. XIII, §2, as follows: The word property, as used in this article, is hereby declared to include moneys, credits, bonds, stocks, franchises, and all matters and things (real, personal, and mixed) capable of private ownership; but this shall not be so construed as to authorize the taxation of the stocks of any company or corporation when the property of such company or corporation represented by such stocks has been taxed. . . .

Also to be noted is paragraph 3 of Art. XIII, $\$ 3$, which was added by the 1930 amendment and which deals with the details of a personal income tax.

A particular problem of uniformity was dealt with by an earlier 1906 amendment to Art. XIII, §3. A proviso was then added which declared: "Provided, further, that mortgages upon both real and personal property shall be exempt from taxation." This amendment dealt with a specific problem of "double taxation," and was a result of the Spencer case decided in 1897. See note 8 , infra. This proviso, of course, was deleted with the 1930 amendment because it was dealt with in the larger intangibles provision. 
$\S 3 .^{3}$ Such taxes must only be uniform within classes, ${ }^{4}$ and a graduated rate schedule has been held reasonable. ${ }^{5}$ of course, the question of graduated rates is expressly settled for income taxation by the requirement in Art. XIII, §3, that "The personal income tax rates shall be graduated."

Because of the strict uniformity requirement applicable to property taxes, it is always of some importance to determine the character of any tax. The court has held that an inheritance tax is not a property tax but a tax upon the privilege of succession. ${ }^{6}$ Moreover, the greatest possible source of controversy was removed by Art. XIII, §12, which approves an income tax.

\section{(1) Property taxation}

From 1896 to 1930 . Before the amendments of 1930 the court had substantially outlined the effective uniformity limitation applicable to property taxes. There was a clear requirement of universality, because exemptions of property (other than those classes designated as exemptible by the constitution) were said to be not only contrary not only to the express requirement of Art. XIII, $\$ 2$ that "All property . . . shall be taxed," but also violations of the uniformity

${ }^{3}$ For example, Salt Lake City v. Christensen Co., 34 Utah 38, 95 Pac. 523 (1908).

${ }^{4}$ Davis v. Ogden City, 117 Utah 315, 330-332, 215 P. 2 d 616 (1950) (local occupation tax, attorneys practicing law to exclusion of attorneys working for others, reasonable class); Dixon v. Ricketts, 26 Utah 215, 72 Pac. 947 (1903) (inheritance tax, exemptions therefrom held valid); Garrett Freight Lines v. State Tax Comm., 103 Utah 390, 135 P. 2 d 523 (1943) (fuel use tax, subject found to be a reasonable class); Ogden City v. Crossman, 17 Utah 66, 53 Pac. 985 (1898).

${ }^{5}$ Salt Lake City v. Christensen Co., supra note 3.

${ }^{6}$ Dixon v. Ricketts, supra note 4 . The present Utah corporate franchise tax has a base of net income. An earlier such tax had a base of authorized capital stock, and was upheld as a nonproperty tax in Blackrock Copper Min. \& Mill. Co. v. Tingey, 34 Utah 369, 38 Pac. 180 (1908). 
clause of Art. XIII, $\S 3$ requiring " $a$ uniform and equal rate of assessment and taxation on all property." As the court stated in Judge v. Spencer, ${ }^{8}$ a leading Utah uniformity case:

The framers of the constitution . . . evidently intended that no property should be relieved from the burden of taxation, except such as was defined and specified for exemption by that instrument. Such intent appears to be emphasized in section 3. . . This provision made it incumbent upon the legislature to provide a uniform system by which every species of property within the state, not exempt by the organic law, should equally and ratably bear its due proportion of the public burden, and the legislature had no power to exempt property not exempt under the constitution.

To carry out the purpose of the uniformity provisions there had to be an absolute uniformity in the effective rate applicable to all property taxed by any one taxing authority. ${ }^{9}$ However, this limitation was not violated by the taxation of both a mortgage and the property mortgaged because, as the court held in the Spencer case, they were two distinctly different species of property; consequently there was no "double taxation." 10 The court never had an occasion to

${ }^{7}$ State ex rel. Richards v. Armstrong, 17 Utah 166, 53 Pac. 981 (1898), in which a statute authorizing the remission or abatement of taxes of any insane, idiotic, infirm, or indigent person to the amount not exceeding $\$ 10$ per year was held contrary to Art. XIII, $\$ \S 2$ and 3 . It was held that calling the tax relief an "abatement" did not remove it from the universality requirement.

815 Utah 242, 245-246, 48 Pac. 1097 (1897).

${ }^{9}$ For example, First Nat. Bank v. Christensen, 39 Utah 568, 118 Pac. 778 (1911), in which it was held that the assessment by county taxing officers of realty, livestock, merchandise and chattels at $50 \%$ to $70 \%$ of actual or cash value and the assessment of moneys or shares of stock in manufacturing or industrial enterprises, or investments, at actual or cash value, was a violation of the uniformity clause, Art. XIII, §3. Also see the dictum in Continental Nat. Bank v. Naylor, 54 Utah 49, 179 Pac. 67 (1919).

${ }^{10}$ Judge v. Spencer, supra note 8 at 247-249. It is to be noted that the original Art. XIII, $\S 2$, see note 2 supra, prohibited the taxation of corporate 
specifically rule that property had to be taxed ad valorem. ${ }^{11}$ In view of the prolix uniformity provisions, however, the answer was hardly in doubt since Art. XIII, §3 required the taxation of all property "according to its value," a "just valuation for taxation of all property," and that every person pay a tax "in proportion to the value" of his property; and, in addition, Art. XIII, $\$ 2$ required all property to be taxed "in proportion to its value." Indeed, the universality requirement, as well, was spelled out in several places, both in Art. XIII, $\S 2$ and $\S 3$. Thus, the strict uniformity limitation under the original Utah uniformity structure might well have stemmed from any one of several provisions, all of which standing alone have served as a basic uniformity clause in some of the other state constitutions.

From 1930 to the present; intangibles taxation. Insofar as the taxation of tangible property is concerned, the same effective uniformity limitation continues to be applicable after 1930 as was applicable before that time. However, the 1930 amendments to Art. XIII, $\$ 2$ and $\$ 3$ limited the uniformity requirement, at least to some degree, to the taxation of tangible property. Thus, since 1930 the problem has been: what degree of uniformity is required in Utah in the taxation of intangible property? There has been no interpretation of the intangibles clause in Art. XIII, §3, and the only

shares as property while the property of the issuing corporation was taxed at the same time. Cases interpreting this provision were: Commercial $\mathrm{Na}$ tional Bank v. Chambers, 21 Utah 324, 61 Pac. 560 (1900); McCornick \& Co. v. Bassett, 49 Utah 444, 164 Pac. 852 (1917); and Stillman v. Lynch, 56 Utah 540, 192 Pac. 272 (1920). Because of the explicit constitutional provisions which deal with this problem, the cases cited must be used with particular care in comparing with cases in other jurisdictions on this particular problem of "double taxation."

${ }^{11}$ But see the recent case, Commercial Bank of Utah v. State, 244 P. $2 \mathrm{~d}$ 364 (1952). Also see State ex rel. Cunningham v. Thomas, 16 Utah 86, 50 Pac. 615 (1898). 
extent to which the Utah legislature has utilized this provision is simply by exempting intangibles from taxation as property. ${ }^{12}$ Certainly there is no doubt that under the amended uniformity provision the total exemption of intangibles is constitutional. However, there might be some question as to the scope of the discretion resting in the legislature insofar as the separate taxation of intangibles is concerned. It would appear to this writer that it is not an unreasonable reading of the intangibles provision to conclude that in the taxation of intangible property, as such, the legislature is not limited either by an ad valorem requirement or a requirement that the effective rate be absolutely uniform as to all intangible property taxed. The key words are: "intangible property may be exempted from taxation as property or it may be taxed in such manner and to such extent as the Legislature may provide." The words "such manner" certainly could well imply a classified intangibles tax or the use of a specific rather than an ad valorem tax. The sole limitation would seem to be in the following sentence: "Provided that if intangible property be taxed as property the rate thereof shall not exceed five mills on each dollar of valuation." This provision, might, of course, carry a backhanded implication that if intangibles are taxed "as property," then a specific property tax would be prohibited, since the rate limitation is stated in terms of value. In any case, the Utah legislature has not separately taxed intangibles as such, and, consequently, the court has had no occasion to go into the ramifications of the intangibles amendment.

12 Utah Code Ann. (1953) §59-1-1. 
G. ANALYSIS OF STATES WITH TYPE VII CLAUSES

\section{Colorado}

\section{a. The provisions; historical note}

Colorado has had but a single constitution, dated 1876. The basic uniformity clause is found in Art. X, $\$ 3$, and has remained unchanged. Section 3 reads:

All taxes shall be uniform upon the same class of subjects within the territorial limits of the authority levying the tax, and shall be levied and collected under general laws, which shall prescribe such regulations as shall secure a just valuation for taxation of all property, real and personal; provided, that the personal property of every person being the head of a family to the value of $\$ 200$ shall be exempt from taxation. ...

A very important clause to be read in connection with the above uniformity clause is Art. X, $\S 6$, which provides:

All laws exempting from taxation, property other than hereinbefore mentioned, shall be void; . . .

The omitted part of Art. X, $\S 6$ is a proviso added by amendment in 1936. It provides for special treatment of motor vehicles, trailers, and semi-trailers. That proviso requires the legislature to classify such vehicles and require the payment of a "graduated annual specific ownership tax thereon," the tax being in addition to the state license fees, but "in lieu of all ad valorem taxes upon such property . . . provided, further, that such laws shall not exempt from ad valorem taxation motor vehicles, trailers and semi-trailers in process of manufacture, or held in storage, or which constitute the stock of manufacturers, or distributors thereof or of dealers therein." Rounding out the uniformity structure

1 The omitted part of Art. $X, \S 3$ concerns certain property used for irrigating land, for which special treatment is provided. 
as it stood in the original constitution are Art. X, $\S \S 4$ and 5, which require the exemption of designated classes of property (the usual public and quasi-public classes). ${ }^{2}$

An important change in the uniformity structure of the Colorado Constitution was made by amendment in 1936. The basic uniformity clause in Art. X, $\S 3$ was left unchanged, and a new section, Art. $X, \S 17$, was added to the constitution. It reads:

The general assembly may levy income taxes, either graduated or proportional, or both graduated and proportional, . . . and may, in the administration of an income tax law, provide for special classified or limited taxation or the exemption of tangible and intangible personal property.

\section{b. Meaning of the uniformity limitation}

The Colorado Supreme Court has simply assumed from the inception of the constitution that the uniformity clause in Art. X, $\S 3$ applies only to property taxes. ${ }^{3}$ Nonproperty taxes are required to be uniform within classes. The objects of such taxes must be reasonable classes, ${ }^{4}$ but may be further

2 For text of Art. X, $\S \S 4$ and 5, see the Appendix, infra. Another provision which has some relevancy for determining the uniformity limitation is Art. $X, \S 10$, which provides that:

All corporations . . . shall be subject to taxation for state, county, school, municipal and other purposes, on the real and personal property owned or used by them within the territorial limits of the authority levying the tax.

${ }^{3}$ An early leading case is Denver City Ry. Co. v. Denver, 21 Colo. 350 , 41 Pac. 826 (1895). For a recent case, see, for example, Jackson v. City of Glenwood Springs, 122 Colo. 323, 221 P. 2 d 1083 (1950).

4 For example, Altitude Oil Co. v. People, 70 Colo. 452, 202 Pac. 180 (1921); Ard v. People, 66 Colo. 480, 182 Pac. 892 (1919); Brown v. Elder, 32 Colo. 527, 77 Pac. 853 (1904); Hughes v. State, 97 Colo. 279, 49 P. 2d 1009 (1935); Public Utilities Comm. v. Manley, 99 Colo. 153, 60 P. 2 d 913 (1936). In all of these cases, classifications were found to be reasonable. 
classified for the purpose of applying classified rate schedules. ${ }^{5}$ It appears that a graduated rate is permissible. ${ }^{6}$ It is interesting to note that in an early case establishing the rule as to nonproperty taxes, the court simply tossed the uniformity clause in section 3 into a single category with all other uniformity clauses found in other state constitutions. No distinctions were made as to differences in phraseology; indeed, the court quoted from a text which implied that regardless of phraseology all "uniformity clauses" produced the same result. ${ }^{7}$

In any case, the distinction between property and nonproperty taxes is accepted, and because of the stricter uniformity required of property taxes it is always of considerable importance to characterize any given tax. As in most of the other states the court has used no ascertainable systematic approach which gives a reasonably sure test to distinguish between property and nonproperty taxes. ${ }^{8}$ However, the court has held that an inheritance tax is a nonproperty tax on the privilege of succession, ${ }^{9}$ and that a corporate franchise

5 Brown v. Elder, supra note 4; Jackson v. City of Glenwood Springs, supra note 3.

The inheritance tax, upheld in Brown v. Elder, supra note 4, had a graduated rate. Also see Jackson v. City of Glenwood Springs, supra note 3, in which a city tax on businesses and professions, graduated according to the number of employees, was upheld.

${ }^{7}$ Denver City Ry. Co. v. Denver, supra note 3 at 353-4.

8 The Colorado court has generally used the term "excise" to designate nonproperty taxes. And, especially in the earlier cases, the court went to some length to distinguish between property and "excise" taxes, ending with the rather hazy distinction that excise taxes were fundamentally grounded in the police power while "taxes" were "purely" revenue measures. At times the court has run into some difficulty, albeit a verbal difficulty of its own making, in determining whether a particular tax was an excise tax when there was little apparent regulatory purpose embodied in the statute. See the cases in notes 3 and 4, supre.

${ }^{\circ}$ Brown v. Elder, supra note 4. 
tax with a base of capital stock was a nonproperty tax. ${ }^{10}$ In Walker v. Bedford, ${ }^{11}$ the court held that a motor vehicle tax with a base of value and a graduated rate schedule was a property tax and a violation of the uniformity clause in Art. $\mathrm{X}, \S 3$, for reasons discussed below. ${ }^{12} \mathrm{~A}$ provision has been added to the Colorado Constitution (Art. X, \$17) which expressly sanctions an income tax. Thus, any controversy over the nature of such a tax has been rendered moot. Nor were there any cases prior to this 1936 amendment which might be useful for a comparative study of the problem.

\section{(1) Property taxation}

From 1876 to 1936. It was never made quite clear just how far, if at all, the legislature was free to classify property for purposes of taxation under Art. X, $\$ 3$, in the absence of Art. $X, \$ 17$. It did seem clear that property could only be taxed by the ad valorem method; thus specific property taxation would have been prohibited. ${ }^{13}$ Also, it was made quite clear that there was a requirement of universality in the tax-

${ }^{10}$ American Smelting \& Refining Co. v. People, 34 Colo. 240, 82 Pac. 531 (1905).

1193 Colo. 400, 26 P. 2d 1051 (1933).

12 The tax which was held invalid in the Walker case was an additional tax, intended to supplement a motor vehicle registration tax having a base of horsepower, rather than value. In Ard v. People, supra note 4, the registration tax was held to be a nonproperty tax. The type of tax struck down in the Walker case is now dealt with specifically by the amendment made in 1936 to Art. X, $\S 6$ of the constitution. Also see Public Utilities Comm. v. Manley, supra note 4.

13 This point has not been squarely passed upon, but see the obvious implication in Kiowa v. Dunn, 21 Colo. 185, 40 Pac. 357 (1895), discussed infra, text at note 20 . This rule would, in any case, pretty obviously stem from the "just valuation for taxation of all property" clause in Art. X, $\$ 3$. The issue was also raised in cases concerning taxes held to be nonproperty taxes, which consequently made it unnecessary to rule upon the question. See, e.g., Altitude Oil Co. v. People, supra note 4, upholding the fuel use tax as a nonproperty tax. 
ation of property, and no distinction was made between "exemption"14 and "selection." The prohibition against exemptions, at least, was spelled out in Art. X, $\S 6$, which is quite explicit on that matter: "All laws exempting from taxation, property other than hereinbefore mentioned, shall be void. . . " The court has not, however, distinguished the failure to select from a positive exemption, ${ }^{16}$ and in an early leading case, Gunnison v. Owen, ${ }^{17}$ the uniformity clause itself was apparently relied on in striking down an exemption of property from taxation.

This development left only the possibility that the legislature might classify that property selected for taxation for the purpose of applying different effective rates to the several classes. Indeed, the court indicated on a number of occasions that such a classification was permissible. However, in fact the court never approved any attempted classifications. The classifications which were reviewed were held to

14 Gunnison v. Owen, 7 Colo. 467, 4 Pac. 795 (1884) (holding invalid a statute which exempted urban property from a general tax imposed by counties for road purposes); Imperial Fire Ins. Co. v. Denver, 51 Colo. 456, $118 \mathrm{Pac} .970$ (1911) (holding invalid the in lieu provision of a statute imposing a gross premiums tax on insurance companies; the in lieu provision purported to exempt the personal property of such corporations from all taxation), followed in Colorado Nat. Life Assur. Co. v. Clayton, 54 Colo. 256, 130 Pac. 330 (1913). In Board of Com'rs of Washington County v. Murray, 71 Colo. 522, 208 Pac. 472 (1922) the court upheld a statute providing for the assessment of real estate mortgages. It had been contended that there was an unconstitutional exemption of property from taxation. But the court said that the taxation of real estate and a mortgage thereon separately would constitute "double taxation." The statute provided that both items should be assessed as a unit, and notes and mortgages were thereafter not to be otherwise assessed. This was not an "exemption." Also see Logan Irr. Dist. v. Holt, 110 Colo. 253, 133 P. 2d 530 (1943), discussed infra, note 28 .

${ }^{15}$ Gordon v. Wheatridge Water Dist., 107 Colo. 128, 109 P. 2d 899 (1941), discussed infra, notes 27 and 28.

${ }^{16}$ See note 15 , supra.

17 Supra note 14. 
be arbitrary discriminations violating the uniformity clause in Art. X, §3. One is perhaps justified in feeling that, apart from the special provisions introduced by Art. X, $\$ 17$, any classification of property more narrow than real property, tangible personal property, and intangible property would in all likelihood be disapproved under the court's construction of Art. X, §3.

Several cases concern the effort of the legislature to subject certain "transient" personal property (livestock entering the county for grazing purposes after the general assessment date of April 1st) to the county general property tax rates. ${ }^{18}$ This statutory scheme was held to be an arbitrary discrimination and therefore a violation of the uniformity clause in Art. $\mathrm{X}, \S 3$. The court reasoned that other property of the same class (i.e., livestock brought into a county, but not for purposes of grazing, as well as all other personal property brought into the county after the general assessment date) would not be subject to the tax. ${ }^{10}$ On closer analysis it would seem that these cases are really problems of selection for the general property tax. The opinions reasoned that all property of a class, presumably personal property, was not subject to the tax. But the differentiation was not between two different rates, but between a rate for part of the class and "zero" rate, i.e., exemption, for the remainder of the class. The court on numerous occasions had held that a rule of universality obtains. It is not a matter of discrimination within a class of property when the question is one of either a tax at the general rate or no tax at all. Rather, all taxable property should be taxed if any is taxed. And there was no question in these transient livestock cases of classifying the prop-

${ }^{18}$ Carbon County Sheep \& Cattle Co. v. Routt, 60 Colo. 224, 152 Pac. 903 (1915); Hutchinson v. Herrick, 70 Colo. 534, 203 Pac. 275 (1922). Also see Leonard v. Reed, 46 Colo. 307, 104 Pac. 410 (1909).

${ }^{19}$ Carbon County Sheep \& Cattle Co. v. Routt, supra note 18 at 226, 229-230. 
erty for different rates. In any case, on whatever rationale decided, the cases do indicate that classifications of property will be very, very critically examined.

More in point is Kiorva v. Dunn. ${ }^{20}$ The legislature had provided that a special tax rate was to be applicable to livestock belonging to nonresidents and brought into the state for grazing. The rate was different from that applied under the general property tax. The court held that the statute was a clear violation of the uniformity clause, Art. X, $\S 3$, because the property of a nonresident was taxed at a different rate than that of a resident. No clarifying statement was offered as to whether livestock was considered a minimum class of property, or whether personal property generally was considered the minimum class. The court simply emphasized that residence of the owner of the property was not a sufficient basis for a reasonable classification.

Finally, in Walker v. Bedford, ${ }^{21}$ a 1933 case, the court quite clearly indicated its view of the rather limited power of classification resting in the legislature by virtue of the words in Art. X, $\S 3$. In that case, the issue concerned the validity of a statute, enacted by the legislature to gain revenue for purportedly emergency purposes, which levied an additional registration fee on motor vehicles used upon highways. There already existed a motor vehicle registration tax which had a base of horsepower and which had been upheld as a nonproperty tax. ${ }^{22}$ The base of the additional

20 Supra note 13. The statute provided that all stock belonging to nonresidents brought into Colorado for grazing purposes was to be taxed at $50 \phi$ per head, except sheep which were to be taxed at $20 \phi$ per head. These taxes were to be in lieu of all local and state taxes.

21 Supra note 11. But see Hughes v. State, supra note 4 , in which an additional emergency tax on inheritances was held to be an excise tax. In that case a vigorous dissent asserted that the problem was identical to that in the Walker Case.

22 Ard v. People, supro note 4. 
tax was to be the value of the vehicle, and the rate was graduated. In a 4-3 opinion, the majority of the court held that this additional motor vehicle tax was in fact a tax upon property, as such, and void as contrary to the uniformity clause in Art. $X, \S 3$. The rationale of the court was as follows:

It appears plain to us that the act imposes a property tax. ... No other kinds of personal property are made the subject of the tax; motor vehicles alone are to bear the burden.

No further elucidation was offered, other than a bare conclusion, stated after the tax had been distinguished from excise taxes upheld in the past:

And since it is a property tax and is manifestly not 'uniform upon the same class of subjects within the territorial limits of the authority levying the tax,' the act . . . is held to be repugnant to [the uniformity clause]. ${ }^{23}$

One may fairly conclude that the court was thinking in terms of personal property-at least-being a minimum class for purposes of taxation.

Thus, before 1936 a reading of the uniformity clause and nothing more than a cursory examination of what the court has said ${ }^{24}$ might well have led one to believe that property

${ }^{23}$ Walker v. Bedford, supra note 11 at 405, 406. Emphasis added.

24 The Colorado case most often quoted concerning the power of the legislature to classify property for purposes of taxation is, in fact, a case concerning classification for the purpose of using different methods of assessment for the several classes. Ames v. People, 26 Colo. 83, 56 Pac. 656 (1899). The legislature may classify property under the general property tax for the purpose of method of valuation; however, those opinions and the broad statements therein must be read in the context of that particular issue. See, besides the Ames case, People v. Henderson, 12 Colo. 369, 21 Pac. 144 (1888) ; Foster v. Hart Consol. Mining Co., 52 Colo. 459, 122 Pac. 48 (1912). Also see the more recent case of Citizens' Committee v. Warner, 127 Colo. 121, 254 P. 2d 1005 (1953). Nor are the cases concerning the issue of uniformity in ratio of valuation of much help on this problem. See, for example, People v. Pitcher, 56 Colo. 343, 138 Pac. 509 (1914). 
could have been classified for the purpose of applying different effective rates. However, a closer examination of the decisions indicates that, in fact, little, if any, classification was permissible. Of course, it must be admitted that at no time was the court faced with a systematic classified property tax which would have forced a closer examination of the uniformity clause.

After 1936. The limited change in the uniformity required of property taxation which occurred in 1936 resulted from the introduction of a new section, Art. X, $\$ 17$, which provides that the legislature

... may, in the administration of an income tax law, provide for special classified or limited taxation or the exemption of tangible and intangible personal property.

The most important feature to note is that the new uniformity limitation applicable to the taxation of "tangible and intangible personal property" is conditional. Any special treatment of personal property based upon the authority of Art. X, $\$ 17$ must be coupled with "the administration of an income tax law." In fact, the legislature has made use of this provision only to the following extent: intangible personal property is now exempt from the general property tax. ${ }^{25}$ This exemption was upheld in City E County of Denver v. Tax Research Bureau, ${ }^{26}$ decided in 1937. In that case the court characterized the income tax as an intended substitute tax for those taxes from which personal property might be relieved.

Other than in the Denver case, the court has had no occasion to interpret the effect of the personal property provision in Art. X, $\S 17$. However, it would appear that unless personal property is dealt with in conjunction with the ad-

${ }^{25}$ Colo. Stat. Ann. c. $84.1, \S 48$.

${ }^{26} 101$ Colo. 140, 71 P. 2d 809 (1937). 
ministration of an income tax the same uniformity limitation is applicable as that in force before the 1836 amendment. Thus, in Gordon v. Wheatridge Water Dist., ${ }^{27}$ decided in 1941, the court held that the imposition of a property tax (it was agreed that the exaction in question was not a special assessment) by a special district only upon real estate violated Art. X, $\S \S 3$ and 6 . The court said:

For these reasons we must conclude that the exaction imposed was intended to be a general tax [i.e. not a special assessment]. Being such, it must conform with the uniformity and exemption clauses of the Constitution. That it does not so comply is evident from the fact that in laying a tax on realty solely, the act excepts and exempts personalty. The act in so far as it attempts to authorize this result thus is void. $^{28}$

Thus, the only definite change wrought by the 1936 amendment was the possibility of the exemption of personal property, in part or in whole, if such an exemption was made in conjunction with an income tax.

An intriguing question remains: What is the meaning or the implication of an amendment to the constitution which provides that, conditionally, the legislature might "provide for special classified or limited taxation" of personal property? Does this mean that such classified treatment (other than exemption) was not permissible under Art. X, §3 providing that "all taxes shall be uniform upon the same class

27107 Colo. 128, 109 P. 2d 899 (1941).

${ }^{28}$ ld. at 137. Emphasis added. Also see Logan Irr. Dist. v. Holt, supra note 14 , in which the court held that a statute was invalid insofar as it attempted to exempt certain property used for irrigation purposes. It was said that the legislature could not expand the provision in Art. X, §3, providing for special treatment in the taxation of such property. In re Hover Motors, 121 Colo. 439, 217 P. 2d 863 (1950), involved an interpretation and application of the special motor vehicle tax and exemption proviso added in 1936 to Art. X, $\S 6$, and the relation of that section to the general prohibition against exemption of property. 
of subjects?" What of the cases which implied that some degree of classification might be permitted under Art. X, §3? The answers are speculative, but under Art. X, $\S 3$ the legislature was probably limited to the broad classification of property into no more than three classes: realty, tangible personalty, and intangible personalty. And, quaere as to the extent to which the court would have allowed even this sort of classification under a systematic classified general property tax. The Colorado situation aptly illustrates how even under one of the apparently more liberal uniformity clauses it may be necessary in the end to amend that provision in order to classify property to any substantial degree for purposes of taxation. The Colorado decisions indicate a judicial attitude which simply ignores the possibility that such a provision means what it says, and continues to lump all uniformity clauses together. ${ }^{20}$

\section{Delaware}

In the original Delaware Constitution of 1776 and the succeeding constitutions of 1792 and 1831 there were no provisions expressly dealing with uniformity of taxation. The present Delaware Constitution, effective in 1897, has a uniformity clause in Art. VIII, $\S 1$, which reads:

All taxes shall be uniform upon the same class of subjects within the territorial limits of the authority levying the tax, and shall be levied and collected under general laws, but the General Assembly may by general laws exempt from taxation such property as in the opinion of the General Assembly will best promote the public welfare.

This brief provision contains substantially the entire uniformity structure of the present Delaware Constitution, although Art. X, $\S 3$, which requires the exemption of certain

${ }^{29}$ But see Gordon v. Wheatridge Water Dist., supra notes 15, 27 at 137. 
property used for educational purposes, must also be considered. $^{1}$

It appears that in Delaware all taxes-nonproperty as well as property - are limited by the uniformity clause found in Art. VIII, $\$ 1$. In the single case concerning uniformity in nonproperty taxes, Conard v. State, ${ }^{2}$ decided in 1940, the court reviewed a statute which imposed an occupation tax having a flat rate on the business of carrying fishing parties for hire with the purpose of fishing in designated waters. The statute exempted the use of boats propelled exclusively by oars. It was held that the tax did not violate either Art. VIII, $\S 1$, or the federal equal protection clause. ${ }^{3}$ The exemption was challenged as being arbitrary. The court, in summing up the uniformity requirement, at least for nonproperty taxes, equated the uniformity clause in Art. VIII, $\S 1$, with the federal equal protection clause in the fourteenth amendment to the United States Constitution. The court said:

In either case [i.e., under the equal protection clause or under Art. VIII, $\S 1$ ] the constitutionality of the act is to be determined by the reasonableness of the classification attempted. The governing rules are largely the same, and generally a tax violating one of the provisions violates the other. . . .

The question, therefore, is whether classifying separately

1 See the Appendix for the provision. Also see Art. IX, §6, which provides that:

Shares of the capital stock of corporations created under the laws of this State, when owned by persons or corporations without this State, shall not be subject to taxation by any law now existing or hereafter to be made.

This section was added to the Delaware Constitution in 1903.

241 Del. 107, 16 A. 2d 121 (1940).

${ }^{3}$ The tax also made a distinction between residents and nonresidents. The tax was $\$ 10$ for residents, $\$ 50$ for nonresidents. This classification was held to be a violation of the federal equal protection clause, but the act was invalid only to the extent that a greater burden was placed on the nonresident. Id. at 116-120. 
boats propelled exclusively by oars, and exempting them from the operation of the act, is a reasonable exercise of the legislative power of classification.

It is generally agreed that a classification for the purposes of taxation, not purely arbitrary but based on reason, is entirely proper; and that uniformity as applied to occupation taxation simply means taxation that acts alike on all persons similarly situated. The differences upon which the classification is based need not be great or conspicuous; nor is it necessary that the court perceive the precise legislative reason for the classification, for in any state of facts can reasonably be conceived that would sustain the classification, the existence of that state of facts at the time of the enactment of the law must be assumed. ${ }^{4}$

That the same liberal interpretation is given to the uniformity clause when it is applied to property taxes is indicated in State v. Pinder, ${ }^{5}$ decided in 1919. In that case, the court upheld the 1917 income tax law. It was argued by the defendant that the tax was a nonproperty tax, that the legislature was limited to taxation of property, and, therefore, that the income tax was not within the power of the legislature. The court rejected this construction of Art. VIII, $\$ 1$, but declared that, in any case, the income tax was a property tax. Its rationale was that the tax was upon income as property. Having determined the nature of the tax, the exemptions in question (certain exemptions according to sources of income, and a minimum exemption of $\$ 1000$ ) were held to be reasonable classifications.

There are only two other Delaware cases pertinent to the uniformity issue, and they concern the classification of realty for the local general property tax. In 1898, the legislature by 21 Del. Laws, c. 106 provided for the classification of realty in the City of Wilmington as follows:

$\S 1$. It shall be the duty of the Board . . . to classify the

${ }^{4}$ Id. at 114-115, emphasis added.

5 30 Del. (7 Boyce) 416, 108 Atl. 43 (1919). 
real estate so assessed in such a manner as to discriminate between the rural or suburban, and the built up portion of said City; ... a and it shall be the duty of the Council [of said City] in determining the rate of taxation for each year to levy a tax upon said rural or suburban property equal to one-half of the highest rate of tax required to be levied for said year; so that upon the real estate assessed in said City there shall be two rates of taxation.

In the case of Monaghan v. Lewis, ${ }^{\circ}$ decided in 1905, the court did not directly pass upon the validity of this classification but did, by implication, approve it as constitutional. A taxpayer had challenged the 1898 act on several counts, primarily attacking its validity under the state constitutional limitations on legislative procedure. The court found that the 1898 act was validly enacted, and that it repealed by implication an 1897 act which had provided that land in a specified area of the city was to be taxed at one fourth the rate applicable to other realty. The court asserted that the 1897 act would have been a violation of that part of Art. VIII, §1 requiring taxes to be "assessed and collected under general laws," because the 1897 act was special rather than general. No question was raised concerning the power to classify as illustrated by the 1898 act.

However, in the very recent case of Philadelphia $B$. E W.R. Co. v. Mayor E Council of Wilmington, the Delaware Court of Chancery was directly faced with determining the validity of tax assessments under the $1898^{\circ}$ act authorizing the above classification. A bill in equity was filed, its purpose being to remove the cloud of an alleged improper municipal tax lien on the plaintiff's property and to secure an injunction against the collection of the tax levied. For

621 Del. 218,59 Atl. 948 (1905).

730 Del. Ch. 213,57 A. 2d 759 (1948).

8 It was held, id. at $218-220$, that the 1898 act was not repealed by implication by 28 Del. Laws, c. 121 (1915). However, the 1898 act has since been expressly repealed by Del. Laws 1949, c. 328 . 
many years prior to 1947 , plaintiff's property located in the city of Wilmington had been classified as rural property, and had consequently been taxed at the lower general property tax rate. In 1947, the proper authorities reclassified plaintiff's property and taxed it at the full rate as "built up" property. One of the questions raised by the pleadings in this case was whether the 1898 law (21 Del. Laws, c. 106) violated Art. VIII, $\S 1$ of the 1897 constitution..$^{9}$ The court, in concluding that it did not, stated:

Under the language of Section 1, Article VIII, it is, necessarily, conceded that the Legislature has the right to classify property for the purpose of taxation, provided the classification adopted is reasonable and not purely arbitrary. ${ }^{10}$

The court concluded that lands used for agricultural purposes might be classified and taxed at a lower rate than other realty within the territory of the taxing authority. ${ }^{11}$

The above four cases are the only Delaware opinions concerning the meaning of the uniformity clause in Art. VIII, $\$ 1$ of the Delaware Constitution. ${ }^{\mathbf{1 2}}$ However, they are sufficient to indicate the considerable discretion with which the Delaware legislature is vested. As a result of this interpretation of the provision, such questions as the nature of an income tax become relatively unimportant. Moreover, though it has not been attempted, it seems clear that the Delaware legislature might enact a classified property tax if it so desired. ${ }^{13}$

${ }^{9} \mathrm{Id}$. at 218 .

${ }^{10} I d$. at 222 , emphasis added.

${ }^{11} I d$. at $222-225$.

12 But see the recent case, Brennan v. Black, 104 A. 2d 777 (1954), which was decided after the analysis in the text was written. The uniformity problem was simply one among many issues, and none of the conclusions in the text are contradicted in any manner.

${ }^{13}$ At present, there is no state general property-tax rate and the local tax is not classified, although all personal property is exempted. Del. Code Ann. tit. $30, \S 102$. 


\section{Georgia}

\section{a. The provisions; historical note}

Georgia has had several constitutions. In the first three, dated 1789,1798 , and 1865 respectively, there were no provisions dealing expressly with uniformity of taxation. The first such provision was incorporated in the Bill of Rights of the constitution of 1868 , of which Art. I, $\$ 27$ read:

... and taxation on property shall be ad valorem only, and uniform on all species of property taxed.

In the next constitution, dated 1877 , the uniformity structure became more complex. The uniformity clause was placed in Art. VII, §II, $\mathbb{I}$, and phrased as follows:

All taxation shall be uniform upon the same class of subjects, and ad valorem on all property subject to be taxed within the territorial limits of the authority levying the tax.

This basic uniformity clause served during the period from 1877 to 1937. In 1937, Art. VII, §II, \1, of the 1877 constitution was amended so that the part indicated by italics was omitted and certain new material added. The amended uniformity provision read:

All taxation shall be uniform upon the same class of subjects within the territorial limits of the authority levying the tax. Classes of subjects for taxation of property shall consist of tangible property, and one or more classes of intangible personal property including money. The General Assembly shall have the power to classify property including money for taxation, and to adopt different rates and different methods for different classes of such property.

The present constitution of Georgia came into effect in 1945. The uniformity clause, now found in Art. VII, $\$ 1$, IIII, is identical to the amended clause of the 1877 constitution. In addition to this uniformity clause, the uniformity 
structure of the 1945 constitution contains an exemption provision, Art. VII, $\S I, ~ \llbracket I V,{ }^{1}$ providing that the legislature may exempt designated classes of property, and concluding as follows:

All laws exempting property from taxation, other than the property herein enumerated, shall be void.

The list of permissible exemptions is quite extensive. The exemption provisions of the prior 1877 constitution were substantially identical to the present Art. VII, §I, $\| I V$, except that the several permissible exemptions were spread over a number of paragraphs, and the final sentence forbidding other exemptions constituted a separate paragraph (Art. VII, §II, $\llbracket I V$ ).

It is clear that the new constitution of 1945 made no real change in the uniformity structure of the Georgia Constitution, so that the present uniformity limitation is in fact a continuation of that limitation established by the amended 1877 constitution. Three periods stand out in determining the meaning of these uniformity provisions. First, there is the effective uniformity limitation which governed from 1868 to 1877 . The years from 1877 to the present may be divided into two significant periods. First, there is the period from 1877 to 1937 under the uniformity clause in the original constitution of 1877 . Second, there is the period from 1937 to the present, under the uniformity clause in the 1877 constitution as amended in 1937 and carried over into the new constitution of 1945 .

\section{b. Meaning of the uniformity limitation}

The court has consistently ruled that the uniformity clause in Art. VII, §II, $\llbracket I$ of the 1877 constitution, carried over in Art. VII, §I, IIII of the present 1945 constitution,

1 Also see Art. VII, §II, $\llbracket I V$, providing for special treatment, to a degree, for public utilities. For the text of that provision see the Appendix, infra. 
limits all taxes, whether considered property or nonproperty taxes. ${ }^{2}$ However, for nonproperty taxes this has not resulted in any different limitation from that ordinarily found in the other states. Such nonproperty taxes need only have reasonable classes as their objects, ${ }^{3}$ and classifications for rate schedules are permitted. ${ }^{4}$ This includes a graduated rate schedule, upheld in Featherstone v. Norman ${ }^{5}$ when the va-

${ }^{2}$ A leading case is Featherstone v. Norman, 170 Ga. 370,153 S.E. 58 (1930), upholding the Georgia income tax. See note 31, infra. Also see the review of the cases in Wright v. Hirsch, 155 Ga. 229, 234-235, 116 S.E. 795 (1922).

3 There are a large number of Georgia cases on this point, far too numerous to analyze here, all concerned with the usual question of reasonableness of classification. For example, see: City of Atlanta v. Georgia Milk Producers Confederation, 187 Ga. 117, 200 S.E. 712 (1938); Camp v. State, 171 Ga. 25, 154 S.E. 436 (1930); Coy v. Linder, 183 Ga. 583, 189 S.E. 26 (1936); City of Douglas v. South Georgia Grocery Co., 180 Ga. 519, 179 S.E. 768 (1935), finding an arbitrary classification; Ewing v. Wright, $159 \mathrm{Ga} .303,125$ S.E. 445 (1924), finding an arbitrary classification; Forrester v. Edwards, 192 Ga. 529, 15 S.E. 2d 851 (1941); Guerry v. Harrison, 178 Ga. 669, 173 S.E. 831 (1934); Head v. Cigarette Sales Co., 188 Ga. 452, 4 S.E. 2d 203 (1939); Hoffman \& Crowell v. Harrison, 171 Ga. 792, 156 S.E. 685 (1930); Lloyd v. Richardson, 158 Ga. 633, 124 S.E. 37 (1924); Mutual Reserve Fund Life Ass'n v. Augusta, $109 \mathrm{Ga} .73,35$ S.E. 71 (1899), finding an arbitrary classification; Richardson v. Citizens Trust Co., 176 Ga. 553, 168 S.E. 306 (1932); Singer Mfg. Co. v. Wright, 97 Ga. 114, 25 S.E. 249 (1895); Southern Transfer Co. v. Harrison, 171 Ga. 358, 155 S.E. 338 (1930); Weaver v. State, 89 Ga. 639, 15 S.E. 840 (1892); Wright v. Fulton County, 169 Ga. 354, 150 S.E. 262 (1929).

${ }^{4}$ For example, see: Farkas v. Smith, 147 Ga. 503, 94 S.E. 1016 (1917) (inheritance tax).

5 Supra note 2. However, in some earlier cases there was controversy concerning this question. In Johnston v. Macon, $62 \mathrm{Ga} .645$ (1879) and O'Neal v. Siloan, 147 Ga. 420, 94 S.E. 238 (1917), certain local occupation taxes with bases of gross value were considered. The court held that the rate for such a tax had to be "ad valorem," that is, a proportional rate as contrasted with the flat rate graduated according to increasing amounts of gross sales. However, those two cases have been distinguished in numerous subsequent cases which have relied on a distinction between the bases of 
lidity of an income tax was considered. However, the graduated rate schedule for the first Georgia chain store tax, dated 1927, was held to be arbitrary for the reason that the rate increased only when more than five stores were owned or operated. ${ }^{6}$ The court has upheld an inheritance tax as a nonproperty tax, ${ }^{7}$ and in a leading case among the state cases on the nature of income taxes, Featherstone v. Norman ${ }^{8}$, that the Georgia income tax was a nonproperty tax. The rationale of the court was that an income tax is not a tax upon property because income is not property within the meaning of the constitutional provisions relating to tax limitations. Consequently, the income tax had only to conform to the uniformity within classes limitation, and the graduated rate schedule and the numerous exemptions were upheld.

\section{(1) Property taxation: 1868 to 1877}

Beginning with the words of Art. I, $\$ 27$ of the 1868 constitution- "taxation on property shall be ad valorem only, and uniform on all species of property taxed"-the court had no trouble in reaching the conclusions that specific property taxes were prohibited, ${ }^{9}$ but exemptions of property were permissible. ${ }^{10}$ Thus, there was no rule of universality.

the taxes under consideration. Other taxes have been upheld in which the tax rate was similar to that struck down in the two cases cited above. For example, an occupation tax on barbershops, with the rate being graduated according to the number of chairs, was upheld in Price v. Richardson, 159 Ga. 299, 125 S.E. 449 (1924).

${ }^{6}$ Woolworth Co. v. Harrison, 172 Ga. 179, 156 S.E. 904 (1931).

7 Farkas v. Smith, supra note 4.

${ }^{8}$ Supra note 2 . The court refused to overrule the Featherstone case in Green \& Milam v. State Revenue Comm., 188 Ga. 442, 4 S.E. 2d 144 (1939). The Featherstone case is discussed in more detail in Part $\mathrm{C}$ of Chapter V.

${ }^{9}$ Livingston v. Albany, 41 Ga. 21 (1870). See the discussion of the tax in question in note 11 , infra.

10 Athens v. Long, 54 Ga. 330 (1875); Waring v. Savannah, 60 Ga. 93 (1878). 
To the contrary, there was considerable controversy concerning the extent to which Art. I, $\$ 27$ limited the effective rates applicable to that property actually selected for taxation. During the nine-year period in which the 1868 constitution was in effect, the confusion which was apparent in the several pertinent opinions was never resolved. The issue turned on a proper construction of the clause "and uniform on all species of property taxed." The difficulty concerned the meaning of the words "species of." A brief chronological review of the decisions will aid in understanding later constitutional development. In Livingston v. Albany ${ }^{11}$ there was dictum to the effect that property had to be uniformly taxed only as to "species" or "classes" of property. However, the statement was wholly unnecessary, the tax being held invalid because it was a specific, rather than an ad valorem tax.

In Augusta v. National Bank $k^{12}$ the plaintiff sought to enjoin the city from collecting a tax levied on shares of stock held and owned by the shareholders in the plaintiff bank on the ground that the tax was illegal. It was alleged that shares were taxed at one per cent, while bonds and notes and other moneyed capital were taxed at only one-fourth of one per cent. The trial court granted an injunction restraining the collection of the tax imposed in excess of one-fourth of one per cent. In affirming this judgment the Georgia Supreme Court clearly stated the view that an absolute uniformity in effective rates was required, saying: "The tax on all species of property must be the same, in order to make it uniform,

${ }^{11}$ Supra note 9. The city enacted an ordinance declaring that "the sum of one dollar be imposed on each and every horse or mule offered and sold within the city by or belonging to horse or mule drovers." The court ruled that the tax was a tax on property, and that it had to fall because it was specific rather than ad valorem.

1247 Ga. 563 (1873). 
as required by the Constitution."13 This view was again expressed two years later in Athens v. Long, ${ }^{14}$ in which the court held that exemptions of property were permitted, but in so holding stated by way of dictum that "upon whatever property a tax is laid, the same shall be by one uniform rate, according to its value."

In the final case on this problem under the 1868 constitution, Waring v. Savannah, ${ }^{15}$ the court indicated its preference for a construction of Art. I, \$27, which would admit the power to classify property for effective rates. However,

${ }^{13} \mathrm{Id}$. at 564 . The court stated:

There can be no discrimination in favor of any one species of property which is taxed, over any other species of property taxed, but the tax imposed must be ad valorem and uniform on all species of property taxed. It necessarily follows, therefore, that the tax to be levied upon the shares of shareholders in the respective banks mentioned in the record by the City . . . must be the same as that levied upon other property-that is to say, the tax on all species of property must be the same, in order to make it uniform, as required by the Constitution. A tax of one per cent on the shares of the shareholders in the respective banks in the record mentioned, and a tax of one fourth of one per cent upon other capital, or other property taxed, is not a uniform tax, within the true intent and meaning of the Constitution. . . . Why should the honestly acquired earning of one man, when lawfully invested in bank stock, be taxed as property, at a higher rate of taxation than the honestly acquired earnings of another man, who has invested the proceeds of his labor in bonds, notes, land, or any species of taxable property? Equality is equity, and when all species of property shall be taxed according to its value, at a uniform rate, then the necessary burden of taxation ... will operate equitably and justly on all. [Emphasis added.]

See note 18 , infra.

14 Supra note 10 at 331 . Also see Wayne v. Savannah, $56 \mathrm{Ga} .449$ (1876), refusing to disturb the injunction granted by a lower court which restrained the taxing of real estate by the city at a greater rate than that applicable to stocks, bonds, moneyed capital, etc. The rates in the ordinance were respectively $21 / 4 \%$ and $1 / 4$ of $1 \%$. The demurrer admitted that the variation in the rates was illegal, and the Supreme Court did not discuss the uniformity question.

$1560 \mathrm{Ga} .93$ (1878). 
the court avoided making a decision on this point. The local general property tax rate was challenged as violating the uniformity clause because (1) it exempted certain property from taxation; (2) realty was taxed at two and one-fourth per cent while interest on bonds, notes, judgments and the like was taxed at only one per cent; and (3) gross earnings of banks and income from certain kinds of business were taxed at one per cent while realty was taxed at two and onefourth per cent. The court first noted that exemptions were clearly permissible. ${ }^{16}$ However, it was admitted that Art. I, $\$ 27$ was ambiguous as to the uniformity required of rates, one possible construction being that all property should be taxed uniformly at the same rate, and the other that "each species" of property should bear the same rate. The court agreed that the language in Augusta v. National Bank and in Athens v. Long seemed to adopt the construction requiring absolute uniformity. However, the language in the Augusta case was set against its background and it was concluded that in the Augusta opinion:

. . . the Chief Justice meant that each species of property should be taxed the same rate. And, by an examination of those cases, it will be seen that the tax complained of was all a tax on personal property-capital employed differently. So that the ruling in that case really is, that tax upon capital - strictly so called-invested in banks, cannot be greater than that invested in bonds, notes, etc. ${ }^{17}$

Falling back on the words of Art. I, $\$ 27$, the court asserted that, certainly, "[ $\mathrm{t}]$ he word 'species' must mean something in the constitution." Otherwise, it could have been omitted. Indicating how it would decide the question the court said:

The true interpretation of the clause is doubtful, and in case ${ }^{16} I d$. at 96.

${ }^{17}$ Id. at $97-98$. The emphasis on the word "meant" is supplied by this writer. Compare note 13, supra. 
of doubt it is, perhaps, best, as we cannot ascertain the precise inequality in this case, to give the benefit of the doubt to the taxing power. Especially, as the Chief Justice, who delivered the opinion in the Augusta Case, informs us that such was his construction and meaning in that case. . . ${ }^{18}$

As for the language of the Athens case, the court discounted it, commenting on the effect of the decision as follows:

Indeed, the principle ruled in the Athens case breaks up the ad valorem and uniform system, if it be construed to be applicable to all property. For, if one species of property can be left out and not taxed at all, what reason can there be for it to be taxed less than another species. . . . ${ }^{19}$

In the final analysis, the court turned the above discussion into dictum when it shifted the basis for the decision from an interpretation of the meaning of the uniformity clause to a decision on the nature of "income." that gross earnings, interest, etc. are "income" rather than "property" in the sense of the constitution and for the purpose at hand. Thus, the "true" question was: "Is income property, in the sense of the Constitution, and must it be taxed at the same rate as other property?" The court ruled negatively on each question, thus concluding that income was not property. ${ }^{21}$ Consequently, it was held that the lower court did not err in sustaining the ordinance of the city as being within the constitution. It was on this last point that the case gained its significance at a later date when the issue arose concerning the validity of an income tax. The Waring

${ }^{18}$ Id. at 98 , emphasis added. But see the words of the Chief Justice, note 13, supra. Note the words emphasized therein.

${ }^{19}$ Id. at 98.

20 The court, id. at 99, also pointed out the difficult problem which would arise concerning an appropriate remedy if it should hold that absolute uniformity should prevail.

21 Id. at 99-100. 
case set the course for the decision on that issue in Featherstone v. Norman ${ }^{22}$ in 1930.

The situation never developed beyond the above discussion under the 1868 uniformity provision. Consequently, it is clear why the Georgia court at a later date could only state that "possibly" taxable property could be classified for rates under the 1868 constitution. ${ }^{23}$ Also, this background of judicial conflict makes for better understanding of the opinions interpreting the uniformity clause under the subsequent constitution of 1877 .

\section{(2) Property taxation: 1877 to 1937}

An increased strictness in the effective uniformity limitation governing the taxation of property was brought about by the 1877 constitution. The uniformity clause of that constitution was substantially different from the clause in the prior constitution of 1868 . The "ad valorem" clause remained, but the "uniform on all species of property taxed" clause was replaced with the words "All taxation shall be uniform upon the same class of subjects."

As indicated above, ${ }^{24}$ the court held that the uniformity clause of the 1877 constitution applied to all taxes. And two cases decided within a few years after the new constitution came into effect spelled out the uniformity required of property taxes. In Verdery v. Summerville, ${ }^{25}$ decided in 1888 , the court held that the imposition of a property tax reaching only real property would violate both the uniformity clause and the clause expressly prohibiting exemptions.

22 Supra notes $2,8$.

23 Thus, in Verdery v. Summerville, 82 Ga. 138, 139, 8 S.E. 213 (1888), citing the Waring case, the court said: "There are, if not direct decisions, some intimations to that effect [that classification for rates was permissible]."

${ }^{24}$ See text at note 2 , supra.

25 Supra note 23. 
As for the latter provision, the court asserted that the failure to tax personalty was, in fact, an exemption..$^{26}$ In addition, distinguishing the 1877 clause from that found in the 1868 constitution, the court began its opinion by expressing the view that the uniformity clause would not permit the classification of property for different rates. Property was a single class. Classification for omission from the tax amounted to no more than classification for a lower rate, namely, "zero." 27

In Savannah v. Weed, ${ }^{28}$ decided two years later, in 1890 , the problem of classification for rates was directly faced. The city of Savannah had classified property under a tax ordinance as follows: real property was to be taxed at two and one-eighth per cent; bank stock at three-tenths of one per cent; and all other personal property at one-half of one per cent. The court held that this system violated the uniformity clause, and in so ruling gave a restrictive interpretation to that constitutional provision. ${ }^{29}$ First, it pointed out that the clause requiring a uniformity within classes of "subjects" was followed in the same sentence by the ad valorem requirement as to "property subject to be taxed." Second, it was ruled that the uniformity clause (apart from the ad valorem clause) applied to all taxes. This aided the court in its conclusion that within the meaning of the uniformity provision, property as a whole was to constitute but a single "subject." Thus, if property was to be taxed, all must be taxed except that designated as exemptible by the constitution; and, once taxed, the ad valorem method must be used and the same effective rate made applicable to all such property taxed.

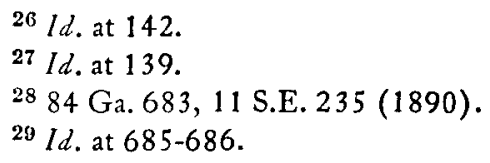


Summarizing, the 1877 uniformity provision, apart from the complementary clause expressly prohibiting exemptions, was interpreted to require universality, ${ }^{30}$ the use of the ad valorem method, and an absolute uniformity in effective rates. ${ }^{31}$ Having thus restrictively interpreted the uniformity provision of the 1877 constitution, ${ }^{32}$ the court set the stage for the amendment of 1937, the purpose of which was to negate to some degree the court's interpretation established in the above line of cases decided during the period from 1877 to 1937.

30 Also see: Georgia State Bldg. \& Loan Ass'n v. Savannah, 109 Ga. 63, 35 S.E. 67 (1899) (holding invalid as contrary to both the uniformity and ad valorem clauses a statutory scheme providing that the taxation of shares to the holders thereof, as property, was to be in lieu of all other taxes assessed against the associations); Brown v. Southern Ry. Co., 125 Ga. 772, 54 S.E. 729 (1906); Georgia R. \& Banking Co.v. Wright, 125 Ga. 589, 54 S.E. 52 (1906); Atlanta Nat. Bldg. \& Loan Ass'n v. Stewart, 109 Ga. 80,35 S.E. 73 (1899).

31 The court seemed to consider both the failure to tax some property (Brown case, supra note 30; Verdery case, supra note 23) and the exemption of property (Atlanta Nat. Bldg. \& Loan Ass'n v. Stewart, supra note 30) as being, in effect, the classification of property for the lower rate of "zero."

32 The scope of the uniformity requirement before the 1937 amendment was rather neatly summed up in the income tax case, Featherstone v. Norman, supra note 2 at 384 , where the court said:

By this provision the makers of the constitution put property in one class and clothed the legislature with ample and full power to classify the subjects of taxation other than property. The legislature cannot classify property, and impose upon one species thereof a different tax from that imposed on other species. Property subject to be taxed is treated as a single class, and there can be levied but one rate on all species of it. . . . But such uniformity does not require that a tax upon all classes of subjects shall be the same or be uniform with the tax imposed upon property. In any class, the uniformity required is that a tax upon each member shall be the same. - . The power of the legislature to classify the subjects of taxation other than property is full, and is subject only to the limitation that the classification must be reasonable and not arbitrary. 


\section{(3) Property taxation: since 1937}

It is important to notice the precise change in terminology made by the 1937 amendment to Art. VII, §II, II, of the 1877 constitution. The "ad valorem" clause was deleted. Two sentences were added which provide that property is to constitute two or more classes: tangible property is a single class, while intangible property (including money) is subject to further classification at the discretion of the legislature. In addition, the specific difficulty of the earlier cases was met by providing that property may be classified and the legislature may "adopt different rates" for the different classes of property. Finally, note the final words, as italicized below:

The General Assembly shall have the power to classify property including money for taxation, and to adopt different rates and different methods for different classes of such property.

The significance of the words concerning "methods" is yet to be determined.

Since the amended provision of the 1877 constitution was carried over verbatim into the new 1945 constitution as Art. VII, §I, IIII, the present effective uniformity limitation in Georgia dates from 1937. Briefly, this is the meaning of that limitation. The requirement of universality remains unchanged..$^{33}$ The express prohibition against exemptions (Art. VII, $\S \mathrm{I}, \llbracket \mathrm{IV})$ is still $a$ source of this requirement. However, under the prior constitution, the requirement of universality was derived from the uniformity clause as such, and it might be pertinent to note that, even in the absence of a clause expressly prohibiting exemptions, the amended uniformity

${ }^{33}$ For example, Sheffield v. State School Bldg. Authority, 208 Ga. 575, 582,68 S.E. $2 \mathrm{~d} 590$ (1952). 
clause expressly mentions the classification of property only for the purpose of using different "rates and methods."

The obvious change made by the amended uniformity clause concerns effective rates. Clearly, an absolute uniformity in effective rates is no longer required; the effective rates need only be uniform within classes of property. But the new requirement in reality makes only a rather limited change, because a large part of property, in general, remains a single minimum class, namely, tangible property. Thus, insofar as tangible property is concerned no change was made by the 1937 amendment. The only real effect of the change was to permit the classification of intangible property for the purpose of applying different effective rates to the different classes. Thus, in Parke, Davis $\mathcal{E}$ Co. v. City of Atlanta, ${ }^{34}$ decided in 1946, the court upheld a statutory scheme providing for the classification and taxation of intangible property. The classification was held not to be unreasonable. And the Georgia legislature has made use of the amended provision to provide for a classified intangibles $\operatorname{tax} .{ }^{35}$

The question remains, must property still be taxed by the ad valorem method, or, does the amended uniformity clause sanction specific property taxes? There has been no interpretation of the provision concerning this particular point. It may be pointed out that the ad valorem clause found in the constitutions of 1868 and 1877 (originally) was deleted by the 1937 amendment. That provision, was, of course, an express source of the ad valorem requirement. However, the deletion of that clause might well be explained by the classification-for-rates problem. In the early cases $^{36}$ under the

34200 Ga. 296, 36 S.E. 2d 773 (1946).

$35 \mathrm{Ga}$. Code Ann. \$92.250.

${ }^{36}$ See Verdery v. Summerville, supra note 23 , and Savannah v. Weed, supra note 28 . 
1877 constitution, the ad valorem clause had been the source of the rationale making property a minimum class. The manner in which the ad valorem clause followed the words of uniformity in the original 1877 uniformity provision was relied on in one line of reasoning to support the conclusion that property was obviously intended to constitute a single class. Thus, the elimination of the prohibition against classification of property for rates might well explain to some extent the deletion of the ad valorem clause.

However, this does not completely explain the new constitutional uniformity provision. What of the words: "to adopt different methods for different classes of such property?" Why include the phrase "different methods" as well as the phrase "different rates?" The express inclusion of reference to rates should indicate an intent for "different methods" to refer to other problems. It would not be unreasonable to conclude that the intent of the amended uniformity clause, as in force today, is that other than the ad valorem method may be used in the taxation of different classes of property. Some question might arise as to whether or not this last sentence concerning rates and methods refers only to the classification of intangible property. In view of the fact that only intangible property may be further classified, it is not unlikely that the Supreme Court of Georgia would take a dim view of a specific property tax on tangible property. ${ }^{37}$

${ }^{37}$ A case decided after the text was written contains dictum indicating that the ad valorem requirement remains for tangible property. See paragraph 2 of Hutchins v. Howard, 211 Ga. 830, 89 S.E. 2d 183 (1955). There was no discussion, only a flat assertion which ignored the abovedescribed textual development of the constitution. As authority, the court simply cited the Verdery case, supra note 23 . The uniformity issue was actually limited to applying the rule requiring absolute uniformity in the effective rate applicable to all tangible property taxed. Perhaps implicit is the idea that this rule of necessity requires the use of the ad valorem method. 
4. Idaho

\section{a. The provisions; historical note}

The uniformity structure of the original and only constitution of Idaho, dated 1890, is found primarily in Art. VII, $\S \S 2$ and 5 , and is rather redundant. There are two provisions, both of which have served as basic uniformity clauses in other state constitutions. The uniformity clause which is used to classify Idaho is found in Art. VII, §5, which also contains both a provision expressly resolving the problem of exemptions of property, and a provision expressly concerning "duplicate taxation." Section 5 of Art. VII reads as follows:

All taxes shall be uniform upon the same class of subjects within the territorial limits, of the authority levying the tax, and shall be levied and collected under general laws, which shall prescribe such regulations as shall secure a just valuation for taxation of all property, real and personal: provided, that the legislature may allow such exemptions from taxation from time to time as shall seem necessary and just . . . : provided further, that duplicate taxation of property for the same purpose during the same year, is hereby prohibited.

The "duplicate taxation" clause is the only such provision found in any of the state constitutions. Of equal importance to the uniformity structure is a "proportionality clause" found in Art. VII, $\$ 2$, similar to the provision which serves as the sole uniformity clause in the states classified as having a Type II clause. Section 2 of Art. VII provides:

The legislature shall provide such revenue as may be needful, by levying a tax by valuation, so that every person or corporation shall pay a tax in proportion to the value of his, her, or its property, except as in this article hereinafter otherwise provided. . . .

1 The omitted part of Art. VII, $\$ 2$ reads:

The legislature may also impose a license tax, both upon natural persons and upon corporations, other than municipal, doing business in this 
In addition to the general clause in Art. VII, $\$ 5$ concerning the power of the legislature to exempt property from taxation, Art. VII, $\S 4$ provides for the mandatory exemption of certain classes of public property. Finally, playing an important part in the development of the meaning of the effective uniformity limitation is Art. VII, $\S 3$, which provides: "The word 'property' as herein used shall be defined and classified by law." This refers to Art. VII, which is entitled "Finance and Revenue."

\section{b. Meaning of the uniformity limitation}

It is clear that taxes in Idaho are classified, for purposes of uniformity of taxation, as either property or nonproperty taxes, ${ }^{2}$ and that nonproperty taxes are required only to be uniform within classes. The objects of such taxes and exemptions therefrom need only be reasonable classifications, ${ }^{3}$ and, in addition, there may be classification of the objects of such taxes for application of different rates. ${ }^{4}$ The court has approved a graduated rate schedule, both under the income

state; also a per capita tax: provided, That the legislature may exempt a limited amount of improvements upon land from taxation.

2 The Diefendorf v. Gallet, 51 Idaho 619, 633, 10 P. 2d 311 (1932), the court stated:

In its modern sense an excise tax is any tax which does not fall within the classification of a poll tax or a property tax, and embraces every form of burden not laid directly upon persons of property.

The Idaho court has used the term "excise tax" to designate the broad class of taxes called "nonproperty taxes" in this comparative study.

${ }^{3}$ See Diefendorf v. Gallet, supra note 2; Idaho Gold Dredging Co. v. Balderston, 58 Idaho 692, 78 P. 2d 105 (1938); Johnson v. Diefendorf, 56 Idaho 620, 57 P. 2d 1068 (1936); J. C. Penny Co. v. Diefendorf, 54 Idaho 374, 32 P. 2d 784 (1934); Smallwood v. Jeter, 42 Idaho 169, 244 Pac. 149 (1926). Finding an arbitrary classification: State v. Crosson, 33 Idaho 140, 190 Pac. 922 (1920).

${ }^{4}$ See Garret Transfer \& Storage Co. v. Pfost, 54 Idaho 576, 33 P. 2 d 743 (1934) and the cases in notes 5 and 6 , infra. 
$\operatorname{tax}^{6}$ and the chain store tax. ${ }^{6}$ The precise source of the uniformity limitation applicable to nonproperty taxes has never been clearly stated. Although the court almost invariably states that the uniformity clauses in Art. VII, $\$ \S 2$ and 5 do not limit nonproperty taxes, nevertheless there is the occasional, rather vague negative assertion that "the equality clause does not forbid reasonable classification." This problem is of trivial concern insofar as nonproperty taxes are concerned; however, it has important implications for the interpretation of the uniformity clause in Art. VII, $\$ 5$ as it applies to property taxes. For, if the court has interpreted the uniformity clause in Art. VII, $\S 5$ as applicable to property taxation alone-and that has probably been its intentthen the phrase "uniform upon the same class of subjects" is limited to property. This, of course, would increase the probability of a decision favoring a classified property tax.

Because of the stricter uniformity required of property taxes it is important to characterize a tax as either property or nonproperty. ${ }^{8}$ No clear test has been developed, but it is of interest to note that a graduated probate fee was held to be a tax on property ${ }^{9}$ and a violation of Art. VII, $\$ 5$ for

${ }^{5}$ Diefendorf v. Gallet, supra note 2.

6 J. C. Penny Co. v. Diefendorf, supra note 3.

7 For example, examine the opinions in Diefendorf v. Gallet, supra note 2, and J. C. Penny Co. v. Diefendorf, supra note 3. Note particularly at pp. 626 and 642 in the Gallet case.

8 There has also been a controversy as to whether the legislature is limited to the property taxes and license taxes enumerated in Art. VII, §2. See note 1 , supra. The court has rejected any restrictive view concerning the types of taxes available. See, for example, the income tax case (Diefendorf $v$. Gallet, supra note 2) and Idaho Gold Dredging Co. v. Balderston, supra note 3, upholding a mining occupation tax which had a base of the value of ore extracted.

${ }^{9}$ Chapman v. Ada County, 48 Idaho 632, 284 Pac. 259 (1930). See note 19 , infra. The court has also held that a mining occupation tax with a base of the value of ore extracted was a nonproperty tax. Idaho Gold Dredging Co. v. Balderston, supra note 3. Idaho has an inheritance tax 
reasons discussed under "Property taxation" below. In Diefendorf $v$. Gallett, ${ }^{10}$ the court held that an income tax was a nonproperty tax. Briefly, the court relied on two lines of argument to reach this conclusion. First, the court made an extensive review of authorities from the other states, and concluded that the weight of authority-with which it agreed -and that an income tax is not a tax on property. The Idaho court favorably viewed the notion that the tax was upon the privilege of producing, creating, and enjoying income. Second, the alternate line of approach was based on Art. VII, $\S 3$ of the state constitution which provides that "The word 'property' as herein used shall be defined and classified by law." The income tax statute purported to "define" income, and defined it as not being property within Art. VII of the constitution. This, the court concluded, was a proper exercise of legislative discretion. But note that implicit in this rationale based on Art. VII, $\S 3$ is the idea that the court is thinking in terms of the power of the legislature to define and classify that which is, and that which is not property. There is no reference here to the classification of property for different treatment of the several classes. Thus, the court reasoned, even if the first line of argument had not been available, the conclusion would still have been reached that the income tax was not a tax on property.

\section{(1) Property taxation}

The meaning of the uniformity limitation has been rather clearly developed by the court, although cases on some points are rather meager; this is understandable in light of the rather prolix uniformity structure. Of course, the Idaho

with a classified object and a graduated rate, but there has been no uniformity case arising thereunder. However, in State v. Dunlap, 28 Idaho 784,156 Pac. 1141 (1916), in relation to a problem of situs and jurisdiction to tax, the court held that the inheritance tax was an excise tax.

10 Supra note 2. 
legislature may classify property for the purpose of exemptions, the only limitation being that such exemptions must constitute reasonable classes of property. ${ }^{11}$ In all cases on this point the court has relied on the provision in Art. VII, §5, which expressly states that "the legislature may allow such exemptions from taxation from time to time as shall seem necessary and just." Thus, the court has not had any occasion to discuss the relation of the uniformity clause in Art. VII, $\$ 5$ and the proportionality clause in Art. VII, $\$ 2$ to the power of the legislature to exempt property. That is, can a rule of universality be derived from one or both of those provisions in the absence of the express exemption clause ${ }^{12}$ It is interesting to note that in a number of cases in which exemptions of property from the general property tax were upheld the exemptions were established by the use of an "in lieu" nonproperty tax. ${ }^{13}$ The court has had no occasion to rule on the obvious - that property must be taxed by the ad valorem method.

Since the Idaho court has tended to restrict the application of the uniformity clause in Art. VII, $\$ 5$ to property taxation, this might lead one to assume that there was a better chance that property could be classified for effective

11 See Williams v. Baldridge, 48 Idaho 618, 284 Pac. 203 (1930), a leading case on the problem, in which the court upheld the exemption from property taxation of the property belonging to power companies used in developing or transmitting electrical energy for pumping water for irrigation purposes. Also see State ex rel. Bank of Eagle v. Leonardson, 51 Idaho 646, 9 P. 2d 1028 (1932).

12 Does the fact that the "proviso" which refers to the power to exempt is so placed as to be a proviso to the uniformity clause carry some implication that in its absence, exemptions would be prohibited?

${ }^{13}$ A leading case is Achenbach v. Kincaid, 25 Idaho 768, 140 Pac. 529 (1914), which upheld the motor vehicle registration tax and the provision therein which provided for the exemption from all other taxes of cars affected by the tax. Also see John Hancock Mut. Life Ins. Co. v. Haworth, 68 Idaho 185, 191 P. 2d 359 (1948); Smallwood v. Jeter, supra note 3. 
rates. However, in this respect, one would have to consider the proportionality clause in Art. VII, §2, which, on its face, probably indicates that absolute uniformity in effective rates is required. The court, in fact, has not seen any possible conflict between the two provisions and has simply cited both provisions in stating its conclusion that there must be absolute uniformity in effective rates.

The cases on the problem are scanty and, with one exception, concerned with the particular problem of the degree of uniformity required of the ratio of valuation. A recent case is Chastain's, Inc. v. State Tax Commission, ${ }^{14}$ decided in 1952. In that case it was established as fact by the pleadings that the county board of equalization had equalized all property in the county at $23 \%$ of its full cash value; that the state board of equalization had raised the assessed valuation of merchandise, machinery, and furniture and fixtures, but of no other taxable property in the county, from $23 \%$ of full cash value to $29.9 \%$; and that the plaintiff and all those in the county similarly situated would be compelled by the acts of the state tax commission to pay a greater proportion of the taxes than would other property owners owning items of property other than merchandise, machinery, and furniture and fixtures in the county. ${ }^{15}$ In an original proceeding the Idaho Supreme Court granted a writ of prohibition to arrest proceedings of the state tax commission on the ground that the action of the commission "as admitted by the pleadings offends the provisions of Article VII, Sections 2 and 5 of the Constitution, requiring uniformity of taxation." ${ }^{36}$ Never distinguishing between the two sections of the

1472 Idaho 344, 241 P. 2d 167 (1952). Also see Anderson's Red \& White Store v. Kootenai County, 70 Idaho 260, 215 P. 2d 815 (1950); Washington County v. First Nat. Bank, 35 Idaho 438, 206 Pac. 1054 (1922).

15 Chastain's, Inc. v. State Tax Comm., supra note 14 at 348.

${ }^{16}$ Id. at 348-349, emphasis added. 
constitution, and never taking notice of the particular terminology of Art. VII, $\$ 5$ ("uniform upon the same class of subjects"), the court simply asserted:

The Constitution requires that for tax purposes the ad valorem tax must be uniform and on the same basis of valuation as other property within the county, and if this requirement of uniformity has not been attained, and retained, then the mandate of Article VII, Sections 2 and 5 of the Constitution, has been violated. ... Uniformity in taxing implies equality in the burden of taxation and this equality of burden cannot exist without uniformity in the mode of assessment as well as in the rate of tax . . .; again, the requirement that all property be assessed at its actual cash value [a statutory requirement] is secondary to the constitutional mandate of equality of taxation. ${ }^{17}$

Note the words of the court: "must be uniform," "requirement of uniformity," "uniformity in taxing," "constitutional mandate of equality of taxation." If Art. VIII, $\$ 5$ is to be limited to property taxes, then what is the meaning of that phrase "upon the same class of subjects?" Does it not carry at least some implication that property may be classified? Certainly the requirement in Art. VII, $\$ 2$ that "every person

${ }^{17} I d$. at 348, emphasis added. However, in Washington County v. First Nat. Bank, supra note 14 at 444 , the court refers only to the uniformity clause in Art. VII, $\S 5$ when faced with a similar problem, saying:

The requirement that all property be assessed at its actual cash value is secondary to the constitutional mandate of equality of taxation. Where certain property is assessed at a higher valuation than all other property, the court will enforce the requirement of uniformity by a reduction of the taxes on the property assessed at the higher valuation, if it be shown that the difference is the result not of mere error in judgment, but of fraud or of intentional and systematic discrimination.

In the Washington County case, even more than in the Chastain case discussed in the text, the court ignored the actual words of the uniformity clause, simply quoting Art. VII, $\$ 5$, and then making the above statement. Somehow the words "uniform upon the same class of subjects" disappeared entirely. 
or corporation shall pay a tax in proportion to the value of his, her, or its property, except as in this article hereinafter otherwise provided" appears to imply a likely prohibition against classification of property. If that is so, how should the conflict be resolved? Which clause should control if there appears to be a conflict? Not bothered by such difficulties, the court has merely asserted that "the provisions of Article VII, Sections 2 and 5 of the Constitution, requir[e] uniformity of taxation." 18

Other than the ratio of valuation cases, Chapman v. $A d a$ County $^{19}$ is of interest. In that case, the court held invalid a statute setting forth the schedule of probate court fees; fixing a minimum fee at five dollars; and providing for a graduated fee scale for estates, the value of which exceeded $\$ 5000$, with the fee increasing as the value of the estate increased. The court held (1) that the statute imposed a "tax" "in guise of a fee," and (2) that the tax could not be held an inheritance tax but was

- a property tax and as such, under the authorities, violates the uniformity provision of the Constitution. . . . We therefore conclude that the statute is unconstitutional in so far as it makes the amount of probate fees depend upon the value of the estate probated. ${ }^{20}$

${ }^{18}$ Chastain's, Inc. v. State Tax Comm., supra note 14 at 348-9. On a number of occasions in cases concerning nonproperty taxes the court has assumed that this requirement of absolute uniformity exists. For example, in Diefendorf v. Gallet, supra note 2 at 625 , concerning the income tax, the court made its often repeated statement that:

In substance the Constitution provides that all property, real and personal, must be taxed uniformly by value. (Const., art. 7, secs. 2 and 5).

1948 Idaho 632, 284 Pac. 259 (1930).

${ }^{20} \mathrm{Id}$. at 635 , emphasis added. The court cites as its authorities the following: Berryman v. Bowers, 31 Ariz. 56, 250 Pac. 361 (1926); Fatjo v. Pfister, 117 Cal. 83, 48 Pac. 1012 (1897); Malin v. Lamoure, 27 N.D. 140, 145 N.W. 582 (1914); Cook County v. Fairbank, 222 Ill. 578, 78 N.E. 895 (1906); State v. Mann, 76 Wis. 469, 45 N.W. 526 (1890); 
This opinion certainly ruled out any classification of property according to quantity. But, quaere, does this mean that a proportional rate would be within "the uniformity provision of the Constitution" even though not correlated with the general property tax? Rather obviously, in light of the other opinions discussed above, such would not be the case, although the court apparently conditioned its opinion by the use of the words "in so far."

Finally, the provision, Art. VII, $\S 5$, which expressly prohibits "duplicate taxation" should be noted. As pointed out in Chapter I, a requirement of absolute uniformity in effective rates would prohibit "double taxation." In a number of Idaho cases the "duplicate taxation" clause of Art. VII, $\$ 5$ has been interpreted as expressing the orthodox conception of "double taxation." that absolute uniformity was required of effective rates, then the "duplicate taxation" clause might have taken on some special significance.

In conclusion, a consideration of the uniformity of taxation requirement under the Idaho Constitution illustrates again the manner in which the numerous types of uniformity pro-

State v. Gorman, 40 Minn. 232, 41 N.W. 948 (1889). However, in each of the states named, with the exception of Arizona, when the case cited was decided the uniformity clause was of a type not having any words of classification.

${ }^{21}$ In Winton Lumber Co. v. Shoshone County, 50 Idaho 130, 294 Pac. 529 (1930) the court said that to assess standing timber as realty and, after severance, to again assess in the same year the wood as sawlogs would be contrary to the duplicate taxation clause. Otherwise the cases have generally been concerned with the relation of an excise tax to the general property tax (State v. Jones, 9 Idaho 693, 75 Pac. 819 (1904)), or the relation of two excise taxes (Utah Power \& Light Co. v. Pfost, 52 F. 2d 226 (1931)), or the relation between the general property tax and a local special assessment for road purposes which was applicable to all property subject to the general property tax (Humbird Lumber Co. v. Kootenai County, 10 Idaho 490, 79 Pac. 396 (1904)). 
visions may be disposed of by a generalization failing to take account of the different wording which might actually have led to different results.

\section{Louisiana}

The present constitution of Louisiana came into force in 1921, and contains one of the most complex tax structures to be found in a constitution. Indeed, typical of the Louisiana Constitution as a whole, the tax structure, at times, approaches a body of statutory law. Because of this lengthy "statutory" type constitutional structure, the general uniformity limitation has little operative effect. Consequently, it is sufficient for the purposes of this monograph to limit the Louisiana study to a mere description of the historical development of uniformity in taxation in Louisiana. With nine constitutions during a period of one hundred and forty-four years, Louisiana has adopted a new constitution on the average of every sixteen years. Moreover, there has been prolific amendment of the present constitution of 1921. The almost yearly amendments are comparable to a compilation of the laws of a legislative session.

In Louisiana's original constitution, dated 1812, there were no provisions dealing with uniformity in taxation. But the constitution of 1845 contained a basic uniformity clause, joined by a supplementary provision dealing with rates in property taxation, and a provision for other taxes. Article 127 read:

Taxation shall be equal and uniform throughout the State. After the year 1848, all property on which taxes may be levied in this State shall be taxed in proportion to its value, to be ascertained as directed by law. No one species of property shall be taxed higher than another species of property of equal value, on which taxes shall be levied; the 
legislature shall have power to levy an income tax, and to tax all persons pursuing any occupation, trade, or profession.

Thus, the first Louisiana uniformity clause conformed to the potentially strict Type V clause, and was coupled with a proportionality clause of Type II. It is interesting to note that the 1845 constitution expressly provided for the power to impose an income tax. A third constitution was adopted in 1852, and Art. 123 thereof was identical to Art. 127 of the 1845 constitution.

In a fourth constitution, adopted in 1864 , the steady expansion of the uniformity structure continued. Again there was but a single provision, substantially similar to the prior provision except for a clause now expressly dealing with the power to exempt property. Article 124 of the 1864 constitution read:

Taxation shall be equal and uniform throughout the state. All property shall be taxed in proportion to its value, to be ascertained as directed by law. The general assembly shall have power to exempt from taxation property actually used for church, school, or charitable purposes. The general assembly shall levy an income-tax upon all persons pursuing any occupation, trade, or calling. . . . All tax on income shall be pro rata on the amount of income or business done.

The italicized portions indicate essentially new material. Note the change in the income tax provision, which now provided that the legislature "shall levy" an income tax. A fifth constitution was adopted in 1868, and Art. 118 thereof was substantially identical to Art. 124 of the 1864 constitution, except that the income tax clause now read: "The general assembly may levy. . . ."

The sixth Louisiana Constitution, dated 1878, brought a more elaborate structure. The same three basic provisions were included: a uniformity clause; provision for income and other taxes; and a limitation on the power to exempt prop- 
erty. However, each provision was now separately numbered and considerably lengthened. In addition, it is interesting to note that the clause providing for the levy of "an income tax" was deleted. Article 203 contained the uniformity clause, still a Type $V$ clause, but elaborated as to uniformity in ratio of valuation:

Taxation shall be equal and uniform through the territorial limits of the authority levying the tax, and all property shall be taxed in proportion to its value ... ; provided, the assessment of all property shall never exceed the actual cash value thereof. . . . In order to arrive at this equality and uniformity the General Assembly shall ... provide a system of equality and uniformity in assessments, based upon the relative value of property in the different portions of the State. The valuation put upon property for the purposes of State taxation shall be taken as the proper valuation for purposes of local taxation in every subdivision of the State.

Article 207, which prohibited all exemptions except those enumerated, read: "The following property shall be exempt from taxation, and no other, viz: . . . " However, the extensive enumeration of classes to be exempt left little to be desired. Article 206 contained the provision as to "license taxes" and was somewhat similar to Art. X, $\S 8$ of the present 1921 constitution.

A seventh constitution followed in 1898, but the structure was substantially the same as in the 1878 constitution. Article 225 was identical to Art. 203 of the 1879 constitution; Article 229 identical to Art. 206. Article 230 was the same as Art. 207, except that more classes of exemptible property were enumerated. There were some changes in the eighth constitution, dated 1913, but the form of the 1878 constitution was substantially followed. The uniformity clause, Art. 225, was the same as Art. 203 in 1879, with the exception that an amendment in 1916 deleted everything after the 
words "In order to arrive at. . . ." Article 229 contained the license tax provision, adding a clause as to a severance tax, and Art. 230 expanded even more the exemptible classes of property.

In the 1921 constitution the basic uniformity clause, Art. $\mathrm{X}, \S 1$, was changed to a Type VII clause, and reads:

.. all taxes shall be uniform upon the same class of subjects throughout the territorial limits of the authority levying the tax. . . . No property shall be assessed for more than its actual cash value. . . The valuation and classification fixed for State purposes shall be the valuation and classification for local purposes; but the taxing authorities of the local sub-division may adopt a different percentage of such valuation for purposes of local taxation.

The second paragraph of Art. X, $\$ 1$ added, again, the provision dealing with income taxes, now providing:

After May 1, 1924, equal and uniform tax, not to exceed three per cent and for state purposes only, may be levied upon net incomes. . . . Reasonable exemptions may be allowed.

In 1934 this paragraph was amended to read as follows:

Equal and uniform taxes may be levied upon net incomes, and such taxes may be graduated according to the amount of the net income. . . Reasonable exemptions may be allowed.

The third paragraph of Art. X, $\$ 1$ dealt with reforestation and provided expressly for a severance tax. That paragraph has been amended several times, so that today it reaches several paragraphs in length and spells out the imposition of such a severance tax.

Article X, $\S 4$ of the 1921 constitution now contains the "no exemption" clause, providing that "The following property, and no other, shall be exempt from taxation. . . ." 
However, not only was the list of exemptibles expanded in the original 1921 version, but it is almost yearly amended to add classes, so that to date it covers five pages of an annotated volume. Other provisions of the constitution deal with special exemptions, too numerous to mention.

The "other tax" provision is now in Art. X, $\S 8$, and reads as follows:

License taxes may be levied on such classes or persons, associations of persons and corporations pursuing any trade, business, occupation, vocation or profession, as the Legislature may deem proper, except clerks, laborers, ministers of religion, school teachers, graduated trained nurses, those engaged in mechanical, agricultural or horticultural pursuits or in operating saw mills. Such license taxes may be classified, graduated or progressive. . . .

However, in addition to this general clause, Art. X, $\$ 7$ provides expressly for "Taxes upon inheritances, legacies and donations, or gifts made in contemplation of death, [which] may be graduated, classified or progressive. . . M" Moreover, for example, Art. VI, §22, and Art. VI-A are, in effect, "statutes" imposing motor vehicle and motor fuel taxes, covering some thirty-five pages of the constitution. An "in lieu" bank tax is provided for in Art. X, $\S 9$, and other provisions deal with special exemptions, for example, Art. X, $\S \S 9$ and 22, and Art. X, $\$ 16.2$.

\section{Minnesota}

\section{a. The provisions; historical note}

Minnesota has had but a single constitution, that of 1857 . However, a radical change was made in the uniformity structure in 1906 by extensive amendment. Thus, a discussion of the uniformity limitation in Minnesota may be divided into two periods: that before 1906 and that subsequent 
to 1906 . There were several amendments before 1906, and there have been several amendments since that time which are pertinent to a study of the uniformity limitation. However, the basic nature of the uniformity limitation remained constant in both periods. The period from 1857 to 1906 may be characterized as the period of the strictest possible uniformity limitation for all taxes. To the contrary, since 1906 the Minnesota uniformity limitation has been one of the most liberal limitations, requiring little more than is required under the federal equal protection clause.

In the original constitution the uniformity structure was found in sections 1, 3, and 4 of Art. IX. Article IX, $\$ 1$ contained the basic uniformity clause and read:

All taxes to be raised in this State shall be as nearly equal as may be, and all property on which taxes are to be levied shall have a cash valuation and be equalized and uniform throughout the State.

Accompanying this uniformity clause was what might be called a "universality" clause, found in Art. IX, §3:

Laws shall be passed taxing all moneys, credits, investments in bonds, stocks, joint stock companies, or otherwise, and also all real and personal property, according to its true value in money. . . .

The remainder of Art. IX, $\S 3$ contained a proviso requiring the exemption of designated classes of property-the usual classes of public and quasi-public property, plus "personal property to an amount not exceeding in value two hundred dollars for each individual." Finally, Art. IX, §4 dealt with the specific problem concerning "all property employed in banking," and required that such property should "always be subject to a taxation equal to that imposed on the property of individuals."

In an effort to break these rigid limitations, several 
amendments were introduced before the radical renovation in 1906. In 1869 a proviso was added to Art. IX, $\$ 1$ expressly providing that special assessments were to be withdrawn from the scope of the uniformity provisions. ${ }^{1}$ Next in order was the amendment of 1871 , adding a section to the legislative articles (Art. IV, $\$ 32(\mathrm{a})$ ) which made possible the taxation of railroads on a gross-earnings basis. In 1894, a further proviso was added to the section containing the basic uniformity clause, Art. IX, $\S 1$, this time expressly sanctioning an inheritance tax and apparently stating the degree of uniformity to govern that particular tax. ${ }^{2}$ Finally, in 1896 an unnumbered section was added to Art. IX. This unnumbered section provided for graded or progressive taxes on enumerated industries and businesses, with the bases of such taxes left to the discretion of the legislature. ${ }^{3}$ This section was never effective because of its poorly drafted and therefore confusing text.

Then came the so-called "Wide Open Tax Amendment" of 1906, establishing the basic uniformity structure which governs in Minnesota today. Article IX, $\S \S 1,3$, and 4 and the unnumbered section to Art. IX were repealed and sup-

1 The proviso added in 1869 read:

Provided, that the legislature may, by general law or special act, authorize municipal corporations to levy assessments for local improvements upon the property fronting upon such improvements, or upon the property to be benefited by such improvements, or both, without regard to a cash valuation, and in such manner as the legislature may prescribe.

This proviso was supplemented by an additional proviso in 1881 .

2 That proviso read:

And, provided further, that there may be by law levied and collected a tax upon all inheritances, devises, bequests, legacies and gifts of every kind and description above a fixed and specified sum, of any and all natural persons and corporations. Such tax above such exempted sum may be uniform, or it may be graded or progressive, but shall not exceed a maximum tax of five per cent.

${ }^{3}$ For the text of that provision, see 2 Minn. Stat. Ann. at 272. 
planted by a single section, Art. IX, $\S 1$. That section contains the uniformity clause and three provisos. The first proviso requires the exemption of certain classes of property, the second concerns special assessments and is substantially identical to that added in 1869 to the original Art. IX, $\$ 1$, and the third ensures the continued taxation, by existing laws, of the gross earnings of railroads. ${ }^{4}$ The basic uniformity clause in section 1 now reads (with the uniformity clause italicized):

. . Taxes shall be uniform upon the same class of subjects . . . , but public burying grounds, public school houses, public hospitals, academies, colleges, universities, and all seminaries of learning, all churches, church property and houses of worship, institutions of purely public charity, public property used exclusively for any public purpose, shall be exempt from taxation, [and there may be exempted from taxation personal property not exceeding in value $\$ 200$, for each household, individual or head of a family, and household goods and farm machinery, as the legislature may determine] ... .

Since 1906 several new sections have been added to the Minnesota constitution, all relating to uniformity of taxation, but none of which alter the fundamental principle expressed in Art. IX, $\$ 1$-indeed, some are thought merely to make express what the legislature might have done without constitutional objection in any case. In 1922, Art. IX, §1A was added. That section provides for a mandatory mining occupation tax with a base consisting of the value of ores produced or mined. The tax is to be "in addition" to all other taxes provided by law. Article XVI, §3, added in 1920 (with a clari-

Also, Art. IV, $\$ 32 a$, referred to in the text, supra, is still in effect.

6 The clause in brackets was added by amendment in 1934. The provisos concerning special assessments and the railroad gross earnings tax are omitted. 
fying amendment in 1932), expressly provides for the "taxation of motor vehicles . . . on a more onerous basis than other personal property. ..."The tax is to be "in lieu" of all other taxes on such property, except local "wheelage taxes." In 1926 Art. XVIII, $\$ 1$ was added. That section expressly provides for limited taxation, including a yield tax, of forest lands. Finally, there are Art. XIX, $\S \S 3$ and 4, added in 1944, which provide, respectively, for a state excise tax on aircraft fuel and for the "taxation of aircraft using the air space overlying the State of Minnesota and the airports thereof." The latter tax is "in lieu" of all other taxation thereon.

\section{b. Meaning of the uniformity limitation}

The Minnesota court has developed the doctrine, under both the pre-1906 uniformity clause and the post-1906 provision, that all taxes are limited by such clauses. Thus, during both periods the determination of the nature of any given tax has often been avoided as simply being unnecessary. Because of the rather peculiar development of the Minnesota material on this problem of uniformity it is convenient to discuss the limitation as to all taxes according to the periods involved.

\section{(1) Taxation, generally: 1857 to 1906}

The restriction during this period constituted the most rigid uniformity limitation theoretically possible. As for the taxation of property, the court ruled that the uniformity clause in the original Art. IX, $\S 1$, taken in conjunction with the provisions in the original Art. IX, $\S \S 3$ and 4, required universality, ${ }^{6}$ prohibited the taxation of property by other

- Le Duc v. Hastings, 39 Minn. 110, 38 N.W. 803 (1888); State v. Pioneer Savings \& Loan Co., 63 Minn. 80, 65 N.W. 138 (1896); State v. Twin City Tel. Co., 104 Minn. 270, 116 N.W. 835 (1908). 
than the ad valorem method, ${ }^{7}$ and required absolute uniformity in effective rates. ${ }^{8}$

The uniformity clause was said to apply to all taxes; thus the imposition of special assessments by local units was impossible because they had to conform to the uniformity limitation rather than to the ordinary "benefit" theory. ${ }^{9}$ One of the earliest efforts to avoid some of the rigidity of the original uniformity limitation was the addition of a proviso to the uniformity provision, Art. IX, $\S 1$, which expressly sanctioned the levying of local special assessments according to the "benefits" theory. ${ }^{10}$ Very important to the development of the doctrine that the uniformity clause limited all taxes were the cases concerning a graduated "probate fee" and several attempted inheritance taxes. State ex rel. Davidson v. Gorman ${ }^{11}$ centered on the validity of a statute requiring the payment of a fee as a condition precedent to probate proceedings. The fee was graduated on a specific rate formula, all estates being divided into classes according to amount, with the increased rate being applied to the entire amount. In addition, there was an exemption of estates of less than $\$ 2000$. The court held that the statute imposed a

${ }^{7}$ State ex rel. Davidson v. Gorman, 40 Minn. 232, 41 N.W. 948 (1889), discussed infra text at note 11; State v. Lakeside Land Co., 71 Minn. 283, 73 N.W. 970 (1898).

${ }^{8}$ State v. Canada Cattle Car. Co., 85 Minn. 457, 89 N.W. 66 (1902).

${ }^{9}$ Bidwell v. Coleman, 11 Minn. 45 (1865); Sanborn v. Rice, 9 Minn. 273 (1864); Sperry v. Flygare, 80 Minn. 325, 83 N.W. 177 (1900); Stinson v. Smith, 8 Minn. 326 (1863). Cf. the development in Arkansas and Tennessee (Part A of this chapter, supra).

10 This provision was carried over in the new Art. IX, $\$ 1$ after 1906. See note 5, supra. See In Re Improvements of Third Street, St. Paul, 185 Minn. 170, 240 N.W. 355 (1932), to the effect that this provision only relieved such special assessments from the "cash valuation" requirement, and that they were still subject to the uniformity clause and had to be uniform within classes. However, this limitation was interpreted so as to accord with the "benefit" theory.

11 Supra note 7. 
tax and that as such it violated the uniformity clause because the rate was not uniform and the tax was not proportional to value. It was not quite clear whether the tax was being characterized as being on the property or on a privilege. Subsequent to this case, the 1894 proviso was added to the original Art. IX, $\$ 1$, which expressly provided for the imposition of a graduated inheritance tax. ${ }^{12}$ However, when a tax was imposed pursuant to that provision the court held in Drew v. Tiff ${ }^{13}$ that the tax was still subject to the uniformity clause in Art. IX, $\S 1$, and also held the tax invalid because of certain exemptions. The Drew case squarely stated the proposition that nonproperty taxes were limited by the original Art. IX, $\S 1$; consequently the discretion of the legislature was severely limited since at that time the clause was not framed in words of "uniform within classes." In 1905 the legislature did pass an inheritance tax statute which was upheld in State ex rel. Foote v. Bazille. ${ }^{14}$

It appears that during this period there were few other taxes imposed which might have tested the view that all taxes were subject to the strict uniformity clause with its resulting rigidity. ${ }^{15}$ However, the need for a judicial departure from the court's earlier views, which would have in all likelihood occurred, never developed because of the radical change made in the uniformity structure by the 1906 amendment.

\section{(2) Taxation, generally: since 1906}

The uniformity clause adopted in 1906, requiring only that "Taxes shall be uniform upon the same class of sub-

12 See note 2, supra.

1379 Minn. 175, 81 N.W. 839 (1900). Also see State ex rel. Frye v. Bazille, 87 Minn. 500, 92 N.W. 415 (1902).

1497 Minn. 11, 106 N.W. 93 (1906).

${ }^{15}$ See Faribault v. Misener, 20 Minn. 396 (1874), in which the court demonstrated a way to avoid the strictness of the interpretation given the uniformity clause in this respect. 
jects," has been held to apply to all taxes. ${ }^{18}$ The attitude of the Minnesota court in spelling out the meaning of this uniformity limitation is well illustrated by the leading case, Reed v. Bjornson, ${ }^{17}$ in which the court upheld a graduated general net income tax and gave a definitive interpretation of the new uniformity clause in Art. IX, $\S 1$. The court said:

The history of the times indicates clearly that the people, in adopting the 1906 amendment, were liberating the legislature from most of the previous constitutional restraints in regard to taxation. The fair adjustment of tax burdens under rapidly changing social conditions demanded more comprehensive powers in the legislature; and the people, relying upon the responsibility of that body to its constituents, relaxed the restraints theretofore existing. They were enlarging, not curtailing, the legislative power. . . . In common parlance throughout the state the proposal was known and characterized as the "wide open tax amendment."18

A result of this approach was to give the fullest possible discretion to the legislature in the matter of classification of subjects for taxation, whether the subject be property or privilege. Thus the court could truly assert that the uniformity clause of Art. IX, $\S 1$, and the equal protection clause of the fourteenth amendment to the federal Constitution are substantially equivalent, and that, in effect, the only limitation of uniformity, regardless of the nature of the tax, is that classifications be reasonable. In Apartment Operators' Ass'n v. City of Minneapolis, ${ }^{19}$ in which the court upheld a graduated property tax rate, the court stated:

${ }^{16}$ For example, Reed v. Bjornson, 191 Minn. 254, 260, 253 N.W. 102 (1934).

17 Ibid.

${ }^{18} I d$. at 259 , emphasis added.

19191 Minn. 365, 254 N.W. 443 (1934). Other leading cases in which the court has equated the uniformity clause with the equal protection clause of the fourteenth amendment of the Federal Constitution are: Reed v. Bjornson, supra note 16; Thomas Stores Sales System v. Spaeth, 209 
It is established that the provision in Art. $9, \S 1$ of the state constitution providing that "taxes shall be uniform upon the same class of subjects" is no more restrictive upon legislative power to tax or classify than is the equal protection clause in the fourteenth amendment to the constitution of the United States. . . . If [a tax] ... does not violate the one it does not violate the other. ${ }^{20}$

Even though there is in fact no real difference in the uniformity applicable to property and nonproperty taxes in Minnesota, for comparative purposes it will be convenient to review the classifications considered by the court according to the nature of the tax in question.

As for taxes clearly held to be nonproperty taxes, the usual requirement of reasonable classifications is illustrated by the cases ruling on the reasonableness of the object of a given nonproperty tax, ${ }^{21}$ or on the reasonableness of the classification for rates. In this latter category, the court has clearly approved the principle of graduated rates. ${ }^{22}$

Because of the flexibility allowed in the imposition of taxes

Minn. 504, 514, 297 N.W. 9 (1941); Lyons v. Spaeth, 220 Minn. 563, 20 N.W. 2d 481 (1945).

20 Id. at 366.

21 Dohs v. Holm, 152 Minn. 529, 189 N.W. 418 (1922); Hassler v. Engberg, 233 Minn. 487, 48 N.W. 2d 343 (1951); McReavy v. Holm, 166 Minn. 22, 206 N.W. 942 (1926); Thomas Stores Sales System v. Spaeth, supra note 19.

${ }^{22}$ A leading case is Reed v. Bjornson, supra note 16 , in which the income tax graduated rates were upheld. See note 32, infra. In State ex rel. Graff v. Probate Court, 128 Minn. 371, 150 N.W. 1094 (1913), the court upheld the graduated rate schedule under the inheritance tax. At present Minnesota has no chain store tax. However, such a tax was imposed by Minn. Laws 1933, c. 213, the tax having two rate schedules. The first was a specific rate graduated according to the number of stores owned or operated. The second was a specific rate graduated according to the volume of gross sales, stores being classified into eleven classes based on amount of gross sales. The graduated gross sales rate was held to be a violation of both the uniformity clause in Art. IX, $\S 1$ and the federal equal protection clause. National Tea Co. v. State, 205 Minn. 443, 286 N.W. 360 (1939). How- 
on property there has not been such a compelling necessity for characterizing any particular tax. However, the court has had occasion to rule that an inheritance tax was a nonproperty tax. ${ }^{23}$ To the contrary, the court has ruled that a mortgage registry tax was a tax upon property, ${ }^{24}$ and a like result was reached as to a tax upon the gross earnings of certain public utilities. ${ }^{25}$ No decision has been made as to the nature of a general net income $\operatorname{tax}^{26}$ although a later development as to the tax reaching income from corporations is of interest on this point, as discussed infra.

\section{(a) Income tax}

The first Minnesota income tax law, enacted in 1933, imposed a general net income tax. This original act was entitled, "An act raising revenues, imposing income taxes and franchises or privilege taxes measured by income. . . . "Section 2 of the act, concerning corporate income, provided:

There is hereby imposed on every domestic and foreign corporation an annual tax for the privilege of existing as a corporation or of transacting any local business within this state during any part of its taxable year, measured by its

ever, the rate graduated according to the number of stores operated was upheld as a reasonable classification. Also see National Tea Co. v. State, 208 Minn. 607, 294 N.W. 230 (1940).

${ }^{23}$ Drew v. Tifft, supra note 13. Also see State ex rel. Graff v. Probate Court, supra note 22.

24 Mutual Benefit Life Ins. Co. v. Martin, 104 Minn. 179, 116 N.W. 572 (1908), discussed note 37 , infra.

25 State v. Wells Fargo \& Co., 146 Minn. 444, 179 N.W. 221 (1920), and cases cited in note 55 , infra.

${ }^{26}$ Similarly the Motor Vehicle Tax at various times has been held to be both property and privilege tax. See the following cases: Dohs $v$. Holm, supra note 21; Railway Express Agency v. Holm, 180 Minn. 268, 230 N.W. 815 (1930); City of Minneapolis v. Armson, 188 Minn. 167, 246 N.W. 660 (1933); Raymond v. Holm, 165 Minn. 216, 206 N.W. 166 (1925); McReavy v. Holm, supra note 21. 
taxable net income for such year, computed in the manner and at the rates hereinafter provided.

Section 3 of the act reached other income and provided:

There is hereby imposed an annual tax for each taxable year upon the taxable net income for such year of [individuals; estates and trusts; and domestic and foreign corporations whose business within the state consisted exclusively of interstate commerce] . . . computed in the manner and at the rates hereinafter provided. ${ }^{27}$

The same graduated rate schedule was applicable to all income, as provided by section 6 of the act.

In Reed v. Bjornson ${ }^{28}$ the validity of the tax under Art. IX, $\S 1$ was sustained, the principal constitutional objections being that the graduated rates and exemptions violated the uniformity clause, as well as the federal equal protection clause. The court treated the act as a whole throughout the opinion, making no distinction between the "income tax" and the "corporate privilege tax."

The court, in its opinion, first noted that much argument in the briefs had been devoted to the nature of the tax. ${ }^{29}$ The court refused to pass definitively on that issue for the important reason that under the Minnesota uniformity clause it would make no difference in result because the limitations of the uniformity clause are the same for either property or nonproperty taxes.

Whether or not income is property and a tax thereon a tax on property, art. $9, \S 1$, of our constitution requires all taxes to be uniform on the same class of subjects, not merely on the same class of property as in some state constitutions. $\mathrm{Ob}-$ viously incomes constitute a subject of taxation, and the uni-

${ }^{27}$ Minn. Laws 1933, c. 405.

28191 Minn. 254, 253 N.W. 102 (1934).

29 Id. at 259. 
formity clause applies regardless of whether or not the tax is upon property as such. ${ }^{80}$

In any case, if the issue had been forced it seemed clear that the court looked favorably on the view that "In many ways such a tax is sui generis."

Facing the specific issues, the court held (1) that the graduated rates were not arbitrary classifications; (2) that the exemptions were not arbitrary classifications; and (3) that there was no offensive "double taxation" because income from property was taxed. A great amount of space was devoted to the justification of graduated rates, the court concluding that in the light of its interpretation of the uniformity clause in Art. IX, $\S 1$, the weight of authority as well as sound logic justified the classification of income taxes

${ }^{30} \mathrm{Id}$. at 260 . On this point the court relied to a considerable degree on a similar ruling by the Oregon court under the Oregon constitution which contained an identical uniformity provision. Standard Lumber Co. v. Pierce, 112 Ore. 314, 228 Pac. 812 (1924), and Portland Van \& Storage Co. v. Hoss, 139 Ore. 434, 9 P. 2 d 122 (1932). Id at 260, 264, 267. See the discussion of Oregon, infra.

${ }^{31}$ Id. at 259-260, saying (emphasis added):

While income as it is received is necessarily property, a tax upon it has many characteristics which differ quite radically from those of a tax levied upon real or invested personal property. Income is a more fleeting or transitory benefit which comes according to present efforts or the wisdom or luck of past accumulations. Many people who own little or no tangible or intangible property have large incomes and enjoy great benefit from the protection which organized society affords. They have not only ability to pay a tax for that protection but get value received in liberal measure for what they may be required to pay. So do those who receive large incomes from property. An income tax is calculated to take toll from the flow of this property to the individual through the arteries of organized social life and to cause it to bear a share of the burden of government. In many ways such a tax is sui generis. It imposes a tax on the net income or revenue which passes into or through a man's hands within a prescribed period, a large share of which never finds permanent investment. 
according to amounts received. ${ }^{92}$ The contention that "unequal double taxation" resulted from the imposition of the tax upon income from property because that amounted to a tax upon the property itself was briefly disposed of, ${ }^{33}$ the court simply saying that it did not follow those authorities like Massachusetts which reasoned to the contrary. In any case, if income could be considered property, this court probably would hold that it is property distinct from the property which is the source of the income.

Later development has found the court in State v. Duluth, Missabe $\mathcal{E}^{2}$ Northern Railway $\mathrm{Co}^{34}$ and in Pullman Co. v. Commissioner of Taxation $^{35}$ ruling that the tax was a tax upon property insofar as it reached corporate income. This development will be considered in the context of the property tax development, infra.

\section{(b) Property taxation}

The Minnesota legislature first utilized its discretion under the amended uniformity structure in 1907, at which time it enacted a mortgage registry tax $\operatorname{law}^{36}$ limited to real estate mortgages. A tax was imposed at the rate of fifty cents per hundred dollars of the principal amount secured by any real estate mortgage. The tax was payable on or before registration, and apportioned to the amount of real estate covered and within the state.

In Mutual Benefit Life Ins. Co. v. Martin, ${ }^{37}$ decided in 1908 , the court held that the registry tax was compatible with the uniformity clause, Art. IX, $\S 1$. The court held that the tax was a property tax the property taxed being the security,

82 Id. at 262-267.

83 See the discussion infra in note 73.

34 207 Minn. 618, 292 N.W. 411 (1939). See note 57, infra.

${ }^{85} 223$ Minn. 96, 25 N.W. 2d 838 (1947). See note 66, infra.

${ }^{86}$ Minn. Laws 1907 , c. 328.

87104 Minn. 179, 116 N.W. 572 (1908). 
not the debt secured. ${ }^{38}$ Facing the uniformity issue, the court held that Art. IX, $\S 1$ does not prohibit the reasonable classifications of property for purposes of taxation, and that the classification of real estate mortgages was a reasonable classification on the facts presented.

Several statements of the court in the case had far-reaching implications, as was borne out subsequently by the upholding of a graduated property tax rate. In describing the purpose of the 1906 "wide open tax amendment," the court stated:

Whatever is of value to a person may be made the subject of taxation. It may be real estate or personal property, securities or privileges, and the tax should be imposed upon the possessors of such property in proportion to their ability to aid in bearing the burdens which result from the existence of organized society. ${ }^{\mathbf{3 9}}$

Note the use of the "ability to pay" rationale, which was later used in sustaining the graduated property tax rates. ${ }^{40}$ Directing its attention specifically to the particular rules of uniformity required of property taxation, the court stated:

Under this provision all property belonging to the same class must be treated alike. . . . The same means and methods

${ }^{38} \mathrm{Id}$. at 181-182, the court saying:

This mortgage registry tax statute declares that mortgages upon real estate shall constitute a class, and provides for the taxation of the security thus provided through the payment of a stated fee when the mortgage is recorded. The subject of the taxation is the security and not the debt which it secures. Whatever is of value to a person may be made the subject of taxation.

${ }^{39} I d$. at 182 , emphasis added.

${ }^{40}$ But see State ex rel. Hildebrandt v. Fitzgerald, 117 Minn. 192, 134 N.W. 728 (1912). In that case the court held that the minimum class for such a mortgage registry tax should be all real estate mortgages. Consequently, it was said that the tax would be 2 violation of the uniformity clause as an arbitrary classification if it were construed as not taxing mortgages securing $\$ 50$ or less. The court construed the act so that it would be constitutional. 
must be applied impartially to all the constituent elements of the class. ${ }^{41}$

Thus, the court concluded, the amount of the debt secured was the natural standard for measuring the amount of the tax to be paid. The value of the property which was the subject of the tax, i.e., the security as such, need not necessarily be the base of the tax. In the court's view an attempt to make the actual value of the security the basis for estimating the tax would be "utterly impracticable." One would certainly seem warranted in concluding that the court was here approving other than the ad valorem method for the taxation of property.

In the second of three steps taken to convert the Minnesota general property tax into a comprehensive classified system, the legislature in 1911 imposed a money and credits $\operatorname{tax}^{42}$ which provided for a low rate of three mills on such intangible property. This tax was upheld in State ex rel. Wi nona Motor Co. v. Minnesota Tax Commission, ${ }^{43}$ decided in 1912. The court simply relied upon the Mutual Benefit Life Ins. Co. case and, without extended discussion, concluded that the separate classification of money and credits was reasonable.

The third and final step taken by the legislature to revise the general property tax structure following the amendment of the uniformity structure in 1906 was to enact in 1913 a classified general property tax, which established numerous classes of property each to be taxed by a different effective rate. The method used by the legislature was to classify property for the purpose of applying a different ratio of valuation to each class, while applying a single percentage rate

${ }^{41}$ Mutual Ben. Life Ins. Co. v. Martin, supra note 37 at 183, emphasis added.

42 Minn. Laws 1911, c. 285.

43117 Minn. 159, 134 N.W. 643 (1912). 
to all property taxed. ${ }^{44}$ The general scheme of classification in this tax, as it first appeared, was upheld in State ex rel. St. Paul City Railway Co. v. Minnesota Tax Commission, ${ }^{45}$ decided in 1915.

Of more importance is a second case directed to a particular classification found in the classified general property tax. In Apartment Operators' Association v. City of Minneapolis, ${ }^{46}$ decided in 1934, the court, in effect, upheld the principle of graduated property-tax rates. In 1934 the following classification of homestead property was used: rural homesteads were to be assessed at twenty per cent of actual value, except where the actual value was more than $\$ 4000$, then the excess of that sum was to be assessed at thirty-three and one-third per cent of actual value; other homesteads

44 The principal classification now in effect is found in Minn. Stat. Ann. $\$ 273.13$, which provides for the following classes: (1) iron ore, $50 \%$ of full value; (1a) direct products of blast and open hearth furnaces, $15 \%$; (2) household goods, $25 \%$; (3) agricultural products, merchandise, machinery, and rural real estate, $33 \mathrm{~L} / 3 \%$; (3a) agricultural products in the hands of the producer, $10 \%$; (3b) rural homesteads, $20 \%$, except where the actual value is more than $\$ 4000$, then the excess of that sum at $33 \mathrm{r} / 3 \%$; however the first $\$ 4000$ of actual value of rural homesteads is exempt from taxation for state purposes; (3c) other homesteads, $25 \%$, except where the actual value is more than $\$ 4000$, then the excess of that sum at $40 \%$, however the first $\$ 4000$ of actual value of urban homesteads is exempt from taxation for state purposes; (3d) livestock and agricultural tools, $20 \%$; (4) all property not included in the preceding classes, at $40 \%$. However, real and personal property of refineries used for processing of petroleum, is to be valued at $27 \%$ of the true value. The distribution lines and appliances of power and light companies (except rural electrical cooperatives, which are subject to an in lieu tax), used primarily for supplying electricity to farmers at retail, is to be assessed at $5 \%$ of actual value. Minn. Stat. Ann. \$273.38. Also, unmined taconite on unproductive tracts is assessed at a maximum of $\$ 1.00$ per acre. Minn. Stat. Ann. $\$ 298.26$.

45 128 Minn. 384, 150 N.W. 1087 (1915). The classification scheme under the original act, Minn. Laws 1913, c. 483, was substantially similar to that found at the present time and described in note 44, supra.

46191 Minn. 365, 254 N.W. 443 (1934). 
were to be assessed in the same manner, except that the ratios of twenty-five per cent and forty per cent, respectively, were used. ${ }^{47}$ In the Apartment Operators' Association case the court held that this classification did not violate the uniformity clause in Art. IX, $\S 1$, and therefore a request for an injunction to restrain the city from enforcing the homestead provision was denied.

The rationale of the opinion is quite important. Pointing out that the legislature might classify property for tax purposes; that the only concern of the court was the reasonableness of the classification; and, further, that the uniformity clause was to be equated with the federal equal protection clause, ${ }^{48}$ the court then approved both "use" and "quantity" as bases for reasonable classifications. The court stated:

The classification . . . in so far as it is based upon use, is in line with the policy of both the state and nation as evidenced by previous legislation enacted for the benefit and relief of occupant owners of homes. . . . The difference in use of the property has a fair and substantial relation to that object of the legislature, and there is no discrimination between persons in similar circumstances; it operates equally upon all coming within the respective classes.

The classification based upon value is not an innovation. The iron ore tax . . . was based upon value, as were also the classifications in the income tax law (wherein $\$ 1,000$ and more exemptions were allowed and a graduated rate imposed), the inheritance tax, and the automobile tax laws. Such classifications have been upheld. Reed v. Bjurnson [Income Tax] . . . ; State ex rel. Graff v. Probate Court [Inheritance $\mathrm{Tax}$ ] ...; Dohs v. Holmes [Motor Vehicle $T a x] . .$.

47 The graduated rate is no longer in effect for purposes of the state general property tax rate, the first $\$ 4000$ of actual value being exempt from state taxation. See note 44, supra. However, this graduated rate is still effective insofar as the local property tax rates are concerned.

${ }^{48}$ Apartment Operators' Ass'n v. City of Minneapolis, supra note 46 at $366-367$, and see the text at note 19, supra. 
Protection and benefits received by the taxpayer and ability to pay may properly be taken into consideration by the legislature in classifying property for the purpose of taxation. ... .

Placing homesteads in two classes on the basis of valuation was within the scope of the broad power of the legislature to classify property for the purpose of taxation. ${ }^{49}$

The importance of the case lies in the fact that the second classification effects a progressively graduated ad valorem property tax. ${ }^{50}$ Although the case has been criticized as upholding the principle "without discussion," parts of the quoted text seem to indicate that the court was discussing such a rate, even though "progressively graduated ad valorem property tax rates" were not spelled out in so many words. Furthermore, the court has not retreated from the substance of the Apartment Operators' Association case, but as late as 1951 has approved the implications of the reasoning in that case. ${ }^{52}$

"In lieu" utilities gross-earnings taxes: corporate privilege tax with a base of net income. Apart from the general property-tax structure, of considerable interest are the several special taxes in Minnesota which have been designated as property taxes. Utilities in Minnesota are classified for the purpose of special gross-earnings taxes as: railroads; telephone and telegraph companies; freight line companies; sleeping car companies; and express companies. A gross earnings tax is imposed upon each class, each tax having a flat proportional rate different for each of the classes, and each tax is in lieu of all taxes on the property of such utili-

49 Id. at 369-370, emphasis added.

${ }^{50}$ See the note, "Taxation-Classification-Requirements for Constitutionality in Case of a Classified Ad Valorem Property Tax," 18 Minn. L. Rev. 751 (1934).

${ }^{61}$ Ibid.

62 See Hassler v. Engberg, supra note 21 at 508. 
ties. ${ }^{53}$ As discussed below, these in lieu provisions have been amended so that they now refer to all ad valorem property taxes on the property of such utilities.

These taxes were originated before the 1906 amendment to the uniformity structure of the Minnesota Constitution, but it was necessary that special constitutional amendments be introduced before such taxes could be held valid. The reasons were that the first taxes of this type were not ad valorem nor were they correlated with the general property-tax rate. A special provision (Art. IV, §32a) was inserted in the constitution in 1871 with the purpose of validating the railroad earnings tax, and the unnumbered section added to Art. IX in 1896 validated the taxes as to other utilities. ${ }^{54}$

For this study it is sufficient to point out that the court, as for example in State v. Wells Fargo E' Co., ${ }^{\text {s5 }}$ has held that these taxes are not upon gross earnings as such, nor are they levied upon a "privilege" with the gross earnings simply being the base. Influenced, it seems, by the "in lieu" provision in each of the taxes, as elaborated below, the court has held that these taxes are property taxes, with the object of such taxes being all the property located within the state, including the franchise, which belongs to such utilities. The base of the tax is gross earnings. Or, as stated by the court, the tax is upon all the property of such a utility, and is "measured by" the gross earnings, which are a convenient substitute for "value" because of the peculiar nature of the property of such utilities.

The in lieu provisions in the gross-earnings taxes have been the source of two interesting problems. First, they have

${ }^{53}$ Minn. Stat. Ann. cc. 294, 295.

54 For a survey of the problems faced under the constitution before the 1906 amendment, see Montague, "The Development and Present Form of the Minnesota Tax System," Minn. Stat. Ann., c. 18, p. 53, at pp. 75-80.

${ }^{65}$ Supra note 25 . And see the cases cited in notes 57,66 , and 77 , infra. 
furnished a basis for a characterization of the corporate privilege tax with a base of net income, and, second, they have been the source of a misleading statement as to "double taxation" which apparently departs from the judicial development of the meaning of the Minnesota uniformity clause.

In 1939, the court ruled on the nature of that part of the original 1933 income tax act $^{56}$ which was concerned with corporate income. The pertinent provision stated:

There is hereby imposed on every domestic and foreign corporation an annual tax for the privilege of existing as a corporation or of transacting any local business within this state during any part of its taxable year, measured by its taxable net income for such year. . . .

In State v. Duluth, Missabe E Northern Railway Co. ${ }^{\mathrm{57}}$ action was brought to recover income taxes for the year 1933 claimed to be due from defendants under the above-quoted section. The defendants were subject to the railroad grossearnings tax which was "in lieu of all other taxes upon the property and franchises so taxed." provision simply conformed to the requirement of Art. IV, $\S 32 a$, added to the constitution in 1871 , which also provides that the gross-earnings tax on railroads shall not be repealed or amended without submission of the same to a vote of the people. ${ }^{59}$ Thus, the court reasoned, ${ }^{60}$ the issue was whether the application of the "income tax" to the railroads was contrary to Art. IV, $\S 32 \mathrm{a}$ which, in turn, depended on whether it amounted to an amendment of the gross-earnings tax law (the in lieu provision) without the submission of the issue to the voters.

\footnotetext{
${ }^{56}$ See text supra at note 27.

57 Supra note 34.

581 Mason Minn. Stats. 1927, $\$ 2246$.

${ }^{69}$ For text of the provision, see the Appendix A, infra.

${ }^{60}$ State v. Duluth, M. \& N. R. Co., supra note 34 at 621.
} 
In resolving the issue, the court first reiterated the proposition that the gross-earnings tax was a property tax levied upon all railroad property owned or operated for railroad purposes measured by-that is, with a base of-gross earnings of such property taken as a whole, intangible as well as tangible property. ${ }^{\text {"1 }}$ It was further held that the "franchise to exist and to operate is a vital part of the railroad's property. . . ." 62 Turning to the "income tax," the court held that such tax was a property tax upon the franchise as property, and, therefore, a tax upon a subject covered by the gross-earnings tax and invalid without a vote of the people to approve it. ${ }^{63}$

It is quite important to emphasize that this was the only rationale used by the court - there was no suggestion that the "income tax" was invalidly applied because of some theory of unconstitutional "double taxation." Indeed, the court went further and stated that the railroads might be subject to the "franchise tax imposed by c. 405" insofar as the franchise was exercised for other than railroad purposes. ${ }^{64}$ Thus, it appears to be without foundation to assert that the rationale of the Duluth, Missabe E Northern Railway Co. case was that the two taxes were on the same property consequently "resulting in double taxation of railroad companies . . . in violation of the uniformity provision of the Minnesota Constitution." $" 05$

However, in a subsequent case, Pullman Company v. Commissioner of Taxation, ${ }^{66}$ the court construed the same provision of the 1933 "income tax" and a similar in lieu

$01 \mathrm{Id}$. at $621-622$.

${ }^{62} \mathrm{ld}$. at 622 .

${ }^{63} I d$. at 623-624.

${ }^{64} I d$. at 624 . And see $I d$. at 628 , where the court emphasized that the constitutional objection was based on Art. IV, \$32a.

${ }^{08} \mathrm{CCH}$ Minnesota Tax Reporter, \10-026.

${ }^{66} 223$ Minn. 96, 25 N.W. 2d 838 (1947). 
provision of the sleeping car companies gross-earnings tax. And it appears that the court injected a misleading statement concerning "double taxation." In the Pullman Company case the situation was similar to that in the Duluth, Missabe $\mathcal{E}^{3}$ Northern Railway Co. case, except that there was no constitutional provision relating to the particular gross-earnings tax. The taxes in question were for the years 1934, 1936, and 1937. The statute providing for the sleeping car companies gross-earnings tax had an in lieu provision which originally provided that such tax was to be "in lieu of all taxes and assessments upon all taxable property. . . " However, in 1937 the in lieu provision was amended to read: "in lieu of all ad valorem taxes upon all taxable property. ..."68 Thus, the contention of the taxpayer in the Pullman Company case was that the "income tax" was not only a tax upon property, but was also an "ad valorem" property tax, and, therefore, the company should be refunded the "income tax" paid for the year 1937 as well as such taxes paid for the prior years in question.

In a 4-3 decision, with a very strong dissenting opinion, it was held that the taxpayer should recover for the following reasons. The majority first pointed out that the Duluth, Missabe $\mathcal{O}^{2}$ Northern Railway Co. case had already determined that the "franchise" on "income" tax was a tax upon property, the property being the franchise. ${ }^{60}$ The important question concerned the kind of property tax which the "franchise" tax might be called. The court concluded that it might properly be called an ad valorem property tax, reasoning that the fact that the tax was "measured by" net income was "persuasively indicative" to the majority that there was a "legislative intent" to base such a tax "upon the value of the

${ }^{67}$ Minn. Laws 1913, c. 480, §2.

${ }^{68}$ Minn. Laws 1937, Ex. Sess., c. 3, §2.

${ }^{60}$ Pullman Co. v. Com'r of Taxation, supra note 66 at 98-99. 
franchise, thereby making it an ad valorem tax, for it is obvious that the value of a franchise is largely determined by the profitableness of the use of such franchise."70 The legislature was only choosing "one of the most dependable methods of measuring the value of the franchise." Having so determined, it followed that the gross-earnings tax was in lieu of the "franchise" tax as stipulated by the statutory in lieu provision. ${ }^{11}$

Summarizing its decision that the "franchise" tax was an ad valorem tax, that the franchise of the company was taxed as property under the gross-earnings tax, and that such grossearnings tax was in lieu of all ad valorem taxes, the court declared:

.. . we must and do hold that the tax imposed upon relator through the franchise tax act is invalid as double taxation, and that the imposition of such franchise tax is also objectionable as being in contravention of Minn. Const. art. 9, $\S 1$, that "Taxes shall be uniform upon the same class of subjects, ... ."72

This is a most dubious conclusion. Nowhere in the opinion, until this final sentence, was either the uniformity clause or any theory of double taxation mentioned. The issue was raised under the in lieu provision of the gross-earnings tax law. Indeed, the use of the words "double taxation" in the quoted conclusion only makes sense if such words are a shorthand way of referring to the in lieu provision, rather than being used in relation to the unformity concept. ${ }^{73}$ The words

\footnotetext{
70 Id. at 100-101.

71 Id. at 101-104.

$72 I d$. at 108 , emphasis added.

73 Compare the opinion in Reed v. Bjornson, supra note 16, in which the income tax was upheld. The court rejected a contention that unequal "double taxation" resulted from the imposition of the tax upon income from property. As for "double taxation," the court said, at 270:
}

Double taxation is not forbidden by either the state or the national con- 
are divorced from the statement concerning the uniformity clause found in the constitution. And, certainly, the alternative conclusion based on the uniformity clause in Art. IX, $\S 1$ was quite unnecessary. A strong dissent attacked the conclusion that the corporate "franchise" tax with a base of net income was a tax upon property and would have overruled the Duluth, Missabe EO Northern Railway Co. case on this point. ${ }^{74}$ The dissent would have held the franchise tax an excise tax or privilege tax rather than a tax upon the franchise as property.

Subsequently, the legislature apparently concerned itself with the rationale of the Pullman Company case and inserted the word "excise" tax in the statutory provision imposing the tax relative to corporate net income, ${ }^{75}$ so that it now reads:

An annual excise tax is hereby imposed upon every domestic corporation ... for the privilege of existing as a corporation during any part of its taxable year, and upon every foreign corporation . . . for the grant to it of the privilege of transacting or for the actual transaction by it of any local business within this state during any part of the taxable year. .76

stitution. It may result in lack of uniformity and hence be illegal. It may offend the equal protection clause, but we do not see that this tax does either. We believe that all of our cases which hold double taxation illegal are based upon one or the other of these grounds, or, as in Railway Express Agency v. Holm, 180 Minn. 268, 272 ... upon a direct constitutional inhibition, art. 16.

74 Pullman Co. v. Com'r of Taxation, supra note 66 at 112-120.

75 The decision was rendered a "few weeks" before the session of the legislature. Note, "Current Legislation-Minnesota, 1947," 33 Minn. L. Rev. 27, 52 (1948).

${ }^{78}$ Minn. Laws 1947, c. $635, \S 2$. It might be well to point out that by Minn. Laws 1937, Ex. Sess., c. 49, alterations were made in sections 2 and 3 of the original act (see text to note 27 , supra) so that section 2 , concerning corporate income, was amended to read as it is quoted in the text to this note, except that the word "excise" did not appear. The 1937 amendments were related to other problems, and, while re-arranging the phraseology 
While it is not certain just what the effect of this amendment will be insofar as the nature of the "franchise" tax is concerned, a 1950 case, Western Union Telegraph Co. v. $S p a e t h{ }^{77}$ is a strong indication that the legislative intent will be followed and that such tax will henceforth be characterized as a nonproperty tax. It is pertinent to note that the entire discussion in the Western Union case revolved about the statutory in lieu provision of one of the gross earnings taxes, with no mention being made of any double taxation theory or the uniformity clause, although the same fact situation was present which gave rise to the prior Duluth, Missabe $\mathcal{E}^{2}$ Northern Railway Co. and Pullman Company cases.

Summary: property taxation. The preceding discussion should sufficiently illustrate the discretion allowed the legislature under the amended uniformity structure of the Minnesota Constitution. Property may not only be classified for different effective rates, but this apparently includes classification for graduated rates. There is no rule of universality; exemptions of property need to conform only to the requirement of reasonable classes. ${ }^{78}$ Furthermore, it seems clear

somewhat, did not substantially alter the substance of sections 2 and 3. An important change, however, was made as to the rates. Since 1937 the graduated schedule has not applied to corporate income, such income being taxed at a rate of $6 \%$.

77232 Minn. 128, 44 N.W. 2d 440 (1950).

78 There are no clear-cut decisions upholding the several exemptions from the general property tax. In one case there is dictum to the effect that exemptions other than those enumerated "might" be prohibited. City of Minneapolis v. Armson, supra note 26 at 170 . However, note that in Reed v. Bjornson, supra note 16 at 269, upholding the income tax, the court pointed out that in the Armson case the above proposition was not decided, the court then finding in fact that there was no exemption under the statute in question. Though the court did not determine the nature of the income tax, exemptions therefrom were upheld, the court saying, "We hold that the enumeration of exemptions in our constitution does not forbid making others which do not offend the uniformity clause or the federal constitution." 
that specific property taxes, as opposed to ad valorem property taxes, may be imposed. ${ }^{79}$

\section{Missouri}

\section{a. Uniformity in taxation prior to $1945^{1}$}

The uniformity structure of the new Missouri Constitution of 1945 is best understood in light of the uniformity structures of the preceding constitutions of 1820,1865 and 1875. The absence in the present constitution of a key provision appearing in all of the prior constitutions, and the addition of rather explicit provisions classifying property are explained by the development of the meaning of those prior uniformity structures.

\section{(1) The provisions and meaning of the uniformity limitation: 1820 to 1875}

1820 to 1865 . In the original Missouri Constitution, dated 1820 , there was but a single provision dealing expressly with problems of uniformity of taxation. Article XIII, the Decla-

${ }^{79}$ In this respect note the following special taxes concerning which no cases have arisen. There is a grain handling tax provided for in Minn. Stat. Ann., \$286.02, imposing "In lieu of all taxes on grain as property of any person handling grain, an annual excise tax ... on the handling of grain. . . The rate is $1 / 2$ and $1 / 4$ mill per bushel, depending on the kind of grain. Although the statute purports to impose an excise tax, note that in Minn. Stat. Ann. the tax is found under the heading: "Special Property Taxes.” In Minn. Stat. Ann., $\$ 289.01$ it is provided that owners of described vessels "may pay into the state treasury a sum equal to five cents per net ton of such registered tonnage," and "Such payments shall be received in lieu of other taxes on such craft. . . ." Cf. Montague, supra note 54 at 81 .

${ }^{1}$ See Garden, "Uniformity of Taxation in Missouri," 24 Wash. U.L.Q. 242 (1939) for one of the few articles attempting to determine the meaning of the entire uniformity limitation within a single jurisdiction. 
ration of Rights, contained a proportionality clause in section 19, which read:

... all property, subject to taxation in this State, shall be taxed in proportion to its value.

This provision applied only to property taxation, and the court interpreted it to require an absolute uniformity in the effective rate applied to all property taxed by any one taxing authority, ${ }^{2}$ and, obviously, specific property taxes were prohibited. ${ }^{3}$ The otherwise strict uniformity limitation was relaxed so that there was no rule of universality, that is, the determination of what property was to be taxed was left to legislative discretion. ${ }^{4}$

1865 to 1875 . The second Missouri Constitution, dated 1865 , also had a very brief uniformity structure. The proportionality clause of the 1820 constitution was carried over in a somewhat altered form. This clause was still located in the Declaration of Rights, Art. I, §30, and read as follows after 1865 :

.. . all property subject to taxation ought to be taxed in proportion to its value.

This was potentially, of course, a substantial change. A second provision of interest was added to the constitution. Article XI, $\$ 16$ dealt with exemption of property and provided that

No property, real or personal, shall be exempt from taxation, except such as may be used exclusively for public schools, and such as may belong to the United States, to this State, to counties, or to municipal corporations within this State.

No change was wrought in the application of the propor-

2 See, for example, the discussion in State v. North \& Scott, 27 Mo. 464, 483 (1858).

${ }^{8}$ Ibid.

4 lbid., and see note 8 , infra. 
tionality clause; it still limited only property taxes. ${ }^{6}$ Nor did the substitution of the words "ought to be" for "shall be" have any effect upon the uniformity required of property taxes, although some argued to the contrary. ${ }^{6}$ The only change in the uniformity required of property taxes was the addition of a universality requirement. ${ }^{7}$ Thus the uniformity limitation was tightened up in that respect. In finding a requirement of universality the court could rely upon the new Art. XI, §16. For example, in Life Association of America v. Board of Assessors, ${ }^{8}$ the court pointed out that the provision expressly prohibited the exemption of any property, and it indicated that under the former constitution the proportionality clause standing alone was not interpreted as containing such a limitation. However, despite this, the tenor of the entire opinion of the Life Association of America case leads one to believe that the court would, if necessary, have relied upon the proportionality clause in Art. I, $\$ 30$ to find a requirement of universality. ${ }^{\circ}$

\section{(2) The provisions and meaning of the uniformity limitation: 1875 to 1945}

The third constitution of Missouri, dated 1875, served for a substantial period of time. In that constitution, there appeared for the first time a Revenue Article, Art. X. The sig-

5 See, for example, Glasgow v. Rowse, 43 Mo. 479 (1869). See note 17, infra. Cf. Garden, supra note 1 at 243-244.

${ }^{6}$ In Life Association of America v. Board of Assessors, 49 Mo. 512 (1872) it was said at 518: "The old constitution used the word 'shall,' but it is evident from a survey of the whole instrument that the substitution of the one word for the other was not intended to produce any change in the construction or the duties enjoined. The word designated is expressive of a duty and equivalent to a prohibition against proceeding in any other way."

7 See, for example, Life Ass'n of America v. Board of Assessors, supra note 6; State v. Hannibal \& St. Joseph R. Co., 75 Mo. 208 (1881).

8 Supra note 6 at 519.

${ }^{8} 1 d$. at 518-521. See State v. Hannibal \& St. Joseph R. Co., supra note 7. 
nificant change from the prior constitutions lay in the addition of a new uniformity clause, found in Art. X, $\S 3$, which read:

Taxes ... shall be uniform upon the same class of subjects within the territorial limits of the authority levying the tax. ...

The insertion of this new provision might have meant a radical change in the meaning of the uniformity limitation. However, any such possibility soon faded away.

The remainder of the uniformity structure ${ }^{10}$ closely resembled those provisions in the prior constitution of 1865 . The proportionality clause was carried over, with the verb reverting back to "shall be," and it was placed in Art. X, §4, which read:

All property subject to taxation shall be taxed in proportion to its value.

Article X, $\$ 6$ provided for both mandatory and permissible exemptions of enumerated classes of property, while Art. X, $\S 7$, spelled out a requirement of universality, reading as follows: "All laws exempting property from taxation, other than the property above enumerated, shall be void." This uniformity structure served until 1945 without any substantial amendment. A survey of the court's interpretation of its meaning will lend some understanding of the uniformity structure of the present constitution of 1945 .

The court held that nonproperty taxes were limited by the new uniformity clause found in Art. X, $\$ 3,{ }^{11}$ but in substance this only meant that such nonproperty taxes must con-

${ }^{10}$ There was also a minor provision in Art. X, $\$ 5$ identical to the present Art. X, §5. See note 35, infra.

${ }^{11}$ A leading case is Ludlow-Saylor Wire Co. v. Wollbrinck, $275 \mathrm{Mo}$. 339, 205 S.W. 196 (1918). 
form to the usual requirement that their objects and exemption therefrom must constitute reasonable classes. ${ }^{12}$ Further, the requirement of reasonable classifications has been held to permit graduated rate schedules, as for example under the income tax ${ }^{13}$ and inheritance tax. ${ }^{14}$

Because of the stricter uniformity limitation applicable to property taxes, the determination of the nature of any given tax was of considerable importance under the 1875 constitution. Thus, the Secured Debts Tax Act of 1917, discussed below, was held to be a property tax, and, consequently, was held unconstitutional because it could not conform to the stricter uniformity requirement. ${ }^{15}$ Also of interest for comparative purposes are the decisions on this point concerning an income tax and an inheritance tax, briefly discussed below. ${ }^{16}$

Income tax. In one of the more important state cases concerning an income tax, Ludlow-Saylor Wire Co. v. Woll-

12 From among the numerous cases, see, for example: American Express Co. v. St. Joseph, 66 Mo. 675 (1878); American Mfg. Co. v. St. Louis, 270 Mo. 40, 192 S.W. 402 (1916); Aurora v. McGannon, 138 Mo. 38, 39 S.W. 469 (1897) ; City of Cape Giradeau v. Groves Motor Co., 346 Mo. 762, 142 S.W. 2d 1040 (1940), finding an arbitrary classification; Massachusetts Bonding \& Ins. Co. v. Chorn, 274 Mo. 15, 201 S.W. 1122 (1918); St. Louis v. Spiegel, 75 Mo. 145 (1881); State ex rel. McClung v. Becker, 288 Mo. 607, 233 S.W. 54 (1921); State ex rel. Missouri Pac. R. Co. v. Danuser, 319 Mo. 799, 6 S.W. 2d 907 (1928); Viquesney v. Kansas City, 305 Mo. 488, 266 S.W. 700 (1924); City of Washington v. Washington Oil Co., 346 Mo. 1183, 145 S.W. 2d 366 (1940), finding an arbitrary classification. And see the discussion in Garden, supra note 1, at 249-252.

13 Bacon v. Ranson, 331 Mo. 985, 56 S.W. 2d 786 (1932).

14 State ex rel. McClintock v. Guinotte, 275 Mo. 298, 204 S.W. 806 (1918).

${ }^{15}$ State ex rel. Tompkins v. Shipman, 290 Mo. 65, 234 S.W. 60 (1921).

${ }^{16}$ Also of interest is the decision that a corporate franchise tax with a base of capital stock was a nonproperty tax. State ex rel. Missouri Pac. R. Co. v. Danuser, supra note 12. 
brinck, ${ }^{17}$ the Missouri income tax act of 1917 was upheld. The court first held that the tax was not a tax upon property, neither as a tax on income as property nor as a tax on the property from which the income was derived. In a 4-3 opinion, with a strong dissent, the court upheld the tax and its exemptions and the classifications of persons and corporations into two basic classes for application of a different flat proportional rate to each class. Subsequently, in Bacon v. Ranson ${ }^{18}$ the court re-affirmed the Ludlow-Saylor rationale and upheld the amended income tax which now had a graduated rate schedule. In approving this classification the court relied on the ability-to-pay rationale, saying:

The basic principle underlying all such classifications is the ability of the taxpayer to pay. Many economists and students of government regard a progressive tax as more just and equal in point of sacrifice than a proportional one, since persons with large incomes can more readily spare a fixed proportion of their income than those who have difficulty in sustaining themselves upon what they receive each year. ${ }^{19}$

Inheritance tax. In the earlier case on this problem, State ex rel. Garth v. Switzler, ${ }^{20}$ decided in 1897 , the court held that the inheritance tax of 1895 , as amended in 1897, was a tax upon property, and a violation of the uniformity limitation for reasons discussed under "Property taxation," infra. The opinion in that case also indicated that the principle of graduated rates was an "arbitrary classification without rhyme or reason."21 The legislature took its cue from the Switzler opinion and in State ex rel. Fath v. Henderson, ${ }^{22}$

17 Supra note 11 . The court relied in part on a similar holding under the 1865 constitution. See Glasgow v. Rowse, supra note 5.

18331 Mo. 985, 56 S.W. 2d 786 (1932).

19 Id. at 995 .

20143 Mo. 287, 45 S.W. 285 (1897).

21 Id. at 332.

22160 Mo. 190, 60 S.W. 1093 (1900). 
decided in 1900 , the court upheld the collateral inheritance tax of 1899 , which, however, did not have a graduated rate. The court held that the tax was upon a privilege rather than upon the property transmitted, the legislature having changed a few words in the operative part of the tax statute. Then in State ex rel. McClintock v. Guinotte ${ }^{23}$ the inheritance tax act of 1917 was upheld as a nonproperty tax. The 1917 tax had a graduated rate schedule which was approved.

\section{(a) Property taxation}

Whatever the source, the court left no doubt that the new constitution of 1875 was to make no change in the uniformity required of property taxes. There was still a requirement of absolute uniformity in effective rates, ${ }^{24}$ only the ad valorem method could be used to tax property, ${ }^{25}$ and the requirement of universality remained. ${ }^{26}$ A leading case was State ex rel. Tompkins v. Shipman, ${ }^{27}$ decided in 1921, in which the court considered the validity of the Secured Debts Tax Act of 1917. The Missouri legislature had provided that "bonds, debentures, or obligations for the payment of money" were

23 Supra note 14.

${ }^{24}$ State ex rel. Tompkins v. Shipman, supra note 15 , discussed in the text, infra note 27. Also see: Brookfield v. Tooly, 141 Mo. 619, 43 S.W. 387 (1897); Booneville Nat. Bank v. Scholtzhauer, 317 Mo. 1298, 298 S.W. 732 (1927); Mercantile Trust Co. v. Schramm, 269 Mo. 489, 190 S.W. 886 (1916). Also see State ex rel. Garth v. Switzler, supra note 20; State ex rel. Johnson v. Chicago B. \& Q. R. Co., 195 Mo. 228, 93 S.W. 784 (1906); State ex rel. Aull v. Field, 119 Mo. 593, 24 S.W. 752 (1894).

${ }^{25}$ For example, the Shipman and the Switzler cases, discussed in the text.

${ }^{26}$ For example, Copeland v. St. Joseph, 126 Mo. 417, 29 S.W. 281 (1895); State ex rel. Musser v. Birch, 186 Mo. 205, 85 S.W. 361 (1905); State ex rel. Missouri State Life Ins. Co. v. Gehner, 320 Mo. 691, 8 S.W. 2d 1068 (1926); State ex rel. Morgan v. Hemenway, 272 Mo. 187, 198 S.W. 825 (1917).

27 Supra note 15. 
to constitute a separate class of property for purposes of taxation. Such securities could be recorded and a tax paid, the rate being so many cents on each $\$ 100$ or fraction thereof of the face value. The size of the rate depended upon the time in which the debt should mature, increasing with the length of the maturity period. The tax was held unconstitutional, both because it did not conform to the requirement of absolute uniformity in effective rates and because it was not ad valorem. Not only was the rate for the tax itself classified, but it was different from that applied to all other property taxed by the state. Similarly, in State ex rel. Garth v. Switzler, ${ }^{28}$ in which the court reviewed the Inheritance Tax of 1895 , it was held that the tax violated the property-tax uniformity limitation because it subjected such estates "to an additional property tax to that levied upon all other like property in the State for the same year, and is not levied in proportion to its value. ${ }^{29}$

As for the source of these limitations, there was no possibility of conflict concerning the ad valorem and universality requirements. The proportionality clause remained in Art. $\mathrm{X}, \S 4$; and Art. $\mathrm{X}, \S 7$ spelled out a prohibition against exemptions. However, on the introduction of the new constitution some controversy arose at once concerning the degree of uniformity required of effective rates.

What was to be the effect of the new uniformity clause found in Art. X, §3? Could property now be classified for the purpose of applying different effective rates? Article $\mathrm{X}$, $\$ 3$ only required that "Taxes... shall be uniform upon the same class of subjects. . . ." How did the introduction

28 Supra note 20.

29 Id. at 331. The words "all other like property" might be construed to mean that the court was thinking in terms of uniformity within classes of property. For a similar inference, see the discussion in that opinion concerning the invalidity of the tax under Art. X, $\$ 3$. 
of this new uniformity clause, framed potentially in terms of classification, affect the proportionality clause in Art. X, $\$ 4$, which was carried over from the old constitutions and which was the source of an absolute uniformity requirement when standing alone?

For example, in the Shipman case it was argued that Art. $\mathrm{X}, \S 3$ authorized the classification of property for rates so that the secured debts tax could be upheld. There has been some confusion as to whether the court ruled that the uniformity clause in Art. $X, \S 3$ refers only to nonproperty taxes. $^{30}$ It is a rather moot question, but to this writer the better view would seem to be that the court has simply ruled that property was a single subject of taxation, not subject to further subclassification. Therefore, the requirement of absolute uniformity in rates could be derived from either Art. $\mathrm{X}, \S 3$ or Art. X, $\$ 4$. Thus, in the Shipman case, when faced with the proposition stated above, the court replied:

. . . the whole question is solved by Section 4 of Article X, of the Constitution, because it puts all property subject to taxes into a single class, and fixed the rule of taxation thereon. ${ }^{31}$

We rule that the General Assembly . . . cannot reclassify property, for to do so would violate section 4 of Article X. It cannot violate the rule of uniformity, for such would violate Section 3 of Article X. ${ }^{32}$

Perhaps indicative of the difficulty facing a contrary interpretation of these provisions is the rather heated personal view of the opinion-writer concerning the tax under considera-

${ }^{30}$ Cf. Garden, supra note 1 at 244 et seq.

31 State ex rel. Tompkins v. Shipman, 290 Mo. 65, 76, 234 S.W. 60 (1921).

$32 I d$, at 81 . 
tion. ${ }^{33}$ In any case, one is not warranted in blaming the strict interpretation solely on the retention of the proportionality clause in Art. X, $\S 4$, because a similar result has been reached in other states having a uniformity clause of this type, but not having such a proportionality clause. ${ }^{34}$

\section{(b) Uniformity in taxation since 1945}

The new constitution of 1945 introduced some definite changes into the uniformity structure. The uniformity clause remains the same and is still numbered Art. X, §3: "Taxes ... shall be uniform upon the same class of subjects within the territorial limits of the authority levying the tax. . . ." However, the proportionality clause found in the old Art. $\mathrm{X}, \S 4$ has been deleted, and in its place is a detailed section which spells out the degree of uniformity required of property taxation; provides for the classification of property but stipulates the minimum classes; and provides for the method by which property may be taxed. Article X, $\$ 4$ now reads:

(A) All taxable property shall be classified for tax purposes as follows: class 1, real property; class 2, tangible personal property; class 3, intangible personal property. The general assembly, by general law, may provide for further classification within classes 2 and 3 , based solely on the na-

${ }^{33}$ Id. at 83, where the court said:

The whole act is but a bungling attempt to exempt these securities from the taxes that they should pay.

But it is urged, that with this insignificant tax, this class of property will emerge from its hiding place, and the State will be benefited thereby. If the penal laws were strengthened, and then enforced, it would require but a few penitentiary sentences to bring to light all such property for the payment of the taxes at the same rate as other property is required to pay. The act is wrong in principle, and against good morals, and a fair sense of justice. All property should bear its proportionate part of the State's necessities. The Constitution so declares, and such declaration voids this law.

${ }^{34}$ See Part G (4) of this chapter. 
ture and characteristics of the property, and not on the nature, residence or business of the owner, or the amount owned. Nothing in this section shall prevent the taxing of franchises, privileges or incomes, or the levying of excise or motor vehicle license taxes, or any other taxes of the same or different types.

(B) Property in classes 1 and 2 and subclasses of class 2, shall be assessed for tax purposes at its value or such percentage of its value as may be fixed by law for each class and for each subclass of class 2. Property in class 3 and its subclasses shall be taxed only to the extent authorized and at the rate fixed by law for each class and subclass, and the tax shall be based on the annual yield and shall not exceed eight per cent thereof.

There has been no substantive change in the exemption section, except that the former Art. X, $\S \S 6$ and 7 have been brought together into a single provision, Art. $X, \S 6$, so that the prohibition against exemptions now constitutes the last sentence of section $6 .^{35}$

Of course, any changes in the uniformity limitation would relate only to property taxation. ${ }^{36}$ There has been no systematic development by the court as to the current meaning of the uniformity limitation applicable to property taxes. However, certain conclusions appear obvious. Certainly the re-

${ }^{35}$ Another provision dealing with a special problem is Art. $\mathrm{X}, \S 7$ which provides for special treatment and taxation of forest lands. For the text, see the Appendix, infra. Article X, $\$ 5$ provides:

All railroad corporations in this state, or doing business therein, shall be subject to taxation for state, county, school, municipal, and other purposes, on the real and personal property owned or used by them, and on their gross earnings, their net earnings, their franchises and their capital stock.

${ }^{86}$ A recent nonproperty tax case is State ex rel. Transport Mfg. \& Equipment Co. v. Bates, 359 Mo. 1002, 224 S.W. 2d 996 (1949), in which the court held that the exemption of motor vehicles having seating capacities of ten passengers or more from the use tax where a sales tax was paid in another state was an arbitrary exemption and therefore contrary to the uniformity clause in Art. X, \$3. Also see Walters v. City of St. Louis, 259 S.W. 2d 377 (1952). 
quirement of universality remains, ${ }^{37}$ since the clause prohibiting exemptions is retained in the new constitution.

The key change was in the deletion of the proportionality clause-which was the basis for ruling that property was a single class-and the addition of a new section, Art. X, \$4, expressly providing that property might be classified. Of course, the legislative discretion is limited by Art. $X, \S 4$, in that the minimum classes of property are set. Real property may not be further classified. And in subclassifying the basic classes of tangible and intangible personalty the legislature is limited by the standard of classification set out in Art. X, $\S 4(A)$, which rules out, for example, a graduated propertytax rate. These classifications of property may be made for the purpose of applying different effective rates. ${ }^{38}$ However, pursuant to Art. $\mathrm{X}, \S 4(\mathrm{~B})$, in taxing tangible property, realty or personalty, the legislature is still limited by a requirement that such taxes be ad valorem.

In summary, the uniformity clause in Art. $\mathrm{X}, \S 3$ remains superfluous insofar as taxation of property is concerned. The particular requirements of uniformity are spelled out in Art. $\mathrm{X}, \S \S 4$ and 6 . The effect of the new constitutional uniformity structure of 1945 is to permit a more flexible means of taxing intangible property, and to allow some classification of tangible personal property. In fact, all tangible property is still subject to the single rate general property tax, ${ }^{39}$ while intangibles are subject to a yield tax which is not classified. ${ }^{40}$

${ }^{37}$ See General American Life Ins. Co. v. Bates, 363 Mo. 143, 249 S.W. 2d 458 (1952). An insurance companies gross premiums tax was imposed which purported to be in lieu of any taxes on the intangibles of companies taxed thereby. The court held the premiums tax to be a nonproperty tax and the in lieu provision to be an exemption of property contrary to Art. $\mathrm{X}, \S 6$.

${ }^{38}$ The uniformity requirement is still territorial. See State v. Metropolitan St. Louis Sewer District, 275 S.W. 2d 225 (1955).

${ }^{89}$ Mo. Rev. Stat. c. 137. Forest lands are separately classified pursuant to Art. X, §7, supra note 35 .

${ }^{10}$ Mo. Rev. Stat. $\$ 146.020$. 


\section{Montana}

\section{a. The provisions; historical note}

Montana has had but one constitution, dated 1889, and there have been no significant amendments to the uniformity structure found in Art. XII. In the introductory chapters to this study it was pointed out that the term uniformity clauses would be used to designate those basic provisions from which have been derived the particular rules of uniformity for taxation. However, it was noted that in some cases several of the basic types of clauses were phrased in terms of "according to value" and "in proportion to value" rather than "uniform and equal." Not infrequently it is shown that a state may have two, or even three, of these basic types of clauses classified according to substantial differences in phraseology. However, the Montana Constitution is one of the very few constitutions having two provisions, either of which might serve as a basic uniformity clause, and both of which are framed in terms of "uniformity." These two Montana provisions are different types which on their face might well lead to conflicting results.

Article XII, $\S 1$ of the Montana Constitution contains a Type VI uniformity clause which reads (with the uniformity clause italicized):

... the Legislative Assembly . . shall levy a uniform rate of assessment and taxation, and shall prescribe such regulations as shall secure a just valuation for taxation of all property, except that especially provided for in this article. The Legislative Assembly may also impose a license tax, both upon persons and upon corporations doing business in the State.

Note that the uniformity clause is combined with a "just valuation" clause, as was the case with all but one of the states having a Type VI clause as the basic provision. To be 
reconciled with Art. XII, $\S 1$, is the uniformity clause found in Art. XII, $\$ 11$. That section reads:

Taxes shall be levied and collected by general laws and for public purposes only. They shall be uniform upon the same class of subjects within the territorial limits of the authority levying the tax.

Two other provisions in Art. XII are of interest in determining the meaning of the uniformity limitation in Montana. ${ }^{1}$ Art. XII, $\$ 2$ is an exemption provision, stating that certain named classes of public property "shall be exempt from taxation," while other named classes of property "may be exempt from taxation." By an amendment in 1918 the following was added to this last category: "evidences of debt secured by mortgages of record upon real or personal property in the state of Montana." Thus, a particular problem of "double taxation" was dealt with by constitutional amendment. The other important provision is Art. XII, §17, which purports to define property as follows:

The word property as used in this article is hereby declared to include moneys, credits, bonds, stocks, franchises and all matters and things (real, personal and mixed) capable of private ownership, but this shall not be construed so as to authorize the taxation of the stocks of any company or corporation when the property of such company or corporation represented by such stocks is within the State and has been taxed.

Again, a particular problem of "double taxation" is dealt with in the proviso.

Finally, Art. XII, §1a, which was added to the constitu-

1 Of minor interest are Art. XII, \$3, providing for special treatment of mines and mining claims, and Art. XII, \$7, which requires that all corporations shall be subject to taxation for state and local purposes on real and personal property owned or used by them and not by the constitution exempted. 
tion by amendment in 1934, expressly authorizes the imposition of an income tax:

The legislative assembly may levy and collect taxes upon incomes of persons, firms and corporations for the purpose of replacing property taxes. These income taxes may be graduated and progressive and shall be distributed to the public schools and to the state government.

As will be explained below, such an authorization was unnecessary insofar as the uniformity limitation might have been an insurmountable barrier.

\section{b. Meaning of the uniformity limitation}

The Montana court has taken the position that nonproperty taxes ${ }^{2}$ are not limited by either of the uniformity clauses found in the Montana Constitution, ${ }^{3}$ although that clause in Art. XII, $\$ 11$ which requires "Taxes [to] be uniform upon

2 In spite of some intimation to the effect that the Montana tax structure is limited to property and "license" taxes conforming to the second sentence of Art. XII, $\$ 1$ (for example, Fruit Growers' Express Co. v. Brett, 94 Mont. 281, 292-293, 22 P. 2d 171 (1933)), it seems clear that taxes other than "license" taxes within the meaning of Art. XII, $\$ 1$ are permissible (for example, O'Connell v. State Board of Equalization, 95 Mont. 91, 25 P. 2d 114 (1933); State v. Driscoll, 101 Mont. 348, 54 P. 2d 571 (1936)).

3 The early case usually cited as establishing this doctrine is State ex rel. Sam Toi v. French, 17 Mont. 54, 41 Pac. 1078 (1895). Subsequent cases simply cite the French case as authority for the proposition without a discussion of the merits. However, the same result could have been reached in the French case without such a rationale. In that case, the court simply lumped the uniformity clause in Art. XII, $\$ 11$ with all such types of clauses without noticing the difference in words, and then proceeded to reason that such limitations could apply only to the taxation of property. Of course, applying the clause in section 11 would achieve the same result because it is in terms of uniformity within classes. However, the rationale of this court did partially pave the way for the liberal decision as to property taxes. See text to note 16, infra. As for the proposition that the application of Art. XII, $\$ 11$ would have made no difference in the French case, compare the implications of Gelsthorpe v. Furnell, 20 Mont. 299, 51 Pac. 267 (1898). 
the same class of subjects" could reasonably be held the source of the requirement that nonproperty taxes must be uniform within classes. ${ }^{4}$ Under this limitation the court has approved the principle of progressively graduated rates as being a reasonable classification.

Because of the more restrictive uniformity limitation applicable to property taxes, as discussed below, it is often crucial to determine the nature of a tax. This is so even though the property-tax uniformity limitation is not nearly so restrictive as in many other states. It is of interest to note that the court has ruled that an inheritance tax was not a property tax, ${ }^{6}$ and a similar result was reached as to an income tax. However, in Hauser v. Miller ${ }^{7}$ the court held that a graduated probate fee was a tax on property and invalid because the rate schedule was contrary to the property-tax uniformity requirement.

Income tax. In O'Connell v. State Board of Equalization, decided in 1933, the Montana court upheld the graduated personal net income tax law enacted in $1933 .^{\circ}$ The act had been copied from the Idaho income tax $\mathrm{law}^{10}$ and a constitu-

4 For example, Gelsthorpe v. Furnell, supra note 3 (inheritance tax, a minimum exemption of $\$ 7500$ held to be a reasonable classification); O'Connell v. State Board of Equalization, supra note 2 (income tax, several exemptions, all held to be reasonable classifications). Also see Hale v. County Treasurer of Mineral County, 82 Mont. 98, 265 Pac. 6 (1928); State ex rel. Griffin v. Greene, 104 Mont. 460, 67 P. 2d 995 (1937); State v. Hennessy Co., 71 Mont. 301, 230 Pac. 64 (1925).

' O'Connell v. State Board of Equalization, supra note 2; State v. Hennessy County, supra note 4.

${ }^{6}$ Gelsthorpe v. Furnell, supra note 3.

737 Mont. 22, 94 Pac. 197 (1908). See text at note 24, infra.

${ }^{8}$ Supra note 2. Also see Mills v. State Board of Equalization, 97 Mont. 13, 33 P. 2d 563 (1934), following in principle the O'Connell case. The Mills case is discussed in the comparative study of the income tax, infro Chapter V.

${ }^{9}$ Mont. Laws 1933, c. 181.

10 O'Connell v. State Board of Equalization, supra note 2. 
tional amendment ${ }^{11}$ was contemporaneously proposed which would have expressly authorized the imposition of such a tax. However, the validity of the tax was determined in the O'Connell case before the amendment became effective. Thus, in effect, that amendment when adopted was only a mere approval of power already existing. Of course, a part of that provision is still important for the diversion of the revenue from an income tax. In any case, it was the conclusion of the Montana court in the O'Connell case that the income tax was not a property tax, and, therefore, not subject to any of the stricter property-tax uniformity requirements. Consequently, exemptions were permissible, as were graduated rates. The court relied to a considerable degree on the Idaho act and the interpretation placed by the Idaho court on that act as it related to the Idaho uniformity limitation in the Diefendorf case. ${ }^{12}$ While clearly holding that the tax was not a property tax, the court never squarely held that it was an "excise" tax, although it concluded that the tax was "in the nature" of an excise tax. The majority in the 3-2 decision looked favorably on the view that such a tax is sui generis. ${ }^{13}$ It may be noted that the two dissenting justices vigorously opposed calling the tax other than a property tax, and they would have held the graduated rates to be arbitrary classifications.

\section{(1) Property taxation}

The two possibly conflicting uniformity clauses found in the Montana Constitution have caused no problem insofar as two of the particular rules of uniformity are concerned. Thus, there is a requirement of universality. ${ }^{14}$ In locating

11 Art. XII, §1 a, quoted in the text, supra.

12 See Part G (4) of this chapter, supra.

13 O'Connell v. State Board of Equalization, supra note 2 at 112-113.

14 See Northwestern Mutual Life Ins. Co. v. Lewis \& Clark County, 28 Mont. 484, 72 Pac. 982 (1903), in which the court considered the validity 
the source of this requirement, the court has generally relied on both the "just valuation for taxation of all property" clause in Art. XII, $\S 1$ and the enumeration of both permissible and mandatory exemptions of property in Art. XII, $\$ 2$. In the latter case, applying the maxim of construction $e x-$ pressio unius est exclusio alterius, the court found authority to prohibit exemption of property other than that enumerated in Art. XII, \$2. Also, the court has clearly ruled that property may only be taxed by the ad valorem method, thus excluding the possibility of using "gross earnings" as the base in taxing property. ${ }^{15}$ The court referred to the "just of section 681 of the Civil Code of 1895 which required that each insurance company transacting business in the state should be taxed upon the excess of premiums received over losses and ordinary expenses incurred within the state, the rate being the same as that applied to all other personal property, and further providing that insurance companies subject to the tax were to be subject to "no other taxation under the laws of the state, except taxes on real estate and fees imposed by laws." The court held that the part of section 681 providing for a tax was valid, saying at 493 : "Whether . . . regarded as a tax upon the value of the franchise right of the company to do business in this state, measured by the net income, or as a tax on the business established and done, regarded as property separate from money received as premiums, the value of which is measured by the same standard, is immaterial." Thus, the act simply provided for the taxation of a class of property within the definition of Art. XII, §17. However, the in lieu provision was held unconstitutional as amounting to an exemption of personal property contrary to Art. XII, §1. Also, Art. XII, §7 was referred to. (See note 1, supra.) The court further held that the Act of March 4, 1897, which enacted the present license fee applicable to all domestic and foreign insurance companies (a graduated flat rate, with a base of gross premiums) did not repeal the "property" tax in question. [Note: the tax upheld in the Northwestern case was repealed by an Act of Mar. 2, 1911.]

Also see Daly Bank \& Trust Co. v. Silver Bow, 33 Mont. 101, 81 Pac. 950 (1905), and Stoner v. Timmons, 59 Mont. 158, 196 Pac. 519 (1921). The Stoner case expressly overruled State ex rel. Lyman v. Stewart, 58 Mont. 1, 190 Pac. 129 (1920), and held invalid Mont. Laws 1919, c. 89, which provided for the levy of a local property tax on real property only.

${ }^{15}$ Fruit Growers Express Co. v. Brett, supra note 2, discussed, infra note 27. But see Northwestern Mutual Life Ins. Co. v. Lewis \& Clark, supra note 14. 
valuation" clause in Art. XII, $\S 1$ in indicating the source of this limitation.

The court has also held, in Hilger v. Moore, ${ }^{16}$ decided in 1919 , that property may be classified for the purpose of applying different effective rates. Thus, the comprehensive classified general property tax enacted by the Montana legislature in 1919 was upheld. The system used by the legislature was a classification of property for the application of different ratios of valuation, with a single percentage rate being used. Property was grouped into seven classes, with the ratio of valuation to be used on the respective classes varying from $7 \%$ to $100 \%$ of the full value. ${ }^{17}$ In approving the act, the court indicated that property might be classified according to its nature and character, its productivity or want of it, its utility, the difficulty of reaching some of it under the nonclassified system, as well as on the basis of "other reasons equally cogent."18

In reaching the conclusion that property might be classified for the purpose of applying different effective rates, the

1656 Mont. 147, 182 Pac. 477 (1919), a 4-1 decision.

17 The classes of property with the respective ratios of valuation applicable thereto were: Class (1), net proceeds of mines, mineral rights, and royalties, $100 \%$ of full value; Class (2), household goods, agricultural and commercial machines, motor vehicles and boats, $20 \%$; Class (3), livestock, poultry and unprocessed produces of both, merchandise, and furniture and fixtures in stores, offices and hotels, $331 / 3 \%$ of full value; Class (4), real estate, improvements, manufacturing and mining machinery, $30 \%$ of full value; Class (5), moneys and credits, $7 \%$ of full value; Class (6) shares of stock in banking corporation, $40 \%$ of full value; Class (7) all other property, $40 \%$ of full value. $I d$. at $162-163,176$. The present system is substantially the same. Mont. Rev. Code, $\$ \$ 84-301,84-302$.

${ }^{18}$ Hilger v. Moore, supra note 16 at 176 . The court considered the reasonableness of the classifications at 174-177. It is interesting to note that once having established the possibility of classification under the state constitutional uniformity clauses, the court considered the contention that the classifications were arbitrary under the federal equal protection clause. Id. at 174. 
court faced the difficulty of reconciling the apparently conflicting uniformity clauses found in Art. XII, $\$ 1$ and Art. XII, $\$ 11$. The difficulty is well illustrated by the following quotation found at the end of the opinion:

In conclusion we may say that, from the similarity of the language employed, it is reasonably certain that sections 1 and 11 of Article XII of our Constitution were borrowed from other states. As no other state Constitution contains both sections, it follows that section 1 was taken from a Constitution which did not contain provisions similar to those in section 11, and likewise that section 11 was borrowed from a Constitution which did not contain a section similar to our section 1. The two provisions are not altogether harmonious, and the construction of them intended by the framers, is not very clear. If we have correctly interpreted their meaning, the validity of House Bill No. 30 is placed beyond the range of controversy. In reaching our conclusion, however, it is not necessary for us to say that we are entirely free from doubt. As said by this court . . . "In the case of a statute assailed as unconstitutional, we stand committed to the rule that no such enactment will be pronounced invalid unless its nullity is made manifest beyond a reasonable doubt."19

The rationale of the court was that the provisions in the revenue article, Art. XII, must be read in pari materia. ${ }^{20}$ Thus, the argument that the classified property tax violated the principle "of a uniform rate of taxation" required by Art. XII, $\S 1$ would have been "persuasive, if not convincing" if Art. XII, $\S 1$ were to be construed independently of any other provision. But Art. XII, $\$ 1$ does not stand alone. The division of the constitution into chapters and sections is a mere matter of convenience for the purpose of reference, with no significance in applying rules of construction and in-

${ }^{19} \mathrm{Id}$. at 177 , emphasis added.

${ }^{20} I d$. at 164-173. The arguments of counsel are set out at 148-162. Of course, each gave predominant consideration to the uniformity clause most favorable to the viewpoint being urged. 
terpretation. What of Art. XII, §11? The opinion anticipates its conclusion: "No where is the legislature prohibited from classifying property for the purpose of taxation [Query: but what of Art. XII, $\S 1$, if it stood alone? ]; but, in the contrary, section 11 contains a distinct recognition of the right to do so." Here, the earlier doctrine that nonproperty taxes are not limited by the requirement in Art. XII, $\$ 11$ that "Taxes . . . shall be uniform upon the same class of subjects" came to the support of the view that classification of property was permissible. Thus, "subjects" of taxation did not necessarily include property as a single subject. Removing all taxes other than property taxes from the operative scope of the uniformity clause in Art. XII, $\$ 11$, “. . . it [was] practically certain that the term subjects in section 11 was used [by the framers of the constitution] in its then popular sense to denote the different kinds of property liable to taxation." The court concluded:

Construing the first sentence of section 1 with section 11 the meaning is reasonably clear: The taxes levied shall be uniform upon the same class of property within the same taxing district. ... Or, stating the principle of sections 1 and 11 in different form, the mandatory injunction to the legislature is that it shall prescribe such uniform mode of assessment as shall secure a just valuation of all taxable property ... and that [all taxes] shall be uniform upon the same class of property within the territorial limits of the authority levying the tax. This is the rule of uniformity declared by our Constitution, if we are able to determine the intention of its framers aright. ${ }^{21}$

${ }^{21}$ Id. at 170 . The dissent, at 178 , with "due deference to the learning and maturity of judgment of [his] distinguished colleagues," stated that in his opinion the classification system "defies the letter, scorns the spirit, and seeks to override the equality clauses of the Constitution and the design of its authors to insure the adoption of some system of uniformity and impartiality making for the just apportionment of the burdens of taxation." (Emphasis added.) 
The case of Hilger v. Moore is extremely valuable for comparative purposes, and the entire opinion illustrates the differences which might flow from the use of different phraseology in the uniformity clauses and the possible arguments for mustering support in the form of interpretations by other state courts of uniformity clauses of both similar and varying phraseology. Most of all, it illustrates the difficulty faced when patently conflicting uniformity clauses are included in a single constitution. When it is viewed against the history of a similar situation such as is found, for example, in Missouri, ${ }^{22}$ one finds diametrically opposed results being reached -results predicated, it seems, on an underlying judicial predeliction as to what should be permitted.

In summary, it is now clear that property may be classified in Montana for the purpose of applying different effective rates. ${ }^{23}$ Indeed, as illustrated by the general property tax, classification for rates may approach "zero" but cannot reach it because that would be an unconstitutional "exemption!" However, at least one case indicates that the legislature has less discretion in classifying property than in classifying the subjects of nonproperty taxes. Hauser v. Miller indicates that a graduated property tax rate is not permissible, ${ }^{24}$ although such a classification founded on quantity alone was allowed for nonproperty taxes.

22 See Part G (7) of this chapter, supra.

${ }^{23}$ Besides Hilger v. Moore, supra note 16, see Bank of Miles City v. Custer County, 93 Mont. 291, 19 P. 2d 885 (1933), in which the classification of money and credits was upheld as reasonable. The most recent case is New Silver Bell Min. Co. v. County of Lewis \& Clark, 284 P. 2d 1012 (1955). For cases finding unreasonable classifications: Hayes v. Smith, 58 Mont. 306, 192 Pac. 615 (1920); State v. North Amer. Car Corp., 118 Mont. 183, 164 P. 2d 161 (1945), discussed infra note 30 . Also see an Op. Atty. Gen. Feb. 29, 1952, reported in the CCH Montana Tax Reporter, $\mathbb{\text { 224-002. }}$.

${ }^{24}$ Supra note 7 and text at note 7. 
Property of "freight line companies." The struggles of the Montana legislature to tax the property of freight line companies is an apt illustration of the application of the general rules already listed. The original scheme for the taxation of the cars of such freight line companies (defined as those engaged in furnishing, operating or leasing cars, not otherwise listed for taxation in Montana, for the transportation of freight over any railway lines not owned, leased, or operated by such company) was that for purposes of taxation all cars used exclusively or partially within the state were declared to have a situs in the state. ${ }^{25}$ The gross earnings of such companies were "deemed and considered as the assessed value" for taxation of all cars operated, furnished, or leased by such companies, and there was to be "levied and assessed" against "such property" a tax of five per cent of such "valuation."26

In Fruit Growers Express Co. v. Brett, ${ }^{27}$ decided in 1933, the court held that the tax was a property tax and therefore invalid because it was not based on value as required by Art. XII, $\S 1$. That is, the arbitrary fixing of the value of the property (the cars) was held to violate the requirement that property be taxed by the ad valorem method.

Thereafter, in 1935, the above-described statute was partially amended so as to avoid the results of the Brett case. Now the official, when valuing the cars, was simply to take into consideration, among other things, the "gross earnings" of the company, and the rate levied against such property was to be equal, as nearly as possible, to the average rate of all state and local general property-tax rates for the preceding year, with such rate being "levied against the property

${ }^{25}$ Mont. Rev. Code (1921) §§2097, 2098; Mont. Laws 1919, Ex. Sess., c. 5 .

${ }^{28}$ Mont. Rev. Code (1921) §2101, as amended by Mont. Laws 1925, c. $185, \S 2$, and Mont. Laws 1931, c. 75, §1.

27 Supra note 2. 
of such companies."28 It was further provided that "in lieu of the foregoing tax and in place thereof," such companies could, in the discretion of the board, "be required to pay a tax of five per cent of its total gross earnings .... which tax shall be in lieu of all other taxes upon its property within this state. ${ }^{\prime 29}$

In State v. North American Car Corporation, ${ }^{30}$ decided in 1945 , the court held that the average rate provision violated the uniformity clauses in Art. XII, $\S \S 1$ and 11, because there was no reasonable classification. The court said:

.. [I]t will be admitted that any tax against the same kind of property used for identical purposes is not uniform when a different valuation and a different rate is applied to two distinct taxpayers, separately distinguishable only in name, and the tax being imposed by the same taxing district. $^{31}$

The specific classification in question was as follows: similar property of companies not within the definition of the freight line companies (e.g., common carriers) was taxed only according to actual physical presence in and use in a taxing district, with the rate of that district being applied.

Thereafter, in 1949, the present tax relative to freight line companies became effective. It is obviously a result of the North American Car Corporation decision. It is now simply provided that such freight line companies "shall pay annually ... a sum in the nature of a tax in the amount of five per cent of the total gross earnings received from all sources by reason of the use or operation of such cars within"

${ }^{28}$ Mont. Laws 1935 , c. $26, \S \S 3$ and 5; Mont. Rev. Code $\$ \S 84-4803$ and $84-4805$.

${ }^{29}$ Mont. Laws 1935, c. 26, §6; Mont. Rev. Code \$48-4806.

${ }^{30}$ Supra note 23. The decision was 3-2, with the two dissenting judges believing there was sufficient basis for classification.

81 Id. at 193. 
the state, and the tax "shall be in lieu of all other taxes upon such property of any freight line company so paying the same. . . ."82 It is further provided that such companies shall be liable for the payment of any additional taxes which the board might find due under its authority to raise or lower the rate to conform to "the taxes which would be payable if the cars were taxed on an ad valorem basis." tion of the legislature "that the tax herein imposed be not greater than the amount of tax such freight line company would pay if its cars were taxed on an ad valorem basis. No tax other than as in this act imposed shall be assessed against the business or income of any such freight line company."34

The provisions of this tax statute have not yet been challenged. In light of the Fruit Growers Express Company case, supra, it would seem clear that the tax cannot be upheld as a property tax. If it is held a nonproperty tax with a base of gross earnings, query whether the "in lieu" provision is not a violation of the rule of universality? ${ }^{35}$

\section{New Mexico}

\section{a. The provisions; historical note}

The original and only constitution of New Mexico is dated 1911; however, the present uniformity structure of that constitution dates from 1914. By an amendment at that time the entire Revenue Article, Art. VIII, was radically changed. The original uniformity structure was quite detailed, and rather repetitive. The uniformity clause would

32 Mont. Rev. Code \$84-4819. Former Mont. Rev. Code $\$ \S 84-4801$ to 84-4817 was superseded by $\S \S 84-4818$ to $84-4826$.

${ }^{83} I d$. at $\$ 84-4820$.

34 Id. at \$84-4822.

${ }^{35}$ See Northwestern Mut. Life Ins. Co. v. Lewis \& Clark County, supra note 14 . 
have been classified as Type $V$, and constituted the entire Art. VIII, §1:

The rates of taxation shall be equal and uniform upon all subjects of taxation.

This provision was followed by a section purporting to authorize enumerated types of taxes, including certain "graduated" taxes, and in addition spelled out a prohibition against "double taxation." Article VIII, \$2 read:

The legislature shall have power to provide for the levy and collection of license, franchise, excise, income, collateral and direct inheritance, legacy and succession taxes; also graduated income taxes, graduated collateral and succession taxes, and other specific taxes, including taxes upon the production and output of mines, oil lands and forest; but no double taxation shall be permitted.

If this were not sufficient, Art. VIII, $\S 3$ provided that the above enumerations of subjects of taxation should not deprive the legislature of the power to tax other subjects "in such manner as may be consistent with the principles of taxation fixed in this constitution." Other important provisions were placed in Art. VIII, $\$ \$ 7$ and 11 , which provide for both mandatory and permissive exemptions of enumerated classes of property from taxation. In addition, there was a universality provision in Art. VIII, $\$ 9$, which read:

All property within the territorial limits of the authority levying the tax, and subject to taxation, shall be taxed therein for state, county municipal and other purposes. . . .

The original Art. VIII, $\S 8$ dealt specifically with the taxation of corporate property, including the enumeration of certain permissible exemptions.

The amended Revenue Article presents a more simplified uniformity structure. Article VIII, $\$ 1$ continues to contain 
only the basic uniformity clause, which has been radically altered in phraseology:

Taxes levied upon tangible property shall be in proportional to the value thereof, and taxes shall be equal and uniform upon subjects of taxation of the same class.

For purposes of analysis, it is evident that Art. VIII, $\$ 1$ may be broken down into two parts. First, there is what might be the "proportionality" clause referring specifically to the taxation of tangible property. Second, there is the more general uniformity clause which has reference simply to "taxes." The only other provisions in the amended constitution which are pertinent to problems of uniformity are Art. VIII, $\S \S 3$ and 5 concerning the exemption of property. Those sections are substantially similar to the former sections 7 and 11 of Art. VIII. Article VIII, $\$ 3$ provides that enumerated classes of property "shall be exempt from taxation." Article VIII, $\$ 5$ provides that the legislature "may exempt from taxation" certain enumerated classes of property. Thus, the uniformity structure, as amended, consists of Art. VIII, §1 (a limited proportionality clause, and a more general uniformity clause), and Art. VIII, $\$ \S 3$ and 5.

\section{b. Meaning of the uniformity limitation}

As expected, and whatever might be the source of the limitation, ${ }^{1}$ nonproperty taxes are only required to be uni-

1 The not unusual vacillation is found in the decisions as to whether the uniformity within classes requirement for nonproperty taxes is derived from the uniformity clause in Art. VIII, $\S 1$, which stipulates that "taxes" are to be uniform within classes. Those cases stating that Art. VIII, $§ 1$ does not limit nonproperty taxes usually simply refer to the uniformity clause therein without reference to the specific language. Compare State v. Gomez, 34 N.M. 250, 280 Pac. 251 (1929); Amarillo-Pecos Valley Truck Lines v. Gallegos, 44 N.M. 120, 99 P. 2 d 447 (1940), with State ex rel. Taylor v. Mirabal, 33 N.M. 553, 273 Pac. 928 (1928); Veterans of Foreign Wars v. Hull, 51 N.M. 478, 188 P. 2 d 334 (1947). 
form within classes, so that the objects of such taxes and exemptions therefrom need only be reasonable classes; ${ }^{2}$ also, classifications may be made for application of different rates. ${ }^{3}$ There has been no occasion either to approve or disapprove a graduated rate schedule. ${ }^{4}$

Because of the more severe uniformity limitation applicable to property taxes, it is always important for purposes of uniformity in taxation to determine the nature of any given tax. An inheritance tax has been held to be a nonproperty tax, ${ }^{5}$ but there has been no decision as to the nature or general validity of the New Mexico net income tax which has a graduated rate schedule. ${ }^{6}$ However, the New Mexico gross income (occupation) tax is considered a nonproperty tax. ${ }^{7} \mathrm{~A}$ severance tax applicable to the production of oil was upheld after being characterized as a nonproperty tax. ${ }^{8}$

\section{(1) Property taxation}

There has been no extensive judicial development of the meaning of the uniformity limitation applicable to property

${ }^{2}$ For example, Breece Lumber Co. v. Mirabal, 34 N.M. 643, 287 Pac. 699 (1930) (fuel use tax, selection of the commodity a reasonable classification); Lougee v. New Mexico Bureau of Revenue Com'r, 42 N.M. 115, 76 P. 2 d 6 (1938) (gross income tax, holding reasonable the exclusion of gross income consisting of salaries). Also see State v. Gomez, supra note 1; State ex rel. Atty. Gen. v. Tittmann, 42 N.M. 76, 75 P. 2d 701 (1938); Veterans of Foreign Wars v. Hull, supra note 1. In Safeway Stores v. Vigil, 40 N. M. 190, 57 P. $2 d 287$ (1936), the court held a merchant's license tax invalid on the ground that the statutory definition of "retail dealer" created an arbitrary class.

${ }^{8}$ For example, Amarillo-Pecos Valley Truck Lines v. Gallegos, supra note 1; Breece Lumber Co. v. Mirabal, supra note 2.

4 But see the dictum in Safeway Stores v. Vigil, supra note 2.

${ }^{5}$ State v. Gomez, supra note 1.

${ }^{6}$ New Mex. Stat. Ann. \$\$76-1201 et seq.

${ }^{7}$ For example, Lougee v. New Mexico Bureau of Revenue Com'r, supra note 2.

${ }^{8}$ Flynn, Welch \& Yates v. State Tax Comm., 38 N.M. 131, 28 P. 2d 889 (1934), discussed infra at note 12. 
taxes. However, the court has made it clear that there is a rule of universality. ${ }^{\circ}$ In establishing this limitation, the court has made no reference either to the proportionality clause (applicable to tangible property taxation) or to the general uniformity clause. The rationale has simply been that the enumeration of exemptions in Art. VIII, $\S \S 3$ and 5, and particularly the enumerations of permissive exemptions in section 5 , indicates an intent that other exemptions of property are not to be permitted. ${ }^{10}$ This prohibition may not be avoided by the use of "in lieu" nonproperty taxes. ${ }^{11}$

- For example, Albuquerque Alumnae Ass'n of Kappa Kappa Gamma Fraternity v. Tierney, 37 N.M. 156, 20 P. 2d 267 (1933); Dillard v. New Mexico State Tax Comm., 53 N.M. 12, 201 P. 2d 345 (1949). In the Dillard case the court held that the exemption of soldier's property in Art. VIll, $\$ 5$ did not extend to the community property of the wife, and therefore the exemption of such property would contravene Art. VIII, $\$ \$ 3$ and 5. Article VIII, $\S 5$ was amended in 1949 to provide specifically for the exemption prohibited theretofore by the Dillard decision. Also see Sims v. Vosburg, 43 N.M. 255, 91 P. 2d 434 (1939).

${ }^{10}$ For example, the Albuquerque Alumnae Ass'n case, supra note 9 at 158. 11 See, for example, Oden Buick, Inc. v. Roehl, 36 N.M. 293, 13 P. 2d 1093 (1932); State ex rel. Atty. Gen. v. State Tax Comm., 40 N.M. 299, 58 P. 2d 1204 (1936). The Oden Buick case provides an interesting study. That case involved the validity of the in lieu provision of the motor vehicle registration tax. Provision was made for the valuation and assessment of motor vehicles under the general property tax. However, it was provided that the taxes paid under the motor vehicle registration tax should be in lieu of all other taxes on such cars: "No vehicle upon which the registration fees herein provided to be paid shall be assessed or taxed upon any property assessment rolls in this state for the period for which such fees are paid." New Mex. Stat. Ann., \$68-234. In the Oden Buick case the issue was raised whether motor vehicles in possession of an automobile dealer for sale, trade, or exchange were to be subject to the general property tax. The decision was resolved as a matter of statutory construction, it being decided that such vehicles were not intended to come within the in lieu proviso. That proviso was limited to vehicles upon which individual licenses had been purchased. Thus, the validity of the in lieu provision was not determined. However, in dictum, the court indicated that it might uphold the tax and proviso as being a combined license and ad valorem tax, thus creating no exemption. The court implied that the license fee for such vehicles was 
As for the method by which property may be taxed, it seems clear that because of the proportionality clause in Art. VIII, $\S 1$, tangible property may only be taxed by the ad valorem method. ${ }^{12}$ The big question is, may specific property taxes be imposed upon intangible property? If there is an ad valorem requirement for the taxation of intangible property, it would apparently have to be derived from the general uniformity clause, which simply requires that "taxes shall be equal and uniform upon subjects of taxation of the same class." There has been no decision indicating just how the court would rule on this issue. ${ }^{13}$ In fact, intangible property is subject to the general property tax. ${ }^{14}$

Also, there has been no clear ruling concerning the degree of uniformity required of the effective rates applicable to all property taxed by any one taxing authority. The problem is twofold because of the "dual" nature of Art. VIII, $\$ 1$. As to tangible property, the probability is greater that an absolute uniformity is required in the effective rate applicable to all such property taxed. For example, does the requirement that taxation of such tangible property be "in proportion to

somewhat larger than any sum which would be required if such vehicles were taxed under the general property tax. Thus, the in lieu provision might be upheld by assuming, as stated by the court at 299 , that:

. . . the Legislature by the act in question decided as a matter of policy to embrace the property tax on an individually owned motor vehicle in the total registration fee charged, and make such fee in lieu of all other property taxes on same. ...

12 See State ex rel. Taylor v. Mirabal, supra note 1 ; Flynn, Welch \& Yates v. State Tax Comm., supra note 8.

${ }^{13}$ But see the statement made in Flynn, Welch \& Yates v. State Tax Comm., supra note 8, at 135-136, which might well imply that intangible property need not be taxed ad valorem.

14 New Mex. Stat. Ann., \$76-101 provides that "All property, real, personal and intangible shall be subject to taxation, except as in the constitution and existing law otherwise provided." No constitutional or statutory provision provides for the exemption of intangibles. 
value" establish all tangible property as a minimum class even though the uniformity clause in Art. VIII, $\$ 1$ might carry the implication that property in general is less than a single subject and consequently classifiable? Such has been the result in other states having a somewhat similar situation; for example, Missouri. ${ }^{15}$ To the contrary, it might be argued that the scope of the proportionality clause in Art. VIII, $\$ 1$ is limited because of the inclusion of the uniformity clause referring to classification. It may be argued that the proportionality clause merely ensures that tangible property will be taxed by the ad valorem method, and that the uniformity clause carries with it the implication that tangible property may be subclassified for the application of different effective rates when taxed by the ad valorem method. The latter approach would emphasize, as did the Montana court, ${ }^{16}$ the uniformity clause which is framed in terms of classification. In any case, the question is an open one in New Mexico. ${ }^{17}$

15 See Part G (7) of this chapter.

${ }^{16}$ See Part G (8) of this chapter.

${ }^{17}$ The only dictum found which has any relevancy is in Love v. Dunaway, 28 N.M. 557, 215 Pac. 822 (1923). The precise issue in that case concerned the territoriality of the uniformity limitation. It had been contended (at 564) that the act in question violated Art. VIII, $\$ 1$ (note: no distinction was made in the opinion between the two clauses contained therein) because the rate of taxation was higher in a particular county than in other counties of the state having the same total valuation of property. In upholding the act in question, and noting the territorial nature of the uniformity limitation (whatever might have been the requirement within a county), the court said (at 564):

It will be noted, however, that the tax is equal and uniform throughout the county, which is all that is guaranteed by the provision of the Constitution relied upon. . . . This provision does not require that the levy for payment of county salaries shall be the same in every county in the state, but only that it shall be equal and uniform throughout the county. [Emphasis supplied.]

This was, of course, dictum and it ignores the "classification" language of the uniformity clause. 
As for the degree of uniformity required of the effective rate applicable to intangible property, an easier case can be made out for permissible classification. As already pointed out, it is likely that intangible property may be taxed by the specific method. If so, it would seem to follow that at least there is no requirement of absolute uniformity in rate as between intangible and tangible property (if absolute uniformity should be required as to the latter). The question would remain, could intangible property be further classified for different rates? If not, it would be because intangible property is held to be a minimum class, or "subject" of taxation. Again, there is little on which one might base a prediction. As pointed out above, the legislature has left intangible property subject, at least in theory, to the general property $\operatorname{tax}$.

\section{Oklahoma}

\section{a. The provisions; historical note}

Oklahoma has had but one constitution, dated 1907, and its uniformity structure has remained unchanged. The basic uniformity clause is found in Art. X, $\$ 5$, and reads as follows:

. . . Taxes shall be uniform upon the same class of subjects. Three other provisions are of primary importance in determining the effective uniformity limitation in Oklahoma. Article X, $\$ 22$ provides:

Nothing in this Constitution shall be held, or construed, to prevent the classification of property for purposes of taxation; and the valuation of different classes by different means or methods.

Article V, $\$ 50$ (a part of the Legislative Article) is directed to a specific problem of property taxation. It reads: 
The Legislature shall pass no law exempting any property within this State from taxation, except as otherwise provided in this Constitution.

Also of major importance in the development of the uniformity limitation is Art. X, $\S 12$, which provides that certain types of taxes may be imposed.

The Legislature shall have power to provide for the levy and collection of license, franchise, gross revenue, excise, income, collateral and direct inheritance, legacy, and succession taxes; also graduated income taxes, graduated collateral and direct inheritance taxes, graduated legacy and succession taxes; also stamp, registration, production or other specific taxes.

Other provisions to be considered include Art. X, §8, which provides:

All property which may be taxed ad valorem shall be assessed for taxation at its fair cash value, estimated at the price it would bring at a fair voluntary sale. . . .

Finally, Art. X, $\S 6$ and Art. XII-A provide for the mandatory exemption of enumerated classes of property.

\section{b. Meaning of the uniformity limitation}

Whatever the source of the limitation might be ${ }^{1}$ nonproperty taxes ${ }^{2}$ are only required to be uniform within classes,

1 As in other states having this type of basic uniformity clause the Oklahoma court has ruled both pro and con on the issue of whether the uniformity clause in Art. X, $\S 5$ is the source of the uniformity limitation applicable to nonproperty taxes. Compare Ex parte Shaw, 53 Okla. 654, 157 Pac. 900 (1916); McGannon v. State, 33 Okla. 145, 124 Pac. 1063 (1912); Trustees, Executors' \& Securities Ins. Corp. v. Hooton, 53 Okla. 530, 157 Pac. 293 (1915); and In re Assessment of Sales Tax against Knapp, 185 Okla. 584, 95 P. 2d 92 (1939).

2 Note the lengthy enumeration of "permissible" taxes found in Art. X, $\$ 12$ quoted in the text, supra. As indicated in Daube v. Oklahoma Tax Comm., 194 Okla. 487, 152 P. 2 d 687 (1944) the enumeration is not 
whether the classification is for the object of such a tax or exemptions therefrom, ${ }^{8}$ or whether the classification is for the purpose of applying different rates. ${ }^{4}$ Within this last rule, the court has approved the principle of graduated rates. ${ }^{5}$

Because of the liberal uniformity limitation applicable to property taxes, as described below, it is not of too much consequence, for purposes of uniformity of taxation, to determine the nature of any given tax in Oklahoma. For example, the mineral production tax has been held first a privilege tax, then a property tax, ${ }^{6}$ and in neither case did it violate the uniformity limitations. There have been no decisions concerning an income tax, but this is not unexpected since a graduated income tax is expressly provided for in Art. X, $\$ 12$. Similarly, a graduated inheritance tax is provided for; however, such a tax has been held to be a nonproperty tax. ${ }^{7}$ Also, the court has held that a mortgage registration tax to be a nonproperty tax. ${ }^{8}$

\section{(1) Property taxation}

Universality; "in lieu" taxes. Article V, $\$ 50$ of the constitution expressly prohibits the exemption of property from taxation. Consequently, in State v. Pioneer Mills, ${ }^{9}$ a statute ${ }^{10}$

exclusive, nor is the express permission to impose graduated inheritance and income taxes an implied limitation upon graduated rates for other taxes.

${ }^{3}$ For example: Daube v. Oklahoma Tax Comm., supra note 2 (selection of object for gift tax valid); In re Assessment of Sales Tax against Knapp, supra note 1; Ex parte Shaw, supra note 1; Trustecs, Exec. \& Sec. Ins. Corp. v. Hooton, supra note 1; Walde v. Oklahoma Tax Comm., 188 Okla. 142, 106 P. $2 d 821$ (1940).

4 For example, In re Harkness' Estate, 83 Okla. 107, 204 Pac. 911 (1922); McGannon v. State, supra note 1.

'See Trustees, Exec. \& Sec. Ins. Corp. v. Hooton, supra note 1, and Daube v. Oklahoma Tax Comm., supra note 2.

${ }^{6}$ See notes 11 and 14 , infra.

${ }^{7}$ McGannon v. State, supra note 1.

${ }^{8}$ See note 15 , infra.

- 122 Okla. 6, 250 Pac. 120 (1926). Also see County Assessor, Oklahoma 
providing that all property, both real and personal, used exclusively for the manufacturing of cotton products and all monies used in the operation of such a business were to be exempt from taxation by the state for a period of ten years was held to be a violation of Art. V, $\S 50$.

However, this restriction is not such a barrier as it might at first appear. In other jurisdictions if the exemption of property from taxation is prohibited, the courts have usually held that an "in lieu" nonproperty tax, that is, a nonproperty tax purporting to be in lieu of a tax upon certain property indirectly reached by the nonproperty tax, is, in effect, an exemption and therefore a violation of the prohibition against exemptions. This is not the case in Oklahoma, as will be shown. The earliest, and leading case on the "in lieu" problem in Oklahoma is In Re Gross Production Tax of Wolverine Oil Co., ${ }^{11}$ decided in 1915. That case dealt with the validity of the early mineral production tax. ${ }^{12}$ Ruling that the tax was an occupation tax, ${ }^{13}$ the court also held that the in lieu provision (stating that the production tax was to be in lieu of all ad valorem and other taxes on both the property used in the production and the minerals) was authorized by Art. X, $\S 12$ and was not an "exemption" within the meaning of Art. V, $\$ 50 .^{14}$

County v. United Brotherhood of Carpenters \& Joiners of America, Local 329, 202 Okla. 162, 211 P. 2d 790 (1949); Gibson v. Phillips University, 195 Okla. 456, 158 P. 2d 901 (1945); Lowden v. Excise Board of Texas County, 185 Okla. 143, 90 P. 2d 923 (1939).

10 Okla. Laws 1915, c. $195, \$ 1$.

1153 Okla. 24, 154 Pac. 362 (1915).

12 Okla. Laws 1915 , c. 107.

18 The tax was said to be upon the privilege of producing the named minerals (ores and oil), with the base being gross value of mineral produced. A different percentage rate was applicable to the two basic classes: ore and oil.

14 Insofar as the Wolverine case held that the mineral production tax was an occupation tax, it was reversed in In re Skelton Lead \& Zinc Co.'s Gross Production Tax for 1919, 81 Okla. 134, 197 Pac. 495 (1921), and 
During the same term in Trustees, Executors ES Securities Insurance Corporation v. Hooton ${ }^{15}$ the court upheld the real estate mortgage registration tax, ${ }^{16}$ which imposed a graduated registration tax "in lieu" of all other taxes, including ad valorem property taxes, upon the notes secured. The court held that the tax was upon the privilege of registering, and that "in lieu" taxes were authorized by Art. X, $\$ 12 .{ }^{17} \mathrm{~A}$ similar result was reached in $E_{x}$ parte Shaw ${ }^{18}$ concerning the in lieu provision of the motor vehicle registration fee law. In that case the court said that ". . . this was not an exemption of property, but a substitution of one form of taxation for another, as held in" the Wolverine Oil Co. case.

Then in In re Diehr, ${ }^{19}$ decided in 1935, the money and credits tax (subsequently repealed in 1939) was sustained. The court held that money, as defined, was a valid class of property which could be segregated for purposes of taxation, and that the tax thereon (one fifth of one per cent) in lieu of all other taxes was not a violation of Art. V, §50. The rationale of the court was that the class of property was taxed, and therefore there was no exemption from taxation within the meaning of section $50 .^{20}$

Bergin Oil \& Gas Co. v. Howard, 82 Okla. 176, 199 Pac. 209 (1921). In those cases the gross production tax, as amended, but substantially the same tax, was held to be upon the property. However, other than the decision as to the nature of the tax, the opinion in the Wolverine case was reaffirmed, including the "in lieu" rationale therein. The reason for the decision concerning the nature of the tax related to issues other than uniformity of taxation.

15 Supra note 1. And see In re Oklahoma Nat. Life Ins. Co., 68 Okla. 219, 173 Pac. 376 (1918); In re Assessment of Conservative Loan Co., 67 Okla. 307, 173 Pac. 654 (1918).

16 Okla. Laws 1913, c. 246.

17 'Trustees, Executors' \& Securities Ins. Corp. v. Hooton, supra note 1 at 534-536.

18 Supra note 1 at 664 .

19174 Okla. 300, 50 P. 2d 725 (1935).

${ }^{20} I d$. at 302. 
However, In re Assessment of Chickasha Cotton Oil Co., ${ }^{21}$ decided in 1921, illustrates a limit to the availability of in lieu nonproperty taxes. In that case, the issue concerned the validity of a statute purporting to relieve raw farm products from ad valorem taxation, but stated that such should be "subject to an income tax." The court held that the statute violated Art. V, $\S 50$ because it operated to exempt this class of property in the hands of some persons who would not be subject to payment of an income tax. Consequently, reasoned the court, the statute in fact exempted that property in the hands of those not paying an income tax.

In summary, while property may not be made the subject of an "outright" exemption from property taxation, there may be, in effect, an exemption when such exemption is coupled with a nonproperty tax indirectly reaching the property. In addition, the legislature may exempt property from the ad valorem general property tax when such property is taxed by a selective specific property tax. Apparently in these cases the court relies to some extent on the enumeration of permissible taxes in Art. $\mathrm{X}, \S 12$, especially the enumeration of "specific taxes" in the last phrase of that section. Consequently, either a nonproperty tax or a specific property tax may be "substituted" for the ad valorem general property tax, and there will be no exemption contrary to Art. V, $\$ 50$. However, if the tax is a nonproperty tax, the property exempted must be indirectly reached by the substituted tax.

Method used. While there are no really clear-cut cases holding a tax to be a specific property tax, the court clearly seems to accept the proposition that there is no ad valorem requirement in the Oklahoma Constitution, i.e., that property may be taxed by the specific method. ${ }^{22}$

Effective rates. The court has clearly held that absolute 2180 Okla. 101, 194 Pac. 215 (1921).

22 See In re Skelton Lead and Zinc Co., supra note 14; In re Diehr, supra note 19. In In re Oklahoma National Life Ins. Co., supra note 15 , in which 
uniformity is not required of effective rates in the taxation of property. ${ }^{23}$ Of course, Art. X, $\$ 22$ expressly states that property may be classified, and Art. $\mathrm{X}, \S 5$ requires only a uniformity upon the same class "of subjects." One of the leading cases for the general proposition is In re Diehr, ${ }^{24}$ in which the court upheld the Money and Credit Tax of 1927 (repealed in 1937). The court held that money as classified was a proper subject for taxation, and that the rates applicable thereto could vary from the rates applicable to other property. The court said ". . . the only constitutional requirement to be observed as to uniformity applies to the different properties of the same class and does not apply as be-

the court held that the mortgage registration tax was a nonproperty tax and valid, the court did say, at 225 , that as to property taxation:

While many states have constitutional provisions requiring that property shall be taxed ad valorem, this state has none unless ... [Art. X, §8] should be so construed. That such is not the meaning of that section is quite clear to us. It is simply a prohibition against undervaluation of property when it is taxed ad valorem, and is not a requirement that it shall be taxed by that method. Property may be valued as a means of measuring the amount of the tax thereon, but the tax may be measured by other means; for example, by the income from the property. Specific taxes may be imposed on property by the head, number, weight, or other measurement.

Also concerning the effect of Art. $\mathrm{X}, \S 8$ (requiring that all property which may be taxed ad valorem shall be assessed for taxation at its fair cash value), see Comanche County v. American National Bank, 122 Okla. 34, 252 Pac. 408 (1927), in which the court apparently approves the principle that the ratio of valuation used under an ad valorem general property tax need not necessarily be $100 \%$ if the ratio is uniform for all property of a certain class. See also In re Assessment of Property of Western Light \& Power Corp., 169 Okla. 53, 35 P. 2d 946 (1934).

${ }^{23}$ Besides the cases discussed in the text, see Love v. Silverthorn, 187 Okla. 114,101 P. 2d 254 (1940), upholding the intangible property tax. Nor would Art. X, $\$ 8$ prevent classification for the purpose of varying the effective rate by application of different ratios of valuation (rather than different percentage rates) to the different classes. See Comanche County v. American Nat. Bank, supra note 22.

24174 Okla. 300, 50 P. 2d 725 (1935). Followed in State v. Chickasha Milling Co., 180 Okla. 611, 71 P. 2d 981 (1937). 
tween the several classes. This is expressed in section 5 , article 10. . . However, as recently as 1949, in Custer County Excise Board v. St. Louis-San Francisco Railway Company, the court ruled that a classification of real property into rural and urban (rural realty was taxed at ten mills, urban at eight and one-half mills) was arbitrary. It stated:

Obviously, there is no difference between rural property and urban property in its relation to an ad valorem tax or a tax based on values so that one property may be distinguished from the other as an object of taxation. Location alone is not a basis for the classification of the property for purposes of taxation on a basis of value. ${ }^{26}$

As a postscript, the writer would point to the very interesting "Graduated Land $\operatorname{Tax}^{\text {"27 }}$ which the legislature at-

${ }^{25}$ Id. at 301-302.

${ }^{26} 201$ Okla. 528, 530, 207 P. 2d 774 (1949).

27 Okla. Laws 1913 , c. 240 , p. 651 ; Okla. Stat. Ann., tit. 68 , c. 19, $\$ \$ 751-759$. Section 751 reads:

Except real estate of common carriers authorized to be held by them by the Constitution of this state, the owner, whether legal or equitable, whether a person, firm, association, joint stock association, or corporation, and whether resident or not of this state, of any land in the state, in excess of an aggregate of 640 acres, shall upon such excess, pay the following annual license tax for the purposes of the general expenses of state government, which is hereby levied, to wit:

For each dollar of valuation as assessed for taxation ad valorem in the preceding year the following schedule:

1 mill where such excess does not exceed 640 acres;

2 mills on such excess exceeding 640 acres and not exceeding 1,280 acres;

3 mills on such excess exceeding 1,280 acres and not exceeding 1,920 acres;

5 mills on such excess exceeding 1,920 acres and not exceeding 2,560 acres;

10 mills on such excess exceeding 2,560 acres and not exceeding 3,200 acres;

15 mills on such excess exceeding 3,200 acres.

Provided that lands of the assessed value of 10,000 Dollars may be exempted to any person in lieu of the 640 acres exempted as herein provided. 
tempted to impose in 1913. The statute is still on the books. The tax is an ad valorem tax on realty, with the rate graduated according to value. There has been serious doubt whether the law was a valid enactment under the constitutional limitations upon legislative procedure, ${ }^{28}$ and the tax has never been enforced. Consequently, the Oklahoma court has had no occasion to rule on the validity of a graduated property-tax rate under an ad valorem type tax.

\section{Oregon}

\section{a. Uniformity in taxation: 1859 to 1917}

Oregon has had but a single constitution, that of 1859 . However, the original uniformity structure underwent significant amendment in 1917. Both before and after 1917 the uniformity structure has been relatively brief, the two pertinent provisions being Art. I, $\S 32$ and Art. IX, $\S 1$. The change made in 1917 relates to the wording of these two provisions.

In the original uniformity structure there were two basic uniformity clauses which would have been classified in this study as Types $\mathrm{V}$ and VI, respectively. The uniformity clause in Art. I [Bill of Rights], §33 read as follows: “. . . and all taxation shall be equal and uniform." The other uniformity clause was found in Art. IX [Finance], $\$ 1$ which read:

The legislative assembly shall provide by law for a uniform and equal rate of assessment and taxation, and shall prescribe such regulations as shall secure a just valuation for taxation of all property, both real and personal, excepting such only for municipal, educational, literary, scientific, religious, or charitable purposes as may be specially exempted by law.

28 See the Historical Note to Okla. Stat. Ann., $\$ 751$. 
In the pertinent opinions of the court, Art. IX, $\$ 1$ was divided into two basic clauses, each having different significant results. A division was made between the uniformity clause and the second clause with its exemption proviso.

During this first period under the Oregon Constitution the strictest degree of uniformity was required of property taxes. ${ }^{1}$ A leading case was Crawford v. Linn County, ${ }^{2}$ decided in 1884, in which the court analyzed the pertinent constitutional provisions and related a particular phrase to each rule of the property-tax uniformity limitation. This preciseness is seldom found in the other jurisdictions. There usually is nothing more than a blanket referral to a constitutional provision. Much of the discussion in the Crawford case might be called dictum, since the issue was the degree of uniformity required of effective rates; however, the other rules stated therein are supported by decisions in other cases.

First, there was a strict rule of universality, the source of this limitation being the second clause of Art. IX, $\$ 1 .^{3}$ The court further reasoned that in the absence of this clause there would have been no such limitation on the power of the legislature to select and exempt property for purposes of taxation because the two uniformity clauses did not contain such a prohibition. Those clauses were said to relate solely to the uniformity required of effective rates and the method of taxation of property."

Second, property could be taxed only by the ad valorem method, the source of this rule being the uniformity clauses

${ }^{1}$ As for nonproperty taxes, see note 11 , infra.

211 Ore. 482, 5 Pac. 738 (1884).

${ }^{3} I d$. at 494 .

Id. at 492-493. However, in Wallace v. Board of Equalization, 47 Ore. 583, 86 Pac. 365 (1906), in which the court held that an exemption of $\$ 300$ of household personal property was void, the court apparently derived the exemptions limitation from the uniformity clause in Art. $X, \S 1$. The court asserted that there would be an imposition of an unequal rate of taxa- 
in Art. IX, $\S 1$ and Art. I, $\S 32 .{ }^{\circ}$ Third, an absolute uniformity was required of the effective rate applied to all property taxed by any one taxing authority, and the source was again the uniformity clauses. ${ }^{\circ}$

In the Crareford case the court stated that the effective limitations derived from both of the uniformity clauses (Art. I, $\S 32$ and Art. IX, §1) were identical, the clauses being the equivalent of each other. ${ }^{7}$ Consequently, there was a superfluity of provisions.

\section{b. Uniformity in taxation since 1917}

The amendment of the uniformity structure in 1917 retained the two uniformity clauses in the separate provisions, but made important changes in phraseology. As will be shown, the two clauses continue to be the equivalent of one another. The uniformity clause found in Art. I, \$32 now reads:

.. all taxation shall be uniform on the same class of subjects within the territorial limits of the authority levying the tax.

The significant change was the switch from "equal and uniform" to "uniform on the same class of subjects."

tion because of the exemption. However, it might be noted that this was the argument presented in the pleadings, and therefore the rationale of the Crawford case was ignored. Also see Hogg v. Mackay, 23 Ore. 339, 31 Pac. 779 (1893).

${ }^{5}$ Id. at 484-485, 492-493. Also see: Ellis v. Frazier, 38 Ore. 462, 63 Pac. 642 (1900) ; Portland v. Portland Ry., L. \& P. Co., 80 Ore. 271, 156 Pac. 1058 (1916); Reser v. Umatilla County, 48 Ore. 326, 86 Pac. 595 (1906).

'Id. at 492-493. Also see: Ellis v. Frazier, supra note 5; Lake County v. Schroder, 47 Ore. 136, 81 Pac. 942 (1905). Smith v. Kelly, 24 Ore. 464, 33 Pac. 642 (1893) does not hold to the contrary, despite some misleading annotations.

TId. at 484-485, 493. 
The second uniformity clause, still found in Art. IX, $\S 1$, now reads:

The Legislative Assembly shall . . . provide by law uniform rules of assessment and taxation. . . .

The change here is quite significant in view of the interpretation given the several parts of the original Art. IX, $\S 1$. First, the basic words of the uniformity clause were changed from "a uniform and equal rate of assessment and taxation" to "uniform rules of assessment and taxation." Second, and more important, was the deletion of the second clause found in the original Art. IX, $\S 1$. Thus, as borne out by the cases, radical changes were made in the effective uniformity limitation.

Meaning of the uniformity limitation. The court has said that under the amended uniformity structure the nature of any tax is no longer of importance for purposes of uniformity of taxation; indeed, the court has equated the two amended uniformity clauses to the federal equal protection clause, saying in the leading case of Standard Lumber Company v. Pierce that:

. . . it is manifest that the only limitation imposed upon the taxing power of the several states by the 14th Amendment is this,-all taxation shall be uniform upon the same class of subjects. For all practical purposes the limitation mentioned is identical with the restrictions imposed by the Oregon Constitution [found in Art. I, $\$ 32$ and Art. IX, §1] upon the power of taxation. ...8

Reviewing the restrictive limitation upon property taxation found in the original constitutional provisions, the court pointed out that

... the conviction became general, that the limitations of the Constitution which confined the legislature in the taxa-

8112 Ore. 314, 333, 228 Pac. 812 (1924). 
tion of property to a proportional tax thereon were no longer adapted to the needs of the state. Demand was made for removal of those constitutional restrictions, which prevented the classification of property in respect to its nature, condition or class, and the imposition thereon of different rates of taxation upon different classes of property; and which excluded considerations of faculty or ability to pay, equality of sacrifice or governmental advantages provided to the taxpayer: See Voter's Pamphlet, Special Election, June 4, 1914, p. 14. . . .

To remedy this situation, Art. I, $\$ 32$ and Art. IX, $\S 1$ were amended with the result above indicated. ${ }^{10}$ The issue in Standard Lumber Company v. Pierce was the validity of a personal net income tax which had a graduated rate schedule and minimum exemptions. Because of its analysis of the uniformity clauses, the court did not find it necessary to determine the nature of the tax-i.e., whether imposed on property or privilege-and held that the classifications in question were valid.

Because of what the court has said, it might not be necessary in stating the uniformity limitation to make a distinction as between property and nonproperty taxes. However, at least for comparative purposes the distinction may be useful. Nonproperty taxes, of course, still have to be uniform only within classes, ${ }^{11}$ and the court has found graduated rates to

$\because$ Id. at 335 . Emphasis added.

${ }^{10}$ As the court stated, id. at 335-336:

As above indicated, the Constitution as amended places no restraint upon the power of the legislature in the matter of taxation which was not already enforced upon it by the 14 th Amendment to the federal Constitution, with this qualification, if it be a qualification, that among the members or objects included in a class selected by the legislature, inherent uniformity as well as territorial uniformity is required.

11 Before the 1917 amendment see: Kellaher v. Portland, 57 Ore. 575, 112 Pac. 1076 (1911). Subsequent to the 1917 amendment see: In re Heck's Estate, 120 Ore. 80, 250 Pac. 735 (1926); Portland Van \& Storage Co. v. Hoss, 139 Ore. 434, 9 P. 2d 122 (1932). 
be reasonable classifications in other than the above income tax case. ${ }^{22}$

As for property taxation, there is no longer a rule of universality, ${ }^{18}$ and it seems clear that Standard Lumber Company v. Pierce is authority for the proposition that property may be classified for the purpose of applying different effective rates to the different classes. ${ }^{14}$ Indeed, in that case the court approved a graduated rate without determining the nature of the tax. However, one should be cautious in drawing any conclusion that a graduated rate could be applied under a general, or even selective property tax which is clearly imposed upon property. And apparently, there is no longer any requirement that property must be taxed by the ad valorem method. No cases on the point have arisen; however, if the Pierce case is to be taken at its face value, since the fourteenth amendment does not demand that property be taxed only ad valorem, ${ }^{15}$ it would follow that neither of the uniformity clauses (Art. I, $\S 32$ and Art. IX, $\S 1$ ) so require.

12 In Safeway Store v. City of Portland, 149 Ore. 581, 42 P. 2d 162 (1935), the court upheld a local chain store tax and the graduated rate thereunder.

${ }^{13}$ Apart from the Pierce case in the text, see Methodist Book Concern v. State Tax Comm., 186 Ore. 585, 208 P. 2 d 319 (1949), and Corporation of Sisters of Mercy v. Lane County, 123 Ore. 144, 261 Pac. 694 (1927).

14 Also see Redfield v. Fisher, 135 Ore. 180, 292 Pac. 813 (1931), in which the court struck down a tax of $5 \%$ upon the gross income from certain intangibles held by individuals. The income from such intangibles going to corporations was exempt. This classification was held arbitrary. The court held that the tax was in fact a property tax. On rehearing, the court distinguished the Pierce case, expressly not overruling it but pointing out that in the tax under consideration the tax was on gross, not net income. In McPherson v. Fisher, 143 Ore. 615, 23 P. 2d 913 (1933), the court upheld the subsequent 1931 tax upon the net income from intangibles so drafted as to overcome the objections in the Redfield case.

${ }^{15}$ See Chapter IV, infra. 


\section{Pennsylvania}

\section{a. The provisions:method of analysis to be used}

The Pennsylvania Constitutions of 1776, 1790, and 1838 contained no provisions expressly concerned with problems of uniformity of taxation. The present constitution of Pennsylvania came into force in 1874, and in comparison with most other state constitutions its uniformity structure is quite short. Nor have the provisions been amended in any substantial manner. The basic uniformity clause is found in Art. IX, $\$ 1$ and is coupled with a clause which permits the exemption of certain property from taxation. Article IX, $\$ 1$ reads:

All taxes shall be uniform, upon the same class of subjects, within the territorial limits of the authority levying the tax, ... but the General Assembly may, by general laws, exempt from taxation public property used for public purposes, actual places of religious worship, places of burial not used or held for private or corporate profit, institutions of purely public charity, [and real and personal property owned, occupied, and used by any branch, post, or camp of honorably discharged soldiers, sailors, and marines].

The last named class of exemptible property, enclosed in brackets, was added by amendment in 1923. The other important provision is Art. IX, $\S 2$, which provides that:

All laws exempting property from taxation, other than the property above enumerated shall be void.

In contrast to these two comparatively brief provisions constituting the source of the effective uniformity limitation in Pennsylvania, there have been a multitude of decisions relevant to a determination of its meaning. Indeed, one writer has ventured to say:

It would be futile to attempt to reconcile all of the decisions of the Supreme Court of Pennsylvania subsequent to the 
adoption of the Constitution of 1873 [regarding the meaning of these provisions], and particularly the dicta expressed in many of the opinions. ${ }^{1}$

After reviewing what he considered the most pertinent cases, the same writer asserted that:

The conclusion is obvious, from a review of these decisions, that the constitutional requirement of uniformity in taxation was not adopted for an idle purpose, and was intended to mean something, although there has been some lack of uniformity of judicial expression as to what uniformity of taxation does actually mean. Terminology may be in part responsible. $^{2}$

The purpose of the present analysis is to determine the meaning of the effective uniformity limitation in Pennsylvania, notwithstanding conflicting statements.

Any generalizations on the meaning of this limitation must be preceded by a "tax by tax" analysis. Using this approach for the difficult and complex situation in Pennsylvania makes possible some conclusions as to the actual status of each of the particular rules of uniformity, and thereby a distinction between apparent and real inconsistencies. Predictability will be more certain if internal consistency can be shown to have developed as to particular taxes, if not as to the tax structure as a whole.

\section{b. General property taxation}

Strictly speaking, there is no single general property tax in Pennsylvania; nor has there been one since the inception

1 Tanner, "Constitutional Limitations of the Taxing Power in Pennsylvania," 7 Univ. of Pitt. L. Rev. 98, 100, 112 (1941). See also the Note, "The Pennsylvania Constitutional Requirement of Uniformity in Taxation," 87 U. of Pa. L. Rev. 219 (1938).

2 Tanner, supra note 1 at 112. 
of the present constitution or for some time before. However, the combination of several separate taxes constitutes, in effect, a general property tax system. First, the Real Property $\mathrm{Tax},{ }^{3}$ which is purely local, reaches all real property except that which is specifically exempt. The act providing for the real property tax also provides for the taxation of "occupations" - a tax similar to the "faculty tax" known in the time of the Colonies.

Second, there is the more complex tax structure reaching personal property. Pennsylvania has no comprehensive personal property tax system comparable to the real property tax. In fact, at the present time only intangible personal property is taxed. The Personal Property $\mathrm{Tax}^{5}$ is presently a local tax, and reaches intangibles (other than "corporate loans" as defined) in the hands of individuals. Those intangibles defined as "corporate loans" which are in the hands of individuals are reached by a Corporate Loans $\mathrm{Tax}^{6}{ }^{6}$ which is a state tax. ${ }^{7}$ The Pennsylvania court has stated that the equivalent of a tax on intangible personal property in the

${ }^{3}$ Infra, text at notes 13-31.

4 Infra, text at notes 32-47.

5 Infra, text at notes 48-83.

Infra, text at notes 84-107.

7 The situation as it existed shortly after the adoption of the present constitution of 1874 may be described as follows. A single act contained both a personal property tax and a corporate loans tax. Both of these were considered state taxes; however, a certain portion of the revenue derived therefrom was returned to the counties which collected the taxes. In 1913 the personal property tax became a county tax exclusively, while the corporate loans tax remained a state tax. The taxes were framed to reach enumerated classes of intangibles, some being reached by the counties, others by the state. For a few years before and after 1940 the state revived the state personal property tax, so that intangibles not taxed by the state under the corporate loans tax were taxed by both a state and a county personal property tax. However, the state personal property tax has since expired, so that the present situation is as described in the text. 
hands of corporations is found in the combination of the Capital Stock Tax (domestic corporations) and the Franchise Tax (foreign corporations), ${ }^{8}$ supplemented by certain other miscellaneous taxes. ${ }^{\circ}$

At an early time certain enumerated types of tangible personal property (e.g., livestock) were listed as taxable under the personal property tax along with the enumerated intangible property. However, even those classes of tangible personal property which were at one time subject to the personal property tax have since been removed from its scope by exemption. ${ }^{10}$ But from time to time there have been both state and local selective tangible personal property taxes, such as the state tax on anthracite coal. ${ }^{11}$

In summary, under what might loosely be called the general property tax system, real property is taxed locally; intangible personal property is taxed either by local units or by

\section{${ }^{8}$ Infra, text at notes 108-130.}

0 The miscellaneous taxes are designed to reach certain financial institutions (national and state banks and savings institutions having capital stock; title insurance and trust companies; private bankers; and savings institutions without capital stock). See the discussion at $\$ 29-001$ et seq., CCH Penna. Tax Reporter.

10 For example, see Pa. Stat. Ann. tit. 72, $\$ 4782$ (Act of 1887, May 13, P.L. 114, \$1), which reads:

All taxes, for whatsoever purpose, laid upon watches, household furniture and pleasure carriages, by and under the revenue laws of this commonwealth, be and the same are hereby abolished, and the laws under which said taxes are levied and collected, so far as they relate to the property herein mentioned, are hereby repealed.

Also see Pa. Stat. Ann. tit. 72, $\$ 3251$ (Act of 1873, March 21, P.L. 46, $\S 1$ ), which provides that any state taxes imposed on horses, mules, and cattle are to be abolished.

11 Infra, text at notes 131-140. There also has been a state "floor tax" on alcoholic beverages, and local severance taxes and billboard taxes. See infra, text at notes 141-149. 
the state, not by both; and tangible personal property is taxed at neither level unless by a selective tax. ${ }^{12}$

\section{(1) Real property tax}

For purposes of local taxation it is provided that "all ... real estate . . . not exempt . . . from taxation" shall be subject to taxation by local governmental units at " an annual rate" determined in each unit by the annual revenue requirements. ${ }^{13}$ This tax represents the closest approach to a "general property tax" in Pennsylvania. Strictly speaking, one should say "taxes," since there are separate acts for the various classes of local governmental units. However, the operative provisions of all the acts are phrased in substantially the same words.

Two early decisions, although not definitive, are of interest in determining the degree of uniformity required of the effective rate applicable to real property. The first is Roup's Case, ${ }^{14}$ decided in 1874. That case is evidently the first concerning uniformity of taxation to be decided under

12 This may be visualized as follows:

\begin{tabular}{|c|c|c|c|c|c|}
\hline & \multirow[b]{3}{*}{$\begin{array}{c}\text { Real } \\
\text { Property }\end{array}$} & \multirow{3}{*}{$\begin{array}{l}\text { Tangible } \\
\text { Personal } \\
\text { Property }\end{array}$} & \multicolumn{3}{|c|}{ Intangible Personal Property } \\
\hline & & & \multicolumn{2}{|c|}{ In hands of individuals } & \multirow[b]{2}{*}{$\begin{array}{l}\text { In hands of } \\
\text { corporations }\end{array}$} \\
\hline & & & $\begin{array}{l}\text { except "cor. } \\
\text { porate loans" }\end{array}$ & $\begin{array}{l}\text { "corporate } \\
\text { loans" }\end{array}$ & \\
\hline $\begin{array}{l}\text { State } \\
\text { taxes: }\end{array}$ & & $*$ & $\begin{array}{l}\text { (see note } \\
7, \text { supra) }\end{array}$ & $\begin{array}{l}\text { Corporate } \\
\text { Loans Tax }\end{array}$ & $\begin{array}{l}\text { Capital Stock } \\
\text { Tax (plus } \\
\text { others; see } \\
\text { note 9, supra) }\end{array}$ \\
\hline $\begin{array}{l}\text { Local } \\
\text { taxes: }\end{array}$ & $\begin{array}{l}\text { Real } \\
\text { Property } \\
\text { Tax }\end{array}$ & $*$ & $\begin{array}{l}\text { Personal } \\
\text { Property } \\
\text { Tax }\end{array}$ & & \\
\hline
\end{tabular}

* Selective taxes from time to time.

13 See Pa. Stat. Ann. tit. 72, $\$ 5020.201,5453.201$.

1481 1/2 Pa. 211 (1874). 
the present constitution. It is somewhat indecisive, but stands substantially for the proposition that real property may be classified into rural and urban for the purpose of applying different rates to each class. ${ }^{15}$ Some fifteen years later one of the most important of the Pennsylvania uniformity cases was decided. In Commonwealth v. Delarware Division Canal Company the court upheld the corporate loans tax, and in so doing made the following significant statement, albeit dictum: "Real estate, for taxation, has been classified as seated and unseated, and for municipal purpose may, perhaps, admit of further classification."16

Then in 1905 the Supreme Court of Pennsylvania clearly faced the issue and, in Jermyn v. Scranton, ${ }^{17}$ held that the city of Scranton could constitutionally classify real estate for purposes of taxation into three classes and apply different rates to each class. The opinion is rather brief and does not describe the nature of the three approved subclasses of real

${ }^{15}$ A statute provided that certain property in the city of Pittsburgh was to be classed as "rural," and that taxes thereon were to be assessed and collected at $2 / 3$ of the rate of city taxation. The lower court held that the statute did not violate the uniformity clause, Art. IX, $\S 1$. It said that the clause was merely declaratory of the law as it stood prior to the adoption of the constitution. The lower court's opinion was affirmed on appeal to the Supreme Court of Pennsylvania by a per curiam opinion, in which it was said that the majority united in affirming the decision below, although not all for the same reasons. No mention was made of the points about which there might be disagreement. However, the per curiam opinion did state, id. at 216: "Hence no opinion is given, except that we all agree that the power to classify the subjects of taxation is not taken away by the nero constitution." [Emphasis added.] There is good reason to believe that the disagreement went to the "special" nature of the statute, i.e., its applicability to Pittsburgh alone and by name.

${ }^{16} 123 \mathrm{~Pa} .594,621,16$ Atl. 584 (1889). That case is discussed infra, text at notes 87 et seq.

17212 Pa. 598, 62 Atl. 29 (1905). There was only a per curiam opinion, which, however, affirmed the decree on the opinion below, which was set out in the Reporter. 
estate. In any case, the court upheld the ordinance, and the following conclusion is found:

It is too late in the day in Pennsylvania to question the power of the legislature to classify subjects of taxation on broad lines and within certain limitations. . . . We shall cite only one case to show that the question before us is definitely and authoritatively settled: Commonwealth v. Delaware Division Canal Co. ....18

Thus, it appears to be settled that the classification of real estate for the purpose of applying different effective rates is permissible. ${ }^{19}$ Other cases have illustrated the territorial nature of the limitation which requires same classes of real estate to be subject to the same rate. ${ }^{20}$

On the other hand, real property may not be classified for the purpose of exemptions. This is the result of Art. IX, $\S 2$, which expressly prohibits exemptions. ${ }^{21}$ Consequently, any

${ }^{18} I d$. at 602 . It might be significant to point out that the party attacking the validity of the ordinance which made the classification evidently admitted the right of the legislature to classify realty for purposes of taxation, but denied the right of a municipality to levy different rates on each class of such property. The court, at 601 , termed this admission as admitting the "principle, but deny [ing] the propriety of applying it so as to produce practical results." The position of the court was that unless there could be different rates of levy on the several classes of realty, why should property be classified at all.

19 See, for example, $\mathrm{Pa}$. Stat. Ann. tit. 72, $\$ 8772,8774$.

${ }^{20}$ See Moore v. Pittsburgh School District, 338 Pa. 466, 12 A. 2 d 29 (1940), holding it immaterial that a different rate might apply to property of the same class, located, however, in different school districts. The facts of the case presented a peculiarly interesting problem in the determination of just what particular taxing authorities were involved. Also see Poor District Case (No. 1), 329 Pa. 390, 197 Atl. 334 (1938).

21 The statements to this effect are usually found to be dictum in cases which were actually decided on a basis of statutory interpretation, that is, a determination of whether the contested property was factually within the class of property exempted by the statute. For example, White v. Smith, 189 Pa. 222, 226-227, 42 Atl. 125 (1899); Commonwealth v. Dauphin County, 335 Pa. 177, 179-180, 6 A. 2d 870 (1939); Ogontz School Tax 
statutory provisions providing for the outright exemption of a class of real property will be held invalid if such class is not designated as exemptible in Art. IX, $\S 1$.

Legislative attempts to classify forest lands for special treatment have been uniformly unsuccessful, ${ }^{22}$ notwithstanding the liberal interpretation given to the uniformity clause in Art. IX, §1. In 1940 the Pennsylvania Supreme Court, in Clearfield Bituminous Coal Corporation v. Thomas, ${ }^{23}$ con-

Exemption Case, 361 Pa. 284, 291, 313, 65 A. 2d 150 (1949); Hill School Tax Exemption Case, 370 Pa. 21, 23, 87 A. 2d 259 (1952). There is a lower-court opinion which actually ruled on the proposition: Pittsburgh v. Phelan (Pa.), 11 Dist. Ct. 572 (1901), holding the Act of June 4, 1879, P.L. 90 to be a violation of Art. IX, $\S \S 1$ and 2. The act purported to exempt churches while in the process of being erected. It was held that such a church was not a place of actual religious worship within the meaning of Art. IX, $\S 1$ and that therefore such property could not be exempted from taxation. The act was repealed in 1933. Pa. Stat. Ann. tit. 72, $\$ 4721$.

22 The first such attempt was by an Act of April 20, 1905, P.L. 246 (Pa. Stat. Ann. tit. $72, \S \$ 5583-5589)$ which provided that owners of forest lands, maintaining a growth of not less than three hundred to the acre, were to receive a rebate of taxes thereon, to the amount of eighty per cent of such taxes, provided that the rebate was not to amount to more than $45 \phi$ per acre. A further proviso stipulated that "the provisions of this act shall not be construed so as to exempt from taxation more than five hundred acres, owned by any one person. . . ." The act was entitled "An Act to encourage the planting and maintaining of sprout forest and timber-trees, and providing that those who thus aid shall be exempt from taxation. . . ." [Emphasis added.] A lower court, in Christley v. Butler County, $37 \mathrm{~Pa}$. Super. 32 (1908), held that the act violated both the exemption prohibition and the uniformity clause, Art. IX, $\S \S 1$ and 2. The primary reason for this ruling was that the act was held to be, at 36, ". . . an attempt by the legislature to exempt to class of real estate from taxation in the teeth of the constitutional mandate withholding from the legislature any such power." In any case, the act could not be upheld as a "classification act, because it [was] not based on any sustainable ground on that theory." Evidently the case was not appealed.

$23336 \mathrm{~Pa}$. 572, 9 A. 2d 727 (1940). The plaintiff was owner of unseated surface land. Pursuant to an Act of June 5, 1913, P.L. 405, plaintiff had caused that land to be classified as auxiliary forest reserve so that it might receive the special treatment provided by statute. A court of common 
sidered the validity of a 1935 act $^{24}$ which provided that surface land classified and set apart as auxiliary forest should be valued for the purpose of taxation at an amount not to exceed one dollar per acre. A ten per cent stumpage tax was to be paid when and if the trees were harvested. The act was held to be unconstitutional for alternate reasons. First, and foremost, the act was held to be in fact an exemption statute which ipso facto violated both Art. IX, $\$ 1$ and the express prohibition against exemptions in Art. IX, $\$ 2 .{ }^{25}$ Concerning the relevancy of Art. IX, $\S 1$ the court said it was ". . . well settled that when the Constitution enumerates the kind of property that may be exempted from taxation, it by implication excludes all other taxable property. ${ }^{\mathbf{2 6}}$

Plaintiff contended that because of the assessed valuation of one dollar per acre the forest lands would be taxed at least to some degree. In reply, the court asserted that it was immaterial if the exemption was only "partial." The difference between a $100 \%$ and, for example, a $50 \%$ exemption is only a "difference in degree." All are odious to the "con-

pleas, however, declared the 1913 act unconstitutional. Borough of Langhorne Manor etc. v. Harvey et al., Ct. of C.P., Bucks County (Feb., 1931). No appeal was taken. Acting on advice of the attorney general, an administrative officer in 1934 notified the owners of all land classified pursuant to the 1913 statute that contracts thereunder were cancelled. Subsequently the Act of 1935 (described in the text at note 24) was passed, and plaintiff brought action to compel the reduction on the records of the assessment of the land to an amount of not more than one dollar per acre pursuant to said 1935 act.

24 Act of July 18, 1935, P.L. 1196.

${ }^{25}$ Clearfield Bituminous Coal Corp. v. Thomas, supra note 23 at 576580. On this point the court relied on In re Cope's Estate, $191 \mathrm{~Pa} .1,43$ Atl. 79 (1899) (discussed infra, text at note 192) which held unconstitutional an act exempting personal property to the amount of $\$ 5,000$ from the inheritance tax. Significantly, the tax was held to be a tax upon the property transmitted. The Cristley case, supra note 22 , was also quoted at length.

${ }^{26} I d$. at 577 . 
stitutional principle of equality and uniformity."27 Stressing this rationale, the court concluded:

The framers of the Constitution, recognizing the fact that every dollar of normal tax burden arbitrarily subtracted from the land of one citizen means a commensurate tax burden added to the property of all other citizens, restricted the legislature's power to exempt taxes to a few classes and then declared all other attempted exemptions "void."28

The alternate reason for declaring the act unconstitutional was that even if the act could be considered nothing more than a statute classifying property for rate purposes, the classification in question was arbitrary..$^{29}$ Evidently the court viewed the classification as one based solely on the owners' use of the land, and such a basis was arbitrary, at least in this particular situation. ${ }^{30}$ The opinion concluded with a violent diatribe against what it considered to be the imposition of unequal tax burdens contrary to the spirit of the uniformity clause in Art. IX, $\$ 1$. In doing so, the spectre of possible classification was pushed to an unwarranted extreme. ${ }^{31}$

$27 I d$. at 579.

28 Id. at 580.

29 For this proposition the court relied to some extent on Commonwealth v. Alden Coal Co., 251 Pa. 134, 96 Atl. 246 (1915), cited as ruling that a classification consisting of hard coal was arbitrary. Id. at 580 . However, the court failed to cite Heisler v. Thomas Colliery Co., $274 \mathrm{~Pa}$. 448, 118 Atl. 394 (1922), in which the classification of hard coal was held to be reasonable. These cases are discussed infra, text at notes 132, 137.

30 The court reasoned that the act created inequalities of tax burden since a person holding adjoining property might be taxed on the actual value, which might be $\$ 100$ or more, while a person cultivating trees might, with consent of the secretary, escape all taxation on the land (until the distant date when the trees are harvested) except a nominal tax on a valuation of $\$ 1$ per acre. Cf. a similar rationale found in Murray v. Philadelphia, 364 Pa. 157, 71 A. 2d 280 (1950), concerning a local wage tax on income from rented houses, infra note 190 . But see Knisely v. Cotterel, $196 \mathrm{~Pa}$. 614, 46 Atl. 861 (1900), infra note 166.

31 Clearfield Bituminous Coal Corp. v. Thomas, supra note 23 at 581. 
Summarizing, it seems clear that real property is not a minimum class (or subject) of taxation. Consequently, such property may be further classified for the application of different rates. However, realty can not be subclassified for the purpose of exempting such subclasses. The source of this rule is the express prohibition against exemptions, although at times some reliance is placed on the "principles of uniformity." The prohibition includes "partial" as well as "total" exemptions of subclasses of realty.

\section{(a) Taxation of "occupations"}

In Pennsylvania "occupations" are taxed in much the same way as real property. An arbitrary valuation is placed on each type of occupation, and the applicable tax rate is the same as that applied to real property. The statutory authority for the taxation of occupations is the act providing for the real property tax. It reads as follows:

The court asserted that if the act were sustained the legislature could enact laws whereby half or some other fraction of all property in a local taxing unit would have to bear the whole burden of governmental costs therein. Such an act, it was said, would give the state government unlimited power "to take from one individual and not from another, as it will." Then, quoting from Professor Burgess' condemnation of the 16th Amendment to the federal Constitution and the principle of graduated income tax rates, the court expressed its philosophy on the whole matter, at 583, note 1:

... a government representing either the property class, or the propertyless class, especially a government representing the propertyless or small-property class, a government representing the modern democracy under universal suffrage, a government representing the class to be benefited by the confiscation and redistribution of wealth through governmental force, cannot be safely trusted with such power. . . .

The court also felt that the power to classify property would be a ". . . despotism, which would destroy property, use up accumulated wealth, make enterprise impossible, discourage intelligence and thrift, encourage idleness and sloth, and pauperize and barbarize the whole people." As will be obvious from a survey of the entire Pennsylvania problem, these particular views-or prejudices- have not prevailed to a great extent beyond Clearfield Bituminous Coal Corporation v. Thomas, supra note 23. 
The following subjects and property shall, as hereinafter provided, be valued and assessed, and subject to taxation for all county, city, borough, town, township, school and poor purposes at the annual rate:

(a) All real estate. ...

(b) All salaries and emoluments of office, all offices, and posts of profit, professions, trades and occupations, except the occupation of farmer, and all persons over the age of twenty-one years who do not follow any occupation or calling. . . . The provisions of this clause shall not apply to counties of the second and third class, or to any other county, the county commissioners of which shall by resolution determine not to levy a tax on trades, occupations, professions and persons who follow no occupation or calling, nor shall the provisions of this clause apply to cities of the second and second A class, or to school districts.

(c) All other things and persons now taxable by the laws of this Commonwealth for county, city and school purposes. ${ }^{32}$

Provision for the taxation of "occupations" antedates the present constitution of $1874 .^{33}$

Two cases concerning the taxation of "occupations" also shed some light on the meaning of the uniformity limitation. They will be given considerable attention, not because of this quite insignificant part of the Pennsylvania tax structure, but because of the role one case has played in relation to other more important taxes and because of the very important doctrinal implications of the second case.

A local ordinance ${ }^{34}$ enacted by the City of Williamsport and purporting to tax "occupations" was challenged as to its

$32 \mathrm{P}$. Stat. Ann. tit. 72, $\S \S 5020-201,5453.201$, emphasis added.

${ }^{83}$ Apart from the antecedents of the provision quoted in the text, an Act of Mar. 18, 1875, P.L. 15, $\$ 1$ provided that cities of the third class might assess and collect taxes not exceeding $1 \%$ per annum upon "all persons, real and personal property, and also all other matters and things within said cities taxable for state and county purposes."

34 The ordinance was enacted pursuant to the 1875 authorizing statute, supra note 33 . 
validity under the uniformity clause, Art. IX, $\S 1$, in Banger's Appeal, ${ }^{35}$ decided in 1885 . This is a leading and often cited case on the meaning of the uniformity of taxation limitation in Pennsylvania. However, as will be pointed out below in discussing other taxes, much of the use made of this opinion has in fact been "misuse."

The Williamsport ordinance provided that a tax was to be assessed on "all personal property, and all objects and things assessed as unclassified." Under this general provision, assessors were directed to "assess all offices and posts of profits, professions, trades and occupations." ${ }^{\mathbf{3 6}}$ The plaintiff's bill in Banger's Appeal averred, and the answer of the city admitted, that the tax upon occupations was "based upon the income from said occupations." ${ }^{37}$ Testimony tended to show that no systematic effort was made to assess the various occupations uniformly. Different assessors used substantially different estimates of income for specific occupations. Apparently, the valuation of occupations by use of income derived therefrom was not based on reported income. Rather, as one assessor testified, it was based on what "he considered a man's occupation to be worth." For merchants and businessmen a most unusual method was used. Such occupations were assessed at what it would take to hire a clerk to do such a man's work. From the report of the opinion it is clear that this tax was intended to be a property tax, under which occupations were to be valued according to income received. And the rate applicable to other property taxed pursuant to the authorizing statute was to be applied to such values of occupations.

The court decided that the city had the power to tax "oc-

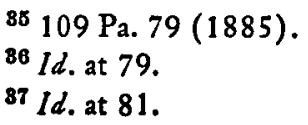


cupations, "38 but that this particular tax was invalid because of the inequality found in the method of valuation. Such "flagrant inequality" was held to be a violation of that degree of uniformity required by Art. IX, $\$ 1 .^{39}$ This was the most obvious reason for striking down the tax ordinance. Indeed, no one could quarrel with that decision in light of the extraordinary testimony of the various assessors concerning their "divining rod" approach to determining the value of occupations. ${ }^{40}$

However, the court offered an alternate reason for finding the tax invalid, and here was sown the trouble to be reaped in later cases. The court stated that "under the guise of an 'occupation tax,' the city of Williamsport has levied, and is seeking to collect, an income tax." But, it was ruled, the city did not have statutory authority to levy an income tax. "The power to levy an occupation tax gave the city no right to levy an income tax." ${ }^{\prime 41}$ At this point, the court indulged in a general condemnation of income taxes, saying: "Of all forms of taxation this is the most odious to the American people." Nevertheless, it is quite important to point out that this often quoted dictum had absolutely no relevancy whatsoever to the issue before the court, namely, that the city had not been authorized by the legislature to impose an income tax. Finally, the court expressed an opinion as to what kind of a tax on occupations would be constitutional under the uniformity clause. Such a tax might be arranged so

38 This ruling concerned the authority of the city pursuant to the 1875 authorizing statute, supra note 33.

89 Banger's Appeal, supra note 35 at 93.

40 Ibid. As the court described the situation, each assessor appeared to have had his own crude notions of his duty, and to have made his assessments according to his own idea of equity. No fixed rule prevailed among them. Such an assessment upon "occupations" was "hopelessly, incurably vicious," and a direct violation of Art. IX, $\S 1$.

${ }^{41}$ Id. at 94. 
that it classified the several occupations, with all the members of a single class being taxed at an identical rate. ${ }^{42}$

The most important point to remember concerning the opinion in Banger's Appeal is the precise scope of the issue which was to be resolved. And in considering the validity of an income tax under the uniformity limitation one should be most careful to distinguish between the holding of that case and the unwarranted dictum found in the opinion. ${ }^{43}$

The second of the two cases concerning the uniformity limitation and the taxation of occupations is a lower-court decision, Thompson v. Indiana County, ${ }^{44}$ from which there was apparently no appeal. That case concerned the validity of the present statute's ${ }^{45}$ antecedent insofar as it excluded the occupation of farmer. The Act of 1834, Public Law 509, had made no exceptions. By an Act of April 29, 1844, Public

42 Id. at 94-95, the court saying:

But what uniformity is there in laying an "occupation" tax of $\$ 100$ upon $A$ and a like levy of $\$ 200$ upon B, the occupation of each being similar? The answer, and the only one that can be urged is, that $B$ earns double the amount that $A$ does. This brings us at once to a vice underlying the whole case. Under the guise of an "occupation" tax, the city . . . has levied ... an income tax.

The hint concerning a proper method was as follows:

The proper result may possibly be reached by classification. Thus it may be that physicians, lawyers [etc.] may be classified, and a uniform occupation tax assessed upon each class.

The court also indicated that an occupation tax, though similar, was in no way an income tax. There might have been some implication that the tax was not a "property" tax. But see In re Brown's Appeal, 111 Pa. 72, 2 Atl. 77 (1885) in which the court held that occupations were property within the meaning of Art. IX, $\S 8$ (concerning the constitutional limitation on debt), and therefore to be included in the aggregate valuation of taxable property upon which a percentage of indebtedness was to be calculated.

43 See the discussion under "Income Taxes," infra, text at notes 181-191.

$4483 \mathrm{~Pa}$. Super. 248 (1924).

${ }^{45}$ See text at note 32 , supra. 
Law 486, the provision was amended to read substantially as the present statutory provision reads, including the following proviso after the enumeration of taxable occupations: "except the occupation of farmer." The tax authorities claimed that this exception of farmers was an exemption, and as such prohibited by Art. IX, $\$ 2$. Rejecting this approach, the court characterized the statute as "not including" the occupation of farmers. That is, not all property must be "selected" for taxation. The only limitation on the selective power is that when a class is selected, then all of that class must be taxed. The statute in question was characterized as simply defining "occupations" as a subject of taxation to be less than all possible occupations.

[T] he Act of 1844 is an act providing for assessments on certain classes of property therein indicated. ... The legislature had authority to select the classes of subjects of taxation and they did not select a class including farmers. ${ }^{46}$

Consequently, the "exclusion of" or "failure to select" the occupation of farmer did not contravene Art. IX, $\$ 2$ prohibiting "exemptions."

46 Thompson v. Indiana County, supra note 44 at 251 , emphasis added. The court explained in detail, as follows:

... the Act of 1844 makes six classifications of subjects which may properly come within the general denomination of occupations: They are, salaries, offices, posts of profit, professions, trades and occupations except farmers. That is, the class of persons known as farmers are not included within the subjects of taxation and there is reason for the distinction. [Emphasis added.]

47 This case apparently overruled Mulberger v. Indiana County (Pa.), 71 Pitts. L. J. 964 (1923), wherein the court ruled that the 1844 act was in effect an "exemption" act and therefore invalid under Art. IX, $\$ \S 1$ and 2 , and that the 1834 act was therefore revived and consequently the levy was validated as to farmers. 


\section{(2) Personal property taxation: intangibles}

(a) The personal property tax (intangibles in the hands of individuals)

Several very important cases concerning uniformity were decided under the personal property taxes (the state and county taxes will be discussed together). Most of them concern the perplexing problem of "exemptions"-perplexing, that is, in light of the meaning which the court has given Art. IX, $\S \S 1$ and 2. The method used to impose the personal property tax has continued substantially unchanged. The pertinent statutes provide that the enumerated classes of property (in fact intangibles in general are covered by the enumeration of several classes) shall be subject to a [county] [state] tax at a specified [presently four mills] rate. ${ }^{48}$ To this extent it differs from the real property tax, the annual rate of which is fixed to meet the revenue needs of the particular taxing unit. Also, it is pertinent to point out that the base of the various personal property taxes, in force from time to time, has consistently been "the value" of such property.

Analysis of Fox's Appeal. One of the most important of all the uniformity cases in Pennsylvania is In re Fox's Appeal, ${ }^{49}$ decided in 1886. In that case the court upheld the state personal property tax then embodied in an 1885 act. $^{50}$ Section 1 of that act provided:

That all mortgages, money owing by solvent debtors, :...; also all articles of agreement and accounts bearing interest, owned or possessed by any person or persons what-

${ }^{48}$ For example, as to the county personal property tax, see: Act of June 17, 1913, P.L. 507, §1, as amended; Pa. Stat. Ann. tit. 72, \$4821. Also see Pa. Stat. Ann. tit. 72, §3244; Pa. Stat. Ann. tit. 72, §581.2, 581.32.

$49112 \mathrm{~Pa} .337,4$ Atl. 149 (1886).

${ }^{50}$ Act of June 30, 1885, P.L. 193. 
soever (except notes or bills for work or labor done, and all obligations given to banks for money loaned and bank notes), and all public loans or stocks whatsoever (except [state or federal]), and all moneys loaned or invested in any other State, and all other moneyed capital in the hands of individual citizens of the State, . . . are hereby taxable for State purposes, at the rate of three mills on the dollar of the value thereof annually; Provided, That the same shall ... . be exempt from all taxation except for State purposes; Provided, The provisions of this Act shall not apply to building and loan associations. [Emphasis added.]

Section 20 of the 1885 act repealed or abolished all taxes laid upon manufacturing corporations by the revenue laws of the Commonwealth, except that the exemption was not to apply to corporations engaged in the distilling business or the manufacture of gas.

The plaintiffs in In re Fox's Appeal challenged the validity of this tax under Art. IX, $\S \S 1$ and 2 on several specific grounds. First, the tax reached only such enumerated intangibles in the hands of individuals (i.e., "owned or possessed by any person or persons," in the words of section 1), and thereby in effect it exempted such property in the hands of corporations. Second, the act exempted such property in the hands of building and loan associations. Third, and last, it was contended that section 20 of the act exempted manufacturing corporations from taxation. The plaintiffs' argument was based on this proposition:

The provisions of the constitution [i.e., Art. IX, $\S \S 1,2$ ] are violated when the legislature taxes property in the hands of one class of persons and omits to tax property in the hands of other classes. A law may exempt persons from taxation by omitting to provide for their taxation as completely as by an express provision exempting them. ${ }^{51}$

${ }^{51}$ In re Fox's Appeal, supra note 49 at 342, emphasis added. Plaintifftaxpayer contended that success on any one of the grounds would be suf- 
Thus, plaintiffs were clearly equating the processes of "selection" and "exemption."

The court rejected each of the above contentions and held that the act did not violate Art. IX, $\$ \S 1$ and 2, except in a respect not questioned by plaintiffs. The court held that the constitutional provisions in question were violated by the exception in section 1 of the act concerning "notes or bills for work or labor done, and all obligations given to banks for money loaned and bank notes." This latter ruling has been quite important in the development of the meaning of the Pennsylvania uniformity limitation.

Justice Paxson (who, incidentally, wrote the opinion in Banger's Appeal) spoke for the court and agreed with plaintiffs' interpretation of the statute's operation, saying:

It is clear, from the language of the Act, that it does exempt building and loan associations from taxation under its provisions; that it does repeal all taxes upon manufacturing corporations with the exceptions therein named and that it does exempt from taxation "notes or bills for work and labor done." We are also of the opinion that mortgages and other moneyed securities held and owned by corporations are not, and were not intended to be taxed by the Act in question. ${ }^{52}$

By interpreting the statute in this manner, the court rejected the construction offered by the taxing officials, namely, that the phrase "any person or persons whatsoever" found in section 1 of the act should be taken to include all owners, including corporations, of such property as was enumerated..$^{\text {s3 }}$

On the basis of this construction the constitutional issue was formed: conceding that the act did not extend the tax to property in the hands of corporations, did it follow that the

ficient to invalidate the entire tax and support the bill to restrain officials from requiring plaintiffs to make returns for the personal property tax.

52 Id. at 350 .

${ }^{63} I d$. at $350-352$. 
act conflicted with the uniformity clause in Art. IX, $\$ 1$ ? The court dealt quite thoroughly with this basic issue ${ }^{54}$ and described the constitutional power of the legislature with these important words:

The power of the state is conceded to select its subjects of taxation. It may tax mortgages or it may omit to tax them. It may tax horses or it may omit to tax them. But this tax, upon whatever laid, must be uniform. Thus it must be laid upon all taxpayers alike. It cannot tax $A$ on his mortgages or his horses, and exempt B from a like tax. Nor do I see any distinction here between persons and artificial persons, commonly called corporations. Each must bear its due share of the public burdens. This is because the constitution declares that "all taxes shall be uniform." "5s

Applying this general proposition to the facts at hand, the court reasoned that although the first section of the Act of 1885 did not extend the tax on intangibles to such intangibles as were held by corporations, nevertheless, this did not necessarily mean that the Act of 1885 was for that reason a violation of the constitution. Why not? Because, it was pointed out, the Act of 1885 which plaintiffs challenged was supplemental to an Act of June 7, 1879, Public Law 112. Section four of the 1879 act imposed a capital stock tax. For corporations declaring either no dividends or dividends of less than six per cent, the rate was three mills on the dollar of the appraised value of the capital stock of such corporations. For those corporations declaring more than six per cent dividends, the rate was one-half mill on the dollar of the appraised value of the capital stock of such corporations for each one per cent of dividend declared. ${ }^{56}$ The 1879 act also contained other provisions for the taxation of banks, insurance

64 1d. at 353-355.

55 Id. at 353 , emphasis added.

${ }^{56}$ See the discussion infra, text at notes 108 , et seq., for the later changes in the base-rate of the capital stock tax. 
companies, limited partnerships, and others which it was not necessary to refer to specifically.

Thus, pursuant to the 1879 act there was a tax on the capital stock of corporations equal to a minimum of three mills on the dollar of appraised value, which the court noted was "the exact amount which the Act of 1885 imposes on mortgages, moneys at interest and moneyed capital in the hands of individuals." One step more was needed to reach a conclusion. Taking it, the court said:

It has been repeatedly decided in this state and is settled law, that a tax upon the capital stock of a corporation is a tax upon its property and assets. . . . The Act of 1885 being a supplement to the Act of 1879 , the two Acts must be read together, and thus we have in the one a tax of three mills on mortgages, etc., in the hands of individual citizens, and what is practically and legally, although not in name, a similar tax upon the same class of subjects in the hands of corporations. ${ }^{57}$

Having thus prepared in advance an answer, Justice Paxson could ask his rhetorical question: "Wherein then is the lack of uniformity, and wherein has the legislature made a discrimination in favor of corporations as against individual citizens?"

One other observation, important for our delineation of the uniformity limitation, was made:

While a different mode of assessing taxation is adopted in dealing with the tax on corporations from that of taxing money in the hands of individuals, the result is substantially the same. Were the tax of 1885 on mortgages extended to

${ }^{57}$ In re Fox's Appeal, supra note 49 at 353-354, emphasis added.

${ }^{68} \mathrm{Id}$. at 354 . Indeed, thought Justice Paxson, if discrimination existed at all, it was against corporations because the tax thereon could amount to six mills or more depending upon the amount of dividends declared. He pointed out that section 17 of the 1879 act had taxed intangibles at the rate of four mills, and that the principal object of the Act of 1885 was to reduce the rate to three mills and as well to provide more efficient enforcement machinery. 
corporations, the result would be double taxation, which, while not beyond the powers of the legislature, is not to be presumed in the absence of a clear intent to impose it. ${ }^{59}$

"Double taxation" would have resulted because, as the court had asserted above, "a tax upon the capital stock of a corporation is a tax upon its property and assets."

Having decided that the Act of 1885 was not unconstitutional even though it failed to extend the tax to "mortgages of corporations," the opinion rather summarily rejected the remaining two contentions made by plaintiffs-not, however, without indicating that the exemption of building and loan associations and manufacturing corporations would be seriously questioned if the issue of its validity was properly raised. ${ }^{60}$

The court did rule that a part of the Act of 1885 was unconstitutional. The exception concerning "notes or bills for work or labor done" was "clearly a violation of the IXth Article of the Constitution." Nevertheless, the court was not required to declare the act as a whole void because it was severable. In so holding, the court referred to the second section of Art. IX of the Constitution, and said:

59 Id. at 354, emphasis added.

${ }^{60}$ As for the proviso in section 1 of the act which exempted building associations from the operation of the act, the court, id. at 355 , felt that it was

... harmless, because said section does not, and was not intended to apply to corporations of any description. If there really was an exemption of such corporations, it would be void under the constitution, for the legislature can only exempt from taxation such property as that instrument authorizes it to exempt.

As for section 20 of the act which repealed taxes theretofore laid on manufacturing corporations by the revenue laws, the case at hand was not affected by the section because the act was severable and because, even if the section "amounted to any unlawful exemption from taxation, . . . the exemption would fall, and leave the balance of the Act in full force." Therefore, the court did "not propose to discuss the effect of the repeal of the tax on this class of corporations." 
The exception of "notes or bills for work or labor done" is void, under this provision, and drops out of the Act of 1885 . The exception falls, but the Act stands. It will be the duty of the assessors to assess and return such bills or notes the same as other moneyed securities in the hands of individuals. ${ }^{61}$

At this point it will be helpful to state as precisely as possible what In re Fox's Appeal held and just what it implied by either its decision or its dictum, since later cases may be better understood in light of doctrine which might be founded on the rationale underlying the decision in In re Fox's Appeal.

First, the opinion seems to accept the distinction between "selection" and "exemption" as one which is valid and quite significant. In making its decision concerning the validity of the 1885 act insofar as the legislature had only selected intangibles held by individuals, the court seemed to accept the proposition that a rule of universality does not govern the selection of the object of a property tax. However, once a given class of property is actually selected for taxation, all of that class must be taxed-that is, subclassifications, however reasonable, cannot be made for the purpose of exemptions. A fair implication to be drawn from the opinion is that neither personal property nor even intangible personal property is a minimum class for purposes of uniformity in taxation. More narrow classifications may be made for selection purposes. However, such classifications of personal property may not be made on the basis of who orens or possesses such property if the purpose of the classification is to select less than all for taxation. Thus, the opinion clearly implied that the uniformity clause in section one of Art. IX would have been violated, since only intangibles in the hands of individuals were selected under the $1885 \mathrm{Act}$, had not the same

${ }^{61}$ Id. at 355, emphasis added. 
type of intangibles held by corporations been subject to a "substantially similar" tax. The legislature "may tax mortgages, or it may omit to tax them. ... [But] [i]t cannot tax $A$ on his mortgages . . ., and exempt $B$ from a like tax." ${ }^{32}$ To the contrary, personal property may be classified on the basis of who owns or possesses such property if the classification is made for the purpose of using different methods of taxation-with the possible qualification that "substantially similar" results must be had. ${ }^{63}$

The second important feature of the opinion in In re Fox's Appeal is found in that part concerning the "exception" as to "bills or notes for work or labor done" in section 1 of the 1885 Act. That "exception" was held to be an "exemption" and a violation of the second section of Art. IX of the constitution. ${ }^{64}$ It is important to remember that the first part of the opinion had laid down the proposition that the legislature was not limited by any rule of universality in exercising its power to select property for taxation. If the court intended to rule that "bills or notes for work or labor done" was an arbitrary classification (that is, they could not reasonably be separated from a larger class consisting of "moneyed securities"), ${ }^{65}$ then the "exception" clause in section 1 of the 1885 Act could have been held to be a violation of the uniformity clause in section one of Art. IX of the constitution. Indeed, the limitation derived from the section one uniformity clause was the basis of the discussion concerning the validity of the object of the 1885 tax. That is, was "intangibles in the hands of individuals" too narrow a class? To the contrary, in determining the validity of the "exception" as to "bills or notes

62 See the quotation at note 55 , supra.

63 See the text at note 59 , supra.

64 See the quotation at note 61 , supra.

65 Note the statement in the quotation at note 61, supra, to the effect that that such bills and notes must be assessed and returned "the same as other moneyed securities in the hands of individuals." 
for work or labor done" the court shifted its ground for decision to section two of Art. IX, and held that the "exception" violated the express prohibition against "exemptions" found in that section. It should be remembered that the plaintiffs in the case had contended that the narrowness of the object of the tax itself was a violation of section two of Art. IX-that is, it was argued that an "exemption" in contravention of Art. IX, $\$ 2$ could be found in a negative "omission" as well as in a positive "exemption." The court chose to ignore this suggested rationale insofar as the validity of the object of the 1885 tax act was concerned, resting its decision on the uniformity clause in Art. IX, $\S 1$, as noted above. Yet, the court shifted to section two of Art. IX to invalidate the "exception" of "bills and notes for work or labor done."

It is submitted that one is not unwarranted in drawing the following implication from the mannner in which In re Fox's Appeal dealt with the tax under consideration. Article IX, $\$ 2$, which prohibits the "exemption" of property other than that classified as exemptible by Art. IX, $\S 1$, will prevent the legislature from separating a subclass from a larger class actually selected for taxation for the purpose of positively "exempting" the subclass. However, it appears that the same result might be reached without violating either section 1 or 2 of Art. IX by simply phrasing the object of the tax so as not to include the subclass in question. ${ }^{66}$ If this is a fair implication, as this writer contends it is, we certainly have a rather dubious system of "shadow" limitations.

A third feature of importance in In re Fox's Appeal was the court's intimation that the exemption of certain classes of corporations (building associations) would have been a violation of Art. IX, $\$ 2$ if the exemption had in fact been effective instead of "harmless." Also, in light of its state-

${ }^{66}$ Cf. Thompson v. Indiana County, supra note 44 , and the text at notes 44 to 47 , supra. 
ments concerning building associations the court obviously wished to avoid ruling upon the validity of the exemption of manufacturing corporations.

It becomes clear upon the examination of later opinions, decided under both the personal property tax and other taxes, that much of the restrictiveness apparent in In re Fox's Appeal has been relaxed considerably, if not expressly, then at least by what has been actually decided. Within a few years after the decision in In re Fox's Appeal, several cases, all having important implications for the rationale of In re Fox's Appeal, were decided under the capital stock and corporate loans taxes. In Commonwealth v. Germania Brewing Company, ${ }^{67}$ the manufacturing corporations' exemption from the capital stock tax was held not to violate Art. IX, $\S \S 1,2$. In Commonwealth v. Fall Brook Coal Company, ${ }^{68}$ the close relationship between the personal property tax and the capital stock tax was reaffirmed as the court upheld the exemption from the personal property tax of shares in corporations subject to or exempt from the capital stock tax. In the leading case of Commonwealth v. Delarvare Division Canal Company ${ }^{69}$ the court held that the taxation by the corporate loans tax of certain classes of intangibles (i.e., "corporate loans" as defined) at a different rate from that applicable to other intangibles did not violate the uniformity clause in Art. IX, §1.

Other cases. Continuing with the personal property tax cases, some consideration must be given to Dupuy v. Johns, ${ }^{70}$ which involved the County Personal Property Tax Act of $1913 .^{71}$ With the 1913 act the personal property tax was made exclusively a county tax and the corporate loans tax was

67145 Pa. 83, 22 Atl. 240 (1891), infra note 112.

${ }^{68} 156 \mathrm{~Pa} .488,26$ Atl. 1071 (1893), infra note 111.

$69123 \mathrm{~Pa} .594,16$ Atl. 584 (1889), infra note 86.

${ }^{70} 261 \mathrm{~Pa} .40,104$ Atl. 565 (1918).

${ }^{71}$ Act of June 17, 1913, P.L. 507, §1. 
left exclusively a state tax; theretofore the personal property tax had been a state tax collected by local agencies, with a part of the revenue being pro-rated to the counties. As in In re Fox's Appeal, the issue in the Dupuy case concerned "exemptions." Section 1 of the 1913 act, in effect, exempted from the personal property tax those shares of stock in corporations either subject to, or exempt from, the capital stock tax.

The plaintiff in the Dupuy case was a taxpayer, resident of Pennsylvania, who failed to include in his personal property tax return for 1916 certain shares of stock of a New Jersey corporation engaged in business, in part, in Pennsylvania. The corporation had paid the capital stock tax for the year 1916. Tax officials assessed the plaintiff's shares in the corporation under the personal property tax, although plaintiff claimed that such shares were exempt pursuant to the terms of the exception proviso in section 1 of the 1913 act. The following method of assessment was used. Officials assessed that proportion of the shares which represented the percent of capital stock not employed in Pennsylvania, upon which there was no liability at that time for the capital stock tax because of the method of computing the base thereunder. Thus, the taxing officials interpreted the exception proviso in section 1 of the 1913 act so that only the following property was exempt: (1) the proportion of the value of a share representing the proportion of capital stock actually taxed under the capital stock tax; and (2) shares of stock in corporations entirely exempted under the capital stock tax act. The taxing officials contended that it was necessary to interpret the provision of the 1913 act to require the method proposed by them because the taxpayer's proposed interpretation would result in a violation of Art. IX, $\S 1$, since it exempted some shares from all taxation. ${ }^{72}$ In other words, the taxing

72 Supra note 70 at 44. 
officials argued that the exception provision of the 1913 act was designed solely to prevent "double taxation."

The court rejected both the taxing officials' interpretation of the 1913 statute and its contention that plaintiff's interpretation would result in a violation of Art. IX, $\$ 1$. It stated that the attack on the constitutionality of the act of $1913 \mathrm{had}$ "no merit, since the fundamental validity of tax immunities such as those therein provided for is now beyond question, ${ }^{\text {"73 }}$ citing Commonwealth v. Germania Brewing Company, ${ }^{74}$ in which the court upheld the exemption of manufacturing corporations from the capital stock tax. Relying on the analysis in the Germania case, the court concluded:

As to the indirect classifying effect of these immunity provisions, the selection and classification of subjects for taxation are, generally speaking, exclusively within control of the legislature, the only restriction being that there must be no discrimination between members of the same class. . . . ${ }^{75}$

Supported by this underlying rationale, the exception clause in the 1913 act was interpreted in the following manner. For the purpose of taxing shares of corporate stock in the hands of the shareholder, the clause, in effect, divided "corporations" into two classes: (1) those doing no business, making no official reports, and paying no capital stock tax in Pennsylvania; and (2) those engaged in business in the state and either taxable under the state capital stock tax or relieved therefrom by law. Upon the stock of the first class the resident shareholder had to pay a personal property tax. To the contrary, the stock of the second class was exempt from the personal property tax when in the hands of resident shareholders. It was said that, on the facts, the classification was not "unwarranted"; and since there was no want of uni-

73 Id. at 48.

74 Supra note 67.

75 Supra note 70 at $48-49$. 
formity within the respective classes the exception proviso in the first section of the 1913 County Personal Property Tax Act was not unconstitutional.

The nature of the classification which was approved in the Dupuy case is of considerable interest. The court referred to a classification of "corporations," with the shares of stock in such corporations being subject to the tax or exempt therefrom according to the class into which the corporation fell. As the present study will make clear, throughout all of its pertinent decisions the court has characterized the personal property tax as a tax upon property. Thus, property (in this particular case, shares of stock) is the thing which must be classified for selection or exemption. Therefore, we must conclude that in the Dupuy case shares of stock were classified according to certain characteristics of the corporations which they represented-namely, whether or not the corporation had paid, or was exempted by law from the capital stock tax. The Dupuy case, then, approved an "exemption" of property from the personal property tax when it could not be said that such property was subject to a "substantially similar" $\operatorname{tax}^{76}$ In addition, the exemption proviso, the general validity of which the court avoided passing on in Fox's Appeal, was now upheld in its particular relationship to the personal property $\operatorname{tax}^{77}$

A more recent case, decided in 1940, in which an exemp-

${ }^{76}$ It might be argued that the part of the exemption clause of the capital stock tax which referred to shares on corporations was not necessarily within the scope of the decision by the court because the corporation in question had paid the capital stock tax for the year in question. However, the court treated the exemption provision as a whole throughout its opinion. Furthermore, the contention of the taxing official that the statute could be validly interpreted only so as to exempt that part of shares subject to "double taxation" certainly brings the entire provision into the issue. In its opinion the court evidently meant to consider the entire exemption provision.

77 Also see Commonwealth v. Germania Brewing Company, supra note 67 , and text at note 112 , infra. 
tion clause was upheld as a reasonable classification, affirms the rationale of the Dupuy case. In Commonwealth v. Pennsylvania Threshermen $E$ Farmers' Mutual Casualty Insurance Company ${ }^{78}$ the validity of the state personal property tax, embodied at that time in an Act of June 22, 1935, Public Law 414, was challenged because of the following exemption provision found in section 3 of that act:

All personal property of the classes hereinafter enumerated, owned, held or possessed by any resident ... is hereby made taxable, annually, for State purposes, at the rate of four mills on each dollar of the value thereof. . . . And provided further, That the provisions of this act shall not apply to ... life or fire insurance corporations having no capital stock. . . . [Emphasis added.]

Thus, life and fire insurance companies having no capital stock were treated differently from casualty insurance companies having no capital stock. The court held that this was not an unreasonable and therefore unconstitutional classification contrary to the uniformity clause in Art. IX, $\S 1 .^{79}$ The taxpayer in the case was a Pennsylvania mutual casualty insurance company, against which a tax under the state personal property tax had been assessed for 1936 on personal property of the kind enumerated in the act and owned by the taxpayer. The taxpayer had claimed an exemption from the levy on the ground that the statute made an unreasonable classification. $^{80}$

$78339 \mathrm{~Pa} .62,14$ A. 2 d 295 (1940).

79 Id. at 64.

${ }^{80}$ It might detract somewhat from the strength of the decision to point out the significant statement by the court to the effect that even if the provision exempting mutual life and fire insurance companies was unconstitutional, this would not help the taxpayer. The result of holding the classification arbitrary would simply be that the exemption provision would fall and the tax be imposed alike upon all mutual companies. By an amendment, both to the expired state and present county personal property taxes, casualty insurance companies without capital stock were included within 
The tax was upon intangible personal property, and the property exempted by the proviso in the above-quoted section of the act was such intangible property "owned, held or possessed" by mutual life or fire insurance corporations having no capital stock. Thus, again a classification based on who oromed, held or possessed the property was approved. ${ }^{81}$ As in the Dupuy case, there was no discussion of the effect of section two of Art. IX. The validity of the exemption depended only on its reasonableness as a classification under the uniformity clause, Art. IX, $\S 1$.

Last to be considered is a 1914 decision, Provident Life and Trust Co. v. McCaughn, ${ }^{82}$ concerning the degree of uniformity required in the rates applicable to that property which is taxed. The case involved the personal propertycorporate loan tax structure, and the court, while recognizing

the exemption. Act of July 11, 1941, P.L. 361 ; Act of July 29, 1941, P.L. 548.

81 Another example in which the court approved a classification according to who owned the intangibles was in In re Pennsylvania Co. for Granting Insurances on Lives \& Granting Annuities, $345 \mathrm{~Pa}$. 130, $27 \mathrm{~A} .2 \mathrm{~d} 57$ (1942). The court upheld the amendment of an Act of May 5, 1939, P.L. 76, which expressly withdrew the exemption formerly found under the state personal property tax as to foreign insurance companies paying the insurance companies gross premium tax, imposed by Act of June 1, 1889, P.L. $420, \$ 24$. In brief, the issue concerned the reasonableness of a class selected for additional taxation, selected because of the withdrawal of a part of an exemption theretofore in force. The court held, at 135, that the placing of "owners of shares of foreign insurance companies in a different class from owners of shares in domestic companies" was a reasonable exercise of the power to classify. (Emphasis supplied.) As in other cases the court referred to a classification of "owners," although in fact it is property which is the subject of the tax, and therefore property is classified for exemption or selection. The cases leading up to this decision (all concerning questions of statutory interpretation) are: Girard Trust Co., Trustee's Appeal, 333 Pa. 129, 3 A. 2d 252 (1937); In re Miller's Estate, 330 Pa. 477, 199 Atl. 148 (1938). Cf. the language as to classification in In re Arrott's Estate, 322 Pa. 367, 185 Atl. 697 (1936).

$82246 \mathrm{~Pa} .370,91$ Atl. 672 (1914). 
that the close relationship of these two taxes to the capital stock tax was such as to make, in effect, a single intangibles tax structure, nevertheless affirmed the power of the legislature to classify property for different rates without violating the uniformity clause in Art. IX, $\S 1$. The personal property and the corporate loans taxes had been amended by the Act of June 7, 1911, Public Law 673. The 1911 act altered the exemption structure of the personal property tax which theretofore had provided that corporations liable to the capital stock tax were not required to pay any further tax on mortgages and other securities owned by them. Thus, as described in In re Fox's Appeal, "double taxation" was avoided because the capital stock tax would have been in substance, a tax upon property already taxed by either the personal property tax or the corporate loans tax. The 1911 act added an "exception" to the above "exception," so that securities held by corporations were not relieved from the personal property or corporate loans taxes if such securities were held in any other manner than for "the whole body of shareholders or members, as such. ..." Such securities were to be taxed under either the personal property tax or corporate loans tax even though the corporations owning them also paid the capital stock tax.

In the Provident Life and Trust Company case the court held that the 1911 amendment did not violate the uniformity clause of Art. IX, $\S 1 .^{83}$ That provision merely requires a uniformity within classes, and the classification made by the 1911 amendment was not arbitrary. Consequently, it was irrelevant to compare the tax burden imposed upon different classes of property. The classification which the court approved may be analyzed as follows: (1) mortgages and other securities (2) owned by corporations (3) which held them in any other manner than for the whole body of shareholders

${ }^{83}$ Id. at $374-375$. 
or members, as such. Generally, the classification was of selected kinds of intangibles further classified on the basis of who owned them. Again, we find judicial approval of classification on the basis of ownership. It should be pointed out that, in effect, the decision actually followed the prior dictum of the court that "double taxation" is permissible but not to be presumed. As the problem illustrates, the basic question underlying "double taxation" is always simply one of classification of property for rates.

\section{(b) The Corporate Loans Tax (intangibles in the hands of individuals)}

The present corporate loans tax is imposed by the Act of June 22, 1935, Public Law 414, §17, as amended. It reads, in part:

All scrip, bonds, certificates, and evidences of indebtedness issued, and all scrip, bonds, certificates and evidences of indebtedness assumed, or on which interest shall be paid by any and every private corporation, incorporated or created under the laws of this Commonwealth, or the laws of any other state or of the United States and doing business in this Commonwealth and having a resident corporate treasurer therein . . . are hereby made taxable for State purposes at the rate of ... four mills on each dollar of the nominal value thereof. ...

The remainder of the section contains several exemptions substantially the same as those in the personal property tax. In addition, the following important proviso is found:

And provided further, That none of the classes of property made taxable by this section for state purposes shall be taxed or taxable for county, school, or other local purposes. . . .

A brief description of the intangibles taxes and their history will facilitate an understanding of the uniformity cases. The personal property tax is a county tax; the corporate loans 
tax is a state tax which takes precedence over the personal property tax. In theory the intent of the system as a whole is to levy a tax on all taxable intangibles in the hands of individuals and to divide the tax between the counties and the state. The rate for both taxes is four mills. However, the base of the personal property tax (discussed supra) is actual value, whereas the corporate loans tax has a base of nominal or face value.

This system, which takes a subclass (i.e., corporate loans as defined) out of the larger class (i.e., intangibles in the hands of individuals) and provides a different base, and at times a different percentage rate, for the taxation of that subclass, was first effectively established by an Act of June 30, 1885, Public Law 193, §4. The first General Revenue Act of Pennsylvania, the Act of April 29, 1844, Public Law 486 (501), had provided for, among other taxes, a three mill tax on the "actual value" of intangibles in the hands of individuals. Thus, "corporate loans" were to be taxed the same as other intangibles. ${ }^{84}$ The base of the tax was "actual value," and collection was to be by local officials. By an Act of June 7, 1879, Public Law 112, the General Revenue Act was revised and re-enacted. In this 1879 act an attempt was made to change the method of taxing corporate loans. After exempting such property from all taxation except for state purposes, the act provided that all corporations paying interest on corporate loans were to deduct the tax on such property from the interest paid and pay the tax to the state treasurer. However, this revision remained ineffective because of the decision in Commonwealth v. Lehigh Valley Railroad Company ${ }^{85}$ In that case the 1879 statutory struc-

84 But note that by section 42 of the 1844 Act provision was made for the separate taxation of municipal loans. The method used was collection at the source.

85104 Pa. 89 (1883). 
ture was held to be deficient because it made no provision for the "assessment and valuation" of corporate loans. Such property was to be taxed on the "value thereof," and the court found that the legislative intent was to retain a base of "actual value." Thus, the statute was incomplete even though it did provide for a tax collector, i.e., the corporation, because there was no provision for "assessment and valuation." Consequently, corporate loans continued to be assessed and levied upon by local collectors using a base of "actual value." ${ }^{86}$ To correct this situation the legislature passed the aforementioned Act of June 30, 1885, Public Law 193, $\S 4$. Officers of corporations were thereby required to assess the tax upon the "nominal value" of corporate loans as defined.

In Commonwealth v. Delaware Division Canal Company ${ }^{87}$ decided in 1889 , the method provided by the 1885 act for the taxation of corporate loans was challenged as a violation of the uniformity clause, Art. IX, $\S 1$. The opinion in that case has played an important role in giving meaning to the uniformity clause. Its significance is increased by the manner in which opposite views were so clearly delineated in the opinions by the lower court and the Supreme Court.

The Delaware Division Canal Company had issued bonds secured by mortgages to the amount of $\$ 800,000$. Part of the bonds were held by nonresidents of Pennsylvania, part were held by resident individuals of Pennsylvania, and the remainder were held by Pennsylvania corporations. State officials made a settlement of taxes with the Canal Company (on a return made under protest) against the nominal value of all the bonds held both by individual residents of Pennsylvania and domestic corporations of Pennsylvania. The Canal

${ }^{86}$ For a historical survey of these problems, see the lower-court opinion set forth in Commonwealth v. Delaware Division Canal Company, infra note 87 at 598-599.

${ }^{87} 123 \mathrm{~Pa}$. 594, 16 Atl. 584 (1889). 
Company appealed the settlement to a lower court. ${ }^{88}$ Two of the several issues concerned uniformity in taxation. First, it was contended that "an arbitrary valuation at par [was] not a valid assessment as the foundation of an ad valorem tax." Second, the Canal Company argued that because of the discriminatory methods used for the assessment of "different subjects of the same class [i.e., nominal value was used as the base in taxing corporate loans, while actual value was used for other intangibles], and of the fact that in taxing corporate loans at par some [were] taxed at very much above and others at very much below their actual values," the resulting taxes were not uniform as required by Art. IX, $\S 1^{89}$ The lower court concluded that the position of the Canal Company was sound and held that the corporate loans tax violated Art. IX, §1. The lower court found as a "fact" that "nominal value" of corporate loans was not "a certain measure" of their actual value. The court also stated that since the tax was on property, it could not be levied without an assessment. Following the Lehigh Valley case, supra, the court found that the "intent" of the act was to tax corporate loans on their "actual value." Taking notice of the subsequent introduction of "nominal value" as a base by the 1885 act, the lower court held that one might well question whether an assessment of the corporate loans tax upon "nominal value" was such an application of a rate to "value" of property as would amount to a valid tax,

. . especially when such assessment is not in any respect the result of the exercise of the judgment of the person making it, but merely an arithmetical calculation made in obedience to the mandate of the law. ${ }^{00}$

${ }^{88}$ The opinion of that court is set forth in the report of the Supreme Court opinion, supra note 87 at 596-606.

${ }^{89}$ Commonwealth v. Delaware Div. Canal Co., supra note 87 at 596.

${ }^{20}$ Id. at 601 . Compare the problem in Michigan of distinguishing between ad valorem and specific taxes. Supra, Part D (1) of this chapter. 
The lower court considered the two sections of the 1885 act (section 1 imposing the personal property tax; section 4, the corporate loans tax) to be a whole, imposing a tax on a single class of property, namely, intangibles.

In order to consider the uniformity issue in its entirety, the lower court assumed that assessment at nominal value would be a valid "assessment." If this were allowed, the result would be as follows:

All mortgages and loans, are by $\S 1$ of the act, taxable at the rate of three mills on the dollar of their actual cash value, and all of them, except corporate mortgages and loans, are in practice so taxed; while corporate mortgages and loans . . . are in practice taxed at the rate of three mills on their nominal value, which often differs by one hundred per cent from their actual value, so that the tax is in many cases doubled and in others not more than one half the amount it would be if the tax were upon the actual value; with the result that of two persons owning taxable property, of exactly the same value, one is taxed twice as much as the other . . . as a necessary result of [the law's] provisions. ${ }^{91}$

If this analysis was correct, then the lower court was of the opinion that the method used violated the uniformity clause, Art. IX, §1. The reason was:

The mandate in favor of uniformity in $\S 1$, article IX, . . is not satisfied until the taxes, which are imposed upon all the subjects of a given class, are so imposed that each person owning the same species of property, shall pay the same amount of tax, upon the same value, when that has been ascertained by the proper authority. ${ }^{92}$

Consequently,

... if in one case the value to which the rate is applied is the expression of the judgment of the proper official, and in

91 Ibid.

02 Id. at 602 . 
another a mere arbitrary nominal value, it is in the very nature of the case that the resulting taxes cannot be uniform. ${ }^{93}$

Viewing the personal property tax and corporate loans tax as an integral whole, the enforcement of section 4 of the act of 1885 would result in a violation of "the constitutional mandate in favor of uniformity." Furthermore, even if corporate loans could be considered a reasonable class apart from those intangibles taxed at actual value under the personal property tax, the uniformity clause would still be violated because the use of "a mere arbitrary nominal value" would result in a lack of uniformity within the class consisting of corporate loans. ${ }^{94}$

On appeal to the Supreme Court of Pennsylvania the opinion of the lower court was reversed, ${ }^{95}$ the Supreme Court holding that section 4 of the 1885 act made a valid classification when it established corporate loans as a separate class for purposes of taxation, and also holding that the use of "nominal value" for a base was valid. The court first distinguished the Lehigh Valley case, supra, relied on by the lower court, asserting that the prior case had simply held that no machinery for assessment had been supplied in the 1879 act and its supplement of 1881 . To the contrary, it was held that the 1885 act, which was under review, did provide such machinery. Moreover, the court held that the legislature

${ }^{93} I d$. at 603 .

$94 I d$. at 603 .

95 The court reversed the judgment of the lower court in part only, although it entirely disagreed with its interpretation of the uniformity clause. The judgment of the Supreme Court, id. at 625, was that the Company was bound to make the assessment and deduct the tax from the interest paid as to those bonds held by resident individuals, which was "all that would appear to be subject to the tax." This is the sole reference to the statutory interrelation of the tax with the capital stock tax which reaches intangibles in the hands of corporations. See text at notes 108-130, infra. 
could legitimately impose the duty of collection upon corporations, both public and private. ${ }^{96}$

In facing the uniformity issue, the court took notice of the manner in which the two taxing sections of the 1885 act were phrased. Section 1 provided for the taxing of "all" mortgages, etc., on their "actual value." Section 4, however, described "corporate loans" and stated that corporate officials were "to assess" the tax upon the "nominal value" of such "corporate loans." The uniformity issue was then resolved to this:

... [It] is argued [by the company] that as by the first section of the act of 1885 individual and corporate obligations constitute a single class of subjects for taxation, the act unjustly discriminates between them in the fourth section, and that therefore the taxes imposed cannot be said to be uniform upon the same class of subjects. ${ }^{97}$

The court rejected this approach, taking a more liberal view of the power of the legislature to classify property for purposes of taxation. The statute was construed in the following manner:

The first section of the act does indicate certain subjects for taxation, at a certain rate, and these may in some sense be said to constitute a general class; but the classification of these subjects is extended by the fourth section; one class, consisting of the securities of private corporations, is to be taxed at their nominal value, and the residue (excepting the securities of municipal corporations, which are still taxable under the $42 \mathrm{~d}$ section of the act of April 29, 1844) constitute another class, taxable at the same rate, but upon their value to be ascertained under the ordinary processes of assessment by the local assessor. ${ }^{98}$

${ }^{96} I d$. at $616-617,618$.

$97 I d$. at 619.

${ }^{88}$ Id. at 619-620, emphasis added. 
The court then made a few general observations on the meaning of the uniformity clause in Art. IX, $\$ 1$. It was conceded that classification should be made according to "some reasonable, practical rule, drawn from experience, which would prevent a gross inequality in the burden of taxation." But more directly concerning the issue at hand:

A mere diversity in the methods of assessment and collection, ... if these methods are provided by general laws, violates no rule of right, if when these methods are applied the results are practically uniform. If there is a substantial uniformity, however different the procedure, there is a compliance with the constitutional provisions: Fox's Appeal. . . .99

Becoming more specific, the court said:

Nor is classification necessarily based upon any essential differences in the nature or, indeed, the condition of the various subjects; it may be based as well upon the want of adaptability to the same methods of taxation, or upon the impracticability of applying to the various subjects the same methods, so as to produce just and reasonably uniform results, or it may be based upon well-grounded considerations of public policy. ${ }^{100}$

The court then described the fact situation existing under the 1885 act:

Corporate obligations [by $\S 4$ of the 1885 act] . . . are taken out of the general designation of subjects contained in the first, and as a distinct class are subject to a different standard of valuation, and the tax to a different method of collection.

The court concluded that the reasons for this classification rested, perhaps, not wholly on any essential difference in the physical nature of the class, but on the "want of adaptation in our general tax laws to reach them, in the ordinary

90 Id. at 620.

100 Id. at 621 , emphasis added. 
methods of taxation."101 Also, the ease with which such property could be concealed was referred to.

As for the use of a different standard of value, the Supreme Court was of the opinion that "Well-informed men must differ greatly in their estimate of the value of such property," and in any case

Presumptively ... the nominal value is the true value of securities yielding and paying interest, and the legislature has therefore fixed the nominal value, or the par value, for the purpose of taxation. ${ }^{102}$

Furthermore, reasoned the court, once the power to classify was conceded, the question of uniformity is disposed of, for then all that is required is that taxes shall be uniform within the same class. To the court it was "plain that the act of 1885 , having constituted corporate loans in the hands of resident holders a distinct class, [did] not discriminate against any member of that class."108 Further, it was held that there was no doubt as to the power of the legislature, under such circumstances, to fix the face value of the obligations as the value for taxing purposes. ${ }^{104}$

There were a number of cases on appeal at this time, all concerning the validity of the corporate loans tax under Art. IX, $\S 1$. Each of these cases ${ }^{105}$ was disposed of by simply citing without any discussion the Delaware Division Cancl Com-

${ }^{101} I d$. at 622, emphasis added.

$102 \mathrm{ld}$. at 623 .

103 lbid.

${ }^{104}$ Id. at 623-624. Also see Commonwealth v. Mortgage Trust Co., 227 Pa. 163, 76 Atl. 5 (1910).

105 Commonwealth v. Chester, 123 Pa. 626, 16 Atl. 591 (1889); Coal Ridge Improvement Co. v. Jennings, $127 \mathrm{~Pa} .397,17$ Atl. 986 (1889); Commonwealth v. Lehigh Valley R. Co., $129 \mathrm{~Pa}$. 429, 18 Atl. 406 (1889). In Commonwealth v. Delaware \& Hudson Canal Co., 150 Pa. 245, 24 Atl. 599 (1892) the position in the principle case was reaffirmed as to the successor of the 1885 act, the Act of June 1, 1889, P.L. 420, $\$ 4$. 
pany case. However, the description of the corporate loans tax found in one of those cases, Commonwealth v. Lehigh Valley Railroad Company, ${ }^{106}$ is of some interest for the general problem of uniformity. After citing the Canal Company case as authoritatively establishing the validity of the tax, the court said:

In the opinion filed in that case, it was our purpose to show that the tax was in the nature of a specific tax, not a tax upon actual value; that the legislature having fixed the nominal value of the bonds as the basis of taxation, no further assessment, properly so called, was required. . . .

... Specific taxes for a long series of years have been imposed within this state, not only upon particular classes of property, but upon classes of persons, and we have never known the power, when properly exercised, to have been called in question.

Taxes are generally classified as specific, ad valorem, and for public benefit. The last two classes are necessarily based upon an assessment of the actual values; whereas, in the first class the valuation is either fixed by statute, or the tax is intended to subserve some supposed public interest or policy. ${ }^{107}$

This analysis will be of considerable importance in summarizing the meaning of the Pennsylvania general uniformity limitation.

(c) The Capital Stock and Franchise Taxes (intangibles in the hands of corporations)

By the Act of June 11, 1840, Public Law 612, domestic corporations and banks were required to pay one half of one mill upon each dollar of their capital stock for each one per cent of dividend or profit made or declared annually for the ensuing five-year period. The tax, at this early date, even though

106 Supra note 105.

107 Id. at 455-456, emphasis added. 
closely linked to dividends, was construed by the court as being a tax upon capital stock rather than upon dividends. ${ }^{108}$

The first General Revenue Act of Pennsylvania was the Act of April 29, 1844, Public Law 486 (501), §33 of which revised the "capital stock tax" of 1840 by providing for a dual base-rate structure. For corporations making and declaring no dividend or profit, or making and declaring a profit of less than six per cent, the appropriate officers of the corporation were required to appraise the capital stock of that corporation at its "actual value in cash," and to pay a tax of three mills on each dollar of such "actual" value. For other corporations, the arrangement of the 1840 act continuedthe base was par value of capital stock, and the rate was graduated depending on the amount of dividends. This dual base-rate structure was retained substantially unchanged until abolished by an act of 1891. The system of appraisal introduced in the 1844 act is still used in substance today.

By the Act of May 1, 1868, Public Law 108, the prior enactments were codified and the taxation of foreign corporations, as well as domestic corporations, was provided for by the same tax. The first change to be made after the new constitution of 1874 came into effect was by the Act of June 7, 1879, Public Law 112, which re-enacted the earlier acts into a General Revenue Act and first provided for the taxation of limited partnerships, as well as corporations, by the capital stock tax. The "manufacturing corporation" exemption was also first introduced in a limited manner by the 1879 act. Subsequently, by the Act of June 30, 1885, Public Law 193, $\$ 20$, the "manufacturing corporation" exemption was fully established.

The statutory form of the present capital stock tax stems from the Act of June 1, 1889, Public Law 420, $\$ 20$ and 21, a General Revenue Act and still known as the Capital Stock

108 See Commonwealth v. Pennsylvania Ins. Co., 13 Pa. 165 (1850). 
Tax Act. However, the Act of June 8, 1891, Public Law 229, $\$ 21$, abolished the dual base-rate structure and substituted a flat rate of five mills on the actual value of the capital stock. This is substantially the present system (i.e., considering the capital stock tax and franchise tax in combination). The Act of July 15, 1897, Public Law 292, §2, introduced the present system of excepting distilling companies from the capital stock tax and imposing on such companies a special rate of ten mills instead of the five mills generally imposed.

In 1935, the present "split" system was introduced. The Act of May 16, 1935, Public Law 184, imposed a franchise tax upon foreign corporations. Domestic corporations remain subject to the capital stock tax, with the exception that both foreign and domestic distilling companies are taxed by a special capital stock tax. Incidently, the "manufacturing corporation" exemption has been subject to frequent amendment.

This brief review of the highlights of the history of the capital stock tax will enable us to examine several uniformity cases in a better perspective. As described above under the discussion of the personal property tax, ${ }^{109}$ the court in the leading case of In re Fox's Appeal, decided in 1886, ruled that the capital stock tax was in fact a tax upon the assets of the corporations, ${ }^{110}$ and, as such, "substantially similar" to the personal property tax. Thus, intangibles in the hands of individuals were reached by the personal property tax, while

109 Supra text to notes 48-83.

${ }^{110} \mathrm{An}$ early case on the nature of the capital stock tax is Commonwealth v. Standard Oil Co., $101 \mathrm{~Pa} .119$ (1882), in which the court analyzed at some length the distinction between property and nonproperty taxes, and held that the capital stock tax was upon the property of the corporation, not the shareholders, and that it was not a franchise or privilege tax. However, caution should be observed in using that case for purposes of uniformity, because the issue in the case was limited to a problem of territorial jurisdiction under the due process clause. 
intangibles in the hands of corporations were reached by the capital stock tax. ${ }^{111}$ We saw further that the court in In re Fox's Appeal avoided passing upon the manufacturing exemption contained in the 1885 Act in its relation to the capital stock tax. There was some indication of serious doubt as to the validity of such an exemption provision.

The validity of such exemptions was passed upon in Commonwealth v. Germania Brewing Co., ${ }^{112}$ decided in 1891, in which the court, notwithstanding the doubt theretofore expressed, held that the exemption of manufacturing corporations was valid. Therefore, the Germania Brewing Company case is another of the more important cases in the development of the meaning of the uniformity limitation in Pennsylvania, and the opinion deserves careful examination. In that case the "manufacturing exemption" proviso in section 20 of the Act of June 30, 1885, Public Law 192 (later revised and placed in section 21 of the Act of June 1, 1889, Public Law 420 ), was challenged as being a violation of Art. IX, $\S \S 1$ and 2 of the constitution. The "exemption" purported to relieve all manufacturing corporations "except distilling corporations" from the capital stock tax. Defendant, a distilling company "excepted" from the "exemption," argued that by section 20 of the 1885 Act all manufacturing companies were put into a single class; therefore, the proviso excepting distilling companies from the exemption was void for want of uniformity. ${ }^{113}$ The Supreme Court in a per curiam opinion

111 On the relation of the capital stock tax to the personal property tax, also see Commonwealth v. Fall Brook Coal Co., 156 Pa. 488, 26 Atl. 1071 (1893), in which the court stated that a tax on capital stock in the hand of the corporation, and, concurrently, a tax on shares to the shareholder would be "double taxation," not to be supported except by express enactment. The court interpreted the capital stock and personal property taxes to be mutually exclusive. Followed in Commonwealth v. Lehigh Coal and Navigation Co., 162 Pa. 603, 29 Atl. 664 (1894).

112145 Pa. 83, 22 Atl. 240 (1891).

113 Id. at 85 . 
of a single sentence simply affirmed upon the opinion of the court below the judgment upholding the exception from the exemption. However, since the case is quite frequently cited by the Supreme Court of Pennsylvania, the reasoning of the lower-court opinion (set forth in the report of the Supreme Court decision) is of controlling importance.

In describing section $20^{114}$ of the 1885 Act, the lower court made the following important analysis:

This relief from taxation is sometimes called an exemption, and the designation is correct, in the ordinary sense of that word. But, when it was attacked as an exemption, in the sense attached to the words by $\S \S 1,2$, Art. IX, . . . the Supreme Court declared in Hawes Mfg. Co.'s Appeal, 1 Mona. 353, that it did not offend against this provision, because manufacturing corporations were not thereby relieved from all taxation, such as county and other local taxes upon their real estate, but only from taxation directly by the state. ${ }^{15}$

It followed, since "[ $t$ ] his relief from state taxation [was not] an unconstitutional exemption," that the only question remaining concerned the validity of the classification.

Was [the exemption] uniform upon the same class of subjects? For if it relieved from taxation certain members of a class, and left other members of that class still subject thereto, the tax would not be uniform, and the exemption which caused this want of uniformity, would fall. ${ }^{116}$

The defendant argued that all manufacturing companies were put into a single class, and that by excepting the distilling companies from such class there was a lack of uniformity. In the opinion of the lower court this analysis could not

114 The decision of the lower court involved section 20 of the $1885 \mathrm{act}$, and it was concluded that on the basis of that ruling no discussion of Section 21 of the 1889 act was needed.

115 Commonwealth v. Germania Brewing Co., supra note 112 at 84-85, emphasis added.

${ }^{116} I d$. at 85 , emphasis added. 
stand. To the contrary, both the exemption (manufacturing companies) and the exception therefrom (distilling companies) were sustainable as valid examples of the legislative power to classify the subjects of taxation. ${ }^{117}$

A second problem is dealt with by other cases decided under the capital stock tax. Such cases affirm the power of the legislature to classify property for the purpose of applying different effective rates to the several classes without violating the uniformity clause of Art. IX, $\S 1$. For example, in Commonwealth v. Sharon Coal Company, ${ }^{118}$ appellant contended that the Act of 1891, then embodying the capital stock tax, was a violation of the uniformity clause in Art. IX, $\S 1$, because it discriminated between property owned by appellant and property owned by natural persons and other corporations. More specifically, the taxpayer contended that a tax of 5 mills was imposed on its capital stock, while stock of other corporations was taxed at only 3 mills, and other property of the same class was taxed at only 4 mills. ${ }^{119}$ In answering this argument, the court stated:

... [I]t has been settled that the legislature can, without making the revenue statute obnoxious to the constitution,

${ }^{117}$ As explained by the lower court, the defendant misconstrued the nature of the classification in the exemption, saying, $i d$. at 86:

In fact, the legislature did not make, and evidently did not intend to make a single class of all manufacturing corporations. The whole section must be taken together; and, thus considered, two classes are plainly visible; one, including corporations which manufacture liquor or gas, and the other, including all other manufacturing corporations. The latter class is severed from the much larger class, or group of classes formed by $\S 4$ of the act of 1879 [i.e., corporations generally, taxed by the Capital Stock Tax, except for insurance companies, banks and savings institutions], and is relieved from taxation; the former is left just where it was.

See Dupuy v. Johns, discussed under "personal property tax," supra note 70.

118164 Pa. 284, 30 Atl. 127, 128 (1894).

${ }^{119}$ Appellant had been assessed under the capital stock tax, then embodied in the Act of June 8, 1891, P.L. 229, §4, and contested the validity 
classify corporations for purposes of taxation; may sever a small class from a larger one; might subject one class to taxation, and leave other untaxed: Commonwealth v. [Germania] Brewing Co. . . . and the cases there cited. And in Commonwealth v. Delaware Division Canal Co. . . . it was decided that a different basis of taxation might be adopted on mortgages and loans held by individuals, and those held by corporations.

All properties, however, in the same class, must be taxed without discrimination in the rate of tax imposed. . . ${ }^{120}$

Similarly, in Commonwealth v. Hannis Distilling Company ${ }^{121}$ the system of singling out distilling companies for a ten mill capital stock tax rate was upheld under Art. IX, $\S 1$.

The next problem of interest concerns the extent, if any, to which the effective uniformity limitation determines the "method (or, standard) of valuation" which may be used. As stated above, the capital stock tax has been characterized as a property tax. More specifically, it has, in fact, been considered a part of an integral intangibles tax structure-being a tax upon intangible personal property in the hands of corporations. In addition, it has apparently been characterized as an ad valorem property tax. As a result of these characterizations several cases concerning the capital stock tax are useful in determining the relation of the uniformity limitation to "method of valuation."

As described above, a dual base-rate structure was used

of the assessment. The opinion did not make clear just what taxes were referred to as imposing three and four mill rates. The capital stock tax had a rate of 5 mills. The four mill rate probably referred to the personal property tax rate.

${ }^{120}$ Commonwealth v. Sharon Coal Co., supra note 118 at 304.

$121265 \mathrm{~Pa} .376,108 \mathrm{Atl} .822$ (1919). Also on classification of property for effective rates, see: Provident Life \& Trust Co. v. McCaughn, supra note 82 , discussed under personal property tax. Cf. Commonwealth v. National Oil Company, $157 \mathrm{~Pa} .516,27$ Atl. 374 (1893), followed in Commonwealth v. Mill Creek Coal Co., 157 Pa. 524, 27 Atl. 375 (1893). 
under the early form of the capital stock tax. For corporations making or declaring no dividend or profit, or making and declaring a profit of less than $6 \%$, the officers of the corporation were required to "appraise" the capital stock at its "actual value in cash" and pay a tax of three mills upon each dollar of such "actual" value. For those corporations making or declaring a profit of six per cent or more, the tax was computed at the rate of one half of one mill upon each dollar of the par value of the capital stock for each one per cent of dividends or profit made or declared. This method (as found in the Act of June 7, 1879, Public Law 112) was challenged in Commonwealth v. Brush Electric Light Company ${ }^{122}$ and held not to violate Art. IX, $\S 1$ of the constitution. Preceding its statement of the governing rule by an evaluation of the uniformity limitation itself, the court said:

Tax-laws have not yet been devised that will work out absolute equality of burden. If the constitution requires this, we have no tax-laws. . . . [W] here the measure of value and the rate are uniform and applicable to all the members of the given class, the incidental hardships and inequalities must be borne.

The object of the tax was the capital stock of corporations. Necessarily, then, some method had to be used to determine the value of such property, i.e., capital stock. Examining and evaluating the dual base-rate structure actually used, the court concluded:

The act looks properly at the earning capacity of the stock or the business it represents, as affording the best measure of its value. ${ }^{123}$

By best "measure" the court referred to the fact that earning 122145 Pa. 147, 22 Atl. 844 (1891).

${ }^{123}$ Id. at 154 , emphasis added. 
capacity of the corporation was used to determine whether the "value" of the stock was to be taken as "par value" or "appraised value." If dividends amounted to six per cent or more, then the base of the tax (i.e., the "value" of the capital stock) was par value. However, if dividends were below six per cent, then it was assumed that the capital stock was worth less than par value and provision was made for an appraisement of its value. For such capital stock the base of the tax (i.e., the "value" of capital stock) was its "actual cash value." It was not for the court to inquire whether some other method (for example, net earnings) might better have been used, "The standard [was] applied impartially." Consequently, there was no constitutional objection. ${ }^{124}$

What the case seems to say is that a class of property (capital stock) may be further classified, and the subclassification may be based upon the earning capacity of the corporation which such property represents. Thus, the court has again approved a classification of property based upon characteristics of the owner, rather than characteristics of the property itself. The uniformity limitation is satisfied if the same "standard of value" is used for the base as to all members of each subclass. In this particular instance, the base of

124 Compare the dictum in Commonwealth v. Sharon Coal Co., supra note 118 at 304-305, decided under the revised capital stock tax as embodied in the Act of June 8, 1891, P.L. 229, $\$ 4$, which established a single base of actual value and a single rate of five mills. The court said, at 305 :

All properties, however, in the same class, must be taxed without discrimination in the rate of tax imposed; and the rule for ascertaining the value of the property must be the same; the actual cash value of one capital stock in the same class cannot be ascertained from net earnings, another from profit, another from surplus and another from dividends, for each method will produce a different valuation, and result in inequality. But each may be taxed on the actual cash valuation from any relative evidence tending to establish the fact. [Emphasis added.]

See the companion case Commonwealth v. Edgerton Coal Co., 164 Pa. 284, 299-303, 30 Atl. 125, 129 (1894). 
"value" for one subclass was equivalent to "par value." For the other subclass, the base of "value" was equivalent to "actual cash value."

The validity of the above method of "self-assessment" was affirmed in Commonwealth v. Southern Pennsylvania Bus Company. ${ }^{125}$ By the time of that case, the base of the tax for all capital stock was the appraised "actual cash value." The method was challenged on two grounds. First, it was contended that the method was not a constitutional method of "assessment" of an ad valorem property tax; and, second, it was contended that such a method violated the uniformity clause in Art. IX, $\$ 1$. While conceding that "an assessment [was] necessary to create and define the liability of the taxpayer, inasmuch as the capital stock tax [was] a property tax, "126 the court ruled that, nevertheless, the assessment made by the taxpayer satisfied that requirement. The fact that the capital stock tax is an

. . ad valorem tax upon property, as distinguished from a franchise or privilege tax, does not affect the validity of this method of assessment. The cases relied upon [to the contrary] . . hold merely that some method of assessment must be provided for an ad valorem property tax; or if none is prescribed, that it must be followed. ${ }^{12}$

It was also held that the argument based on Art. IX, $\$ 1$ was devoid of merit. Uniformity of taxation did not require that the statute establish a single agency for the assessment of all property within a single class. It was sufficient if such property was assessed in the "same manner and on the same standards of valuation."128

To conclude the discussion of the capital stock taxation

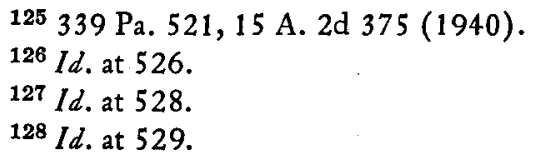


system, some comment should be made concerning the establishment in 1935 of a dual structure consisting of the capital stock tax and the franchise tax. By the Act of May 16, 1935, Public Law 292, §2, a franchise tax was imposed upon foreign corporations. The object of this new tax was the privilege of doing business in the state, and the base was the value of the franchise to do business as determined by the application of allocation factors to the actual value of the capital stock. Domestic corporations remained subject to the capital stock tax. Thus, while one might say in a general sense that all corporations are still subject to a "capital stock" tax, it should be noted that domestic corporations are reached by a "property tax" upon the "capital stock" as property, and foreign corporations are reached by a "privilege or franchise" tax upon the privilege of doing business-but the value of the privilege is established by reference to the value of the capital stock.

The reason for the change stems from the "jurisdiction to tax" limitation, derived from the due process clause in the fourteenth amendment to the federal Constitution. For the purpose of conforming to this limitation upon state taxes, Pennsylvania found it desirable to reach foreign corporations by a tax characterized as a "franchise" tax, instead of a "property" tax. The change had nothing to do with the uniformity in taxation limitation as derived from the state constitution. There was no intention to alter the basic tax structure.

One of the earliest Pennsylvania cases construing this change in facade was In re Arrott's Estate. ${ }^{129}$ The court took note of the basic "similarity" of the two taxes and ruled that for the purpose of applying the personal property tax, the exemption therefrom of shares of stock in corporations paying a tax upon their capital stock was intended to include shares

129322 Pa. 367, 185 Atl. 697 (1936). 
in foreign corporations paying the franchise tax, even though the latter tax ostensibly was not imposed on property (i.e., capital stock) but on a privilege. A "close identity" between the capital stock tax and the franchise tax was found. In 1939 in Commonwealth v. Columbia Gas E Electric Corporation the court held that the newly designed "method" of taxing foreign corporations did not discriminate in favor of domestic corporations. Different methods might be used where there was no substantial difference in tax burden. In addition, the court squarely ruled that the tax was not upon the property of foreign corporations. ${ }^{130}$

Thus, the cases concerning this structural split are apt illustrations of how different constitutional tax limitations (e.g., uniformity and equality in taxation; and limitations on the jurisdiction to tax) are often dependent for their application or meaning upon the characterization of a given tax as property or nonproperty. Moreover, the characterization of a given tax for the purposes of one limitation is not necessarily controlling for the other. These cases, along with other material in this monograph, should serve as warning of the danger in indiscriminately citing cases ruling upon the nature

$130336 \mathrm{~Pa} .209$, 8 Atl. 2d 404 (1939). This is probably the leading case on the franchise tax. See the subsequent cases: Commonwealth v. Ford Motor Co., 350 Pa. 236, 38 A. 2d 329 (1944); Commonwealth v. Quaker Oats Co., 350 Pa. 253, 38 A. 2d 825 (1944); Commonwealth v. Monessen Amusement Co., 352 Pa. 120, 42 A. 2d 158 (1945); Commonwealth v. American Gas Co., 352 Pa. 113, 42 A. 2d 161 (1945). In interpreting the franchise tax it was held that there was no intention to permit foreign corporations, in computing the value of their capital stock, to deduct the shares held in other corporations paying the capital stock tax, even though such a deduction was allowed for domestic corporations under the capital stock tax. It was held that this difference in "method" did not violate either the uniformity clause in Art. IX, $\$ 1$, or the equal protection clause of the fourteenth amendment to the federal Constitution. The Arrott case, supra note 129 , was distinguished on the ground that it was interpreting the exemption provisions embodied in the personal property tax. However, the "close identity" between the capital stock tax and the franchise tax was admitted. 
of a given tax without carefully considering the particular constitutional limitation which was in issue in the cases.

\section{(3) Personal property taxation: tangibles}

(a) "Hard" coal tax

An excellent illustration of the extent to which property may be classified in Pennsylvania for purposes of direct property taxation is found in the treatment accorded the hard coal tax, discontinued since 1931. ${ }^{131}$ The tax was imposed upon coal as property, and the amount of the tax was computed at a stated per cent of the value of coal when prepared for market. The first such tax, imposed in 1913, was held to violate the uniformity clause. Substantially the same tax was held constitutional in 1922. The two opinions are interesting illustrations of how different results may be reached as to similar facts under the identical uniformity provision.

By the Act of June 27, 1913, Public Law 639, entitled "An Act levying a tax on anthracite coal and providing for the collection and distribution of the same," every ton of anthracite coal prepared for market within the state was made subject to a state tax of two and one-half per cent of the value thereof. In Commonwealth v. Alden Coal Company, ${ }^{132}$ the court, in a 5-2 decision, held that the act created an arbitrary classification and consequently violated the uniformity clause in Art. IX, $\S 1$. The opinion was written by Justice Stewart, who noted that the act was challenged on one ground, namely, that it violated the uniformity clause inasmuch as it made "artificial and arbitrary distinction and discrimination between anthracite and bituminous coal, subjecting the former to tax . . . and not the latter." ${ }^{133}$ Refer-

$131 \mathrm{~Pa}$. Stat. Ann. tit. 72, $\$ 2501$.

$132251 \mathrm{~Pa} .134,96 \mathrm{Atl} .246$ (1915). Followed in the companion case of Commonwealth v. St. Clair Coal Co., 251 Pa. 159, 96 Atl. 254 (1915).

133 Id. at 137. 
ring to the uniformity clause, Justice Stewart stated: "It is constantly to be borne in mind that the right of classification is allowed in order to avoid or correct inequalities, never to create them." the court was convinced that the single basis offered to support the classification was "market price or value"-hard coal selling at from four to eight dollars per ton, while soft coal sold at from one to two dollars per ton. In the view of the majority: "The one reason expressed is so wholly inadequate as a basis of differentiation that we need not take time in discussing it." ${ }^{135}$ That being so, the act was held to violate the uniformity clause in Art. IX, $\$ 1$ of the constitution.

Evidently not convinced by the majority opinion in the Alden Coal Company case, the legislature passed an act in 1921 phrased in substantially identical words (except that the rate was lower). ${ }^{136}$ In Heisler v. Thomas Colliery Company, ${ }^{137}$ by a 5-2 vote, the 1921 act was held to have created a reasonable classification. Therefore, it did not violate the uniformity clause in Art. IX, $\$ 1$. The majority attempted to avoid an outright overruling of the Alden Coal case by stating that certain facts which justified the classification were not before the court in that case; consequently it could be "distinguished." However, the Heisler opinion leaves little of the Alden Coal case rationale undisturbed. The majority opinion viewed the argument against the validity of the tax as being in substance an argument that

... "coal is coal, and all must be taxed or none may be taxed"; to which we may answer "land is land," "ice is ice," and "gas is gas," but no one doubts the legislative power to

134 Id. at 140.

135 Id. at 141.

136 Act of May 11, 1921, P.L. 479, \$1.

137274 Pa. 448, 118 Atl. 394 (1922). 
differently tax seated and unseated land, natural ice and artificial ice, and natural gas and manufactured gas. ${ }^{138}$

The court concluded that it had before it findings "of undisputed facts, showing a wide difference in the character of these coals and the use to which they are put. . . ."139 Such facts were sufficient to support a legislative classification for purposes of taxation. ${ }^{\mathbf{1 4 0}}$

\section{(b) Other tangible personal property taxes}

Alcoholic Beverage Floor Tax. By the Act of Nov. 22, 1933 (Sp. Sess.), Public Law 5, the legislature attempted to impose a tax upon alcoholic beverages lodged or stored in the state between the date the act became effective and the date that the twenty-first amendment to the constitution of the United States should become effective. The tax was imposed at a rate of two dollars a gallon. In Commonwealth v. $A$. Overholt and Company, ${ }^{141}$ the court held that the tax violated the uniformity clause of Art. IX, $\S 1$, since it was a specific property tax, and the uniformity clause required that property, if taxed, be taxed ad valorem. ${ }^{142}$ The opinion demonstrated that as a consequence of the tax rate which the

138 Id. at 455.

139 Id. at 459-461.

140 Followed in Commonwealth v. Hudson Coal Co., $287 \mathrm{~Pa} .64,134$ Atl. 413 (1926) and Commonwealth v. Philadelphia \& Reading Coal \& Iron Co., $278 \mathrm{~Pa} .338,123$ Atl. 315 (1924).

$141331 \mathrm{~Pa} .182,200$ Atl. 849 (1938).

142 Compare Folcroft Borough v. General Outdoor Adv. Co., 72 D. \& C. (Pa.) 539, 42 Mun. 9 (1950), an inferior-court decision which stated that an ordinance imposing a tax of fifty cents per square foot of surface upon billboards was a violation of the uniformity clause, Art. IX, $\S 1$. The Court of Common Pleas first ruled that the tax was a property tax and therefore not within the power of the borough to impose. However, the court offered the further reason that in any case the tax would violate Art. IX, $\$ 1$, stating (at 543): "The principle of uniformity requires that property taxes be imposed on an ad valorem basis." Cited as authority were the cases discussed infro under "local severance taxes." 
tax would have imposed, the ratio of the tax to the value of the property in the hands of the several defendants would vary from $12 \mathrm{~T} / 2 \%$ on whiskey valued at sixteen dollars a gallon, to $500 \%$ on alcohol valued at forty cents a gallon. The court reasoned that when property in the form of a gallon of liquid was valued at forty cents and taxed at two dollars, five times its value, while a gallon of liquid valued at sixteen dollars was also taxed at two dollars, or one-eighth of its value, then the uniformity clause was violated as

... precisely as it would be violated if in imposing taxes on two properties of exactly the same value, the legislature imposed on one a tax of forty cents and on the other a tax of sixteen dollars. If the owner of land worth $\$ 400$ is taxed exactly the same as the owner of land worth $\$ 16,000$, the former's constitutional right to uniformity of taxation is breached.

The nature of the property involved was said to be immaterial:

The burden of a property tax rests upon the property on which it is imposed and if the same tax is laid on two properties of unequal supporting economic power, the burdens are unequal.... Uniformity of taxation means equality of burden. ${ }^{143}$

Unquestionably the Overholt case represents an outright condemnation of specific property taxes.

Local severance taxes. Several decisions concerning certain local "severance" taxes imposed in recent years are relevant to the problem of uniformity in taxation. In Dunkard Township School Tax Case, ${ }^{144}$ the court considered the validity of a tax imposed by the school district upon the "privilege, transaction or occupation of mining, processing and marketing

143 Commonwealth v. A. Overholt \& Co., supra note 141 at 191.

144359 Pa. 605, 608, 60 A. 2d 39 (1948). 
of bituminous coal mined by strip mining methods at the time of its severance from the realty within the boundaries" of the township. The rate was ten cents per ton of bituminous coal "so mined, processed and marketed from and within the township." The court upheld the tax as "an excise tax on the privilege or occupation of strip mining coal," consequently there was no "double taxation" since the tax on the coal in place was a property tax and the object was a reasonable class. ${ }^{145}$

In subsequent cases this type of local tax became involved with a problem wholly different from uniformity of taxation, but it continued to raise certain questions of uniformity as well. The statute authorizing school districts to levy taxes also prohibited the imposition of local taxes on personal property subject to a state tax or license fee. ${ }^{146}$ In Lawrence Township School District Tax Case, ${ }^{147}$ the court ruled that a tax similar to that involved in the Dunkard case was, in fact, a tax upon the property involved. Consequently, since the corporations paid the capital stock tax (among others) to the state and that tax was upon all property and assets of the companies, then such local taxes were prohibited. The Dunkard case was distinguished on the basis of the words found in the different tax laws.

Subsequently, as to a similar local tax the rationale of the Lawrence case was avoided in Hampton Township School District Tax Case $^{148}$ by giving effect to an additional phrase

$145 \mathrm{Id}$, at 610 . The court relied here on Dufour v. Maize, $358 \mathrm{~Pa} .309$, 56 A. 2 d 675 (1948), which, however, upheld an act more in the nature of a police regulation.

${ }^{146}$ Act of June 25, 1947, P.L. 1145.

147362 Pa. 377, 67 A. 2d 372 (1949); followed in Jamison Coal \& Coke Co. v. Unity Twp. Sch. Dist., 362 Pa. 389, 66 A. $2 d 759$ (1949)'. 148362 Pa. 395, 397, 67 A. 2d 376 (1949); controlling in Jones \& Laughlin Steel Corp. Appeal, 362 Pa. 400, 67 A. 2d 378 (1949). 
in the authorizing statute which prohibited any such local tax being imposed "on the privilege of employing such tangible property as is now or does hereafter become subject to a State tax." Thus, it was ruled that even if such a tax was a "privilege" tax it was still prohibited by the authorizing statute. Then on reargument of the Larorence Township case, the court took cognizance of the Hampton Township case rationale by simply stating that the "grounds" upon which it had made its decision in the original hearing did not have to be reviewed, since by the Hampton Township rationale the tax would be invalid even if it.were held to be an excise and not a property tax.

The preceding discussion has no intrinsic value for a study of the uniformity problem. However, there is considerable language in the opinions concerning "double taxation" which is, in fact, a reference to the statutory prohibition against "double taxation." In addition, the sequence of cases also gives perspective to an alternative ruling found in the Larorence Township case which is relevant to the uniformity limitation. The resolution reviewed in the Lawrence Town ship case provided that the township was to levy a tax "of Five Cents per net ton of 2,000 pounds on all coal mined from property located in Lawrence Township. . . ." That case concerned both a corporation which paid the state capital stock tax, referred to above, and an individual taxpayer engaged in the mining operation. After ruling on the statutory "double taxation" issue, which really would have affected the tax only as to the corporation, the court continued:

Since, in our opinion, the tax imposed by the Resolution under consideration is a property tax, and since according to a stipulation filed by the parties, the value of coal mined in Lawrence Township varies from $\$ 4.25$ per ton to $\$ 5.25$ per ton, it is also invalid as violating the constitutional re- 
quirement of uniformity in that, being a property tax, it is imposed on a quantity and not an ad valorem basis. . . . ${ }^{\mathbf{1 4 0}}$

The Overholt case concerning the state alcoholic beverage floor tax was cited as authority for this proposition.

\section{c. Transfer taxes}

By an Act of Dec. 27, 1951 (No. 467), Public Law 1742, the legislature imposed a realty transfer tax amounting to $1 \%$ of the "value" of real property or any interest therein transferred by "document." In Sablosky v. Messner ${ }^{150}$ the tax was brought under attack for several reasons, two of which concerned uniformity of taxation. The definition of the term "document," found in section 2 of the act, included a proviso which excluded "wills, mortgages, transfers between husband and wife, transfers between parent and child or the spouse of such child, and leases." The court rejected the contention that this exclusion violated either section 1 or 2 of Art. IX. ${ }^{151}$

\section{d. Corporation taxes}

The Pennsylvania corporate net income tax was first imposed in $1935 .^{152}$ Section 3 of the act imposing the tax provided:

Every corporation shall be subject to, and shall pay for the privilege of doing business in this Commonwealth, or having capital or property employed or used in this Commonwealth

${ }^{140}$ Lawrence Township School District Tax Case, supra note 147 at 383. Also see Dick Contracting Co. v. School Dist. of Hazel Twp., 362 Pa. 387, 65 A. 2d 381 (1949) for a similar statement and alternate reason for striking down a local tax upon strip mining equipment at the rate of $\$ 1.50$ per horsepower.

150372 Pa. 47, 92 A. $2 d 411$ (1952).

151 Id. at 57.

162 Act of May 16, 1935, P.L. 208. The discussion of the Individual Income Tax Act of 1935 is found infra, text to notes 181-190. 
- a State excise tax at the rate of six per centum per annum upon each dollar of net income of such corporation received by, and accruing to, such corporation during the calendar year. ... .

The tax hereby imposed shall be in addition to all taxes now imposed on any corporation under the provisions of existing laws.

In defining "corporation," section 2 of the act provided for the following exclusions:

The word "corporation" shall not include building and loan associations, banks, bank and trust companies, national banks, savings institutions, trust companies, title insurance companies, beneficial life and limited life insurance companies, mutual fire, mutual casualty and mutual life insurance companies, and foreign stock companies registered in this Commonwealth and therein engaged in doing business as life, fire, and casualty insurance companies, and surety companies.

The validity of the corporate net income tax was challenged on several grounds in Turco Paint $\mathcal{E}$ Varnish Com pany v. Kalodnor. ${ }^{153}$ The court did not consider the tax to be an "income" tax, but throughout its opinion dealt with the tax as " $a$ tax on the privilege of doing business measured by income accumulated within the state. . . ."154 First the court

153320 Pa. 421, 184 Atl. 37 (1936).

154 Id. at 429, 423. But see Roy Stone Transfer Corp. v. Messner, 377 Pa. 234, 103 A. 2d 700 (1954), for an example of the usual confusion on the point when the separate constitutional limitations of uniformity in taxation (state) and the prohibition against state taxation of interstate commerce (federal) get tangled. By the Act of Aug. 24, 1951, P.L. 345, the Pennsylvania legislature imposed the so-called "Corporation Income Tax Law." The purpose of the 1951 law was to avoid restrictions imposed by the "commerce clause," Art. I, $\$ 8$ of the federal Constitution. The act, in short, purported to tax the income, as property, of certain corporations which it could not reach with the corporate net income tax because of the commerce clause restriction. The attempt was unsuccessful. The court, in Roy Stone Transfer Corp. v. Messner, supra, held that the act violated the federal commerce clause. But of interest to this particular study of uniform- 
rejected the contention that the act imposed a "graduated" income tax in violation of Art. IX, $\S 1$ of the constitution. It pointed out that the rate $(6 \%)$ was the same for all corporations, and that the tax base (net income attributable to Pennsylvania) was also identical for all corporations. "Where different rates are legislatively imposed on varying amounts or quantities of the same tax base, then you have a graduated tax that lacks uniformity under our Constitution."155 Refer-

ity in taxation is the manner in which the court treated the corporate net income tax. After quoting the taxing provisions from both the Corporate Net Income Tax Act of 1935 and the 1951 Corporation Income Tax Law, the court made this statement, at 238:

The Corporate Net Income Tax Act of 1935 imposing a tax on the net income of a corporation based upon its tangible property in Pennsylvania and the wages paid to its employees in Pennsylvania, and that part of its gross receipts attributable to business carried on within Pennsylvania, was declared to be a property tax in spite of the declaration in the Act that it was an excise tax; and as such, its Constitutionality was sustained. . . .

The emphasis is by the court. The several cases then cited for authority that the Corporate Net Income Tax Act of 1935 was a "property tax" were all concerned with the individual income taxes imposed by certain cities and the state, all of which have received a very different treatment in Pennsylvania from the corporate net income tax. See text at notes 181-190, infra. Those cases had nothing to do with the corporate net income tax, and the cases actually decided under that tax (e.g., the 'Turco Paint \& Varnish case, supra) were not mentioned. The court, moreover, after reviewing the general principles controlling in the "state taxation of interstate commerce" field, then indicated that its decisions are "not harmonious" on the nature of the corporate net income tax, citing not only the cases dealing with the individual income taxes but also the corporate net income tax cases. The point was felt to be of some importance by both sides in the Roy Stone case, each certain that by labeling the 1951 Corporation Income Tax property or privilege the commerce clause limitation of the federal Constitution could either be avoided or used to invalidate the tax.

155 Turco Paint \& Varnish Co. v. Kalodner, supra note 153 at 426 . Also see Commonwealth v. Warner Bros. Theaters, 345 Pa. 270, 27 A. 2 d 62 (1942), although the principal issue in that case was a problem of incorporation by reference, and the graduated rate problem was dealt with only slightly. 
ence was made to the individual income tax case, Kelley $\mathrm{v}$. Kalodner. ${ }^{156}$

The taxpayer next contended that the act, in excluding from its operation building and loan associations, banks, etc., violated Art. IX, $\$ 2$ of the constitution, which prohibits the exemption of property from taxation. In addition, because of this exclusion of certain corporations, it was contended that the tax was not uniformly applied to the same class of taxable objects. Rejecting this argument based on the exclusion proviso, the court said: "An exemption contemplated by . . . Art. IX, $\S 2$, is an exemption from all taxation in any form."157 The legislature under Art. IX, $\$ 1$ has full power to classify corporations into subclasses, the only limitation being that such classifications cannot be arbitrary. ${ }^{158}$ The

$166320 \mathrm{~Pa} .180,181$ Atl. 598 (1935), discussed infra, note 181.

157 Turco Paint \& Varnish Co. v. Kaloduer, supra note 153 at 432-435, emphasis added.

${ }^{158}$ On the power of the legislature to classify corporations, see the following cases: Germania Life Ins. Co. v. Commonwealth, 85 Pa. 513 (1877), in which the court held that Art. IX, $\$ 1$ did not prevent the classification of insurance companies into foreign and domestic, domestic companies being subject to the capital stock tax (with a rate of $3 \%$ of the value of capital stock), and foreign companies subject to a $3 \%$ gross premiums tax; Commonwealth v. Girard Life Ins. Co., 305 Pa. 558, 158 Atl. 262 (1932), in which it was held that the uniformity clause in Art. IX, $\$ 1$ was not violated by the classification of life insurance companies into stock companies and mutual companies, the first being subject to a tax upon gross premiums and the second being exempted from such tax. Also see Commonwealth v. Lukens, $312 \mathrm{~Pa}$. 220, 167 Atl. 167 (1933), upholding the classification and exemption of "taxicabs, motor buses and motor omnibuses" from an act imposing a tax of 8 mills on the gross receipts of motor carriers.

Also see Kittanning Coal Co. v. Commonwealth, 79 Pa. 100 (1875), one of the first cases interpreting the uniformity clause incorporated in Art. IX, $\S 1$ of the 1874 constitution. That case concerned the validity of section 7 of an Act of April 24, 1874, P.L. 68, which provided that

... every company ... which possesses the corporate right or privilege to mine, or to purchase or sell coal, . . . shall pay . . . an additional tax upon its corporate franchises, created by or used within this 
classification at hand was held to be reasonable, and the use of the generic term "corporations" did not estop the legislature from narrowing this class by excluding certain types of associations.

\section{e. "Business" taxes}

Mercantile License Taxes. An historic form of taxation in Pennsylvania has been the "Mercantile License Tax," both on state and local levels. The tax in its narrowest form (e.g., the former state tax) has been limited to wholesalers and retailers. However, at times a more general business tax has been imposed (e.g., the tax recently imposed by the Philadelphia School District). A number of cases concerning problems of uniformity in taxation have arisen under these taxes.

In Williamsport v. Wenner, ${ }^{159}$ decided in 1896, an

Commonwealth at the rate of three cents upon each and every ton ... of coal so mined or purchased as aforesaid ... ; And provided further, That said tax shall not be payable more than once in respect to the same ton of coal.

In an appeal from the settlement of the tax against the Kittanning Coal Company the court held that the tax did not violate the uniformity clause of the new constitution. The court rejected the argument that the tax was upon coal as property, saying at 104:

... the tax ... is upon the corporate franchise of this company measured by its business, to wit: by the number of tons of coal mined or purchased and sold by it, and is not upon the coal itself. . . . The tax thus imposed upon the franchise is uniform, it being at the rate of three cents upon every gross ton mined or purchased and sold.

Referring to the power of the legislature to classify subjects of taxation (noting that "no change was made in the power to classify" that had existed before the 1874 constitution) the court stated, at 105:

The whole argument on this question of uniformity rests on this right of the citizen to be exempt from unequal burthens in supporting government. That he who has more to be protected by government, should pay more for its support, is a plain rule. [Emphasis supplied.]

${ }^{159} 172$ Pa. 173, 33 Atl. 544 (1896). 
ordinance imposing the more general form of business tax was challenged under the uniformity clause, Art. IX, $\$ 1$. The ordinance purported to impose "an annual license tax" on enumerated businesses, few, if any, being omitted. ${ }^{100}$ Section 2 of the ordinance set up the rate schedule. Eighteen classes of businesses were enumerated, with a different rate schedule provided for each class. The eighteenth class consisted of "merchants." This class was further subdivided into nine classes, according to the amount of annual gross sales, with each subclass paying a flat sum, or license fee. In fact, the schedule amounted to a very rough sort of proportional rate amounting to one tenth of one per cent. For each class except the ninth, the flat sum amounted to one tenth of one per cent of the maximum amount of gross sales in each class (the several classes for the most part were formed in $\$ 10,000$ brackets). The defendant in the Williamsport case was a merchant whose annual sales put him into class four, so that he was subject to a $\$ 20$ fee or tax. Defendant failed to pay, suit was brought to enforce payment, and the defense was offered that the ordinance violated the uniformity clause in Art. IX, $\S 1$ in that the classification of merchants according to amount of sales was arbitrary. In a per curiam opinion the Supreme Court affirmed and approved the opinion of the court below holding that the tax was constitutional. In its ruling the lower court had found it necessary to distinguish Banger's Appeal, ${ }^{161}$ in which a tax upon "occupations" as property had been held invalid, saying:

That was an attempt to classify the same occupation according to the earnings of individuals. It was very properly ruled that such a tax would be an income tax, measured by the earnings of the party, but even in that case the right to classify the tax upon property is, at least impliedly, recog-

$160 \mathrm{Id}$. at 174-176.

161 Supra note 35. 
nized. The tax in controversy is clearly not an income tax in any sense, but it is a tax of the defendant's property estimated by the volume of his annual sales. ${ }^{\mathbf{1 6 2}}$

Subsequently, in Commonwealth v. Clark, ${ }^{163}$ another per curiam opinion affirming and approving a lower-court opinion, the court considered the license tax imposed by the city of Titusville. The ordinance classified merchants into retailers and wholesalers, with each of the two subclasses being subject to the same sort of rate schedule as that used under the Williamsport ordinance. By a further classification in the ordinance it was provided that "contractors whose business and real estate agents whose sales exceed $\$ 1,000$ per annum, shall be classified and rated" in the same manner as merchants, and pay a fee according to that scale. The classifications of "merchants" into retailers and wholesalers, with different rate schedules applicable to each class, and the rate scales themselves were upheld as valid classifications under Art. IX, $\$ 1 .^{164}$ However, the validity of the exemptions found in the ordinance was another question. The lower court pointed out:

By section 3 [classifying merchants] no exemption is allowed to persons doing an annual business of less than $\$ 1,000$, and as contractors and real estate agents are otherwise classified with the persons making and effecting sales, to thus exempt a part of the class doing business of less than $\$ 1,000$, and impose a tax upon others belonging to the same class is clearly violative of sections 1 and 2 , article $9 . . . .^{165}$

162 Williamsport v. Wenner, supra note 159 at 181 . The lower court relied on similar holdings in the previous cases of Allentown v. Gross, 132 Pa. 319, 19 Atl. 269 (1890), and Hadtner v. Williamsport, 15 Wkly. Notes Cas. (Pa.) 138 (1883).

163195 Pa. 634, 46 Atl. 286 (1900).

164 1d. at 638-639.

${ }^{105} I d$. at 635 , emphasis added. 
Note that the invalidity was not based on a rationale which would void all classifications based solely on quantity.

These per curiam opinions were subsequently approved by the Supreme Court, with some limitations, in Knisely v. Cotterel. ${ }^{166}$ In that case the court considered the now abolished state mercantile license tax, imposed by Act of May 2, 1899, Public Law 184. The court upheld the classifications of retailers (who were to pay a tax of one mill on each dollar of gross receipts), wholesalers (one half of one mill) and dealers at any board of trade or any exchange (twenty five cents on each $\$ 1,000$ worth of goods sold). Taxpayer alleged that the tax was on property, and the classification invalid. The court answered that even assuming the tax was upon property it would not follow that the classifications were unconstitutional. "The purpose for which property is kept or used has long been a recognized and to some extent a favorite basis for distinction in taxation." on to hold that the tax was "upon the business of vending merchandise,"168 and it suggested that any indication to the contrary in the Allentown case was "not upon the decisions themselves, but upon language supposed to indicate the ratio decidendi." 189

The mercantile license taxes are still quite frequently used by the local tax units. For example, in the Philadelphia School District a "General Business Tax" is imposed by an Act of May 23, 1949, Public Law 1669, as amended. The term "business" is defined by $\S 1(2)$ of that act as follows:

Carrying on, or exercising for gain or profit within a school district of the first class, any trade, business, including financial business as hereinafter defined, profession, vocation, or

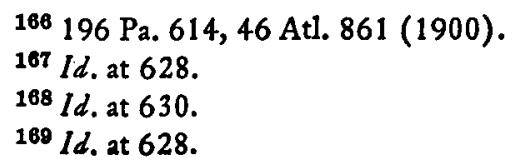


commercial activity, or making sales to persons within such school district of the first class. 'Business' shall not include the following: Any business conducted by a non-profit corporation or association organized for religious, charitable, or educational purposes. ... [ [Emphasis added.]

The validity of the exclusion was challenged in Board of Christian Education v. Philadelphia School District, ${ }^{170}$ decided by a Pennsylvania Superior Court, with allocatur being refused by the Supreme Court of Pennsylvania. The Superior Court asserted that the exclusion would: (1) violate Art. IX, §2, if considered an "exemption"; and (2) violate Art. IX, $\S 1$, as being an arbitrary classification if considered "an immunity conferred by legislative classification of the subject of taxation." However, a decision on the constitutionality of the section was avoided since it was construed not to include the business conducted by the Board. But some very interesting language was used by the Superior Court concerning both the force of Art. IX, $\$ 2$ and exemptions. Quoting both Art. IX, $\S \S 1$ and 2, the court said:

The two sections, read together, impose limitations upon the power of the legislature to exempt property from taxation. It is beyond legislative competence to exempt more than the property used as a place of public worship or for purely charitable activities. ${ }^{171}$

Consequently, the court asserted, "It follows that the expression 'Any business,' if intended by the legislature to exempt the Board's rental receipts from taxation, is void under the express limitation provided by Art. IX, $\$ 2$. . .172 Then the court made a significant extension of the language al-

$170171 \mathrm{~Pa}$. Super. 610, 91 A. 2d 372 (1952), allocatur refused by the Supreme Court of Pennsylvania, $171 \mathrm{~Pa}$. Super. xxv, $172 \mathrm{~Pa}$. Super. xxvi. $171 \mathrm{Id}$. at 616.

172 Ibid. 
ready used and spelled out its view concerning the scope of the second section of Art. IX, saying:

Nor can the nature of the tax enlarge the legislature's power or diminish the limitation under which it acts. Whether the tax in question be regarded as a tax upon property or an excise upon the privilege of doing business, the result is the same, the General Assembly can exempt only the property which is used as a purely public charity. . . Engagement in a business enterprise or commercial activities is not a primary function of a public charity, and any provision which relieves it from the payment of taxes imposed upon such enterprise or activities is an invalid exemption. ${ }^{173}$

However, the actual decision was limited to a problem of statutory construction in order to avoid the constitutional issue. Thus, in all probability, the language quoted may be relegated to the status of some rather peculiar dicta of a lower court.

Chain Store Tax. By an Act of June 5, 1937, Public Law 1656, the Pennsylvania legislature imposed a chain store and theater tax which contained the usual type of graduated rate schedule found in such taxes. The tax was immediately challenged in American Stores Company v. Boardman, ${ }^{174}$ in which the court held that the act imposed a graduated rate in violation of the uniformity clause, Art. IX, $\S 1$. As in the individual income tax case, Kelley v. Kalodner, ${ }^{175}$ the court condemned the classification as being one based solely upon a difference in quantity of precisely the same tax base; and it asserted that there was no basis for classification according to differences in control and operation. ${ }^{176}$ The court ruled that it was immaterial whether the tax was considered to be an

173 Id. at 617, emphasis added.

$174336 \mathrm{~Pa} .36,6$ A. 2d 174 (1939).

175 Infra, text at note 181 .

${ }^{176}$ American Stores Co. v. Boardman, supra note 174 at 40-41. 
excise or a property tax, both being subject to Art. IX, $\$ 1$, and stated:

This court has long held and it is now well established in this Commonwealth that a progressively graduated tax is lacking in uniformity and violates Art. IX, section 1 of our Constitution. From Banger's Appeal ... - the first instance such a tax came before this court for consideration after the adoption of our present Constitution-down to Butcher v. Philadelphia ...., we have consistently and unalterably held that a graded tax cannot be sustained. ${ }^{177}$

The Butcher case ${ }^{178}$ concerned a local wage tax, and query whether Banger's Appeal ${ }^{179}$ may be correctly cited for this proposition. However, the court also relied on In re Cope's Estate, ${ }^{180}$ which did declare a minimum exemption under the inheritance tax to be invalid for the same reason, i.e., classification based on quantity alone is not permissible.

\section{f. Individual income taxes}

By an Act of July 12, 1935, Public Law 970, the Pennsylvania Legislature enacted an individual net income tax, section 201 of which provided that

A tax is hereby ... imposed upon every resident taxpayer ... which tax shall be levied ... annually, with respect to his entire net income as herein defined. . . .

A like tax is hereby imposed, and shall be levied . . upon and with respect to the entire net income as herein defined, from all property owned and from every business, trade, occupation, or profession carried on in this Commonwealth by natural persons not residents of the Commonwealth.

177 Id. at 41.

${ }^{178}$ See note 186 , infra.

179 Supra note 35.

180 Infra text at notes 192 et seg. 
The act provided for a graduated rate, and certain minimum personal exemptions were allowed. Entire net income, as defined, included income from all sources, both earned and unearned. Thus, income derived from property, as well as income derived from an occupation or business, was to be taxed.

Immediately after the passage of the act, it was challenged in Kelley v. Kalodner ${ }^{181}$ and held to violate the uniformity clause in Art. IX, $\$ 1$ of the constitution. It was argued that while Art. IX, $\S \S 1$ and 2 applied undisputedly to property taxes, the provision had no application to nonproperty taxes; consequently the tax in question did not have to conform to the uniformity clause. Thus, the first inquiry of the court was in "ascertaining the nature of a graduated income tax." The court concluded that, insofar as the tax in question attempted to levy a tax on income "from real estate or from stocks, bonds and similar securities in the hands of the owner thereof, it [was] a property tax [upon the property from which the income was derived] and subject to the constitutional requirement of uniformity."182 The court limited its decision to precisely that part of the tax, stating: "We pass no opinion upon the question of whether a tax upon the income from trades, occupations or professions is a tax on property, although respectable judicial opinion has indicated that

181320 Pa. 180, 181 Atl. 598 (1935).

182 Id. at 187 . In reaching its conclusion as to the nature of an income tax, the court noted that the question was a controversial one, and that the courts of other jurisdictions were clearly split on the issue. Therefore, since there were no former decisions in Pennsylvania, the court felt

... at liberty to determine the question along normal, natural lines. In doing so we are inevitably impelled to the conclusion that an income tax is a property tax. This result seems particularly clear in so far as a tax upon the income from real and personal property is concerned ( $p$. 186). 
it is not. ${ }^{\prime 183} \mathrm{~A}$ determination as to the nature of a tax upon such income was unnecessary because the two parts of the act were not severable, and that reaching income from property was definitely a violation of the uniformity clause.

Having determined that the act was at least in part subject to the "uniformity prescribed by the Constitution," the court held that the minimum exemption provisions were a violation of that constitutional prescription. ${ }^{184}$ Secondly, the court held that the graduated rate feature also violated the uniformity clause in Art. IX, $\$ 1$, saying that it had "previously ruled that a tax which is imposed at different rates upon the same kind of property, solely on the basis of the quantity involved, offends the uniformity clause."185

The well-known Philadelphia "income" tax has resulted in several cases that clarify to some extent the nature of an income tax which might constitutionally be imposed in Pennsylvania. The City of Philadelphia enacted an ordinance in 1938 which imposed a tax on the earned income of individuals. The ordinance taxed salaries, rates, commissions, and other compensations of residents, and the net profits of business or other activities conducted by such residents. Nonresidents were subject to the tax on an apportioned part of their earned income derived from Philadelphia. The tax had a flat proportional rate of $11 / 2 \%$. Provisions stipulated that domestic servants, farm laborers, or farmers selling their own products were not within the meaning of "taxpayer" as used in the ordinance. A credit of $\$ 15$ was allowed for the prompt making and filing of returns. For all practical purposes, such a credit may be considered a form of minimum personal deduction. The constitutionality of the ordinance was immediately challenged in Butcher v. Philadelphia, in

183 Id. at 187.

184 Id. at 189.

${ }^{185}$ Ibid. See note 196, infra. 
which the court issued a very brief per curiam opinion, saying:

Under the severability clause in the income tax ordinance ... the majority, one Justice disagreeing, hold that the income tax ordinance is constitutional, with all exemptions stricken out, including the credit for making and filing the return....188

The tax was never enforced, and the ordinance was repealed on January $7,1939 .{ }^{187}$

The present Philadelphia income tax was first imposed by an ordinance enacted December 13, 1939. The features of the prior act which had been held to be objectionable were eliminated. The rate continued to be a flat rate of $11 / 2 \%$. In Dole v. Philadelphia, ${ }^{188}$ on the basis of the opinion below, the Supreme Court affirmed a decree dismissing the bill challenging the validity of the tax under Art. IX, $\S 1$ of the constitution. There was no discussion of the nature of an income tax on earned income; however, we may assume that these opinions implicitly establish that income generally may be validly classified as earned and unearned for purposes of taxation, and the subject of a tax may be limited to earned income. ${ }^{189}$ However, the Butcher case would seem to indicate that further classification of income according to who earns such income is forbidden, at least, for purposes of exemptions.

In Kelley v. Kalodner, the court gave no indication of the validity of a flat proportional rate levied upon income derived from property. However, action under the Philadelphia tax possibly throws some light on the problem. In 1949

186333 Pa. 497, 6 A. 2 d 298 (1938), emphasis added.

$187 \mathrm{Id}$. at 497 , a note by the reporter.

188337 Pa. 375, 11 A. 2d 163 (1940).

189 This classification was approved in Pennsylvania Co. for Ins. on Lives \& Granting Annuities v. Philadelphia, 346 Pa. 406, 31 A. 2d 137 (1943). 
the city of Philadelphia tried to extend its "wage and net profit tax" to cover income from all sources, thus converting the tax into a general income tax. The validity of the amendment was challenged in Murray v. Philadelphia. ${ }^{100}$ The basic issue was one of statutory authority. The court held that the amendment was not authorized by the enabling act; thus no constitutional issue had to be faced. However, the court did comment by way of dictum upon the constitutional validity of the amendment insofar as it would have reached rent received from real estate. It was necessary for the court to hold that the tax upon income from property was upon the property itself (the Kelley case being cited as authority for the proposition) in order to reach its decision under the statutory issue. However, the court went on to say, assuming that such a tax (i.e., one reaching income derived from property) was authorized by the statute, it would nevertheless violate the uniformity clause in Art. IX, $\S 1$ of the constitution. The basis of this conclusion was that such a tax would create an inequality of burden among land owners, some of whom rented and some of whom did not. In addition it was said that the classification of realty owners into two classes (those who occupy their dwelling houses and those who let them to tenants) would not be such a reasonable classification as would avoid an unconstitutional inequality of tax burden.

\section{g. Inheritance tax}

In 1897 the Pennsylvania legislature attempted to impose a "Direct Inheritance Law,"

190364 Pa. 157, 71 A. 2d 280 (1950).

191 Act of May 12, 1897, P.L. 56. Pennsylvania was one of the first states to levy an inheritance tax. By an act of April 7, 1826, it was provided that all real and personal estates passing to other than "direct" heirs was "made subject to a tax or duty of" $\$ 2.50$ on every $\$ 100$ of the clear value of such estates. Subsequent amendments were made, and in 1887 the prior laws were then codified without substantial change, except that estates 
that "all personal property . . . which shall pass by will, or by the intestate law of this State . . . shall be . . subject to a tax of two dollars on every one hundred dollars of the clear value of such personal property. . . ." A proviso to section 1 of the act stipulated that "personal property to the amount of five thousand dollars shall be exempt from the payment of this tax in all estates. . . "This act was challenged in In re Cope's Estate, ${ }^{192}$ the court holding that it violated the uniformity clause in Art. IX, $\$ 1$. First, the tax was characterized as a tax upon personal property. ${ }^{193}$ Then the court ruled that the exemption proviso in the act violated the uniformity clause. The fair implication of the decision is not that exemptions would never be permitted, but that the exemption made, namely, a classification based on quantity alone, was arbitrary. The court said:

These limitations on the power of the legislature . . . are of under $\$ 250$ in value were exempted. In 1917 a direct inheritance tax was imposed, and two years later in 1919 the two acts were repealed and the present tax was imposed by Act of June 20, 1919, P.L. 521, reaching the property going to both collateral and direct heirs. The minimum exemption of $\$ 250$ was not carried over for collateral heirs; however, a minimum exemption was added for widows. Section 1 of the 1919 act is framed in terms of being "upon the transfer of" property.

192191 Pa. 1, 43 Atl. 79 (1899).

${ }^{193}$ Id. at $19-20$. However, in characterizing the tax a property tax the court was responding to the contention that the measure was not a "tax" law but an act simply regulating the disposition of property. It might be pointed out that the early collateral act which was framed in similar words was held, in In re Finnen's Estate, 196 Pa. 72, 46 Atl. 269 (1900), to be a tax upon the privilege of succession. The issue in the Finnen case did not, however, concern uniformity. Also see Commonwealth v. Randall, $225 \mathrm{~Pa}$. 197, 73 Atl. 1109 (1909), in which an amendment (Act of April 22, 1905, P.L. 258) excluding "stepchildren" from the definition of collateral heirs under the collateral tax was upheld. The court, in a brief opinion, without referring to the nature of the tax, and simply assuming it was subject to Art. IX, §1, said at 198: "The power of the legislature to classify subjects for purposes of taxation has long ceased to be a matter of controversy." The classification in question was held to be reasonable. 
plainly intended to secure, as far as possible, uniformity and relative equality of taxation, by prohibiting generally the exemption of a certain part of any recognized class of property, and subjecting the residue to a tax that should be borne uniformly by the entire class. . . .

The court concluded that the proviso attempted to exempt a part of "the same class of property," the reason being:

A pretended classification that is based solely on a difference in quantity of precisely the same kind of property is necessarily unjust, arbitrary and illegal. ${ }^{104}$

In stating this rule the court used a hypothetical in which it said that graduated rates upon property illustrated the forbidden type of classification. ${ }^{195}$ It was this dictum which was later quoted in striking down the graduated rate under the individual income tax. ${ }^{106}$

\section{h. A summary of the meaning of the uniformity limi- tation}

The preceding tax-by-tax analysis affords some basis for a summary statement of the meaning of the general effective uniformity limitation. It should be clear that the Pennsylvania court has made no substantial distinction between "property" and "nonproperty" taxes for the purpose of determining the applicability of the uniformity clause in Art. IX, $\S 1$ of the con-

104 In re Cope's Estate, supra note 192 at 22, emphasis added.

195 The court stated, id. at 22:

For example, a division of personal property into three classes with the view of imposing a different tax rate on each,-class 1 , consisting of personal property exceeding in value of the sum of one hundred thousand dollars ...., class 2, consisting of personal property exceeding in value twenty thousand dollars ... and not exceeding one hundred thousand dollars ...., and class 3, consisting of personal property not exceeding in value twenty thousand dollars ...- -would be so manifestly arbitrary and illegal that no one would attempt to justify it.

${ }^{196}$ Supra, text at note 185. 
stitution. All taxes are limited by that clause. Any doubt concerning this proposition was dispelled in the chain store tax case, ${ }^{197}$ in which the court held that the graduated rate schedule embodied in that tax violated the above provision.

For comparative purposes it will be helpful to discuss separately the particular rules of uniformity applicable to nonproperty and property taxes, respectively. It is apparent that substantially the same particular rules which are found in other states govern nonproperty taxes. Thus, the objects of such taxes, and exemptions therefrom, need only be reasonable classes. Such objects may be further classified for the application of different rates to the different classes. However, a restrictive interpretation is found concerning progressively graduate rates. Such a classification is held to be by nature arbitrary. Classifications based on quantity alone are said to be unreasonable. Thus, the graduated rate in the chain store tax was held invalid. ${ }^{108}$

\section{(1) Property taxation}

The importance of the Pennsylvania study stems from the interesting results which were found in developing the meaning of the uniformity limitation when applied to property taxes. First, to what degree, if any, does the uniformity limitation govern the method of taxation? The Supreme Court of Pennsylvania has seldom had occasion to consider the question whether property might be taxed by other than the ad valorem method. In the one case in which the court was squarely faced with the issue, it held that the state alcoholic beverage floor tax was a specific property tax and therefore a violation of the uniformity clause in Art. IX, $\S 1 .{ }^{199} \mathrm{How}$ -

197 American Stores Co. v. Boardman, supra note 174.

198 But see Commonwealth v. McCarthy, $332 \mathrm{~Pa} .465,3$ A. 2d 267 (1938).

${ }^{199}$ Commonwealth v. A. Overholt \& Co., supra note 141. 
ever, it should be pointed out that the tax was an almost undisguised regulatory measure and insignificant as a revenue producer. It was of doubtful validity even as a regulatory measure, although the court preferred to deal with it as a tax. A lower court has also ruled on the precise issue, holding that a specific property tax was unconstitutional. ${ }^{200}$ The opinion was not appealed. In addition, there is the dictum of the Supreme Court in the local severance tax cases ${ }^{201}$ which agrees with the rationale of the Floor Tax case. But this must be contrasted with the language in the Southern Pennsylvania Bus Company case ${ }^{202}$ which concerned the capital stock tax. As a result of this meager precedent one must conclude that in Pennsylvania property must be taxed ad valorem in order for the tax to be "uniform upon the same class." However, that conclusion must be read in light of the fact that the court has expressly approved the use of "nominal" value as the base for certain taxes characterized as property taxes. ${ }^{203}$ In addition, the description of the corporate loans tax in Commonrwealth v. Lehigh Valley Railroad Company ${ }^{204}$ is of interest because it clearly described that tax as a specific rather than an ad valorem tax. The statement in that case has not been considered in subsequent cases.

The second question concerns the degree of uniformity required of the object of property taxes. Is there a rule of universality? Some of the most conflicting, or at least apparently conflicting, statements on the meaning of the effective uniformity limitation are found in those cases concerning this particular problem of uniformity in taxation. It is believed that the only case which cannot be reconciled with the

200 Folcroft Borough v. General Outdoor Adv. Co., supra note 142.

201 Supra, text at notes 144-149.

202 Supra note 125.

${ }^{203}$ For example, Commonwealth v. Delaware Division Canal Co., supra note 87 , concerning the corporate loan tax.

204 Supra note 105. 
other decisions on the problem is the early case In re Fox's Appeal, ${ }^{205}$ which dealt with the personal property tax. Incidentally, this was the first case involving the problem. It is suggested that a coherent pattern of decisions can be established which refutes the rather sweeping language condemning the "exemption" of property. The numerous cases on the problem may be synthesized as follows. There is no requirement of universality. Only a "class" of property need be selected for taxation. And, since absolute uniformity is not required of the effective rates applicable to that property actually taxed, there may be separate property taxes with different effective rates, each tax having a different class of property as its object. In effect, then, property may be "exempted" from a particular tax by the simple process of "omission," that is, the failure to select such property.

However, once a "class" of property is selected as the object of a particular property tax, an additional problem arises. It is true that the opinions contain language which suggests that the exemption of property, other than the kind designated as exemptible by Art. IX, $\S 1$, is prohibited by Art. IX, $\$ 2$. However, the court has, in fact, considered the express prohibition against exemption found in Art. IX, $\S 2$ and the uniformity clause in Art. IX, $\S 1$ as laws in pari materia, so to speak, with the result that once a "class" of property has been "selected" as the object of a tax, the legislature is subject to only one limitation in "exempting" reasonable "subclasses" of that object from the tax. That single limitation provides that if the "class" of property "selected" for the tax is considered a minimum class, the legislature may "exempt" a part of that "class" only if the part is one of the kinds of property designated as exemptible by Art. IX, $\S 1$. This rather abstract generalization is made more meaningful by answering the following important question. Just what

205 Supra note 49. 
minimum classes of property has the court established for purposes of uniformity in the object of property taxes? The tax-by-tax analysis indicates that only real property is considered a minimum class. Thus, once real property is selected as the object of a property tax, none may be exempted therefrom unless it is a kind of property enumerated in Art. IX, $\S 1$. An example would be public property used for public purposes, or, real property owned, occupied, and used by a post of honorably discharged marines. It should be pointed out, by way of contrast, that real property may be subclassified for the application of different effective rates to the different classes.

Summarizing, Art. IX, §2, which prohibits the exemption of property other than that enumerated in Art. IX, $\S 1$, is actually effective only as a restriction upon the taxation of real property. There is no set minimum class insofar as the taxation of tangible and intangible personal property is concerned. Various classifications of personal property have been allowed, both for purposes of selection and exemption. For example, hard coal has been approved as a valid class of property for the object of a special tax. Exemptions from the several "intangibles" taxes have been approved, and, incidentally, such classifications were based upon characteristics of the owner of the property. The only limitation on classification of property, other than real property, for the purpose of exemption is that such classes be reasonable.

Third, the tax-by-tax analysis shows that property may be classified for the purpose of applying different effective rates to the several classes. For example, the court has expressly sanctioned the classification of real property into urban and rural for the application of different rates to each class. ${ }^{208}$ But a subclassification of realty consisting of forest lands was

206 Supra, text at notes 13-31. 
condemned as arbitrary. ${ }^{207}$ Another restrictive interpretation was found in the income tax case, Kelley v. Kalodner, ${ }^{208}$ which held that graduated rates were arbitrary classifications. Evidently, for the same reason minimum exemptions are likely to be closely examined because they are classifications based solely on quantity. ${ }^{209}$ The final point to be noted is that the court has approved another method of varying the effective rates applicable to property; namely, it approved the use of different standards of valuation for different classes of property. ${ }^{210}$

In conclusion, the only restrictive particular rules contained in the effective uniformity limitation for property taxation are: (1) property must be taxed ad valorem; (2) classification may not be based solely on differences in quantity of precisely the same thing; thus graduated rates and minimum exemptions are prohibited; and (3) while real property may be classified for the application of different effective rates, it may not be classified for exemptions, either total or partial.

\section{Virginia}

\section{a. The provisions; historical note}

Virginia, one of the original states, has had six constitutions, dated respectively $1776,1830,1850,1864,1870$, and the present constitution of 1902 . In the first two constitutions (1776 and 1830) there were no provisions dealing expressly with uniformity in taxation. The first uniformity clause made its appearance in the constitution of 1850 , Art. IV, $\$ 22$ of which provided:

207 Ibid.

208 Supra note 181.

209 See In re Cope's Estate, supra note 192.

210 For example, Commonwealth v. Delaware Division Canal Co., supra note 86; Commonwealth v. Brush Electric Co., supra note 122. 
Taxation shall be equal and uniform throughout the Commonwealth, and all property other than slaves shall be taxed in proportion to its value, which shall be ascertained in such manner as may be prescribed by law.

Article IV, $\$ 25$ of the 1850 constitution also provided that the legislature might "levy a tax on incomes, salaries, and licenses; but no tax shall be levied on property from which any income so taxed is derived, or on the capital invested in the trade or business in respect to which the license so taxed is issued." In the succeeding constitution of 1864 both the above uniformity clause and Art. IV, $\$ 25$ of the 1850 constitution were incorporated substantially without change into a single provision, Art. IV, $\S 23$. The next constitution, dated 1870 , retained this "equal and uniform" type uniformity clause, numbering it Art. X, $\S 1$. A new clause was added providing that "No one species of property, from which a tax may be collected, shall be taxed higher than any other species of property of equal value." The provision as to incomes, etc., was carried over into Art. X, $\S 4$ with some additional details. Another new provision was added, Art. X, §3, which provided that the legislature "might" exempt certain classes of property.

In the present constitution of 1902 a different type of uniformity clause was introduced in Art. XIII, $\$ 168$, which reads:

All property, except as hereinafter provided, shall be taxed; all taxes, whether State, local or municipal, shall be uniform upon the same class of subjects within the territorial limits of the authority levying the tax, and shall be levied and collected under general law. ...

The new uniformity clause, as the quotation indicates, is accompanied by a clause which on its face requires universality. The provision in the prior constitutions concerning 
specific types of taxes has been carried over, and Art. XIII, $\$ 170$ now reads:

The General Assembly may levy a tax on incomes in excess of six hundred dollars per annum; may levy a license tax upon any business which cannot be reached by the ad valorem system; and may impose State franchise taxes, and imposing a franchise tax may, in its discretion, make the same in lieu of taxes upon other property, in whole or in part, of a transportation, industrial, or commercial corporation. . . .

Article XIII, \$171, amended in 1928, provides: “No State property tax for State purposes shall be levied on real estate or tangible personal property, except the rolling stock of public service corporations. . . ." Article XIII, $\$ 183$ provides: "Unless otherwise provided in this Constitution, the following property and no other shall be exempt from taxation, State and local, including inheritance taxes. ..." There follows a lengthy enumeration of exemptible property. Special exemptions are provided for in Art. XIII, $\$ 189$. Article XIII, $\S 169$, as amended in 1928, provides: "Except as hereafter provided, all assessments of real estate and tangible personal property shall be at their fair market value, to be ascertained as prescribed by law. . . ." Section 169 also deals with a special problem and makes an exception to uniformity required by Section 170 in that it provides:

. . . The General assembly may allow a lower rate of taxation to be imposed for a period of years by a city or town upon land added to its corporate limits, than is imposed on similar property within its limits at the time such land is added.

1 The omitted part of section 170 provides:

Whenever a franchise tax shall be imposed upon a corporation doing business, in this State, or whenever all the capital, however invested, of a corporation chartered under the laws of the State, shall be taxed, the shares of stock issued by any such corporation shall not be further taxed. ... 


\section{b. Meaning of the uniformity limitation}

There has been very little judicial development concerning the meaning of the present Virginia uniformity limitation. In part, this would seem to be a result of the rather detailed constitutional structure. As for nonproperty taxes, it is clear that only a uniformity within classes is required. ${ }^{2}$ Apparently, this limitation permits progressively graduated rates. ${ }^{3}$ The express words of section 170 of the constitution have foreclosed any controversy on the nature and validity of an income tax. However, under the prior uniformity provisions the court held that an inheritance tax was a nonproperty tax. ${ }^{4}$

As for property taxation, the words of the constitution (Art. XIII, $\S 168$ and $\$ 183$ ) leave little doubt that there is a requirement of universality. ${ }^{5}$ This is complicated somewhat by the system of separating classes of property for either local or state taxation, as provided for in section 168. In any case, it would seem that all property not enumerated as exemptible in section 183 must be taxed-either by state or local authorities. The express ad valorem requirement in the prior constitutions has been deleted, and there has been no court decision which would indicate that specific taxes may not be levied upon property.

While Virginia at one time had a comprehensive classified

${ }^{2}$ For example, Pocahontas Consol. Collieries Co. v. Commonwealth, 113 Va. 108, 73 S.E. 446 (1912).

${ }^{8}$ See City of Fredericksburg v. Sanitary Grocery Co., 168 Va. 57, 190 S.E. 318 (1937), upholding the classification embodied in a local chain store tax.

${ }^{4}$ See Eyre v. Jacob, 14 Gratt. (55 Va.) 422, 73 Am. Dec. 367 (1858). Also see Pocahontas Consol. Collieries Co. v. Commonwealth, supra note 2, on the nature of a recordation tax.

${ }^{5}$ For example, Woolfolk v. Driver, 186 Va. 174, 41 S.E. 2d 463 (1947). Cf. Atlantic \& Danville Ry. Co. v. Lyons, 101 Va. 1, 42 S.E. 932 (1902). Under the prior uniformity limitations the court held that there was no rule of universality-exemptions were permissible. Williamson v. Massey, 33 Gratt. (74 Va.) 237 (1880). 
property $\operatorname{tax},{ }^{6}$ at the present time all tangibles are taxed by the local rates without classification. The comprehensive system was apparently never challenged under the uniformity clause of the constitution. However, at the present time intangibles (the only property taxable by the state) are classified for the application of different percentage rates, and the court has said that there can be no question concerning the power of the state to tax different classes of intangible property at different rates. ${ }^{7}$

H. ANALYSES OF STATES WITH TYPE VIII CLAUSES

1. Arizona

a. The provisions; historical note

The basic uniformity clause of the Arizona Constitution of 1912 is found in Art. IX, $\$ 1$, which reads:

. . All taxes shall be uniform upon the same class of property within the territorial limits of the authority levying the tax. ...

Accompanying this provision is Art. IX, §2, as amended, which contains an enumeration of both mandatory and permissive exemptions of designated classes of property, and concludes with this limitation:

All property in the state not exempt under the laws of the United States or under this constitution, or exempt by law under the provisions of this section shall be subject to taxation to be ascertained as provided by law.

'Leland, The Classified Property Tax in the United States, 228 et seq. (1928).

${ }^{7}$ See City of Richmond v. Drewry-Hughes Co., 122 Va. 178, 90 S.E. 635 (1918). 
Article IX, $\$ 12$, which refers to types of taxes which the legislature may impose, provides:

The law-making power shall have authority to provide for the levy and collection of license, franchise, gross revenue, excise, income, collateral and direct inheritance, legacy, and succession taxes, also graduated income taxes, graduated collateral and direct inheritance taxes, graduated legacy and succession taxes, stamp, registration, production, or other specific taxes.

Rounding out the uniformity structure of the Arizona Constitution is a provision added in 1940, Art. IX, $\$ 11, \mathbb{2}$, which provides in detail for a "license tax" to be "imposed on vehicles," "which license tax shall be in lieu of all ad valorem property taxes on any vehicle subject to such license tax." In fact, the constitutional provision itself imposes the tax.

\section{b. Meaning of the uniformity limitation}

As expected, the uniformity clause in Art. IX, $\$ 1$ is limited in its application to property taxation. ${ }^{1}$ Nonproperty taxes ${ }^{2}$ need only be uniform within classes. ${ }^{3}$ There has been no occasion for the Arizona court to approve or disapprove the principle of graduated rates. Nor has there been any occasion

${ }^{1}$ See, for example, Stults Eagle Drug Co. v. Luke, 48 Ariz. 467, 475, 62 P. 2d 1126 (1936).

2 In Arizona nonproperty taxes have been generally grouped under the heading of "excise" taxes. See, for example, the Stults Eagle Drug Co. case, supra note 1 at 475 , to the effect that excise has come to include every form of taxation which is not a burden laid directly on persons or property.

${ }^{8}$ For example: Gila Meat Company v. State, 35 Ariz. 194, 276 Pac. 1 (1929) (finding an arbitrary classification based on location of business); City of Phoenix v. State ex rel. Conway, 53 Ariz. 28, 85 P. 2d 56 (1938); State v. Williams, 53 Ariz. 319, 89 P. 2d 34 (1939) (finding an arbitrary classification based on location of business). In White v. Moore, 46 Ariz. 48, 46 P. 2d 1077 (1935) the court upheld the Arizona business and occupation (gross income) tax and the classifications thereunder based on source of income. 
to pass on the nature of the graduated net income tax which has been imposed, since such a tax is expressly sanctioned in Art. IX, §12. Indeed, the extensive nature of section 12, Art. IX, leaves little to be decided concerning the validity of many of the more commonly used taxes. However, the court has held that a graduated "probate fee" was a tax upon property and a violation of the property-tax uniformity limitation.

There is no requirement of absolute uniformity governing the effective rates applicable to that property which is taxed. Consequently, as the court has stated in a leading case,

.. . there is no constitutional prohibition against classifying property for taxation purposes into tangibles and intangibles and levying a different rate upon tangibles than upon intangibles. Nor is there any against subdividing intangibles into classes . . . and imposing a different rate on each class, provided the same tax is imposed on all members of the class and the classification is reasonable and not arbitrary. ${ }^{5}$

However, the several attempts made by the Arizona legislature to utilize this power of classification have, as often as not, met with adverse results at the hands of the Arizona Supreme Court. In fact, few attempts have been made to utilize this power fully. When minor classifications have been made, they have been upheld. For example, the classification and separate taxation of the property belonging to private car line companies has been held valid. ${ }^{6}$ In fact, however, there was an ultimate equality in tax burden between the property of this class and all other property. ${ }^{7}$

4 Berryman v. Bowers, 31 Ariz. 56, 250 Pac. 361 (1926).

5 State Tax Comm. v. Shattuck, 44 Ariz. 379, 394, 38 P. 2d 631 (1934).

6 Pacific Fruit Express Co. v. City of Yuma, 32 Ariz. 601, 261 Pac. 49 (1927); also see People's Finance \& Thrift Co. v. Pima County, 44 Ariz. 440, 38 P. 2 d 643 (1934); Brophy v. Powell, 58 Ariz. 543, 121 P. 2 d 647 (1942).

7 Pacific Fruit Express Co. v. City of Yuma, supra note 6, at 605. 
Indeed, only two attempts have been made by the legislature to establish classifications which would result in the classified property being subjected to rates substantially different from the rate applicable to all other property. In State Tax Commission v. Shattuck ${ }^{8}$ the court struck down an attempt to impose an intangibles property tax. The decision was based on the proposition that there was a denial of due process because of a lack of notice and hearing in determining the value of the intangibles. However, in making its decision, the court, while acknowledging the power of the legislature to classify intangibles, nevertheless considered most of the classifications embodied in the act to be arbitrary.

In Powell v. Gleason, a statute providing that motor vehicles were to constitute a single class of property subject to a special ad valorem tax, the same to be in lieu of all other property taxes, encountered similar difficulties. While the court said that such vehicles could constitute a valid class of property, ${ }^{10}$ the act was held invalid because its parts were not severable and certain classifications resulted in exemptions or partial exemptions contrary to Art. IX, §2. Furthermore, in Berryman v. Bowers ${ }^{11}$ the court held that a graduated probate "fee" was an ad valorem tax on property, and the graduated rate was held to be a violation of "uniformity."

While property may be classified for purposes of applying different rates, a stricter limitation governs exemptions because of Art. IX, $\$ 2$. The court has held that Art. IX, $\$ 2$ embodies a rule of universality, and that this includes a prohibition of "partial" exemptions. ${ }^{12}$ Thus, in Poroell v.

8 Supra note 5.

9 50 Ariz. 542, 74 P. 2 d 47 (1937).

${ }^{10} \mathrm{Id}$. at 551-552.

11 Supra note 4.

12 Powell v. Gleason, supra note 9; Miners \& Merchants Bank v. Board of Sup'rs of Cochise County, 55 Ariz. 357, 101 P. 2d 461 (1940); Weller v. City of Phoenix, 39 Ariz. 148, 4 P. 2d 665 (1931). But see Maricopa 
Gleason, a statutory provision which would have taxed motor vehicles under the special motor vehicle property tax proportionally for that part of the year for which such vehicles were registered was construed to be an exemption contrary to Art. IX, §2.

However, the restriction in Art. IX, $\$ 2$ does not prevent an "in lieu" property tax; that is, a tax upon a class of property may be in lieu of all other property taxes. ${ }^{13}$ This does not permit the substitution of an indirect tax by way of an in lieu excise tax. Such a substitution has been held to violate the exemption restriction. ${ }^{14}$

\section{Kentucky}

\section{a. The provisions; historical note}

In the first three constitutions of Kentucky, dated 1792, 1799 , and 1850 , respectively, there were no provisions dealing expressly with uniformity of taxation. The uniformity structure of the present 1891 constitution was altered by the addition of a significant phrase to the uniformity clause in 1915. The uniformity clause is found in section 171, and reads as follows, with the phrase added in 1915 italicized:

County v. Trustees Arizona Lodge No. 2, F. \& A. M., 52 Ariz. 329, 80 P. 2d 955 (1938), in which the court was concerned with the fact that the legislature had failed to provide means for the assessment of intangibles under the general property tax, although the statute in question provided that "all" property was to be subject to the tax. The court, while saying that Art. IX, $\$ 2$ requires such intangibles to be taxed, did not find a violation of Art. IX, §2. The issue was really limited to one of statutory construction, and no question was raised as to whether this failure effectively to tax intangibles would invalidate the tax upon the remainder of property.

${ }^{13}$ Pacific Fruit Express Co. v. City of Yuma, supra note 6; Powell v. Gleason, supra note 9.

${ }^{14}$ Miners \& Merchants Bank v. Board of Sup'rs of Cochise County, supro note 12. 
Taxes shall be levied and collected for public purposes only and shall be uniform upon all property of the same class subject to taxation within the territorial limits of the authority levying the tax. ...

A second paragraph of section 171 is of interest. It reads:

The General Assembly shall have power to divide property into classes and to determine what class or classes of property shall be subject to local taxation. . . .

Three other provisions (sections 3, 170, and 174) deal with the uniformity required of the selective and exclusionary processes. Section 174 contains an express rule of universality, as well as certain other pertinent clauses:

All property, whether owned by natural persons or corporations, shall be taxed in proportion to its value, unless exempted by this Constitution; and all corporate property shall pay the same rate of taxation paid by individual property. Nothing in this Constitution shall be construed to prevent the General Assembly from providing for taxation based on income, licenses or franchises.

Section 3 provides:

... no property shall be exempt from taxation except as provided in this Constitution. . . .

Section 170, after listing certain mandatory and permissible exemptions of designated classes of property, provides:

... all laws exempting or commuting property from taxation other than the property above mentioned shall be void.

Section 181 should also be considered. It states that the legislature may provide for the "payment of license fees on franchises, stock used for breeding purposes, the various trades, occupations and professions, or a special or excise tax. 
..." A proviso added to section 181 in 1902 reads as follows:

And the General Assembly may, by general laws only, authorize cities or towns of any class to provide for taxation for municipal purposes on personal property, tangible and intangible, based on income, licenses or franchises, in lieu of an ad valorem tax thereon. . . .

There are certain exceptions for cities of the first class. Finally, section 172 requires that "All property, not exempted from taxation by this Constitution, shall be assessed for taxation at its fair cash value. . . ." The Kentucky Constitution does not lack quantity, at least, in its provisions concerning uniformity of taxation.

\section{b. Meaning of the uniformity limitation}

In direct conflict, it would seem, with the words of section 171 , the Kentucky court has ruled that nonproperty taxes are limited by the uniformity clause therein, which, however, is interpreted to require only a uniformity within classes. ${ }^{1}$ That conclusion was reached even before the amendment of section 171 in 1915 . The result is that after having made what was probably an unnecessary decision as to the application of the uniformity clause, the court by interpolation then had to state that the uniformity clause will apply in its "fullness" only to the "direct" taxation of property. ${ }^{2}$ Articles by Trimble ${ }^{8}$ and Matthew ${ }^{4}$ have quite thoroughly explored the ramifications and difficulties brought about by the acrobatics of the Ken-

1 For example, Great Atlantic \& Pacific Tea Co. v. Kentucky Tax Comm., $278 \mathrm{Ky} .367,128 \mathrm{~S}$.W. 2d 581 (1939). See the articles cited in notes 3 and 4, infra.

${ }^{2}$ Id. at 378-379.

3 Trimble, "Excise Taxes and the Uniformity Clause of the Constitution of Kentucky," 25 Ky. L. J. 342 (1937).

4 Matthews, "Constitutional Uniformity as a Rule for the Validity of License Taxes in Kentucky," 36 Ky. L. J. 357 (1948). 
tucky court, and they adequately support the conclusion that the limitation of section 171, insofar as nonproperty taxes are concerned, is substantially equivalent to the limitation of the equal protection clause in the federal Constitution, fourteenth amendment. ${ }^{5}$ However, it might be pointed out that while the Kentucky court has approved the principle of graduated rates, such as used in the income tax ${ }^{6}$ and the inheritance tax, ${ }^{7}$ it has nevertheless held that the chain store type of graduated rate (the rate increasing according to number of stores owned or operated) is without rational basis and therefore an arbitrary classification. ${ }^{8}$

Because of certain more restrictive property-tax uniformity requirements, a Kentucky tax will face less obstacles if it can be characterized as a nonproperty tax. In addition, for the comparative purposes in this study, it is of interest to note that the court has held that the following taxes are not property taxes: an income tax, ${ }^{0}$ an inheritance tax, ${ }^{10}$ a mortgage recording tax, ${ }^{11}$ and an oil production tax with a base of value of oil produced. ${ }^{12}$

Id. at 378.

${ }^{6}$ Reynolds Metals Co. v. Martin, 269 Ky. 378, 107 S.W. 2d 251 (1937).

7 Booth's Exr. v. Commonwealth, 130 Ky. 88, 113 S.W. 61 (1908), also upholding a minimum exemption.

${ }^{8}$ Great Atlantic \& Pacific Tea Co. v. Kentucky Tax Comm., supra note 1; principle reaffirmed in Reeves v. Adam Hat Stores, Inc., $303 \mathrm{Ky} .633$, 198 S.W. 2d 789 (1947). See the discussion in Matthews, supra note 4 at 371-374. Also see City of Greenville v. Martin, $308 \mathrm{Ky} .247,214$ S.W. 2d 271 (1948); Martin v. City of Greenville, $312 \mathrm{Ky} .292$, 227 S.W. $2 \mathrm{~d} 435$ (1940).

${ }^{9}$ Reynolds Metals Co. v. Martin, supra note 6. Also see City of Louisville v. Sebree, $308 \mathrm{Ky} .420,214$ S.W. 2d 248 (1948), concerning a local "wages and net profit" tax.

${ }^{10}$ Booth's Exr. v. Commonwealth, supra note 7.

${ }_{11}$ Middendorf v. Goodale, 202 Ky. 118, 259 S.W. 59 (1923).

12 Raydure v. Board of Sup'rs of Estill County, $183 \mathrm{Ky} .84,209$ S.W. 19 (1919). 


\section{(1) Property taxation}

Insofar as the uniformity required of property taxes is concerned, the primary change brought about by the 1915 amendment to section 171, adding the phrase "of the same classes" to the uniformity clause, is that absolute uniformity in effective rates, which was required under the uniformity clause as originally phrased, ${ }^{13}$ is no longer required. Property may now be classified for the purpose of applying different effective rates to the different classes. ${ }^{14}$ However, there is still a requirement of universality for the state property tax, because, as explained in Martin v. High Splint Coal Company, ${ }^{15}$ the introduction of the classification phrase did not alter the explicit prohibitions found in sections 3,170 , and 174 , insofar as the state property tax is concerned. It was admitted that the new second paragraph added to section 171 in 1915 did authorize the exemption of property from local taxation, "but it will be perceived that the authorization was confined solely to such taxes. . . ."16 Nor can this strict limitation be avoided by the substitution of an "in lieu" nonproperty tax which reaches a class of property indirectly. ${ }^{17}$ Finally, it is quite obvious that property may be taxed only

${ }^{13}$ For example, see Eminence Distillery Co. v. Henry County Board of Sup'rs, $178 \mathrm{Ky} .811,200$ S.W. 347 (1918), in which the decision was made under the uniformity clause in $\$ 171$ as it existed prior to its amendment in 1915. In that case the constitutional requirement of uniformity was held to prevail over the requirement in $\$ 172$ that property be assessed at "fair cash value."

14 See, for example, Klein v. Jefferson County Board of Tax Sup'rs, 230 Ky. 182, 18 S.W. 2d 1009 (1929). Cf. Fayette County Board of Sup'rs v. O'Rear, 275 S.W. 2d (Ky.) 577, 580 (1955).

${ }^{15} 268$ Ky. 11, 103 S.W. 2d 711 (1937). Also see Reeves v. Island Creek Fuel \& Transp. Co., 313 Ky. 400, 230 S.W. 2d 924 (1950).

${ }^{16}$ Martin v. High Splint Coal Co., supra note 15 at 19-20.

${ }^{17}$ Intercounty Rural Elec. Co-op. Corp. v. Reeves, 294 Ky. 458, 171 S.W. $2 d 978$ (1943). Also see Raydure v. Board of Sup'rs, supra note 12. 
by the ad valorem method ${ }^{18}$ because, apart from the possible derivation of such a principle from the uniformity clause in section 171 , section 174 expressly requires that "All property . . . shall be taxed in proportion to its value. . . ."

\section{Maryland}

\section{a. The provisions; historical note}

The uniformity structure of the present constitution of Maryland, dated 1867, is found in Art. 15 of the Declaration of Rights. A substantial change was made in that provision by amendment in 1915. Originally, Art. 15 had read:

... every person in the State, or person holding property therein, ought to contribute his proportion of public taxes for the support of the Government, according to his actual worth in real or personal property; yet fines, duties or taxes may properly and justly be imposed, or laid with a political view for the good government and benefit of the community. ${ }^{1}$

The first clause in the quoted excerpt from Art. 15 served as the source of the Maryland uniformity limitation, ${ }^{2}$ and it was this clause which was changed in 1915, so that Art. 15 now reads:

... the General Assembly shall, by uniform rules, provide for separate assessment of land and classification and subclassifications of improvements on land and personal prop-

${ }^{18}$ For example, see the dictum in Raydure v. Board of Sup'rs, supra note 12 at $97-98$.

${ }^{1}$ The prior Maryland Constitutions (Art. 13, 1776; Art. 13, 1851; Art. 15, 1864) had substantially the same provision. See Lewis, "The Tax Articles of the Maryland Declaration of Rights," 13 Md. L.R. 83 (1953), on the historical development.

${ }^{2} C f$. the uniformity clause classified as Type IX, infra Part I of this chapter. 
erty, as it may deem proper; and all taxes . . . shall be uniform as to land within the taxing district, and uniform within the class or sub-class of improvements on land and personal property which the respective taxing powers may have directed to be subject to the tax levy. . . .

The final clause as to "fines, duties or taxes" was left unchanged.

\section{b. Meaning of the uniformity limitation}

The usual division of taxes for purposes of uniformity into property taxes and nonproperty taxes has long been established in Maryland, and nonproperty taxes have been free from the restrictive limitations of the uniformity clause in Art. 15. Nonproperty taxes have only been required to meet a standard of uniformity within classes. ${ }^{4}$ Because of the more restrictive property-tax limitation, it was of crucial importance, at least before 1915 , to determine the nature of a given tax. Thus, in an early case, the determination that a tax of five per cent on the gross receipts of railroads was a nonproperty tax meant that the uniformity limitation was not a substantial barrier to its validity..$^{5}$ Also, an inheritance tax was held to be a nonproperty tax. ${ }^{6}$ Subsequent to the 1915 amendment to the uniformity clause, the court has avoided any

3 The omission after "all taxes" is a phrase indicating that both state and local taxes are referred to.

4 See the leading case of State v. Philadelphia, W. \& B. R. Co., $45 \mathrm{Md}$. 361, 24 Am. Rep. 511 (1876). Also see: Bevard v. Baughman, $167 \mathrm{Md}$. 55, 173 Atl. 40 (1934) (motor vehicle license tax, classifications of object for different rates, held to be reasonable classes); Jones v. Gordy, $169 \mathrm{Md}$. 173, 180 Atl. 272 (1935) (exemptions from sales tax held valid); Rohr v. Gray, 80 Md. 274, 30 Atl. 632 (1894); Ruggles v. State, 120 Md. 553, 87 Atl. 1080 (1913); State v. Applegarth, 81 Md. 293, 31 Atl. 961 (1895); State v. Dalrymple, 70 Md. 294, 17 Atl. 82 (1889); Tyson v. State, $28 \mathrm{Md}$. 586 (1868).

${ }^{5}$ State v. Philadelphia, W. \& B. R. Co., supra note 4.

${ }^{6}$ Tyson v. State, supra note 4; State v. Dalrymple, supra note 4. 
possible constitutional doubt by holding that an income tax is not a tax upon property. ${ }^{?}$

Before 1915, the original uniformity clause was interpreted to require the strictest degree of uniformity. Consequently, absolute uniformity was required of the effective rate applied to all property by a single taxing authority, ${ }^{8}$ property could be taxed only by the ad valorem method, and there was a rule of universality. ${ }^{10}$

Dissatisfaction with the existing tax structure led to the socalled classification amendment of 1915. As a result of the amendment, the uniformity limitation has been relaxed to some degree. The ad valorem method is still required, and that requirement is derived from the word "uniform." The

7 Oursler v. Tawes, supra note 4.

${ }^{8}$ State v. Philadelphia, W. \& B. R. Co., supra note 4. But the requirement was only territorial. McGraw v. Merryman, $133 \mathrm{Md}$. 247, 104 Atl. 540 (1918). It is interesting to note that there was a low rate intangibles tax imposed in 1896 and never challenged, although generally considered to be unconstitutional. See Lewis, supra note 1 at 99-100; Leland, The Classified Property Tax in the United States 333-334 (1928); Jensen, Property Taxation in the U.S. 193 (1931).

${ }^{\circ}$ State v. Cumberland \& P. R. Co., 40 Md. 22 (1873); and see State v. Philadelphia, W. \& B. R. Co., supra note 4.

${ }^{10}$ Leading cases usually cited for this proposition are Wells $\mathrm{v}$. Hyattsville, 77 Md. 125, 26 Atl. 357 (1893), and Baltimore v. Starr Methodist Protestant Church, 106 Md. 281, 67 Atl. 261 (1907). However, note that there was not a list of the usual public and quasi-public property designated as exemptible in the constitution. Consequently, there were cases upholding certain exemptions which were characterized as having a public benefit; see, for example, Simpson v. Hopkins, $82 \mathrm{Md}$. 478, 488-489, 33 Atl. 714 (1896).

11 Anne Arundel County Com'rs v. English, 182 Md. 514, 35 A. 2d 135 (1943). A flat tax of $\$ 30$ a year upon trailers used for habitation was held to be a revenue measure and a tax upon property-not a "use" tax. It was held to be invalid because it was not levied according to value; the court saying, at 527, the tax must be uniform, "and where the tax is the same upon" trailers of different values "there is, of course, no uniformity. ... . Arbitrary taxes on property without regard to value, are expressly prohibited. ..."However, it might be pointed out that the cases quoted and cited 
extent to which the legislature may classify property for the purpose of either applying different rates to, or exempting classes of property has not yet been determined by the court. This is probably explained by the lack of any utilization of its new powers by the legislature. However, a reading of the words seems to indicate that property may be classified for the purpose of applying different effective rates to different classes, the only limitation being that the classifications of property be reasonable. ${ }^{12}$ However, the uniformity provision does limit the power to classify to this degree: real property is established as a minimum class. Discretion rests in the legislature only insofar as it might wish further to classify personal property. Finally, it would seem that Art. 15 no longer contains a rule of universality, except as to real property as a class. ${ }^{13}$ Thus, personal property may be classified for purposes of exemption, but real property may not be so classified. This result would stem from the final phrase in the uniformity clause: "all taxes . . . shall be uniform as to land within the taxing district, and uniform within the class or sub-class of improvements on land and personal property which the respective taxing powers may have directed to be subject to the tax levy. . . ." The final phrase appears to modify only "improvements on land and personal property."

were decided before the 1915 amendment to Art. 15. Cf. the decision in Herman v. Baltimore, 189 Md. 191, 196-200, 54 A. 2d 491 (1947).

${ }^{12}$ See Lewis, supra note 1 at 103-109, for a problem relating to the application of the uniformity clause in Art. 15 when the variation in the ratio of valuation is not a systematic, intentional classification but a discrepancy found as to a single taxpayer's property. Also see State Tax Commission v. Brandt Cabinet Works, 97 A. 2d 290 (1953).

${ }^{13}$ See the assertion by Lewis, supra note 1 at 102 . 
4. North Carolina

\section{a. The provisions; historical note}

In the original North Carolina Constitution of 1776 there were no provisions expressly dealing with uniformity in taxation. The present constitution of 1868 incorporated a uniformity structure which was fundamentally altered by amendment in 1935. The basic uniformity clause of the 1868 constitution is found in Art. V, $\S 3$, and it originally read as follows:

Laws shall be passed, taxing by a uniform rule all moneys, credits, investments in bonds, stocks, joint-stock companies, or otherwise; and, also, all real and personal property, according to its true value in money. The general assembly may also tax trades, professions, franchises, and incomes: Provided, That no income shall be taxed when the property from which the income is derived is taxed. ${ }^{1}$

The words of this original uniformity clause were clearly phrased to require universality. Furthermore, Art. V, $\$ 6$ spelled out both mandatory and permissible exemptions of designated classes of property. Article VII, $\$ 9$ specifically concerned the uniformity required of local taxes. It provided:

All taxes levied by any county, city, town, or township shall be uniform and ad valorem upon all property in the same, except property exempted by this constitution.

In 1935, the uniformity structure of the North Carolina Constitution was changed by introducing a new uniformity

${ }^{1}$ In 1917 Art. V, $\$ 3$ was amended by introducing the following clause to modify the word "moneys":

Provided, notes, mortgages, and all other evidence of indebtedness given in good faith for the purchase price of a home, when said purchase price does not exceed $\$ 3,000$, and said notes, mortgages, and other evidence of indebtedness shall be made to run for not less than five nor more than twenty years, shall be exempt from taxation of every kind: Provided, that the interest carried by such notes and mortgages shall not exceed $5.5 \%$. 
clause. The "local" uniformity provision in Art. VII, $\$ 9$ was repealed, and the uniformity clause and accompanying provisions in Art. V, $\S 3$ were changed so that they now read:

Taxes on property shall be uniform as to each class of property taxed. . . The General Assembly may also tax trades, professions, franchises, and incomes: Provided, the rate of tax in income shall not in any case exceed ten per cent, and there shall be allowed the following [certain minimum personal exemptions]. . . .

The exemption section, formerly Art. V, §6, was renumbered Art. V, $\S 5$; it now reads as follows:

Property belonging to the State, or to municipal corporations, shall be exempt from taxation. The General Assembly may exempt cemeteries and property held for educational, scientific, literary, charitable, or religious purposes; also wearing apparel, arms for muster, household and kitchen furniture, and mechanical and agricultural implements of mechanics and farmers; libraries and scientific instruments, or any other personal property, to a value not exceeding three hundred dollars. The General Assembly may exempt from taxation not exceeding one thousand dollars in value of property held and used as the place of residence of the owner.

The last sentence of Art. V, $\S 5$ was added in 1935 at the time the provision was renumbered.

\section{b. Meaning of the uniformity limitation}

Even before the amendment in 1935, the court had held that the "uniform rule" requirement in Art. V, §3 governed the imposition of nonproperty taxes; but, as expected, it was also ruled that this limitation only required such nonproperty taxes to be uniform within classes. ${ }^{3}$ Subsequent to the 1935

${ }^{2}$ In 1920 the proviso found in the original Art. V, $\$ 3$ which limited the taxation of income was changed to impose the present limitation, with the exception that in 1920 a $6 \%$ limitation on the rate was provided.

3 See, for example, State v. Stevenson, 109 N.C. 730,14 S.E. 385 
amendment, the court has held that the same requirement is derived from the new uniformity clause in Art. V, $\$ 3 .{ }^{4}$ Of course, this is another example of rather loose treatment of the sources of constitutional limitations. In the first place, a statement to the effect that either type of uniformity clause found in the successive North Carolina Constitutions is applicable to nonproperty taxes is questionable when the words of such provisions are actually examined. All the reference really means is that nonproperty taxes will have to conform to the limitation of reasonable classifications, regardless of the rather hazy designation of the source of that limitation.

Because of the provision which expressly provides for an income tax, and appeared in Art. V, $\$ 3$ both before and after 1935 , there has been no doubt as to the power of the legislature to impose such a tax; however, the court did find it necessary under the old uniformity limitation to hold that the income tax was not a property tax and consequently did not have to be taxed by the ad valorem method. ${ }^{5}$ The graduated rate schedule of that tax has not been challenged. Inciden-

(1891); Gatlin v. Tarboro, 78 N.C. 119 (1878). Also see Clark v. Maxwell, 197 N.C. 604,150 S.E. 190 (1929); Dalton v. Brown, 159 N.C. 175, 75 S.E. 40 (1912); Great Atlantic \& Pacific Tea Co. v. Maxwell, 199 N.C. 433, 154 S.E. 838 (1930); Great Atlantic \& Pacific Tea Co. v. Doughton, 196 N.C. 145, 144 S.E. 701 (1928); Maxwell v. KentCoffey Mfg. Co., 204 N.C. 365, 168 S.E. 397 (1933); In re Morris' Estate, 138 N.C. 259, 50 S.E. 682 (1905); Roach v. Durham, 204 N.C. 587, 169 S.E. 149 (1933); State v. Carter, 129 N.C. 560, 40 S.E. 11 (1901); Wayne Mercantile Co. v. Mt. Olive, 161 N.C. 121, 76 S.E. 690 (1912); Worth v. Wilmington \& W. R. Co., 89 N.C. 291, 45 Am. Rep. 679 (1884).

4 See, for example, Charlotte Coca-Cola Bottling Co. v. Shaw, Com'r of Revenue, 232 N.C. 307, 59 S.E. 2 d 819 (1950); Kenny Co. v. Town of Brevard, 217 N.C. 269, 7 S.E. 2 d 542 (1940) ; Leonard v. Maxwell, 216 N.C. 89, 3 S.E. 2d 316 (1939); Nesbitt v. Gill, Com'r of Revenue, 227 N.C. 174, 41 S.E. $2 d 646$ (1947) ; State v. Harris, 216 N.C. 746, 6 S.E. 2d 854 (1940); Wachovia Bank \& Trust Co. v. Maxwell, 221 N.C. 528, 20 S.E. $2 d 840$ (1942).

- Maxwell v. Kent-Coffey Mfg. Co., supra note 3. 
tally, at an early date the North Carolina court ruled that an inheritance tax was a nonproperty tax. ${ }^{6}$

Property Taxation: before 1935. Under Art. V, §3, as it was originally phrased, the strictest degree of uniformity governed the taxation of property. The requirement of universality was explicit, and this was confirmed by the decisions. ${ }^{7}$ Absolute uniformity was required of the effective rate applied by any one taxing authority, ${ }^{8}$ and the taxation of property by other than the ad valorem method was forbidden by the "uniform rules" requirement." The court applied the same uniformity limitation regardless of whether the tax under consideration was a local or state property-tax rate. It made no distinction as to the different phraseology which was found in Art. V, §3 and Art. VII, §9. Usually it simply cited both of the provisions when dealing with a local tax rate. ${ }^{10}$

Property Taxation: since 1935. The changes made in the uniformity provision have not altered the universality rule; the court now holds that the enumeration of permissible exemptions of property in Art. $\mathrm{V}, \S 5$ forbids the exemption of other property. "The grant [to exempt] is limited in its

'In re Morris' Estate, supra note 3.

${ }^{7}$ Charlotte Bldg. \& Loan Ass'n v. Mecklenburg, 115 N.C. 410, 20 S.E. 526 (1894); Drainage Com'rs v. C. A. Webb \& Co., 160 N.C. 594, 76 S.E. 552 (1912); Redmond v. Tarboro, 106 N.C. 122, 10 S.E. 845 (1890); Southern Assembly v. Palmer, 166 N.C. 75, 82 S.E. 18 (1914); United Brethren of Salem \& Vicinity v. Forsyth, 115 N.C. 489, 20 S.E. 626 (1894).

8 Anderson v. City of Asheville, 194 N.C. 117, 138 S.E. 715 (1927). That the requirement was only territorial, see Jones v. Com'rs, 143 N.C. 59 (1906).

'See Bickett v. State Tax Comm., 177 N.C. 433, 99 S.E. 415 (1919); Pocomoke Guano Co. v. Biddle, 158 N.C. 212, 73 S.E. 996 (1912).

${ }^{10}$ For example, Anderson v. City of Asheville, supra note 8.

11 Rockingham County v. Board of Trustees of Elon College, 219 N.C. 342, 13 S.E. 2d 618 (1941); Sir Walter Lodge No. 411, I.O.O.F. v. Swain, 217 N.C. 632, 9 S.E. 2 d 365 (1940): 
terms, and the power to exempt stops at the boundary of the grant."12 Nor has any case indicated that the requirement of ad valorem method has been relaxed. ${ }^{13}$ It would appear that the only certain change has been the deletion of the requirement of absolute uniformity in effective rates, so that at the present time property may be classified for the purpose of applying different rates to the different classes. There have been no cases dealing with the validity of the rather limited classification introduced by the legislature. ${ }^{\mathbf{1 4}}$

\section{North Dakota}

\section{a. The provisions; historical note}

The uniformity structure of the original and present North Dakota Constitution, dated 1889, consists of Art. XI, §176. The uniformity clause of that section was originally a Type IV clause, and it read:

Laws shall be passed taxing by a uniform rule all property according to its true value in money. . . .

The original section also provided for the mandatory exemption of designated classes of property, including personal property not exceeding $\$ 200$ in value for each individual liable to taxation. In addition, a proviso stated that the legislature might provide for the payment of a railroad gross

${ }^{12}$ Sir Walter Lodge No. 411, I.O.O.F. v. Swain, supra note 11 at 638.

${ }^{18}$ But see Nesbitt v. Gill, Com'r of Revenue, supra note 4.

${ }^{14}$ In a recent case the court indicated that the limitation is, in any case, territorial. Jamison v. City of Charlotte, 80 S.E. 2d 904 (1954). In referring to the substance of the new limitation applicable to effective rates, the court said: "Uniformity in taxation on real and personal property is effected, when the tax is levied equally and uniformly on all property in the same class." Id. at 912 . Emphasis by the court. The court pointed out that the legislature had classified intangible personal property for taxation at a lower rate than tangible personal property or realty. 
earnings tax "to be paid in lieu of all" state and local taxes on property used exclusively in and about the prosecution of the business of such companies as common carriers. An amendment in 1899 added a proviso stating: "The legislative assembly [might] further provide that grain grown within the state and held therein in elevators, warehouses and granaries [might] be taxed at a fixed rate." (Emphasis supplied.)

In 1911 a radical change was made in the type of uniformity clause found in Art. XI, $\$ 176$. That section was amended so that the uniformity clause now reads:

Taxes shall be uniform upon the same class of property including franchises within the territorial limits of the authority levying the tax.

The mandatory exemptions found in the original section 176 were carried over.

In 1918 the uniformity structure was again amended. The uniformity clause was left intact, but the rule of universality was expressly abolished in part. Also the minimum exemption of personal property was deleted, so that at the present time Art. XI, $\$ 176$ reads (with that part added in 1918 indicated by brackets):

Taxes shall be uniform upon the same class of property including franchises within the territorial limits of the authority levying the tax. [The legislature may by law exempt any or all classes of personal property from taxation and within the meaning of this section, fixtures, buildings and improvements of every character, whatsoever, upon land shall be deemed personal property.] The property of the United States and of the state, county and municipal corporations and property used exclusively for schools, religious, cemetery, charitable or other public purposes shall be exempt from taxation. . . .

Also in 1918, Art. XI, $\$ 177$ was amended in order to provide 
for a special "acreage tax on lands within the state" with the proceeds being earmarked for a special indemnity fund.

\section{b. Meaning of the uniformity limitation}

Before the amendment in 1911 the court ruled that nonproperty taxes were not limited by the uniformity clause in Art. XI, \$176, and that such taxes only had to be uniform within classes. ${ }^{1}$ While the same distinction has been made since the amendment of $1911,{ }^{2}$ it is no longer likely to be of substantial importance for purposes of uniformity because of the liberal interpretation given the new uniformity limitation. In its original form, the uniformity clause was said to require the strictest degree of uniformity in the taxation of property, universality, absolute uniformity in effective rates, and the ad valorem method. ${ }^{3}$

After the amendment of 1911, which introduced the new uniformity clause, and before the 1918 amendment, which expressly provided for exemptions, the uniformity structure was interpreted and applied in the important case of State ex rel. Fargo v. Wetz.. The Wetz case concerned the validity of a graduated license tax on motor vehicles which was intended to be in lieu of all other taxes, including both local and state property taxes. In the opinion it was indicated that only the requirement of universality was retained, and, indeed, that this requirement was retained only to the extent

${ }^{1}$ See, for example, In re Lipschitz, 14 N.D. 622, 95 N.W. 157 (1902); State v. Klectzen, 8 N.D. 286, 78 N.W. 984 (1899).

${ }^{2}$ See Figenskau v. McCoy, 66 N.D. 290, 265 N.W. 259 (1936).

${ }^{3}$ There was no development of these rules by the court, but such was the nature of the limitation as described in a case under the amended clanse, State ex rel. Fargo v. Wetz, 40 N.D. 299, 168 N.W. 835 (1918). In Malin v. Lamoure, 27 N.D. 140, 145 N.W. 582 (1914) a graduated probate fee was held unconstitutional as a tax upon property and a violation of the original uniformity clause.

4 Supra note 3. 
that property could not be exempted from all taxes-that is, it only had to be taxed by some taxing jurisdiction. Thus, property might be exempted from either the state or the local property tax. It was also indicated that property could now be taxed by other than the ad valorem method, and that it could be classified for application of different rates. Consequently, the court upheld the motor vehicles tax and the in lieu provision. It should be pointed out that the court was in effect permitting an indirect form of taxation to be substituted for all taxes upon a class of property, since the tax was characterized as a license tax. ${ }^{5}$ In any case, whatever the rationale, the court asserted that the substitution could be allowed without the prohibition against exemptions being violated. In reviewing the changes made in the uniformity limitation, the court made the often repeated statement that the new uniformity clause was no more restrictive than the federal equal protection clause.

The particular problem of the Wetz case was met by the 1918 amendment to Art. XI, $\$ 176$ which stated that "any or all" classes of personal property may be exempted. The first case of interest decided after 1918 was Northwestern Im provement Company v. State. ${ }^{6}$ In that case, the court struck down a specific property tax as a violation of the uniformity clause. The tax was three cents per acre on all mineral reserves where the ownership thereof was severed from the overlaying strata and surface of the land. The basis of the decision was not that the method of taxation violated the uniformity clause in $\$ 176$, but that the classification was based solely on ownership and was consequently arbitrary.

5 But see the statement, $i d$. at 319 , in which the court indicates that "really" the tax is both property and license tax.

657 N.D. 1, 220 N.W. 436 (1928).

7 Id. at 8, 10-11. See Northwestern Improvement Company v. County of Morton, 78 N.D. 29, 47 N.W. 2d 543 (1951) in which the same classification was struck down as arbitrary. This time the tax was framed in terms 
Subsequently, the leading case of State ex rel. Haggart v. Nichols, ${ }^{8}$ decided in 1936, illustrated the dictum of the Wetz case concerning the liberality of the new uniformity clause. In the Nichols case the court had to pass upon the validity of a graduated net income tax. The tax was upheld in a unanimous decision. The majority opinion of three ruled that the nature of the tax was immaterial; consequently, it took no stand on the arguments of opposing counsels on that question, the reason being:

The view which we take of the matter renders it unnecessary to consider whether or not the law under discussion imposed an excise tax or a property tax ...., for the members of the court are all agreed that under $\$ 176 \ldots$ of the state constitution the legislature has wide discretionary powers to classify property for the purposes of taxation, and that the standard of uniformity under section 176 of the state constitution is substantially the same as the standard of equality under the Fourteenth Amendment to the constitution of the nation."

Consequently, the majority was of the opinion that even if the tax had to be characterized as a property tax, the graduated rate was permissible. ${ }^{10}$ Two judges concurred in "the result" solely on the ground that the income tax was not a property tax and hence did not come within the scope of the uniformity provisions in section 176. In summary, the court

of being a tax on a "privilege." Also see Gamble-Robinson Fruit Co. v. Thoresen, 53 N.D. 28, 204 N.W. 861 (1925).

866 N.D. 355,265 N.W. 859 (1936).

Id. at 363. Emphasis added. Northwestern Improvement Co. v. State, supra note 6 , was distinguished as simply finding an arbitrary classification. The court concluded, at 370, that "in this state the legislative power to classify property for purposes of taxation is subject only to the limitation against arbitrary classification imposed by the due process and equal protection clauses in the fourteenth amendment to the Constitution of the United States."

${ }^{10} \mathrm{Id}$. at 373 . 
has given every indication that considerable discretion is allowed the legislature under the amended uniformity limitation.

\section{South Dakota}

\section{a. The provisions; historical note}

The uniformity structure of the original South Dakota Constitution of 1889 was found in several sections. One uniformity clause, Art. XI, §2, provided:

All taxes ... . shall be uniform on all real and personal property, according to its value in money, to be ascertained by such rules of appraisement and assessment as may be prescribed by the legislature by general law, so that every person and corporation shall pay a tax in proportion to the value of his, her or its property. And the legislature shall provide by general law for the assessing and levying of taxes on all corporation property as near as may be by the same methods as are provided for assessing and levying of taxes on individual property. ${ }^{1}$

In addition, a second clause was found in section 17 of Art. VI [the Bill of Rights], reading: “. . . and all taxation shall be equal and uniform." Accompanying these two uniformity clauses was the following provision in Art. XI, §4:

The legislature shall provide for taxing all moneys, credits, investments in bonds, stocks, joint stock companies, or otherwise; and also for taxing the notes and bills discounted or purchased, moneys loaned and all other property, effects or dues of every description, of all banks and of all bankers, so that all property employed in banking shall always be subject to a taxation equal to that imposed on the property of individuals.

${ }^{1}$ Article XI, $\$ 2$ was amended in 1912 , but the uniformity clause therein was not substantially altered. 
Article XI, $\$ \S 5$ and 6 , provided for the mandatory exemption of designated classes of property, and section 7 of Art. XI ruled out other exemptions by stating that "All laws exempting property from taxation, other than that enumerated in sections 5 and 6 of this article, shall be void." Finally, just to be sure, the framers of the constitution stated in Art. XI, $\$ 10$, that “. . . [local] tax shall be uniform in respect to persons and property within the jurisdiction of the body levying the same."

But the prodigious efforts of the drafters to leave no word unsaid went for naught. In 1918, less than thirty years later, an amendment brought about a radical change in the effective uniformity limitation. The amendment was limited to the basic uniformity clause in the second section of Art. XI, which was changed to read:

To the end that the burden of taxation may be equitable upon all property, and in order that no property which is made subject to taxation shall escape, the legislature is empowered to divide all property including moneys and credits as well as physical property into classes and to determine what class or classes of property shall be subject to taxation and what property, if any, shall not be subject to taxation. Taxes shall be uniform on all property of the same class. ... Taxes may be imposed upon any and all property including privileges, franchises and licenses to do business in the state. Gross earnings and net incomes may be considered in taxing any and all property, and the valuation of property for taxation purposes shall never exceed the actual value thereof. The legislature is empowered to impose taxes upon incomes and occupations, and taxes upon incomes may be graduated and progressive and reasonable exemptions may be provided.

For reasons which will be explained, this was apparently not enough, so that Art. VIII, $\S 15$ was amended in 1930 by the addition of this sentence: 
The legislature is empowered to classify properties within school districts for purposes of school taxation, and may constitute agricultural lands a separate class. Taxes shall be uniform on all property in the same class.

Finally, it must be emphasized that the amendment of 1918 was limited to a change in the words of Art. XI, §2. The second uniformity clause, found in Art. VI, $\$ 17$; the local uniformity clause in Art. $\mathrm{XI}, \S 10$; and the prohibition against exemptions, found in Art. XI, \$7-all remained, although obviously modified, or even "repealed," by the amended Art. XI, §2.

\section{b. Meaning of the uniformity limitation}

Nonproperty taxes are required to be uniform within classes, ${ }^{2}$ and the source of the limitation is said to be the uniformity clause in Art. VI, §17: "[A]ll taxation shall be equal and uniform." Again, it is seen that if a uniformity clause framed in "absolute" terms is interpreted as applying

2 Before 1918, see: Ex parte Hoffert, 34 S.D. 271, 148 N.W. 20 (1914); In re McKennan's Estate, 27 S.D. 136, 130 N.W. 33 (1911); Queen City Fire Ins. Co. v. Basford, 27 S.D. 164, 130 N.W. 44 (1911); State v. Doran, 28 S.D. 486, 134 N.W. 53 (1912); In re Watson, 17 S.D. 486, 97 N.W. 463 (1904). Since 1918, see: Eastern Dakota Elec. Co. v. Kirlin, 48 S.D. 462, 205 N.W. 33 (1925); Schmitt v. Nord, 71 S.D. 575, 27 N.W. 2d 910 (1947); Standard Oil Co. v. Jones, 48 S.D. 482, 205 N.W. 72 (1925); State v. Black Hills Transp. Co., 71 S.D. 28, 20 N.W. $2 d 683$ (1945) ; State ex rel. Roddewig v. Kutcher, 68 S.D. 366, 2 N.W. 2d 669 (1942); State ex rel. Botkin v. Welsh, 61 S.D. 593, 251 N.W. 189 (1933).

${ }^{3}$ See State ex rel. Botkin v. Welsh, supra note 2 at 640 , in which the court stated:

For the purposes of this case, however, the existence of section 17, art. 6, will probably have little, if any, practical effect upon the result arrived at, for it seems universally agreed so far as concerns occupational taxation, that a general constitutional provision requiring equality and uniformity of taxation imposes upon the legislature no limitation or restriction different from or beyond that imposed by the Federal Constitutional require- 
to nonproperty taxes, the result is that the limitation is met when all in the same class are treated alike.

Before the amendment to the property tax uniformity limitation there was no occasion for the court to rule upon the nature and validity of an income tax. However, in In re McKennan's Estate, ${ }^{4}$ the court did hold that an inheritance tax was a nonproperty tax and that the graduated rate schedule found therein was a reasonable scheme of classification. The court has also ruled that a mortgage registration tax was a nonproperty tax. ${ }^{6}$ In State ex rel. Botkin v. Welsh ${ }^{7}$ the court considered the validity of the 1933 "Occupation Tax with a base of Gross Income from all sources." In a very lengthy opinion the tax was distinguished from an "income tax" (said to be limited to "net" income taxes) and held to be a tax upon the privilege of engaging in occupations. Consequently, the tax was upheld only insofar as it reached income from the occupation engaged in. The rate schedule which made five classifications based on the source of income was upheld.

In view of the numerous overlapping provisions in the original uniformity structure, it should come as no surprise that before 1918 the strictest degree of uniformity was re-

ment of equal protection of the laws, and there is therefore little practical difference whether our standard of constitutionality be sought in the federal equal protection clause or Art. VI, $\$ 17$.

\section{Supra note 2.}

It should be noted that the graduated rate schedule was not graded according to the process with which we are familiar today. The increasing rates were applied to the entire amount taxed, not to just the increment. It was on this point that a prior opinion (25 S.D. 369 (1910)) was overruled on rehearing. In the original opinion the rate has been held to be arbitrary. In State ex rel. Roddewig v. Kutcher, supra note 2, the graduated rate under the chain store tax was upheld.

Eastern Dakota Elec. Co. v. Kirlin, supra note 2.

7 Supra note 2. 
quired in the taxation of property. ${ }^{8}$ With the particular rules being derived from several alternate sources, it was clear that there was a requirement of universality, absolute uniformity was required in effective rates, and property could be taxed only by the ad valorem method.

Since 1918, property taxes are required to conform only to a limitation of uniformity within classes. Exemptions are permitted, ${ }^{9}$ and it is possible that specific property taxes are not forbidden. ${ }^{10}$ While property may be classified for different effective rates, some classifications have been adversely dealt with by the court. In Commercial State Bank v. Wilson, ${ }^{11}$ the court upheld the separate classification of money and credits for a low rate tax, indicating that the uniformity clause in Art. VI, $\$ 17$, which was left unchanged, no longer prevents such classification. Insofar as the provisions from the original uniformity structure which have been retained (i.e., Art. VI, §17; Art. XI, §7; and Art. XI, §10) are inconsistent with the power of classification, they are superseded by the new uniformity provision in Art. XI, $\$ 2$.

However, in Simmons v. Ericson ${ }^{12}$ the court struck down an attempt by the legislature to classify land in school districts into agricultural land and other realty for the purpose of applying a lower property-tax rate to the former. It held that there was no "reasonable" basis for the classification. The next year the clause expressly sanctioning such a classification was added to Art. VIII, $\S 15$, as pointed out above.

${ }^{8}$ See, for example, In re Construction of Revenue Law, 2 S.D. 58, 48 N.W. 813 (1891).

${ }^{\theta}$ State ex rel. Eveland v. Johns, 43 S.D. 279, 178 N.W. 945 (1920); State ex rel. Bottum v. Knudtson, 65 S.D. 547, 276 N.W. 150 (1937).

10 There have been no pertinent cases on this point. However, note the deletion of the several phrases in the original Art. XI, $\$ 2$ which might have required the ad valorem method.

1153 S.D. 82, 220 N.W. 152 (1928).

12 54 S.D. 429, 223 N.W. 342 (1929). 
Subsequently, such a classification for school district property taxes was upheld in Great Northern Railway Company v. Whitfield. ${ }^{13}$ Obviously, the Simmons rationale was now immaterial insofar as the state constitutional limitation was concerned. However, in effect, the court overruled its opinion in Simmons and held that there was a reasonable classification. Consequently, it held that the statute violated neither the state constitution nor the federal equal protection clause.

\section{Washington}

\section{a. The provisions; historical note}

Washington has had but a single constitution, that of 1889. Its uniformity structure was originally found in Art. VII, $\S 1-3$ and 9. Article VII, $\S 1$ contained a Type II "proportionality" clause, and read:

All property in the state, not exempt under the laws of the United States, or under this constitution, shall be taxed in proportion to its value, to be ascertained as provided by law. ...

Section 2 of Art. VII, which contained a uniformity clause similar to the Type VI clause, read:

The legislature shall provide by law a uniform and equal rate of assessment and taxation on all property in the state, according to its value in money, and shall prescribe such regulations by general law as shall secure a just valuation for taxation of all property, so that every person and corporation shall pay a tax in proportion to the value of his, her or its property; Provided, That a deduction of debts from credits may be authorized; Provided further, That the property of the United States and of the state, counties, school districts and other municipal corporations, and such other property as

1365 S.D. 173, 272 N.W. 787 (1937). 
the legislature may by general laws provide, shall be exempt from taxation. [Emphasis added.]

Like so many of the constitutions which were drafted in the latter part of the nineteenth century, its drafters inserted sufficient verbiage from which the uniformity limitation might be drawn. Article VII, $\S 3$ provided that taxes on corporate property were to be assessed and levied by the same methods as were provided for assessing and levying of taxes on individual property. Finally, Art. VII, $\$ 9$ was directed specifically to local taxation. It read:

... For all corporate purposes, all municipal corporations may be vested with authority to assess and collect taxes, and such taxes shall be uniform in respect to persons and property within the jurisdiction of the body levying the same.

In 1930, a significant change was made in the uniformity structure of the Washington Constitution. By Amendment Fourteen it was provided that Art. VIII was to be amended by striking out all of sections $1,2,3$, and 4 , and inserting in lieu thereof a new Art. VII, $\S 1$. The new Art. VII, $\S 1$ contains a different type of uniformity clause and, in addition, spells out certain particular limitations. It now reads:

. . . All taxes shall be uniform upon the same class of property within the territorial limits of the authority levying the tax. . . . The word "property" as used herein shall mean and include everything, whether tangible or intangible, subject to ownership. All real estate shall constitute one class: Provided, That the legislature may tax mines and mineral resources and lands devoted to reforestation by either a yield tax or an ad valorem tax at such rate as it may fix, or by both. Such property as the legislature may by general laws provide shall be exempt from taxation.

The new section 1 further provides that public property and "credits secured by property actually taxed in this state" shall be exempt from taxation, and that the legislature "shall 
have power . . . to exempt" $\$ 300$ of personal property to each head of a family liable to taxation. The "local" provision found in Art. VII, $\$ 9$ remains unchanged, so that the present uniformity structure is found in sections 1 and 9 of Art. VII.

\section{b. Meaning of the uniformity limitation}

Both before ${ }^{1}$ and after ${ }^{2} 1930$ the court has ruled that nonproperty taxes are not limited by the uniformity clauses found in Art. VII, $\S \S 1$ and 9. Such taxes need only be uniform within classes. ${ }^{3}$ There is no clear-cut ruling that the principle of progressively graduated rates meets the reason-

${ }^{1}$ A leading case is Fleetwood v. Read, 21 Wash. 547, 555, 58 Pac. 665 (1899). And see the three cases: State v. Ide, 35 Wash. 576, 77 Pac. 961 (1904); Thurston v. Tenino Stone Quarries, 44 Wash. 351,87 Pac. 634 (1906); and Tekoa v. Reilly, 47 Wash. 202, 91 Pac. 769 (1907), in which the court engaged in the not unusual process of finding a uniformity clause of the type found in the "local" provision, Art. VII, $\S 9$, applicable to nonproperty taxes but then interpreting that provision to mean that such taxes, as opposed to property taxes, had only to be uniform within classes.

2 For example, see the very important case of State ex rel. Stiner v. Yelle, 174 Wash. 402, 25 P. 2d 91 (1933), discussed infra notes 46-51. Also see the cases in note 3 , infra.

${ }^{8}$ Before 1930, see: Fleetwood v. Read, supra note 1; State v. Clark, 30 Wash. 439, 71 Pac. 20 (1902); State v. Hart, 125 Wash. 520, 217 Pac. 45 (1923); Stull v. DeMattos, 23 Wash. 71, 62 Pac. 451 (1900). Since 1930, see the following cases: Morrow v. Henneford, 182 Wash. 625, 47 P. 2d 1016 (1935) (retail sales tax, upholding the exemption of certain foodstuff sold for consumption off the premises and casual and isolated sales by persons not engaged in the business of selling tangible personal property at retail) ; Vancouver Oil Co. v. Henneford, 183 Wash. 317, 49 P. 2 d 14 (1935) (general compensating use tax); State ex rel. Hansen v. Salter, 190 Wash. 703, 70 P. 2d 1056 (1937) (motor vehicle use tax); Gruen v. State Tax Comm., 35 Wash. 2d 1, 211 P. 2d 651 (1949) (cigarette tax, the object held to be a reasonable class); Puget Sound Power \& Light Co. v. City of Seattle, 172 Wash. 668, 21 P. 2d 727 (1933) (local public utilities gross receipts tax, object held to be a reasonable class). Also see Benjamin Franklin Thrift Stores v. Henneford, 187 Wash. 472, 60 P. 2d 86 (1936); Golden Age Breweries, Inc. v. Henneford, 193 Wash. 536, 76 P. 2d 598 
able classification test. ${ }^{4}$ However, the discussion of income taxes, infra, indicates that under the property-tax uniformity clause in Art. VII, $\S 1$, even though classification is permitted, graduated rates have been held to be inherently arbitrary.

Before the amendment of 1930 it was obviously of the utmost importance to determine the nature of a given tax before reaching a conclusion on its validity under the uniformity limitation. Since the 1930 amendment, even though some degree of classification is allowed for property taxes, a decision favorable to the validity of any given tax is more likely if that tax is characterized as a nonproperty tax. For comparative purposes it is of interest to note that the court has held the following taxes to be nonproperty taxes: an inheritance $\operatorname{tax} ;{ }^{5}$ a corporate franchise tax with a base of capital stock, ${ }^{6}$ and a general compensating "use" tax. ${ }^{7}$ To the contrary, a graduated probate "fee" was held to be on the property involved and a violation of the pre-1930 property-tax uniformity limitation. ${ }^{8}$ In 1952, the court held that a con-

(1938). Compare State v. Inland Empire Refineries, 3 Wash. 2d 651, 101 P. 2d 975 (1940) with Texas Co. v. Cohn, 8 Wash. 2d 360, 112 P. 2d 522 (1941) for the treatment of classifications found in the fuel use taxes.

4 But note that in State v. Clark, supra note 3, decided in 1902, the court held that the inheritance tax was a nonproperty tax and held that the challenged classifications were reasonable. The tax had a graduated rate schedule. However, for the most part, the controversy centered on the nature of the tax. The validity of a minimum exemption was upheld as reasonable. No mention was made of the graduated rate.

5 State v. Clark, supra note 3.

${ }^{6}$ Spokane International R. Co. v. State, 162 Wash. 395, 299 Pac. 362 (1931). However, no issue was raised in this case as to a state constitutional requirement. The primary issue concerned the federal constitutional limitation on state taxation of interstate commerce, and in addition a problem of discrimination under the federal equal protection clause.

7 Vancouver Oil Co. v. Henneford, supra note 3; Spokane v. State, 198 Wash. 682, 89 P. 2d 826 (1939), affirming the Vancouver Oil Co. case. And see St. Paul \& Tacoma Lumber Co. v. State, 40 Wash. 2d 347, 243 P. 2d 474 (1952).

${ }^{8}$ State ex rel. Nettleton v. Case, 39 Wash. 177, 81 Pac. 554 (1905). 
veyancing tax was a tax on the sale of real estate, and not a tax on the property itself. ${ }^{9}$ The treatment accorded certain "income" taxes-on both net income and gross income-is worthy of a separate discussion which will be delayed until after the general uniformity limitation governing the taxation of property has been described.

\section{(1) Property taxation}

Prior to 1930. The strictest degree of uniformity in the taxation of property was required under the original uniformity provisions found in Art. VII, $\S \S 1$ and 2. First, there was a requirement of universality. In State ex rel. Chamberlin v. Daniel ${ }^{10}$ the court held that a statute providing for a minimum exemption of $\$ 500$ of personal property to each taxpayer was a violation of Art. VII, $\S \S 1$ and 2 . In so holding the court was faced with an interpretation of the last clause of Art. VII, §2, which read: "and such other property as the legislature may by general laws provide, shall be exempt from taxation." Admitting that the clause considered in isolation might lead to the conclusion that the legislature could exempt such property as it might choose, the court ruled that this interpretation had to yield to a reading of the two sections as a whole. ${ }^{11}$ Emphasizing the words in section 1 to the effect that "All property in the state . . . shall be taxed ...", and the following words in section 2 that "The legislature shall provide by law a uniform and equal rate of assessment and taxation on all property in the state ...", the court ruled that it was the intention of the framers to

${ }^{8}$ Mahler v. Tremper, 40 Wash. 2d 40 5, 243 P. 2d 627 (1952).

1017 Wash. 111, 49 Pac. 243 (1897). Also see Pacific Cold Storage Co. v. Pierce, 85 Wash. 625, 149 Pac. 34 (1915) (emphasizing the words of the uniformity clause in Art. VII, $\$ 2)$; and MacLaren v. Ferry County, 135 Wash. 517, 238 Pac. 579 (1925).

11 Id. at 113-115. 
prohibit the exemption of property, other than the classes enumerated in Art. VII, $\$ 2 .^{12}$ The exemption clause in Art. VII, §2 was interpreted to refer to "such other property" of the same classes which were enumerated, i.e., public property and possibly property of a quasi-public nature. ${ }^{13}$

Second, under the original effective limitation it was ruled that absolute uniformity was required of the effective rate applied to all property taxed by any one taxing authority. ${ }^{14}$ Third, property could be taxed only by the ad valorem method. ${ }^{15}$

It is important to note that the principle of universality

12 Id. at 119-121. Note the court's review of other constitutional provisions, at 117-118, in which it used a common technique when it found no support in the interpretation of other constitutions. It said "our constitution is materially different from any other constitution in the Union, and the cases cited under the constitutions of different states are of very little value in construing this constitution."

${ }^{13}$ Id. at 121 .

14 The same ratio of valuation had to be used for all property taxed by a single jurisdiction, Spokane \& Eastern Trust Co. v. Spokane, 70 Wash. 48, 126 Pac. 54 (1912). Also see State ex rel. State Board of Tax Com'rs v. Cameron, 90 Wash. 407, 156 Pac. 537 (1916); Hammond Lumber Co. v. Cowlitz, 84 Wash. 462, 147 Pac. 19 (1915). However, classification of property for purposes of the mechanics of determining value was not prohibited; Pacific National Bank v. Pierce, 20 Wash. 675, 683-684, 687-688, 56 Pac. 936 (1899); Spokane \& I. E. R. Co. v. Spokane, 75 Wash. 72, 85-88, 134 Pac. 688 (1913) ; Puget Sound Power \& Light Co. v. Seattle, 117 Wash. 351, 201 Pac. 449 (1921).

Also see the following cases dealing with a particular problem of uniformity and rates; i.e., whether the taxation of both corporate property and corporate shares was "double taxation": Pacific National Bank v. Pierce, supra; Ridpath v. Spokane, 23 Wash. 436, 63 Pac. 261 (1900); Lewiston Water \& Power Co. v. Asotin, 24 Wash. 371, 64 Pac. 544 (1901); Dexter Horton Nat. Bank v. McKenzie, 69 Wash. 314, 124 Pac. 915 (1912); Spokane \& Eastern Trust Co. v. Spokane County, 153 Wash. 332, 280 Pac. 3 (1929).

${ }_{15}$ MacLaren v. Ferry County, supra note 10; State ex rel. Nettleton v. Case, supra note 8. 
was avoided in one instance when that principle was found to be in an apparent conflict with the principle of absolute uniformity in effective rates. In State ex rel. Wolfe v. Parmenter $^{16}$ the court held that the general property-tax act did not violate the requirement of universality, as established in the Chamberlin case, even though that act so defined personal property as to exclude "credits" and, therefore, in effect exempt such items from taxation. ${ }^{17}$ However, the exclusion of "moneys" was held to violate the universality requirement. The court reasoned that all property in the state could be taxed without the taxation of "credits."

The constitution simply requires that all property shall be taxed, but the method of doing it is left to the legislature. ... The constitutional requirement that all property shall be taxed is certainly satisfied through a method by which the total of all wealth in the state is once taxed. Double taxation should be avoided as far as possible, and in any event the constitution should not be so construed as to require it. ${ }^{18}$

The court then proceeded to demonstrate to its satisfaction that "credits" were only representative of tangible property which would be taxed. Thus, to tax the "credits" as well would not simply tax all wealth in the state once, but instead would result in "double taxation."19 "Moneys," however, were not considered to be representative of tangible property. Consequently, the statute was held to be void insofar as it attempted to exclude "moneys" from the definition of

1650 Wash. 164, 96 Pac. 1047 (1908). And see State ex rel. Egbert v. Gifford, 151 Wash. 43, 275 Pac. 74 (1929), in which the court affirmed the Parmenter case, but pointed out that the case did not hold that the legislature must so exempt credits.

${ }^{17} \mathrm{Id}$. at $171-172,175$. The reference was to "mortgages, notes, accounts, moneys, certificates of deposit, etc." Moneys was, of course, deleted by the force of the decision as noted in the text.

${ }^{18} I d$. at 173-4. Cf. the cases cited in note 14 , supra.

${ }^{19} \mathrm{Id}$. at 175-176. 
personal property. Nonetheless, it was held that "the omission of credits from a scheme of taxation [did] not violate the requirement that all actual property shall be taxed."20

Subsequent to 1930. The new uniformity clause in Art. VII, $\S 1$ has been subject to little interpretation by the court. Immediately after the amendment came into force the legislature enacted a statute ${ }^{21}$ exempting intangibles from "ad valorem taxation." This exemption statute was challenged and upheld in State ex rel. Atwood v. Wooster, ${ }^{22}$ decided in 1931. That case was the first to comment fully on the meaning of the new Art. VII, $\S 1$. It was said:

. . the requirements that a uniform tax be assessed against all property were swept away, and in their place were adopted constitutional provisions which say nothing about uniformity, and do not provide that all property shall be taxed, but which do permit of the classification of all property, and provide that all taxes shall be uniform upon the same class of property, and also that such property as the legislature may provide shall be exempt from taxation. So that the legislature, freed from the former limitations, may now determine what property shall be taxed, the different rates upon which different classes of property shall be taxed, and what property shall pay no tax at all, subject only to the limitations found in the new constitutional provisions. ${ }^{23}$

Turning to the precise issue at hand, the court held that intangibles constituted a reasonable class of property and that consequently the exemption was valid. ${ }^{24}$

Thus, as illustrated by the decision, there is no longer a rule of universality. ${ }^{25}$ There may be some question as to

20 Id, at 177.

21 Wash. Laws 1931, c. $96, \S 1$.

22163 Wash. 659, 2 P. 2 d 653 (1931).

23 Id. at 663 , emphasis added.

24 Id. at 664.

${ }^{25}$ And see Miethke v. Pierce County, 173 Wash. 381, 23 P. 2d 405 
whether the ad valorem method limitation continues, or whether specific property taxes are now permissible. If an ad valorem requirement is found, it will have to be derived from the words "taxes shall be uniform upon the same class of property," because the words in the old provisions which spelled out this requirement are no longer present. Certainly their deletion could stand as a good argument for the proposition that property may be classified and the classes taxed by the specific method. ${ }^{26}$ Turning to classification of property for different rates, one limitation is spelled out in the new Art. VII, §1. Real estate may not be further classified, except for certain express exceptions. The discussion below of the income taxes indicates that classifications of property may well be looked upon much more critically than classifications found in nonproperty taxes. Moreover, the court has ruled out graduated property tax rates as being arbitrary classifications.

\section{(2) Net income and gross income taxes}

The record of the Washington legislature's attempt to incorporate a net income tax of some form (whether on individual income, or corporate income, or both) into the Wash-

(1933); Libby, McNeill \& Libby v. Ivarson, 19 Wash. 2d 723, 144 P. 2d 258 (1943).

${ }^{26} \mathrm{~A}$ problem arising under the proviso in Art. VII, $\$ 1$ (which provides "that the legislature may tax mines and mineral resources and lands devoted to reforestation by either a yield tax or an ad valorem tax at such rate as it may see fit, or by both") was dealt with in State ex rel. Mason County Logging Co. v. Wiley, 177 Wash. 65, 31 P. 2d 539 (1934). The proviso states an exception to the requirement that real estate shall be one class. In the Wiley case the court, by a 6-3 decision, upheld a specific tax upon such property. The issue involved only an interpretation of the proviso, however, and, in particular, the words reading "either a yield tax or an ad valorem tax as such rate as it may see fit, or by both." By a rather strained interpretation of the word "rate," the majority decided that the proviso sanctioned a tax upon an arbitrary or fixed value of such land per acre. The dissent contended that the proviso ruled out a specific property tax. 
ington tax structure is a record of frustration, albeit by a slim judicial majority. The record perhaps justifies the apparent attitude on the part of the legislature, which might be characterized as, "if at first you don't succeed. . . ." A chronological review of the cases, including those cases marking the success of the legislature in the gross income tax field, will be most enlightening.

The first cases pertinent to this particular problem were decided immediately before the adoption of the new uniformity clause in Art. VII, $\S 1$ by the amendment of 1930 . However, they laid the groundwork for the later judicial bulwark erected to prevent the use of a net income tax in Washington. In 1929 the legislature enacted a statute purporting to impose a "tax measured by income upon banks and financial corporations." 27 The statute, in sections 3 and 4, recited that banks, other than national banking associations, ${ }^{28}$ and financial corporations, as defined, were to pay annually,

in addition to all other taxes or charges, for the privilege of exercising its corporate franchise within this state, a tax according to or measured by its net income . . . at the rate of five per cent upon the basis of its net income. . . .

The tax was immediately challenged in Aberdeen Savings $\mathcal{E}^{\circ}$ Loan Association v. Chase, ${ }^{29}$ and Burr, Conrad E Broom v. Chase. ${ }^{30}$ The only issue which the court actually faced concerned the validity of the tax under the equal protection clause of the fourteenth amendment to the United States Constitution. The court first held that the tax was a property tax-that is, the tax was upon income, income is property,

27 Wash. Laws 1929, c. 151.

28 National banks were dealt with separately in section 2 of the act, the different method being necessary in order to conform to the federal limitation in R.S. $\$ 5219$.

29157 Wash. 351,289 Pac. 536 (1930).

30157 Wash. 393, 289 Pac. 551 (1930). 
therefore the tax was upon property. ${ }^{31}$ Relying solely upon Quaker City Cab Company v. Pennsylvania, ${ }^{\mathbf{3 2}}$ a United States Supreme Court decision applying the federal equal protection clause to a Pennsylvania tax, the court held that the tax under consideration violated the equal protection clause because co-partnerships and individuals engaging in the same type financial business as the corporations subject to the tax, and consequently engaging in competition with those corporations, were not subject to the tax.$^{\mathbf{3 3}}$ Translated into terms of the object of the tax-i.e., income-, the court was saying that it was discriminatory to tax the property (income) of a certain class of corporations (the class being based on the type of business done), when the same type of property in the hands of others engaged in a similar business was not taxed. It should be noted that the minimum class referred to was not "income" as such, but a class of property characterized by the kind of business conducted by the owner of the property taxed. Both of these cases were 6-3 decisions, the dissenting judges vigorously disagreeing with the determination of the majority that the tax was a property tax. ${ }^{34}$

In 1932 a general net income tax law was passed as an initiative measure. ${ }^{35}$ The measure provided for a tax which was to reach income from all sources. Various exemptions from gross income were allowed in computing net income, and various deductions were allowed in computing the taxable net income. There were minimum personal exemptions,

31 Aberdeen Savings \& Loan Ass'n v. Chase, supra note 29 at 361, 363364; Burr, Conrad \& Broom v. Chase, supra note 30 at 397. On rehearing, at 392 .

32277 U.S. 389,48 S. Ct. 553 (1928).

33 Aberdeen Savings \& Loan Ass'n v. Chase, supra note 29 at 373 ; Burr, Conrad \& Broom v. Chase, supra note 30 at 395-396. On rehearing, at 392. 34 Aberdeen Savings \& Loan Ass'n v. Chase, supra note 29 at 375, 379.

${ }^{35}$ Initiative Measure No. 69; Wash. Laws 1933, c. 5. 
and the rate schedule was progressively graduated. Section 1 of the measure stated:

Present conditions point the need of a new subject matter for taxation, which should be based on the ability to pay. Earnings for a given period are a fair measure of such ability.

The people of the state of Washington, therefore, exercising herein their supreme power and fundamental right, declare their purpose hereby to tax all anmual incomes. within the state as such, and not as property.

There shall be assessed, levied, collected and paid annually, a tax on all net income as hereinafter provided. . . . (Emphasis supplied.)

The measure was adopted on November 8, 1932, to be effective a month later.

The tax was immediately challenged and held unconstitutional in Culliton v. Chase. ${ }^{36}$ The opinion, delivered on September 8, 1933, was 5-4, with very strong dissents. The language of all the opinions, when considered together with the opinions in the 1936 Jensen case, infra, suggest almost violent controversy. ${ }^{37}$ The majority first held that the tax was a property tax. ${ }^{38}$ It reasoned that the tax was imposed directly on income, and, notwithstanding the recital to the contrary, income is property: therefore the tax was upon property. Two factors supported this conclusion. First, Art. VII, §1 defined "property" to ". . . mean and include everything, whether tangible or intangible, subject to ownership." Second, the majority asserted that the Aberdeen case, supra, "definitely decided in this state that an income tax is a property tax. . . ."39

36174 Wash. 363, 25 P. 2d 81 (1933).

${ }^{37}$ Cf. Pound, "Cacoethes Dissentiendi: the Heated Judicial Dissent," 39 A.B.A.J. 794 (1953).

38 Culliton v. Chase, supra note 36 at 374-378, 380-381.

${ }^{39} \mathrm{Id}$. at 376 . The majority asserted that the numerous cases from other jurisdictions on this problem had no relevancy because "of our peculiarly 
Being characterized as a property tax, the act was therefore subject to the requirement of Art. VII, $\S 1$ that "taxes shall be uniform upon the same class of property." And it was held that the graduated rate feature was an arbitrary classification of property, the majority opinion simply asserting that "It needs no argument to demonstrate that the income taxes here levied are wholly lacking in uniformity. . . .\$40 The opinion is not clear as to precisely what extent the majority of five felt that income might be classified. That two of the five in the majority looked upon income as a minimum class is indicated by the dictum in the chief opinion, concurred in by one other justice.

It may be possible to frame an income tax law which will assess all incomes uniformly and comply with our constitution, which, of course, is not now before us and we need not consider it. ${ }^{41}$

However, the three other concurring justices made it quite clear that the objectionable feature of the tax was the graduated rate schedule. ${ }^{42}$

The dissent in the Culliton case took issue with the majority on all points. First, it asserted that regardless of the words in the statute the tax was an "exaction for the enjoyment of privileges, made possible by the protection of the organized

forceful constitutional definition and the difference in their constitutional authorization or restriction." In further support of its analysis of the problem, the majority noted (at 377) that the Aberdeen case was decided in June of 1930 , and that the present Art. VII, $\S 1$ was adopted by amendment in November of 1932; therefore, it was concluded that "After the decision by this court in the Aberdeen Savings $\mathcal{E}$ Loan Assn. case . . . deciding that income was property for the purposes of taxation, the people adopted the fourteenth amendment [i.e., that amendment altering Art. VII, \$1] ... which made it a part of the fundamental law of the state. . . "

t0 Id. at 378 .

41 Id. at 379.

42 Id. at 382, 384. 
state," and, therefore, a nonproperty tax. ${ }^{43}$ Second, even assuming that the tax was upon property, the dissent would have held that the graduated rates were reasonable classifications and therefore within the limitation of Art. VII, $\$ 1 .^{44}$

At the same time that a majority of the Washington Supreme Court was looking unfavorably upon net income taxes, a different majority of the court was willing to view more liberally a Business and Occupation $\mathrm{Tax}^{45}$ first imposed in 1933. The tax was upheld in State ex rel. Stiner v. Yelle, ${ }^{46}$ decided in 1933. The opinion was handed down on the date of the Culliton case opinion. Section 2(2) of the act which imposed the tax provided that there was to be levied upon

every person an annual tax or excise for the privilege of engaging in business activities. Such tax or excise shall be measured by the application of rates against values, gross proceeds of sales, or gross income, as the case may be, as follows. . . .

There followed an enumeration of the several "classes" of business, classified according to type of business done, with a different proportional rate applicable to each class. The rates ranged from $.25 \%$ to $5 \%$ of gross income derived from the particular type of business. The governor had vetoed two provisions of the act-one as to that part which classified the business of those engaged in agriculture, and, second, the

43 Id. at 389-390, 393. The dissent by Judge Blake supported this position in part by a reference to Pacific Telephone \& Telegraph Co. v. City of Seattle, 172 Wash. 649, 21 P. 2d 721 (1933) (also see Puget Sound Power \& Light Co. v. Seattle, supra note 3), decided some few months previously, and in which the court had upheld a local occupation tax with a base of gross revenue as a nonproperty tax. It was his position, at 394, that "If a tax on gross revenue is an excise, a tax on net income must be."

44 Id. at 396-401.

15 Wash. Laws 1933, c. 191.

10174 Wash. 402, 25 P. 2d 91 (1933). 
final "catch-all" clause 2(f), which described a "class" as follows:

Upon every person engaging in or continuing within this state in any business not included in [the enumerated classes], and upon every person engaging or continuing within this state in the business of rendering, performing or selling services, professional or otherwise. . . .

Obviously, the scope of the act as originally conceived by the legislature was considerably restricted by force of the governor's veto.

In the Yelle case, it was first held that the tax was not a property tax, and therefore not within the scope of Art. VII, $\S 1$ of the constitution. ${ }^{47}$ The majority on this point distinguished the tax from a net income tax, saying:

The act does not concern itself with income which has been acquired, but only with the privilege of acquiring, and that the amount of the tax is measured by the amount of the income in no way affects the purpose of the act or the principle involved. ${ }^{48}$

This, of course, is the same argument used by the dissent in the Culliton case. If perchance the distinctions have become too finely drawn for the casual reader, perhaps the dilemma which produced such fine distinctions is explained by this statement of the majority:

. . . we are well satisfied that this is not a property tax, even under the broad and all inclusive terms of our constitution. To hold otherwise would render it exceedingly difficult if not impossible to sustain any excise tax. ${ }^{49}$

Having held that the tax was a nonproperty tax, the majority then held that the classifications in the act were not

47 Id. at 404-407.

48 Id. at 407.

${ }^{49}$ Id. at 406. Emphasis added. 
arbitrary, ${ }^{50}$ that is, that the object was not unreasonable even though all possible businesses or occupations were not included.

Finally, it might be of interest to note that the decision which upheld the Business and Occupation Tax was also a 5-4 decision, as was the decision striking down the Net Income Tax, supra. The majority in Yelle consisted of the four dissenters in Culliton plus Judge Holcomb. However, two of the four dissenting judges in Yelle agreed as to the nature of the tax, but would have ruled that the exclusion of farmers and professionals was arbitrary. ${ }^{51}$

When the legislature evidently took its cue from the $Y$ elle case, and in 1935 again enacted net income tax measures, but now framed in terms of "privileges," it failed to estimate the court majority's aversion to net income measures in any form. The legislature imposed a Personal Net Income $\mathrm{Tax}{ }^{52}$ and a companion Corporate Net Income Tax. ${ }^{53}$

Section 2 of the Personal Net Income Tax provided that there was to be

levied, collected and paid to the state for each income year by every resident of the State of Washington for the privilege of receiving income therein while enjoying the protection of its laws...

a "normal tax" of $3 \%$ of taxable net income, and a "surtax" of $4 \%$ of all "surtax net income in excess of $\$ 4,000$. ." The tax reached income from all sources, with certain credits and minimum personal exemptions being allowed. In Jensen v.

00 Id. at 408-412. And see Supply Laundry Co. v. Jenner, 178 Wash. 72, 34 P. 2d 363 (1934), upholding particular classifications under the act as amended in 1933 (Wash. Laws 1933, Ex. Sess., c. 57) which considerably broadened the scope of the act.

${ }^{51} I d$. at 421-425.

52 Wash. Laws 1935, c. 178.

${ }^{63}$ Wash. Laws 1935, c. 180, Title XVII, \$§159-184. 
Henneford, ${ }^{54}$ decided in 1936, this tax was challenged and held to violate the uniformity clause in Art. VII, $\S 1$ of the state constitution. As in the Culliton case, this was a 5-4 decision. The bench was composed of the same nine judges, and there was the same division among them on this question. First, the majority held that the tax was a property tax, notwithstanding the words of the statute. "The character of a tax is determined by its incidents, not by its name." ${ }^{155} \mathrm{~A}$ legislative body cannot change a tax's fundamental features by use of a title. To the majority, the act was clearly concerned with the property, i.e., income, upon which the rate was to be applied, not with the mere privilege of receiving such income.

Having held that the tax was a property tax, the majority in the Jensen case then ruled that the tax violated the uniformity clause of Art. VII, $\S 1$ for three reasons. ${ }^{56}$ First, the surtax provision was held to be a graduated rate and therefore invalid on the authority of the Culliton case. However, the surtax provision was said to be severable, and for that reason the remainder of the tax might stand. Second, as for the normal tax provision, the court reasoned as follows: rents from real estate were included as a part of taxable net income. A tax upon the income from realty was ruled to be a tax upon the realty itself. Thus, the act in effect divided real estate into two classes (i.e., that which produced rent and that which did not) and taxed only one. This was a violation of the limitation in Art. VII, $\$ 1$ which declares that "real estate shall constitute one class" of property. Third, the provisions under the normal tax rate providing for credits and minimum personal exemptions were held to constitute a violation of the classification limitation in Art. VII, $\S 1$. This re-

54185 Wash. 209, 53 P. 2 d 607 (1936).

55 Id. at 217-219.

s6 Id. at 220-223. 
sult was required because "net income" under Art. VII, $\$ 1$ "constitutes one class of property." This ruling made it unnecesary for the court to pass on the taxpayer's contention that there was an arbitrary classification because the act reached only the income of individuals. However, the court did note that the two companion acts should be read in pari materia, and that, consequently, they showed an intent to reach all income. ${ }^{57}$ Thus, the foundation for the decision on the Corporate Net Income Tax was laid.

In Petroleum Navigation Company v. Henneford $d^{68}$ the remainder of the 1935 net income tax structure was killed when the court held that the Corporate Net Income $T_{a x}{ }^{69}$ violated the uniformity clause in Art. VII, $\$ 1$. In a 6-3 decision (one of the dissenting judges in the Jensen case now saw fit to join the majority) the court briefly disposed of the tax. Relying on the Aberdeen case, the court held that the tax imposed a property tax, not an excise tax. Citing the Burr case, the court without discussion stated that the tax was a violation of the uniformity clause because " $[t]$ he property of the respondent may not be subjected to a tax not imposed upon the property of copartners and individuals." mitted that this proposition is really broader than the Burr case, for, as pointed out above, the decision there rested on

57 Id. at 224.

58185 Wash. 495, 55 P. 2d 1056 (1936).

${ }^{50}$ Wash. Laws 1935, c. $180, \S 161$, provided that:

Every bank and corporation other than a national bank or national banking association, for the privilege of exercising its corporate franchise in this state or for the privilege of doing business in this state, shall annually pay to the state, in addition to annual license fees, a tax according to, or measured by, its net income equal to four per cent of such net income. ...

The phrasing of the statute is substantially identical to the 1930 financial institutions tax, supra, which was held in the Aberdeen case, supra note 29, to be on net income.

${ }^{60}$ Petroleum Nav. Co. v. Henneford, supra note 58 at 497. 
the fact that the property (i.e., income) of copartners and individuals engaged in similar business (i.e., the banking business) was not taxed. No suggestion was made in the Burr and Aberdeen cases that income was a single minimum class.

Some sixteen years later the Washington legislature again made an effort to use net income as the base of a corporate excise tax. Using language almost identical to that in the 1935 statute which was struck down in the Petroleum Navigation Company case, the legislature provided that

Every bank and corporation other than a federal savings and loan association or national banking association, for the privilege of exercising its corporate franchise in this state or for the privilege of doing business in this state, shall annually pay to the state, in addition to annual license fees, an excise tax according to, or measured by, its net income equal to four per cent of such net income. . . . ${ }^{\text {B1 }}$

If the Aberdeen, Burr, Culliton, Jensen, and Petroleum Navigation Company cases were to be followed, the result was a foregone conclusion.

With one exception (Judge Beal) there had been a complete turnover on the court. Judge Beal had been in the minority in the Jensen case, but had switched to the majority in the Petroleum Navigation Company case. Whatever might have been the hopes of the legislative branch of the government, the court did not reverse itself, and in Power, Incorporated v. Huntley, ${ }^{62}$ decided in 1951, the 1951 Corporate Excise Tax was held to violate the uniformity clause in Art. VII, $\S 1$ of the Washington Constitution. The majority asserted that "[i]t is no longer subject to question in this court that income is property." Relying on the Jensen

61 Wash. Laws 1951 , Ex. Sess., c. 10, \$7.

6239 Wash. 2d 191, 235 P. 2 d 173 (1951).

${ }^{63} I d$. at 194. 
and Petroleum Navigation Company cases, the majority concluded that

the tax is a mere property tax "masquerading as an excise." ... It has no reference to income from the various business activities on which the business and occupation tax, a true excise tax, is based, but taxes any income from almost every source. . . .

We recognize the right to levy an excise tax on the privilege of doing business or exercising corporate franchises and to base that tax on income; but the tax must be, "in truth, levied for the exercise of a substantive privilege granted or permitted by the state. ${ }^{\prime 84}$

The majority held that the act violated the uniformity clause because "it levies no tax on the incomes of individuals and copartnerships which may be in competition with corporations required to pay the tax. ${ }^{385}$ The Burr and Aberdeen cases were cited, as well as the Culliton and Petroleum Navigation Company cases. It should be noted that the court here revived the phrase "in competition with," which narrows the minimum class to less than income as a whole. It is interesting to note that this decision was again a split decision, now 6-3. Thus, perhaps the legislature should not feel that all hope is lost.

\section{ANALYSES OF STATES WITH TYPE IX CLAUSES}

\section{Rhode Island}

The present constitution of Rhode Island was adopted in 1843. Prior to that time the 1663 Charter of Rhode Island and the Providence Plantations served as the organic document of the state. In the present constitution of Rhode Is-

${ }^{64}$ Id. at 196-197.

65 Id. at 195. Emphasis added. 
land there is a single provision concerning uniformity of taxation. Section 2 of Art. I (the Declaration of Rights) reads:

All free governments are instituted for the protection, safety and happiness of the people. All laws, therefore, should be made for the good of the whole; and the burdens of the state ought to be fairly distributed among its citizens.

The underlined clause is the nearest thing to a uniformity clause in the Rhode Island Constitution.

There has been little positive judicial development of the meaning of the effective uniformity limitation in Rhode Island. No statements are found concerning the distinction between property and nonproperty taxes. Indeed, there is nothing to indicate the source of the uniformity required of nonproperty taxes. The few cases have dealt with property taxation. Those cases indicate that the limitation in Art. 1, $\$ 2$, which is applicable to property taxation, is no greater a limitation than that found in the equal protection clause of the fourteenth amendment to the United States Constitution. ${ }^{1}$ However, there have been few occasions for the Rhode Island court to test this proposition. It has held that there is no rule of universality. ${ }^{2}$ In upholding the exemption of property the court stated:

That the last clause of said article [i.e., Art. I, §2] relates to and was intended to control, in a general way at least, the framing of laws relating to taxation, there can be no doubt. It clearly means that taxes are to be fairly distributed; that A ought not to be taxed and B exempted from taxation, they being similarly situated; nor ought the one to be taxed on a different basis from the other. . . . But that it means that

${ }^{1}$ For example, Manufacturers' Mutual Fire Ins. Co. v. Clarke, 41 R.I. 277, 281-283, 100 Att. 400 (1918).

${ }^{2}$ See Manufacturers' Mutual Fire Ins. Co. v. Clarke, supra note 1; Brown University v. Granger, 19 R.I. 704, 36 Atl. 720 (1897). Cf. McTwiggan v. Hunter, 18 R.I. 776, 30 Atl. 962 (1895). Any implications to the contrary in the McTwiggan case were dispelled in the Brown University case. 
the General Assembly has no power to exempt any property whatever from taxation, or that property theretofore exempted by charter was to be affected thereby, is wholly unreasonable. ${ }^{3}$

The court has not faced the problem of approving or disapproving a particular classification of property for the purpose of applying different effective rates. ${ }^{4}$ Nor is there any indication whether property may be taxed by the specific method.

\section{Vermont}

The present constitution of Vermont came into effect in 1793. Serving as the basic uniformity clause of that constitution is the following italicized part of Art. IX of the Bill of Rights (chapter I):

.. . every member of society hath a right to be protected in the enjoyment of life, liberty, and property, and therefore is bound to contribute his proportion toward the expense of that protection. ...

The same provision appeared in substantially the same form in the prior constitutions of 1777 (Ch. I, Art. IX) and 1786 (Ch. I, Art. X).

The Vermont court has ruled that Art. IX, of Chapter I, limits all taxes, and has equated that provision to the equal protection clause of the fourteenth amendment to the United States Constitution, saying:

The equality clause [in the Fourteenth Amendment of the Federal Constitution] and the proportional clause of our

3 Brown University v. Granger, supra note 2, at 710 . Emphasis added.

4 However, see the dictum in Manufacturers' Mutual Fire Ins. Co. v. Clarke, supra note 1, at 281, 283. Also, cf. Mexican Petroleum Corp. v. Bliss, 43 R.I. 243, 100 Atl. 867 (1920). 
Constitution are of the same effect so far as the question of classification is concerned. ${ }^{1}$

As for the taxation of property, the court has indicated that there is no rule of universality, ${ }^{2}$ and that property may be classified for the purpose of applying different effective rates. ${ }^{8}$ However, the court has had no occasion to test in any critical way these propositions and the equation of the uniformity limitation with the federal equal protection clause. For example, there has been no test of a comprehensive classified property tax, or the principle of progressively graduated rates. The court has ruled that an inheritance tax was a nonproperty tax. ${ }^{4}$ There have been no uniformity cases concerning the Vermont graduated personal net income tax.

${ }^{1}$ Clark v. City of Burlington, 101 Vt. 391, 409, 143 Atl. 677, 684 (1928), emphasis supplied. Also see Great Atlantic \& Pacific Tea Co. v. Harvey, 107 Vt. 215, 225, 177 Atl. 423 (1935). In the Atlantic \& Pacific Tea Company case the court struck down the state chain store tax on the authority of Stewart Dry Goods Co. v. Lewis, 294 U.S. 550 , 55 S. Ct. 525 (1934). The tax had a base of gross sales receipts, with a rate progressively graduated according to the amount of gross sales. Also see State v. Caplan, 100 Vt. 140, 135 Atl. 705 (1927) upholding a classification under the motor vehicle registration tax, a nonproperty tax.

2 See Colton v. Montpelier, 71 Vt. 413, 45 Atl. 1039 (1899); Village of Hardwick v. Wolcott, 98 Vt. 343, 129 Atl. 159 (1925). In the Hardwick case, the court said at 349 :

The only requirement of our Constitution in this matter is that every member of society shall contribute his proportion towards the expense of the governmental protection afforded him. . . . It is enough to say for the purpose of this case, at least, that the limitation imposed by our Constitution does not forbid any classification of property for the purpose of taxation, or the adoption of any scheme of taxation, provided that they do not offend the Federal Constitution, the equality clause in the former and the uniform clause in the latter being in effect the same for such purposes. [Emphasis supplied.]

${ }^{3}$ Clark v. City of Burlington, supra note 1.

In re Hickok's Estate, 78 Vt. 259, 62 Atl. 724 (1904). 


\section{J. ANALYSES OF STATES WITHOUT UNIFORMITY CLAUSES}

\section{Connecticut}

The constitution of Connecticut, which came into force in 1818 , has no provisions expressly dealing with uniformity of taxation. Any requirement of uniformity of taxation must be derived from section 1 of Art. I (Bill of Rights). Section 1 is the equivalent of an "equal protection" clause, and reads:

That all men when they form a social compact, are equal in rights; and that no man, or set of men are entitled to exclusive public emoluments or privileges from the community.

The Connecticut court, in holding that there is no provision in the state constitution which requires uniformity and equality of taxation, has stated:

... [I]s there in our fundamental law any express provision, or clear implication from provisions therein contained, that "taxation shall be uniform and equal?"

There can be no claim that such a mandate is directly expressed, either in the State or National Constitution. Express provisions of that nature may be found in the local Constitutions of many States, and have proved a source of practical difficulties for legislatures and courts. They are not found in our own, which assumes that experience has taught that the power of taxation cannot safely be cabined within a theory of uniformity and equality. Taxes, to be both uniform and equal, affecting each inhabitant in proportion to his ability to contribute, can only be devised by a government unhampered by the limitations of humanity. . . .

Is this maxim necessarily implied from any provisions of our fundamental law? Unless the vague notion of a higher law is claimed as a constitutional provision, we are pointed to no provision, nor to any combination of provisions, from which it is claimed that such a maxim is a necessary implication. ${ }^{1}$

${ }^{1}$ State v. Travelers Ins. Co., 73 Conn. 255, 261-262, 47 Atl. 299 (1900). And see In re Nettleton's Appeal, 76 Conn. 235, 243, 56 Atl. 565 
Generally, when a particular tax has been challenged on the principle of uniformity (the cases are extremely few) the discussion has turned chiefly on the equal protection clause in the fourteenth amendment to the United States Constitution. ${ }^{2}$

While one may conclude that in Connecticut there is only a requirement that taxes be uniform within classes (whether the tax be property or nonproperty), few cases have arisen concerning the many specific problems of uniformity of taxation as analyzed in this monograph. In State v. Travelers Insurance Company ${ }^{3}$ the court upheld a minor classification of property for the application of different effective rates. In In re Nettleton's Appeal ${ }^{4}$ the court upheld an exemption under the inheritance tax. All estates of deceased persons were exempted from the tax if such estates amounted to less than $\$ 10,000$. The court held that the tax was an exaction from the estate of the decedent.

\section{Iowa}

The present constitution of Iowa, dated 1857, contains a single provision which deals expressly with uniformity of taxation. Article VIII, \$2 concerns a particular problem, and reads:

(1903). In Phelps Montgomery v. Branford, 107 Conn. 697, 142 Atl. 574 (1928), the court equated the federal equal protection clause and Art. I, $\$ 1$ of the Connecticut Constitution.

2 For example, State v. Murphy, 90 Conn. 662, 98 Atl. 343 (1916), and the cases cited supra note 1 .

${ }^{3}$ Supra note 1, and see the dictum in Bassett v. Rose, 104 A. 2d 212, 214 (1954).

4 Supra note 1. Also see State v. Murphy, supra note 2, in which the court upheld as reasonable an exemption from a license tax on the use of billboards on land, with the rate being so much per square foot, and with an exemption of all signs four square feet or less. Other recent cases are Hoenig v. Connelly, 105 A. 2d 775 (1954), and First Federal Svg. \& Loan Ass'n v. Connelly, 115 A. 2d 455 (1955). 
The property of all corporations for pecuniary profit shall be subject to taxation, the same as that of individuals.

Any other requirement of uniformity in taxation must be derived from the Bill of Rights, Art. I, $\S 6$, which provides that

All laws of a general nature shall have a uniform operation; the General Assembly shall not grant to any citizen, or class of citizens, privileges or immunities, which, upon the same terms shall not equally belong to all citizens.

In the original constitution of Iowa (1846), only Art. I, §6 was present.

All taxes-property or nonproperty-are limited only by the requirement that they be uniform within classes. ${ }^{1}$ This requirement stems from Art. I, $\S 6$, which is the rough equivalent of the federal equal protection clause. For this particular purpose, the court has equated the uniformity required by the Iowa Constitution with that degree of uniformity required by the fourteenth amendment to the federal Constitu-

1 For example, in Pierce v. Green, 229 Iowa 22, 294 N.W. 237 (1940) the court stated, at 28:

In almost all of the constitutions of the states there are provisions requiring that taxation be equal and uniform. These provisions vary in their phraseology. Some are general, and others are quite specific and definite. These provisions of the Iowa constitution are of the first class.

The court had reference to Art. I, \$6. However, the court indicated, at 29, that the "purpose of equality and uniformity provisions of the constitution" is accomplished when all property of the same class is treated alike. And see, as to nonproperty taxes: Vilas v. Iowa State Board of Assessment and Review, 223 lowa 604, 273 N.W. 338 (1937) (Income Tax); Tolerton \& Warfield Co. v. Iowa State Board of Assessment \& Review, 222 lowa 908, 270 N.W. 427 (1937) (Chain Store Tax); Plank v. Grimes, 238 Iowa 594, 28 N.W. 2d 34 (1947) (Motor Vehicle Fuel Tax); W. J. Sandberg Co. v. Iowa State Board of Assessment \& Review, 225 Iowa 103, 278 N.W. 643 (1938) (Sales Tax); lowa Motor Vehicle Ass'n v. Board of Railroad Com'rs, 207 lowa 461, 221 N.W. 364 (1928) (Motor Carrier Tax). 
tion. ${ }^{2}$ The court has upheld the validity of graduated rates found in certain nonproperty taxes, ${ }^{3}$ and has ruled that the Iowa income tax is a nonproperty tax. The distinction in Iowa between property and nonproperty taxes becomes important only insofar as the special limitation found in Art. VIII, $\$ 2$ is concerned. ${ }^{5}$

As for property taxation, there have been few cases developing particular rules of uniformity. However, it does seem clear that property may be classified for the application of different effective rates to the different classes. ${ }^{\circ}$ The court has held that there is no rule of universality. ${ }^{7}$ However, the requirement in Art. VIII, $\$ 2$ limits to a degree the possible

2 For example, in Dickinson v. Porter, 240 Iowa 303, 400, 35 N.W. $2 d$ 66 (1949), the court said:

Article III, section 30, and Article 1, section 6, of our state constitution, ... require that the law in question have a uniform operation throughout the state. The effect of section 1, Fourteenth Amendment to the Constitution of the United States as applied to this case is substantially the same as these uniformity provisions of our own constitution. In general, if a law does not offend against one constitution it is inoffensive to the other.

Also see Tolerton \& Warfield Co. v. Iowa State Board of Assessment \& Review, supra note 1 .

3 Vilas v. Iowa State Board of Assessment \& Review, supra note 1, upholding the graduated rate schedule under an income tax. Also see Tolerton \& Warfield Co. v. Iowa State Board of Assessment \& Review, supra note 1, as to the graduated rate schedule under the chain store tax, and following the federal cases discussed infra, Chap. IV, in striking down as an arbitrary classification that part of the act which imposed a graduated rate according to the amount of gross sales.

4 Vilas v. Iowa State Board of Assessment \& Review, supra note 1.

5 For example, the Vilas case, supra note 1 , in which the court found that the income tax was not a property tax and therefore not limited by Art. VIII, §2. Also see Scottish Union \& National Ins. Co. v. Herriott, 109 Iowa 606, 80 N.W. 665 (1899).

- For example, Pierce v. Green, supra note 1.

7 See Leicht v. Burlington, 73 lowa 29, 34 N.W. 494 (1887); Dickinson v. Porter, supra note 2. 
classes of property which may be exempted. Thus exemptions relating solely to corporate property are likely to run afoul of Art. VIII, $\$ 2 .^{8}$

\section{New York}

The state of New York has had three constitutions, dated 1777,1846 , and 1894, respectively. There have been several substantial revisions of the existing constitution of 1894 , the latest being by the constitutional convention of 1938. Until 1938 there were no provisions expressly dealing with uniformity of taxation other than the provision of the 1894 constitution (Art. III, $\S 18$, renumbered $\S 17$ in 1938) prohibiting a private or local bill from granting an exemption from taxation on real or personal property. Nor was any provision in the Bill of Rights equivalent to an equal protection clause.

Some minor changes were made (insofar as the problem of uniformity of taxation is concerned) by the 1938 convention. An equal protection clause was added, numbered Art. I, §11. A new "Taxation" article was added. Article XVI, §1 provides that "Exemptions from taxation may be granted only by general laws." A special problem is dealt with by Art. XVI, §3, which does not change the uniformity structure, but does restrict the manner in which intangible personal property may be taxed. That section provides:

. . . Intangible personal property shall not be taxed ad valorem nor shall any excise tax be levied solely because of the

${ }^{8}$ For example, Dubuque v. Illinois Cent. R. Co., 39 Iowa 56 (1874), in which the court held that a gross-earnings tax on railroads, purportedly in lieu of all property taxes, was a violation of Art. VIII, \$2; similarly in Hawkeye Ins. Co. v. French, 109 Iowa 585, 80 N.W. 660 (1899) the court held invalid the in lieu provision of an insurance company gross-earnings tax, exempting the companies from payment of all other taxes, except those on realty and special assessments. 
ownership or possession thereof, except that the income therefrom may be taken into consideration in computing any excise tax measured by income generally. Undistributed profits shall not be taxed.

The New York court has ruled that taxes in New York need only be uniform within classes, whether the particular tax is characterized as a property tax or a nonproperty tax. ${ }^{1}$ Before 1938, the source of the limitation was solely the equal protection clause of the fourteenth amendment to the federal Constitution. Since 1938, the equal protection clause of the New York Constitution (Art. I, §11) has also served as a source for the limitation. There has been little controversy in New York as to particular rules of uniformity, the cases cited being generally limited to the problem of whether the object of a given tax was a reasonable class. It might be noted that under the new Art. XVI, $\$ 3$ the nature of a mortgage tax has become of some importance. Thus, in Franklin Society for Home Building and Savings v. Bennett, ${ }^{2}$ the court held that the tax was a recording privilege tax and therefore not within the limitation of Art. XVI, $\S 3$.

1 Perhaps the cases which might be singled out as leading cases are In re McPherson, 104 N.Y. 306, 10 N.E. 685 (1887); People ex rel. Hatch v. Reardon, 184 N.Y. 431, 77 N.E. 970 (1906); and In re Watson's Estate, 226 N.Y. 384, 123 N.E. 758 (1919). Also see: In re Bank of Manhattan Co., 293 N.Y. 515 , 58 N.E. 2 d 713 (1944), affirming 267 App. Div. 456; In re Keeney's Estate, 194 N.Y. 281, 87 N.E. 428 (1909); New York Steam Corp. v. City of N.Y., 268 N.Y. 137, 197 N.E. 172 (1935); People ex rel. Moskowitz v. Jenkins, 202 N.Y. 53, 94 N.E. 1065 (1911); People ex rel. Eisman v. Ronner, 185 N.Y. 285, 77 N.E. 1061 (1906); In re Wendel's Estate, 223 N.Y. 433, 119 N.E. 879 (1918); Woodruff v. Oswego Starch Factory, 177 N.Y. 23, 68 N.E. 994 (1903). And see People v. Equitable Trust Co., 96 N.Y. 387 (1884).

2282 N.Y. 79, 24 N.E. $2 d 854$ (1939). 


\section{Uniformity and Equality in Taxation Required by the Federal Equal Protection Clause}

THE primary purpose of this monograph is to make a comparative study of the state constitutional limi-

1 tation of uniformity in taxation. Such a study would not be complete, however, without some consideration of the equal protection clause of the fourteenth amendment to the United States Constitution, as it is applied to state taxes. The equal protection clause provides a minimum standard of uniformity within classes. Therefore, it protects the interests of the taxpayer wholly apart from any state constitutional uniformity limitation and regardless of the identity of the state levying the tax. However, because an analysis of this federal limitation is essentially collateral to the primary purpose of this monograph, the degree of uniformity required of state taxes by the equal protection clause will only be briefly outlined. ${ }^{1}$

Prior controversy was settled in 1890, when Justice Bradley stated, in Bell's Gap Railroad Co. v. Pennsylvania, ${ }^{2}$ that the equal protection clause does limit state revenue legislation. ${ }^{3}$ The "formula" by which the court has guided itself

${ }^{1} \mathrm{~A}$ comprehensive analysis of the meaning of the federal equal protection clause as it applies to state taxes was made in 1938 by Professor Sholley, "Equal Protection in Tax Legislation," 24 Va. L. Rev. 229, 388 (1938). Also see The Constitution of the United States of America, 1146-1153 (Edward S. Corwin, Editor; S. Doc. No. 170, 82nd Cong., 2d Sess., 1953); and Rottschaefer, Handbook of American Constitutional Law, 664675 (1939). The present writer is greatly indebted to these sources.

2134 U.S. 232 (1890).

${ }^{3}$ See the discussion in Sholley, supra note 1, at 230-232, which traces the development from the position taken by Justice Miller in Davidson v. New Orleans, 96 U.S. 97 (1878), to the statement by Justice Bradley in 
in cases concerning the validity of state taxes under the equal protection clause has been restated as late as the spring of 1954. Justice Jackson, speaking for the court, stated:

Equal protection does not require identity of treatment. It only requires that classification rest on real and not feigned differences, that the distinction have some relevance to the purpose for which the classification is made, and that the different treatment be not so disparate, relative to the difference in classification, as to be wholly arbitrary. ${ }^{4}$

This standard determines the legitimacy of state legislative classifications in general, ${ }^{5}$ and here it is applied in particular to tax legislation.

This formula is not too helpful in determining results in particular cases. Just when do classifications rest on "real and not feigned differences?" More significantly, when is "different treatment . . . so disparate, relative to the difference in classification, as to be wholly arbitrary?" As for "the purpose for which the classification is made," remember that ostensibly, at least, the purpose of revenue legislation is to obtain revenue. Consequently, while the "purpose" test can have real meaning in cases involving police power regulation, one may doubt the extent to which it aids in evaluating classifications in tax legislation. ${ }^{\circ}$ Nevertheless, the standard is used, and the decisions of the court may be arranged according to coherent patterns. It will be helpful for the purposes

the Bell's Gap case, supra note 2. Also see The Constitution of the United States of America, supra note 1 at 1146.

4 Walters v. City of St. Louis, 347 U.S. 231, 237, 74 S. Ct. 505 (1954), summarized in note 21 , infra.

- However, classifications based on either race or alienage must be excepted from any generalizations made in the text. See, for example, the court's latest major pronouncement on such classifications in Brown v. Board of Education, 347 U.S. 483, 74 S. Ct. 686 (1954), discussed in Kauper, "Segregation in Public Education-The Decline of Plessy v. Ferguson," 52 Mich. L. Rev. 1137 (1954).

"For a hypercritical view of the court's "verbal formula," see Sholley, 
of this monograph to follow the outline used for analysis of the state uniformity limitations. " However, it should be noted that the Supreme Court has never made a distinction between property and nonproperty taxes for the purpose of applying a stricter limitation to the former. Nevertheless, for comparative purposes that distinction can be made.

First, as for property taxes, the federal equal protection clause, in general, does not contain a rule of universality, requires only a uniformity within classes for effective rates, and does not restrict the method of taxation of property to the ad valorem method. ${ }^{8}$ The precise issues have not too often been ruled upon, perhaps because it is simply accepted as dogma not open to challenge that the equal protection clause does not prohibit state legislatures from classifying property, either for the taxation of such classes at different effective rates or for their exemption. The validity of the broadest types of classification of property such as realty and personalty, tangible and intangible, was early established in principle. ${ }^{9}$ The United States Supreme Court decisions have for

supra note 1 at 232 . A more restrained characterization of the formula is made by Rottschaefer, supra note 1 at 665 .

The principal problem under the equal protection clause has been the degree of classification permitted thereby. The rule, as generally stated, is that it prohibits unreasonable classifications only. The decisions show that there exist no universally applicable tests by which to determine whether a given classification is reasonable or unreasonable. A classification on a given basis may be valid with respect to one tax and invalid with respect to another.

${ }^{7} C f$. the analysis by Sholley, supra note 1 , and his arrangement according to the characteristics of the classifications reviewed by the Supreme Court.

8 For the first two propositions, see the cases in notes 9 through 20, infra. On the second proposition, see, for example, Lake Superior Mines v. Lord, 271 U.S. 577, 46 S. Ct. 627 (1926).

${ }^{\circ}$ For example, see the following dictum from Justice Bradley in the Bell's Gap case, supra note 2 at 237 :

[The equal protection clause] was not intended to prevent a State from adjusting its system of taxation in all proper and reasonable ways. It may, 
the most part been concerned with more refined classifications. A number of decisions have sustained subclassifications of intangibles. For example, in Klein v. Board of Tax Supervisors, ${ }^{10}$ the Supreme Court sustained a Kentucky statute which taxed shares of stock in all corporations, but excepted shares in corporations which had paid property taxes in Kentucky upon seventy-five per cent or more of their total assets. In a later decision, Madden v. Kentucky, ${ }^{11}$ the court sustained a tax of fifty cents per one hundred dollars on deposits in banks out of the state, in contrast with a rate of ten cents per one hundred dollars on deposits in the state. ${ }^{12}$ Other cases have sustained the subclassification of tangible personalty; for example, in Heisler v. Thomas Colliery $\mathrm{Co}^{13}$ the court sustained a Pennsylvania special ad valorem tax on hard coal, although no similar tax was laid on soft coal or other personal property. It will be recalled that that tax was a good illustration of the Pennsylvania uniformity limita-

if it chooses, exempt certain classes of property from any taxation at all, such as churches, libraries and the property of charitable institutions. ... [I]t may tax real estate and personal property in a different manner; it may tax visible property only, and not tax securities for payment of money; it may allow deductions for indebtedness, or not allow them. . . . We think that we are safe in saying, that the Fourteenth Amendment was not intended to compel the State to adopt an iron rule of equal taxation. If that were its proper construction it would not only supersede all those constitutional provisions and laws of some of the States, whose object is to secure equality of taxation, and which are usually accompanied with qualifications deemed material; but it would render nugatory those discriminations which the best interests of society require. . . .

10282 U.S. 19,51 S. Ct. 15 (1930).

11309 U.S. 83, 60 S. Ct. 406 (1940).

12 And see, for other examples, Bell's Gap Railroad Co. v. Pennsylvania, supra note 2; Home Insurance Company v. New York, 134 U.S. 594, 10 S. Ct. 593 (1890); Coulter v. L. \& N.R. Co., 196 U.S. 599, 25 S. Ct. 342 (1905) ; Royster Guano Co. v. Virginia, 252 U.S. 412 , 40 S. Ct. 371 (1920).

${ }^{13} 260$ U.S. 245,43 S. Ct. 83 (1922). 
tion. ${ }^{14}$ It has been said, "Another classification of property which has always been sanctioned by the Supreme Court is that between railroad property and all other property."15 However, the court has found certain classifications of property to be arbitrary. For example, in Wheeling Steel Corporation v. Glander, ${ }^{10}$ decided in 1949 , the court held invalid that part of the Ohio ad valorem property tax which levied the tax on accounts receivable owned by foreign corporations, but exempted accounts receivable of an identical nature which were owned by residents and domestic corporations. ${ }^{17}$

The general principle is well illustrated in those cases concerning the application of a different ratio of valuation to a complaining taxpayer's property. In another recent case, Hillsborough Township v. Cromwell, ${ }^{18}$ the court indicated that the consistent, systematic, and intentional discrimination in the assessment of a taxpayer's property for the purposes of ad valorem taxation would be invalid under the equal protection clause. However, it should be noted that the application of a different ratio of valuation will not run afoul the equal

14 See the discussion in the Pennsylvania study, chapter III, part G supra. 15 Sholley, supra note 1, 235, with citation of authorities.

16337 U.S. 562, 69 S. Ct. 1291 (1949).

17 The court said that the inequality was not based on the owner's relation to the decisive transaction but solely on a difference in residence of the owners of accounts receivable, and that the foreign corporation was due as equal a treatment as that given domestic corporations, at least in so far as the ad valorem tax was concerned.

Also see Louisville Gas \& Electric Company v. Coleman, 277 U.S. 32, $48 \mathrm{~S}$. Ct. 423 (1928), in which the court held invalid a tax on the recording of mortgages because it applied only to mortgages which did not mature within five years. A very severe and telling criticism of the Coleman case is found in Sholley, supra note 1 at 241-243. The opinion of the majority did not square with numerous prior cases, and it is not consistent with the trend of subsequent decisions.

18326 U.S. 620, 66 S. Ct. 445 (1946). The decision of the court concerned remedies available to the taxpayer. On this problem, see Note, "Remedies for Unequal Tax Assessments," 45 Harv. L. Rev. 1000 (1933). 
protection clause if the property affected might reasonably be placed in a separate class for purposes of taxation. ${ }^{10}$ Thus, it is clear that under the equal protection clause the state legislatures retain a great deal of discretion in classifying property, subject only to a minimum standard protecting the taxpayer against patently arbitrary classifications, an extreme case being the singling out of an individual's property. ${ }^{20}$

Second, as for nonproperty taxes the same limitation applies, namely, a requirement of uniformity within classes. ${ }^{\mathbf{2 1}}$ This, of course, is substantially the same limitation which was found to limit nonproperty taxes in practically all of the forty-eight states. More significant is the ruling of the

${ }^{10}$ Charleston Federal Savings \& Loan Assn. v. Alderson, 324 U.S. 182, 65 S. Ct. 624 (1945).

${ }^{20}$ Cf. Independent Warehouses v. Scheele, 331 U.S. 70; 67 S. Ct. 1062 (1947), in which the court sustained a New Jersey municipal license tax. The court held that the fact the ordinance applied only to commercial storage facilities, and that there were no other commercial storage facilities in the municipality subject to taxation, did not result in a violation of the equal protection clause. The principal issue concerned state taxation of interstate commerce, and on that issue there were dissents.

21 The most recent decision is Walters v. City of St. Louis, supra note 4, in which the court upheld the constitutionality of the St. Louis "income tax." The ordinance on its face classified income for taxation according to its source. One category consisted of salary and wage income, the other of profits from self-employment or business enterprise. The court did not pass upon regulations under the tax which granted employers deductions for taxes paid the federal government, but which did not allow employees a deduction for the same tax. Justices Douglas and Black expressly suggested that this latter classification raised a "serious and substantial question under the Equal Protection Clause. . . ." (p. 510). Selected important cases are Quong Wing v. Kirkendall, 223 U.S. 59, 32 S. Ct. 192 (1937) (sustaining a state license tax on hand laundries employing more than two women); Magnano Company v. Hamilton, 292 U.S. 40, 54 S. Ct. 599 (1934) (sustaining a discriminatory tax on oleomargarine); Southwestern Oil Co. v. Texas, 217 U.S. 114, 30 S. Ct. 496 (1910) (sustaining a two per cent tax on the gross receipts of wholesale dealers in mineral oils against the contention that dealers in other commodities were not subject to comparable tax burdens). 
Supreme Court that progressively graduated rates are reasonable classifications. ${ }^{22}$ The court has rarely found a classification under a nonproperty tax to be unreasonable and arbitrary.

Thus, there is a minimum standard of uniformity to which state tax legislation must conform, apart from any state constitutional limitation. The federal equal protection clause stands as a barrier to "unreasonable" classifications in state tax legislation. Of course, the difficulty here is in the use of the question-begging term "unreasonable." And like the due process limitation, ${ }^{23}$ the equal protection limitation permits a margin for differences of opinions even as to this minimum standard of uniformity.

${ }^{22}$ In the leading case, Magoun v. Illinois Trust \& Savings Bank, 170 U.S. 283, 18 S. Ct. 594 (1898), the court sustained the provisions of an Illinois inheritance tax law which granted exemptions and established rate differentials depending on the total amount of the legacy and the relationship of the beneficiary to the deceased. Also see Shaffer v. Carter, 252 U.S. 37, 40 S. Ct. 221 (1920) (graduated net income tax); Metropolis Theater Co. v. Chicago, 228 U.S. 61, 33 S. Ct. 441 (1913) (graduated license tax on theaters, the rate graduated according to the price of admission). The graduated rate principle embodied in the ordinary chain store tax was approved in Great Atlantic \& Pacific Tea Company v. Grosjean, 301 U.S. 412, $57 \mathrm{~S}$. Ct. 772 (1937), in which the court sustained a tax on chain stores graduated according to the total number of stores in the chain, including stores located outside of the state. In Grosjean the court distinguished L. K. Liggett Co. v. Lee, 288 U.S. 517, 53 S. Ct. 481 (1933), in which the court had held invalid a chain store tax under which the graduation depended upon whether the chain had stores in more than one county in the state. The first of these chain store tax cases was State Board v. Jackson, 283 U.S. 527, 51 S. Ct. 540 (1931), in which the court upheld the Indiana tax under which the graduated rate depended only on the number of stores within the state. To be contrasted with these cases is Stewart Dry Goods Co. v. Lewis, 294 U.S. 550, 55 S. Ct. 525 (1935), in which the court held invalid a chain store tax under which the graduated rate depended upon total volume of business and was applied to gross sales. See the discussion in Sholley, supra note 1 at 250-256, 261-265. Also see the discussion in Chapter V, Part C, infra.

${ }^{23}$ See Paulson, "The Persistence of Substantive Due Process in the States," 34 Minn. L. Rev. 91 (1950). 
In substantially all cases the state constitutions have the equivalent of an "equal protection" limitation-that is, some clause of the state constitution will bar "unreasonable" classifications in state legislation. While the United States Supreme Court will have the last word as to the meaning of "reasonable" under the federal equal protection clause, so will the forty-eight state courts have the last word to say as to the meaning of "reasonable" under their respective state constitutional limitations.

But in the final analysis the important point is, that even though as to some individual cases there will be differences of opinion concerning the reasonableness of the classification, the state and federal equal protection limitations will afford this minimum standard of protection even in the absence of state constitutional uniformity in taxation clauses. Indeed, many would contend that the abolition of the state uniformity in taxation clauses would not be undesirable, since legislative discretion-though obviously increased-would still be subject to this minimum standard of reasonableness, which would, however, permit a great flexibility in arranging a state revenue structure to approach more nearly a just distribution of the tax burden. ${ }^{24}$ Again, however, a question-begging term is used. For, indeed, advocates of the strictest degree of uniformity in taxation will insist that such absolute uniformity is the key to a "just" distribution of the tax burden. Thus, ultimately, the decision must be one of fiscal policy, which in turn governs the choice of constitutional doctrine. If one does accept the view that absolute uniformity is not necessarily the sine qua non for a wise fiscal policy, then the needed protection against arbitrary legislative action is found in the federal and state equal protection limitations.

${ }^{24}$ Cf. Matthews, Wm. L., Jr., "The Function of Constitutional Provisions Requiring Uniformity in Taxation," $38 \mathrm{Ky}$. L. J. 503 at 525-526 (1950). 


\section{Chapter V}

\section{A Comparative Analysis of the Uniformity}

\section{Limitations}

\section{A. ORIGIN AND DEVELOPMENT}

$S$ pointed out in the introduction, this monograph has
two major purposes. First, it should provide an un-
derstanding of the existing state constitutional limitations concerning uniformity and equality in taxation. Second, it should provide material for study in a revision of those state constitutional limitations. Both of these purposes were served by the empirical analysis of the judicial gloss given the constitutional provisions. That analysis, in Chapter III, forms the larger part of this monograph. The present section will trace briefly, and in a very general manner, the origin and subsequent development of the several types of basic uniformity clauses. ${ }^{1}$ Some knowledge of this historical development will serve, primarily, to provide light for the second purpose of the monograph. This writer recognizes that an analysis and evaluation of the economic, political, and social factors underlying this skeletonic description would be helpful. However, such a study is not deemed absolutely essential, and several factors preclude this writer from including it in this monograph.

The existing uniformity clauses, so-called, have been classified according to phraseology. The following nine basic Types were found:

I. Property shall be taxed according to its value.

II. Property shall be taxed in proportion to its value.

III. The legislature may impose proportional and rea-

${ }^{1}$ Cf. Jensen, Property Taxation in the United States 35-43 (1931). 
sonable assessments, rates, and taxes upon all persons and estates within the state.

IV. There shall be a uniform rule of taxation.

V. Taxation shall be equal and uniform.

VI. The legislature shall provide by law for a uniform and equal rate of assessment and taxation.

VII. Taxes shall be uniform upon the same class of subjects.

VIII. Taxes shall be uniform upon the same class of property.

IX. There shall be a fair distribution of the expense of government.

This classification merely reflects the existing basic uniformity clauses, and it should be emphasized that the Types are hypothetical. For example, the actual uniformity clauses found in the four states classified as Type II states will vary in their precise phraseology from the hypothetical Type II clause. Also, some of the predecessors of the existing clauses, no longer in use, cannot conveniently be fitted into any of the nine Types used for this study. Throughout this discussion, the writer will use the hypothetical Types for a common reference, but note will be taken of the several variations of each clause which have appeared.

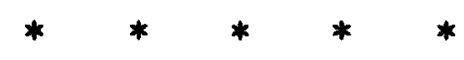

At the time the Union was formed, ten of the original thirteen states (Connecticut, Delaware, Georgia, New Jersey, New York, North Carolina, Pennsylvania, Rhode Island, South Carolina, and Virginia) had constitutions which contained no provisions either framed in terms of "uniformity" or "equality" or interpreted as providing an effective uniformity limitation. However, the constitutions of three of the original states (Maryland, Massachusetts, and New Hampshire) contained provisions which have proved to be the source of effective uniformity limitations even though 
they were not framed in the "uniform and/or equal" terminology. Of these three, the Maryland Constitution contained a variation of the basic Type IX uniformity clause, the provision reading:

Every person in the state ought to contribute his proportion of public taxes for the support of the government, according to his actual worth in real or personal property. . . .'

In the constitution of Massachusetts there was a provision similar to basic Type III, reading:

[The legislature may] impose and levy proportional and reasonable assessments, rates and taxes, upon all the inhabitants of, and persons, residents, and estates lying within the said commonwealth. . . .

The New Hampshire Constitution contained two provisions, ${ }^{4}$ one of which was substantially identical to the Type III clause in the Massachusetts Constitution, and another which was a second variation of the Type IX clause found in Maryland. The latter clause read:

Every person of the community has a right to be protected by it, in the enjoyment of his life, liberty, and property; he therefore is bound to contribute his share in the expense of such protection.

Thus it appears that historically the first of the so-called uniformity clauses were Types III and IX, even though those types are not phrased in "uniform and/or equal" terminology. Massachusetts and New Hampshire still retain the Type III uniformity clause without change, although, as will be pointed out, New Hampshire has avoided the effect of

2 Supra, p. 554. The present section is based on the historical notes included in the separate studies of the several states in Chapter III.

3 Supra, p. 172.

4 Supra, p. 181. 
that clause to some degree by special constitutional amendment.

The first two states admitted to the Union after its formation were Vermont (1791) and Kentucky (1792). Vermont included in its constitution a variation of the Type IX uniformity clause, substantially identical to that originated by New Hampshire. The Vermont provision has remained unchanged, and is in effect today. The first Kentucky Constitution had no provision relating to uniformity. At the same time that Vermont and Kentucky were admitted as new states, Delaware adopted a new constitution (1792). However, no provision relating to uniformity was included in that constitution; consequently, Delaware remained among those states having no uniformity clause of any kind.

With the admission of Tennessee into the Union in 1796, there appeared what has been characterized as the "first real uniformity provision." This characterization is accurate only if one considers terminology apart from effective limitation. As the state studies in Chapter III have shown, the Type III "proportionality" clause found in Massachusetts and New Hampshire provides a very strict property-tax uniformity limitation. Indeed, although this first Tennessee clause did use the terms "uniform" and "equal," it was a provision with a very special and limited character, requiring a quantitative rather than a qualitative uniformity. The provision read:

All lands liable to taxation, in this state, shall be taxed equal and uniform, in such manner, that no one hundred acres shall be taxed higher than another, except town lots, which shall not be taxed higher than two hundred acres of land each. 7

\section{Supra, p. 573.}

6 Matthews, Wm. L., Jr., "The Function of Constitutional Provisions Requiring Uniformity in Taxation," 38 Ky. L. J. 31, 41 (1949-1950).

7 Supra, p. 66. 
This original Tennessee provision does not easily fall within any of the nine basic types of today's uniformity clauses. However, terminology-wise, this provision is the predecessor of the basic clauses Types V and VI.

Following this innovation in the Tennessee Constitution of 1796 , there was no new development until the period from 1818 to 1821 . The four states admitted to the Union prior to 1818 (Ohio in 1803; Louisiana in 1812; Indiana in 1816; and Mississippi in 1817) and the three states adopting new constitutions prior to 1819 (Georgia in 1798; Kentucky in 1799; and Connecticut in 1818) did not include in their constitutions any provisions which might be characterized as uniformity clauses.

However, each of the three states entering the Union during the period from 1818 to 1821 (Illinois in 1818; Alabama in 1819; and Missouri in 1821) did incorporate a uniformity clause into their respective constitutions. None employed the terms "uniform" or "equal," but used the term "value" which is characteristic of basic clauses Types I and II. Specifically, the Illinois Constitution of 1818 introduced the first version of the Type II basic uniformity clause. It read:

. . . the mode of levying a tax shall be by valuation, so that every person shall pay a tax in proportion to the value of the property he or she has in his or her possession. ${ }^{8}$

Alabama followed in its constitution of 1819 with a second variation of basic Type II, which read:

All lands liable to taxation in this state shall be taxed in proportion to its value. ${ }^{\circ}$

\footnotetext{
8 Supra, p. 117.

- Supra, p. 94.
} 
The Alabama provision is more limited in scope than the Illinois clause, being limited to real property taxes. A third variation of basic Type II was introduced in the Missouri Constitution of 1820 :

All property subject to taxation shall be taxed in proportion to its value. ${ }^{10}$

The Missouri version of Type II was more akin to the briefer Alabama clause, but broader in application, being applicable to the taxation of all property. The fourth of these new states, Maine, introduced in its constitution of 1819 the original version of the Type I basic uniformity clause:

All taxes upon real estate, assessed by authority of this state, shall be apportioned and assessed equally, according to the just value thereof. . . . .11

Thus, within a three-year period, the two basic uniformity clauses characterized by the use of the word "value" (Types I and II) were introduced by Maine ("according to value") and Illinois ("in proportion to value"), with Alabama and Missouri following Illinois in the use of the word "proportion."

A very definite trend was established in 1818-1821 by these four states. Since that period, with three exceptions (Michigan, Iowa, and Nebraska), every newly admitted state has included some type of uniformity clause in its original constitution. Indeed, of the three exceptions, two adopted new constitutions within thirteen years or less (Michigan, 1837-1850; Nebraska, 1867-1875) which did contain some form of uniformity clauses. In addition, steady inroads have been made among those ten original states having no uniformity clause of any type, so that, at the present

10 Supra, p. 417.

11 Supra, p. 58. 
time, only two (Connecticut and New York) remain without any such provision.

Following the innovations in Illinois, Alabama, Missouri, and Maine there was little further development before 1838 . New constitutions were adopted in Delaware (1831), Virginia (1830), and Mississippi (1832), none of which contained uniformity clauses, thus leaving unchanged the status of each of the three states. Tennessee adopted a new constitution in 1834, and in doing so abandoned its original "quantitative" uniformity clause previously described, which was applicable only to the taxation of realty. In its place a second version of basic Type I was inserted, the first version having been introduced by Maine. Of most importance was the manner in which the Type I clause was coupled with "equal and uniform" terminology. The revised Tennessee provision now read:

All property shall be taxed according to its value, that value to be ascertained in such manner as the legislature shall direct, so that taxes shall be equal and uniform throughout the state. ${ }^{12}$

Thus, Tennessee retained the "equal and uniform" language, but now subordinated it to a basic clause of the "value" type. This subordinate clause was soon to be separated and to stand as a primary clause in other states, thus establishing the basic Type $\mathrm{V}$ provision in full force. Tennessee also included in its 1834 constitution a supplementary provision, later adopted by a number of other states, which specified:

No one species of property from which a tax may be collected, shall be taxed higher than any other species of property of the same value. ${ }^{13}$

Upon admission to the Union in 1836, Arkansas' original constitution included a basic uniformity clause which was a

12 Supra, p. 65. Emphasis added.

13 Supra, p. 65. 
third variation of the type originated by Maine in 1819, i.e., Type I. However, like Tennessee, Arkansas tacked the words "uniform and equal" onto this ad valorem type provision, with this important distinction that in the Arkansas provision the words "uniform and equal" clearly referred to "valuation." The Arkansas provision read:

All property subject to taxation shall be taxed according to its value, that value to be ascertained in such manner as the General Assembly shall direct, making the same equal and uniform throughout the state. ${ }^{14}$

Adhering closely to the Tennessee uniformity structure, the Arkansas Constitution ${ }^{15}$ also included the supplementary provision concerning rates, referred to above.

* * * * * *

The period from 1838 to 1851 (with activity concentrated in the years from 1845 to 1851 ) saw the first use of uniformity clauses phrased in "equal and uniform" language such as is used in existing uniformity clauses. In 1838, the original Florida Constitution was drafted, and it included a provision which is the distinct predecessor of basic Types $\mathrm{V}$ and VI, though closer in phraseology to Type V. The provision read:

The General Assembly shall devise and adopt a system of revenue, having regarded to an equal and uniform mode of taxation throughout the state. ${ }^{18}$

The Florida Constitution did not come into effect until 1845, because it was not until that year that Florida was admitted to the Union.

Also, in 1845 we find the first clear formulation of Type V. In that year Louisiana adopted a new constitution, which was

14 Supra, p. 49. Emphasis added.

15 Supra, p. 49.

16 Supra, p. 274. 
actually drafted in 1844, and for the first time adopted a uniformity clause. That clause was the first version of Type $V$, and it read: "Taxation shall be equal and uniform throughout the state."17 But the Louisiana basic clause did not stand alone, and we have here the first example of several overlapping uniformity clauses being included in a single uniformity structure. Louisiana's basic clause, Type V, was accompanied ${ }^{18}$ by the version of the Type II clauses ("in proportion to value") first introduced in 1820 by Missouri. In addition, there was the special supplementary clause ${ }^{10}$ concerning rates first introduced in 1834 by Tennessee.

In the same year in which the new Louisiana Constitution came into force, 1845, Texas was admitted to the Union, and in its constitution ${ }^{20}$ followed the Louisiana pattern in so far as both the Type V "equal and uniform" clause and the Type II "proportionality" clause were included. However, the Tennessee type provision concerning rates was omitted.

During the period of the Florida-Louisiana-Texas innovations, Pennsylvania (1838) and New Jersey (1844) adopted new constitutions, but no uniformity clauses of any kind were introduced. Michigan (1837) and Iowa (1846) were admitted as new states, but neither of those two states included in its original constitution any form of a uniformity clause. On the other hand, when Rhode Island adopted a new constitution in 1843, it joined those states having uniformity clauses, and included a third variation of the Type IX basic clause: ". . . the burdens of the state ought to be fairly distributed among its citizens."21

Within six years of the Florida-Louisiana-Texas development, both Types IV and VI of the basic uniformity clauses

${ }^{17}$ Supra, p. 387.

18 Supra, p. 387.

10 Supra, p. 387.

20 Supra, p. 254.

21 Supra, p. 592. 
had been introduced. Upon being admitted to the Union in 1848, Wisconsin included in its original constitution the first version of Type IV: "The rule of taxation shall be uniform. ...222 In 1851 Indiana, in adopting a new constitution, introduced the precise phraseology of Type VI, which is a modified version of the 1838 Florida provision:

The General Assembly shall provide, by law, for a uniform and equal rate of assessment and taxation, and shall prescribe such regulations as shall secure a just valuation for taxation of all property, both real and personal. . . . ${ }^{23}$

The prior Indiana Constitution had not contained any form of uniformity clause.

During this period of the Wisconsin-Indiana innovation, from 1848 to 1851 , there was considerable other activity. California and Virginia followed the pattern set by Texas in 1845, and combined a Type V clause with a Type II provision. This was done by California in its original constitution $^{24}$ when admitted to the Union in 1850, and by Virginia in the same year when a new constitution ${ }^{25}$ was adopted.

Michigan also adopted a new constitution in 1850, and in doing so joined for the first time the ranks of those states with uniformity clauses. A second version of Type IV, similar to the 1848 Wisconsin provision, was introduced, this version reading:

The legislature shall provide by law a uniform rule of taxation, except on property paying specific taxes. ${ }^{26}$

This provision, with its "except" clause, established a unique situation in Michigan, as described in the Michigan study in Chapter III. On the basis of the "except" clause taxes are

\footnotetext{
22 Supra, p. 234.

23 Supra, p. 281.

24 Supra, p. 107.

25 Supra, p. 542.

26 Supra, p. 197.
} 
classified for purposes of uniformity into ad valorem and specific rather than property and nonproperty.

Ohio's new constitution of 1851 contained that state's first uniformity clause. This provision was a third variation of basic Type IV, similar to those clauses already used by Wisconsin and Michigan. The provision read:

Laws shall be passed, taxing by a uniform rule, all moneys, credits, investments in bonds, stocks, joint stock companies, or otherwise; and also all real and personal property, according to its true value in money. ${ }^{27}$

Note that the Ohio clause, while predominantly a Type IV clause, also contains language characteristic of the Type I ad valorem clause.

In 1848 Illinois adopted a new constitution. The Type II clause ("in proportion to value") which Illinois had originated in 1818 was retained. However, it was amended, so that we now find a fourth version of Type II in use. The provision, as rephrased, read:

The General Assembly shall provide for such revenue as may be needful by levying a tax, by valuation, so that every person and corporation shall pay a tax in proportion to the value of his, her, or its property. . . .

This flurry of activity during the period from 1845 to 1851 set the pace for the last half of the nineteenth century. Until 1900 there was a steady adoption of uniformity provisions which, with one important exception to be noted, were simply variations on the types of uniformity clauses already introduced by 1851 .

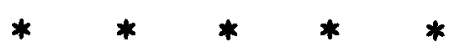

In 1852 , Louisiana adopted a new constitution, but made no change in its prior uniformity structure, notably consisting

27 Supra, p. 221.

28 Supra, p. 117. 
of the first version of Type $\mathrm{V}$, introduced in 1845. Kentucky (1850) and Iowa (1857) also adopted new constitutions without changing their prior status. That is, Kentucky and Iowa had not yet included any form of uniformity clause in their constitutions.

Minnesota was admitted to the Union in 1858 and its constitution contained the following unique provisions:

All taxes to be raised in this state shall be as nearly equal as may be, and all property on which taxes are to be levied shall have a cash valuation and be equalized and uniform throughout the state. ${ }^{20}$

Supplementing this basic clause was a new version of the Type I clause first introduced by Maine in 1820:

Laws shall be passed taxing all [property] according to its true value in money. ${ }^{30}$

Minnesota later abandoned its unique basic uniformity clause to which the court had given a most restrictive interpretation. As shown in the Minnesota study, in Chapter III, the provision caused no end of trouble. Fortunately, no other state adopted it.

The next succeeding four states to be admitted to the Union were Oregon (1859), Kansas (1861), West Virginia (1863), and Nevada (1864). All continued the trend started by Florida in 1838 by using a basic uniformity clause phrased in terms of "equal and uniform." Oregon, leaving nothing to chance, included in its constitution of $1859^{31}$ both a Type $\mathrm{V}$ clause (introduced in 1845 by Louisiana and Texas) and a Type VI clause (introduced in 1851 by Indiana). Thus, Oregon combined two clauses, both in "uniform and equal" language. This is fairly unusual, although it is evident that

\footnotetext{
29 Supra, p. 392.

${ }^{30}$ Supra, p. 392.

81 Supra, p. 455.
} 
the combination of a "uniform and equal" clause with one or more "value" clauses was quite common. Kansas, in its 1861 constitution, ${ }^{32}$ and Nevada, in its 1864 constitution, ${ }^{33}$ were satisfied with a single clause, namely, the first version of Type VI introduced by Indiana in 1851 .

West Virginia, like Oregon, was not satisfied with a single provision. Its 1863 constitution ${ }^{34}$ contained the original Type $\mathrm{V}$ clause, first introduced in 1845 by Louisiana and Texas. Unlike Oregon, the second West Virginia provision ${ }^{35}$ was the third version of a Type II proportionality clause, first introduced by Missouri in 1820. In addition, a third provision $^{36}$ was included, the special provision concerning rates introduced by Tennessee in 1834. Thus, the West Virginia structure of 1863 was identical to the complex structure first introduced in 1845 by Louisiana. Remember that in 1850 Virginia had copied the Texas structure, which, unlike Louisiana's, was limited to a combination of Type $\mathrm{V}$ and Type II. However, in a new constitution adopted in 1870, Virginia added the supplementary provision concerning rates, ${ }^{37}$ so that its structure was now identical to that in Louisiana and West Virginia.

Florida adopted new constitutions in 1861 and 1865 but left its uniformity clause of 1838 unchanged. However, when adopting a new constitution in 1868, Florida modified its original clause, the predecessor of both Types V and VI, so that it now conformed to the version of Type VI introduced by Indiana in $1851 .^{\mathbf{3 8}}$ At about this same time four "old" states joined the parade, and in adopting new con-

\footnotetext{
32 Supra, p. 307.

33 Supra, p. 333.

${ }^{34}$ Supra, p. 261.

35 Supra, p. 262.

86 Supra, p. 261.

${ }^{37}$ Supra, p. 542.

88 Supra, p. 274.
} 
stitutions also acquired for the first time uniformity clauses. They were Mississippi (1869), South Carolina (1865, 1868), North Carolina (1868), and Georgia (1868).

The new Mississippi Constitution of 1869 added another example of a multi-clause structure. Principally, the structure consisted of the Type V clause, introduced in 1845 by Louisiana and Texas, joined by the 1820 Missouri version of the Type II ad valorem clause. ${ }^{30}$ This was a combination which was to become quite popular. In addition, the Mississippi Constitution contained a third clause, which was a mixture of a Type IV clause, such as introduced in 1848 by Wisconsin, with Type I language:

Property shall be assessed for taxes by uniform rules, according to its true value. ${ }^{40}$

A similar approach was taken by South Carolina. When that state adopted a new constitution in 1865 and acquired its first uniformity clause, a new variation of Type I, a single provision was sufficient. It read:

All taxes upon property, real and personal, shall be laid upon the actual value of the property taxed, as the same shall be ascertained by an assessment made for the purpose of laying such a tax. ${ }^{41}$

However, within a few years South Carolina adopted another constitution (1868), and in that constitution there was the most redundant uniformity structure yet to be found. ${ }^{42}$ The Type I clause introduced in 1865 was retained. Three other clauses were added. A Type VI clause, introduced by Indiana in 1851 , was combined with the 1820 Missouri version of the Type II ad valorem clause. The fourth provision was the variation of Type IX, introduced by New Hampshire.

39 Supra, p. 249.

40 Supra, p. 249.

41 Supra, p. 338.

42 Supra, p. 338. 
North Carolina and Georgia were satisfied with less redundant uniformity structures. In its new constitution of 1868, North Carolina included a single uniformity clause, ${ }^{43}$ the version of the Type IV "uniform rule" provision first used by Ohio in 1851 . Georgia also settled for a single uniformity clause, and in its new 1868 constitution included the following:

Taxation on property shall be ad valorem, and uniform on all species of property taxed. ${ }^{44}$

This clause does not comfortably fit into any of the basic classifications heretofore used, and it was never adopted by any other state.

During this period, Arkansas indulged in considerable constitutional revision. ${ }^{45}$ As pointed out above, the original Arkansas Constitution of 1836 contained a variation of the Type I ad valorem clause, supplemented by the special provision concerning rates first introduced by Tennessee in 1834 . A new constitution adopted in 1861 left the situation unchanged. However, in its next new constitution, adopted in 1868, Arkansas altered its uniformity structure, abandoning the provisions introduced in 1836 and adopting the Ohio 1851 version of the Type IV "uniform rule" clause. But this change lasted for only a very brief period. In 1875, another new constitution was adopted, and Arkansas reverted to its original uniformity clauses, which are still in force today.

Action was taken by Nebraska in 1875. That state was first admitted to the Union in 1867 , but the original constitution did not include a uniformity clause of any kind. However, in 1875 , a new constitution was adopted and it included ${ }^{46}$

\footnotetext{
48 Supra, p. 558.

44 Supra, p. 364.

45 Supra, p. 50.

46 Supra, p. 166.
} 
the version of the Type II "in proportion to value" clause introduced by Illinois in 1848 .

Before continuing the chronological development, it is interesting to note a trend which developed following the introduction of the clauses containing "uniform and/or equal" terminology during the period from 1845 to 1851 . When a Type V or Type VI clause was adopted it was not at all unusual for the state to adopt also one of the "value" clauses. Types I and II. When a Type IV "uniform rule" clause was adopted, we find quite often that within the basic uniformity clause itself was inserted "ad valorem" terminology which before 1845 had been sufficient standing alone to constitute the basic uniformity clause.

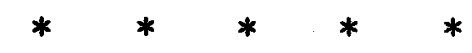

The year 1874 marks a very important date in the historical development of uniformity clauses. As the precursor of an era of liberalization, Pennsylvania introduced the original basic uniformity clause Type VII. This was the first uniformity clause to add to the words "taxes shall be uniform" the phrase "uniform within classes." Pennsylvania, one of the original thirteen states, had no uniformity clause of any kind in its original constitution. When a new constitution was adopted in 1874, the following provision was inserted:

All taxes shall be uniform, upon the same class of subjects, within the territorial limits of the authority levying the tax. ... .47

The Pennsylvania study in Chapter III showed that the introduction of this uniformity clause had no effect upon the effective uniformity limitation in Pennsylvania. However, the clause did expressly provide for a limitation which theretofore had been implied.

Pennsylvania's action was followed immediately by 17 Supra, p. 461. 
Missouri in 1875. When Missouri was admitted to the Union in 1820, it had been one of the originators of the Type II "in proportion to value" clause. The first version was introduced in 1818 by Illinois, a second version in 1819 by Alabama, and a third version in 1820 by Missouri. The Missouri version was adopted by several states, as this review has shown. In its new constitution of 1875, Missouri retained its Type II proportionality clause, but added the Type VII clause originated by Pennsylvania the prior year. ${ }^{48}$ The word "all" which modified the word "taxes" in the Pennsylvania clause was omitted. This combination of Type II with Type VII resulted in a great deal of confusion, as the Missouri study in Chapter III indicated, because the court found the two provisions in conflict. In determining the effective uniformity limitation a priority was given the Type II clause, with the effect of negating the newly introduced Type VII clause. However, this conflict was resolved in 1945 by constitutional amendment which removed the source of conflict. In its new 1945 constitution Missouri deleted the Type II provision and inserted in its place a provision expressly authorizing the classification of property. ${ }^{49}$

The experience of Georgia has been very similar to that of Missouri. As indicated above, Georgia adopted its first uniformity clause in 1868 , providing that "Taxation on property shall be ad valorem, and uniform on all species of property taxed." When adopting a new constitution in 1877, Georgia modified this original provision so that it was phrased in substantially the same words of the Missouri 1820 version of Type II. Then, like Missouri, a second provision was added in the 1877 constitution, the Type VII clause originated by Pennsylvania. Continuing the similarity, the resulting conflict in the Georgia judicial opinions was resolved by a 1938

48 Supra, p. 419.

49 Supra, p. 425. 
amendment to the Georgia Constitution which deleted the Type II clause. ${ }^{\text {so }}$

The pattern established by Pennsylvania, Missouri, and Georgia was also adopted by Colorado. Upon being admitted to the Union in 1876, Colorado included in its original constitution $^{\text {51 }}$ the Pennsylvania Type VII provision. Colorado, like Pennsylvania, but unlike Missouri and Georgia, was satisfied with the single clause. At approximately the same time that the Type VII clause was being introduced, action was also taken in New Jersey and California. The New Jersey Constitution was amended in 1875 by the adoption of the 1868 Mississippi version of the Type IV "uniform rule" provision. ${ }^{62}$ Prior to 1875 , New Jersey had no uniformity clause of any kind. In 1879, California adopted a new constitution, and in doing so simplified its prior structure. As indicated above, when admitted to the Union in 1850, California had incorporated both a Type $\mathrm{V}$ and Type II clause in its constitution. In the new 1879 constitution, the Type V clause was deleted, leaving only the Type II proportionality clause. $^{\text {s3 }}$

In marked contrast to the preceding forty years, there was no activity in this field during the decade of 1879-1889. This period of inactivity was ended with the entrance of six states into the Union from 1889 to 1890 (Montana, North Dakota, South Dakota, Washington, Idaho, and Wyoming). Two of these six states, Montana in its constitution of $1889^{54}$ and Idaho in its constitution of $1890,{ }^{\text {b5 }}$ followed, in part, the example of Pennsylvania and adopted a Type VII clause. However, in each of those states the Type VII clause was ac-

\footnotetext{
${ }^{50}$ Supra, p. 364.

61 Supra, p. 349.

52 Supra, p. 217.

63 Supra, p. 107.

54 Supra, p. 428.

6s Supra, p. 378.
} 
companied by a basic clause of another type. The second Montana provision was the Type VI "uniform and equal" clause originated in 1851 by Indiana. The second Idaho provision was the variation of the Type II proportionality clause originated in 1848 by Illinois. The studies of these two states, in Chapter III, revealed a conflict similar to that found in Missouri and Georgia where the Type VII clause was combined with a potentially strict clause. However, the studies show that the Montana and Idaho courts resolved the conflict in diametrically opposed manners.

The remaining four of these six states adopted pre-1874 type uniformity clauses. In its constitution of 1889 North Dakota introduced a new version of the Type IV provision, which contained, as well, words characteristic of Type I:

Laws shall be passed taxing by a uniform rule all property according to its true value in money. ${ }^{58}$

This version of Type IV is quite similar to that originated by Mississippi in 1869. Both South Dakota in its 1889 constitution $^{57}$ and Wyoming in its 1890 constitution $^{58}$ relied primarily on the Type $V$ "equal and uniform" clause first introduced in 1845 by Louisiana and Texas. However, the South Dakota Constitution contained a second clause drawing on the combined characteristics of Types V, I and II:

All taxes shall be uniform upon all real and personal property, according to its value in money, to be ascertained, . . . so that every person and corporation shall pay a tax in proportion to the value of his, her or its property. ${ }^{50}$

No other state has ever adopted this rather unusually phrased provision.

56 Supra, p. 562.

57 Supra, p. 576.

58 Supra, p. 270.

59 Supra, p. 567. 
Washington also included two uniformity clauses of different types in its 1889 constitution. ${ }^{60}$ There was the now familiar combination of a Type VI clause, originated by Indiana in 1851, with the 1820 Missouri version of a Type II proportionality clause. It is interesting to note that only Wyoming retains today the strict "equal and uniform" type clause, while North Dakota, South Dakota, and Washington have all adopted a "uniformity within classes" provision originated in 1911 by North Dakota.

At the time these six states were admitted to the Union the only other activity in the field of uniformity in taxation clauses was in Kentucky. In its new constitution of 1891, Kentucky adopted a new version of the Type $V$ clause first originated in 1845 by Louisiana and Texas. The provision read:

Taxes shall be uniform upon all property subject to taxation within the territorial limits of the taxing authority. . . .

Before this time, Kentucky had no uniformity clause of any kind in its constitution.

Subsequent to $1889-1891$, there was only intermittent activity on this front for nearly twenty years, to be exact, until 1911, when North Dakota introduced another new basic type of uniformity clause. Five states took some action of interest. On adopting its new constitution in 1897 Delaware followed the lead of Pennsylvania. Originally, Delaware had no uniformity clause of any kind, but in its 1897 constitution $^{62}$ incorporated a Type VII clause originated in 1874 by Pennsylvania. Three more states were soon added to the rapidly growing list adopting the Pennsylvania type clause. Virginia and Minnesota converted to the "uniformity

${ }^{60}$ Supra, p. 572.
${ }^{61}$ Supra, p. 549.
${ }^{62}$ Supra, p. 359. 
within classes" type provision after having first adopted the stricter type clauses. In 1902, Virginia adopted a new constitution and substituted the Type VII clause ${ }^{63}$ for its prior Type V "equal and uniform" clause, which had been supplemented by a Type II proportionality provision. In 1908, Minnesota adopted its so-called "wide open" tax amendment which abandoned its prior uniquely phrased provision which had been the source of so much trouble and confusion, and adopted the Type VII clause. ${ }^{64}$ Oklahoma, when admitted to the Union in 1907, incorporated a Type VII clause in its uniformity structure. ${ }^{65}$ In contrast to the "liberalizing" action taken during this twenty-year period by Delaware, Virginia, Minnesota, and Oklahoma, Utah adopted two of the stricter type clauses. Admitted to the Union in 1896, Utah incorporated in its constitution a Type VI clause, originated in 1851 by Indiana, supplemented by the 1848 Illinois version of Type II "in proportion to value" clause. ${ }^{66}$

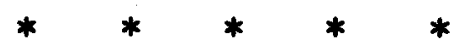

In 1911, North Dakota introduced the newest, and most liberal, of the several types of uniformity clauses. As indicated above, North Dakota, on being admitted to the Union in 1889, had adopted a version of the Type IV "uniform rule" clause. Twenty-two years later North Dakota amended its constitution and adopted the original Type VIII clause:

Taxes shall be uniform upon the same class of property within the territorial limits of the authority levying the tax. ${ }^{67}$

By 1935, six other states (Arizona, Kentucky, South Dakota,

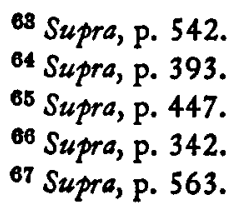


Washington, North Carolina, and Maryland) had adopted this type of uniformity clause.

Arizona incorporated the provision in its original constitution $^{68}$ upon being admitted to the Union in 1912. The remaining five states converted to Type VIII from a more strict uniformity clause. In 1915, Kentucky abandoned its version of Type $V$ which it had adopted in 1891, having had no uniformity clause before that time. By amendment of its constitution, Kentucky substituted a Type VIII clause. ${ }^{69}$ South Dakota also abandoned a basic Type V clause when it amended its constitution in 1918 and joined its sister state, North Dakota, in relying on a Type VIII clause. ${ }^{70}$ Like North Dakota, South Dakota had adopted the stricter type uniformity clause on being admitted to the union in 1889 .

About the same time that Arizona, Kentucky, and South Dakota were adopting verbatim the North Dakota clause, Maryland amended its constitution (1915) and incorporated therein a basic uniformity clause which may be classified as Type VIII, but which differs substantially from the North Dakota phraseology. The provision reads:

... all taxes ... shall be uniform as to land within the taxing district, and uniform within the class or sub-class of improvements on land and personal property which the respective taxing powers may have directed to be subject to the tax levy. . . .

Several years later, Washington (in 1930) and North Carolina (in 1935) amended their constitutions ${ }^{72}$ and adopted verbatim the original North Dakota clause. Washington converted from a combination of the Type VI clause,

\footnotetext{
68 Supra, p. 545.

69 Supra, p. 550.

70 Supra, p. 568.

71 Supra, p. 554.

72 Supro, pp. $559,573$.
} 
supplemented by a Type II proportionality provision. North Carolina had previously had a version of the Type IV "uniform rule" clause as a basic uniformity clause.

During this period of the growth of the Type VIII clause, two states joined the substantial number of states having a basic clause of Type VII as the primary uniformity provision. Oregon was one of those states which had redundantly combined two uniformity clauses of Types $\mathrm{V}$ and VI, doing this in its original 1859 constitution. In 1917, the Oregon Constitution was amended to substitute a single provision, a Type VII clause, as its basic provision. ${ }^{73}$ Louisiana converted from its Type $V$ clause, which it had originated in 1845, when it adopted a new constitution in 1921 and included a Type VII clause. ${ }^{74}$ Thus, the trend to adopt one of the two "uniformity within classes" type provisions was continued at a steady pace. As a result, at the present time thirteen states have a provision of the type originated in 1874 by Pennsylvania, Type VII, and seven have the North Dakota innovation, Type VIII.

This trend towards adopting one of the "uniformity within classes" provisions, however, is only one branch of this "liberalizing" trend. The second branch occurred concurrently with the origin and growth of the liberal Type VIII clause. In a number of states the liberalization was brought about without an abandonment or change of a strict type uniformity clause. The method has been to leave the strict type provision unchanged, and amend the effective uniformity limitation of the state by adding a constitutional provision expressly sanctioning special treatment for a class or classes of property, usually intangible property, notwithstanding the basic uniformity clause. This technique was introduced in 1913 by Maine. Maine has a Type I clause, and the court

73 Supra, p. 457.

74 Supra, p. 390. 
had ruled that property taxation was governed by a strict degree of uniformity: requiring absolute uniformity in rates and the use of the ad valorem method. In 1913, the Type I clause was left unchanged, but a new provision provided that special "rate" might be applied to intangible property. ${ }^{75}$

Very similar situations are found in Nebraska, Kansas, Florida, Utah, and South Carolina. Nebraska had a Type II proportionality clause, and the effective uniformity limitation required the strictest degree of uniformity in the taxation of property: universality, absolute uniformity in rates, and the use of the ad valorem method. A 1920 amendment left the basic uniformity clause intact, but limited its application to the taxation of tangible property, with taxes to be "uniform as to class" and "by valuation upon all other property." The result is that intangibles may be classified for rates. ${ }^{76}$

Kansas, Florida, Utah, and South Carolina all have a Type VI uniformity clause requiring "a uniform and equal rate of assessment and taxation." With the exception of Kansas, all required the strictest degree of uniformity in property taxation. In Kansas exemptions were permitted. In 1924, both Kansas and Florida provided by amendment for special treatment of intangible property. ${ }^{77}$ In Kansas only the rule requiring absolute uniformity in rates has been relaxed, and probably the same can be said of Florida. In 1930, Utah removed intangibles from the scope of the strict uniformity clause, and a fair reading of the amendment indicates that the taxation of intangibles is no longer limited by any of the three strict rules. ${ }^{78}$ In 1933, South Carolina also used an amendment to provide for special treatment of intangible property, but like Maine apparently the only relaxation of

\footnotetext{
75 Supra, p. 58.

76 Supra, p. 167.

77 Supra, pp. 273, 307.

78 Supra, p. 342.
} 
strict uniformity is that a single special rate may be applied to such property. ${ }^{79}$

Action taken in Nevada in 1942 also is of interest at this point. Nevada had a Type VI uniformity clause, and an amendment in 1942 also provided for special treatment of intangible property. But in Nevada the special treatment consists of requiring the exemption of intangibles from any taxation. ${ }^{80}$ It is interesting to note that of the six states presently having a basic uniformity clause of Type VI all but Indiana have provided in this manner for the taxation of intangible property to be removed from the scope of the uniformity limitation. However, in Indiana such an amendment was unnecessary, because, as the study in Chapter III showed, an unusual interpretation of the uniformity limitation has in fact permitted the exemption of intangibles from the general property tax and their separate taxation by a tax, conveniently characterized as a nonproperty tax not subject to the strict property uniformity limitation. ${ }^{81}$

In Ohio, the special treatment proviso has a much broader scope. Prior to 1928, the Ohio court had given a Type IV "uniform rule" clause the strictest interpretation. In 1928, an amendment limited the application of that basic clause to taxation of "land and improvements," with the result that taxes on all personal property-not just intangibles-need only be uniform within classes. ${ }^{82}$ California made an abortive attempt in 1924 to provide special treatment for intangible property. In 1933, success was had with a broad amendment which, in fact, limited the Type II proportionality clause, formerly interpreted to require the strictest degree of uniformity, to the taxation of real property. The amendment

\footnotetext{
79 Supra, p. 337.

80 Supra, p. 333.

81 Supra, p. 303.

82 Supra, p. 222.
} 
expressly permits the classification of all personal property for rates, its exemption from taxation, and the use of different methods of taxation. ${ }^{83}$

But this technique of modification through amendments providing for special treatment has found its broadest scope in West Virginia. The basic uniformity clause in that state is Type V, "taxation shall be equal and uniform." The effective uniformity limitation in that state required the strictest degree of uniformity. However, in 1932, West Virginia amended its constitution, and qualified the basic clause by this phrase: "subject to the exceptions in this section contained." The "exceptions" in fact included a classification of all property, real and personal, into defined classes subject to different maximum rates. The rules concerning universality and ad valorem method were left unchanged. ${ }^{84}$

Since 1911, which marked the origin of the Type VIII basic clause and preceded by only two years the use of "special treatment" amendments, only a single exception to the liberalizing trend has occurred. New Mexico was admitted to the Union in 1912, and its original constitution contained a new version of the Type VI uniformity clause: "The rates of taxation shall be equal and uniform upon all subjects of taxation. . . ." Two years later, in 1914, there was a comprehensive revision of the New Mexico uniformity structure. The basic uniformity clause was now an unusual combination of Type VII, first originated in 1874 by Pennsylvania, and Type II. The provision reads:

Taxes levied upon tangible property shall be in proportion to the value thereof, and taxes shall be equal and uniform upon subjects of taxation of the same class. ${ }^{85}$

Thus, like several other states having a basic clause of Type

83 Supra, p. 106.

84 Supra, p. 261.

80 Supra, p. 440. 
VII, this potentially liberal provision was coupled with a clause which could potentially restrict the operation of the liberal provision.

The preceding chronological review of the origin and growth of the so-called uniformity clauses reveals three definite periods. The first period might be called the period of inactivity, and extended from 1789 (the origin of the Union) to 1818 . This period is characterized by a lack of any form of uniformity clause. The second period extends from 1818 to 1896 , and might be called the restrictive period. This middle period is characterized by the adoption of the several basic types of uniformity clauses which may be called strict provisions-Types I through VI, and several clauses of peculiar phraseology no longer used by any state. The third period may be called the period of liberalization, and extended from 1874 to 1945 . This period has two branches. First, there was the adoption of the two basic clauses, Types VII and VIII, which may be categorized as potentially liberal provisions, originating respectively in 1874 and 1911. The adoption of the Type VIII clause coincided with the beginning of the second branch of the "liberalization" trend; in 1913, there began the practice of introducing constitutional amendments providing for special treatment of enumerated classes of property, notwithstanding the presence of a strict type of uniformity clause which was left unchanged. Since 1945, there has been no activity of any kind in this field, which leaves us to speculate concerning the future course of events, since this summary will show that the counteracting third period has placed the situation in a near balance.

During the first period, from 1789 to 1818 , twenty states entered the Union. Only five of those twenty states had pro- 
visions of any kind in their constitutions which might be called uniformity clauses. Of the original thirteen states, ten (Connecticut, Delaware, Georgia, New Jersey, New York, North Carolina, Pennsylvania, Rhode Island, South Carolina, and Virginia) had no clause, one (Maryland) had a basic clause of Type IX, and two (Massachusetts and New Hampshire) had a "strict" clause. Three states were admitted in the next decade, 1790 to 1800 . One state (Kentucky) had no clause, one (Vermont) had a Type IX clause, and one (Tennessee) introduced the first version of a clause actually phrased in the words "uniform and equal," which was a "strict" clause. During the next two decades, to 1818, four states were admitted to the Union (Ohio, Louisiana, Indiana, and Mississippi) but none had any form of uniformity clause.

In 1818 , the year marking the beginning of a second period, the trend of the first period came to an abrupt halt. Since that time, twenty-eight states have entered the Union. Only three (Michigan in 1837, Iowa in 1846, and Nebraska in 1867) of those states have failed to include some sort of uniformity clause in its constitution. And in no case has any state which had a uniformity clause of some kind removed that clause without substituting another. Indeed, by 1897, only three of these eighteen states having once had no uniformity clause still remained without such a provision. They are Connecticut and New York of the original ten, and Iowa from among the others. This conversion occurred substantially during the heart of the second period of "strict clauses," from 1840 to 1875 .

The second period, characterized by the creation and adoption of the potentially strict uniformity clauses (Types I through VI), was begun in $1818-1820$ by four new states (Illinois, Alabama, Maine, and Missouri). Each of those four states adopted some version of either Type I or Type II. 
However, this was not typical of the period. A trend was clear by the 1850 's. Not only was a potentially strict basic uniformity clause adopted, but the trend was heavily weighted in favor of adopting two or more of the several potentially strict type clauses, quite often combining one of the clauses actually phrased in terms of "equal and/or uniform" (Types IV through VI) with an ad valorem type clause (Types I and II).

Three states (Massachusetts, New Hampshire, and Tennessee) had adopted strict clauses before this second period had begun. Thus, combined with the four states above, this meant by 1830 seven states of the twenty-four then in the Union fell within the "strict clause" group. One other state (Arkansas) joined the trend in the 1830 's, but the greatest concentration of activity during this second period occurred from 1840 to 1870 . During the 1840's four more states (Louisiana, Florida, Texas, Wisconsin) adopted a strict clause, three of the states being new states and the fourth converting from "no clause." Now twelve of thirty states fell within the "strict clause" group, an increase from about $29 \%$ to $40 \%$ since the period began.

The "strict clause" became even more popular during the next two decades. In the 1850's seven states (Virginia, Ohio, Indiana, Michigan, California, Minnesota, and Oregon) fell in line and adopted one or more strict uniformity clauses. Three of those seven states were new states-all of the new states admitted during the 1850's. Four of those seven states were old states converting from "no clause." The next decade saw the continuance of this strong trend. During the 1860's seven more states (Georgia, North Carolina, South Carolina, Mississippi, Kansas, West Virginia, and Nevada) adopted one or more strict uniformity clauses. The division of those seven states was the same as in the 1850's, but during the 1860 's there was not a single state which chose to "adopt" no 
uniformity clause at all. Thus, by the end of the 1860's twenty-six states fell within the "strict clause" group. There were now thirty-seven states in the Union, which meant that the "strict clause" group constituted approximately $70 \%$ of the total states. This was close to the peak of this trend, although as the period ended in 1896 there was a minute percentage gain.

The 1870's saw the tapering off of the second period. During that decade only two states (New Jersey and Nebraska) adopted a strict uniformity clause. Both states converted from "no clause" status. Balanced against this gain of two was a loss of two states (Georgia and Missouri) to the embryo period of "liberalization." Those two states adopted the new "uniformity within classes" type of provision. The 1880's saw a clean gain of three states (North Dakota, South Dakota, and Washington) for the "strict clause" group, all three being new states. Again in the 1890's three more states (Kentucky, Wyoming, and Utah) adopted strict uniformity clauses. Two of these three were new states, one was an old state converting from "no clause."

The second period in the development of the so-called uniformity clauses came to an end with the adoption of a strict clause by Utah in 1896. And this was the peak of the trend toward the development of the strict type uniformity clause. Now there were thirty-two states having such a clause, and only forty-five states in the Union. Thus, about $71 \%$ could be grouped among the "strict clause" states. Since 1896, only one state (New Mexico in 1912) has adopted a "strict clause," and that state was to convert to the liberal provision within two years. Beginning in the early 1900's there was a steady erosion of the "strict clause group," so that today only twenty-three states have a basic uniformity clause of the potentially strict type. Moreover, this does not take into account the trend among those twenty-three states 
to amend the effective uniformity limitation by special treatment amendments. But even considering the twenty-three states, this means that the percentage of states classifiable as "strict clause" states is only about $48 \%$-a considerable loss from the peak $71 \%$.

The erosion of this substantial group of states having some form of a "strict type" uniformity clause can be credited to the new force of liberalization given its initial impetus in 1874. At the very time when the second period in the development of uniformity in taxation was reaching its summit and gaining adherents in the greatest numbers a strong reaction had set in, and the third period of development of the so-called uniformity clauses overlapped in its origin the demise of the "strict clause" period. This third period has two branches, and is characterized as a period of "liberalization." The first branch has its root at the beginning of the period, and is the introduction of a potentially liberal clause framed in terms of "uniformity within classes." Two types of clauses are here considered, Type VII (uniformity within the same class of subjects) and Type VIII (uniformity within the same class of property). The second of these two liberal types of clauses was not introduced until 1911, and thus preceded by two years the second branch of the period of liberalization, which has been the trend to deal with the uniformity problem where necessary by "special treatment" amendments to the constitution.

In 1874, Pennsylvania introduced the Type VII clause, which was adopted by three other states during the 1870's (Missouri, Colorado, and Georgia). One of these four states (Colorado) was a new state, one was an old state converting from the "no clause" status (Pennsylvania), and two were old states converting from the "strict clause" status (Missouri and Georgia). After this there was a slow, but steady, increase in the number of "liberal clause" states during the next 
thirty years. One state (Montana) adopted the liberal Type VII clause during the 1880 's, that state being a new state. Two states (Delaware and Idaho) were added to this growing group during the 1890 's, one being a new state and the other converting from "no clause." Three states (Virginia, Minnesota, and Oklahoma) adopted the liberal clause during the period from 1900 to 1910 . One was a new state, and two of the states converted from a "strict clause."

During the second decade of the 1900's the growth of the "liberal clause" continued rapidly. Two states (Oregon and New Mexico) continued the trend by adopting the Type VII clause. Both of these states were converting from a "strict clause." During the same period, North Dakota originated the Type VIII clause in converting from a "strict clause" and four other states (Maryland, Kentucky, South Dakota, and Arizona) immediately adopted it. One of the four was a new state, two were converting from a "strict clause," and the fourth converted from a Type IX clause.

During this same decade, 1910 to 1920 , Maine began the second branch of the liberalization trend by leaving its strict uniformity clause untouched, but introducing an amendment providing for special treatment of some property, thus modifying to a degree the effective strict uniformity limitation.

The remainder of the third period of development of the so-called uniformity clauses is characterized essentially by the trend to follow the lead of Maine and deal with the problem by special treatment amendments. In the 1920's one state (Louisiana) adopted a Type VII clause, converting from a strict clause, but no state adopted a Type VIII clause. In the 1930's two states (North Carolina and Washington) converted from a strict clause in adopting the Type VIII clause. Since the action taken by North Carolina in 1935, no state has converted to either a Type VII or Type VIII clause. 
This period from 1920 to 1940 marked the rapid growth of the special treatment amendments. During the 1920's, four states having a "strict clause" (Nebraska, Ohio, Florida, and Kansas) adopted a constitutional amendment providing for special treatment for enumerated classes of property, the strict clause to the contrary notwithstanding. Similarly, four states (South Carolina, California, West Virginia, Utah) took such action during the 1930's. The only action taken since that time has been a special treatment amendment adopted in 1942 by Nevada.

However, the enumeration of the adoptions by thirteen states of the Type VII clause, originated in 1874 by Pennsylvania, does not accurately reflect the status of uniformity clauses since, of the first six states to adopt such a clause prior to 1890 , four joined it with one of the strict clauses: Missouri, Georgia, Montana, and Idaho. Seven states have adopted a Type VII clause since that time, and only one (New Mexico) combined it with a strict clause. The experience of the four states combining the liberal and strict provisions has well illustrated the confusion which stems from such a combination, and during the development of the second branch of this period of liberalization, two states (Missouri in 1945 and Georgia in 1938) have amended their constitutions to delete the strict clause.

Since 1945 , no action has been taken, either to continue the liberal period, or revive the strict period. Thus, in brief, the tendency originally was to omit any reference in the state constitutions to uniformity and equality in taxation. However, this tendency soon gave way to the trend which marks the second period-a tendency to insert in the constitution a clause which provided, on its face, for a strict degree of uniformity and equality in taxation. It should be noted that these strict clauses were phrased in various ways, many omitting any reference to the terms "uniform or equal" and relying on 
"according to" or "in proportion to value." At the same time, during this second period there was a tendency to complicate the uniformity structure by the inclusion of several clauses, any one of which might have served as a source of the strict degree of uniformity limitation. Before this second period had ended a third had already begun - the trend to return to the original effective status. But, there was this important difference. Originally, there was no requirement of strict uniformity because of the absence of any express uniformity provision. Now the result was to be reached by express provisions phrased in terms of "uniformity within classes."

In summary, we find that twenty-three states retain today the basic uniformity clause of a potentially strict type. This is a considerable recession from the one-time high of thirtytwo. Twenty states now have a basic uniformity clause of a potentially liberal type, and to these twenty must be added the three states which remain without a uniformity clause of any kind, and the two states having a Type IX clause. Thus, there appears to be a near balance of twenty-three to twentyfive. However, this does not take into account the fact that ten of the twenty-three strict states have modified to some degree their effective limitation by special treatment amendments. Thus, there remain only thirteen states having the strict clause standing alone. However, a severe imbalance has not yet been created, and there is great room for development. Especially is there room for development in light of the disparity which oftentimes exists between literal and effective uniformity limitations. Moreover, it must be remembered that even among the so-called strict and liberal states, there are several varying degrees of effective uniformity limitations. 
B. A SUMMARY COMPARISON OF EFFECTIVE AND LITERAL IIMITATIONS IN TERMS OF PARTICULAR RULES OF UNIFORMITY

An attempt will now be made to make certain generalizations concerning the meaning of the several types of uniformity clauses, as classified according to phraseology, ${ }^{1}$ with primary interest being in the uniformity limitation applicable to the taxation of property. The state by state analysis in Chapter III should have impressed one with the fact that the effective uniformity limitation is quite often determined not only by almost imperceptible gradations in the phraseology of the basic uniformity clauses themselves, but as well by other provisions in the constitution of a given state. These other provisions are either alternate uniformity clauses or provisions dealing with some particular rule of uniformity for the taxation of property. In addition, the complex historical growth of the uniformity provisions, described in the preceding section of this chapter, emphasizes the danger of referring to "the" requirement of uniformity and equality found in state constitutions, for such a reference is latent with potentially misleading conclusions. Not only do the words of the basic uniformity clauses vary considerably, but the combinations of provisions which make up the uniformity structures of the several state constitutions are seldom identical.

Nevertheless, as long as one bears in mind the dangers of generalizations in this area, it will be helpful to recapitulate in general terms the effective uniformity limitations as compared with the literal uniformity limitations. Two distinctly different approaches will be used in making this analysis. First, the particular rules of uniformity derived from

${ }^{1}$ Cf. Matthews, Wm. L., Jr., "The Function of Constitutional Provisions Requiring Uniformity in Taxation," $38 \mathrm{Ky}$. L. J. 31, 187, 377, 503 (1949-1950); Note, "Uniformity of Taxation," 88 U. of Pa. L. Rev. 728 (1940). 
the general uniformity clauses will be summarized. Secondly, a comparison will be made of the uniformity structures of the several states taken as a whole.

\section{A "Rule by Rule" Summary Analysis}

Throughout this monograph, four basic inquiries have been made into the operative effect of each state's uniformity structure. First, does the uniformity clause apply to all taxes, or only property taxes? Second, is there a rule of universality? In other words, must all property, except that designated as exemptible by the constitution, be selected for taxation? Third, what does the uniformity clause require in respect to the effective rate of a property tax? Or more precisely, must all property taxed by a single taxing authority be assessed for taxation at the same ratio of valuation and subject to the same percentage rate so that an absolute uniformity is required of the effective rate? Or, to the contrary, is only a uniformity within classes required? Fourth, does the uniformity clause require that property be taxed only by the ad valorem method, or may specific taxes be used? The answers to each of these questions in respect to each type of uniformity clause, as classified according to phraseology, will now be summarized.

\section{a. Application}

Do the uniformity clauses apply to all taxes, or only to the taxation of property? The results as to this question are, for the most part, not unexpected. For example, among those states (Arkansas, Maine, and Tennessee) having a Type I basic clause (Property shall be taxed according to its value), and those states (Alabama, California, Illinois, and $\mathrm{Ne}$ braska) having some version of a Type II clause (Property shall be taxed in proportion to its value), it would have been surprising, indeed, startling to have found a ruling that such 
provisions applied to other than property taxation. There were no surprises. ${ }^{2}$

Similarly, one would expect that a Type III basic uniformity clause (The legislature may impose proportional and reasonable assessments, rates, and taxes upon all persons and estates within the commonwealth) would in all likelihood apply only to property taxes. Such is the case in Massachusetts. ${ }^{3}$ However, a very unusual situation exists in New Hampshire, the second of the two states having this type of basic clause. As shown in the New Hampshire study, in that state only "property" taxes are permissible, and, consequently, all taxes are subject to the proportionality limitation. However, the apparent rigidity of that situation was relieved in 1903 by an amendment of the constitution. Before 1903, only the ad valorem general property tax was permissible. Under the 1903 amendment a second category of "property" taxes is permissible, namely, taxes on "other classes of property," as opposed to the taxation of "estates." The latter is the characterization given the ad valorem general property tax. The practical effect of this amendment is to permit the imposition of most taxes, but not quite all, usually characterized as nonproperty taxes in the other forty-seven states. However, these taxes upon "other classes of property" are still limited by the proportionality clause. Here, too, an impossible rigidity is avoided by an interpretation which admits that there is no necessity of a "correlation" of the uniformity requirement among the several "property" taxes. Nevertheless, the result is that these taxes upon "other classes of property" are subject to a degree of uniformity somewhat stricter than that required of nonproperty taxes in the other states. This unique situation must

2 Supra, pp. 51, 59, 67, 96, 109, 118, 168.

${ }^{8}$ Supra, p. 173.

${ }^{4}$ Supra, p. 182. 
be kept constantly in mind when making any comparative survey, because the characterization of any tax, for example, an income tax, as a "property" tax is the prime requisite for its existence in New Hampshire. To the contrary, in most states the problem is one of characterizing an income tax as a nonproperty tax in order that it may be upheld.

Among those states having some version of the Type IV basic uniformity clause (A uniform rule of taxation), three states (New Jersey, Ohio, and Wisconsin) limit the application of the clause to property taxes-however, all such taxes are limited. ${ }^{5}$ In New Jersey and Ohio the phraseology of the respective provisions is expressly framed in reference to the taxation of property. However, the same result was reached in Wisconsin where the clause is not so phrased. The fourth state having a Type IV clause is Michigan. There we found a unique application of the basic uniformity clause. ${ }^{6}$ For purposes of uniformity all taxes in Michigan are classified as either ad valorem or specific. The Type IV clause applies only to ad valorem taxes. Thus, the clause, while limiting only property taxation, does not limit all such taxation. All nonproperty taxes are characterized as specific taxes, but property taxes may be either ad valorem or specific, depending on the method of taxation. Thus, all nonproperty taxes and some property taxes are specific taxes, while only some property taxes are ad valorem taxes. Specific taxes are limited by a separate uniformity clause which only requires that such taxes "shall be uniform upon the classes upon which they operate." This distinction is unique, in that all other states the basic distinction for purposes of uniformity is between property and nonproperty taxes. Consequently, contrary to the usual situation, the method of taxing property is not governed by the uniformity limitation, rather the ap-

5 Supra, pp. 218, 224, 235.

6 Supra, p. 198. 
plicable rules of uniformity are determined by the method used to tax property. The result in Michigan, as in New Jersey and Ohio of this group, was foreshadowed by the particular phraseology of the Michigan version of the Type IV clause: "The legislature shall provide by law a uniform rule of taxation, except on property paying specific taxes. ..." (Emphasis added.)

Unanimity is found among those ten states having either a Type $\mathrm{V}$ basic uniformity clause (Taxation shall be equal and uniform) or a Type VI clause (The legislature shall provide by law for a uniform and equal rate of assessment and taxation). Neither of these basic types has been held applicable to other than property taxation. Of course, the words of the Type $\mathrm{V}$ clause do not necessarily preclude a larger scope of operation, although the result is probable in view of the literal strictness of the provision. Wyoming ${ }^{7}$ is the only state which has a Type $V$ clause standing alone, unaccompanied by any supplementary provisions similar to other basic types. Indeed, the word "taxation" in the Wyoming clause is modified by the word "All," which is not the case in the other three states having this type basic clause (Mississippi, Texas, and West Virginia). ${ }^{8}$ The result was more certain under the Type VI clause, considering phraseology alone. Moreover, five of the six states having this type clause (Florida, Indiana, Nevada, South Carolina, and Utah) coupled in the same sentence with the basic clause a provision requiring the just valuation of all property. ${ }^{9} \mathrm{Kan}-$ sas, the sixth state in this group, did not incorporate the supplementary clause into its basic uniformity clause. ${ }^{10}$

The greatest diversity in result, as might well have been

7 Supra, p. 271.

${ }^{8}$ Supra, pp. 250, 255, 263.

O Supra, pp. 275, 282, 334, 339, 344.

10 Supra, p. 308. 
expected, was found among the thirteen states having a Type VII basic uniformity clause (Taxes shall be uniform upon the same class of subjects). This clause could very well be applied to all taxes without regard to the nature of the tax, and no unusual rules would necessarily result from this application. However, if this type clause is held applicable to all taxes, one may more logically reach the result that a strict uniformity governs the taxation of property by holding that property constitutes a single "subject" of taxation. In seven of these thirteen states the courts have ruled that the clause applies to all taxes. The seven are: Delaware, Georgia, Minnesota, Missouri, Oklahoma, Oregon, and Pennsylvania. ${ }^{11}$ And, contrary to what might be expected, among these seven states are found some of the most liberal interpretations given the property tax uniformity limitation. Thus, in Delaware, Minnesota, Oklahoma, Oregon, and, with some reservation, Pennsylvania, only a uniformity within classes is required of property taxes. ${ }^{12}$ In Georgia and Missouri the strictness of the property tax uniformity limitation stemmed from supplementary provisions which were interpreted to mean that property was to be a single "subject" of taxation. These supplementary provisions have since been deleted by amendment. ${ }^{13}$ No clear ruling on the question of application has been made in New Mexico and Virginia. ${ }^{14}$ However, in both of those states at least some degree of classification is allowed in effective rates, although other strict rules of uniformity apply.

The remaining three states having a Type VII clause are Colorado, Idaho, and Montana. ${ }^{15}$ In those states, the uniformity clause applies only to property taxes. And here we 11 Supra, pp. 360, 366, 378, 419, 448, 458, 537.

12 Infra, p. 678.

13 Infra, p. 678.

14 Supra, pp. 442, 544.

15 Supra, Pp. 350, 380, 430. 
find excellent illustrations of diametrically opposed judicial attitudes toward the uniformity in taxation concept. ${ }^{16}$ In Montana classification of property for effective rates is permissible. To reach this conclusion, the Montana court relied on the Type VII clause which it said sanctioned such legislative discretion notwithstanding a Type VI clause also found in the Montana constitution. An opposite tack was taken by the Idaho court. The Idaho constitution also contained a supplementary provision which might have conflicted with a liberal interpretation of the Type VII clause. But the Idaho court, which ruled that the strictest degree of uniformity applies to property taxes, saw no potential conflict. Rather, the court simply referred to the Type VII clause as "a" uniformity clause, applicable only to property taxation, and necessarily requiring of its own force a strict uniformity. All types of uniformity clauses were simply lumped together, ignoring marked differences in phraseology. In Colorado the court has indicated that the Type VII clause limits only property taxes, and lip service has been given to the power of the legislature to classify property for effective rates. There has been very little judicial development on the matter, and a subsequent constitutional amendment expressly provides for the classification of personal property.

One would naturally expect that the words of a Type VIII basic uniformity clause (Taxes shall be uniform upon the same class of property) would limit its application to property taxes. However, such was the case only in Arizona, Maryland, North Dakota, South Dakota, and Washington. ${ }^{17}$ To the contrary, in both Kentucky and North Carolina the courts have started from the premise that the clause limits all taxes. ${ }^{18}$ The only result of this position is that the courts

${ }^{10}$ See the discussion, infra, pp. 660-662.

17 Supra, pp. 545, 555, 564, 569, 574.

18 Supra, pp. 551, 559. 
of those two states simply erected unnecessary obstacles which it then became necessary to avoid.

Finally, in Vermont the Type IX basic uniformity clause has been held to be applicable to all taxes. ${ }^{19}$ There has been no clarification of the problem in Rhode Island, the only other state having this type clause. In any case, in neither state has this particular rule played a role of any importance because of the liberal content of the property tax uniformity limitation.

\section{b. The requirement of universality}

The next question to be considered is whether the legislature may exempt classes of property from taxation. Conversely stated, is there a rule of universality. In making a comparative study of the effective uniformity limitations as to this particular rule one must be very careful to avoid generalizations which may be misleading, because in a great many cases the rule of universality (or, the lack of such a rule) will stem expressly from some supplementary provision of the uniformity structure of a given state.

There is some apparent diversity in result among those three states (Arkansas, Maine, and Tennessee) having a Type I basic uniformity clause. Both Arkansas and Tennessee require universality in the taxation of property. ${ }^{20}$ To the contrary, in Maine there is no requirement of universality. ${ }^{\mathbf{2 1}}$ However, in the constitutions of both Arkansas and Tennessee there are elaborate provisions dealing with the exemption of constitutionally designated classes of property. In Maine, the constitution does not enumerate exemptible classes of property. Nevertheless, the Maine court has held that exemptions must be on a statewide basis so that there must be a

19 Supra, p. 593.

${ }^{20}$ Supra, pp. 54, 68.

21 Supra, p. 62. 
correlation between state and local exemptions, although correlation is not necessary as between state and local property tax rates. It is of further interest that in Tennessee the exemption of all representative intangible property is now permissible under a "double taxation" rationale, although such property may be taxed. As for the source of the universality limitation, in both Tennessee and Arkansas the courts have indicated that the requirement might well be derived from the basic uniformity clause itself. Nevertheless, in each state there are other provisions which are sufficient to support a rule of universality even in the absence of a ruling that the requirement that "property be taxed according to its value" means all property must be taxed.

Again, a diversity in results is found among the four states having a Type II basic clause. There is no requirement of universality in Alabama, ${ }^{22}$ but the opposite holds true in California, Illinois, and Nebraska ${ }^{23}$ However, in California an amendment was adopted in 1933 expressly removing this requirement insofar as personal property is concerned. In the two states (Massachusetts and New Hampshire) having a Type III basic clause, one finds an interesting similarity in the status of this rule. In neither of these states is there a requirement of universality. ${ }^{24}$ However, in both states the power of the legislature to exempt classes of property is limited to a considerable extent. In New Hampshire, the reasonable classification test is coupled with a test of "just reason" and "public welfare." In Massachusetts, exemptions are limited to those "not impairing the force" of the constitutional principle of proportionality.

The diversity in results continues among the four states (Michigan, New Jersey, Ohio, and Wisconsin) having a

\footnotetext{
22 Supra, p. 99.

23 Supro, pp. 113, 126, 169.

24 Supra, pp. 176, 189.
} 
Type IV basic uniformity clause. In Michigan, with its unique situation, the applicability of the uniformity clause is determined by the "rate-base" structure, i.e., the method of taxation of property. Since the uniformity clause applies only to property taxed ad valorem, there is no requirement of universality derived from the requirement of "a uniform rule" of taxation. Thus, even as to property selected for ad valorem taxation, subclassifications may be made for the purposes of exemptions. ${ }^{25}$ In New Jersey there is no rule of universality, ${ }^{26}$ and the same now holds true for Wisconsin. However, in Wisconsin this result was reached only after extended controversy and conflict among the cases. These conflicts were reconciled in 1906 with a definitive ruling that the "uniform rule" requirement does not demand that all property be taxed. ${ }^{27}$ The fourth of these four states has reached an opposite result. In Ohio the court has ruled that the words "uniform rule" demand universality. ${ }^{28}$ That result was reached even though a universality requirement was spelled out in supplementary words. This situation in Ohio was changed by amendment in 1929 . Since that time, there is no requirement of universality for personal property, but as to realty there remains some doubt which has not yet been settled.

Turning now to those four states (Mississippi, Texas, West Virginia, and Wyoming) having the Type $\mathrm{V}$ uniformity clause, we continue to find diversity in results as to this particular rule of uniformity. In both Texas and West Virginia, there is a requirement of universality, which the courts have said is derived from the basic uniformity clause, even though the limitation is also found in supplementary provisions. ${ }^{20}$ To

25 Supra, p. 212.

26 Supra, p. 218.

27 Supra, p. 245.

28 Supra, p. 227.

29 Supra, pp. 257, 266. 
the contrary, in Wyoming there is no requirement of universality. ${ }^{30}$ However, this is so only because the power to exempt classes of property from taxation is spelled out in a supplementary provision. Indeed, the Wyoming court has indicated that this express clause makes an exception to the rule of uniformity embodied in the requirement that "taxation shall be equal and uniform," which would otherwise require universality. In Mississippi, no requirement of universality is found, but there has been no indication whether or not the power of exemption is an exception to the requirement of uniformity and equality in taxation. ${ }^{\mathbf{3 1}}$

Among the six states (Florida, Indiana, Kansas, Nevada, South Carolina, and Utah) having a Type VI basic uniformity clause there is a greater similarity in result. As pointed out before, in the constitutions of all of these states, except Kansas, the basic uniformity clause is coupled with a provision in the same sentence providing for a "just valuation" of property. In Florida, Nevada, South Carolina, and Utah there is a clear requirement of universality. ${ }^{32}$ It is true that in all of those four states the courts have at times relied upon the "just valuation" clause as well as other supplementary provisions to reach this conclusion; nevertheless, they have all given indications that the requirement would in any case be derived from the basic uniformity clause itself. The universality requirement in those four states has been avoided to some degree, for example, as in Nevada where by amendment since 1942 it has been required that intangibles be exempt from taxation. Similarly, by an amendment of the Utah Constitution in 1930 intangibles are no longer subject to the requirement of universality.

In Kansas, we find a direct conflict with the interpretation

80 Supra, p. 272.

31 Supra, p. 252.

82 Supra, pp. $278,335,340,345$. 
given this type of clause by the above states. The Kansas court has ruled that this provision does not require universality. ${ }^{33}$ However, in Kansas exemptions must meet, in addition to the test of reasonable classification, a test of "public interest." But the most interesting result among this group of states is found in Indiana ${ }^{34}$ In that state we find a sharp distinction being made between the "selection" of property for taxation and the "exemption" of property from taxation. The court has ruled that once the legislature has selected a general class of property for ad valorem taxation, any attempt to "exempt" a part of that general class-however reasonable that sub-classification might appear to be as a class-is a violation of the requirement that there be a "uniform and equal rate of assessment and taxation" because such "exemptions" produce "inequality" in the tax burden. However, one is not unwarranted in concluding that the court has in fact permitted the exemptions of intangibles from the ad valorem general property tax. It reasoned that the uniformity clause does not limit the power of the legislature to "select" a general class of property, such general class being less than the whole which it might "select" as object for the general property tax. This sharp, and perhaps overly refined line of distinction, as was described in the separate state study, stemmed from the attempts to devise new ways of taxing intangibles in Indiana. The legislature, recognizing the need to reach all intangibles by a lower rate tax, and being restricted by the requirement of absolute uniformity in effective rates, enacted a separate intangibles tax which contained an in lieu provision removing, in effect, all intangibles from the general property tax. The intangibles tax itself was upheld by the process of designating it a nonproperty tax, not upon intangibles themselves, but upon certain named

${ }^{33}$ Supra, p. 310.

34 Supra, p. 303. 
privileges. The in lieu provision was then upheld by the process of designating the same as being nothing more than a "withdrawal" of intangibles from the general class of property taxables. This power of "withdrawal" was said to be simply one aspect of the power of "selection," thus there was no restriction placed upon the "withdrawal" by the uniformity clause. Consequently, a "withdrawal" was said to be something other than, and not synonymous with, "exemption." This distinction was based to some degree on the rationale that the general class of property "selected" was to be based upon the character or nature of the property, not upon its use as are the "exemptions."

\section{c. Uniformity and effective rates}

The third question to be considered, in comparing the effective uniformity limitations as to the particular rules of uniformity, concerns the degree of uniformity which is required of effective rates. That is, may a classified property tax be levied?

As might be expected, in all of the states (Arkansas, Maine, and Tennessee) having a basic clause of Type I (Property shall be taxed according to its value) that provision is interpreted as requiring absolute uniformity in the effective rate applicable to all property taxed by any one taxing authority. In Arkansas and Tennessee there is a supplementary provision dealing directly with this problem, but the requirement is said to be derived from the basic uniformity clause as well. ${ }^{35}$ In Maine, the situation has been altered to some degree by an amendment providing for special treatment of intangible property. Such property may be taxed at a different "rate" from that applied to other property actually taxed. ${ }^{36}$

${ }^{85}$ Supra, pp. 55, 86.

36 Supra, p. 61. 
Among those four states (Alabama, California, Illinois, and Nebraska) having the Type II clause (Property shall be taxed in proportion to value) a uniformity of result was also found, disregarding subsequent amendments making express inroads on this limitation. In each of the states an absolute uniformity in effective rates was required. However, in California an amendment now provides that personal property is to be excepted from the operation of the uniformity clause and it may be classified for application of different rates. ${ }^{37}$ Similarly, in Nebraska there has been a modification by amendment adopted in 1920 providing for the classification of intangible property for the application of rates. ${ }^{38}$ As for the development in Illinois on this point, we find one of the most interesting situations revealed by the entire state by state analysis. The Illinois court has constantly given lip service to the doctrine that absolute uniformity of effective rates is required. Nevertheless, it was shown that in fact the Illinois court has sanctioned a de facto system of classification of property for the purpose of applying different ratios of valuation, consequently permitting to some degree a classified property tax even though an absolute uniformity is actually required as to the percentage rate. ${ }^{39}$ True to form, the unanimity of result as to this problem continues in Massachusetts and New Hampshire, the two states having a Type III clause. In both of these states, an absolute uniformity in effective rates is required. ${ }^{40}$

Turning to those four states having basic uniformity clauses of Type IV (A Uniform Rule of Taxation), or some variation of that clause, we find some diversity in the effective limitations. In two states (Ohio and Wisconsin) absolute

\footnotetext{
87 Supra, p. 113.

88 Supra, p. 170.

${ }^{39}$ Supra, p. 129.

40 Supra, pp. 179, 190.
} 
uniformity in effective rates is without any question required, the requirement being derived from this type clause. ${ }^{41}$ However, in Ohio by an amendment adopted in 1929, personal property has been expressly removed from the scope of the operation of the uniformity clause and such property may be classified for the application of different effective rates. An opposite result was found in New Jersey, where it has been held that classification of property for rates is permissible. ${ }^{42}$ It should be pointed out that since 1947 it appears that real property in New Jersey constitutes a minimum class by force of an express amendment to the uniformity provision. In the fourth state of this group, Michigan, we have the unique situation already referred to in the preceding discussion of universality. In Michigan, the uniformity clause of Type IV limits only property taxed ad valorem. As to such property an absolute uniformity in effective rates is required. As to that property taxed by a "specific" property tax, the only requirement is that the rates be uniform within classes. ${ }^{43}$

A uniformity in results was also found among those four states (Mississippi, Texas, West Virginia, and Wyoming) having a Type $V$ clause (Taxation shall be equal and uniform), and those six states (Florida, Indiana, Kansas, Nevada, South Carolina, and Utah) having a Type VI clause (The legislature shall provide by law for a uniform and equal rate of assessment and taxation). In all of those states it was ruled that an absolute uniformity in effective rates was required by such uniformity clauses. ${ }^{44}$ However, in the Kansas study ${ }^{45}$ the pattern was disturbed by an anomalous case decided in 1949 in which the court apparently relaxed or, at

41 Supra, pp. 227, 245.

12 Supra, p. 219.

43 Supra, p. 213.

44 Supra, pp. 253, 259, 266, 272, 279, 303, 311, 335, 340.

15 Supra, p. 320. 
least, ignored the strict uniformity requirement in upholding a tax on the property of private car companies. It was pointed out that the single case hardly warranted a conclusion that the Kansas court has reversed the interpretation formerly given to the basic uniformity clause, but that the case simply stands as an interesting anomaly illustrating the manner in which the strict uniformity limitations have caused much difficulty. Because of the inflexibility of this strict limitation a substantial number of these ten states have seen fit to partially avoid the result. This has not been done by the adoption of a more liberal type of uniformity clause. Rather, in each case, the procedure has been to retain the same uniformity clause while adopting an amendment providing for special treatment of named classes of property. Thus, for example, in West Virginia (of Group V) an amendment adopted in 1932 classifies all property and provides for a different maximum rate to be applied to each of the classes. ${ }^{48}$

Indeed, in five of the six states having a Type VI clause an amendment has been adopted which alters to some degree the effective uniformity limitation. Since 1924, in Florida it has been permissible to classify intangibles for different rates. ${ }^{47}$ In Indiana, there has been no amendment; however, the interpretation referred to in the universality discussion has permitted the "exemption" of intangibles from the property tax and the imposition thereon of a "nonproperty" tax, the rate of which obviously differs from the general property tax rate. ${ }^{48}$ Since 1924 , in Kansas an amendment has expressly provided for the classification of intangible property for rates. ${ }^{49}$ In Nevada no modification has been made as to rates; however, as noted above, all intangibles must be ex-

\footnotetext{
46 Supra, p. 268.

17 Supra, p. 280.

48 Supra, p. 285.

49 Supra, p. 323.
} 
empt by authority of a 1942 amendment. ${ }^{50}$ A 1932 amendment to the South Carolina Constitution provides for the classification of intangibles for a different "rate" from that applied to other property. ${ }^{51}$ And in Utah a 1930 amendment provides for special treatment of intangibles by classification for application of different rates. ${ }^{.2}$

In summary, of the twenty-three states which have basic uniformity clauses ranging from Type I through Type VI, only one state, New Jersey, permits property to be classified for the purpose of applying different effective rates. Otherwise, there was a unanimity of agreement that those types of uniformity clauses require an absolute uniformity in effective rates, which, however, has been avoided in nine states by amendments withdrawing to varying degrees certain classes of property (usually intangibles) from the scope of the uniformity clause. In addition, there is the unique situation in Michigan which results in the absolute uniformity in rates requirement being only "partially" applicable; that is, only as to property taxed ad valorem. Finally, there is the very unusual development in Illinois where a de facto classification system has been sanctioned, the continuation of which could well make a farce out of the apparent strict uniformity limitation.

Turning now to those twenty states having basic uniformity clauses of either Type VII (Taxes shall be uniform upon the same class of subject) or Type VIII (Taxes shall be uniform upon the same class of property), we find a result as completely in favor of classification-at least by way of lip service-as was the result against classification under the basic clauses of Types I through VI.

Of the thirteen states having a Type VII basic uniformity

'00 Supra, p. 333.

51 Supra, p. 341.

62 Supra, p. 347. 
clause, only one, Idaho, has clearly ruled that an absolute uniformity in effective rates is required, ${ }^{53}$ but in the Idaho Constitution there is a plenitude of uniformity provisions. The Type VII basic uniformity clause is coupled with a "just valuation" type clause, and in another section of the constitution there is a Type II "proportionality" clause. Nevertheless, the Idaho court has never recognized any possible conflict among these several provisions. The basic clause of Type VII is simply referred to as requiring an absolute uniformity in effective rate, even though the court has limited the application of that provision to the taxation of property. As pointed out in the Idaho study, the court as recently as 1952 refers to the Type VII clause as one requiring taxes to "be uniform," or containing a "requirement of uniformity" and "equality in burden," or as "the constitutional mandate of equality of taxation." The words "upon the same class of subjects" have simply been ignored.

In the remaining twelve states of this group property may ostensibly, at least, be classified for the purpose of applying different effective rates. This result has not been easily reached in all cases, and, indeed, in some instances it would appear that this power to classify will be viewed rather hostilely by the court when exercised. For example, the Colorado court in its opinions has indicated that classification of property is permissible, but in fact its decisions indicate that in all likelihood little classification will be approved other than a broad classification such as personal property and real property, with intangible property possibly being a permissible class. The power to classify personal property into further subclassifications was spelled out in a 1936 amendment adding a new section to the Colorado Constitution. In fact, however, the express proviso may well result in even further limiting the power to classify personal property because it

53 Supra, p. 383. 
apparently is now conditioned upon the imposition of an income tax. ${ }^{54}$ In New Mexico no categorical answer as to classification has been given. ${ }^{\text {b5 }}$ Some question might well arise as to the extent of permissible classification because of the unusual phraseology of the New Mexico uniformity clause. "Tangible property" is to be taxed in proportion to value, and in the absence of decisions one is not warranted in concluding that classification of "tangible property" into subclassifications would be permitted. The supplementary "proportionality" clause might well be used to establish "tangible property" as a minimum subject of taxation as occurred in Georgia and Missouri.

There has been considerable confusion and difficulty concerning this question in Georgia, ${ }^{56}$ Missouri, ${ }^{57}$ and Montana. ${ }^{58}$ In all three states, the Type VII clause was accompanied by a supplementary clause which on its face would be more strict. In Georgia and Missouri, there appeared, in addition to the Type VII clause, supplementary clauses of Type I (property shall be taxed according to its value) and Type II (property shall be taxed in proportion to its value). In both states, the courts held that the supplementary provisions established property as a single minimum subject of taxation, and consequently a further subclassification for effective rates was not permissible. An opposite result was found in Montana, where the court had to reconcile a potential conflict between a Type VII clause and a supplementary provision of Type VI (The legislature shall provide by law for a uniform and equal rate of assessment and taxation). The Montana court held that had there been no clause of

\footnotetext{
54 Supra, p. 357.

55 Supra, p. 445.

56 Supra, p. 376.

67 Supra, p. 427.

58 Supra, p. 434.
} 
Type VII then property taxation would have been limited by a requirement of absolute uniformity in effective rates, this limitation being derived from the Type VI supplementary clause. However, the "uniformity within classes" clause of Type VII was held to take precedence on this particular point, and the intent of the clause was said to be that property might be classified for applying different effective rates.

In both Georgia and Missouri this problem was subsequently dealt with by amendments, dated 1937 and 1945 respectively. These amendments deleted the supplementary clauses requiring taxation of property to be according or in proportion to its value, and expressly provided that property might be classified. However, in each case the minimum classes are spelled out. In Missouri, real property is a minimum class, all other property being subject to further subclassification. In Georgia, even greater restriction upon potential classifications is made, the amendment expressly establishing two general classes of property, tangible and intangible. Only intangible property is subject to further classification.

These three states furnish an excellent illustration of how the subjective predilections of the various courts must have had much to do in determining whether a classified property tax might be enacted. In Georgia and Missouri, the potentially liberal uniformity clause was construed to apply to all taxes, and the supplementary clauses were held to predominate, consequently preventing classification of property for taxation. To the contrary, in Montana the court took express notice of the conflict and gave a preference to the constitutional provision which permitted the greater legislative discretion. Any other course by the Montana court would have meant that little was accomplished by the introduction of the "uniformity within classes" type clause of more recent origin. The studies of these three states further emphasize 
how hazardous generalizations are in this area of "the" state constitutional requirement of uniformity in taxation. Although having identical clauses, different results will often be dictated by supplementary provisions which are often ignored by writers when classifying the several states as to their types of uniformity limitations.

In the remaining six states (Delaware, Minnesota, Oklahoma, Oregon, Pennsylvania, and Virginia) having a Type VII clause, classification of property for application of different effective rates is permitted, ${ }^{59}$ and among those six states are found some of the most liberal in terms of degree of classification allowed. For example, in Minnesota, Oregon, and Pennsylvania, the courts have permitted the legislatures the greatest degree of discretion for the purpose of classifying property for effective rates, including the subclassification of real property as well as other extensive classifications.

As for those seven states (Arizona, Kentucky, Maryland, North Carolina, North Dakota, and South Dakota) having a Type VIII basic clause, we find the anticipated result. In all of those states property may be classified for application of different effective rates. ${ }^{60}$ However, one might note how the apparently liberal limitation has not been in all cases liberally applied. In Arizona, the court, despite giving lip service to the classification principle, has indicated that any classifications of property whatsoever are likely to face considerable difficulty in being established as reasonable. In Maryland, real property is made a minimum class by express constitutional provision, and a similar situation is found in Washington.

The last five states are Rhode Island and Vermont, having a Type IX basic uniformity clause, and Connecticut, Iowa and New York which have no provision of any kind.

s0 Supra, pp. 363, 404, 453, 460, 540, 544.

${ }^{60}$ Supra, pp. $547,553,557,561,566,571,580$. 
It appears certain that in all of those five states property may be classified for application of different effective rates. ${ }^{61}$ However, before one concludes that the two states having a clause of Type IX should simply be included in the group which have no uniformity provision of any kind, one should note that in Maryland before 1915, the only provision in its constitution relating to uniformity in taxation was a Type IX clause, and under that provision the strictest degree of uniformity was required. ${ }^{02}$

We can return now to the question originally posed, may a classified property tax be imposed in any of the states? Remember that we are here concerned only with classification for rates, not for exemptions. On the basis of this study it would appear that in twenty-five states a classified property tax is possible. The writer emphasizes "possible" because not every state which can apparently utilize classification for rates has done so. States in which a classified property tax is permissible are: Type IV (a uniform rule of taxation): New Jersey; Type VII (taxes shall be uniform upon the same class of subjects): Colorado, Delaware, Georgia, Minnesota, Missouri, Montana, New Mexico, Oklahoma, Oregon, Pennsylvania, and Virginia; Type VIII (taxes shall be uniform upon the same class of property): Arizona, Kentucky, Maryland, North Carolina, North Dakota, South Dakota, and Washington; and among those states having either Type IX or no clause of any kind: Rhode Island, Vermont, Connecticut, Iowa and New York. However, it should be remembered, as pointed out above, that in a number of those twenty-five states the power to classify is limited in varying degrees by supplementary provisions. In a twentysixth state, Michigan (having a Type IV clause) a classified

61 Supra, pp. 591, 595.

62 Supra, p. 556. 
property tax is partially possible, that is, as to that property taxed other than by the ad valorem method.

Furthermore, of those states having uniformity structures interpreted to require the strictest of uniformity, it was pointed out that ten states have avoided this result by amendment, leaving the basic uniformity clause unchanged but expressly providing for the power to classify to some degree. Those ten states are: Type I (property shall be taxed according to its value): Maine; Type II (property shall be taxed in proportion to its value): California and Nebraska; Type IV (uniform rule of taxation): Ohio; Type V (taxation shall be equal and uniform): West Virginia; Type VI (legislature shall provide by law for a uniform and equal rate of assessment and taxation): Florida, Kansas, Nevada, South Carolina, and Utah. However, in most of these ten states the power to classify extends only to a limited class of property, for example, classification of intangibles.

Twelve states have the strict uniformity requirement unaltered by any exceptions. ${ }^{63}$ They are: Type I (property shall be taxed according to its value): Arkansas and Tennessee; Type II (property shall be taxed in proportion to its value): Alabama and Illinois; Type III (proportional and reasonable assessments, rates, and taxes etc.): Massachusetts and New Hampshire; Type IV (uniform rule of taxation): Wisconsin; Type $\mathrm{V}$ (taxation shall be equal and uniform): Mississippi, Texas and Wyoming; Type VI (uniform and equal rate of assessment and taxation): Indiana; Type VII (taxes shall be uniform upon the same class of subjects): Idaho. Among these twelve states, a trend in Illinois permitting different valuations changes considerably the apparent strict requirement.

Having determined that in some of the states a classified

03 Cf. the classification made by Cushman, "The Proposed Revision of Article IX of the Illinois Constitution," 1952 IIl. L. Forum 226, 236-237. 
property tax is permissible, the next question to be asked is this: may a graduated property tax rate be imposed in those states? It should come as no surprise to anyone even slightly familiar with this general problem of uniformity in taxation, that this is a question which has not often been raised in the cases, even by implication. In the cases concerning classified property taxes the discussion seldom departs from the more basic question of whether any classification is permissible. However, in a very limited number of cases, the question of a graduated rate applicable to property has been touched upon, by implication if not directly.

The most important discussion is found in the Minnesota development of the uniformity limitation. ${ }^{64}$ In the Minnesota study it was shown that the principle of a graduated property tax rate was expressly approved, although not elaborated upon to any great extent. In approving this principle, the court emphasized that "ability to pay may properly be taken into consideration by the legislature in classifying property for the purpose of taxation." On the other hand, in Washington the court has expressly ruled out graduated property tax rates on the grounds of arbitrary classification. ${ }^{\mathbf{6 5}}$ This decision, it should be noted, was made in relation to an income tax which was held to be a tax upon property. Indeed, it is among the income tax decisions that we find the few other decisions pertinent to the immediate question. In both Oregon ${ }^{66}$ and North Dakota ${ }^{67}$ the courts have upheld income taxes which had graduated rates, and in neither case did the courts determine the nature of the tax on the ground that this question was immaterial since the uniformity required of property taxes was said to be no greater than

\footnotetext{
64 Supra, p. 406.

65 Supra, p. 580.

66 Supra, P. 459.

67 Supra, p. 566.
} 
that required of nonproperty taxes. In both cases, incidentally, the courts equated the respective uniformity clause with the equal protection clause of the fourteenth amendment to the United States Constitution. Furthermore, it might be pertinent to note that the concurring opinion in the North Dakota case was on the ground that the tax was a nonproperty tax. Thus, it would appear to be evident that outside of the Minnesota case, anything pertinent to this question is derived from a discussion of the more controversial and larger issue, the validity of an income tax under these state constitutional uniformity provisions. In fact, the only straightforward graduated property tax was found in Oklahoma, but that tax was never enforced and no opinion was ever rendered as to its validity under the uniformity limitation. $^{68}$

It is also pertinent at this point to raise the question whether the uniformity clauses apply to the method of assessment used under the property tax; i.e., the mechanics of assessing and valuing the property in order to determine the value of the property. Without exception, the state by state analysis indicated that regardless of the strictness of the uniformity limitation applicable to the effective rate (that is, percentage rate plus ratio of valuation) there was no prohibition against classification of property for the purpose of reaching a figure to be used as the "value" of the property. The only reason for giving any attention to this problem is because the statement of the rule has often been the basis for later unwarranted generalizations. ${ }^{69}$ It was shown in the state by state analysis that in several states in which absolute uniformity is required of effective rates some confusion was caused by a somewhat careless use of the method of assessment cases. The statements in such cases to the effect that

68 Supra, p. 454.

${ }^{69}$ For example, see the Arkansas study, C. III, $\S \mathrm{A} / 1$, note 8 , supro. 
classification of property was permissible for determining a single ratio of valuation applicable to all property were then used, without any basis, as authority for indicating that property might be classified for application of different effective rates. Sometimes the confusion stemmed from a somewhat unnecessarily broad generalization in the case on method of assessment. At other times, for example, in some digests and annotations the quotations from such cases are used under a heading which indicates that property may be classified generally.

\section{d. Method of taxation}

The last problem in comparing results as to particular rules of uniformity applicable to the taxation of property is this: may a specific tax (as opposed to an ad valorem tax) be levied upon property? That is, what does the uniformity limitation require of the "method" of taxation of property?

As for those states (Arkansas, Maine, Tennessee, Alabama, California, Illinois, and Nebraska) having either a Type I or Type II basic uniformity clause, property may be taxed only by the ad valorem method. ${ }^{70}$ This rule, of course, is derived from the express words of the "uniformity" clauses since they are framed in terms of "according to value" or "in proportion to value." In California, a 1933 amendment withdrew all personal property from the operation of the uniformity clause and expressly provides that such property may be taxed in any "manner" as the legislature may choose. In Massachusetts and New Hampshire, having Type III basic uniformity clauses, the same general result was reached, i.e., property may be taxed only by the ad valorem method. ${ }^{71}$ However, at this point, the rather unusual situation in New Hampshire is of interest. All taxes in New Hampshire are

${ }^{70}$ Supra, pp. 54, 60, 86, 98, 113, 126, 169.

71 Supra, pp. 175, 187. 
"property" taxes. Taxes on "estates" conform to what are designated as property taxes in the other forty-seven states and taxes on "other classes" of property conform to the usual concept of nonproperty taxes. The important point is that even the taxes on "other classes" of property must ostensibly meet the ad valorem requirement. However, as pointed out in the New Hampshire study this limitation has been usually avoided in any case where it would have invalidated the tax, the court using a technique of designating the revenue producer as either a "charge" or "toll." This was done in the case of the fuel tax which has a specific base-rate structure.

The remaining types of uniformity clauses are framed in words of "uniform" and/or "equal" rather than words of "value," and consequently one would expect more diversity in results. Of those four states having a Type IV clause (a uniform rule of taxation), three have a requirement that property must be taxed by the ad valorem method. They are New Jersey, Ohio, and Wisconsin. ${ }^{72}$ In New Jersey there was no judicial development of this particular rule and the conclusion here made is drawn from the words "according to value" which are added to the words "uniform rule." The same situation is found in Ohio where the phrase "uniform rule" is joined with the word "proportional." However, the Ohio court has had occasion to state that the ad valorem requirement would be derived from the uniformity clause even without the additional words of proportionality. Also in Wisconsin the uniformity clause is accompanied by other clauses which might well be the source of the ad valorem requirement. The Wisconsin court has never made it precisely clear whether the requirement would exist in the absence of the supplementary provisions. In both Ohio and New Jersey this strict rule has been alleviated to some degree. In 1929, an amendment to the Ohio Constitution limited the

72 Supra, pp. 218, 224, 239. 
operation of the basic uniformity clause to taxation of real property. Consequently one may conclude that personal property may now be taxed by the specific method. A similar conclusion may be drawn from the 1947 revision of the New Jersey Constitution. The fourth state, Michigan, has a unique status. ${ }^{73}$ Contrary to the rule in the other forty-seven states, the method of taxation of property is not determined by the uniformity clause. Rather, the applicability of the strict uniformity clause (strict in that absolute uniformity in rates is required) is determined by the method by which property is taxed, that limitation applying only to that property taxed ad valorem. Thus, the Michigan legislature apparently has a free choice in determining the method of taxing property, with the method chosen in turn determining the rule of uniformity which will apply. For example, intangibles have been subjected to a "specific" tax which is called a property tax but not subject to the rule of absolute uniformity in effective rates.

Surveying those ten states having either a Type V (taxation shall be equal and uniform) or Type VI (a uniform and equal rate of assessment and taxation) clause, we find that in all cases there is a requirement that property be taxed only by the ad valorem method. However, in all but two states there has been little judicial opinion on the problem, the source of the limitation being in any case expressly spelled out in a supplementary clause of either Type $I$ or Type II, or, with one exception, a “just valuation" clause coupled to the Type VI uniformity clause. The states are Mississippi, Texas, West Virginia, and Wyoming having a Type V clause, ${ }^{74}$ and Florida, Nevada, South Carolina, and Utah having a Type VI clause. ${ }^{75}$ In Indiana, which has a

73 Supra, p. 198.

74 Supra, pp. 252, 258, 266, 271.

75 Supra, Pp. 278, 335, 340, 345. 
Type VI clause coupled with a "just valuation" clause, the court seems to have expressly derived the limitation from the basic uniformity clause as well. ${ }^{76}$ The most significant result among these ten states is found in Kansas ${ }^{77}$ which has a Type VI clause standing alone. There are no provisions in the Kansas Constitution containing any express words of "value." Nevertheless, the Kansas court has ruled that the ad valorem method is required. The only change by amendment among these ten states is found in Utah, that state's constitution being amended in 1930 in order to remove intangible property from this limitation.

Among those thirteen states having a Type VII basic uniformity clause (taxes shall be uniform upon the same class of subjects) we find some rather diverse results which are usually explained by the appearance of supplementary provisions framed in words of "value." In Colorado, the problem has not been clearly ruled upon, but there is most likely an ad valorem requirement, probably stemming from the "just valuation" clause which follows the basic uniformity clause. ${ }^{78}$ Before 1937, in Georgia there was an ad valorem requirement spelled out in a Type I clause, but by an amendment in 1937 that clause was deleted and the requirement may no longer exist. ${ }^{79}$ The reason for the deletion of the supplementary provision did not concern the method for taxation requirement. Rather, the Georgia court had used that provision to establish property as a single subject of taxation, consequently preventing classification for rates. In Idaho, there has been no judicial development, but quite likely the ad valorem requirement is present in view of the supplementary clause of Type II. ${ }^{80}$ In any case, one might note that as to

\footnotetext{
76 Supra, p. 303.

77 Supra, p. 310.

78 Supra, p. 352.

79 Supra, p. 372.

80 Supra, p. 381.
} 
effective rates, the Idaho court has ruled that absolute uniformity is required, simply referring to the Type VII clause as simply a "constitutional mandate of equality in taxation." Even in the absence of the supplementary clause, therefore, one cannot be sure just how the court would react to a specific property tax. In Missouri, ${ }^{81}$ the experience has been quite similar to that in Georgia. Before 1945, there was a Type II supplementary clause in the Missouri Constitution which was relied upon by the court in finding an ad valorem requirement. An amendment in 1945 deleted the supplementary clause; however, there was inserted a detailed provision in which it is expressly provided that tangible property must still be taxed by the ad valorem method, while intangibles are now to be taxed by the yield method. The detailed provision introduced by amendment leaves the basic uniformity almost without purpose, certainly as to this particular limitation. In Montana, as in Georgia and Missouri, a supplementary clause of Type VI was the source of the ad valorem limitation. ${ }^{82}$ The deletion of this supplementary provision from the Montana Constitution has not been necessary because the Montana court has construed the basic clause of Type VII to predominate as to the limitation applicable to effective rates. Consequently, classification is permissible. In New Mexico, we find a supplementary provision which is the source of the requirement that tangible property must be taxed by the ad valorem method. ${ }^{83}$ There is some question in New Mexico concerning the rule applicable to the taxation of intangibles. In Virginia, as in Missouri and Georgia, a supplementary ad valorem type clause was deleted by amendment, and, while there has been no judicial development, it is likely that there is no longer any ad

\footnotetext{
81 Supra, p. 422.

82 Supra, p. 432.

83 Supra, p. 443.
} 
valorem requirement. ${ }^{84}$ The study of the Pennsylvania uniformity limitation revealed some confusion on this point. ${ }^{85}$ The Pennsylvania court has on occasion ruled that property may only be taxed by the ad valorem method. The only decision by the highest Pennsylvania court concerned a "tax" (the alcoholic floor tax) which was in reality a regulatory measure. The study revealed an earlier case in which the court apparently approved a specific property tax, but that opinion has been ignored in the later cases. The remaining four states in this group (Delaware, Minnesota, Oklahoma, and Oregon) have no ad valorem requirement. ${ }^{86}$ In the constitutions of those states there are no supplementary provisions. It is also pertinent to note that they are among the most liberal of the states in discretion allowed the respective legislatures in taxation of property.

Examining that group of seven states having the Type VIII clause (taxes shall be uniform upon the same class of property) we again find some diversity in results. In three of these states (Kentucky, Maryland, and North Carolina) there is possibly an ad valorem requirement. In Kentucky this is certain, the limitation being spelled out, however, by a Type II supplementary clause. ${ }^{87}$ Also in Maryland, the problem is settled. ${ }^{88}$ However, the Maryland court has ruled that the ad valorem requirement is derived from the word "uniform" in the Type VIII basic uniformity clause. In North Carolina there is some doubt whether the ad valorem limitations still exists. ${ }^{89}$ On the other hand, in the remaining four states of this group (Arizona, North Dakota, South Dakota, and Washington) there is no requirement that

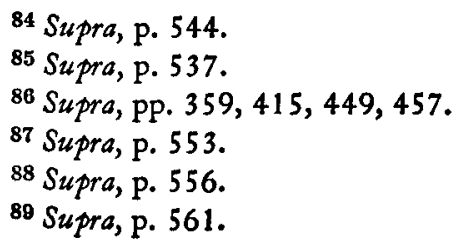


property be taxed by ad valorem method only. ${ }^{90}$ One might note, however, that in Arizona there is no judicial opinion available, and in view of the strict interpretation used by the Arizona court in reviewing legislative classification of property for rates it is not too unlikely that the court would be equally hostile to any attempted specific property taxes. The most significant result among these states is that in Maryland, where the court clearly derived the ad valorem requirement from the basic uniformity clause of Type VIII. As would be expected, there is no ad valorem requirement among those states having a clause of Type IX (Rhode Island) or having no clause of any kind (Connecticut, Iowa, and New York).

\section{A Summary Comparison of Effective Uniformity Limitations}

Thus far in this study the states have been grouped on the basis of a classification of their respective uniformity clauses based on phraseology alone. For convenience, the nine basic classes of such provisions were referred to as Types of clauses. These basic uniformity clauses standing alone, without interpretation, might be referred to as literal limitations of uniformity. A state by state study was made to determine the effective uniformity limitation which exists in each state, this effective limitation being the literal limitation plus the judicial gloss. Having made a "rule by rule" comparison among the forty-eight states, it will now be helpful to compare the effective uniformity limitations found in the several states to the literal limitations, and in that way one may determine to what degree they coincide. For the purpose of the present comparison it is possible to classify the several types of possible effective limitations in the fol-

${ }^{90}$ Supra, pp. 546, 564, 569, 579. 
lowing manner, ranging from the most strict possible to the most liberal. The degree of strictness is determined by a combination of the three particular rules of uniformity.

(1) There is an effective limitation of:
(a) universality;
(b) absolute uniformity in effective rates;
(c) ad valorem method only.

(2) There is an effective limitation of:
(a) NO UNIVERSALITY;
(b) absolute uniformity in effective rates;
(c) ad valorem method only.

(3) There is an effective limitation of:

(a) NO UNIVERSALITY;

(b) absolute uniformity in effective rates;

(c) NO AD VALOREM REQUIREMENT.

(4) There is an effective limitation of:

(a) universality;

(b) RATES UNIFORM WITHIN CLASSES;

(c) ad valorem method only.

(5) There is an effective limitation of:

(a) universality;

(b) RATES UNIFORM WITHIN CLASSES;

(c) NO AD VALOREM REQUIREMENT.

(6) There is an effective limitation of:

(a) NO UNIVERSALITY;

(b) RATES UNIFORM WITHIN CLASSES;

(c) ad valorem method only.

(7) There is an effective limitation of:

(a) NO UNIVERSALITY;

(b) RATES UNIFORM WITHIN CLASSES;

(c) NO AD VALOREM REQUIREMENT.

Thus, in (7) the only requirement is a uniformity within classes, the most liberal effective limitation. The key requirement in determining the strictness of the limitation is that degree of uniformity required of the effective rates. It is this requirement that determines whether a classified prop- 
erty tax, as such a tax is generally conceived, is possible. In this respect the effective limitations (1), (2) and (3) are the strictest limitations. Thus, those effective limitations permitting classified property taxes would be (4), (5), (6) and (7). However, only (6) and (7) would permit the most flexible types of classified property tax, one under which free exemption is permitted.

The author has classified the states according to the gradations of effective limitations of uniformity as set forth above. This classification is based on the conclusions reached in the state by state study, and is reproduced graphically on the accompanying chart. In the following discussion the roman numeral following each state signifies the nature of its basic type of uniformity clause. First, there are thirteen states which have an effective uniformity limitation of the strictest degree, class (1). They are: Arkansas (I), Tennessee (I), California (II), Illinois (II), Nebraska (II), Ohio (IV), Texas (V), West Virginia (V), Florida (VI), Indiana (VI), Nevada (VI), South Carolina (VI), and Utah (VI). However, seven of these thirteen states have subsequently modified this effective limitation by amendment without altering the basic uniformity clause in its phraseology. Those seven states are indicated by italics. Indiana is included in this group although in that state a distinction is made between the "exemption" and "selection" of property for taxation, with the result being that there is not a full rule of universality governing in that state.

Second, there are nine states which have an effective uniformity limitation of class (2), which is also a strict limitation, although exemptions are permitted. These states are: Maine (I), Alabama (II), Massachusetts (III), New Hampshire (III), Wisconsin (IV), Mississippi (V), Wyoming (V), Kansas (VI), and Idaho (VII). Two of these nine states have modified this effective limitation by amend- 
CHART OF LITERAL AND EFFECTIVE PROPERTY TAX UNIFORMITY LIMITATIONS

(continued on p. 678)

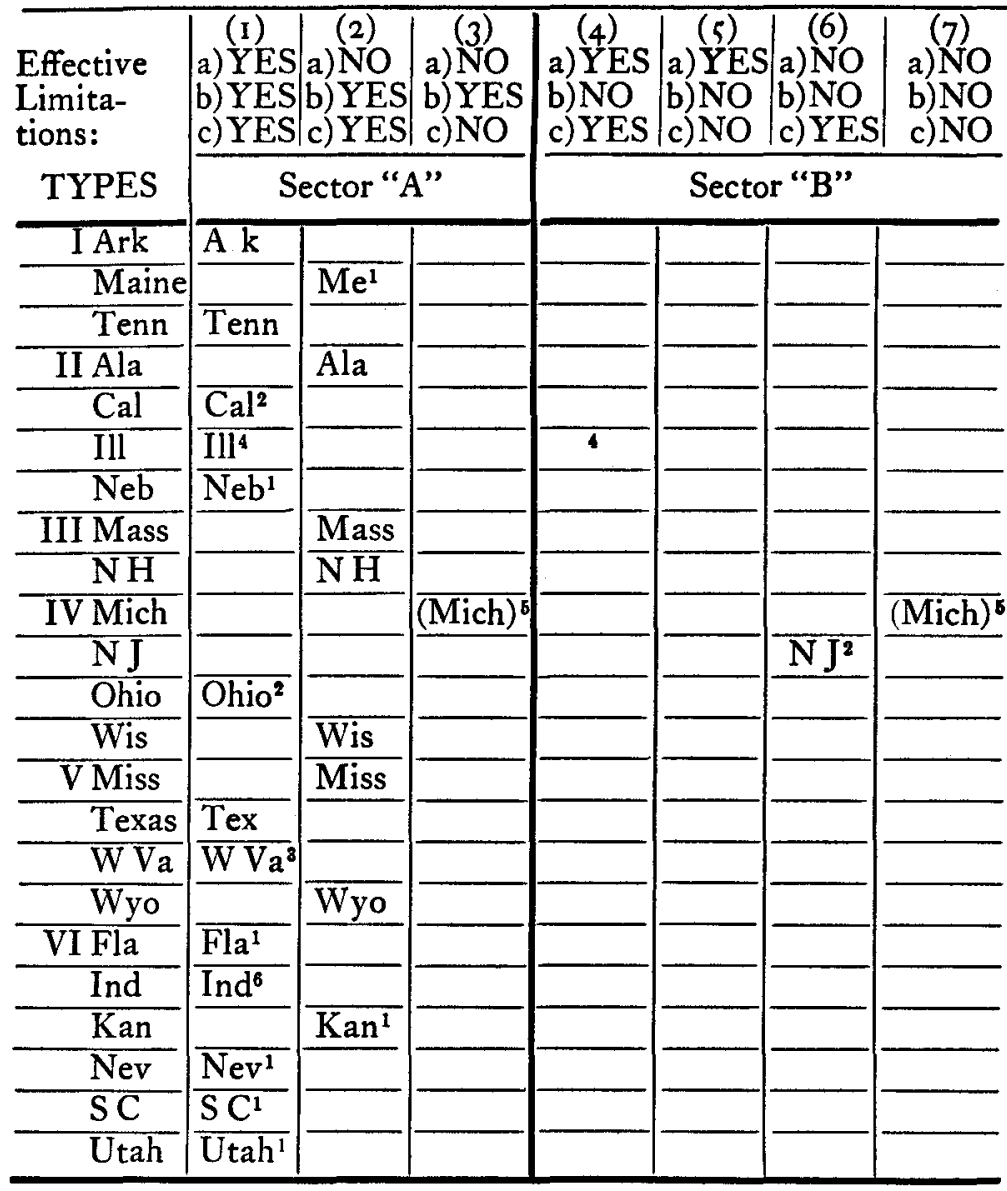

Reading down, states are grouped according to types of uniformity clauses; the literal limitations. . . Reading from left to right, classification is from strict to liberal effective uniformity limitation, depending on answers to three questions: (a) Is there a rule of universality? (b) Is absolute uniformity required of effective rates? (c) Is the ad valorem method required? Heavy lines separate strict from liberal limitations. The four sectors, reading clockwise, are: A) Strict literal-strict effective. B) Strict literal-liberal effective. C) Liberal literal-liberal effective. D) Liberal literalstrict effective.

I. The effective limitation has been modified, constitutionally, by a "special treatment" amendment for intangible property.

2. Same as note 1 , except special treatment is for tangible property.

3. Same as note I, except special treatment is for all property-that is, all property is classified by amendment, leaving the basic clause unchanged. 


\begin{tabular}{|c|c|c|c|c|c|c|c|}
\hline \multirow[t]{2}{*}{$\begin{array}{l}\text { Effective } \\
\text { Limita- } \\
\text { tions: }\end{array}$} & \multicolumn{3}{|c|}{\begin{tabular}{|l|l|l|} 
(I) & $(2)$ & $(3)$ \\
a) YES & a) NO & a) NO \\
b) YES & b) YES & b) YYS \\
c) YES & c) $Y$ YES & c) NO \\
\end{tabular}} & \multicolumn{4}{|c|}{\begin{tabular}{l|l|l|l|} 
a) (4) & $(5)$ & (6) & (7) \\
a) YES & a)YES & a)NO & a)NO \\
b) NO & b)NO & b)NO & b)NO \\
c)YES & c)NO & c)YES & c)NO \\
\end{tabular}} \\
\hline & \multicolumn{3}{|c|}{ Sector "D" } & \multicolumn{4}{|c|}{ Sector "C" } \\
\hline VII Colo & 7 & & & Colo ${ }^{2}{ }^{7}$ & & & \\
\hline Del & & & & & & & Del \\
\hline $\mathrm{Ga}$ & 8 & & & $\mathrm{Ga}^{8}$ & & & \\
\hline $\mathrm{Ida}$ & & Ida & & & & & \\
\hline $\mathrm{La}$ & & & & & & & \\
\hline Minn & & & & & & & Minn \\
\hline Mo & 8 & & & $\mathrm{Mo}^{8}$ & & & \\
\hline Mont & & & & Mont ${ }^{9}$ & & & \\
\hline N M & & & & $\mathrm{NM}^{10}$ & & & \\
\hline Okla & & & & & & & Okla \\
\hline Ore & & & & & & & Ore \\
\hline$\overline{\text { Penn }}$ & & & & & & Penn & \\
\hline $\mathrm{Va}$ & & & & & $\mathrm{Va}$ & & \\
\hline VIII Ariz & & & & & Ariz & & \\
\hline $\mathrm{Ky}$ & & & & $\mathrm{Ky}$ & & & \\
\hline $\mathrm{Md}$ & & & & $\mathrm{Md}$ & & & \\
\hline $\mathrm{NC}$ & & & & & $\mathrm{NC}$ & & \\
\hline $\mathrm{ND}$ & & & & & & & ND \\
\hline SD & & & & & & & SD \\
\hline Wash & & & & & & & Wash \\
\hline IX R I & & & & & & & R I \\
\hline$V_{t}$ & & & & & & & $V_{t}$ \\
\hline X Conn & & & & & & & Conn \\
\hline Iowa & & & & & & & Iowa \\
\hline NY & & & & & & & NY \\
\hline
\end{tabular}

4. A de facto classification for rates is sanctioned in Illinois. See text.

5. In Michigan the method of taxation (ad valorem or specific) determines the applicable rules of uniformity for exemptions and rates. See text.

6. In Indiana a distinction is made between "selection" and "exemption," no rule of universality applies to "selection." See text.

7. Probably only a very limited classification would have been actually permitted in Colorado; and now an amendment expressly provides for the classification of personal property.

8. In Georgia and Missouri the strictest degree of uniformity was in force until the deletion of supplementary clauses of Types I or II. The classification for rates is now spelled out by amendment. There is some doubt as to the ad valorem rule being applicable in Georgia.

9. There is some question as to the ad valorem rules being applicable in Montana.

10. In New Mexico the strict rules apply only to the taxation of tangible property because of peculiar phraseology. 
ment without altering the basic uniformity clause in its phraseology. Those two states are indicated by italics.

Third, a single state, Michigan (IV), has a modified form of effective limitation (3). One must say modified because of the unique situation found in Michigan. There only that property taxed ad valorem is subject to the strict rule of uniformity as to rates.

Fourth, there are six states which have an effective limitation of class (4). Those states are: Kentucky (VIII), Maryland (VIII), North Carolina (VIII), Colorado (VII), Missouri (VII), and New Mexico (VII). Only Colorado has modified this effective limitation by amendment without altering the basic uniformity clause in its phraseology. A further qualification should be noted in respect to Missouri and New Mexico in which the ad valorem requirement applies in part only, namely, to the taxation of tangible property.

Fifth, there are four states which have an effective limitation of class (5). Those states are: Arizona (VIII), Georgia (VII), Montana (VII), and Virginia (VII). A qualification should be made as to Virginia in which the rule of universality applies in part only.

Sixth, two states, New Jersey (IV) and Pennsylvania (VII), have effective limitations of class (6). However, as pointed out in the Pennsylvania study, substantial arguments may be made against the continuing validity of the ad valorem requirement.

Seventh, there are twelve states which have an effective limitation of class (7). Those states are: North Dakota (VIII), South Dakota (VIII), Washington (VIII), Delaware (VII), Minnesota (VII), Oklahoma (VII), Oregon (VII), Rhode Island (IX), Vermont (IX), and the three states which have no clause of any kind: Connecticut, Iowa, and New York. 
Summarizing, we find that twenty-three states have the strictest types of effective uniformity limitations. This includes Michigan, which might be subject to question. However, of these twenty-three states there are nine which have modified the effective limitation to permit to some degree classification of property for taxation. These modifications have been made without altering the basic uniformity clause. On the other hand, there are twenty-five states which permit classification for rates. However, of these twenty-five there are ten states which do not permit classification for exemptions. Thus, in terms of the existing effective limitation of uniformity in taxation, a substantial majority of the states (twenty-five plus nine) have an effective limitation of uniformity in taxation which does not prohibit some form of a classified property tax.

$* * * * *$

Having classified the states according to their effective limitations, it will be helpful to approach the matter from another direction. What generalizations may be made in comparing the literal words of the basic uniformity clauses to the effective uniformity limitations? What sort of results were found in those states having the types of basic uniformity clauses which, on their face, would most likely be construed as requiring the stricter degree of uniformity in the taxation of property? Those types of clauses are:

I. Property shall be taxed according to its value.

II. Property shall be taxed in proportion to its value.

III. The legislature may impose proportional and reasonable assessments, rates, and taxes upon all persons and estates. ...

IV. There shall be a uniform rule of taxation.

V. Taxation shall be equal and uniform.

VI. The legislature shall provide by law for a uniform and equal rate of assessment and taxation. 
Looking to the accompanying chart, it can be seen that there was an almost complete correlation here, there being only two important exceptions, Michigan and New Jersey.

Putting aside for the moment the two exceptions, twentyone states have these types of basic clauses. The only relaxation in the degree of uniformity required was found in the nine states having no requirement of universality. But even on this point, one finds that the power to exempt is hedged to a considerable extent in a number of those nine states.

The states which relax the strict form of uniformity only by permitting exemptions are Maine, Alabama, Massachusetts, New Hampshire, Wisconsin, Mississippi, Wyoming, Indiana, and Kansas. Indiana may be included here only because of a rather finely drawn theory which makes a distinction between "selection" and "exemption." In two of these nine states (Maine and Kansas) the strict rules have been modified to a degree by collateral amendment.

Thus, twelve states of the twenty-one (Arkansas, Tennessee, California, Illinois, Nebraska, Ohio, Texas, West Virginia, Florida, Nevada, South Carolina, and Utah) require the strictest degree of uniformity: universality, absolute uniformity in effective rates, and ad valorem method. However, in eight of the twelve states (California, Nebraska, Ohio, West Virginia, Florida, Nevada, South Carolina, and Utah) the effective limitation has been modified by collateral amendment to the basic uniformity clause. In addition, in Illinois there was the very interesting situation in which a de facto system of classification of property for effective rates was given court approval. Consequently, in only three of these twelve states has the effective uniformity limitation been left unchanged. Those three states are Arkansas, Tennessee, and Texas.

As indicated in the state by state study, and as well in the rule by rule comparison, in substantially all of these twenty- 
one states the effective limitation of uniformity in taxation of property was derived from numerous variations of supplementary provisions as well as the basic uniformity clauses. However, there was no indication that the requirements would not have been derived from the basic uniformity clause had it stood alone. To the contrary, the study had indicated that in some of the states permitting exemptions (for example, Wyoming) this was the result of supplementary provisions and would not have been permitted had there been only the basic uniformity clause. Furthermore, it should be noticed that the diversity in result as to the rule of universality was found under each of the five types of basic clauses being considered.

The two important exceptions among these twenty-three states are Michigan and New Jersey. In New Jersey we find that the only strict rule of uniformity is that property must be taxed ad valorem, while there is no requirement of universality and property may be classified for rates. There is some uncertainty whether real property could be further classified, and since 1947 it is possible that personalty no longer need be taxed by the ad valorem method. This result in New Jersey does not appear to stem from any unique phraseology of the basic uniformity clause. To the contrary, the unique result in Michigan stems precisely from the unusual manner in which the basic uniformity clause of Type IV is phrased. In that state we found that, contrary to the approach in the forty-seven other states, the manner in which property is taxed determines the applicable uniformity clause, and as to that property taxed ad valorem there is no requirement of universality but the effective rate must meet the test of absolute uniformity. As to property taxed by a specific method the only limitation is a uniformity within classes. This unusual situation stems from the phraseology: "The legislature shall provide by law a uniform rule of tax- 
ation, except on property paying specific taxes. . . ." Consequently, the result in Michigan does not indicate a significant difference of judicial opinion as to the meaning of one of the more literally strict types of basic uniformity clause.

A greater and significant diversity of results is found among those states having the basic types of uniformity clauses which on their face are more susceptible of being construed so as to permit some degree of classification in the taxation of property. Those types are:

VII: Taxes shall be uniform upon the same class of subjects.

VIII: Taxes shall be uniform upon the same class of property.

There are twenty states having one of these types of clauses as their basic uniformity provisions. To these may be added the two states having a basic clause of Type IX, and those three states without a uniformity provision of any kind.

The most marked deviation among this group of twentyfive states was found in Idaho, where the court has ruled that property in that state when taxed is governed by a requirement of absolute uniformity in effective rates and the method used must be ad valorem. While there is no requirement of universality in Idaho, this was only because the power to exempt was expressly spelled out. It is true that the Idaho Type VII basic clause is accompanied by a Type II clause. However, the court has not necessarily relied on that second provision and has found no conflict between the two, merely referring to the basic clause of Type VII as establishing "a requirement of uniformity." Consequently, in Idaho the existence of one of the more liberally phrased basic uniformity clauses has not prevented the effective uniformity limitation from being one of the strictest.

Along with Idaho, there are other states among these 
twenty-five which are of interest because of their strict effective limitations. For example, in Colorado we found that for all practical purposes there was an effective limitation of the strictest character. However, an amendment in 1936 expressly provided that personal property may be classified for rates or exemptions, but this power is conditioned upon the imposition of an income tax law. Similarly, in Missouri, before a 1945 amendment, there was an effective limitation of the strictest degree even though the basic uniformity clause was Type VII. However, for each of the fundamental particular rules of uniformity the source was not the clause of Type VII but a supplementary provision (Type II). The 1945 amendment deleted this supplementary Type II provision and consequently removed a part of the strict effective limitation. However, the universality limitation remained because of a supplementary provision which spelled out this requirement. While classification of property for rates is no longer prohibited, there remains additional constitutional limitation on this power because the minimum classes of property are spelled out in the constitution by the 1945 amendment. In addition, other words of the 1945 amendment spell out the requirement that tangible property must still be taxed by the ad valorem method.

In New Mexico, where there is a Type VII basic clause, the effective uniformity limitation requires the strictest degree of uniformity for the taxation of tangible property. This result stems from a rather unusually phrased provision which directly modifies the basic uniformity clause. Before 1937, Georgia had a situation similar to that found in Missouri. The Georgia Constitution had in addition to the Type VII basic clause a Type I supplementary provision. It was the latter provision which was the source of a strict effective uniformity limitation. The universality rule was spelled out by words dealing expressly with that problem, but was also 
said to be derived from the basic uniformity clause itself. The supplementary provision of Type I was used to establish property as a minimum class. The Type I provision was deleted by the 1937 amendment; however, new words were introduced which limit the power of the legislature to the classification of intangibles into subclassifications.

Summarizing, among the twenty-five states having potentially liberal uniformity limitations, there are five in which the effective uniformity limitation is of the strictest degree. However, as the state studies indicated, only in Idaho, and to a degree, New Mexico, has this strict type of uniformity limitation prevailed. In the other states (Colorado, Georgia, and Missouri) amendments have removed the collateral provisions which were the sources of the strict rules. It is significant that in all five states other than Idaho (and, perhaps, Colorado) the source of the restrictive limitation was always a supplementary provision which was interpreted by the court in such a manner as to limit the potentially liberal limitation inherent in the Type VII or Type VIII clauses. In the final analysis, it was only in Idaho that the court simply ignored the words of the conflicting uniformity provisions found in a single constitution and categorized all the provisions as simply "uniformity clauses."

Turning to the remainder of these twenty-five states we still find considerable diversity in results. In addition to Colorado, Missouri and New Mexico, there are three other states (Kentucky, Maryland and Montana) which permit classification for rates but require universality and the use of the ad valorem method. In Kentucky these two strict rules are both derived from collateral provisions. The rule of universality is spelled out and a supplementary clause of Type II is the source of the ad valorem requirement. Consequently, the Type VIII basic clause in the Kentucky Constitution is restricted so as to permit only the classification of 
property for rates. To the contrary, in Maryland, which also has a basic clause of Type VIII, the ad valorem requirement is derived from the word "uniform" in the basic clause. In both Kentucky and Maryland, the rule of universality is somewhat limited in operation. In Kentucky, by express amendment property may be exempted from local property taxation, and in Maryland the rule is applied only to the exemption of any sub-classifications of real property. In Montana, which has a basic clause of Type VII, we find a situation similar to that in Idaho, but with an opposite result. The Montana Constitution contains a Type VI clause which might well be used to negate any liberal effect of the Type VII basic clause which was also found in the Montana Constitution. However, the Montana court recognized the potential conflict and reconciled the two provisions by giving pre-eminence to the more liberal Type VII clause. The Type VI clause was allowed to require universality and the ad valorem method, but the Type VII clause was relied upon as definitely indicating the intent of the framers that property might be classified for rates.

Three of the remaining states (Arizona, North Carolina, and Virginia) have a strict rule of universality but permit classification of property for rates, or the use of other than the ad valorem method in taxing property. In Arizona, this strict rule of universality is not derived from the Type VIII basic clause but is spelled out in a supplementary provision. The rule of universality may be avoided in Arizona by the use of an in lieu tax if the in lieu tax is a property tax. It might be noted, however, that the Arizona court has given the impression that any but the most basic classification of property for rates would be frowned upon. Similarly, in North Carolina, which has a basic clause of Type VIII, the requirement of universality is derived from collateral provisions which enumerate permissible exemptions. In addition, 
some doubt might be raised as to the assertion that the requirement of ad valorem method is not now present in the North Carolina Constitution. In Virginia, the rule of universality is also derived from a collateral provision expressly prohibiting exemptions, but by amendment of the constitution there are no state taxes on real property and no local taxes on personal property.

Pennsylvania is in a rather unusual position. That state has a basic uniformity clause of Type VII, and stands as having one of the more liberal uniformity limitations in many aspects. However, that state does have a requirement that property be taxed ad valorem only, although it may be classified for both rates and exemptions. The cases which ruled upon the ad valorem requirement derived that limitation from the basic clause Type VII. Illustrating a different attitude by the same court, the provision in the constitution spelling out the requirement that property may not be exempted is avoided by limiting its operation to the exemption of real property; but real property is subject to further classification for rates.

The remaining nine states (North Dakota, South Dakota, Washington, Delaware, Minnesota, Oklahoma, and Oregon) having basic clauses of Types VII and VIII, along with Rhode Island and Vermont, which have the basic clause Type IX, and the three states (Connecticut, Iowa and New York) having no clause of any kind, all require only a uniformity within classes. There is no rule of universality or ad valorem method, and property may be classified for rates.

Among those states one might call particular attention to North Dakota, Minnesota, Oklahoma, and Oregon. Those four states are the ones in which the liberal interpretation of the uniformity clause has been most extensively developed. In the other states, there has been less use of legislative power, and consequently less judicial development. In all 
of these four states, the courts have appeared to give the legislature the greatest discretion in classification of property, and, most significantly, they have equated the property tax uniformity limitation with the federal equal protection clause limitation.

Another interesting point to note is that in Washington and Pennsylvania extensive classifications of property for effective rates have been upheld, but in these two states income taxes have been held to be property taxes and consequently struck down because of their graduated rate features. The courts of the two states ruled out classifications of property according to quantity as arbitrary. On the other hand, in North Dakota, Minnesota, and Oregon the courts found that it was immaterial to consider the nature of a graduated net income tax, finding that the graduated rates would stand in any case, the classification on the basis of quantity or ability to pay being reasonable.

Summarizing, the study has shown that in substantially all (but cf. Idaho) cases of diversity in result on particular rules of uniformity among those states having potentially liberal uniformity clauses, the diversity is a result of supplementary provisions of varying nature. When such supplementary provisions made their appearance in the constitutions of those states having the potentially restrictive uniformity clauses (Types I, II, III, IV, V, and VI) there was no necessary conflict, such supplementary provisions merely buttressing the effective limitation which might likely be derived from the basic clause itself. To the contrary, the appearance of these supplementary provisions in the constitutions of those states having the more potentially liberal provisions (Types VII, VIII, and IX) often meant conflicting results among states having identical basic provisions. 


\section{A COMPARISON OF RESULTS AS TO PARTICULAR TAXES}

As stated in the introduction to this monograph, in most states when a tax is challenged as violating the constitutional limitation of uniformity in taxation, the crucial problem is the determination of the nature of the tax. Is the tax a "property" or "nonproperty" tax? The reason the answer to this question often determines the constitutionality of the tax is that most state constitutional provisions provide more strict uniformity limitations for property taxes than for nonproperty taxes. Although the distinction between property and nonproperty taxes may with justification be assailed as artificial and unsound, ${ }^{1}$ it remains the crucial question in most states. Even among the twelve states which have the most liberal effective uniformity limitations, ${ }^{2}$ only half (North Dakota, Minnesota, Oregon, Connecticut, Iowa, and New York) equate the property tax uniformity limitation, however liberal, to the uniformity required of nonproperty taxes. Therefore, it will be enlightening to consider the problems involved in characterizing the nature of a particular tax when its validity has been questioned.

The income tax has been selected for this purpose, since the validity of this tax has probably raised the most controversy concerning the requirements of uniformity in taxation. Although there is a fairly exhaustive amount of legal literature concerning the income $\operatorname{tax}^{3}{ }^{3}$ it will be helpful to review

${ }^{1}$ Cf. Matthews, Wm. L., Jr., "The Function of Constitutional Provisions Requiring Uniformity in Taxation," $30 \mathrm{Ky}$. L. J. 31, 33-34 (1949).

2 See the discussion in the preceding section, supra, p. 679.

${ }^{3}$ See, for example, Matthews, supra, note 1, 504-514; Brown, "The Nature of the Income Tax," 17 Minn. L. Rev. 127 (1933); Allen, "Limitations of Uniformity Provisions of State Constitution upon Income Tax Legislation," 11 Tax Mag. 420, 464 (1933). Also see Note, "State Income Tax Laws and the Uniformity Clause," 3 Rocky Mt. L. Rev. 32 (1930), 5 id. 70 (1932). 
the treatment afforded that tax in the context of a study of uniformity in taxation.

\section{Judicial Precedent and the Income Tax}

The sharp division of judicial opinion concerning the nature of an income tax came into focus for the purposes of this monograph with the opposite views taken by the Massachusetts and Missouri courts in 1915 and 1918, respectively." The Massachusetts advisory opinion, given in $1915,{ }^{5}$ established the beachhead for the restrictive viewpoint. The Massachusetts Supreme Court ruled that a tax upon the income from property would be, in effect, a tax upon the property itself. Consequently, such a tax came within the strict uniformity limitation applicable to property taxation, which required an absolute uniformity in effective rates. The rationale of the court was as follows:

A tax upon the income of property is in reality a tax upon the property itself. Income derived from property is also property. Property by income produces its kind, that is, it produces property and not something different. It does not matter what name is employed. The character of the tax cannot be changed by calling it an excise and not a property tax. In its essence a tax upon income derived from property is a tax upon the property. This was decided after most elaborate consideration, with affluent citation of authorities, in

4 In 1912 the Wisconsin Court decided State v. Frear, 148 Wis. 456, 134 N.W. 673 (1912). It ruled that the income tax under attack was not a property tax. However, the decision loses impact because of the 1908 amendment to the Wisconsin constitution which expressly authorized the imposition of an income tax. Consequently, the Frear case has had no appreciable effect on the precedent concerning this question.

5 In re Opinion of the Justices, 220 Mass. 613 (1915). Cf. the earlier case, Wilcox v. Middlesex, 103 Mass. 544 (1870). For further discussion, see the Massachusetts study, supra, p. 180. 
Pollock v. Farmers' Loan \& Trust Co., 157 U.S. 429, 581. B

Thus, the Massachusetts court cited as its authority for this proposition the discussion in the famous Pollock case. When the United States Supreme Court decided that case in 1895, the problem faced was entirely different from that which state courts subsequently faced in determining the nature and validity of general net income taxes. In the Pollock case, the United States Supreme Court was concerned with the federal constitutional requirement that direct taxes be apportioned. For that purpose it ruled that a tax on the income derived from land or personal property was to be characterized as a direct tax on such income-producing property. There were vigorous dissents from the 5-4 decision, and subsequent cases $^{7}$ by the United States Supreme Court have somewhat discredited the Pollock rationale. Nevertheless, that majority opinion has played its role in the state constitutional problem of uniformity in taxation. Massachusetts relied on the opinion, and later state courts taking the restrictive view also have gained comfort from the Pollock majority rationale, although not so directly relying on it.

It should be noted that the Massachusetts court did not rule on the nature of a tax on "earned" income. As pointed out in the Massachusetts study this 1915 ruling was avoided to some extent by an amendment to the Massachusetts Constitution which expressly provides for a "tax on income." But in a subsequent 1929 advisory opinion ${ }^{8}$ the court ruled that the amendment did not alter the nature of the tax, and since the amendment did not expressly provide for graduated rates, such rates were prohibited by the strict property tax

Id. at 623-624.

7 See, for example, New York ex rel Cohn v. Graves, 300 U.S. 308, 57 S. Ct. 466 (1937), and Brushaber v. Union Pacific R. Co., 240 U.S. 1, 36 S. Ct. 236 (1916).

8 In re Opinion of the Justices, 266 Mass. 583 (1929). 
uniformity limitation. Any classifications were limited strictly to those spelled out in the amendment. ${ }^{9}$

The Massachusetts view did not go long unchallenged. Within three years, the Supreme Court of Missouri faced the same problem. In 1918, the Missouri court decided LudlowSaylor Wire Co. v. Wollbrinck ${ }^{10}$ and reached a conclusion opposite from that taken by the Massachusetts court. The decision was 4-3, with a vigorous dissenting opinion. Indeed, one may safely assert that both majority and minority opinions in most all of the state cases on this problem have reflected deeply felt attitudes concerning the income tax. As the Missouri study ${ }^{11}$ indicated, in 1918 the constitution of that state contained a Type VII basic uniformity clause (taxes shall be uniform upon the same class of subjects), but that clause was supplemented by an ad valorem clause of Type II from which was derived the strict degree of uniformity required of property taxes. One may characterize the majority opinion in the Ludlow-Saylor case as ruling that the income tax under consideration was not a tax upon property-that is, it was neither a tax on income as property, nor a tax upon the property from which the income was derived. Relying in part on the rationale of an 1869 opinion, Glasgow v. Rowse, ${ }^{12}$ the court reasoned as follows:

The reasoning and conclusion of the court in the above case [the Glasgow case] has never been disapproved in this

${ }^{\theta}$ It is interesting to note that the Massachusetts court has ruled that the Massachusetts corporate franchise tax with a base of net income is an "excise" tax, not a property tax. See, for example, Alpha Portland Cement Co. v. Comm., 244 Mass. 530, 139 N.E. 158 (1923).

10275 Mo. 339, 205 S.W. 196 (1918).

11 Supra, p. 418.

1243 Mo. 479 (1869). The basic uniformity clause in effect at the time of the Glasgow decision read as follows: ". . . all property subject to taxation ought to be taxed in proportion to its value." Art. I, \$30, Const. 1865. 
State. . . . It is predicated upon a distinction made by the court as to the application of the term "property" used in the Constitution. In law and in the broadest sense "property" means a "thing owned," and is, therefore, applicable to whatever is the subject of legal ownership. ... In short it embraces anything and everything which may belong to a man and in the ownership of which he has a right to be protected by law. The court held, in effect, that in directing, as the Constitution does, that taxes on property should be levied according to value, reference was intended to be made to other species of property than that which a person has in his income; that the Constitution did not abridge the power of the Legislature to provide revenue by a taxation of income; that its command was directed to other and distinct classes of property which (on account of their peculiar nature could be measured on value) become the object of taxation independent of the owner, and are susceptible, by proper procedure, to lien or seizure for the enforcement of the tax. The court held that it was property having such a nature and characteristics, and not the mere usufruct of such property, nor the earnings of physical or mental labor, which was referred to in the clause under review and intended thereby to be subjected to taxation according to its value. . . .

In consonance with these distinctions the court held . . . that the term "property" in the Constitution did not apply to that species of ownership enjoined by the possessor of an income, and hence the Legislature was no more restricted in taxing incomes than it or its subordinate agencies are restricted in laying occupation and other taxes relating to the activities or personalty of the individual taxed; indeed, the fact that the act in question is a tax upon the owner of an income is distinctly recognized and stated in Section 2 of the act, which uses these words; "the net income of a taxable person". ...

That income is property because it is an ownable thing, is a matter of simple apprehension which has been affirmed under the definition of property above stated. That it is, "in 
effect," a taxation of the labor or capital which produced it, may be conceded, since by reason it affects the value of the thing or things from which it is derived. But none of these considerations alter the fact that incomes are distinguishable from the tangible or intangible property yielding them, nor do they affect the established law in Missouri, that incomes are thus connoted by our Constitution and decisions. These recognize incomes as one of the classes entering in proportion to value, and, therefore, not falling within the designation of property which the Legislature is forbidden to tax except in that way. . . 13

This quite lengthy quotation is set forth in order to illustrate the way in which the court avoided the application of the strict uniformity limitation. This writer has characterized the decision as ruling that the tax was a nonproperty tax. However, as the quotation illustrates, the Missouri court did not spell it out so neatly. Indeed, one can understand why the decision has been referred to as ruling that the tax was a property tax, but not limited by the property tax uniformity limitation. ${ }^{14}$ However, it is suggested that the court verged closer to finding the tax sui generis, as, indeed, later states expressly decided. For example, the court relied in part upon the words of the statute to indicate that the tax was upon the owner as much as upon the income as such. Further, if income was to be considered property, it was not property within the constitutional sense; hence, the tax was not, constitutionally, a tax upon property, that is, a property tax. The important point is that the court avoided applying the harsher uniformity limitation, and vaguely touched upon the approaches later explicitly used in different instances to characterize the tax as not being a property tax.

However viewed, the Missouri court held that the income tax was not to be characterized as a property tax. Just what

13 Supra note 10, at 352-3, 354, 355.

${ }^{14}$ Cf. Matthews, supra note 1, at 511-512. 
the court believed to be its nature may be left to speculation. The court did not feel compelled to force the tax into some concept of privilege or excise tax. It was sufficient to rely on a property-nonproperty tax dichotomy, with a property tax being one with an object of "property" in the constitutional sense, and all other taxes being loosely joined as the opposite in a two-class analysis. Had the tax been held to be a tax upon property, it would have violated the property tax strict uniformity requirement. In 1932, the Missouri court in $\mathrm{Ba}$ con v. Ransom ${ }^{15}$ reaffirmed the rationale of Ludlow-Saylor, and further extended its position in holding that a graduated rate schedule was a reasonable classification. In so ruling, the court relied on the ability to pay rationale.

It might be pointed out that the dissenters in the Ludlow case relied strongly upon both the Pollock rationale used by the United States Supreme Court and the Massachusetts opinions. The tenor of the dissent is aptly illustrated by the following typical statement found therein: "However, the origin of the heresy is not important now, for scarcely any respectable court is adhering to the view that income derived from real and personal property, at least, is not itself property and that a tax upon such income is not a charge against and a tax upon such property itself." 16 The following discussion will show that a substantial number of courts never enjoyed reaching that "respectable" status.

At the same time that this general controversy was brought into sharp focus by the divergent Massachusetts and Missouri opinions, there was a third case which illustrates what might be called a second theme running throughout this

16331 Mo. 985, 56 S.W. 2d 786 (1932).

16 Supra note 10 , at 370 . 
general controversy. In 1919, the Supreme Court of Delaware in State v. Pinder ${ }^{17}$ asserted:

In the absence of any authority on the subject, this court would unhesitatingly hold that income is property within the meaning of section 1 , article 8 of our Constitution, and, therefore, subject to taxation or exemption. . . . ${ }^{18}$

Yet this opinion cannot be taken as support for the general position taken by the Massachusetts court. The Delaware court's characterization of the tax was made in answer to the argument that the income tax was a nonproperty tax and that the legislature's power was limited to the taxation of property. The court, in the final analysis, rejected this construction of the constitution. However, it was said that the argument could also be met on the ground that income was property within the meaning of the tax clause of the constitution.

It is interesting to note how the early Missouri case, Glasgow v. Rorese, was distinguished. The Delaware court expressed an attitude quite diametrically opposed to that implicit in the Massachusetts opinions. The court said:

This case [Waring v. Savannah, a Georgia case discussed infra] is similar in principle to Glasgow v. Rowse, in which it was held that income tax "did not come within the meaning of the term 'property' as used and designated in the Constitution." Necessarily it was so held, because the Constitution required that taxation on property should be in proportion to its value, and a tax on income would be in violation of the ad valorem principle. The tax could not, therefore, be sustained if income was property within the meaning of the Constitution. ...

In the absence of any authority on the subject, this court 1730 Del. (7 Boyce) 416, 108 Atl. 43 (1919).

${ }^{18} \mathrm{Id}$. at 421 . 
would unhesitatingly hold that income is property within the meaning of ... our Constitution, and therefore, subject to taxation or exemption, shall we hold differently because the court, in a Georgia case, decided in 1850, declared that income was not property within the meaning of the taxation laws of that state then before the Court? ${ }^{19}$

It should be observed that the Georgia case, cited by Delaware, held as it did in order to sustain the tax. The quotation illustrates without elaboration the distinctly different problems faced by the Massachusetts and Delaware courts in characterizing an income tax. In one case, the tax was challenged as a property tax in order to invalidate it. In the other, the tax was challenged as a nonproperty tax in order to invalidate it. For purposes of uniformity in taxation, as the Delaware study indicated, ${ }^{20}$ the nature of a tax is apparently of no importance in that state since all taxes are limited by the same liberal uniformity limitation which, significantly, has been equated to the equal protection clause of the Federal fourteenth amendment.

Therefore, it will be necessary to deal quite cautiously with any state opinions which have characterized income taxes as property taxes when such characterization was necessary in order to establish the validity of the tax. The Delaware opinion showed considerable hostility to the view that income was not property, and that an income tax was not a property tax, if such characterization would deny the legislature the power to impose the tax. That is, the view of the court was, "Income is property . . . and therefore subject to taxation." Unquestionably the characterization by the Delaware court reflects an acute awareness of the result to be thereby achieved. Had the Massachusetts court faced a situation identical to that faced by the Delaware court, would

${ }^{19}$ Id. at 420, 421. Emphasis added.

20 Supra, p. 360. 
it have hastened to agree with the contention that the tax on income was not a tax on property?

Decisions by two southern states followed sharply on the heels of the Missouri decision and furnished support for each side of the controversy. In 1920, the Alabama court showed its preference for the strict position and ruled in Eliasberg Bros. Mercantile Co. v. Grimes ${ }^{21}$ that a tax upon income was a property tax. Consequently, the court held that the tax in question violated the property tax maximum rate limitation in the Alabama Constitution. The uniformity limitation was not involved. Nevertheless, the property tax maximum rate and uniformity limitations are closely related in principle and the Alabama court apparently realized the consequence of its ruling in relation to the established interpretation that the uniformity limitation required absolute uniformity in the property tax rate. ${ }^{22}$ The rationale of the Alabama court was not precisely that of the Massachusetts court. Rather the Alabama court relied on the theory that income was embraced within the meaning of the word "property" as used in the constitution, and, consequently, any tax upon income was a tax upon property. The majority opinion concluded:

If they [the constitution makers] regarded money as property-and it is inconceivable that they could have regarded it otherwise-they must have entertained a general purpose to protect it from excessive or unequal taxation, by whatever name it might be called, and by whatever scheme it might be taxed. Money, when received as income, is visible, tangible, concrete, and that, in its last analysis, is what is taxed. It is of no consequence that items of money are added to-

21204 Ala. 492, 86 So. 56 (1920).

22 See the Alabama study, supra, p. 103. 
gether, and the sum, reduced by the cost of its acquisition, is designated as income. That indicates merely the mode and extent of its taxation. Nor is it of any consequence that the money thus taxed has left the hands of its quondam owner, however speedily; for the state has the inherent power to tax property owned at any time during the tax year, though it has not always seen fit to do so. ${ }^{23}$

A large part of the opinion was devoted to an evaluation of prior Alabama decisions, and the majority did not, therefore, consider it necessary to dwell at length on any developments in other states. However, support for its conclusion was found by the court not only in the Pollock case, but as well in the Ludlow-Saylor dissenting opinion in Missouri, and the Pinder decision in Delaware. Again, one may venture the conclusion that the opinion, read as a whole, exhibits a hostility to the idea of an income tax as a revenue producer.

The response to the Eliasberg decision was similar to the response to the earlier Massachusetts advisory opinion. In 1933, the Alabama Constitution was amended so as to avoid the Eliasberg rationale. The amendment expressly provides for a graduated income tax. But contrary to the Massachusetts experience, the Alabama court in a decision subsequent to the amendment, while disclaiming any intent to "discredit" the Eliasberg opinion, in fact tends to question the validity of the reasoning therein. ${ }^{24}$ However, because of the 1933 amendment it was not necessary to overrule the Eliasberg case. The later decision is significant in evaluating the

\section{Supra note 21, at 498.}

24 State v. Weil, 232 Ala. 578, 168 So. 679 (1936). See especially p. 582 , referring to the Alabama decisions prior to Eliasberg which the court asserted did not support the Eliasberg rationale, and noting that subsequent to Eliasberg the Georgia court had approved the older Georgia decision there criticized. See note 46 , infra. But the Weil case must be read in light of a 1950 decision, discussed in note 33 to $\mathrm{Ch}$. III, §B/1, supra, p. 104. 
weight to give Eliasberg as precedent for this restrictive view.

Paired against the Alabama Eliasberg opinion is the view of the Mississippi court, first expressed in 1921 in Hattiesberg Grocery v. Robertson, ${ }^{25}$ and reaffirmed in 1925 in State ex rel. Knox v. Gulf, M. E N N.R. Co. ${ }^{26}$ The Mississippi Supreme Court ruled that the net income tax under attack in the Knox case was an "excise" and not a tax upon property. Consequently, the tax was not subject to the stricter uniformity limitation. In addition, in the Knox case, the court upheld the graduated rate schedule under attack as a reasonable classification. The dissenting opinion adopted the view that a tax on income derived from property is a tax on the property itself, and therefore that a tax on such income would result in an illegal "double taxation" on the income-producing property. Indicating the continued heated nature of this controversy, the dissenting opinion concluded:

Good-bye section 112 [the basic uniformity clause], this is the last of you. The framers of our Constitution by your adoption thought they were affording the taxpayers of the state some security against unjust and unequal taxation. They were mistaken. Little by little you have been whittled away by the courts until there was little left. By this stroke that small remaining vestige has been swept away. Now by giving each scheme of taxation a new name, property may be taxed times without number. It is all in the name. The state now, without let or hindrance from the Constitution may fill its insatiate tax maw to overflowing. ${ }^{27}$

There was really little, if anything, new added to the controversy either by the majority or minority of the Mississippi court. At most, there is the stress by the majority that the in-

${ }^{25} 126$ Miss. 34, 88 So. 4 (1921).

26138 Miss. 70, 104 So. 689 (1925).

27 Id. at 115. 
come tax partakes of the nature of both a property and personal tax, and is, therefore, an "excise" tax.

In less than a decade the controversy had reached this high pitch. Because of the somewhat logical approaches taken by both sides to the controversy, one wonders whether the opinions are merely reflections of the attitudes of individuals concerning the desirability of imposing an income tax.

The opinion by the Georgia court in 1930, in the case of Featherstone v. Norman, ${ }^{28}$ is considered by this writer to be the turning point in the controversy. But even before this time there were decisions in three states which indicated that a trend was in the making. Oregon, Arkansas, and New Hampshire became aligned with those states whose decisions made the imposition of an income tax possible. However, the decision in New Hampshire must be cautiously dealt with for comparative purposes because of the unique constitutional limitation in that state.

In Standard Lumber Company v. Pierce, ${ }^{2 \theta}$ decided in 1924, the Oregon court did not find it necessary to determine the nature of a general net income tax with a graduated rate schedule in order to conclude that the tax did not violate the uniformity limitation. The reason was that an income tax could be characterized as a property tax and still not run afoul the uniformity limitation. In other words, the situation was similar to that in Delaware. Both states had Type VII uniformity clauses (taxes shall be uniform upon the same class of subjects). The Oregon court, like the Delaware court, equated the uniformity clause with the equal protection clause of the fourteenth amendment to the federal constitution. Essentially the same limitation was said to apply

28170 Ga. 370, 153 S.E. 58 (1930).

29112 Ore. 314,228 Pac. 812 (1924). 
to all taxes, whatever their nature might be. Consequently, the classification features of the Oregon general net income tax, including the graduated rate feature, were held valid regardless of the nature of an income tax. Reading the Pierce opinion in combination with the 1931 decision, Redfield v. Fisher, ${ }^{30}$ one is warranted in concluding that the Oregon court has not unequivocally committed itself on the issue of the nature of a net income tax, and if pushed on the question might well align itself with the position found in other later state decisions, namely, that an income tax is just that, an "income tax"-sui generis, if a categorization is necessary.

The Arkansas court also reached a conclusion favorable to the imposition of an income tax, but not without some confusion in the process. The Arkansas legislature's first experiment was with an abortive general gross income tax, the validity of which was passed on in 1925 in Sims v. Ahren. ${ }^{31}$ A majority of three agreed that the tax was not a property tax, but that the tax as levied was discriminatory and consequently invalid under the uniformity within classes limitation applicable to nonproperty taxes. The two concurring justices did not disagree as to the nature of the tax, but would have struck it down for other constitutional reasons,

30135 Ore. 180, 292 Pac. 813 (1931). In that case the court held that a tax of $5 \%$ upon the gross income from certain intangibles was in fact a property tax, and that the tax violated the federal equal protection clause because it reached only the income of intangible belonging to individuals. The classification was said to be arbitrary, the court relying for this proposition on the somewhat discredited case of Quaker City Cab Co. v. Pennsylvania, 277 U.S. 389, 48 S. Ct. 553 (1928). On rehearing (p. 205) the court distinguished the Pierce case, expressly not overruling it and stressing that the tax under consideration was on gross income, not net income. In McPherson v. Fisher, 143 Ore. 615, 23 P. 2 d 913 (1933) the court sustained the subsequent 1931 tax upon the net income from intangibles which was so drafted to overcome the objections in the Redfield case.

81167 Ark. 557, 271 S.W. 720 (1925). 
explained more fully in the Arkansas study, namely, under a theory that the legislature was limited to the imposition of property taxes and the taxation of "occupations" or "privileges" not of "common right." In any case, the legislature subsequently enacted a general net income tax, with a classified and graduated rate schedule. This tax was upheld in Stanley v. Gates, ${ }^{32}$ decided in 1929. All justices (now numbering seven) agreed as to the nature of the tax, saying:

Reference to the various opinions in that case [Sims $\mathrm{v}$. Ahren] will show that the court recognized that there was a division in the authorities upon the subject whether an income tax was a property tax or not, and we deliberately adopted the view that it was not a property tax. If it is not a property tax, it does not make any difference what name it is called. Whether it is called an excise tax, or a tax in the nature of an excise tax, or a personal tax, is a mere matter of definition, and does not in any wise change its character. ${ }^{33}$

This being the case, the strict property tax uniformity limitation was not applicable, classifications were permissible, and the classifications embodied in the tax under consideration were held to be reasonable. While no rationale was ever fully developed by the court, the usual arguments were recognized, the usual precedents were cited, and the opinion concluded, ". . . a majority of the court holds that 'property,' as the term is used in art. $16, \S 5$ of the Constitution [the uniformity clause, Type I], means the property itself as distinguished from the annual gain or revenue from it." ${ }^{34}$

A third ruling favorable to the imposition of an income tax was made by the New Hampshire court at approximately

82179 Ark. 886, 19 S.W. 2d 1000 (1929).

33 Id. at 891 .

${ }^{84} \mathrm{Id}$. at 893-894. Also see the separate opinion by Wood, J., on rehearing, in the Sims case, supra note 31, at 586-593. 
the same time as the first Oregon and Arkansas cases. However, in evaluating New Hampshire decisions concerning the nature and validity of an income tax one must always keep in mind the unique situation under the New Hampshire Constitution. To designate a tax a property tax is a sine qua non for its existence in New Hampshire, because in theory only property taxes are permissible in that state, the legislature having no authority to levy nonproperty or "excise" taxes. As the New Hampshire study ${ }^{\mathbf{3 5}}$ demonstrated, taxes in New Hampshire are either taxes on "estates" or "other classes of property." The "estates" tax conforms to the usual notion of a general ad valorem property tax. The taxes on "other classes of property" conform to what are known as nonproperty taxes in other states. However, because of this designation of the second general class of taxes the New Hampshire legislature is somewhat more restricted in its taxing power than other states. But for purposes of this comparison, it must be remembered that if an income tax is to be levied at all it must be characterized as a tax upon property, either "estates" or "other classes of property." Understanding that, one is better able to evaluate the first New Hampshire ruling on the nature of an income tax. This was an advisory opinion ${ }^{36}$ given in 1915 , the same year in which the first Massachusetts opinion on this issue was given. A majority of the New Hampshire court ruled that income from certain intangibles (interest or dividends from bonds, notes, interest bearing credits, and corporate stock) could be taxed at the same rate as that levied upon all other property in the taxing district. ${ }^{37}$ Thus such income could be taxed by the "estates" tax-a general ad valorem tax in any other state. Justice Peaslee dissented in an extended and elaborate opin-

86 Supra, p. 182.

${ }^{36}$ In re Opinion of the Justices, 77 N.H. 611,93 Atl. 311 (1915).

${ }^{87}$ See note 46 to Ch. III, \$C/2, supra, p. 195. 
ion, contending that the tax under consideration was in reality an income tax, an income tax was an excise tax, and, therefore, not permissible under the New Hampshire Constitution. The reason this is stressed is because Justice Peaslee's characterization of the tax is quite often cited and quoted by justices in other states who would characterize an income tax as a nonproperty tax and, consequently, not only permissible but also not subject to the stricter property tax uniformity limitation.

The care with which Justice Peaslee's opinion must be handled is well illustrated by the definitive New Hampshire ruling on the problem in 1925 in Conner v. State ${ }^{38}$ for which Justice Peaslee wrote the opinion of the court. The court upheld an intangibles income tax, but the basis for the ruling was different from that of the 1915 advisory opinion. The tax imposed a proportional rate, but a rate different from that levied under the "estates" tax. The ruling of the court was that the tax was not an "excise" tax, but a property tax upon "other classes of property" than "estates." The 1915 advisory opinion was not overruled, being distinguished as simply indicating that income could be taxed as property under the "estates" tax (that is, the general property tax). Justice Peaslee rejected his dissent in the prior case insofar as it assumed that there was no constitutional basis for the imposition of an income tax; that is, he took the position that an income tax need not necessarily be characterized as a nonproperty tax. The basis for this conclusion was that in the 1915 advisory opinion the interpretation of taxes on "other classes of property" was not given sufficient consideration. In addition, it is significant that in the 1925 decision no mention is made of the precedents found in other states pro and con the nature of an income tax for the purpose of applying the uniformity clause. It should be stressed that the New Hamp-

8882 N.H. 126, 130 Atl. 357 (1925). 
shire opinions have at all times been concerned with the characterization of an income tax in relation to the unique constitutional situation in New Hampshire. ${ }^{39}$

Chronologically the next development was in Tennessee. The Tennessee opinions on the nature of an income tax normally would merit no more than passing reference in the context of a comparative analysis were it not for the fact that they are often cited in both judicial and other discussions of the problem. Consequently, they should be placed in their proper perspective in order to show that they have little relevance to the particular problem. As pointed out in the Tennessee study, ${ }^{40}$ the power of the legislature to impose an income tax in that state is governed by the following constitutional provision: "The legislature shall have power to levy a tax upon incomes derived from stocks and bonds that are not taxed ad valorem." A tax upon the income from stocks and bonds was upheld in Shields v. Williams, ${ }^{41}$ with the court not finding it necessary to determine the nature of the tax in order to determine the uniformity limitation applicable. A strict rule of uniformity governs the taxation of property in Tennessee, but it was held not to be applicable to this special tax because the special constitutional provision was interpreted as withdrawing the tax from the scope of the property tax uniformity limitation-regardless of the nature of the tax. Then in Evans v. McCabe, ${ }^{42}$ decided in 1932, the court held that a general net income tax which the legislature attempted to impose was prohibited by that provision of the constitution. As the court stated:

${ }^{39}$ See the text to notes 49 through 51 , Ch. III, $\$$ C $/ 2$, supra, p. 196, for illustrations of how in New Hampshire the uniformity limitation applicable to taxes on "other classes of property" is somewhat stricter than that limiting nonproperty taxes in other states.

40 Supra, p. 91.

41 159 Tenn. 349, 19 S.W. 2d 261 (1929).

$\$ 2164$ Tenn. 672, 52 S.W. 2 d 159 (1932). 
In Shields v. Williams we did not find it necessary to express our opinion as to the nature of an income tax. No such necessity arises now. The income tax clause of our constitution ... destroys chapter 21 of the Acts of the Extra session of 1931 [the general net income tax], whether that Act undertakes to levy a property tax or a privilege tax. ${ }^{43}$

In both opinions the court referred to the considerable conflict as to the nature of income tax for purposes of determining applicable uniformity principles, and recognized that the problem would have been crucial in Tennessee in view of the strict property tax uniformity limitation had it not been for the special constitutional provision.

The Georgia decision of 1930, Featherstone v. Norman, ${ }^{44}$ may rightfully be termed the turning point in this controversy. No new arguments or theories were introduced; much the same approach was taken as that found in the state decisions already described. However, in a lengthy opinion, the Georgia court canvassed the field and took a vigorous stand in favor of the position that an income tax is not to be subjected to the strict property tax uniformity limitation. With this decision by the Georgia court the scales were definitely weighted in favor of the income tax. Six years later, the controversy approached a standstill, although during the intervening period the fight was no less heated. By 1937, a very definite majority of the states passing on the question had construed their constitutional uniformity limitations so that an income tax might be levied. Since that time, there has been a tendency in some states to by-pass the judicial controversy and spell out in the constitution the extent to which an income tax might be levied.

As the Georgia study ${ }^{45}$ indicated, at the time of the

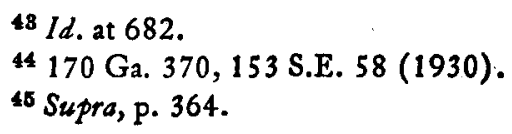


Featherstone opinion, Georgia had-and still has-a Type VII basic uniformity clause (taxes shall be uniform upon the same class of subjects). However, at that time there was an accompanying provision of Type I, and from this ad valorem clause the Georgia court derived a strict property tax uniformity limitation. Property was said to constitute a single class and had to be taxed ad valorem. Therefore, if any really effective income tax was to survive in Georgia, it could not be characterized a property tax. In 1929, the legislature imposed a general net income tax. In the Featherstone case, the court adopted the view that an income tax is not a tax upon property because income is not property within the meaning of the constitutional provisions relating to tax limitations-in particular, the uniformity in taxation limitation. In so deciding, the Georgia court could find support in an 1868 decision of its own, Waring v. Savannah, ${ }^{46}$ a decision often quoted in this respect. In the main, however, the opinion was a thorough review of other state decisions to date on the income tax-uniformity limitation problem, with the court viewing its conclusion as supported by the number and weight of "outside authorities." ticular rationale of its own as support for its conclusion. Rather, the conclusion was based upon an approval of the rationale running through those past cases ruling that, for purposes of uniformity, an income tax is not to be considered a property tax.

${ }^{46} 60 \mathrm{Ga} .93$ (1878). The discussion of this case in the Georgia study should be reviewed at this point. See the text to notes 15 through 22, Ch. III, $\S \mathrm{G} / 3$, supra, p. 369. Also, see the discussion in the Featherstone case, supra note 44 , at 380 .

47 Supra note 44, at 384. A quotation, at p. 383 from the New Hampshire advising opinion of 1915 , supra note 36 , is a good example of how that opinion may be misused because of a failure to appreciate the unique constitutional situation in New Hampshire. 
Between 1930 and 1936, seven state courts passed upon the issue, and four other state decisions might be mentioned in passing. The Georgia decision, plus the decisions in Idaho, Illinois, Montana, Washington, Minnesota, Pennsylvania and North Dakota represent the most important phase of the controversy. There was considerable pressure for the imposition of income taxes to supplement the traditional tax structures in order to meet the growing revenue needs of state governments. Criticism was mounting against the alleged defects of the general property tax as the bedrock of state tax structures. Could net income taxes and sales taxes be introduced to shore up the weakening tax structures? The sales taxes ran into no serious state constitutional objections, and the battles pro and con were confined to the legislative fora where the fiscal wisdom or unwisdom of sales taxes could be avowedly argued. However, the net income tax not only had to overcome that obstacle, but also the state constitutional obstacle in the form of uniformity limitations. Ostensibly in the judicial fora after enactment of a tax law, there is no longer any concern about the wisdom of the tax, the question being reduced to one of legitimacy. Was the uniformity limitation an insurmountable obstacle to any effective revenue producing income tax-for example, one reaching unearned as well as earned income, and having a classified rate structure, including graduated rates? The answer depended on whether the tax was to be limited by the stricter property tax uniformity limitation. Therefore, under the analysis used by the courts, it was necessary to determine the nature of an income tax. This, then, was the only issue before the judicial fora, the fitting of the income tax into the property-nonproperty tax dichotomy. However, as might be expected, in determining this issue the judicial opinions reflected the partisan policy arguments, and at times those opinions were not exactly models of judicial restraint. 
When there was a divided opinion, the heat engendered could hardly stem from division on so conceptual an issue as the nature of an income tax. Among those seven states, the courts of Illinois, Washington, and Pennsylvania fought the losing battle for a restrictive interpretation which rather effectively prevented any net income tax without constitutional amendment. However, the courts of Idaho, Montana, Minnesota, and North Dakota joined the Georgia court in accepting the view that the income tax was not a property tax, whatever else one might wish to call it.

Chronologically Idaho and Illinois led the way with decisions in 1932. On March 11 of that year, a unanimous Idaho court decided Diefendorf v. Gallet. ${ }^{48}$ The opinion is certainly one of the outstanding state opinions on the controversy at hand. Furthermore, it is quite interesting to compare the attitude of the Idaho court on this question with its attitude in determining the degree of uniformity required of property tax effective rates. As indicated in the Idaho study, ${ }^{40}$ the Idaho Constitution contains not only a Type VII basic uniformity clause (taxes shall be uniform upon the same class of subjects), but a provision similar to Type II, a proportionality clause. The Idaho court has found no possible conflict between the two, but simply refers to them as "uniformity clauses" limiting property taxes only, and requiring an absolute uniformity in rate as well as ad valorem method of property taxes. A separate provision is the source of a requirement of universality. Thus, property taxes are governed by the strictest uniformity requirement in Idaho. A more thorough analysis, in the Idaho study, suggested that this approach by the court demonstrated one of the most strict attitudes among those thirteen states having Type VII basic uniformity clauses, and one which ruled out a classified

4851 Idaho 619, 10 P. 2d 311 (1932).

49 Supra, p. 378. 
property tax although this construction was not the only reasonable one. Nevertheless, when faced with the question of determining the validity of a general net income tax, modeled after the federal income tax of that date, the court unanimously agreed that the tax was a nonproperty tax, and consequently not subject to the strict property tax uniformity limitation which would have invalidated the tax because of its features, such as a progressive graduated rate. The court made an extensive review of the authorities to date from other states, and concluded that the weight of authority-with which it agreed-was that an income tax was not a tax on property, but an "excise" tax. The term was used in the sense the term "nonproperty" tax is used in this monograph, the court saying:

It is difficult to arrive at any all-inclusive definition of the term excise tax, since it has long been changed from its original connotation of an impost upon a privilege. In its modern sense an excise tax is any tax which does not fall within the classification of a poll tax or a property tax, and embraces every form of burden not laid directly upon persons or property. ${ }^{\text {so }}$

As seems to be the case with most of the income tax-uniformity limitation opinions those other state decisions in line with the court's conclusion were most prominent and the basis for the conclusion that the weight of authority agreed with the court's ruling. The court simply failed to stress the Delaware and New Hampshire opinions to the contrary, although, as indicated above, they might well have been distinguished. In any case, the court relied on the Ludlow-Saylor opinion by the Missouri court as "representing a sound and clear summary" of the view which the Idaho court adopted. Moreover, the Idaho court found the income tax best char-

50 Supra note 48 , at 633. 
acterized as a tax upon the right or ability to produce, create, receive, and enjoy, and not on specific property. ${ }^{51}$

Some months after the Idaho decision, the Illinois court decided Bachrach v. Nelson. ${ }^{52}$ The basic uniformity clause in the Illinois Constitution is Type II, and the Illinois study ${ }^{\mathbf{5 3}}$ pointed out that there is the strictest degree of uniformity required of property taxes in Illinois. In the Bachrach case, the court was faced with determining the validity of the personal net income tax act which had a graduated rate and certain exemptions and was passed by the legislature of Illinois in a special session during February, 1932. The court held that the tax was a property tax, and, obviously, a violation of the property tax uniformity limitation. The rationale of the court was that income was property within the meaning of the constitutional limitation, the tax was upon income, and, therefore, upon property. In addition, the court agreed with the Massachusetts position that a tax upon income from property would be upon the property from which the income was derived. ${ }^{54}$ The opinion by the Illinois court was quite dogmatic, asserting, for example, that "The over-

${ }^{81}$ Id. at 634. The court used two arguments, either of which was sufficient to support the result. The second argument was based on Art. VII, $\$ 3$ of the constitution, which provided that "The words 'property' as herein used shall be defined and classified by law." The act levying the tax purported to "define" income, and so defined it that it was not property within the meaning of the constitutional tax article. The court concluded that this classification of income as not being property was a proper exercise of legislative discretion under Art. VII, §3.

52349 III. 579, 182 N.E. 909 (1932).

53 Supra, p. 125.

${ }^{54}$ Supra note 52, at 595. Also see Ohio Oil Co. v. Wright, 386 Ill. 206, 53 N.E. 2d 966 (1944), discussed in the text to footnotes 22 to 31 , Ch. III, §B/3, supra, p. 124. An earlier case, Young v. Ill. Athletic Club, 310 III. 75,141 N.E. 369 (1923) is distinguished in footnote 22 to Ch. III, $\$ B / 3$, supra, p. 123. See pp. 584 to 591 in the Bachrach case for the tenuous "historical" argument of the court, from which it was concluded that the purpose of the framers of the present Illinois Constitution had been 
whelming weight of judicial authority holds that [income] is [property]." ${ }^{\text {55 }}$ For this proposition, the court cited the Alabama Eliasberg case, as well as other Alabama decisions, certain Massachusetts opinions, certain United States Supreme Court opinions, and the Missouri Ludlow case and the Delaware Pinder case. These cases were cited as defining:

What is personal property and in substance hold that money or any other thing of value acquired as gain or profit from capital or labor is property, and that, in the aggregate, these acquisitions constitute income, and, in accordance with the axiom that the whole includes all of its parts, income includes property and nothing but property, and therefore is itself property. ${ }^{50}$

This statement is hardly accurate as to the Ludlow opinion, which held that income was not property within the sense used by the constitutional uniformity limitation. In addition, this writer has already suggested that the Pinder case should be cited with considerable caution in this field. Apart from that, the court cited the Alabama, Massachusetts, and Delaware opinions, along with the Pollock case, as basis for its "overwhelming weight" of judicial authority. Missouri cases constitute authority to the contrary, as do the Mississippi, Oregon, Arkansas, Georgia, and Idaho opinions. The court in a later paragraph does refer to those states as having statutes providing for income taxes, along with the states of New York, North Carolina, North Dakota, Oklahoma, South Carolina, Tennessee, Utah, and others. No judicial authority is referred to, these states being dismissed by citing Wisconsin and New York as states in which either an income tax

to limit the legislature to the same sources of revenue to which it had been limited by the prior constitution of 1848 . Considerable comfort was derived from the fact that there was no express authorization for an income tax included in the present 1870 constitution.

$55 I d$. at 591.

${ }^{56}$ Id. at 592. 
was expressly sanctioned by the constitution or no constitutional uniformity limitations existed. ${ }^{57}$ The point is, the Illinois court had no basis for its evaluation of the precedent in other states-if weight of number is to be so important. But this assertion by the Illinois court is typical of the approach used by a good many of the opinions on this particular problem.

$$
* * * * *
$$

Within nine months of the Illinois decision, the Montana court in 1933 decided O'Connell v. State Board of Equalization. ${ }^{58}$ The Montana legislature had enacted a graduated personal net income tax law, copied from the Idaho law. Contemporaneously, a constitutional amendment was proposed which would have expressly authorized the imposition of such a tax. The court, however, in the O'Connell case determined the validity of the tax before the amendment became effective. In a 3-2 decision, the majority concluded that the income tax was not a tax on property, and, therefore, not subject to any of the property tax uniformity requirements which might be stricter than the uniformity required of nonproperty taxes. ${ }^{39}$ Consequently, both the exemptions and the graduated rate schedule were held reasonable classifications, neither of which could stand in a property tax. The majority relied a great deal upon the Idaho act and the interpretation placed thereon by the Idaho court in the Diefendorf case. The decision of the majority was that the tax was "in the nature of an excise," precise nature of the tax was not elaborated upon. It was sufficient that the tax was not a property tax. Recognizing the controversy the court said:

${ }^{57} \mathrm{Id}$. at 594-595.

6895 Mont. 91, 25 P. 2 d 114 (1933).

60 See the Montana study, supra, p. 431.

${ }^{60}$ Supra note 58, at 120. 
. . . we do not feel disposed, nor do we think it necessary, to enter into a lengthy discussion as to the character of the tax imposed by the chapter here under consideration. . . . We content ourselves with saying that there are reasons why such a tax might be classed as a property tax, and reasons why it should be classed as an excise tax. Volumes, in fact libraries, have been written in a vain endeavor to accurately classify the income tax. Courts and text-writers have endeavored to argue the world into the belief that the income tax is a property tax. . . . Other courts are just as emphatic in the claim that it is an excise tax. . . .

It is not necessary for us to declare the exact nature of the income tax under consideration. It is apparent that the legislature of the state of Montana intended to enact an income tax and did not intend that it should be considered as a property tax law. ...

Perhaps in the end, the majority could be said to have looked quite favorably on the view that an income tax is sui generis, the idea presented in a well-known law review article quoted by the court. ${ }^{62}$ If the majority did not seek to find the definitive answer in view of the clashing opinions by courts of last resort in other states, but found in this clashing opinion itself the basis for upholding the tax, this was grounded upon the premises the majority began with, that the court was to indulge in every possible presumption in favor of the constitutionality of a legislative act. The court was sitting to determine "not whether it [was] possible to condemn but whether it [was] possible to uphold the Act." ${ }^{\text {"63 }}$ No doubt the clashing opinion furnished a reasonable doubt to be resolved in favor of the validity of the act. ${ }^{64}$

61 Id. at $112-113$.

${ }^{62} I d$. at 113 , quoting Brown, supra note 3.

13 Id. at 107.

${ }^{64} \mathrm{Cf}$. the dissenting opinion by Blake, J., infra note 82 , in the Washington Culliton case. 
To dissenting Chief Justice Callaway, there was no reasonable doubt. In a vitriolic dissenting opinion, he asserted that an income tax is a property tax, and consequently had to fall under the Montana property tax uniformity limitation. In reaching his conclusion Justice Callaway, too, was guided by certain premises.

We should observe at the outset ... that the settled determination of the people in framing and adopting the Constitution to restrict the legislature in matters of taxation is an outstanding feature of that fundamental law. The historic tendency of governments constantly to exact more money from the taxpayer pursuant to popular desire in furthering public activities was in the mind of the framers; they knew that the history of the human race tells with startling repetition the story of ships of state going to destruction upon the rocks of high taxation. ${ }^{65}$

First, he considered the idea that income was not property within the contemplation of constitutional provisions. This, he said, seems to have had its origin in the $W$ aring case decided by the Georgia court, and the idea there expressed (and so often quoted) that income is "the fruit" and property, labor and capital "the tree," and that "the fruit" is no "tree" so long as it is "plucked to eat, and consumed in the eating."

Upon this and similar fallacious reasoning a number of respectable courts have declared that income is not property. It would be useless to discuss these authorities. . . . Their sophistry is adequately exposed by the eminent Justice Somerville speaking for the Supreme Court of Alabama, in Eliasberg Bros. Merc. Co. v. Grimes. . . .68

Other arguments were reviewed, ${ }^{67}$ but Justice Callaway's

${ }^{65}$ Supra note 58, at 122-123.

${ }^{66} 1 d$. at 123-124. Emphasis added.

${ }^{67}$ Note particularly his discussion of the "privilege" tax argument, at pp. 127-128. 
patience seemed to wear thin and he concluded, "But the idea that an income tax is an excise under our Constitution is a fantasy."

Admitting that income taxes are desirable, that, as different writers say, the income tax system is a long step in advance, which in the interest of good government should be taken, and that it is the only practical system to reach intangibles which to a large extent are and have been escaping taxation, and is generally conceded by economists and tax experts to be the most equitable and just of all kinds of taxes, the question to be decided by us is whether that system is permissible under the Constitution, or whether it will be necessary to amend it in order that the system may be employed. My answer is: The Constitution must be amended to warrant a valid income tax law. ${ }^{69}$

It is interesting to note how the Montana court's approach to the income tax problem is of the same spirit as its approach to the problem of a classified property tax. As pointed out in the Montana study, the Montana Constitution contains both a Type VII and Type VI clause, the latter being generally interpreted as requiring strict uniformity in property taxes. When faced with determining the validity of a classified general property tax the Montana court in 1919 had reconciled the two conflicting clauses so as to permit classification for rates, though no exemptions could be made and the ad valorem method was required. In other words, whether it be a classified property tax or an income tax, the majority of the Montana court would start with the premise that it was sitting to determine "not whether it was possible to condemn but whether it was possible to uphold" legislative enactments. Where reasonably possible, legislative discretion is given the benefit of the doubt.

$68 \mathrm{Id}$. at 128 .

$69 \mathrm{Id}$. at 131 . 
In the same year of the Montana decision, but nearly two months later, the Washington court entered the arena to reveal a bitter internal split on this highly controversial problem. As related in the Washington study, ${ }^{70}$ a graduated general net income tax was passed in 1932 in Washington as an initiative measure. The act stated its purpose to be the taxation of "all annual incomes within the state as such, and not as property." This was to no avail. The act was challenged immediately and a majority of the court on September 8, 1933, in Culliton v. Chase, ${ }^{71}$ held it unconstitutional. The decision was 5-4. The majority's rationale was: the act imposed a tax directly on income (notwithstanding the legislative recital to the contrary), income is property, therefore the tax was a property tax. Being a property tax, the act was subject to the uniformity limitation applicable to property taxes. In 1930, the Washington Constitution was amended to change the basic uniformity clause to Type VIII (taxes shall be uniform upon the same class of property). Before that time, property taxes were subject to the strictest uniformity limitation. All five of the majority were agreed that the graduated rate feature was not such a classification as was provided for under the new and, to a limited extent, more liberal property tax uniformity limitation. Indeed, two of the majority indicated that income would be a minimum class. Consequently, even in a state having modified its strict property tax uniformity requirement, the characterization of the income tax as a property tax was fatal-at least, insofar as a graduated income tax was desired.

The rationale of the majority depended, first, upon the definition of property found in the Washington Constitution in the same provision containing the uniformity clause: "The word 'property' as used herein shall mean and include

70 Supra, p. 582.

71 174 Wash. 363, 25 P. 2d 81 (1933). 
everything, whether tangible or intangible, subject to ownership." Income was said to be "something," and surely "subject to ownership," while "everything" includes "something," Because of this "peculiarly forceful constitutional definition"73 - as characterized by the principal opinion-the majority could assert that none of the decisions from other states had any bearing on the problem before the Washington court. ${ }^{74}$ However, as an aside, without reference to such judicial authority, it could also be asserted that "The overwhelming weight of judicial authority is that 'income' is property and a tax upon income is a tax upon property." 75 An almost identical statement in the Illinois case has already been considered. Second, the majority could assert that in a 1930 opinion, Aberdeen Savings $\mathcal{E}^{7}$ Loan Assn. v. Chase, ${ }^{78}$ it had "definitely decided ... that an income tax is a property tax, which should set the question at rest. . . ."77 The significance of that case is more closely examined in the Washington study, ${ }^{78}$ and that analysis could be referred to at this point with profit.

The tone of the principal and concurring opinions of the

${ }^{72} \mathrm{Cf}$. the analysis of the majority rationale in the concurring opinion by Steinert, J., at p. 384. See the principal opinion at p. 374.

73 Id. at 374.

${ }^{74}$ However, the court did have to distinguish the Idaho Diefendorf case, supra note 48, and the Montana O'Connell case, supra note 58. The basis upon which the majority could distinguish the Idaho case was the second reason used in that opinion, supra note 51 , which was based on the provision in the Montana constitution defining property. The majority asserted that the Montana majority had been unduly swayed by the Idaho decision. Id. at 376-377. However, it should be pointed out that the majority in the Idaho Diefendorf decision did not rely on the special constitutional provision referred to for its nonproperty tax argument.

${ }^{75} \mathrm{Id}$. at 374.

76157 Wash. 351,289 Pac. 536 (1930).

77 Supra note 71 , at 376 .

${ }^{78}$ See the text to notes $28-34$ in Ch. III, $\S \mathrm{H} / 7$, supra, p. 581. 
majority hint at a bitter dispute lying close to the surface but not yet spilling over into the printed opinion. This is reflected in the rather defensive tone of the dissenting opinion. This feeling about the several opinions in the Culliton case is confirmed by the 1936 Jensen case in which acrimonious debate was not kept in the conference room.

In the eyes of the four dissenting justices the tax was a nonproperty tax, with its object the enjoyment of privileges made possible by the protection of the organized state. Furthermore, the dissent felt that even if the tax were characterized as a property tax it was not unconstitutional because the uniformity clause for property taxes required only a uniformity within classes. The dissenting opinion preceded its discussion of the meaning of the constitutional provision with a review of "not only its historical background, but the social and economic condition of the state when" the original, and superseded, uniformity clause was written into the constitution in $1889 .{ }^{70}$ It is interesting to set forth this discussion at some length, as it illustrates the justification used by those who would liberally interpret the uniformity limitations as opposed to the justification typical of those opposing the income tax. Judge Blake wrote:

In 1889 , the major portion of the wealth of the state lay in its lands and their produce-agricultural, mineral and timber. Taxation was a fairly simple process. Its subjects were tangible, visible-easy to evaluate. The functions of government were also fairly simple. Relatively speaking, in those days the value of tangible property was great and the cost of government little. The burden of taxation was nothing compared to the benefits the owner of real property received as the result of his comparatively small contribution to the organized state, which protected him in his ownership and use of property.

But even then, the economic complexion of the country

${ }^{79}$ Supra note 71, at 385. 
was changing. More and more of the country's wealth was going into intangibles-into stocks, bonds, securities of various sorts-indicia of property which could easily elude the search of the tax collector. In the light of subsequent history, even then it should have been obvious that the powers of taxation must be elastic. . . .

This . . . was a new state, whose vast resources of wealth that lay in and on the land seemed inexhaustible. After the depression of the middle nineties, a tide of immigration started, which continued until toward the end of the first decade of this century. As a result of this influx of people, and the still popular belief that wealth lay in the land, values of real property increased amazingly and kept relatively well ahead of increasing taxes. But in the latter part of that decade the tide of immigration began to ebb rapidly, and real property value receded with equal celerity.

In the meantime, due to a growing complexity in organic society, the state had been called upon to take over an everincreasing burden of functions, and the cost of government had relatively increased. As long as property values were increasing, the additional tax burden went unnoticed. But when property values collapsed, the problem of taxation began to be acute-and for twenty odd years it has been increasing. The cry for reduction of taxes has become ever louder in the face of increasing cost of government.

The burden of taxation on real estate became more onerous during the second and third decades of this century by reason of several facts, among which were the following:

(2) as the burden of taxes on real property increased, capital sought investment in bonds, stocks and other securities, and escaped taxation entirely, or carried, at most, only a small portion of the burden.

A growing agitation for decrease in taxes developed. But the relief was not available, because the state found itself in a strait-jacket in the shape of article VII of the constitution [the original uniformity clause, Type VI, a uniform and equal rate of assessment and taxation], with the judicial interpretation that had been placed upon it. . . . 
As a result of these years of agitation and investigation of the subject, there was submitted to the people and adopted by them at the general election of 1930 [an amendment which substituted the present uniformity provision.$^{80}$

That provision contained a Type VIII clause (taxes shall be uniform upon the same class of property). Having made this review, Judge Blake observed,

As I see it, the real question presented on this appeal is whether, by construction of this amendment, we are going to thwart the effort of the state to throw off the straitjacket in which it was bound. To do so requires a literal, technical construction of a few words of the amendment, in perversion of their true and obvious intent and purpose and in total disregard of its historical background and the conditions which brought it into being. ${ }^{81}$

Of course, the attitudes of the majority and minority in this case are excellent illustrations of the techniques of interpretation of written law. Shall we do as the majority, look at the words of the instrument and thereby determine the "plain meaning" of the words, or shall we, with the dissenting justices, look to historical scene to determine the "true" meaning of the words? What was the intention of those who drafted and those who approved the words of the new uniformity provision? Choose your technique of interpretation, and the opposing conclusions may reasonably follow. Perhaps it is superfluous to say that what seemed a wise result might have influenced the choice of interpretive technique used to justify the conclusion drawn. In any case, the dissenting opinion, in light of these interpretive considerations, reasoned to its above conclusion. Recognizing that other decisions were not binding, the dissent nevertheless

${ }^{80}$ Id. at $385,386-387$.

81 Id. at 388 . 
noted that if one is to follow the principle that legislation is presumptively valid, then " $[t]$ he disagreement of courts and judges on identical problems seems to afford the highest proof that 'reasonable doubt' does exist." ${ }^{82}$ Consequently, such reasonable doubt should be resolved in favor of the legislation.

In order best to evaluate the Culliton decision one must consider State ex rel. Stiner v. Yelle, ${ }^{83}$ an opinion handed down on the same day of the Culliton opinion. In the Yelle case a majority of five (the minority of Culliton plus one) upheld a Business and Occupation Tax first imposed in 1933. That Act, described in more detail in the Washington study, purported to levy upon "every person an annual tax or excise for the privilege of engaging in business activities." The base of the tax was gross income from the business engaged in, with a different proportional rate applicable to different classes of business, as classified in the Act. Because of a veto the tax did not reach either those engaged in agriculture or professionals. The majority of five, in the Yelle case, agreed that the tax was not a property tax, distinguishing it from a net income tax as follows:

The act does not concern itself with income which has been acquired, but only with the privilege of acquiring, and that the amount of the tax is measured by the amount of the income in no way affects the purpose of the act or the principle involved. ${ }^{84}$

If one recognizes this argument as having a familiar ring, remember it is by the "dissent-plus-one" of the Culliton case. If one wonders how the "plus-one" (Judge Holcomb) could be convinced by such finely drawn distinctions, con-

82 Id. at 396.

${ }^{83} 174$ Wash. 402, 25 P. 2d 91 (1933).

84 Id. at 407. 
sider this statement by the writer of the majority opinion, concurred in by Judge Holcomb:

... it seems necessary first to determine whether the tax under consideration is a property tax or an excise tax, because of the uniformity clause. . . .

Time and space will not permit a review of the authorities on this question. Slight differences in the terms of the acts considered, or in constitutional provisions, have led to a maze of conflicting and bewildering decisions. It may be that we have, in some prior case, used language not wholly consistent with our present views. After an exhaustive study of the cases, we are all well satisfied that this is not a property tax, even under the broad and all inclusive terms of our constitution. To hold otherwise would render it exceedingly difficult if not impossible to sustain any excise $\operatorname{tax}^{85}$

The juxtaposition of these two cases in the jurisprudence of a single court, indeed in the same volume of reports, decided on the same day and found on adjoining pages of the reports, should serve as well as any example to illustrate the almost hopeless task of arranging the precedent on this general problem with any reasonable degree of symmetry. Two of the four dissenting justices in the Yelle case agreed that the tax was not a property tax, but disagreed with the conclusion of the majority that the exclusion of farmers and professionals was not arbitrary. Two dissenters adamantly clung to their view that this tax, as well as a net income tax, was a tax upon property within the scope of the uniformity limitation.

But this was not the last word in Washington. As described in the Washington study, the legislature tried again in 1935, enacting a personal net income tax and a companion

${ }^{85} l d$. at 405-406. Emphasis added. 
corporate net income tax. Apparently finding some faint hope in the Yelle case, the legislature framed the acts in terms of "privileges," providing that the personal net income tax was to be paid by every resident of the state "for the privilege of receiving income therein while enjoying the protection of its laws." The Culliton majority was not to be so easily persuaded. In Jensen v. Henneford, ${ }^{86}$ decided in 1936, the personal net income tax was held to be unconstitutional. Again there was a 5-4 decision, with majority and minority being composed of the same judges composing the majority and minority in the Culliton case. The majority ruled that the tax was a property tax, regardless of the statutory recitation to the contrary.

The 1935 act purpcrts to levy a tax upon "the privilege of receiving income." But an examination of the various provisions of the act shows clearly that the legislature was concerned with the property (income) upon which the amount of the tax was to be levied, not with the mere privilege of the individual to receive the income. When a tax is, in truth, levied for the exercise of a substantive privilege granted or permitted by the state, the tax may be considered as a excise tax and sustained as such. Illustrations of such taxes are found in the cases of State ex rel. Stiner v. Yelle.... (for the privilege of engaging in business activities)....

But the mere right to own and hold property cannot be made the subject of an excise tax, because to tax by reason of ownership of property is to tax the property itself. . . .

The right to receive property (income in this instance) is but a necessary element of ownership, and, without such right to receive, the ownership is but an empty thing and of no value whatever. . . . The right to receive, the reception, and the right to hold, are progressive incidents of ownership and indispensable thereto. To tax any one of these

${ }^{86} 185$ Wash. 209, 53 P. 2 d 607 (1936). 
elements is to tax their sum total, namely, ownership, and, therefore, the property (income) itself. . . ${ }^{87}$

Having disposed of the first issue with this specious but common reasoning, the majority then ruled that the tax violated the property tax uniformity limitation on several counts. It is sufficient to note that the majority viewed the power of the legislature to classify income (as property) as a very limited one, even though, ostensibly, property taxes need only be uniform within classes in Washington.

Judge Blake wrote the Jensen dissenting opinion, as he had written the dissenting opinion in Culliton. Admitting that if Culliton stood unimpaired it would dispose of the present case, Judge Blake proposed that Culliton had for all intents and purposes been destroyed as precedent by cases decided between 1933 and 1936. His persuasive argument rested primarily on the Yelle case, in which the business and occupation tax with a base of gross income was upheld as a nonproperty tax, the object of which was the privilege of engaging in enumerated occupations. The Yelle rationale had been reaffirmed in a subsequent case. ${ }^{88}$ In addition, the case $^{89}$ upholding the Washington sales tax as a nonproperty tax was cited, and, more significantly, he referred to the case $^{90}$ which ruled that the compensating use tax was a nonproperty tax, the use tax being on the "privilege of using" tangible personal property. Judge Blake could find no significant difference between those taxes and a net income tax, insofar as their nature was concerned. Using the rationale

87 Id. at 218-219.

${ }^{88}$ See Supply Laundry Co. v. Jenner, 178 Wash. 72, 34 P. 2d 363 (1934), and note 50 to Ch. III, §H/7, supra, p. 587.

89 Morrow v. Henneford, 182 Wash. 625, 47 P. $2 \mathrm{~d} 1016$ (1935), and note 3 to $\mathrm{Ch}$. III, $\$ \mathrm{H} / 7$, supra, p. 574.

00 Vancouver Oil Co. v. Henneford, 183 Wash. 317, 49 P. 2 d 14 (1935), and notes 3 and 7 to $\mathrm{Ch}$. III, $\S \mathrm{H} / 7$, supra, pp. $574,575$. 
of the majority, he could find no basis upon which to differentiate among the enumerated taxes.

Apart from the arguments on legal issues, the Jensen decision is illustrative of how this general issue of the validity of a net income tax has resulted in bitter controversy. The concurring opinion of Millard, C.J., must be set forth substantially in full in order to reveal the acrimonious nature of the debate:

None of the authorities cited justifies or excuses the minority's disregard of the doctrine of stare decisis. We held in [the Aberdeen case, supra] ... and in [the Culliton case, supra] . . that, under our constitution, income is property and that an income tax is a property tax. From that declaration, this court has never departed, and the people have not seen fit to amend the constitution to permit us to hold otherwise. It is true that some of the judges who concurred in the majority view in the first case cited dissented when the second case was decided.

"In future cases, even a dissenting justice should be bound by the decision of the majority until and unless authoritatively overruled or reversed by some higher tribunal. . . ." Culliton v. Chase. . . .

Surely, the rule of stare decisis-a rule whereby uniformity, certainty and stability in the law are obtained-should apply. This is not a forum where personal predilection should obtain. Political expediency has no place on this tribunal. Neither threats nor promises should dissuade one from the performance of duty. To sacrifice the rule of legal stability for acquisition or retention of official position is a price no honest person can exact, a price no self-respecting person can pay. Is a legal principle more than once enunciated, and from which the court has never receded, to have no binding effect? ${ }^{\text {?1 }}$

These are, indeed, rather harsh words.

Returning to the legal issues, the remainder of the 1935

91 Supra note 86, at 225. Emphasis added. 
net income tax structure was killed in Petroleum Navigation Company v. Henneford, ${ }^{02}$ a case decided later in the same term in which Jensen was decided. The corporate net income tax was held to be a property tax, by a 6-3 majority, with the majority briefly disposing of the tax on the ground that it was a violation of the property tax uniformity limitation, again indicating the very limited extent to which income (as property) might be classified. An effort made in 1951 by the Washington legislature to revive the issue in the form of a corporate net income tax met with failure in Powers v. Huntley ${ }^{93}$ for the same reasons expressed in the Petroleum case. The Washington study contains a more detailed analysis of these corporate net income taxes and points to certain inconsistencies in the opinions as to permissible minimum classes of income (as property).

$$
\text { * * * * * }
$$

This "holding" action by the small Washington majority could not balance the steadily growing trend which favored the constitutionality of a net income tax under state uniformity and equality limitations. In the spring following the Washington Culliton case, the Minnesota court passed on the question. On March 23, 1934 the Minnesota court, in Reed v. Bjornson, ${ }^{94}$ upheld a general net income tax law enacted in 1933 as against the contentions that the tax violated the state uniformity limitation and the federal equal protection clause. The principal arguments were directed at the graduated schedule and exemptions.

The Reed decision was unanimous, something of a rarity in this controversial area. Justice Loring, writing the opinion for the court, noted as the first issue that the briefs had

92185 Wash. 495, 55 P. 2d 1056 (1936).

9339 Wash. 2d 191, 235 P. 2d 173 (1951).

${ }_{94} 191$ Minn. 254, 253 N.W. 102 (1934). 
substantial parts devoted to a discussion of whether or not the tax involved was a property tax. The court was quite aware of the heated controversy on this question, but did not find it necessary to enter the fray. The reason for this was the interpretation placed by the court upon the Minnesota basic uniformity clause which is Type VII (taxes shall be uniform upon the same class of subjects). The court ruled that this uniformity clause limited all taxes-whether property or nonproperty. And, most importantly, the court was convinced that its uniformity clause was no more restrictive than the equal protection clause of the fourteenth amendment of the federal constitution. Consequently, regardless of the nature of the tax, the graduated rates and exemptions were not ruled out. As indicated in the Minnesota study, ${ }^{95}$ the court has, at least in one case, approved a form of graduated rate under an obvious property tax. If the issue concerning the nature of the tax had been forced, it seems that the court did not look unfavorably on the view that an income tax is sui generis. This is evident in the following discussion by the court:

While income as it is received is necessarily property, a tax upon it has many characteristics which differ quite radically from those of a tax levied upon real or invested personal property. Income is a more fleeting or transitory benefit which comes according to present efforts or the wisdom or luck of past accumulations. Many who own little or no tangible or intangible property have large incomes and enjoy great benefit from the protection which organized society affords. They not only have ability to pay a tax for that protection but get value received in liberal measure for what they may be required to pay. So do those who receive large incomes from property. An income tax is calculated to

${ }^{95}$ Supra, p. 406. See the text discussion therein to footnotes 53 through 77 for the development concerning the Minnesota corporate franchise tax with a base of net income, and the confusion concerning its nature. 
take toll from the flow of this property to the individual through the arteries of organized social life and to cause it to bear a share of the burden of government. In many ways such a tax is sui generis. It imposes a tax on the net income or revenue which passes into or through a man's hands within a prescribed period, a large share of which never finds permanent investment. ${ }^{96}$

On this analysis of the nature of an income tax and the meaning of the uniformity clause the court found much comfort in the Oregon Standard Lumber Co. decision.

One further point of interest in the Reed case is the approach taken by the court. Reminiscent of Justice Blake's opinion, dissenting in the Washington Culliton v. Chase, the opinion in the Reed case noted that the present uniformity clause in the Minnesota constitution was adopted in 1906, replacing the clause theretofore governing taxation. The meaning of the new uniformity clause was to be determined from "the history of the times" which "indicates clearly that the people, in adopting the 1906 amendment, were liberating the legislature from most of the previous constitutional restraints in regard to taxation." ${ }^{\text {"97 }}$ The opinion then proceeded to give full play to this intention in its interpretation of the "wide open tax amendment," as the provision was designated when up for adoption.

At this point it will be interesting to return for a moment to the situation in Montana. Recall that in the summer of 1933, the Montana court decided the O'Connell case, in which a personal net income tax was characterized as a nonproperty tax and upheld, but not without the outspoken opposition of two dissenting justices. Winter did not have a cooling effect upon the rather heated differences, and less than two months after the Minnesota opinion, in the spring

${ }^{96}$ Supra note 94, at 260.

97 Id. at 259. 
of 1934, the Montana court faced the problem again in a manner reminescent of the second Washington case of 1936, discussed above. On May 12, 1934, the Montana court in Mills v. State Board of Equalization ${ }^{08}$ reaffirmed its general position stated in the O'Connell case. After the O'Connell case the legislature had amended the income tax law to add a surtax provision. In the Mills case, taxpayers not only attacked the validity of the surtax provision, but would have re-opened the question of the validity of the tax in the absence of the surtax provision.

As to the validity in general of an income tax, the majority opinion noted that attention had been directed to the assertion by Holcomb, J., in the Washington Culliton case, to the effect that "the overwhelming weight of judicial authority" favors the view that an income tax is a property tax. The Montana majority's response was to refer to the article $^{99}$ written by Professor Allen in 1933 in which he discussed the court opinions to that date and concluded that, while earlier state decisions were about equally divided, by 1933 opinions rendered were "preponderantly" in favor of the view that an income tax is a nonproperty tax. The Montana majority concurred in this, saying:

Through the course of his article Professor Allen refers to the decisions pro and con on this question, and then demonstrates by his citations the truth of his observations. The learned jurist from our neighboring state does not fortify his conclusion by any such array of citations, and in fact our investigation of the adjudicated cases leads to the conclusion reached by Professor Allen. ${ }^{100}$

The majority further noted that some of the briefs "severely" condemned the court for not "defining or classify-

\footnotetext{
9897 Mont. 13, 33 P. 2d 563 (1934).

99 Allen, supra note 3.

${ }^{100}$ Supra note 98 , at 17-18.
} 
ing" the income tax in the O'Connell case. The majority properly responded, "We did, however, decide that the income tax is not a property tax." ${ }^{101}$ That is, the crucial issue is not so much what an income tax "is," as what it "is not." If the tax is not a property tax, it makes little difference how it is defined. In other words, we reach the dichotomy used throughout this monograph-property taxes and nonproperty taxes, with the latter category simply all taxes not falling in the first class. Thus, the majority did not retreat from its position in the $O^{\prime}$ Connell case. ${ }^{102}$

Mr. Chief Justice Callaway was still not convinced-nor did any concept of stare decisis suppress his contempt for the majority rationale. In his opinion, O'Connell should be overruled. One reason given was:

... the majority [in O'Connell] declared an excise tax to be an income tax, contrary to our Constitution and the great weight of authority.

... [here the opinion by Holcomb, J., in the Washington Culliton case is referred to, and his assertion as to the weight of authority]. . . .

That there is ample authority for the statement is seen by referring to the authorities cited in my opinion in the O'Connell case. In view of the "conclusion" of Professor Allen, referred to in the majority opinion, it may not be amiss to call attention to the fact that the "weight of authority" does not depend upon the number of opinions upon one side or another of a debated question. It rests upon the sounder opinions, those which are supported by reason, experience and wisdom. Upon this foundation there cannot be any doubt that the great weight of authority sustains the assertion that income is property; . . . . ${ }^{103}$

101 Id. at 18.

102 However, the surtax provision was held invalid because of poor drafting which resulted in an unintentional arbitrary discrimination. See note 8 to Ch. III, §G/8, supra, p. 431 .

${ }^{103}$ Supra note 98, at 34 . Emphasis added. 
All would agree that a "box-score" jurisprudence is not desirable. Sheer weight of numbers need not necessarily be persuasive. However, the "weight of authority" is usually distinguished when not followed as being contrary to the "sounder" premises. But this is hardly the place to become embroiled in controversy over that concept. ${ }^{104}$ For, however that may be, Mr. Chief Justice Callaway's Procrustean definition is really most persuasive of one thing: Justice Callaway was convinced he was "right," and that should be the end of the matter. Further evidence of the basic "error" of the O'Connell decision was, in Justice Callaway's view, as follows:

The result of the decision in the O'Connell case was foreseen; in my dissenting opinion it was predicted that the operation of [the income tax law] would increase taxes during the present biennium. It has. It was also pointed out that "if the legislature has the right, under the Constitution, as it now exists, to levy an income tax, it may employ that tax to raise large sums of money in addition to the ad valorem tax as provided by the Constitution."

The Extraordinary Session ... attempted through the surtax device to increase the income taxes of individuals. ... And it is to be noted that the legislature, unless restricted by the Constitution, may do so again and go still further, by employing the pen of a more skilled draughtsman, and thus the tax burden, now oppressive, will become unbearable, entailing ills upon the people beyond their sufferance....

The constitutional barriers so carefully erected by the people in their Constitution have been broken down by the O'Connell case. I call attention again to the desirability of enacting the pending constitutional amendment which provides that the legislative assembly may levy "and collect taxes upon incomes and persons, firms and corporations for the purpose of replacing property taxes."1105

${ }^{104}$ Cf. note 167 , infra.

108 Supra note 98, at 34-35. Emphasis added. 
One may well wonder how that passage got into an opinion concerning the constitutionality of an income tax, that question ostensibly depending upon the nature of the tax and the applicable uniformity limitation. The majority opinion did attempt to answer this type of objection, and while having no bearing on the constitutional issue, that answer may be quoted to catch the full flavor of this judicial battle.

Again our attention is invited to the impending disaster which will overtake the citizens of this state, by holding that the legislature in the enactment of future income tax laws is in nowise limited by the provisions of our Constitution. . . . The states of New York, Iowa, Connecticut, Vermont and Rhode Island have practically no constitutional limitations whatever upon the exercise of the taxing power by their legislatures. It cannot be said that these states have not prospered during their existence to any less degree than have the neighboring states of similar areas and resources. The lack of constitutional restriction upon the taxing power has not operated to drive wealth beyond their borders. The state of New York, without such constitutional restriction, is first in wealth and population, and, indeed, within its confines is the city said to be the financial center of the business world. ${ }^{108}$

However persuasive these various arguments may be as to the wisdom, or lack of wisdom in imposing income taxes, they offer little aid in reaching some conclusion as to the proper interpretation of the pertinent constitutional limitations. Finally, it is interesting to surmise whether Justice Millard of the Washington court would have invoked the spectre of stare decisis to condemn so thoroughly the dissent of Justice Callaway in the Mills case, as he did to condemn the continued dissent of Washington justices in the Jensen case. Was the continuing dissent of Justice Callaway a "personal predilection?"

106 Id. at 18. 
Over a year went by after the Minnesota and second Montana decisions before another state court considered the problem. In the fall of 1935, the Pennsylvania Supreme Court decided Kelley v. Kalodner ${ }^{107}$ in which it held unconstitutional a personal net income tax law enacted in the summer of 1935. The law imposed a graduated rate, contained certain minimum exemptions, and reached the entire income from all sources, earned and unearned. Thus, income derived from property-tangible or intangible-was reached. The court accepted as its first inquiry the determination of the nature of an income tax. Pointing out that there were no Pennsylvania cases determinative of the issue, the court noted that the numerous decisions on the point in other jurisdictions showed a clear-cut division of authority, referring to the Idaho, Missouri, and Arkansas decisions as holding the tax to be a nonproperty tax and Massachusetts, Delaware, Illinois, and Washington decisions to the contrary. The United States Pollock decision was, quite properly, distinguished as shedding no light on the particular problem at hand-the validity of income taxes under state constitutional uniformity provisions. This split of authority appearing, the court concluded:

We are at liberty to determine the question along normal, natural lines. In so doing we are inevitably impelled to the conclusion that an income tax is a property tax. This result seems particularly clear in so far as a tax upon the income from real and personal property is concerned. ${ }^{108}$

Consequently, insofar as income from property was taxed the tax was held to be a property tax. It was not necessary to go further because the tax was not severable. Thus, the court could assert:

We pass no opinion upon the question of whether a tax 107320 Pa. 180, 181 Atl. 598 (1935).

108 Id. at 186 . Emphasis added. 
upon the income from trades, occupations or professions is a tax on property, although respectable judicial opinion has indicated that it is not. ${ }^{109}$

That part of the act passed upon-the tax upon income derived from property - was held to violate the property uniformity limitation because of both the minimum exemptions and the graduated rate schedule. Classifications based upon quantity of the same thing were held to be unreasonable classifications.

Thus, the court in the Kelley case never actually ruled on the nature or validity of an income tax limited to earned income. However, the Pennsylvania study-both in general and on the income tax in particular-showed that there would be little significance in holding the tax on earned income to be a nonproperty tax because the Pennsylvania court, after the Kelley case, clearly ruled that graduated rates were not permitted for any taxes-property or nonproperty-in Pennsylvania, and that all taxes are limited by the basic uniformity clause, which is Type VII. ${ }^{110}$ Subsequent cases have also indicated, as demonstrated at length in the Pennsylvania study, ${ }^{111}$ that only to a limited extent will it be possible to impose a tax on unearned income in Pennsylvania under the existing constitutional uniformity limitation as it has been interpreted. Thus, however indecisive was the Kelley case, Pennsylvania decisions have definitely been adverse to the imposition of income taxes.

The spring following the Pennsylvania decision saw the controversy come substantially to a standstill-that is, insofar as judicial development was concerned. On March 7, 1936, the North Dakota court, in State ex rel. Haggart v.

$109 \mathrm{Id}$. at 187-188.

110 See especially the text to notes $174-180$ and 197 of $\mathrm{Ch}$. III, $\S \mathrm{G} / 12$, supra, pp. 529-530.

111 Id., see text to notes $186-190$. 
Nichols, ${ }^{112}$ unanimously held that a graduated net income tax did not violate the North Dakota uniformity clause, which was a Type VIII clause (taxes shall be uniform upon the same class of property). The writer of the principle opinion, concurred in by two other justices, viewed any discussion of the nature of the income tax as immaterial. The reason offered was similar to that found in Minnesota; after equating the uniformity clause to the federal equal protection clause, the principal opinion then found that even if the tax was held to be a property tax, the classifications (e.g., graduated rates) were permissible. ${ }^{113}$ Two justices specially concurred, both on the basis that an income tax was not a property tax. ${ }^{114}$

\section{$* * * * *$}

During this period of the early thirties, other decisions favorable to the imposition of an income tax ${ }^{115}$ were made in North Carolina, ${ }^{116}$ Maine, ${ }^{117}$ Iowa, ${ }^{118}$ and Kentucky. ${ }^{119}$

11266 N.D. 355,265 N.W. 859 (1936).

${ }^{113}$ However, for the record, the court did hold that the tax on income from realty was not a tax on such realty. This decision was necessary because of another constitutional limitation. Id. at $387 \mathrm{ff}$.

114 Id. at 388.

115 For inconclusive precedent in West Virginia, see the text and notes 10 and 11 to $\mathrm{Ch}$. III, §E/3, supra, pp. 264-265.

116 An income tax has been expressly sanctioned in the North Carolina constitution since as early as 1868 . See the text in $\mathrm{Ch}$. III, $\S \mathrm{H} / 4$, supra, pp. 560-561. At the present time North Carolina has a Type VIII basic clause. However, before 1935 the basic clause was Type IV, and it required a very strict rule of uniformity of property taxes. In 1933, in Maxwell v. Kent-Coffey Mfg. Co., 204 N.C. 365, 168 S.F. 397 (1933), the North Carolina court found it necessary to rule that an income tax under attack was a nonproperty tax. Although the income tax is expressly permitted, there is no mention of method or rates, and the tax was challenged as not conforming to the ad valorem requirement which existed before 1935. The court ruled that the tax did not have to conform to the limitation because it was a nonproperty tax.

${ }^{117}$ In 1935 the Supreme Court of Maine ruled in an advisory opinion, In re Opinion of the Justices, 133 Me. 525, 178 N.E. 621 (1935), that a net 
There has been no judicial development on this problem since the thirties, with the exception of decisions favorable to the imposition of an income tax in Maryland in $1940,{ }^{120}$ and in Kansas in $1947 .^{121}$

\section{A Special Note on "Gross" Income Taxes and Cor- porate Franchise Taxes with a Base of Net Income}

Before attempting any evaluation of this judicial development concerning net income taxes, it will be of interest to survey very briefly the treatment given to gross income taxes by the state courts. The first of these decisions has al-

income tax would not be a property tax, and consequently would not be limited by the strict uniformity required of property taxes. The Maine basic clause is a Type I provision. However, in fact, Maine has never enacted any form of an income tax. See the text to notes 9-11 in Ch. III, $\S A / 2$, supra, p. 61.

118 Vilas v. Iowa State Board of Assessment \& Review, 223 Iowa 604, 273 N.W. 338 (1937). lowa has no uniformity clause of any kind, and normally it will not make any substantial difference whether a tax is characterized as property or nonproperty. See Ch. III, $\S \mathrm{J} / 2$, supra, pp. 596-598. However, because of Art. VIII, $\$ 2$, which provides that "The property of all corporations for pecuniary profit shall be subject to taxation, the same as that of individuals," it was necessary to characterize the income tax as a nonproperty tax in the Vilas case in order to sustain it against objections that Art. VIII, $\S 2$ was violated.

119 Reynolds Metals Co. v. Martin, 269 Ky. 378, 107 S.W. 2d 251 (1937). While Kentucky has a Type VIII basic clause, the limitation on property taxes is still somewhat stricter than that applied to nonproperty taxes. See Ch. III, $\S \mathrm{H} / 2$, supra, Pp. 551-553. Consequently, the characterization in the Reynolds case was of real importance, especially because of the graduated rates feature.

${ }^{120}$ Oursler v. Tawes, 178 Md. 471, 13 A. $2 d 763$ (1940). Maryland has had a Type VIII clause since 1915, but the characterization of the income tax as a property tax avoided certain stricter property-tax requirements, although classification for rates is now permitted in Maryland.

121 Hartman v. State Comm. of Revenue and Taxation, 164 Kan. 67, 187 P. 2d 939 (1947). However, this decision was preceded by a constitutional amendment in 1932 which expressly authorized the imposition of a graduated net income tax. See note 9 to Ch. III, $\$$ F/3, supra, p. 309. 
ready been mentioned. In 1925, in Sims v. Ahrens, ${ }^{122}$ the Arkansas Supreme Court struck down the Arkansas gross income tax because of certain arbitrary classifications, although the court characterized the tax as a nonproperty tax. Subsequent Arkansas development centered on the more orthodox net income tax.

The other gross income tax cases were decided during the early 1930's, the same period during which the battle over the net income taxes reached its peak. The leading case is Miles v. Department of Treasury, ${ }^{\mathbf{1 2 3}}$ decided in 1935 by the Indiana court. Like the Arkansas tax, the Indiana 1933 gross income tax can be distinguished from a net income tax in that the base of the tax is gross income. However, it is to be distinguished from the ordinary "gross receipts" tax in that it applied to all persons, whether in business or not, and included all forms of earned and unearned income. ${ }^{124}$ The Indiana act was sustained, the court ruling that it was a nonproperty tax and therefore not subject to the strict property tax uniformity requirement. ${ }^{125}$ The tax was characterized as being "upon the right or ability to produce, create, receive, and enjoy, and not upon specific property."126 Any distinction between gross income and net income taxes was belittled.

Although selective gross receipts taxes are quite common, and the broader "business and occupation tax," which

122 Supra note 31 , and text thereto.

123209 Ind. 172,193 N.E. 855 (1935).

124 See text to notes 52-62, Ch. III, §F/2, supra, pp. 304-306. A more detailed analysis of the Indiana tax and judicial development is found in that material.

125 Also see Notgrass Drug v. State, 175 Miss. 358, 165 So. 884 (1936), discussed note 5 to $\mathrm{Ch}$. III, $\S \mathrm{E} / 1$, supra, p. 250 in which the Mississippi court characterized a broad business and occupation tax as a nonproperty tax. Of course, the Mississippi decisions had already characterized a net income tax as a nonproperty tax. Notes $25-27$, supra. Cf. Redfield v. Fisher, supra note 30 , decided by the Oregon court.

${ }^{126}$ See text to notes 56 and 61, Ch. III, §F/2, supra, pp. 305-306. 
is a general gross receipts tax, is found in a few states, the true "gross" income tax is rare. However, there have been some developments concerning the broad business and occupations taxes which are also of interest. In some states which have been the most severe on the net income tax, the business and occupation tax has survived. The best example of this is found in Washington. At the same time the Washington court was placing an insurmountable barrier before a net income tax, a very broad business and occupation tax was sustained in State ex rel. Stiner v. Yelle. ${ }^{127}$ That decision has already been referred to in the net income tax discussion. The Washington legislature had attempted to impose, in fact, a tax having the scope of the Indiana gross income tax. However, because of a veto by the governor of a part of the act, the tax did not reach those engaged in agriculture and the professions. Also, the catch-all clause was knocked out. As noted before, in the Culliton case, ${ }^{128}$ decided on the same day as Yelle, the court by a 5-4 decision ruled that the net income tax was a property tax and contrary to the uniformity clause. In the Yelle case, a 5-4 opinion characterized the business and occupation tax as a nonproperty tax, and consequently the tax was sustained, not having to meet the strict property tax uniformity limitation. ${ }^{29}$ Two dissenters, from the majority in Culliton, would have ruled that the tax was a property tax.

The judicial development concerning the corporate franchise tax with a base of net income has paralleled the gross income tax development. In several states in which the

127 Supra note 83 , and text thereto.

128 Supra note 71 .

$120 \mathrm{Cf}$. the discussion of Winter v. Barrett, 352 Ill. 441, 186 N.E. 113 (1933) and Reif v. Barrett, 355 Ill. 104, 188 N.E. 889 (1934), in note 8 to Ch. III, $\S B / 3$, supra, p. 119 . Also see: Laing v. Fox, 115 W. Va. 272, 175 S.E. 354 (1934), and Lougee v. New Mexico Bureau of Revenue Com'r, 42 N.M. 115, 76 P. 2d 6 (1938). 
courts have ruled that a general or personal net income tax was a tax upon property, and therefore subject to strict uniformity limitations, a more lenient attitude has been taken toward the corporate franchise tax with a base of net income. For example, in Massachusetts, ${ }^{130}$ Tennessee, ${ }^{131}$ and Pennsylvania ${ }^{132}$ the courts have ruled that such taxes are privilege taxes, even though having a base of net income. It should be pointed out that the taxation of corporate income by either a direct income tax or a franchise tax runs into certain federal constitutional law problems. Each method has its disadvantages. Consequently, in those states having no uniformity limitation barrier, there is a freedom of choice in selecting either the corporate franchise tax with a base of net income or the corporate income tax. Indeed, Minnesota, for example, uses both to get the greatest possible coverage. ${ }^{133}$

\section{An Evaluation of the Property-Nonproperty Tax Di- chotomy in Light of the Special Study of the Income Tax}

Having reviewed the cases which reveal the sharp division of judicial opinion on the nature of an income tax for the purpose of applying the constitutional limitation of uniformity in taxation, what conclusions may be drawn? First, note

130 See, for example, Alpha Portland Cement Co. v. Comm., 244 Mass. 530, 139 N.E. 158 (1923), note 9 to Ch. III, §C/1, supra, p. 174.

${ }^{131}$ See Bank of Commerce \& Trust Co. v. Senter, 149 Tenn. 569, 260 S.W. 144 (1923), note 66 to Ch. III, §A/3, supra, p. 91.

132 See Turco Paint \& Varnish Company v. Kalodner, $320 \mathrm{~Pa} .421,184$ Atl. 37 (1936), note 153 to Ch. III, $\S \mathrm{G} / 12$ and text thereto, supra, pp. 521-524.

${ }^{133}$ And see the abortive attempt made by Pennsylvania, described in note 154 to $\mathrm{Ch}$. III, §G/12, supra, p. 521. No challenge was made on the basis of the Pennsylvania constitution's restrictive ruling as to income taxes. The invalidity of the supplementary tax was based on the federal constitutional limitation on state taxation of interstate commerce. 
that this controversy concerning the income tax ran its course over a period roughly coinciding with the last trend which has developed in the historical growth of the so-called uniformity clause. ${ }^{134}$ In general terms that period covered the first forty years of the present century. In Section A of this Chapter it was pointed out that the historical growth of the so-called uniformity clauses has fallen into three periods. The third period was characterized by a liberalization of the effective uniformity limitation and covered the years 1874 to 1945 . However, this period of liberalization had two branches, the second of which originated with Maine in 1913. This second branch was characterized by a tendency to modify the strict uniformity limitation in the following manner. A basic clause of a strict type was left unchanged but a constitutional amendment was introduced providing for special treatment of certain classes of property.

As pointed out earlier in this monograph, the income tax development and the trend originating with Maine in 1913 are both results of the social, economic, and political pressures of the period. An increased demand for state services meant that additional revenue had to be produced. This demand for substantial increases in revenue threw a severe strain on the traditional state tax structures. Many difficult fiscal policy problems were raised. What sort of tax structure was desirable? These controversies over fiscal policy brought with them difficult problems concerning state constitutional limitations. One such constitutional limitation is the subject of this monograph - the constitutional requirement of uniformity and equality in taxation. The controversy over the uniformity limitation has centered principally on two issues. First, there was the stress on the traditional, but creaking ad valorem general property tax which brought a demand for classification in the taxation of property. That demand raised

${ }^{134}$ See Chapter V, §A, supra. 
a constitutional issue concerning the scope and content of the uniformity limitation in terms of particular rules of uniformity as applied to property taxes. Section B of the present Chapter dealt with that problem; indeed, that problem was the principal feature of the state-by-state analysis in Chapter III.

Second, the demand for additional revenue brought with it demands for new sources of revenue, new taxes. Considerable controversy was centered on such taxes as sales and use taxes, but it did not principally involve the constitutional issue of uniformity in taxation. Serious attention was also centered on the income tax as a new source of state revenue. Beyond the hotly debated fiscal policy issues obviously raised by the discussion of the income tax, there was the difficult constitutional problem of uniformity in taxation. If an income tax was adopted, would it have to conform to the property tax uniformity limitation? That is, what was the legal nature of an income tax-property or nonproperty?

\section{a. Some preliminary information}

One way of approaching this comparative summary is to simply "sum up." What states, and how many, have ruled that an income tax for purposes of uniformity is a property tax, nonproperty tax, or that its nature is immaterial? A bird's-eye summary of the preceding chronological development of judicial precedent follows. Seven states (Alabama, Illinois, Massachusetts, New Hampshire, Delaware, Pennsylvania, in part, and Washington) have ruled that an income tax is a property tax. On the other hand, thirteen states (Arkansas, Maine, Wisconsin, Mississippi, Kansas, Georgia, Idaho, Missouri, Montana, Kentucky, Maryland, North Carolina, and Iowa) have ruled to the contrary, that an income tax is a nonproperty tax. One might add Indiana 
to those thirteen states, although the tax actually ruled upon by the Indiana court was a gross income tax. Finally, four states (Tennessee, Minnesota, Oregon, and North Dakota) have ruled that an income tax could be either property or nonproperty, since under their respective limitations the nature of the tax was immaterial.

Of course, such a summary as this, without more, would be "boxscore" jurisprudence at its worst. No such tabulation of state decisions concerning the nature of an income tax for purposes of uniformity in taxation is sufficiently informative. Indeed, such a tabulation is rather misleading. For example, the tabulation just made does not reflect the unique constitutional situation found in New Hampshire which detracts from the weight of its decision that an income tax is a property tax. A somewhat similar situation underlies the Delaware decision. Also, this "boxscore" does not reflect the interrelation between the court decisions and the constitutional provisions which expressly deal with the income tax problem. For example, the Tennessee decisions are intelligible only against the background of its unique constitutional provision which expressly sanctions a very limited type of income tax. If there is a constitutional provision, it is always helpful to know whether it preceded the court decision.

Furthermore, before the significance of the above "boxscore" can be determined it will be necessary to set forth certain other data. First, it will be helpful to indicate which states have dealt with the income tax problem by way of a special constitutional provision. ${ }^{133}$ There are twenty such states, in all. Eighteen states have constitutional provisions which expressly sanction the imposition of an income tax. One state, Florida, is unique in that it has a constitutional

135 The information in this summary is based on the historical note on each state in the state by state study, Chapter III. The provision will also be found in the Appendix, infra. 
provision expressly prohibiting the imposition of an income tax. ${ }^{136}$ That provision was added to the Florida Constitution by an amendment in 1924. The twentieth state, Tennessee, has presented an unusual situation. Its constitution expressly sanctions the imposition of a tax on the income from intangibles, and the court has interpreted that clause as implicitly prohibiting the imposition of any other tax on incomes regardless of the nature of such a tax. ${ }^{137}$

It will be helpful to make a few comments concerning the eighteen states having constitutional provisions favorable to the imposition of an income tax. This will be done by reference to the Groups established hereinbefore. Of the states in Group I, only Tennessee has any provision concerning income taxes and uniformity. Two states in Group II have income tax provisions. They are Alabama and California. The Alabama provision was added by an amendment to the Alabama Constitution in 1933. It expressly provides for a maximum rate, but says nothing concerning either exemptions or graduated rates. ${ }^{138}$ The California provision does nothing more than sanction the taxation of "incomes," and it was adopted in 1879 at the time of the adoption of the present California Constitution. ${ }^{139}$ Only one of the two states in Group III has an income tax provision. In 1915 the Massachusetts Constitution was amended to permit the taxation of income. Exemptions were expressly provided for, but no mention was made of graduated rates. ${ }^{140}$

Two of the four states in Group IV have income tax provisions. The Ohio Constitution was amended in 1912 to sanction an income tax. Minimum exemptions and graduated

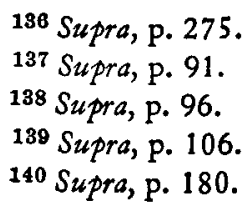


rates are permissible. ${ }^{141}$ In 1908 , at approximately the same time, the Wisconsin Constitution was amended to provide that an income tax might be imposed and that it might be "graduated and progressive."142

Similarly, two of the four states in Group $V$ have income tax provisions. The present constitution of Texas came into force in 1876 . From the first it has contained a clause providing that the legislature might "tax incomes."143 More explicit, in West Virginia an amendment, adopted in 1932, provides that the legislature may "classify and graduate a tax on all incomes according to the amount thereof."144

In Group VI five of the six states have income tax provisions. However, one of those five is Florida, which bans an income tax, as noted above. In 1932 the Indiana Constitution was amended by adding a provision permitting an income tax "at such rates, in such manner, and with such exemptions as may be prescribed by law."145 In the same year, 1932, the constitutions of Kansas ${ }^{146}$ and South Carolina ${ }^{147}$ were also amended to permit the imposition of graduated income taxes. In Utah's first and only constitution, which came into force in 1896, provision was made not only for an income tax, but in addition the rates are required to be graduated. ${ }^{148}$

Six of the thirteen states in Group VII have income tax provisions. Such a provision was added to the Colorado Constitution by an amendment in 1936. It permits either a

$$
\begin{aligned}
& 141 \text { Supra, p. } 223 . \\
& 142 \text { Supra, p. } 238 . \\
& 143 \text { Supra, p. } 254 . \\
& 144 \text { Supra, p. } 262 . \\
& 145 \text { Supra, p. } 306 . \\
& 146 \text { Supra, p. } 309 . \\
& 147 \text { Supra, p. } 336 . \\
& 148 \text { Supra, p. } 345 .
\end{aligned}
$$


"graduated or proportional" income tax. ${ }^{149}$ As early as 1845 Louisiana included in its constitution a provision permitting an "income tax." However, the provision was omitted in the 1878 constitution. The present constitution of Louisiana, adopted in 1921, re-adopted an income tax provision, this time permitting an "equal and uniform tax" to be "levied upon net incomes" and sanctioning "reasonable exemption." In 1934 this provision was amended to provide: "Equal and uniform taxes may be levied upon net incomes, and such taxes may be graduated according to the amount of the net income. . . . Reasonable exemptions may be allowed."150 In Missouri a provision was added to the new constitution of 1945 which indicated that nothing in the tax article was to prevent the taxation of incomes. Having already judicially approved an income tax, the purpose of this provision was apparently to explain a new provision added to the uniformity clause and spelling out the extent to which property might be classified for taxation. ${ }^{151}$ The Montana Constitution was amended in 1934 to permit the imposition of a "graduated and progressive" income tax. ${ }^{152}$ The original and present constitution of Oklahoma, adopted in 1907 , provides expressly that a graduated income tax may be imposed. ${ }^{153}$ Like Louisiana, Virginia dealt with this problem at an early date. The present constitution of Virginia was adopted in 1902, and included a provision permitting the taxation of incomes. The antecedent of this provision first appeared in the Virginia Constitution of $1850 . .^{154}$ The only case of a state abandoning an income tax provision, with the exception of Louisiana, which re-adopted its provision, is

\footnotetext{
149 Supra, p. 350.

150 Supra, p. 387.

151 Supra, p. 426.

152 Supra, p. 431.

153 Supra, p. 448.

104 Supra, p. 542.
} 
found in New Mexico, also in Group VII. In its original constitution of 1911 New Mexico included a provision similar to the Oklahoma provision permitting the imposition of a graduated income tax. However, in 1914 the New Mexico uniformity structure was substantially revised. A more liberal Type VII clause was substituted for a Type V provision, and the structure was considerably reduced. This included the deletion of the income tax provision. ${ }^{155}$

In Group VIII only one state has an income tax provision. North Carolina, like Louisiana and Virginia, adopted such a provision at an early date. North Carolina first adopted a provision permitting the taxation of income in its constitution of 1868 , and the provision has been retained in substantially the same form to date. No mention is made of exemptions or graduated rates. ${ }^{156}$ There are no states in Groups IX and X which have special income tax provisions.

Other data which will aid in evaluating the above "boxscore" concerns income taxes actually in force in the several states. ${ }^{157}$ For present purposes it will be helpful to make the following classification of income taxes: personal net income taxes, direct corporate net income taxes, and corporate franchise taxes having a base of net income. Twenty-eight states have, in effect, a general net income tax-that is, a combination of a personal net income tax with one or both of the corporate income taxes. The use of two types of corporate income taxes stems from federal constitutional law problems. ${ }^{158}$ Twenty states combine a personal income tax with a direct corporate net income tax. They are: Arkansas, Alabama, Wisconsin, Mississippi, Kansas, South Carolina, Colorado,

155 Supra, P. 440.

156 Supra, p. 558.

157 The following information is based on the latest data collected in the $\mathrm{CCH}$ State Tax Reporters for each state, and the All States volume.

${ }^{158}$ See the text to note 133 , supra. 
Georgia, Idaho, Louisiana, Missouri, New Mexico, Oklahoma, Virginia, Arizona, Kentucky, Maryland, North Carolina, North Dakota, and Iowa. Six states combine a personal net income tax with a corporate franchise tax having a base of net income. They are: Massachusetts, Utah, Montana, Oregon, Vermont, and New York. Two states, California and Minnesota, combine the personal net income tax with both a direct corporate income tax and a corporate franchise tax with a base of net income. The two corporate taxes are not overlapping but complementary, and so devised in order to get the widest possible coverage under federal constitutional limitations. A twenty-ninth state, Indiana, might well be grouped with the above twenty-eight states even though the Indiana tax is a gross income tax.

One state, Delaware, has a personal net income tax only. Three states reach only corporate income, Rhode Island by a direct corporate income tax, and Pennsylvania ${ }^{159}$ and Connecticut by corporate franchise taxes with bases of net income. Tennessee has a corporate franchise tax with a base of net income, and in addition there is a limited personal net income tax, reaching only the income from intangibles. In New Hampshire there is only limited income taxation, the tax being limited to income from intangibles.

Thus, some thirty-five states have an income tax of some form or degree, leaving thirteen states with no income tax of any kind according to the usual classification. However, it should be noted that this group of thirteen states includes Michigan. And the Michigan Intangibles Tax is, in fact, a limited income tax such as is found in New Hampshire. For income-producing intangibles, the base of the tax is income. ${ }^{100}$ The twelve remaining states are Maine, Illinois, Ne-

${ }^{159}$ For the abortive attempt by Pennsylvania to impose a companion direct corporate income tax, see note 154 to $\mathrm{Ch}$. III, $\$ \mathrm{G} / 12$.

${ }^{160}$ See text to notes 28 through 30 to $C h$. III, $\S \mathrm{D} / 1$, supra. 
braska, New Jersey, Ohio, Texas, West Virginia, Wyoming, Florida, Nevada, South Dakota, and Washington. However, it should be noted that in Ohio income taxes are found in the major cities.

b. A classification according to results favorable to the imposition of an income tax

As stated before, it is inadequate merely to classify the states into those having held that an income tax, for purposes of uniformity in taxation, is either a property tax or a nonproperty tax. Only seven state courts have ruled that an income tax is a property tax, as opposed to the fourteen which have ruled that such a tax is a nonproperty tax and the three (omitting Tennessee) which have decided that the nature of the tax was immaterial because of the liberal property tax uniformity limitation. A more significant classification is based on whether the ruling of the court was favorable to the imposition of an income tax. Admittedly, the property-nonproperty tax division generally coincides with an adverse-favorable division; however, this is not always the case-witness the decisions in New Hampshire and Delaware in which the courts ruled that the income taxes under consideration were property taxes, such rulings making the imposition of such a tax possible. In New Hampshire, while the income tax was held to be a property tax, in fact all taxes are "property" taxes in that state. However, "property" taxes are divided into taxes on "estates" and taxes on "other classes of property." The second category conforms to the usual classification of nonproperty taxes, and the New Hampshire tax was held to be a tax "on other classes of property."

Even a classification of favorable-adverse effect is not sufficiently refined. It does not take into consideration the impact of constitutional provisions dealing expressly with 
the imposition of an income tax. If there is such a constitutional provision in a given state, it is necessary to relate that provision to judicial decisions in that state, if any, in the following manner. Did the constitutional provision precede or come after the court decision; and, is the constitutional provision in agreement with the judicial decision? That is, for example, did the constitutional provision follow the judicial decision and, in effect, "overrule" the court, either by expressly permitting or forbidding the imposition of an income tax?

The first classification is of those states in which a court decision was favorable to, and made possible the imposition of an income tax when that tax was challenged as being a violation of the state constitutional uniformity limitation. The ruling of the courts concerning the nature of the tax is disregarded. Thus, in Arkansas, Maine, Mississippi, Georgia, Idaho, Minnesota, Oregon, Kentucky, Maryland, North Dakota, and Iowa court decisions that an income tax was a nonproperty tax removed such tax from the scope of the strict property tax uniformity limitation. It is true that in Minnesota, Oregon, and North Dakota the courts never really decided on the nature of the tax, indicating however, that if pushed, the tax would not be characterized as a property tax. In New Hampshire, as pointed out above, the decision of that court that an income tax was a property tax was necessary to impose any tax at all. Similarly, in response to the argument that only property taxes were permissible in Delaware the court was willing to characterize the tax as a property tax. Since the Delaware court has equated the property tax uniformity limitation to the federal equal protection clause this characterization of the tax did not have the effect of subjecting it to a stricter uniformity limitation. Summing up, there are thirteen states in which court decisions made possible the imposition of an income tax. 
The second classification consists of three states and is quite closely related to the first classification. The only difference is that subsequent to the favorable judicial opinion a constitutional provision was approved expressly sanctioning the imposition of an income tax. In Indiana and Montana the constitutional provisions were introduced by way of amendment at almost the same time the court decision was made. Thus, both possibly indicate some doubt on the part of those proposing the tax as to the outcome of the court battle. However, in both states the favorable court decisions were not influenced by or dependent upon the constitutional provisions then up for adoption. In Missouri the decision that an income tax was a nonproperty tax occurred in 1918, and the constitutional provision made its appearance nearly thirty years later in the constitutional revision of 1945 . The adoption of the provision was obviously designed to forestall any future argument that certain alterations in the uniformity clause might be taken to have overruled the earlier court decision of 1918.

Thus, the first two classifications, consisting of sixteen states, constitute the strongest judicial precedent in favor of the imposition of an income tax. To this may be added the less significant authority of three states making up a third classification. In Wisconsin, Kansas, and North Carolina it is true that the courts have ruled that an income tax is a nonproperty tax and consequently not subject to the property tax uniformity limitation. However, in each case there already was in force a constitutional provision expressly sanctioning the imposition of an income tax, and, in addition, in Wisconsin and Kansas the constitutional amendments provided for graduated income taxes. Consequently, the Wisconsin and Kansas decisions have little persuasive weight for courts of other jurisdictions. The decision of the North Carolina court is more important. Although the taxation "of 
incomes" was expressly permitted by the constitution at the time of the decision, it was necessary for the court to decide whether the tax was subject to the property tax ad valorem rule.

The fourth classification is made up of those states in which an income tax is expressly permitted by constitutional provision, and in which there is no judicial decision on the matter. Here the problem was solved by the people themselves, without resort to judicial controversy. There are ten such states: California (1879), Ohio (1912), Texas (1876), West Virginia (1932), South Carolina (1932), Utah (1896), Colorado (1936), Louisiana (1845, 1921, 1934), Oklahoma (1907), and Virginia (1850). It is significant that the Ohio amendment, while not following a judicial decision concerning the income tax, did follow, and "overrule" to some degree, a decision severely restricting the power of the legislature to impose an inheritance tax. The 1912 amendment expressly permits both income and inheritance taxes with graduated rates. ${ }^{161}$ In addition to these ten states, in Tennessee the constitution expressly permits the taxation of income from intangibles, a limited form of income tax. But judicial decisions have interpreted this provision so that it prohibits by implication any other form of income tax.

To be considered now are those judicial decisions which have been adverse to the imposition of an income tax. The fifth classification consists of two states, Alabama and Massachusetts. In those states the courts decided that an income tax was a property tax, and such decisions were adverse to the imposition of such a tax. However, constitutional amendments were adopted subsequent to such decisions and, in effect, "overruled" the courts, expressly permitting the imposition of income taxes. In neither case were graduated rates

161 See the Ohio study, Ch. III, §D/3, text to notes 9-15. 
mentioned by the amendments. In Massachusetts a subsequent decision restrictively interpreted the constitutional amendment, with the result that graduated rates were ruled out under the strict property tax uniformity limitation. A contrary attitude was found in Alabama. A court decision there, subsequent to the amendment of the constitution, seriously questioned the rationale of its original adverse decision, but did not find it necessary to overrule that decision because of the constitutional amendment.

It does seem significant that while in two instances we have a court decision adverse to the imposition of an income tax which was later "overruled" by constitutional amendment, in not a single instance do we find a court decision favorable to the imposition of an income tax later "overruled" by constitutional amendment. Indeed, at the present time general net income taxes are out of the question for all practical purposes in only four states. A sixth classification of states is composed of those in which judicial decisions were adverse to the imposition of an income tax, essentially because the tax was characterized as a property tax. Illinois and Washington fall squarely into that category. However, in Pennsylvania, this is only partially so because as illustrated by the Pennsylvania study a limited form of tax on the earned income of individuals is possible. And, of course, the characterization of the Pennsylvania corporate franchise tax with a base of net income as a nonproperty tax avoided in part the restrictive Pennsylvania interpretation. Florida constitutes a seventh classification. In this state alone has the constitution been amended so as to prohibit the imposition of an income tax of any kind. ${ }^{162}$

${ }^{162}$ A proposed Illinois amendment would permit an income tax, but prohibit graduated rates. See the discussion in Cushman, "The Proposed Revision of Art. IX of the Illinois Constitution," 1952 Ill. L.F. 226, at 243. 
This leaves those states in which there is neither a court decision nor a constitutional provision dealing with the imposition of an income tax. There are twelve such states. However, for reasons set forth below, those twelve states may be divided into those having some sort of income tax in force, and those having no form of income tax in form. Thus, the eighth classification consists of the six states (New Mexico, Arizona, Rhode Island, Vermont, Connecticut, and New York) having an income tax of some form, but having neither judicial decision nor constitutional provision on the matter. The ninth classification consists of the six states (Nebraska, Michigan, New Jersey, Wyoming, Nevada, and South Dakota) in which there is no income tax of any kind in force, and in which there are neither judicial decisions nor constitutional provisions concerning the validity of such a tax.

At this point it is pertinent to note that, at least in terms of sheer weight of numbers among the forty-eight states, the scales are balanced in favor of the validity of an income tax. Leaving aside those twelve states which have no decision of any kind on the problem, this means that thirty-six states have passed, in one manner or another, on the problem. In thirty-one of those thirty-six states the final decision to date has been in favor of the validity of an income tax. In sixteen of those thirty-one states the primary decision was made by the judiciary. In fifteen of those thirty-one states the primary decision was made by way of constitutional provision. And of these fifteen states, in two the decision of the people overruled the judicial opinion.

c. A classification relating the results concerning the income tax to types of uniformity clauses

At the risk of being unduly repetitious it will be interesting to relate the prior information to the types of basic uniformity clauses. Except for a few exceptions which will be 
noted, the judicial decisions and constitutional provisions dealing with the income tax problem occurred in each state at a time when the present uniformity clause was in force. All states in Group I have dealt with the problem in some manner. In Arkansas and Maine judicial decisions have characterized the income tax as a nonproperty tax and consequently made such a tax feasible. In Tennessee there has been a combination of constitutional provision plus judicial decision. The constitutional provision sanctions the taxation of incomes from intangibles, and the judicial decision construed the constitutional provision to prohibit implicitly all other forms of income taxes.

The greatest hostility to an income tax is found among the states in Group II. The problem was settled at an early date (1879) in California by an approving constitutional provision. However, in Illinois an income tax is ruled out because of an adverse judicial decision which characterized an income tax as a property tax. In Alabama such an adverse judicial decision was overcome only by constitutional amendment. In Nebraska the problem remains open.

The income tax has met a mixed reception in Group III. The tax was made possible in New Hampshire because of a judicial characterization of the tax as a property tax. To the contrary, in Massachusetts an income tax is possible only because a constitutional amendment "overruled" to some degree an adverse judicial decision which had characterized the income tax as a property tax.

The greatest room for speculation is found in Group IV. Two states (Michigan and New Jersey) have not dealt with the problem either by judicial decision or constitutional amendment. In the other two states in Group IV income taxes have been made possible by way of constitutional amendment. In Wisconsin the amendment has been followed and "affirmed" by a judicial decision. In Ohio the 
constitutional provision stands alone, although a decision adverse to the imposition of an inheritance tax had clearly foreshadowed an adverse judicial decision as to an income tax in the absence of the constitutional amendment.

In Group $V$ there is one state, Wyoming, which has not dealt with the income tax problem. In the remaining three states in this group the results to date have been favorable to the imposition of an income tax. In Mississippi an early leading judicial decision made this possible by characterizing the tax as a nonproperty tax. In both Texas and West Virginia there are favorable constitutional provisions.

Group VI presents an interesting situation. Nevada has not dealt with the income tax problem. However, the other five states in this group have dealt with the matter by constitutional provision. In Indiana a judicial decision was contemporary with the constitutional amendment, but placed no reliance on the amendment in reaching a result favorable to the tax. To the contrary, in Kansas the judicial decision simply applied the constitutional provision which expressly permits the imposition of an income tax. In South Carolina and $U$ tah the favorable constitutional provisions stand alone. In the fifth state, Florida, we find the single case of a state prohibiting by constitutional amendment the levying of any form of income tax. It is interesting to note that each state, except one, has adopted a special constitutional provision to deal with the general problem. Compare the similar course of action taken by this Group of states concerning the property tax uniformity limitation. As the previous sections of this Chapter revealed, in all of the states in this Group, except Indiana, the strict effective uniformity limitation has been modified by the use of constitutional amendments which permit the special treatment of certain classes of property. The strict basic uniformity clause has been left unchanged. Thus, as to the two most difficult of the uniformity 
in taxation problems the states in Group VI have tended to deal with the matter by introducing special constitutional provisions which bypass the strict basic clause.

Group VII has the largest number of states, thirteen, and represents a considerable diversity in experience. In one state, New Mexico, there is neither judicial decision nor constitutional provision dealing with the problems concerning an income tax. In another state, Pennsylvania, there is a judicial decision adverse to the levying of an income tax. The Pennsylvania court has ruled that, at least as to income derived from property, an income tax is a property tax. As a result the tax is subjected to a more strict uniformity requirement. The remaining eleven states in Group VII are to be counted among those favorable to the imposition of an income tax. In four states (Colorado, Louisiana, Oklahoma, and Virginia) constitutional provisions expressly permit the imposition of an income tax. In the remaining seven states (Delaware, Georgia, Idaho, Minnesota, Missouri, Montana, and Oregon) there is some of the strongest judicial precedent favorable to the imposition of an income tax without hindrance from the uniformity limitation. Although most of those seven states have a liberal property tax uniformity limitation, that limitation is usually somewhat stricter than that which limits nonproperty taxes and, in a good many cases, would probably stand in the way of a graduated income tax. Thus, in Georgia, Idaho, Missouri, and Montana it was of considerable importance that the income tax was characterized as a nonproperty tax. To the contrary, in Minnesota, Oregon, and even Delaware the characterization of the tax was said to make little difference because the property tax uniformity in those states is said to be the same as the uniformity required of nonproperty taxes.

Two states in Group VIII, Arizona and South Dakota, have not dealt with the problem. In only one of the seven 
states in this Group has the result been adverse to the imposition of an income tax. The Washington court characterized the tax as a property tax, subject to a stricter uniformity limitation. In the remaining four states the courts have ruled favorably on the income tax. In Kentucky and Maryland judicial decisions characterized the income tax as a nonproperty tax and thereby avoided certain uniformity limitations. In North Carolina the judicial decision was preceded by a constitutional provision which permitted an income tax. However, the decision was made at a time when North Carolina had a strict uniformity clause, and the decision was necessary in order to avoid the ad valorem method requirement. In North Dakota the court found it unnecessary to rule on the nature of an income tax because there was said to be no substantial difference in the uniformity rules applicable to property and nonproperty taxes.

The income tax problem as it relates to uniformity of taxation has not been dealt with either by judicial decision or constitutional provision in four of the five states in Groups IX and X (Rhode Island, Vermont, Connecticut, and New York). Only in Iowa has there been any development. A judicial decision in that state ruled that the income tax was not a property tax and thereby avoided a minor uniformity limitation applicable only to property taxes. From this review, no significant pattern relating to the basic types of uniformity clauses seems to have developed. The unfavorable judicial decisions are scattered throughout all the groups: Alabama and Illinois in Group II, Massachusetts in Group III, Pennsylvania in Group VII, and Washington in Group VIII. In Group VI there has been no judicial opposition, but a constitutional provision in Florida prohibits the tax.

Recall that there are twelve states which have neither judicial opinion nor constitutional provision settling the issue. It does seem significant that the following division may be made 
among those states on the basis of whether they have income taxes actually in force. The six states which have some form of an income tax are all states which either have basic uniformity clauses of Types VII, VIII, or IX, or have no clause of any kind. They are New Mexico, Arizona, Rhode Island, Vermont, Connecticut, and New York. With one exception, South Dakota, the remaining six states are states having basic uniformity clauses which have in most all cases been interpreted to require a strict effective uniformity limitation as applied to property taxes. They are: Nebraska from Group II, Michigan and New Jersey from Group IV, Wyoming from Group V, and Nevada from Group VI. It is a fair implication that in those six states having an income tax of some form there simply has not been sufficient doubt as to the validity of the tax under the uniformity limitation to challenge it. It is also fair to suggest that if the question as to the nature and validity of an income tax remains open in a state, that the most vigorous controversy concerning the problem would in all likelihood arise in states having the strict uniformity clauses, namely Types I through VI. And note that five of the six states which have no such tax of any kind are found to have a strict uniformity clause. However, caution should be used in making any generalization concerning the Michigan problem because of the unique constitutional development in that state which makes it possible for the income tax to be characterized as a property tax and still avoid a strict uniformity limitation. That is, in Michigan such a tax could be characterized as a specific property tax, as opposed to an ad valorem property tax.

\section{d. Conclusions}

As stated at the beginning of the present section, the reason for making the special study of the income tax was to use the history of a single tax to illustrate not only the im- 
portance of the property-nonproperty tax dichotomy in relation to the uniformity in taxation limitation, but also to reveal the pitfalls of this division. It is a fact that this dichotomy has been accepted and used by the state courts in their interpretation and application of the state constitutional limitation of uniformity in taxation. It is also a fact that in those states having a strict effective uniformity limitation applicable to property taxes, this dichotomy is of controlling importance because in most cases the characterization of a tax as either a property or nonproperty tax will be the most important factor in determining its validity. It is also a fact that the income tax controversy represents the quintessence of this conceptual battle.

What conclusions, then, may be drawn from the income tax experience-just what is the "test" which distinguishes a property tax from a nonproperty tax? This writer, after puzzling over the relevant material, tends to feel that none of the several tests and, oftentimes, bare conclusions offered by the courts are really convincing as absolutes. He found no revelation of some "true" test. There was much discussion of the nature of an income tax. But in the final analysis the really decisive questions were as follows. First, how did the justices look upon the income tax from a fiscal policy viewpoint? Second, how much discretion was the legislature to be allowed, even though the tax in question might be distasteful to the justices? How much flexibility should the lawmakers be allowed in their efforts to meet the new and expensive demands for service from the government? Having assumed the fiscal wisdom or unwisdom of the tax, or having assumed that the legislature should have the leeway to make that decision, there was not too much difficulty in deciding that the tax was a property tax or nonproperty tax as the result might demand. Characterize the tax as a property tax and it was doomed. Actually, even those writers severely 
criticizing the mere use of a property-nonproperty tax test as being "sacerdotal conceptualism" and "unrealistic" have done so because its use prevented in some instances the imposition of an income tax, whereas the critic viewed such a tax as a sound, desirable and "modern" fiscal measure. ${ }^{163}$

However, it is suggested that this inconclusive state of affairs is not so much a reflection of the injection of "policy" factors into issues of "legality," as it is of the obsoleteness of the dichotomy, and its consequent inadequacy as an interpretive aid. The interpretation and application of the "uniformity clauses," so-called, is an outstanding example of the problem with which courts are faced when interpreting constitutions. This is an area of constitutional law in which the courts have a minimum of objective guideposts to channel their "interstitial" lawmaking.

[C] onstitutional interpretation is no .. simple matter. The judge faces the task of giving meaning to words very often in the context of broad phrases that admit of a great variety of interpretations. Whether he takes into account the historical circumstances that gave birth to the words, whether he draws upon judicial tradition and precedent, whether he resorts to a process of didactic interpretation that gives logical meaning to words apart from their setting in time and place, whether he measures the results of his interpretation by the interests at stake and his conception of the kind of politico-socio-economic order that should function within the structure of the constitutional system, he is in any event determining the meaning of words in a situation where meaning is not automatically decipherable. A host of considerations may converge upon and condition his thinking but in the end choose and decide he must. ${ }^{164}$

${ }^{163}$ See, for example, Matthews, supra note 1, at 515 . Also see pp. 33-34, 506, 520-526.

${ }^{104}$ Kauper, "The First Ten Amendments," 37 A.B.A.J. 718, 780 (1951). 
Certainly if there was ever a case of words not being "automatically decipherable" it is that of the uniformity clauses. The courts could not refuse to decide, for the purpose of courts is to settle disputes. There are no gaps in the law. Thus, the courts were saddled with interpreting and applying clauses conceived at a time when the nation's economy, and consequently its revenue structure, was relatively simple. Property was essentially tangible property. Intangible wealth had not yet become so important. The general property tax was easily distinguished from other revenue producers of the times. However, as the economy grew more complex, as demands for state services increased, attempts to reach all the wealth of society in order to spread fairly the tax burden taxed the ingenuity of the tax-makers, and taxes no longer in fact fell into the simple property-nonproperty division. Yet, in determining the validity of new experiments in taxes, the courts had to continue to apply the constitutional limitations conceived for a different economy. It is not really too surprising that the property-nonproperty test was retained, although it should be evident that the test was inadequate and became in point of fact a legal facade for a rehash of fiscal policy arguments. At this point the writer is reminded of an aphorism made in another context, but apropos to the present discussion.

There is an old Chinese proverb which runs something like this: "One should always have in the background of one's mind a multiplicity of definitions covering the subject at hand, in order to prevent oneself from accepting the most obvious." And Cardozo said: "If the result of a definition is to make ... [ [facts] seem to be illusions, so much the worse for the definition; we must enlarge it till it is broad enough to answer the realities."165

${ }^{168}$ Jessup, "The Reality of International Law," 18 Foreign Affairs 244, $245($ Jan. 1940). 
But, appealing as a project of redefinition might be, ${ }^{168}$ this writer is convinced that a "new" formulation of a "test" or even of the "function" of these uniformity clauses would truly be to "plow in the sea."

Consequently, one must work with the property-nonproperty tax dichotomy. And, in point of fact, one is not completely at a loss for a test which will give a modicum of service. It is suggested that the "weight of authority"167 supports a test related to the standard used throughout the present monograph. Herein a tax has been characterized by the object of the tax, that is, the thing taxed. A majority of the courts considering the validity of an income tax under the uniformity limitation (and this majority has been established by the more recent decisions) have characterized the income tax as a nonproperty tax. Whatever its precise nature might be in relation to all those various kinds of taxes which are not property taxes, it was held not to be a tax upon property. It would seem that all of these courts can find support in the following proposed test. Society organizes itself in the form of a government in order to promote the common good and to contribute benefits and protection to the citizens.

186 Such a "new" approach, with a "fresh" outlook was the purpose of Matthews, supra note 1. See pp. 520-526 for his conclusions. However, persuasive as it might be, the problem remains, will such a "different" approach be accepted and used?

167 Cf. Patterson, Jurisprudence: Men and Ideas of the Law 308 (1953): [T] he "weight of authority", a favorite device of textwriters and law teachers, is some indication that in states having no decision of the question the "majority rule" will be adopted, more likely than not. This inference is based on the belief that the other courts will consider the need for uniformity or that they will respect the opinions of able and learned men charged with official responsibility to determine the law. Yet the "weight-of-authority" inference has a low degree of probability unless supported by qualitative factors, such as the oldness or recency of the cases, the prestige of the courts that rendered them, and the like. The inference from weight of authority is not of the statistical type. 
However, this organization costs money. Civilization is expensive. Therefore, those who are privileged to receive the benefits and protections of the organized arm of society should have to support that arm. The privilege of receiving the benefits and protections of government is then a rational "thing" to be taxed, the object of a tax to produce the needed revenue. Net income is selected as the base of that tax simply because net income is pragmatically related to the object of the tax, which is the privilege of receiving the benefits and protections of organized society. Not all, if any, of the court decisions characterizing an income tax as a nonproperty tax have spelled out the test in the above manner. However, it is suggested that all may be conveniently fitted within it.

Unfortunately, however, the suggested test is no panacea because there is a question-begging aspect to it. Just how is one to determine whether the object of the tax is "really" the privilege, income itself, or even the property from which income is derived? Some of the minority courts have refused to accept a legislative recital that the purpose of the tax was to reach a privilege, with income simply being the base. For example, recall the history of the ill-fated Washington income taxes. There seems to be no way around this impasse; that is, no way insofar as the constitutional legal issue is concerned, because the controversy over the nature of the income tax, it must be remembered, simply reflects the economic arguments. Thus, in the final analysis, the best solution for dealing with the income tax problem is by spelling out in the constitution itself the extent to which an income tax will be permissible. In this way the pros and cons on the fiscal wisdom of the income tax as a revenue measure will be the determinants, and those arguments can be pressed and met openly, not under a facade of a legal issue. Thus, if it is thought that no income tax of any form is desirable, then do as Florida did and spell out in the constitution the gen- 
eral prohibition. On the other hand, if an income tax is thought desirable; then the legislative power to impose such a tax should be expressly granted in the constitution, in general terms, of course. However, the Massachusetts experience indicates that the issue of graduated rates should also be dealt with expressly. If policywise the income tax should be limited to proportional rates, then it should be so stated. ${ }^{168}$ On the other hand, if graduated rates are considered desirable, then the income tax provision should indicate that the tax, if imposed, may have progressively graduated rates. ${ }^{169}$ The experience of the substantial number of states which have dealt with the problem by constitutional provision indicates that this is the most desirable course of action. However, the writer recognizes the difficulty in many states in getting any sort of constitutional revision because of amendment requirements which are too rigid. ${ }^{170}$ Thus, it may be that the express constitutional provision, while the desirable solution, is not a practical one at the present time. If that is the case, and the problem has not already been solved by judicial precedent, then one simply must work with the property-nonproperty tax dichotomy. In such a case there is the suggested test to fall back upon.

168 See, for example, the Illinois proposed amendment, discussed in Cushman, "The Proposed Revision of Art. IX of the Illinois Constitution," 1952 Univ. of Ill. L.F. 226, at 243. The proposal was defeated in the 1952 elections. However, the amendment will be submitted again in the fall of 1956. Ill. Regular Session, Senate Joint Resolution No. 16, Adopted June 24, 1955.

169 On the difficult problems concerning the progressively graduated rate, see Blum and Kalven, "The Uneasy Case for Progressive Taxation," 19 Chi. L. Rev. 417 (1952).

${ }^{170} \mathrm{See}$, for example, the experience in Tennessee, described by Trewhitt, H. L., "Tennessee Amends Her Constitution," State Government 119 (June 1954). 


\section{Chapter VI \\ Conclusion}

EVERAL general conclusions may be drawn from the preceding study of the state constitutional limitation $D$ of uniformity and equality in taxation. First, there should be unanimous agreement that the so-called uniformity clauses and their supplementary provisions dealing with particular rules of uniformity have produced, more than anything else, confusion and litigation. This has been accomplished without achieving to any substantial degree the ideal of "absolute uniformity" in the distribution of the property tax burden when such was the ideal. The Illinois experience illustrates as well as any, how if legal classification is outlawed a de facto classification tends to come to life, but without the safeguards of a system of classification based on law. However fair-minded tax officials may be, their own private views and administration of a classification system is hardly a substitute for a legal classification carrying with it procedural safeguards. The Illinois experience also illustrates how a de facto classification system can eventually have a semblance of de jure characterization bestowed upon it. Furthermore, this study has concerned itself only with the problem of classification for effective rates and exemptions. There is no consideration of the very acute problem of actually achieving equal assessment under some method of valuation. ${ }^{1}$

Second, it should also be clear that no policy, whether it favors a strict or liberal limitation, has profited by the overlapping and redundant uniformity structures which were so often

${ }^{1}$ See Jensen, Property Taxation in the United States (1931), especially Chapters 12 and 18. 
found. Too often there has been a tendency to clutter up the constitution with a prolix and complicated uniformity structure which still left many of the really hard problems unsolved. Whatever policy one adheres to, it would profit by a clarification of the uniformity structures in many of the states. Of course, to the other extreme, some uniformity structures consist primarily of nothing more than one of the several types of basic clauses. In those instances problems and controversies are bound to arise as to the particular rules by which the general policy might be implemented since there is an insufficient guide to or delineation of the policy underlying the provision.

Third, a definite trend to "return" to a policy permitting some degree of classification in the taxation of property was revealed. The situation is now in a near balance, but with a slant toward the liberalization trend. There remains considerable room for future development.

Fourth, and perhaps most important, it should be clear that whatever one's policy might be, the concept of uniformity and equality in taxation as a desirable goal should be fully understood before an attempt is made to formulate that policy in the form of a constitutional limitation. Probably a good part of the confusion has stemmed from a failure to adhere to that fundamental principle. This is so because "uniformity and equality in taxation" as a policy goal is subject to much controversy. If the fundamental tenet is to ensure a "fair distribution" of the tax burden, that alone is not a sufficient guide because opposite viewpoints claim that their way-classification or absolute uniformity, as the case might be-is the means to fulfillment of such a policy. Thus, a more definite policy must be formulated-precisely what is necessary to achieve the policy goal which underlies the constitutional limitation of uniformity in taxation?

In the absence of a sufficiently formulated policy-even 
when such a policy is clearly had, in the absence of sufficient guides in the constitutional limitation to implement that goal-, the problem of interpreting and applying the uniformity limitation will remain unsettled and subject to considerable controversy. It is suggested that the wise solution to the problem is to spell out, in a general way, in the constitution the degree of uniformity desired of all taxes. The writer emphasizes "in a general way" because this is quite a different thing from putting the details of a tax structure into the constitution, such as is done in Louisiana. Rather, the suggestion is to be more precise in formulating the general limitation of uniformity. This requires a real understanding of the many ramifications of the limitation which have developed over a period of years, and the degrees of uniformity which may be possible. Consequently, for property taxes it is suggested that the uniformity limitation be spelled out in terms of the three basic particular rules of uniformity used throughout this monograph: universality, effective rates, and method of taxation. The many words, the different phrases of the numerous court opinions can be fitted into these rules and make sense wholly apart from apparent clashes in language used. The actions of the courts in fact have followed this division of uniformity, and future action can well be planned on the basis of the three particular rules of uniformity with a result which should leave little room for controversy in the application and interpretation of the limitation. Thus, if property may be exempted, say so. If not, spell that out. Again, this limitation should be in general terms, it is not necessary to clutter up the constitution with innumerable classes of property enumerated as exemptible. Certainly, if property may be exempted a limitation of reasonable classifications should suffice. Again, the policy desired as to the degree of uniformity in effective rates should be spelled out in general terms. 
Finally, the method by which property may be taxed should be specified. In the same vein, the controversial taxes such as the income tax can be dealt with by the same method.

Of course, there can be no specific recommendations of particular phraseology because much depends on local policy factors. There is no reason for uniformity among the states in dealing with this matter. Different areas will very properly differ as to a desirable fiscal policy. Consequently, once that policy is agreed upon in terms of the content of the uniformity limitation which will effectively implement that policy, then the problem of drafting the individual clauses can be accomplished without substantial difficulties. 


\section{Appendix}

\section{COMPILATION OF CONSTITUTIONAL PROVISIONS}

Art. XI \$211.

All taxes levied on property in this state shall be assessed in exact proportion to the value of such property, but no tax shall be assessed upon any debt for rent or hire of real or personal property, while owned by the landlord or hirer during the current year of such rental or hire, if such real or personal property be assessed at its full value.

Art. XI §217.

The property of private corporations, associations, and individuals of this state shall forever be taxed at the same rate; provided, this section shall not apply to institutions devoted exclusively to religious, educational, or charitable purposes.

Art. IV $\$ 91$.

The Legislature shall not tax the property, real or personal, of the state, counties, or other municipal corporations or cemeteries; nor lots in incorporated cities and towns, or within one mile of any city or town to the extent of one acre, nor lots one mile or more distant from such cities or towns to the extent of five acres, with the buildings thereon, when same are used exclusively for religious worship, for schools, or for purposes purely charitable.

\section{Amdt. XXIII [Art. XXI]}

Section 219 of the present constitution is hereby annulled and set aside and hereafter the legislature of Alabama may provide for the assessment, levy and collection of a tax upon inheritances and for the levying of estate taxes not to exceed in the aggregate the amounts which may by any law of the United States be allowed to be credited against or deducted from any similar tax upon inheritances or taxes on estates assessed or levied by the United States on the same subject. . . .

Art. XXII.

The legislature shall have the power to levy and collect taxes for state purposes on net incomes from whatever source derived within this state, including the incomes derived from salaries, fees and compensation paid from the state, county, municipality, and any agency or creature thereof, for the calendar year, 1933, and thereafter and to designate and define the incomes to be taxed and to fix the rates of taxes provided that the rate shall 
not exceed 5 per cent nor 3 per cent on corporations. Income, shall not be deemed property for purposes of ad valorem taxes. From net income an exemption of not less than fifteen hundred dollars $(\$ 1500.00)$ shall be allowed to unmarried persons and an exemption of not less than three thousand dollars ( $\$ 3000.00)$ shall be allowed to unmarried persons and an exemption of not less than three thousand dollars $(\$ 3000.00)$ shall be allowed to the head of a family, provided that only one exemption shall be allowed to husband and wife where they are living together and make separate returns for income tax. An exemption of not less than three hundred dollars $(\$ 300.00)$ shall be allowed for each dependent member of the family of an income tax payer under the age of 18 years. $* * *$ In the event the legislature levies an income tax, such tax must be levied upon the salaries, incomes, fees, or other compensation of state, county and municipal officers and employees, on the same basis as such income taxes are levied upon other persons.

\section{ARIZONA}

Const. 1912.

\section{Art. IX §1.}

The power of taxation shall never be surrendered, suspended, or contracted away. All taxes shall be uniform upon the same class of property within the territorial limits of the authority levying the tax, and shall be levied and collected for public purposes only.

\section{Art. IX $\$ 2$.}

There shall be exempt from taxation all federal, state, county and municipal property. Property of educational, charitable and religious associations or institutions not used or held for profit may be exempt from taxation by law. Public debts, as evidenced by the bonds of Arizona, its counties, municipalities, or other subdivisions, shall also be exempt from taxation. There shall be further exempt from taxation the property of widows, honorably discharged soldiers, sailors, United States marines, members of revenue marine service, nurse corps, or of the components of auxiliaries of any thereof, residents of this state, not exceeding the amount of two thousand dollars $[\$ 2,000.00]$, where the total assessment of such widow and such other persons named herein does not exceed $\$ 5,000.00$; provided, that no such exemption shall be made for such persons other than widows unless they shall have served at least sixty [60] days in the military or naval service of the United States during time of war, and shall have been residents of this state prior to September 1, 1945. All property in the state not exempt under the laws of the United States or under this constitution, or exempt by law under the provisions of this section shall be subject to taxation to be ascertained as provided by law. This section shall be self-executing. 
Art. IX $\S 11 \llbracket 2$.

... Beginning January 1, 1941, a license tax is hereby imposed on vehicles registered for operation upon the highways in Arizona, which license tax shall be in lieu of all ad valorem property taxes on any vehicle subject to such license tax. Such license tax . . . shall be (a) at a rate equal to the average ad valorem rate for all purposes in the several taxing districts of the state for the preceding year, but in no event to exceed a rate of four dollars on each one hundred dollars in value, and (b) during the first calendar year of the life of the vehicle upon a value equal to sixty per cent of the manufacturer's list price of such vehicle, and during each succeeding calendar year upon a value twenty-five per cent less than the value for the preceding calendar year.

Art. IX $\$ 12$.

The law-making power shall have authority to provide for the levy and collection of license, franchise, gross revenue, excise, income, collateral and direct inheritance, legacy, and succession taxes, also graduated income taxes, graduated collateral and direct inheritance taxes, graduated legacy and succession taxes, stamp, registration, production, or other specific taxes.

\section{ARKANSAS}

Const. 1874.

Art. XVI $\S 5$.

All property subject to taxation shall be taxed according to its value, that value to be ascertained in such manner as the General Assembly shall direct, making the same equal and uniform throughout the State. No one species of property from which a tax may be collected shall be taxed higher than another species of property of equal value, provided the General Assembly shall have power from time to time to tax hawkers, peddlers, ferries, exhibitions and privileges, in such manner as may be deemed proper. Provided, further, that the following property shall be exempt from taxation: Public property used exclusively for public purposes; churches used as such; cemeteries used exclusively as such; school buildings and apparatus; libraries and grounds used exclusively for school purposes; and buildings and grounds and materials used exclusively for public charity.

\section{Art. XVI §6.}

All laws exempting property from taxation other than as provided in this Constitution shall be void.

Amdt. No. 12.

All capital invested in a textile mill in this State for manufacturing of cotton and fiber goods in any manner shall be and is hereby declared to be 
exempt from taxation for a period of seven years from the date of the location of said textile mill.

Amdt. No. 22.

The homestead of each and every resident of the State, whether or not such resident be married or unmarried, male or female, shall be wholly exempt from all state taxes authorized or referred to in Section 8 of Article $\mathrm{XVI}$ of the Constitution of Arkansas * * *

Amdt. No. 27.

* * * [Provision may be made by contract] for the exemption from State property taxation of any such new manufacturing or processing establishment, or any addition or additions to any such existing manufacturing or processing establishment, upon such terms and conditions as the Governor and the said Commission may deem to the best interests of the State; provided, that no exemption from taxes shall be granted under this amendment for a longer period than ten (10) calendar years succeeding the date of any such contract. ***

\section{CALIFORNIA}

Const. 1879.

\section{The Provisions.}

Art. XIII §1.

All property in the State except as otherwise in this Constitution provided, not exempt under the laws of the United States, shall be taxed in proportion to its value, to be ascertained as provided by law, or as hereinafter provided. The word 'property', as used in this article and section, is hereby declared to include moneys, credits, bonds, stocks, dues, franchises, and all other matters and things, real, personal, and mixed, capable of private ownership; provided, that a mortgage, deed of trust, contract, or other obligation by which a debt is secured when land is pledged as security for the payment thereof, together with the money represented by such debt, shall not be considered property subject to taxation; and further provided, that property used for free public libraries and free museums, growing crops, property used exclusively for public schools, and such as may belong to this State, or to any county, city and county, or municipal corporation within this State shall be exempt from taxation, [with a certain exception]. *** The Legislature may provide, except in the case of credits secured by mortgage or trust deed, for a deduction from credits of debts due to bona fide residents of this State.

\section{Art. XIII \$14 đs 4-7,}

[I14] The Legislature shall have the power to provide for the assessment, 
levy and collection of taxes upon all forms of tangible personal property, all notes, debentures, shares of capital stock, bonds, solvent credits, deeds of trust, mortgages, and any legal or equitable interest therein, not exempt from taxation under the provisions of this Constitution, in such manner, and at such rates, as may be provided by law, and in pursuance of the exercise of such power the Legislature, two-thirds of all of the members elected to each of the two houses voting in favor thereof, may classify any and all kinds of personal property for the purposes of assessment and taxation in a manner and at a rate or rates in proportion to value different from any other property in this State subject to taxation and may exempt entirely from taxation any or all forms, types or classes of personal property.

[I5] The total tax imposed on notes, debentures, shares of capital stock, bonds, solvent credits, deeds of trust, mortgages and any legal or equitable interest therein in pursuance of the provisions of this section shall not be at a rate in excess of four-tenths of 1 percent of the actual value of such property and no tax burden shall be imposed upon any personal property either tangible or intangible which shall exceed the tax burden on real property in the same taxing jurisdiction in proportion to the actual value of such property.

[П7] Nothing herein contained shall be construed to subject to assessment and taxation property which is exempt from taxation under other provisions of this Constitution.

Art. XIII §14 Ts 1-3.

[T1] [All property, other than franchises, owned or used by enumerated utilities] shall be assessed annually by the State Board of Equalization, at the actual value of such property.

[โ2] All property so assessed by said board shall be subject to taxation to the same extent and in the same manner as other property.

[I3] All companies herein mentioned and their franchises, other than insurance companies and their franchises, shall be taxed in the same manner and at the same rates as mercantile, manufacturing and business corporations and their franchises are taxed pursuant to Section 16 of this article; provided, that nothing herein shall be construed to release any company mentioned in this section from the payment of any amount agreed to be paid or required by law to be paid for any special privilege or franchise granted by any political subdivision or municipality of this State; provided further, that no excise, or income tax or any other form of tax or license charge shall be levied or assessed upon or collected from the companies, or any of them, mentioned in the first paragraph of this section, in any manner or form, different from, or at 2 higher rate than that imposed upon or col- 
lected from mercantile, manufacturing and business corporations doing business within this state.

\section{Art. XIII §I1.}

Income taxes may be assessed to and collected from persons, corporations, joint-stock associations, or companies resident or doing business in this State, or any one or more of them, in such cases and amounts, and in such manner, as shall be prescribed by law.

Art. XIII $\$ 144 / 4$.

[A lengthy section provides that "An annual tax is hereby imposed on each insurer doing business in this State on the bases, at the rates, and subject to the deductions from the tax hereinafter specified." The remainder of the Section is, in effect, a "statute" which includes definitions, determines the base-gross premiums-, and provides for detailed instructions as to deductions. The rate is set forth, and the tax is to be "in lieu of all other taxes and licenses, State, county, and municipal, upon such insurers and their property, except. . . ." Among other exceptions to the in lieu provision are taxes upon real estate. A special tax is provided for insurers transacting the business of ocean marine insurance business.]

Art. XIII §16. 1. (a) Banks, including national banking associations, located within the limits of this State, shall annually pay to the State a tax, at the rate to be provided by law according to or measured by their net income, which shall be in lieu of all other taxes and licenses, state, county and municipal, upon such banks, or the shares thereof, except taxes upon their real property and, when permitted by the Congress of the United States with respect to national banking associations, motor vehicle and other vehicle registration license fees and any other tax or license fee imposed by the State upon vehicles, motor vehicles or the operation thereof.

(b) The Legislature may provide by law for any other form of taxation now or hereafter permitted by the Congress of the United States respecting national banking associations; provided, That such form of taxation shall apply to all banks located within the limits of this State.

2. The Legislature may provide by law for the taxation of corporations, their franchises, or any other franchises, by any method not prohibited by this Constitution or the Constitution or laws of the United States.

3. Any tax imposed pursuant to this section must be under an act passed by not less than two-thirds vote of all the members elected to each of the two houses of the Legislature.

Exemptions are provided for in:

Art. XII §la (college property, etc., generally); Art. IX $\S \S 10-13,15$ (named colleges, exemptions); XIII $\$ 1 b$ (cemetery exemption); XIII $\S 1 \mathrm{c}$ (religious, hospital, charitable purposes, generally); XIII $\$ 11 / 4$ (Vet's 
exemption); XIII $\S 11 / 2$ (church exemption); XIII $\$ 11 / 2 a$ (orphanage); XIII $\$ 13 / 4$ (public bonds); XIII $\S 4$ (vessels, except state taxes); XIII $\$ 101 / 2$ (household goods).

\section{COLORADO}

Const. 1876.

Art. X §3.

All taxes shall be uniform upon the same class of subjects within the territorial limits of the authority levying the tax, and shall be levied and collected under general laws, which shall prescribe such regulations as shall secure a just valuation for taxation of all property, real and personal; Provided, that the personal property of every person being the head of a family to the value of $\$ 200$ shall be exempt from taxation. Ditches, canals and flumes owned and used by individuals or corporations, for irrigating land owned by such individuals or corporations, or the individual members thereof, shall not be separately taxed so long as they shall be owned and used exclusively for such purposes.

\section{Art. $\mathrm{X} \S 4$.}

The property, real and personal, of the state, counties, cities, towns and other municipal corporations and public libraries, shall be exempt from taxation.

\section{Art. X $\S 5$.}

Property, real and personal, that is used solely and exclusively for religious worship, for schools or for strictly charitable purposes, also cemeteries not used or held for private or corporate profit, shall be exempt from taxation, unless otherwise provided by general law.

Art. $X \S 6$.

All laws exempting from taxation, property other than that hereinbefore mentioned, shall be void; provided, however, that the general assembly shall enact laws classifying motor vehicles, trailers and semi-trailers and requiring the payment of a graduated annual specific ownership tax thereon, which said tax shall be in addition to, and payable to the proper county officer at the same time as state registration or license fees.

Said graduated annual specific ownership tax shall be in lieu of all ad valorem taxes upon such property, and shall be distributed, apportioned, credited and paid over to the State and its political subdivisions as provided by law with reference to ad valorem taxes; provided, further, that such laws shall not exempt from ad valorem taxation motor vehicles, trailers and semitrailers in process of manufacture, or held in storage, or which constitute the stock of manufacturers, or distributors thereof or of dealers therein. 
Art. $X \S 17$.

The general assembly may levy income taxes, either graduated or proportional, or both graduated and proportional, for the support of the state, or any political subdivision thereof, or for public schools, and may, in the administration of an income tax law, provide for special classified or limited taxation or the exemption of tangible and intangible personal property.

\section{CONNECTICUT}

Const. 1818.

\section{Art. I $\$ 1$.}

... [A]ll men when they form a social compact, are equal in rights; and ... no man, or set of men are entitled to exclusive public emoluments or privileges from the community.

\section{DELAWARE}

Const. 1897 .

Art. VIII $\S 1$.

All taxes shall be uniform upon the same class of subjects within the territorial limits of the authority levying the tax, and shall be levied and collected under general laws, but the General Assembly may by general laws exempt from taxation such property as in the opinion of the General Assembly will best promote the public welfare.

Art. IX $\$ 6$.

Shares of the capital stock of corporations created under the laws of this State, when owned by persons or corporations without this State, shall not be subject to taxation by any law now existing or hereafter to be made.

Art. X $\$ 4$.

. . provided, that all real or personal property used for school purposes, where the tuition is free, shall be exempt from taxation and assessment for public purposes.

\section{FLORIDA}

Const. 1885.

\section{Art. IX $\S 1$.}

The Legislature shall provide for a uniform and equal rate of taxation, except that it may provide for special rate or rates on intangible property, but such special rate or rates shall not exceed two mills on the dollar of the assessed valuation of such intangible property; provided, that as to any obligations secured by mortgage, deed of trust, or other lien, the Legislature may prescribe an intangible tax of not more than two (2) mills on the dol- 
lar, which shall be payable at the time such mortgage, deed of trust, or other lien is presented for recordation, said tax to be in lieu of all other intangible assessments on such obligations. The special rate or rates, or the taxes collected therefrom, may be apportioned by the Legislature, and shall be exclusive of all other State, County, District and Municipal taxes; and shall prescribe such regulations as shall secure a just valuation of all property, both real and personal, excepting such property as may be exempted by law for municipal, educational, literary, scientific, religious or charitable purposes.

\section{Art. IX $\$ 11$.}

No taxes upon inheritances or upon the income of residents or citizens of this State shall be levied by the State of Florida, or under its authority, and there shall be exempt from taxation to the head of the family residing in this State, household goods and personal effect to the value of Five Hundred $(\$ 500.00)$ Dollars, provided, however, that the Legislature may provide for the assessment, levying and collection of a tax upon Inheritances, or for the levying of Estate taxes, not exceeding in the aggregate the amounts which may by any law of the United States be allowed to be credited against or deducted from any similar tax upon Inheritances, or taxes on estates assessed or levied by the United States on the same subject.

\section{Art. IX $\$ 13$.}

Motor vehicles, as property, shall be subject to only one form of taxation which shall be a license tax for the operation of such motor vehicles, which license shall be in such amount and levied for such purpose as the Legislature may, by law, provide, and shall be in lieu of all ad valorem taxes assessable against motor vehicles as personal property.

Art. IX §2.

. . a after December 31 st, A.D. 1940, no levy of ad valorem taxes upon real or personal property except intangible property, shall be made for any State purpose whatsoever. . .

\section{Art. XVI $\$ 16$.}

The property of all corporations, except the property of a corporation which shall construct a ship or barge canal across the peninsula of Florida, if the Legislature should so enact, whether heretofore or hereafter included, shall be subject to taxation unless such property be held and used exclusively for religious, scientific, municipal, educational, literary or charitable purposes.

\section{Art. X §7.}

[Homestead exemption of $\$ 5,000$.] 
Art. IX $\$ 9$.

There shall be exempt from taxation property to the value of five hundred dollars to every widow and to every person who is a bona fide resident of the State and has lost a limb or been disabled in war or by misfortune.

\section{GEORGIA}

Const. 1945.

\section{Art. VII $\$ 1 . ~ \llbracket 3$.}

All taxes shall be levied and collected under general laws and for public purposes only. All taxation shall be uniform upon the same class of subjects within the territorial limits of the authority levying the tax. Classes of subjects for taxation of property shall consist of tangible property and one or more classes of intangible personal property including money. The General Assembly shall have the power to classify property including money for taxation, and to adopt different rates and different methods for different classes of such property.

\section{Art. VII \$2. 14 .}

The General Assembly may provide for a different method and time of returns, assessments, payment and collection of ad valorem taxes, of public utilities, but not at a greater basis of value or at a higher rate of taxation than other properties.

Art. I §3. I3.

All exemptions from taxation heretofore granted in corporate charters are declared to be henceforth null and void.

\section{Art. VII $§ 1 . \Uparrow 4$.}

The General Assembly may, by law, exempt from taxation all public property; places of religious worship or burial; all institutions of purely public charity; all intangible personal property owned by or irrevocably held in trust for the exclusive benefit of, religious, educational and charitable institutions, no part of the net profit from the operation of which can inure to the benefit of any private person; All buildings erected for and used as a college, incorporated academy or other seminary of learning, and also all funds or property held or used as endowment by such colleges, incorporated academies or seminaries of learning, providing the same is not invested in real estate; and provided, further, that said exemptions shall only apply to such colleges, incorporated academies or other seminaries of learning as are open to the general public; provided further, that all endowments to institutions established for white people, shall be limited to white people, and all endowments to institutions established for colored people, shall be limited to colored people; the real and personal estate of any public library, and 
that of any other literary association, used by or connected with such library; all books and philosophical apparatus and all paintings and statuary of any company or association, kept in a public hall and not held as merchandise or for purposes of sale or gain; provided the property so exempted be not used for the purpose of private or corporate profit and income, distributable to shareholders in corporations owning such property or to other owners of such property, and any income from such property is used exclusively for religious, educational and charitable purposes, or for either one or more of such purposes and for the purpose of maintaining and operating such institution; this exemption shall not apply to real estate or buildings other than those used for the operation of such institution and which is rented, leased or otherwise used for the primary purpose of securing an income thereon; and also provided that such donations of property shall not be predicated upon an agreement, contract or otherwise that the donor or donors shall receive or retain any part of the net or gross income of the property. The General Assembly shall further have power to exempt from taxation, farm products, including baled cotton grown in this State and remaining in the hands of the producer, but not longer than for the year next after their production.

All personal clothing, household and kitchen furniture, personal property used and included within the house, domestic animals and tools, and implements of trade of manual laborers, but not including motor vehicles, are exempted from all State, County, Municipal and School District ad valorem taxes, in an amount not to exceed $\$ 300.00$ in actual value.

The Homestead of each resident of Georgia actually occupied by the owner as a residence and homestead, and only so long as actually occupied by the owner primarily as such, but not to exceed $\$ 200.00$ of its value, is hereby exempted from all ad valorem taxation for State, county and school purposes, except taxes levied by municipalities for school purposes and except to pay interest on and retire bonded indebtedness, provided, however, should the owner of a dwelling house on a farm, who is already entitled to homestead exemption, participate in the program of rural housing and obtain a new house under contract with the local housing authority, he shall be entitled to receive the same homestead exemption as allowed before making such contract. The General Assembly may from time to time lower said exemption to not less than $\$ 1250.00$. The value of all property in excess of the foregoing exemptions shall remain subject to taxation. Said exemptions shall be returned and claimed in such manner as prescribed by the General Assembly. The exemption herein provided for shall not apply to taxes levied by municipalities.

All cooperative, non-profit, membership corporations organized under the laws of this State for the purpose of engaging in rural electrification, as defined in subsection I of Section 3 of the Act approved March 30, 1937, 
providing for their incorporation, and all of the real and personal property owned or held by such corporations for such purpose, are hereby exempted from all taxation, state, county, municipal, school district and political or territorial subdivisions of the State having the authority to levy taxes. The exemption herein provided for shall expire December 31, 1961.

There shall be exempt from all ad valorem intangible taxes in this State, the common voting stock of a subsidiary corporation not doing business in this State, if at least ninety per cent of such common voting stock is owned by a Georgia corporation with its principal place of business located in this State and was acquired or is held for the purpose of enabling the parent company to carry on some part of its established line of business through such subsidiary.

All laws exempting property from taxation, other than the property herein enumerated, shall be void.

IDAHO

Const. 1890.

Art. VII $\$ 2$.

The legislature shall provide such revenue as may be needful, by levying a tax by valuation, so that every person or corporation shall pay a tax in proportion to the value of his, her, or its property, except as in this article hereinafter otherwise provided. The legislature may also impose a license tax both upon natural persons and upon corporations, other than municipal, doing business in this state; also a per capita tax: provided, the legislature may exempt a limited amount of improvements upon land from taxation.

\section{Art. VII $\$ 5$.}

All taxes shall be uniform upon the same class of subjects within the territorial limits, of the authority levying the tax, and shall be levied and collected under general laws, which shall prescribe such regulations as shall secure a just valuation for taxation of all property, real and personal: provided, that the legislature may allow such exemptions from taxation from time to time as shall seem necessary and just, and all existing exemptions provided by the laws of the territory, shall continue until changed by the legislature of the state: provided, further, That duplicate taxation of property for the same purpose during the same year, is hereby prohibited.

Art. VII $\$ 3$.

The word "property" as herein used shall be defined and classified by law.

\section{Art. VII §4.}

The property of the United States, except when taxation thereof is authorized by the United States, the state, counties, towns, cities, villages, 
school districts, and other municipal corporations and public libraries shall be exempt from taxation.

\section{ILLINOIS}

Const. 1870.

Art. IX $\S 1$.

The general assembly shall provide such revenue as may be needful by levying a tax, by valuation, so that every person and corporation shall pay a tax in proportion to the value of his, her or its property - such value to be ascertained by some person or persons, to be elected or appointed in such manner as the general assembly shall direct, and not otherwise; but the general assembly shall have power to tax peddlers, auctioneers, brokers, hawkers, merchants, commission merchants, showmen, jugglers, innkeepers, grocery keepers, liquor dealers, toll bridges, ferries, insurance, telegraph and express interests or business, vendors of patents, and persons or corporations owning or using franchises and privileges, in such manner as it shall from time to time direct by general law, uniform as to the class upon which it operates.

Art. IX \$2.

The specification of the objects and subjects of taxation shall not deprive the general assembly of the power to require other subjects or objects to be taxed in such manner as may be consistent with the principles of taxation fixed in this constitution.

\section{Art. IX $\$ 3$.}

The property of the state, counties, and other municipal corporations, both real and personal, and such other property as may be used exclusively for agricultural and horticultural societies, for school, religious, cemetery and charitable purposes, may be exempted from taxation; but such exemption shall be only by general law. ...

Art. IX §9.

For all other corporate purposes, all municipal corporations may be vested with authority to assess and collect taxes; but such taxes shall be uniform. in respect to persons and property, within the jurisdiction of the body imposing the same.

Art. IX $\$ 10$.

The general assembly shall require that all the taxable property within the limits of municipal corporations shall be taxed for the payment of debts contracted under authority of law, such taxes to be uniform in respect to persons and property, within the jurisdiction of the body imposing the same. . . . 
Art. X $\S 1$.

The General Assembly shall provide, by law, for a uniform and equal rate of assessment and taxation; and shall prescribe such regulations as shall secure a just valuation for taxation of all property, both real and personal, excepting such only for municipal, educational, literary, scientific, religious, or charitable purposes, as may be specially exempted by law.

Art. X §8.

The General Assembly may levy and collect a tax upon income, from whatever source derived, at such rates, in such manner, and with such exemptions as may be prescribed by law.

\section{IOWA}

Const. 1857.

Art. 1 \$.

All laws of a general nature shall have a uniform operation; the General Assembly shall not grant to any citizen, or class of citizens, privileges or immunities, which, upon the same terms shall not equally belong to all citizens.

Art. VIII §2.

The property of all corporations for pecuniary profit, shall be subject to taxation, the same as that of individuals.

\section{KANSAS}

Const. 1859.

Art. XI $\$ 1$.

The legislature shall provide for a uniform and equal rate of assessment and taxation, except that mineral products, money, mortgages, notes and other evidence of debt may be classified and taxed uniformly as to class as the legislature shall provide. All property used exclusively for state, county, municipal, literary, educational, scientific, religious, benevolent and charitable purposes, and personal property to the amount of at least two hundred dollars for each family, shall be exempted from taxation.

Art. XI §2.

The state shall have power to levy and collect taxes on incomes from whatever source derived, which taxes may be graduated and progressive. Art. XI $\$ 10$.

The state shall have power to levy special taxes, for road and highway purposes, on motor vehicles and on motor fuels. 
$\S 171$.

... Taxes shall be levied and collected for public purposes only and shall be uniform upon all property of the same class subject to taxation within the territorial limits of the authority levying the tax; and all taxes shall be levied and collected by general laws.

The General Assembly shall have power to divide property into classes and to determine what class or classes of property shall be subject to local taxation. Bonds of the state and of counties, municipalities, taxing and school districts shall not be subject to taxation. . . .

$\S 174$.

All property, whether owned by natural persons or corporations, shall be taxed in proportion to its value, unless exempted by this Constitution; and all corporate property shall pay the same rate of taxation paid by individual property. Nothing in this Constitution shall be construed to prevent the General Assembly from providing for taxation based on income, licenses or franchises.

\section{$\S 181$.}

... The General Assembly may, by general laws only, provide for the payment of license fees on franchises, stock used for breeding purposes, the various trades, occupations and professions, or a special or excise tax; and may, by general laws, delegate the power to counties, towns, cities, and other municipal corporation, to impose and collect license fees on stock used for breeding purposes, on franchises, trades, occupations and professions. And the General Assembly may, by general laws only, authorize cities or towns of any class to provide for taxation for municipal purposes on personal property, tangible and intangible, based on income, licenses or franchises, in lieu of an ad valorem tax thereon: Provided, Cities of the first class shall not be authorized to omit the imposition of an ad valorem tax on such property of any steam railroad, street railway, ferry, bridge, gas, water, heating, telephone, telegraph, electric light or electric power company.

$\$ 3$.

... but no property shall be exempt from taxation except as provided in this Constitution, and every grant of a franchise, privilege or exemption, shall remain subject to revocation, alteration or amendment.

$\$ 170$.

There shall be exempt from taxation public property used for public purposes; places actually used for religious worship, with the grounds at- 
tached thereto and used and appurtenant to the house of worship, not exceeding one-half acre in cities or towns, and not exceeding two acres in the country; places of burial not held for private or corporate profit, institutions of purely public charity, and institutions of education not used or employed for gain by any person or corporation, and the income of which is devoted solely to the cause of education; public libraries, their endowments, and the income of such property as is used exclusively for their maintenance; all parsonages or residences owned by any religious society, and occupied as a home, and for no other purpose, by the minister of any religion, with not exceeding one-half acre of ground in towns and cities and two acres of ground in the country appurtenant thereto; household goods and other personal property of a person with a family, not exceeding two hundred and fifty dollars in value; crops grown in the year in which the assessment is made, and in the hands of the producer; and all laws exempting or commuting property from taxation other than the property above mentioned shall be void. The General Assembly may authorize any incorporated city or town to exempt manufacturing establishments from municipal taxation, for a period not exceeding five years, as an inducement to their location.

$\$ 172$.

All property, not exempted from taxation by this Constitution, shall be assessed for taxation at its fair cash value, established at the price it would bring at a fair voluntary sale; ...

\section{LOUISIANA}

Const. 1921.

\section{Art. X §1.}

The power of taxation shall be vested in the Legislature; shall never be surrendered, suspended or contracted away; and all taxes shall be uniform upon the same class of subjects throughout the territorial limits of the authority levying the tax, and shall be levied and collected for public purposes only. No property shall be assessed for more than its actual cash value, ascertained as director by law. . . . The valuation and classification fixed for State purposes shall be the valuation and classification for local purposes; but the taxing authorities of the local subdivision may adopt a different percentage of such valuation for purposes of local taxation.

Equal and uniform taxes may be levied upon net incomes, and such taxes may be graduated according to the amount of the net income. Public officials shall not be exempted. Reasonable exemptions may be allowed.

For the purpose of encouraging the reforestation of denuded lands, contracts fixing the assessed valuation of the specific lands for the duration of the agreements, and fixing a total severance tax based on the value of 
forest products when severed, three-fourths of which shall go to the parish where they are severed, and which severance tax, for a period not to exceed fifty years from the date of such contract, shall be in lieu of all other taxes on said forest products, are hereby authorized under such regulations, terms and conditions as may be prescribed by law; and the regulations, term and conditions of such contracts as authorized may be made retroactive by the consent of the parties as respects the limit of taxation, on contracts theretofore entered into. . . .

Art. X $\$ 7$.

Taxes upon inheritances, legacies and donations, or gifts made in contemplation of death, may be graduate, classified or progressive; provided, such taxes shall not exceed three per cent as to ascendants, descendants or surviving spouse; ten per cent as to collateral heirs; or fifteen per cent as to others; and exemptions to a reasonable amount may be allowed. Donations and legacies to charitable, religious or educational institutions located within the State shall be exempt from such tax.

\section{Art. $X \S 8$.}

License taxes may be levied on such classes of persons, associations of persons and corporations pursuing any trade, business, occupation, vocation or profession, as the Legislature may deem proper, except clerks, laborers, ministers of religion, school teachers, graduated trained nurses, those engaged in mechanical, agricultural or horticultural pursuits or in operating saw mills. Such license taxes may be classified, graduated or progressive. . . . Those who pay municipal license taxes equal in amount to such taxes levied by the parochial authorities shall be exempt from such parochial license taxes.

Art. X $\S 9$.

[All foreign banks engaging in business in Louisiana shall pay annually a $\$ 500$ license fee, and $5 \%$ on the gross amount of interest earned. To be in lieu of all other taxes, except on such bank's real estate.]

Art. $X \$ 21$.

[1] Taxes may be levied on natural resources severed from the soil or water, to be paid proportionately by the owners thereof at the time of severance. . . Such natural resources may be classified for the purpose of taxation and such taxes may be predicated upon either the quantity or value of the product at the time and place of severance. No severance tax shall be levied by any parish or other local subdivision of the State.

No further or additional tax or license shall be levied or imposed upon oil, gas or sulphur leases or right, nor shall any additional value be added to the assessment of land, by reason of the presence of oil, gas or sulphur 
therein or their production therefrom. . . Provided, that sulphur in place shall be assessed for ad valorem taxation to the person, firm or corporation having the right to mine or produce the same in the parish where located, at no more than twice the total assessed value of the physical property subject to taxation excluding the assessed value of sulphur above ground, in such parish as is used in sulphur operations. . . .

Art. VI §22.

[Self-executing legislative provisions imposing motor vehicle and motor fuel taxes.]

Art. X $\S 4$.

[After stating that "The following property, and no other, shall be exempt from taxation ....", section 4 includes more than fourteen paragraphs of exemptions. There are other provisions dealing with special exemptions.]

\section{MAINE}

Const. 1819.

Art. IX $\$ 8$.

All taxes upon real and personal estate, assessed by authority of this state, shall be apportioned and assessed equally, according to the just value thereof; but the legislature shall have power to levy a tax upon intangible personal property at such rate as it deems wise and equitable without regard to the rate applied to other classes of property.

\section{MARYLAND}

Const. 1867.

Decl. Rts. Art. 15.

That the levying of taxes by the poll is grievous and oppressive and ought to be prohibited; that paupers ought not to be assessed for the support of the Government; that the General Assembly shall, by uniform rules, provide for separate assessment of land and classification and subclassifications of improvements on land and personal property as it may deem proper; and all taxes thereafter provided to be levied by the State for the support of the general State Government, and by the counties and by the City of Baltimore for their respective purposes, shall be uniform as to land within the taxing district, and uniform within the class or sub-class of improvements on land and personal property which the respective taxing powers may have directed to be subjected to the tax levy; yet fines, duties or taxes may properly and justly be imposed, or laid with a political view for the good government and benefit of the community. 


\section{Pt. Two, Ch. I, §1, Sub§ IV}

And further, full power and authority are hereby given and granted to the said general court, . . . to impose and levy proportional and reasonable assessments, rates and taxes, upon all the inhabitants of, and persons resident, and estates lying, within the said commonwealth; and also to impose and levy, reasonable duties and excises, upon any produce, goods, wares, merchandise, and commodities, whatsoever, brought into, produced, manufactured, or being within the same; . . .

Amdts: Art. XLIV.

Full power and authority are hereby given and granted to the general court to impose and levy a tax on income in the manner hereinafter provided. Such tax may be at different rates upon income derived from different classes of property, but shall be levied at a uniform rate throughout the commonwealth upon incomes derived from the same class of property. The general court may tax income not derived from property at a lower rate than income derived from property, and may grant reasonable exemptions and abatements. Any class of property the income from which is taxed under the provisions of this article may be exempted from the imposition and levying of proportional and reasonable assessments, rates and taxes as at present authorized by the constitution. This article shall not be construed to limit the power of the general court to impose and levy reasonable duties and excises.

Amdts: Art. XLI.

Full power and authority are hereby given and granted to the general court to prescribe for wild or forest lands such methods of taxation as will develop and conserve the forest resources of the commonwealth.

Pt. I, Art. X.

Each individual of the society has a right to be protected by it in the enjoyment of his life, liberty and property, according to standing law. He is obliged, consequently, to contribute his share to the expense of this protection.

\section{MICHIGAN}

Const. 1908.

\section{Art. X \&3.}

The legislature shall provide by law a uniform rule of taxation, except on property paying specific taxes, and taxes shall be levied on such property as shall be prescribed by law: Provided, That the legislature shall provide 
by law a uniform rule of taxation for such property as shall be assessed by the state board of assessors, and the rate of taxation on such property shall be the rate which the state board of assessors shall ascertain and determine is the average rate levied upon other property upon which ad valorem taxes are assessed for state, county, township, school and municipal purposes.

\section{Art. X §4.}

The legislature may by law impose specific taxes, which shall be uniform upon the classes upon which they operate.

\section{Art. $X \S 5$.}

The legislature may provide by law for the assessment at its true cash value by a state board of assessors, of which the governor shall be ex-officio a member, of the property of corporations and the property, by whomsoever owned, operated or conducted, engaged in the business of transporting passengers and freight, transporting property by express, operating any union station or depot, transmitting messages by telephone or telegraph, loaning cars, operating refrigerator cars, fast freight lines or other car lines and running or operating cars in any manner upon railroads, or engaged in any other public service business; and for the levy and collection of taxes thereon.

\section{Art. X §7.}

All assessments hereafter authorized shall be on property at its cash value.

\section{MINNESOTA}

Const. 1857.

\section{Art. IX $\$ 1$.}

The power of taxation shall never be surrendered, suspended or contracted away. Taxes shall be uniform upon the same class of subjects, and shall be levied and collected for public purposes, but public burying grounds, public school houses, public hospitals, academies, colleges, universities, and all seminaries of learning, all churches, church property and houses of worship, institutions of purely public charity, public property used exclusively for any public purpose, shall be exempt from taxation, and there may be exempted from taxation personal property not exceeding in value $\$ 200$, for each household, individual or head of a family, and household goods and farm machinery, as the legislature may determine. Provided, that the legislature may authorize municipal corporations to levy and collect assessments for local improvements upon property benefited thereby without regard to a cash valuation, and provided further, that nothing herein contained shall be construed to affect, modify or repeal any existing law providing for the taxation of the gross earnings of railroads. 
Art. IX §1A.

Every person, co-partnership, company, joint stock company, corporation, or association however or for whatever purpose organized, engaged in the business of mining or producing iron ore or other ores in this State, shall pay to the State of Minnesota an occupation tax on the valuation of all ores mined or produced, which tax shall be in addition to all other taxes provided by law, said tax to be due and payable from such person, co-partnership, company, joint stock company, corporation, or association however or for whatever purpose organized, on May first of the calendar year next following the mining or producing thereof. The valuation of ore for the purpose of determining the amount of tax to be paid shall be ascertained in the manner and method provided by law. . . .

\section{Art. XVI §3.}

The legislature is hereby authorized to provide, by law, for the taxation of motor vehicles, using the public streets and highways of this state, on a more onerous basis than other personal property; provided, however, that any such tax on motor vehicles shall be in lieu of all other taxes thereon, except wheelage taxes, so-called, which may be imposed by any borough, city or village, and except that the legislature may impose such tax upon motor vehicles of companies paying taxes under gross earnings system of taxation and upon the right to use such vehicles upon the public highways notwithstanding the fact that earnings from such vehicles may be included in the earnings of such companies upon which such gross earnings taxes are computed. Any such law may, in the discretion of the legislature, provide for the exemption from taxation of any motor vehicle owned by a nonresident of the state. . . .

\section{Art. XIX §4.}

The legislature is hereby authorized to provide, by law, for the taxation of aircraft using the air space overlying the State of Minnesota and the airports thereof, including any contrivance, now known or hereafter invented, used or designed for navigation of or flight in the air, on a more onerous basis than other personal property; provided, however, that any such tax on aircraft shall be in lieu of all other taxation thereon, and except that the legislature may impose such tax upon aircraft of companies paying taxes under any gross earnings system of taxation, and upon the right to use such aircraft in the air space overlying the State of Minnesota and upon the airports thereof, notwithstanding the fact that earnings from such aircraft may be included in the earnings of such companies upon which such gross earnings taxes are computed. Any such law may, in the discretion of the legislature, provide for the exemption from taxation of any aircraft 
owned by a nonresident of the state and transiently or temporarily using the air space overlying the State of Minnesota or the airports thereof.

\section{Art. XVIII $§ 1$.}

Laws may be enacted for the purpose of encouraging and promoting forestation and reforestation of lands in this state, whether owned by private persons or the public, including the fixing in advance of a definite and limited annual tax on such lands for a term of years and yield tax at or after the end of such term upon the timber and other forest products so grown, but the taxation of mineral deposits shall not be affected by this amendment.

\section{MISSISSIPPI}

Const. 1890.

\section{Art. IV $\$ 112$.}

Taxation shall be uniform and equal throughout the state. Property shall be taxed in proportion to its value. The legislature may, however, impose a tax per capita upon such domestic animals as from their nature and habits are destructive of other property. Property shall be assessed for taxes under general laws, and by uniform rules, according to its true value. But the legislature may provide for a special mode of valuation and assessment for railroads, and railroad and other corporate property, or for particular species of property belonging to persons, corporations, or associations not situated wholly in one county. ...

\section{Art. VII $\$ 181$.}

The property of all private corporations for pecuniary gain shall be taxed in the same way and to the same extent as the property of individuals, but the legislature may provide for the taxation of banks and banking capital, by taxing the shares according to the value thereof (augmented by the accumulations, surplus, and unpaid dividends), exclusive of real estate, which shall be taxed as other real estate. Exemptions from taxation to which corporations are legally entitled at the adoption of this Constitution, shall remain in full force and effect for the time of such exemption as expressed in their respective charters, or by general laws, unless sooner repealed by the legislature. And domestic insurance companies shall not be required to pay a greater tax in the aggregate than is required to be paid by foreign insurance companies doing business in this state, except to the extent of the excess of their ad valorem tax over the privilege tax imposed upon such foreign companies; and the legislature may impose privilege taxes on building and loan associations in lieu of all other taxes except on their real estate. 
Art. VII §182.

The power to tax corporations and their property shall never be surrendered or abridged by any contract or grant to which the state or any political subdivison thereof may be a party, except what the legislature may grant exemption from taxation in the encouragement of manufactures and other new enterprises of public utility extending for a period of not exceeding five years, the time of such exemptions to commence from date of charter, if to a corporation; and if to an individual enterprise, then from the commencement of work; but when the legislature grants such exemptions for a period of five years or less, it shall be done by general laws, which shall distinctly enumerate the classes of manufactures and other new enterprises of public utility entitled to such exemptions, and shall prescribe the mode and manner in which the right to such exemptions shall be determined.

Art. VII §192.

Provision shall be made by general laws whereby cities and towns may be authorized to aid and encourage the establishment of manufactories, gasworks, waterworks, and other enterprises of public utility other than railroads, within the limits of said cities or towns, by exempting all property used for such purposes from municipal taxation for a period not longer than ten years.

\section{Art. XI \$236.}

The legislature shall impose for levee purposes, in addition to the levee taxes heretofore levied or authorized by law, a uniform tax of not less than two nor more than five cents an acre per annum upon every acre of land now or hereafter embraced within the limits of either or both of said levee districts .... and all reductions in such taxation shall be uniform in each of said districts; but the rate of taxation need not be the same in both of them. ...

\section{MISSOURI}

Const. 1945.

\section{Art. X §3.}

Taxes may be levied and collected for public purposes only, and shall be uniform upon the same class of subjects within the territorial limits of the authority levying the tax. . . Except as otherwise provided in this constitution, the methods of determining the value of property for taxation shall be fixed by law.

Art. $\mathrm{X} \S 4$.

(a) All taxable property shall be classified for tax purposes as follows: class 1, real property; class 2, tangible personal property; class 3, intangible 
personal property. The general assembly, by general law, may provide for further classification within classes 2 and 3 , based solely on the nature and characteristics of the property, and not on the nature, residence or business of the owner, or the amount owned. Nothing in this section shall prevent the taxing of franchises, privileges or incomes, or the levying of excise or motor vehicle license taxes, or any other taxes of the same or different types.

(b) Property in classes 1 and 2 and subclasses of class 2, shall be assessed for tax purposes at its value or such percentage of its value as may be fixed by law for each class and for each subclass of class 2. Property in class 3 and its subclasses shall be taxed only to the extent authorized and at the rate fixed by law for each class and subclass, and the tax shall be based on the annual yield and shall not exceed eight per cent thereof.

(c) All taxes on property in class 3 and its subclasses, and the tax under any other form of taxation substituted by the general assembly for the tax on bank shares, shall be assessed, levied and collected by the state and returned as provided by law, less two per cent for collection, to the counties and other political subdivisions of their origin, in proportion to the respective local rates of levy.

\section{Art. X §7.}

For the purpose of encouraging forestry when lands are devoted exclusively to such purpose, and the reconstruction, redevelopment and rehabilitation of obsolete, decadent or blighted areas, the general assembly by general law, may provide for such partial relief from taxation of the lands devoted to any such purpose, and of the improvements thereon, by such method or methods, for such period or periods of time, not exceeding twenty-five years in any instance, and upon such terms, conditions, and restrictions as it may prescribe.

Art. X $\S 6$.

All property, real and personal, of the state, counties and other political subdivisions, and non-profit cemeteries, shall be exempt from taxation; and all property, real and personal, not held for private or corporate profit and used exclusively for religious worship, for schools and colleges, for purposes purely charitable, or for agricultural and horticultural societies may be exempted from taxation by general law. All laws exempting from taxation property other than the property enumerated in this article, shall be void.

\section{Art. X $\$ 5$.}

All railroad corporations in this state, or doing business therein, shall be subject to taxation for state, county, school, municipal and other purposes, on the real and personal property owned or used by them, and on their gross earnings, their net earnings, their franchises and their capital stock. 


\section{Art. XII $\$ 1$.}

The necessary revenue for the support and maintenance of the state shall be provided by the legislative assembly, which shall levy a uniform rate of assessment and taxation, and shall prescribe such regulations as shall secure a just valuation for taxation of all property, except that specially provided for in this article. The legislative assembly may also impose a license tax, both upon persons and upon corporations doing business in the state.

\section{Art. XII $\$ 11$.}

Taxes shall be levied and collected by general laws and for public purposes only. They shall be uniform upon the same class of subjects within the territorial limits of the authority levying the tax.

\section{Art. XII $\$ 1$ a.}

The legislative assembly may levy and collect taxes upon incomes of persons, firms and corporations for the purpose of replacing property taxes. These income taxes may be graduated and progressive and shall be distributed to the public schools and to the state government.

\section{Art. XII $\$ 17$.}

The word property as used in this article is hereby declared to include moneys, credits, bonds, stocks, franchises and all matters and things (real, personal and mixed) capable of private ownership, but this shall not be construed so as to authorize the tax of the stocks of any company or corporation when the property of such company or corporation represented by such stocks is within the state and has been taxed.

\section{Art. XII $\S 2$.}

The property of the United States, the state, counties, cities, towns, school districts, municipal corporations and public libraries shall be exempt from taxation; and such other property as may be used exclusively for the agricultural and horticultural societies, for educational purposes, places for actual religious worship, hospitals and places of burial not used or held for private or corporate profit, institutions of purely public charity and evidences of debt secured by mortgages of record upon real or personal property in the state of Montana, may be exempt from taxation.

\section{Art. XII \$3.}

All mines and mining claims, both placer and rock in place, containing or bearing gold, silver, copper, lead, coal or other valuable mineral deposits, after purchase thereof from the United States, shall be taxed at the price paid the United States therefor, unless the surface ground, or some part 
thereof, of such mine or claim, is used for other than mining purposes, and has a separate and independent value for such other purposes, in which case said surface ground, or any part thereof, so used for other than mining purposes, shall be taxed at its value for such other purposes, as provided by $\mathrm{Jaw}_{\text {; }}$ and all machinery used in mining, and all property and surface improvements upon or appurtenant to mines and mining claims which have a value separate and independent of such mines or mining claims, and the annual net proceeds of all mines and mining claims shall be taxed as provided by law.

NEBRASKA

Const. 1875 .

\section{Art. VIII §1.}

The necessary revenue of the state and its governmental subdivisions shall be raised by taxation in such manner as the Legislature may direct. Taxes shall be levied by valuation uniformly and proportionately upon all tangible property and franchises, except that the Legislature may provide for a different method of taxing motor vehicles. . . . Taxes uniform as to class may be levied by valuation upon all other property. Taxes, other than property taxes, may be authorized by law. . . .

\section{Art. VIII §2.}

The property of the state and its governmental subdivisions shall be exempt from taxation. The Legislature by general law may exempt property owned by and used exclusively for agricultural and horticultural societies, and property owned and used exclusively for educational, religious, charitable or cemetery purposes, when such property is not owned or used for financial gain or profit to either the owner or user. Household goods of the value of two hundred $(\$ 200.00)$ dollars to each family shall be exempt from taxation. The Legislature by general law may provide that the increased value of land by reason of shade and ornamental trees planted along the highway shall not be taken into account in the assessment of such land. No property shall be exempt from taxation except as provided in this section.

\section{Art. VIII §6.}

... such [municipal] taxes shall be uniform in respect to persons and property within the jurisdiction of the body imposing the same.

\section{Art. VIII §1A.}

When a general sales tax, or an income tax, or a combination of a general sales tax or income tax, is adopted by the Legislature as a method of raising revenue for the State of Nebraska for state purposes, the state shall be prohibited from levying a property tax for state purposes. 
Art. X $\$ 1$.

The legislature shall provide by law for a uniform and equal rate of assessment and taxation, and shall prescribe such regulations as shall secure 2 just valuation for taxation of all property, real, personal and possessory, except mines and mining claims, when not patented, the proceeds alone of which shall be assessed and taxed, and when patented, each patented mine shall be assessed at not less than five hundred dollars, except where one hundred dollars in labor has been actually performed on such patented mine during the year, in addition to the tax upon the net proceeds; shares of stock (except shares of stock in banking corporations), bonds, mortgages, notes, bank deposits, book accounts and credits, and securities and choses in action of like character are deemed to represent interest in property already assessed and taxed, either in Nevada or elsewhere, and shall be exempt. No inheritance or estate tax shall ever be levied, and there shall also be excepted such property as may be exempted by law for municipal, educational, literary, scientific or other charitable purposes.

\section{Art. VIII §2.}

All real property and possessory rights to the same, as well as personal property in this state, belonging to corporations now existing or hereafter created, shall be subject to taxation the same as property of individuals; provided, that the property of corporations formed for municipal, charitable, religious, or educational purposes may be exempted by law.

\section{NEW HAMPSHIRE}

Const. 1784.

Pt. II Art. 5.

[The Legislature may] impose and levy proportional and reasonable assessments, rates, and taxes, upon all the inhabitants of, and residents within, the said state; and upon all estates within the same . . . ; for the purpose of encouraging conservation of the forest resources of the state, the general court may provide for special assessments, rates and taxes on growing woods and timbers.

Pt. II Art. 6.

The public charges of government, or any part thereof, may be raised by taxation upon polls, estates, and other classes of property, including franchises and property when passing by will or inheritance; and there shall be a valuation of the estates within the state taken anew once in every five years, at least, and as much oftener as the general court shall order. 
Pt. I Art. 12.

Every member of the community has a right to be protected by it, in the enjoyment of his life, liberty, and property; he is therefore bound to contribute his share in the expense of such protection. . . .

\section{NEW JERSEY}

Const. 1947.

\section{Art. VIII $\$ 1$. \1.}

Property shall be assessed for taxation under general laws and by uniform rules. All real property assessed and taxed locally or by the State for allotment and payment to taxing districts shall be assessed according to the same standard of value; and such real property shall be taxed at the general tax rate of the taxing district in which the property is situated, for the use of such taxing district.

Art. VIII §1. $\llbracket 2$.

Exemption from taxation may be granted only by general laws. Until otherwise provided by law all exemptions from taxation validly granted and now in existence shall be continued. Exemptions from taxation may be altered or repealed, except those exempting real and personal property used exclusively for religious, educational, charitable or cemetery purposes as defined by law, and owned by any corporation or association organized and conducted exclusively for one or more of such purposes and not operating for profit.

Art. VIII §1. \3.

... [veterans, citizens and residents of New Jersey,] shall be exempt from taxation on real and personal property to an aggregate assessed valuation not exceeding five hundred dollars, which exemption shall not be altered or repealed. ... [disabled veterans] shall be entitled to such further exemption from taxation as from time to time may be provided by law. The widow of any citizen and resident of this State who has met or shall meet his death on active duty in time of war in any such service shall be entitled, during her widowhood, to the exemption in this paragraph provided for honorably discharged veterans and to such further exemption as from time to time may be provided by law.

\section{NEW MEXICO}

Const. 1911.

\section{Art. VIII $\$ 1$.}

Taxes levied upon tangible property shall be in proportion to the value thereof, and taxes shall be equal and uniform upon subjects of taxation of the same class. 


\section{Art. VIII §3.}

The property of the United States, the state and all counties, towns, cities and school districts, and other municipal corporations, public libraries, community ditches and all laterals thereof, all church property, all property used for educational or charitable purposes, all cemeteries not used or held for private or corporate profit, and all bonds of the state of New Mexico, and of the counties, municipalities and districts thereof shall be exempt from taxation. ...

\section{Art. VIII $\$ 5$.}

The legislature may exempt from taxation property of each head of the family to the amount of two hundred dollars $(\$ 200)$, and the property, including the community or joint property of husband and wife, of every honorably discharged member of the armed forces of the United States who served in the armed forces of the United States at any time during which the United States was regularly and officially engaged in any war, in the sum of two thousand dollars $(\$ 2,000)$. . .

Art. VIII $\$ 6$.

Lands held in large tracts shall not be assessed for taxation at any lower value per acre than lands of the same character or quality and similarly situated, held in smaller tracts. The plowing of land shall not be considered as adding value thereto for the purpose of taxation.

\section{NEW YORK}

Const. 1938.

\section{Art. I $\$ 11$.}

No person shall be denied the equal protection of the laws of this state or any subdivision thereof. ...

Art. XVI $\$ 1$.

... Exemptions from taxation may be granted only by general laws. Exemptions may be altered or repealed except those exempting real or personal property used exclusively for religious, educational or charitable purposes as defined by law and owned by any corporation or association organized or conducted exclusively for one or more of such purposes and not operating for profit.

Art. XVI §3.

... Intangible personal property shall not be taxed ad valorem nor shall any excise tax be levied solely because of the ownership or possession thereof, except that the income therefrom may be taken into consideration in computing any excise tax measured by income generally. Undistributed profits shall not be taxed. 


\section{Art. XVI \$4.}

Where the state has power to tax corporations included under the laws of the United States there shall be no discrimination in the rates and methods of taxation between such corporations and other corporations exercising substantially similar functions and engaged in substantially similar business within the state.

\section{NORTH CAROLINA}

Const. 1876.

Art. V \$3.

-. Taxes on property shall be uniform as to each class of property taxed. . . . The General Assembly may also tax trades, professions, franchises, and incomes: Provided, the rate of tax on income shall not in any case exceed ten per cent $(10 \%)$, and there shall be allowed the following exemptions, to be deducted from the amount of annual incomes, to-wit: for married man with a wife living with him, or to a widow or widower having minor child or children, natural or adopted, not less than $\$ 2,000$; to all other persons not less than $\$ 1,000$, and there may be allowed other deductions (not including living expenses) so that only net incomes are taxed.

\section{Art. V $\$ 5$.}

Property belonging to the State, or to municipal corporations, shall be exempt from taxation. The General Assembly may exempt cemeteries and property held for educational, scientific, literary, charitable, or religious purposes; also wearing apparel, arms for muster, household and kitchen furniture, the mechanical and agricultural implements of mechanics and farmers; libraries and scientific instruments, or any other personal property, to a value not exceeding three hundred dollars. The General Assembly may exempt from taxation not exceeding one thousand dollars $(\$ 1,000.00)$ in value of property held and used as the place of residence of the owner.

\section{NORTH DAKOTA}

Const. 1889.

\section{Art. XI §176.}

Taxes shall be uniform upon the same class of property including franchises within the territorial limits of the authority levying the tax. The legislature may by law exempt any or all classes of personal property from taxation and within the meaning of this section, fixtures, buildings and improvements of every character, whatsoever, upon land shall be deemed personal property. The property of the United States and of the state, county and municipal corporations and property used exclusively for schools, religious, cemetery, charitable or other public purposes shall be exempt from taxation. Except as restricted by this article, the legislature may provide for raising revenue and fixing the situs of all property for the purpose of 
taxation. Provided that all taxes and exemptions in force when this amendment is adopted shall remain in force until otherwise provided by statute.

\section{Art. XI $\$ 177$.}

The legislature may by law provide for the levy and collection of an acreage tax on lands within the state in addition to the limitations specified in Section 174 in Article 11 of the constitution. The proceeds of such tax shall be used to indemnify the owners of growing crops against damages by hail, provided that lands used exclusively for public roads, rights of way of common carriers, mining, manufacturing or pasturage may be exempt from such tax.

\section{OHIO}

Const. 1851.

Art. XII \$2.

Land and improvements thereon shall be taxed by uniform rule according to value ... [certain bonds exempt] ... and without limiting the general power, subject to the provisions of article $I$ of this constitution, to determine the subjects and methods of taxation or exemptions therefrom, general laws may be passed to exempt burying grounds, public school houses, houses used exclusively for public worship, institutions used exclusively for charitable purposes, and public property used exclusively for any public purpose, but all such laws shall be subject to alteration or repeal; and the value of all property so exempted shall, from time to time, be ascertained and published as may be directed by law.

\section{Art. XII $\S 7$.}

Laws may be passed providing for the taxation of the right to receive, or to succeed to, estates, and such taxation may be uniform or it may be so graduated as to tax at a higher rate the right to receive, or to succeed to, estates of larger value than to estates of smaller value. Such tax may also be levied at different rates upon collateral and direct inheritances, and a portion of each estate not exceeding twenty thousand dollars may be exempt from such taxation.

\section{Art. XII §8.}

Laws may be passed providing for the taxation of incomes, and such taxation may be either uniform or graduated, and may be applied to such incomes as may be designated by law; but a part of each annual income not exceeding three thousand dollars may be exempt from such taxation.

Art. XII $\$ 10$.

Laws may be passed providing for excise and franchise taxes and for the imposition of taxes upon the production of coal, oil, gas and other minerals. 


\section{Art. XIII \$4.}

The property of corporations, now existing or hereafter created, shall forever be subject to taxation, the same as the property of individuals.

\section{Art. II §36.}

Laws may be passed to encourage forestry, and to that end areas devoted exclusively to forestry may be exempted, in whole or in part from taxation. ...

\section{Art. II $\$ 1(e)$.}

The powers defined herein as the "initiative" and "referendum" shall not be used to pass a law authorizing any classification of property for the purpose of levying different rates of taxation thereon or of authorizing the levy of any single tax on land or land values or land sites at a higher rate or by a different rule than is or may be applied to improvements thereon or to personal property.

\section{OKLAHOMA}

Const. 1907.

\section{Art. X \$5.}

The power of taxation shall never be surrendered, suspended, or contracted away. Taxes shall be uniform upon the same class of subjects.

Art. X \$12.

The Legislature shall have power to provide for the levy and collection of license, franchise, gross revenue, excise, income, collateral and direct inheritance, legacy, and succession taxes; also graduated income taxes, graduated collateral and direct inheritance taxes, graduated legacy and succession taxes; also stamp, registration, production or other specific taxes.

Art. X §22.

Nothing in this Constitution shall be held, or construed, to prevent the classification of property for purposes of taxation; and the valuation of different classes by different means or methods.

Art. $V \S 50$.

The Legislature shall pass no law exempting any property within this State from taxation, except as otherwise provided in this Constitution.

\section{Art. X §6.}

All property used for free public libraries, free museums, public cemeteries, property used exclusively for religious and charitable purposes, and all property of the United States, and of this State; household goods of the heads of families, tools, implements, and live stock employed in the support 
of the family, not exceeding one hundred dollars in value, and all growing crops, shall be exempt from taxation. . . .

The Legislature may authorize any incorporated city or town, by a majority vote of its electors voting thereon, to exempt manufacturing establishments and public utilities from municipal taxation, for a period not exceeding five years, as an inducement to their location.

Art. XII-A.

[Homestead exemption.]

Art. X \$8.

All property which may be taxed ad valorem shall be assessed for taxation at its fair cash value, estimated at the price it would bring at a fair voluntary sale. . . .

\section{OREGON}

Const. 1859.

Art. IX $\$ 1$.

The Legislative Assembly shall, and the people through the initiative may, provide by law uniform rules of assessment and taxation. All taxes shall be levied and collected under general laws operating uniformly throughout the state.

Art. I \&32.

No tax or duty shall be imposed without the consent of the people or their representatives in the Legislative Assembly; and all taxation shall be uniform on the same class of subjects within the territorial limits of the authority levying the tax.

\section{PENNSYLVANIA}

Const. 1874.

Art. IX $\$ 1$.

All taxes shall be uniform, upon the same class of subjects, within the territorial limits of the authority levying the tax, and shall be levied and collected under general laws, but the General Assembly may, by general laws, exempt from taxation public property used for public purposes, actual places of religious worship, places of burial not used or held for private or corporate profit, institutions of purely public charity, and real and personal property owned, occupied, and used by any branch, post, or camp of honorably discharged soldiers, sailors and marines.

\section{Art. IX §2.}

All laws exempting property from taxation, other than the property above enumerated shall be void. 


\section{Art. I \$2.}

All free governments are instituted for the protection, safety and happiness of the people. All laws, therefore, should be made for the good of the whole; and the burdens of the state ought to be fairly distributed among its citizens.

\section{Art. $\mathrm{X} \S 1$.}

The General Assembly shall provide by law for a uniform and equal rate of assessment and taxation, and shall prescribe regulations to secure a just valuation for taxation of all property, real, personal and possessory, except mines and mining claims, the products of which alone shall be taxed; and also excepting such property as may be exempted by law for municipal, educational, literary, scientific, religious or charitable purposes: Provided, however, That the General Assembly may impose a capitation tax upon such domestic animals as from their nature and habits are destructive of other property: And provided, further, That the General Assembly may provide for a graduated tax on incomes, and for a graduated license on occupations and business. Provided, further That the General Assembly may provide by law for the assessment of all intangible personal property, including moneys, credits, bank deposits, corporate stocks, and bonds, at its true value for taxation for State, County and municipal purposes or either thereof; Provided, that the total rate of taxation imposed thereon shall never exceed one-half of one per centum of the actual value of such intangible property; Provided, further, That such intangible personal property shall not be subject to the three mill levy provided by $\$ 10$, Art. 11 , of this instrument or to any other general or special tax levy, except such as is especially provided by the General Assembly by the authority and within the limitation of this provision; nor shall such intangible personal property be considered a part of "taxable property," as such term is used in this instrument, of the State or any subdivision thereof.

Art. I $\$ 6$.

All property subject to taxation shall be taxed in proportion to its value.

Art. III $\$ 29$.

All taxes upon property, real and personal, shall be laid upon the actual value of the property taxed, as the same shall be ascertained by an assessment made for the purpose of laying such tax. 
Art. $X \S 13$.

The General Assembly shall provide for the assessment of all property for taxation; and State, county, township, school, municipal and all other taxes shall be levied on the same assessment which shall be that made for State taxes. ...

Art. X $\S 4$.

There shall be exempted from taxation all County, township and municipal property used exclusively for public purposes and not for revenue, and the property of all schools, colleges and institutions of learning, all charitable institutions in the nature of asylums for the infirm, deaf and dumb, blind, idiotic and indigent persons, except where the profits of such institutions are applied to private uses; all public libraries, churches, parsonages and burying grounds; but property of associations and societies, although connected with charitable objects, shall not be exempt from State, County or municipal taxation: Provided, That as to real estate this exemption shall not extend beyond the buildings and premises actually occupied by such schools, colleges, institutions of learning, asylums, libraries, churches, parsonages and burial grounds, although connected with charitable objects.

\section{Art. VIII §8.}

Cities and towns may exempt from taxation, by general or special ordinance, except for school purposes, manufactories established within their limits for five successive years from the time of the establishment of such manufactories. ....

\section{Art. VIII $§ 6$.}

The corporate authorities of cities and towns in this State shall be vested with power to assess and collect taxes for corporate purposes said taxes to be uniform in respect to persons and property within the jurisdiction of the body composing the same; and all the property, except such as is exempt by law, within the limits of cities and towns shall be taxed for the payment of debts contracted under authority of law. License or privileged taxes imposed shall be graduated so as to secure a just imposition of such tax upon the classes subject thereto.

Art. VI $\$ 17$.

No tax or duty shall be imposed without the consent of the people or their representatives in the legislature, and all taxation shall be equal and uniform. 


\section{Art. XI §2.}

To the end that the burden of taxation may be equitable upon all property, and in order that no property which is made subject to taxation shall escape, the legislature is empowered to divide all property including moneys and credits as well as physical property into classes and to determine what class or classes of property shall be subject to taxation and what property, if any, shall not be subject to taxation. Taxes shall be uniform on all property of the same class, and shall be levied and collected for public purposes only. Taxes may be imposed upon any and all property including privileges, franchises and licenses to do business in the state. Gross earnings and net incomes may be considered in taxing any and all property and the valuation of property for taxation purposes shall never exceed the actual value thereof. The legislature is empowered to impose taxes upon incomes and occupations, and taxes upon incomes may be graduated and progressive and reasonable exemptions may be provided.

\section{Art. XI $\S 4$.}

The legislature shall provide for taxing all moneys, credits, investments in bonds, stocks, joint stock companies, or otherwise; and also for taxing the notes and bills discounted or purchased, moneys loaned and all other property, effects or dues of every description, of all banks and of all bankers, so that all property employed in banking shall always be subject to a taxation equal to that imposed on the property of individuals.

\section{Art. XI $\$ 5$.}

The property of the United States and of the state, county and municipal corporations, both real and personal, shall be exempt from taxation. . . Art. XI §6.

The legislature shall, by general law, exempt from taxation, property used exclusively for agricultural and horticultural societies, for school, religious, cemetery and charitable purposes, and personal property to any amount not exceeding in value two hundred dollars for each individual liable to taxation.

\section{Art. XI §7.}

All laws exempting property from taxation other than that enumerated in sections 5 and 6 of this article, shall be void.

Art. XI \$10.

... such [local] tax shall be uniform in respect to persons and property within the jurisdiction of the body levying the same.

\section{Art. VIII §15.}

The legislature shall make such provision by general taxation and by authorizing the school corporations to levy such additional taxes as with the 
income from the permanent school fund shall secure a thorough and efficient system of common schools throughout the state. The legislature is empowered to classify properties within school districts for purposes of school taxation, and may constitute agricultural lands a separate class. Taxes shall be uniform on all property in the same class.

\section{TENNESSEE}

Const. 1870.

\section{Art. II $\$ 28$.}

All property, real, personal or mixed, shall be taxed but the Legislature may except such as may be held by the State, by counties, cities or towns, and used exclusively for public or corporation purposes, and such as may be held and used for purposes purely religious, charitable, scientific, literary or educational, and shall except one thousand dollars' worth of personal property in the hands of each taxpayer, and the direct product of the soil in the hands of the producer, and his immediate vendee. All property shall be taxed according to its value, that value to be ascertained in such manner as the Legislature shall direct, so that taxes shall be equal and uniform throughout the State. No one species of property from which a tax may be collected, shall be taxed higher than any other species of property of the same value. But the Legislature shall have power to tax Merchants, Peddlers and privileges, in such manner as they may from time to time direct. The portion of a Merchant's Capital used in the purchase of Merchandise sold by him to nonresidents and sent beyond the State, shall not be taxed at a rate higher than the ad valorem tax on property. The Legislature shall have power to levy a tax upon incomes derived from stocks and bonds that are not taxed ad valorem. . . .

Art. II $\$ 30$.

No article manufactured of the produce of this State shall be taxed otherwise than to pay inspection fees.

Art. II $\$ 29$.

The General Assembly shall have power to authorize the several counties and incorporated towns of this State, to impose taxes for county and corporation purposes respectively, in such manner as shall be prescribed by law; and all property shall be taxed according to its value, upon the principles established in regard to State taxation. ...

\section{TEXAS}

Const. 1876.

Art. VIII §1.

Taxation shall be equal and uniform. All property in this State, whether owned by natural persons or corporations, other than municipal, shall be 
taxed in proportion to its value, which shall be ascertained as may be provided by law. The Legislature may impose a poll tax. It may also impose occupation taxes, both upon natural persons and upon corporations, other than municipal, doing any business in this State. It may also tax incomes of both natural persons and corporations other than municipal, except that persons engaged in mechanical and agricultural pursuits shall never be required to pay an occupation tax; Provided, that two hundred and fifty dollars worth of household and kitchen furniture, belonging to each family in this state shall be exempt from taxation. . . .

\section{Art. VIII \$2.}

All occupation taxes shall be equal and uniform upon the same class of subjects within the limits of the authority levying the tax; but the Legislature may, by general laws, exempt from taxation public property used for public purposes; actual places of religious worship; also any property owned by a church or by a strictly religious society for the exclusive use as a dwelling place for the ministry of such church or religious society; provided that such exemption shall not extend to more property than is reasonably necessary for a dwelling place and in no event more than one acre of land; places of burial not held for private or corporate profit; all buildings used exclusively and owned by persons or associations of persons for school purposes and the necessary furniture of all schools and property used exclusively and reasonably necessary in conducting any association engaged in promoting the religious, educational and physical development of boys, girls, young men or young women operating under a State or national organization of like character; also the endowment funds of such institutions of learning and religion not used with a view to profit; and when the same are invested in bonds or mortgages, or in land or other property which has been and shall hereafter be bought in by such institutions under foreclosure sales made to satisfy or protect such bonds or mortgages, that such exemption of such land and property shall continue only for two years after the purchase of the same at such sale by such institutions and no longer, and institutions of purely public charity; and all laws exempting property from taxation other than the property above mentioned shall be null and void.

\section{Art. VIII $\$ 17$.}

The specification of the objects and subjects of taxation shall not deprive the Legislature of the power to require other subjects or objects to be taxed in such manner as may be consistent with the principles of taxation fixed in this Constitution.

\section{Art. XI $\$ 9$.}

[Municipal property used for public purposes, all property used for 
extinguishing fires, and] all other property devoted exclusively to the use and benefit of the public shall be exempt ... from taxation. . . .

Art. VIII $\S 1 \mathrm{~b}$.

[Homesteads of assessed taxable value of $\$ 3,000$ ] shall be exempt from all taxation for all State purposes.

\section{UTAH}

Const. 1896.

Art. XIII $\S 2$.

All tangible property in the state, not exempt under the laws of the United States, or under this constitution, shall be taxed in proportion to its value, to be ascertained as provided by law. The property of the state, counties, cities, towns, school districts, municipal corporations and public libraries, lots with the buildings thereon used exclusively for either religious worship or charitable purposes, and places of burial not held or used for private or corporate benefit, shall be exempt from taxation. Water rights, ditches, canals, reservoirs, power plants, pumping plants, transmission lines, pipes and flumes owned and used by individuals or corporations for irrigating lands within the state owned by such individuals or corporations, or the individual members thereof, shall not be separately taxed as long as they shall be owned and used exclusively for such purposes. Power plants, power transmission lines and other property used for generating and delivering electrical power, a portion of which is used for furnishing power for pumping water for irrigation purposes on lands in the state of Utah, may be exempted from taxation to the extent that such property is used for such purposes. These exemptions shall accrue to the benefit of the users of water so pumped under such regulations as the legislature may prescribe. The taxes of the indigent poor may be remitted or abated at such times and in such manner as may be provided by law. The legislature may provide for the exemption from taxation of homes, homesteads, and personal property, not to exceed $\$ 2,000$ in value for homes and homesteads, and $\$ 300$ for personal property. Property not to exceed $\$ 3,000$ in value, owned by disabled persons who served in any war in the military service of the United States or of the state of Utah and by the unmarried widows and minor orphans of such persons may be exempted as the legislature may provide. . . .

\section{Art. XIII §3.}

The Legislature shall provide by law a uniform and equal rate of assessment and taxation on all tangible property in the State, according to its value in money, and shall prescribe by law such regulations as shall secure a just valuation for taxation of such property, so that every person or corporation shall pay a tax in proportion to the value of his, her, or its tangible property, 
provided that the Legislature may determine the manner and extent of taxing transient live stock and live stock being fed for slaughter to be used for human consumption. Intangible property may be exempted from taxation as property or it may be taxed in such manner and to such extent as the Legislature may provide. Provided that if intangible property be taxed as property the rate thereof shall not exceed five mills on each dollar of valuation. When exempted from taxation as property, the taxable income therefrom shall be taxed under any tax based on incomes, but when taxed by the State of Utah as property, the income therefrom shall be taxed under any tax based on incomes, but when taxed by the State of Utah as property, the income therefrom shall not also be taxed. The Legislature may provide for deductions, exemptions, and/or offsets on any tax based upon income. The personal income tax rates shall be graduated but the maximum rate shall not exceed six per cent of net income. No excise tax rate based upon income shall exceed four per cent of net income. ...

\section{Art. XIII §4.}

All metalliferous mines or mining claims, both placer and rock in place, shall be assessed as the Legislature shall provide. . . . All other mines or mining claims and other valuable mineral deposits, including lands containing coal or hydrocarbons and all machinery used in mining and all property or surface improvements upon or appurtenant to mines or mining claims, and the value of any surface use made of mining claims, or mining property for other than mining purposes, shall be assessed as other tangible property.

Art. XIII §12.

Nothing in this Constitution shall be construed to prevent the Legislature from providing a stamp tax, or a tax based on income, occupation, licenses or franchises.

\section{VERMONT}

Const. 1793.

\section{Ch. I Art. 9.}

That every member of society hath a right to be protected in the enjoyment of life, liberty, and property, and therefore is bound to contribute his proportion toward the expense of that protection....

\section{VIRGINIA}

Const. 1902.

\section{Art. XIII $\S 168$.}

All property, except as hereinafter provided, shall be taxed; all taxes, whether State, local or municipal, shall be uniform upon the same class of subjects within the territorial limits of the authority levying the tax, and 
shall be levied and collected under general law. The General Assembly may define and classify taxable subjects, and, except as to classes of property herein expressly segregated for either State or local taxation, the General Assembly may segregate the several classes of property so as to specify and determine upon what subjects State taxes, and upon what subjects local taxes may be levied.

\section{Art. XIII $\$ 170$.}

The General Assembly may levy a tax on incomes in excess of six hundred dollars per annum; may levy a license tax upon any business which cannot be reached by the ad valorem system; and may impose State franchise taxes, and in imposing a franchise tax, may in its discretion, make the same in lieu of taxes upon other property, in whole or in part, of a transportation, industrial, or commercial corporation. Whenever a franchise tax shall be imposed upon a corporation doing business, in this State, or whenever all the capital, however invested, of a corporation chartered under the laws of the State, shall be taxed, the shares of stock issued by any such corporation shall not be further taxed. . . .

\section{Art. XIII §171.}

No State property tax for State purposes shall be levied on real estate or tangible personal property, except the rolling stock of public service corporations. Real estate and tangible personal property, except the rolling stock of public service corporations, are hereby segregated for, and made subject to, local taxation, only, and shall be assessed or reassessed for local taxation in such manner and at such times as the General Assembly has heretofore prescribed, or may hereafter prescribe, by general laws.

\section{Art. XIII $\$ 169$.}

Except as hereafter provided, all assessments of real estate and tangible personal property shall be at their fair market value, to be ascertained as prescribed by law. So long as the State shall levy upon any public service corporation, other than a railway or a canal corporation, a State franchise, license, or other tax, based upon or measured by its gross receipts, or gross earnings, or any part thereof, its real estate and tangible personal property shall be assessed by the State Corporation Commission, or other central State agency, in the manner prescribed by law. The General Assembly may allow a lower rate of taxation to be imposed for a period of years by a city or town upon land added to its corporate limits, than is imposed on similar property within its limits at the time such land is added.

Art. XIII $\$ 183$.

Unless otherwise provided in the Constitution, the following property and 
no other shall be exempt from taxation, State and local, including inheritance taxes:

(2) Property owned directly or indirectly by the Commonwealth or any political subdivision thereof, and obligations of the Commonwealth issued since February fourteenth, eighteen hundred and eighty-two, or hereafter exempted by law.

(b) Buildings with land they actually occupy, and the furniture and furnishings therein and endowment funds lawfully owned and held by churches or religious bodies, and wholly and exclusively used for religious worship, or for the residence of the minister of any such church or religious body, together with the additional adjacent land reasonably necessary for the convenient use of any such building.

(c) Private or public burying grounds or cemeteries and endowment funds, lawfully held, for their care, provided the same are not operated for profit.

(d) Property owned by public libraries, incorporated colleges or other incorporated institutions of learning, not conducted for profit, together with the endowment funds thereof not invested in real estate. But this provision shall apply only to property primarily used for literary, scientific or educational purpose or purposes incidental thereto. It shall not apply to industrial schools which sell their product to others than their own employees or students.

(e) Real estate belonging to, actually and exclusively occupied and used by, and personal property, including endowment funds, belonging to Young Men's Christian Associations, and other similar religious associations, orphan or other asylums, reformatories, hospitals and nunneries, conducted not for profit, but exclusively as charities, also parks or playgrounds held by trustees for the perpetual use of the general public.

(f) Buildings with the land they actually occupy, and the furniture and furnishings therein, belonging to any benevolent or charitable association, together with such additional adjacent land as may be necessary for the convenient use of the buildings for such purposes; and

(g) Property of the Association for the Preservation of Virginia Antiquities, the Confederate Memorial Literary Society, the Mount Vernon Ladies' Association of the Union, the Virginia Historical Society, the Thomas Jefferson Memorial Foundation, Incorporated, the posts of the American Legion and such other similar organizations or societies as may be prescribed by law.

Except as to class (a) above, general laws may be enacted restricting but not extending the above exemptions.

Nothing contained in this section shall be construed to exempt from taxation the property of any person, firm, association, or corporation, who 
shall, expressly or impliedly, directly or indirectly, contract or promise to pay a sum of money or other benefit, on account of death, sickness, or accident to any of its members or other person.

Whenever any building or land, or part thereof, mentioned in this section, and not belonging to the State, shall be leased or shall otherwise be a source of revenue or profit, all of such buildings and land shall be liable to taxation as other land and buildings in the same county, city or town. But the General Assembly may provide for the partial taxation of property not exclusively used for the purposes herein named.

Nothing herein contained shall be construed as authorizing or requiring any county, city, or town to tax for county, city, or town purposes, in violation of the rights of lessees thereof, existing under any lawful contract heretofore made, any real estate owned by such county, city or town, as heretofore leased by it.

Obligations issued by counties, cities or towns may be exempted by the authorities of such localities from local taxation.

\section{Art. XIII §189.}

The General Assembly may, by general law, authorize the governing bodies of cities, towns and counties to exempt manufacturing establishments and works of internal improvement from local taxation for a period not exceeding five years, as an inducement to their location.

\section{WASHINGTON}

Const. 1889.

\section{Art. VII §1.}

The power of taxation shall never be suspended, surrendered or contracted away. All taxes shall be uniform upon the same class of property within the territorial limits of the authority levying the tax and shall be levied and collected for public purposes only. The word "property" as used herein shall mean and include everything, whether tangible or intangible, subject to ownership. All real estate shall constitute one class: Provided, That the legislature may tax mines and mineral resources and lands devoted to reforestation by either a yield tax or an ad valorem tax at such rate as it may fix, or by both. Such property as the legislature may by general laws provide shall be exempt from taxation. Property of the United States and of the state, counties, school districts and other municipal corporations, and credits secured by property actually taxed in this state, not exceeding in value the value of such property, shall be exempt from taxation. The legislature shall have power, by appropriate legislation, to exempt personal property to the amount of three hundred $(\$ 300.00)$ dollars for each head of a family liable to assessment and taxation under the provisions of the laws of this state of which the individual is the actual bona fide owner. 
Art. VII $\S 9$.

The legislature may vest the corporate authorities of cities, towns, and villages with power to make local improvements by special assessment, or by special taxation of property benefited. For all corporate purposes, all municipal corporations may be vested with authority to assess and collect taxes, and such taxes shall be uniform in respect to persons and property within the jurisdiction of the body levying the same.

\section{WEST VIRGINIA}

Const. 1872.

\section{Art. $X \S 1$.}

Subject to the exceptions in this section contained, taxation shall be equal and uniform throughout the State, and all property, both real and personal, shall be taxed in proportion to its value to be ascertained as directed by law. No one species of property from which a tax may be collected shall be taxed higher than any other species of property of equal value; except that the aggregate of taxes assessed in any one year upon personal property employed exclusively in agriculture, including horticulture and grazing, products of agriculture as above defined, including live stock, while owned by the producer, and money, notes, bonds, bills and accounts receivable, stocks and other similar intangible personal property shall not exceed fifty cents on each one hundred dollars of value thereon and upon all property owned, used and occupied by the owner thereof exclusively for residential purposes and upon farms occupied and cultivated by their owners or bona-fide tenants one dollar; and upon all other property situated outside of municipalities, one dollar and fifty cents; and upon all other such property situated within municipalities, two dollars; . . . but property used for educational, literary, scientific, religious or charitable purposes, all cemeteries, public property, the personal property, including live stock, employed exclusively in agriculture as above defined and the products of agriculture as so defined while owned by the producers may by law be exempted from taxation; household goods to the value of two hundred dollars shall be exempted from taxation. The legislature shall have authority to tax privileges, franchises, and incomes of persons and corporations and to classify and graduate the tax on all incomes according to the amount thereof and to exempt from taxation, incomes below a minimum to be fixed from time to time. . . .

\section{Art. VI $\$ 53$.}

The legislature may by general law define and classify forest lands. . . . Forest lands embraced in any such contract may be exempted from all taxation or be taxed in such manner, including the imposition of a severance tax or charge as trees are harvested, as the legislature may from time to time provide. ... 
Art. X $\$ 9$.

... but such [local] taxes shall be uniform, with respect to persons and property within the jurisdiction of the authority imposing the same.

\section{WISCONSIN}

Const. 1848.

\section{Art. VIII §1.}

The rule of taxation shall be uniform but the legislature may empower cities, villages or towns to collect and return taxes on real estate located therein by optional methods. Taxes shall be levied upon such property with such classifications as to forests and minerals including or separate or severed from the land, as the legislature shall prescribe. Taxes may also be imposed on incomes, privileges and occupations, which taxes may be graduated and progressive, and reasonable exemptions may be provided.

\section{WYOMING}

Const. 1890.

\section{Art. I §28.}

No tax shall be imposed without the consent of the people or their authorized representatives. All taxation shall be equal and uniform.

Art. XV §11.

All property, except as in this constitution otherwise provided, shall be uniformly assessed for taxation, and the legislature shall prescribe such regulations as shall secure a just valuation for tax of all property, real and personal.

\section{Art. XV §3.}

All mines and mining claims from which gold, silver and other precious metals, soda, saline, coal, mineral oil or other valuable deposit, is or may be produced shall be taxed in addition to the surface improvements, and in lieu of taxes on the lands, on the gross product thereof, as may be prescribed by law; provided, that the product of all mines shall be taxed in proportion to the value thereof.

\section{Art. XV §12.}

The property of the United States, the state, counties, cities, towns, school districts, municipal corporations and public libraries, lots with the buildings thereon used exclusively for religious worship, church parsonages, public cemeteries, shall be exempt from taxation, and such other property as the legislature may by general law provide. 


\section{Table of Cases}

\section{Alabams}

Alabama Gold Life Ins. Co. v. Lott, 54 Ala. 499 (1876) . . 100 American Bakeries Co. v. City of Huntsville, 232 Ala. 612, 168 So. 880 (1936) . . . . . 97

Barnes v. Moragne, 145 Ala. 313, 41 So. 947 (1906) . . . . . 99

Board of Revenue v. Montgomery Gas-Light Co., 64 Ala. 269 (1897) .............999

Board for Assessment of Property of R. Cos. v. Alabama Cent. Ry., 59 Ala. 551 (1877) ........102 Capital City Water Co. v. Board of Revenue, 117 Ala. 303, 23 So. 970 (1897) . . . . . . . .98

Clark \& Murrell v. Port of Mobile, 67 Ala. 217 (1880) . . . . .96 Eliasberg Bros. Mercantile Co. v. Grimes, 204 Ala. 492, 86 So. 56 (1920) . . . . . . 100, 103, $104,698,699,700,713,716$ Frazier v. State Tax Comm., 234 Ala. 353, 175 So. 402 (1937) 97 Goldsmith v. Huntsville, 120 Ala. 182, 24 So. 509 (1897) . . .98 Hamilton v. Adkins, 250 Ala. 557, 35 S. 2d 183 (1948) ......102 Jefferson County Sav. Bank v. Hewitt, 112 Ala. 546, 20 So. $926(1896) \ldots \ldots \ldots \ldots 100$

Lee v. State Tax Comm., 219 Ala. 513,123 So. $6(1929)$ $96,97,98,100$

Mobile v. Stonewall Ins. Co., 53 Ala. 570 (1876) . . . 100, 101 Moog v. Randolph, 77 Ala. 597 (1884) .........99, 101

Nachman v. State Tax Comm., 233 Ala. 628, 173 So. 25 (1937) . . $.96,97$

National Linen Service Corp. v.
State Tax Comm., 237 Ala. 360 , 186 So. 478 (1939) . . . . 96, 98 In $\operatorname{Re}$ Opinion of the Justices, 234 Ala. 358,175 So. 690 (1937) 99 Opinion of the Justices, 249 Ala. 572, 32 S. 2d 297 (1947) . . 99 Phoenix Carpet Co. v. State, 118 Ala. 143, 22 So. 627 (1897).. $\ldots \ldots \ldots \ldots \ldots . \ldots 9,98$

Proctor v. State, 215 Ala. 6, 109 So. 105 (1926) ....... 100

Pullman Car \& Mfg. Corp. of Alabama v. Hamilton, 229 Ala. 184, 155 So. 616 (1934) ...99, 100 Republic Iron \& Steel Co. v. State, 204 Ala. 469, 86 So. 65 (1920) 98

Saks v. Birmingham, 120 Ala. 190, 24 So. 728 (1897) . . . . . 98 State v. Alabama Fuel \& Iron Co., 188 Ala. 487, 66 So. 169 (1914) $\ldots \ldots \ldots \ldots \ldots$ 98, 99, 100 State v. Alabama Power Co., 254 Ala. 327, 48 S. 2d 445 (1950) $100,102,104$ State v. Birmingham Southern R. Co., 182 Ala. 475,62 So. 77 (1913) .......99, 100, 101 State v. Board of Revenue \& Road Com'rs, 73 Ala. 65 (1882) . 99

State v. Weil, 232 Ala. 578, 168 So. 679 (1936) . . . . 104, 699

State v. West Point Mfg. Co., 236 Ala. 467, 183 So. 449 (1938)

State Bank v. Board of Revenue, 91 Ala. 217, 8 So. 852 (1890) 101 Warrior Water Co. v. Long, 218 Ala. 125, 117 So. 656 (1928)

Western Union Tel. Co. v. State Board of Assessment, 80 Ala. 273, 60 Am. Rep. 99 (1885) . 96, 98 


\section{Arizono}

Berryman v. Bowers, 31 Ariz. 56, 250 Pac. 361 (1926) . . . . . . $385,547,548$

Brophy v. Powell, 58 Ariz. 543, 121 P. 2d 647 (1942) . . .547

City of Phoenix v. State ex rel. Conway, 53 Ariz. 28,85 P. 2d 56 (1938) .......... 546

Gila Meat Co. v. State, 35 Ariz. 194, 276 Pac. 1 (1929) . .. 546

Maricopa County v. Trustees of Arizona Lodge No. 2, F. \& A.M., 52 Ariz. 329, 80 P. 2d 955 (1938)

.548

Miners \& Merchants Bank v. Board of Sup'rs of Cochise County, 55 Ariz. 357, 101 P. 2d 461 (1940) ........548, 549

Pacific Fruit Exp. Co. v. City of Yuma, 32 Ariz. 601, 261 Pac. 49 (1927) . . . . . 547,549

People's Finance \& Thrift Co. v. Pima County, 44 Ariz. 440, 38 P. 2d 643 (1934) . ... . 547

Powell v. Gleason, 50 Ariz. 542,74 P. 2d 47 (1937) . . . . . 548

State v. Williams, 53 Ariz. 319, 89

P. $2 d 34$ (1939) . . . . . 546 State Tax Comm. v. Shattuck, 44 Ariz. 379, 38 P. 2d 631 (1934) $\ldots \ldots \ldots \ldots \ldots 547,548$

Stults Eagle Drug Co. v. Luke, 48 Ariz. 467, 62 P. 2d 1126 (1936) ...........546

Weller v. City of Phoenix, 39 Ariz. 148, 4 P. 2d 665 (1931) . 548 White v. Moore, 46 Ariz. 48, 46 P. 2d 1077 (1935) ..... 546

\section{Arkansas}

Baker v. Hill, 180 Ark. 387,21 S.W. 2d 867 (1929) .....58 Bensberg v. Parker, 95 S.W. $2 d 892$ (1936)
Ex parte Byles, 93 Ark. 612, 126 S.W. 94 (1910) . . . . . .. 51

Caton v. Western Clay Drainage Dist., 87 Ark. 8, 112 S.W. 145 (1908) ...........54

Davis v. Gaines, 48 Ark. 370,3 S.W. 184 (1886) ......53 Floyd v. Miller Lumber Co., 160 Ark. 17, 254 S.W. 450 (1923) $\ldots \ldots \ldots \ldots \ldots 52,53$

Fort Smith v. Scruggs, 70 Ark. 549, 69 S.W. 679 (1902) ......51 Ex parte Fort Smith \& Van Buren Bridge Co., 62 Ark. 461, 36 S.W. 1060 (1896) ..........55

Fulkerson v. Refunding Board, 201 Ark. 957, 147 S.W. 2d 980 (1941) .........51,58

Hardin v. Vestal, 204 Ark. 492, 162 S.W. 2 d 923 (1942) . . .52 Hays v. Missouri Pac. R. Co., 159 Ark. 101, 250 S.W. 879 (1923) $\ldots \ldots \ldots \ldots \ldots$

Little Rock \& Ft. S. R. Co. v. Worthen, 46 Ark. 312 (1885)

Martin v. Reynolds, 125 Ark. 163, 188 S.W. 4 (1916) .......53

Monticello v. Banks, 48 Ark. 251, 2 S.W. 852 (1886) . . . . . . 53 St. Louis, I. M. \& S. R. Co. v. Worthen, 52 Ark. 529, 135 S.W. 254 (1889) ...........55 St. Louis Southwestern R. Co. v. State, 106 Ark. 321, 152 S.W. 110 (1913) .........52 Sims v. Ahrens, 167 Ark. 557, 271 S.W. 720 (1925) .......51, $53,56,57,58,702,703,739$ Standard Oil Co. v. Brodie, 153 Ark. 114, 239 S.W. 753 (1922)

Stanley v. Gates, 179 Ark. 886, 19 S.W. 2d 1000 (1929) . . . . . $\ldots \ldots .51,52,56,57,58,703$ State v. Handlin, 100 Ark. 175, 139 S.W. 1112 (1911). .51, 52 
State ex rel. Nelson v. Meek, 127 Ark. 349, 192 S.W. 202 (1917) $\ldots \ldots \ldots \ldots \ldots \ldots 5$

Ward v. Bailey, 198 Ark. 27, 127 S.W. 2d 272 (1939) . . .51, 58 Waters-Pierce Oil Co. v. Hot Springs, 85 Ark. 509, 109 S.W. 293 (1942) . . . . . . . 52 Wiseman v. Phillips, 191 Ark. 63, 84 S.W. 2d 923 (1942). .51, 52

\section{California}

Arnold v. Hopkins, 203 Cal. 553, 265 Pac. 223 (1928) . . . 108 Bacon Service Corp. v. Huss, 199 Cal. 21, 248 Pac. 235 (1926)

Bank of California v. San Francisco, 142 Cal. 276, 75 Pac. 832 (1904) . . . . . . . . 112

Bank of California, Nat. Ass'n v. Roberts, 173 Cal. 398, 160 Pac. 225 (1916) . . . . . . . 114

Bueneman v. City of Santa Barbara, 8 Cal. 2d 405, 65 P. 2d 884 (1937) . . . . . . . . 111

Canfield v. Los Angeles, 157 Cal. 617, 108 Pac. 705 (1910) . 114 Chesebrough v. San Francisco, 153 Cal. 559, 96 Pac. 288 (1908).. 113,114

Crocker v. Scott, 149 Cal. 575, 87 Pac. 102 (1906) . . . . . . 114 Crosby v. Lyon, 37 Cal. 242 (1869) ............113

Dawson v. County of Los Angeles, 15 Cal. 2d 77, 98 Pac. 2d 495 (1940) . . . . . . . . 115

Douglas Aircraft Co. v. Johnson, 13 Cal. 2d 545, 90 P. 2d 572 (1939) . . . . . . 110,112 Fatjo v. Pfister, 117 Cal. 83, 48 Pac. 1012 (1897) 112, 113, 385 Flynn v. City \& County of San Francisco, $18 \mathrm{Cal}$. 2d 210, 115 P. $2 \mathrm{~d} 3$ (1941) . 112, 114, 115
Fox Bakersfield Theatre Corp. v. City of Bakersfield, 36 Cal. 2d 136, 222 P. 2d 879 (1950). 110 Germania Trust Co. v. San Francisco, $128 \mathrm{Cal} .589,61 \mathrm{Pac} .178$ (1900) . . . . . . . . 114

Ingels v. Riley, 5 Cal. 2d 154, 53 P. 2d 939 (1936) . . . . 112

Kaiser Land \& Fruit Co. v. Curry, 155 Cal. 638, 103 Pac. 341 (1909) . . . . . . . 110, 112

Los Angeles v. Los Angeles Independent Gas Co., 152 Cal. 765, 93 Pac. 1006 (1908) ..... 111 McAdams Oil Co. v. City of Los Angeles, 32 Cal. App. 2d 359, 89 P. 2d 729 (1939) . .111, 112

McClelland v. Board of Sup'rs, 30 Cal. 2d 124, 180 P. 2d 676 (1947) ............114

McKay v. San Francisco, 113 Cal. 392, 45 Pac. 696 (1896)

113,114

People v. Keith Ry. Equipment Co., 70 Cal. App. 2d 339, 161 P. 2d 244 (1945) .......321, 322

People v. Latham, 52 Cal. 598 (1878) ........... 113

People ex rel. Burke v. Badlam, 57 Cal. 594 (1881) .......114 Pullman Co. v. Richardson, 185 Cal. 484, 197 P. 346 (1922) . . 321,322

Ex parte Richardson, 170 Cal. 68, 148 Pac. 213 (1915) . . . . 111

Roehm v. County of Orange, 32 Cal. 2d 280, 196 P. 2d 550 (1948) . . . . . . . 116 Roth Drugs v. Johnson, $13 \mathrm{Cal}$. App. 2d 720, 57 P. 2d 1022 (1936) . . . . . . .111, 114 Sacramento v. Crocker, 16 Cal. 119 (1860) 109

San Francisco v. Anderson, 103 Cal. 69, 36 Pac. 1034 (1894) . . 114 San Francisco v. Fry, 63 Cal. 470 (1883) ............ 114 
Ex parte Schmolke, 199 Cal. 42, 248 Pac. 244 (1926) . . . . . 111 Spring Valley Water Works v. Schottler, 62 Cal. 69 (1882) 112 Town of St. Helena v. Butterworth, 198 Cal. 230, 244 Pac. 357 (1926).

In re Wilmerding's Estate, 117 Cal. 281, 49 Pac. 181 (1897)

110,111

\section{Colorado}

Altitude Oil Co. v. People, 70 Colo. 452, 202 Pac. 180 (1921).... 350,352

American Smelting \& Refining Co. v. People, 34 Colo. 240, 82 Pac. 531 (1905) . . . . . . 352

Ames v. People, 26 Colo. 83, 56 Pac. 656 (1899) ...... . 356 Ard v. People, 66 Colo. 480, 182 Pac. 892 (1919) . 350, 352, 355 Board of Com'rs of Washington County v. Murray, 71 Colo. 522 , 208 Pac. 472 (1922) . . . . 353 Brown v. Elder, 32 Colo. 527, 77 Pac. 853 (1904) .... 350, 351 Carbon County Sheep \& Cattle Co. v. Routt, 60 Colo. 224, 152 Pac. 903 (1915) .......... 354 Citizens' Committee v. Warner, 127 Colo. 121, 254 P. 2d 1005 (1953) ............ 356

City and County of Denver v. Tax Research Bureau, 101 Colo. 140, 71 P. 2d 809 (1937) . . . . 357 Colorado Nat. Life Assur. Co. v. Clayton, 54 Colo. 256, 130 Pac. 330 (1913) . . . . . . 353 Denver City Ry. Co. v. Denver, 21 Colo. 350, 41 Pac. 826 (1895) 350,351

Foster v. Hart Consol. Mining Co., 52. Colo. 459, 122 Pac. 48 (1912)......... 356
Gordon v. Wheatridge Water Dist., 107 Colo. 128, 109 P. 2d 899 (1941) ......353, 358, 359 Gunnison v. Owen, 7 Colo. 467, 4 Pac. 795 (1884) ........353 In re Hover Motors, 121 Colo. 439, 217 P. 2d 863 (1950) . . . 358 Hughes v. State, 97 Colo. 279, 49 P. 2d 1009 (1935) . . 350, 355 Hutchinson v. Herrick, 70 Colo. 534, 203 Pac. 275 (1922) . 354 Imperial Fire Ins. Co. v. Denver, 51 Colo. 456, 118 Pac. 970 (1911)

363

Jackson v. City of Glenwood Springs, 122 Colo. 323, 221 P. 2 d 1083 (1950) ......... 350,351

Kiowa v. Dunn, 21 Colo. 185, 40 Pac. 357 (1895) . . . 352, 355 Leonard v. Reed, 46 Colo. 307, 104 Pac. 410 (1909) . . . . 354 Logan Irr. Dist. v. Holt, 110 Colo. 253, 133 P. 2d 530 (1943) ... 353,358

People v. Henderson, 12 Colo. 369, 21 Pac. 144 (1888) ...... 356 People v. Pitcher, 56 Colo. 343, 138 Pac. 509 (1914) . . . . 356 Public Utilities Comm. v. Manley, 99 Colo. 153, 60 P. 2d 913 (1936) ......... 350, 352 Walker v. Bedford, 93 Colo. 400 , 26 P. 2d 1051 (1933) ........

$352,355,356$

\section{Connecticut}

Bassett v. Rose, 104 A. 2d 212 (1954) ........... 596

First Federal Svg. \& Loan Ass'n v. Connelly, 115 A. 2d 455 (1955)

Hoenig v. Connelly, 105 A. 2 d 775 (1954) ........... 596 In re Nettleton's Appeal, 76 Conn. 235, 56 At1. 565 (1903) ..... $.595,596$ Phelps Montgomery v. Branford, 
107 Conn. 697, 142 Att. 574 (1928) .......... 596 State v. Murphy, 90 Conn. 662, 98 Atl. $343(1916) \ldots \ldots \ldots 596$ State v. Travelers' Ins. Co., 73 Conn. 255, 47 Atl. 299 (1900) ............595, 596

\section{Delaware}

Brennan v. Black, 104 A. 2d 777 (1954) . . . . . . . . . 363

Conard v. State, 41 Del. 107, 16 A. 2d 121 (1940) . . . . . 360 Monaghan v. Lewis, 21 Del. 218, 59 Atl. 948 (1905) . . . . . 362 Philadelphia, B. \& W. R. Co. v. Mayor \& Council of Wilmington, 30 Del. Ch. 213, 57 A. 2d 759 (1948) ........... 362

State v. Pinder, 30 Del. (7 Boyce) 416, 108 Atl. 43 (1919) ..... $\ldots \ldots \ldots 361,696,699,713$

\section{Florida}

Bentley-Gray Dry Goods Co. v. City of Tampa, 137 Fla. 641, 188 So. 758 (1939) . . . . .278

Camp Phosphate Co. v. Allen, 77 Fla. 341,81 So. 503 (1919) 279 City of Lakeland v. Amos, $106 \mathrm{Fla}$. 873,143 So. 744 (1932) . . 277 Colonial Investment Co. v. Nolan, 100 Fla. 134, 131 So. 178 (1930) ............ 279

Coombes v. City of Coral Gables, 124 Fla. 374, 168 So. 524 (1936) . . . . . . . 279

Florida Sugar Distributors v. Wood, 135 Fla. 126, 184 So. 641 (1938) . . . . . . . . 276

Floyd Fruit Co. v. Florida Citrus Comm., $128 \mathrm{Fla} .565,175$ So. 248 (1937) . . . . . . . 277

Gaulden v. Kirk, 47 S. 2d 567 (1950) ........275, 276 Howey Co. v. Williams, 142 Fla. 415,195 So. 181 (1940) . .279
Jackson v. Neff, 64 Fla. 326, 60 So. 350 (1912) . . . 275, 276 Jacksonville Gas Co. v. Lee, 110 Fla. 61, 148 So. 188 (1933) 276 Klemm v. Davenport, 100 Fla. 627, 129 So. 904 (1930) . . . . .279 Louisville \& N.R. Co. v. Amos, 98 Fla. 350,123 So. 745 (1929)

Merrell v. St. Petersburg, 64 Fla. 367, 60 So. 349 (1912) . . 281 Owens v. Fosdick, 153 Fla. 17, 13 S. 2d 700 (1943) . . . . . 278 Peninsular Industrial Ins. Co. v. State, 61 Fla. 376,55 So. 398 (1911) . . . . . . . 276 Porter v. First Nat. Bank, 96 Fla. 740,119 So. 130 (1928) ..... 279,280

Shiep Co. v. Amos, 100 Fla. 863, 130 So. $699(1930) \ldots 275,277$ State v. City of Miami, $103 \mathrm{Fla} .54$, 137 So. 261 (1931) . . . . .279 State ex rel. Burbridge v. St. John, 143 Fla. 544, 197 So. 131 (1940) . . . . . . . . 278

State ex rel. Chavers v. Lee, 122 Fla. 638, 163 So. 92 (1935) .. .

State ex rel. Lane Drug Stores v. Simpson, 122 Fla. 582, 166 So. 227 (1935) . . . . . . 276 State ex rel. McKay v. Keller, 140 Fla. 346, 191 So. 542 (1939) 278 Town of Palm Beach v. City of West Palm Beach, 55 S. 2d 566 (1951) . . . . . . . . 279

\section{Georgia}

Athens v. Long, 54 Ga. 330 (1875) $\ldots \ldots \ldots 367,369,370,371$ Atlanta Nat. Building \& Loan Ass'n v. Stewart, 109 Ga. 80, 35 S.E. 73 (1899) .......... 374 Augusta v. National Bank, $47 \mathrm{Ga}$. $563(1873) \ldots .368,370,371$ 
Brown v. Southern Ry. Co., 125 Ga. 772, 54 S.E. 729 (1906) $\ldots \ldots \ldots \ldots \ldots \ldots 34$

Camp v. State, 171 Ga. 25, 154 S.E. 436 (1930) . . . . . 366

City of Atlanta v. Georgia Milk Producers Confederations, 187 Ga. 117, 200 S.E. 712 (1938) ............ 366

City of Douglas v. South Georgia Grocery Co., $180 \mathrm{Ga} .519,179$ S.E. 768 (1935) . . . . 366

Coy v. Linder, 183 Ga. 583, 189 S.E. $26(1936) \ldots \ldots \ldots 366$

Ewing v. Wright, 159 Ga. 303, 125 S.E. 445 (1924) . . . . 366

Farkas v. Smith, 147 Ga. 503, 94 S.E. $1016(1917) \ldots .366,367$

Featherstone v. Norman, $170 \mathrm{Ga}$. 370, 153 S.E. 58 (1930) . 366, $367,372,374,701,707,708$

Forrester v. Edwards, 192 Ga. 529, 15 S.E. 2d 851 (1941) . . 366 Georgia R. \& Banking Co. v. Wright, 125 Ga. 589 , 54 S.E. 52 (1906) . . . . . . . . 374

Georgia State Bldg. \& Loan Ass'n v. Savannah, 109 Ga. 63, 35 S.E. 67 (1899) . . . . . . . . . 374

Green \& Milam v. State Revenue Comm., 188 Ga. 442, 4 S.E. 2d 144 (1939) . . . . . . . 367

Guerry v. Harrison, 178 Ga. 669, 173 S.E. 831 (1934) ....366 Head v. Cigarette Sales Co., 188 Ga. 452, 4 S.E. 2d 203 (1939)

Hoffman \& Crowell v. Harrison, 171 Ga. 792, 156 S.E. 685 (1930) ........... 366

Hutchins v. Howard, 211 Ga. 830, 89 S.E. 2d 183 (1955) . . . 377 Johnston v. Macon, 62 Ga. 645 (1879) ...........366

Livingston v. Albany, 41 Ga. 21 (1870) ........367, 368
Lloyd v. Richardson, 158 Ga. 633, 124 S.E. 37 (1924) . . . . 366 Mutual Reserve Fund Life Ass'n v. Augusta, $109 \mathrm{Ga} .73,35$ S.E. 71 (1899) . . . . . . . . 366

O'Neal v. Siloam, 147 Ga. 420, 94 S.E. 238 (1917) . . . . 366 Parke, Davis \& Co. v. City of Atlanta, $200 \mathrm{Ga} .296,36$ S.E. 2d 773 (1946) ..........376

Price v. Richardson, 159 Ga. 299, 125 S.E. 449 (1924) . . . . 367 Richardson v. Citizens Trust Co., 176 Ga. 553, 168 S.E. 2d 306 (1932) . . . . . . . 366

Savannah v. Weed, 84 Ga. 683,11 S.E. 235 (1890) . . . 373, 376 Sheffield v. State School Bldg. Auth., 208 Ga. 575, 68 S.E. 2d 590 (1952) ........... 375 Singer Mfg. Co. v. Wright, $97 \mathrm{Ga}$. 114, 25 S.E. 249 (1895) . . 366 Southern Transfer Co. v. Harrison, 171 Ga. 358, 155 S.E. 338 (1930) ........... 366

Verdery v. Summerville, 82 Ga. 138,8 S.E. $213(1888) \ldots \ldots$ $.372,374,376,377$

Waring v. Savannah, 60 Ga. 93 (1878) . . . . . . . . 367, $369,371,372,696,708,716$ Wayne v. Savannah, 56 Ga. 449 (1876) ............ 369

Weaver v. State, 89 Ga. 639, 15 S.E. 840 (1892) .......366 Woolworth Co. v. Harrison, 172 Ga. 179, 156 S.E. 904 (1931) .............. 367

Wright v. Fulton County, $169 \mathrm{Ga}$. 354, 150 S.E. 262 (1929) . 366 Wright v. Hirsch, 155 Ga. 229, 116 S.E. 795 (1922) . . . .366

\section{Idaho}

Achenbach v. Kincaid, 25 Idaho 768, 140 Pac. 529 (1914) . 382 
Anderson's Red \& White Store $\mathbf{r}$. Kootenai County, 70 Idaho 260, 215 P. 2d 815 (1950) .... 383

Chapman v. Ada County, 48 Idaho 632, 284 Pac. 259 (1930) . 380

Chastain's, Inc. v. State Tax Comm., 72 Idaho 344, 241 P. 2d 167 (1952) ......383, 384, 385 Diefendorf v. Gallet, 51 Idaho 619, 10 P. 2 d 311 (1932) . 379, 380, $381,385,432,710,714,719$ Garrett Transfer \& Storage Co. v. Pfost, 54 Idaho 576, 33 P. 2d 743 (1934) . . . . . . . 379

Humbird Lumber Co. v. Kootenai, 10 Idaho 490, 79 Pac. 396 (1904) . . . . . . . . 386

Idaho Gold Dredging Co. v. Balderston, 58 Idaho 692, 78 P. $2 \mathrm{~d}$ 105 (1938) . . . . . 379, 380

J. C. Penney Co. v. Diefendorf, 54 Idaho 374, 32 P. $2 d 784$ (1934)

John Hancock Mut. Life Ins. Co. v. Haworth, 68 Idaho 185, $191 \mathrm{P}$. 2d 359 (1948) . . . . . . 382 Johnson v. Diefendorf, 56 Idaho 620, 57 P. 2d 1068 (1936) 379 Smallwood v. Jeter, 42 Idaho 169 , 244 Pac. 149 (1926) . .379, 382 State v. Crosson, 33 Idaho 140,190 Pac. 922 (1920) .......379 State v. Dunlap, 28 Idaho 784, 156 Pac. 1141 (1916) . . . . . 381 State v. Jones, 9 Idaho 693, 75 Pac. 819 (1904) . . . . . . 386 State ex rel. Bank of Eagle v. Leonardson, 51 Idaho 646, 9 P. 2d 1028 (1932) . . . . . . . 382 Washington County v. First Nat. Bank, 35 Idaho 438, 206 Pac. 1054 (1922) . . . . . 383, 384 Williams v. Baldridge, 48 Idaho 618, 284 Pac. 203 (1930) . . 382

Winton Lumber Co. v. Shoshone County, 50 Idaho 130, 294 Pac. 529. (1930) . . . . . . 386

\section{Illinois}

Anderson v. City of Park Ridge, 396 Ill. 235, 72 N.E. 2 d 210 (1947) .........132, 160

Ayres v. Chicago, 239 Ill. 237, 87 N.E. 1073 (1909) .....120

Bachrach v. Nelson, 349 Ill. 579, 182 N.E. 909 (1932) . . . . . $121,122,123,125,131,712$ Bistor v. McDonough, 348 Ill. 624, 181 N.E. 417 (1932) . . . 136 Board of Highway Com'rs v. Bloomington, 253 I11. 164, 97 N.E. 280 (1912) ........131

Braun v. Chicago, 110 Ill. 186 (1884) .......... 120 Bureau County v. Chicago B. \& Q.R. Co., 44 Ill. 229 (1867) . . $\ldots \ldots \ldots 135,138,144,145$ Chicago \& A.R. Co. v. Livingston County, 68 Ill. 458 (1873). 145 Chicago \& N.W. Ry. Co. v. Boone County, 44 Ill. 240 (1867) .... $\ldots \ldots \ldots \ldots \ldots 144,145$

City of Chicago v. Ames, 365 Ill. 529, 7 N.E. 2d 294 (1937) ... 120,121

City of Metropolis v. Gibbons, 334 III. 431,166 N.E. 115 (1929) $\ldots \ldots \ldots \ldots \ldots \ldots 120$

Coal Run Coal Co. v. Finlen, 124 Ill. 666,17 N.E. 11 (1888) . 150,155

Consolidated Coal Co. v. Miller, 236 Ill. 149, 86 N.E. 205 (1908) ............ 127 Cook County v. Fairbank, 222 Ill. 578,78 N.E. 895 (1906) . . . $\ldots \ldots \ldots \ldots 122,131,385$

Crane v. West Chicago Park Com'rs, 153 Ill. 348, 38 N.E. 943 (1894) ........... 126

Danville Banking \& Trust Co. v. Parks, 88 Ill. 170 (1878)..131 Department of Revenue v. Warren Petroleum Corp., 2 Ill. 2d 483, 
119 N.E. 2d 215 (1954)..... 148,149

Dunham v. Chicago, 55 Ill. 357 (1870).

First Nat. Bank v. Holmes, 246 Ill. 362, 92 N.E. 893 (1910) . 137 Friedrich v. Wright, 386 Ill. 229, 53 N.E. 2d 974 (1944) ..... 124,131

Harder's Fireproof Storage \& Van Co. v. Chicago, 235 Ill. 58, 85 N.E. 245 (1908) . . . 118, 120 Hub v. Hanberg, 211 Ill. 43, 71 N.E. 826 (1904) . . . . . 150 Illinois Central R. Co. v. Emmerson, 299 Ill. 328,132 N.E. 471 (1921) 128,129

Illinois Central R. Co. v. McLean, 17 Ill. 291 (1855) . . 128, 129 Illinois Nat. Bank v. Kinsella, 201 Ill. 31, 66 N.E. 338 (1903) . .

Illinois \& St. Louis Railroad \& Coal Co. v. Stookey, 122 Ill. 358, 13 N.E. 516 (1887) . . . . . 145 Johnson v. Daley, 403 Ill. 338, 86 N.E. 2d 350 (1949). 119 Johnson v. Halpin, 413 Ill. 257, 108 N.E. 2 d 429 (1952).

Kochersperger v. Drake, 167 Ill. 122, 47 N.E. 321 (1897) . . . $118,120,122$

Koester v. McDonough, 351 Ill. 492, 184 N.E. 826 (1933) 137 Law v. People, 87 111. 385 (1877) 145

McGrath v. Chicago, 309 Ill. 515, 141 N.E. 299 (1924) . . . 120 Melton v. City of Paris, 333 Ill. 190, 164 N.E. 218 (1928) 120 Metropolis Theater Co. v. Chicago, 246 III. 20,92 N.E. 597 (1910) aff'd 228 U.S. $61 \ldots \ldots \ldots 120$ Mobile \& Ohio R. Co. v. State Tax
Comm., 374 III. 75, 28 N.E. 2d $100(1940) \ldots \ldots \ldots \ldots \ldots$ $146,147,148,149,155$, $156,160,161,162,164,166$ Mutual Tobacco Co. v. Halpin, 414 III. 226, 111 N.E. $2 \mathrm{~d} 155$ (1953) ........... 121

Oak Ridge Cemetery Corp. v. Tax Comm., 299 Ill. 430, 132 N.E. 553 (1921) . . . . . . 127

Ohio Oil Co. v. Wright, 386 Ill. 206, 53 N.E. 2d 966 (1944). $.120,124,125,131,712$ Ottawa Gaslight \& Coke Co. v. Downey, 127 Ill. 201, 20 N.E. 20 (1889) . . . . . . . 150

People v. Cook County, 221 III. 493, 77 N.E. 914 (1906) . 126 People v. Deep Rock Oil Corp., 343 Ill. 388,175 N.E. 572 (1931) .............. 120

People v. Deutsche Gemeinde, 249 Ill. 132,94 N.E. 162 (1911) : .

128

People v. First Congregational Church, 232 Ill. 158,83 N.E. 536 (1907) . . . . . . . 127

People v. Keokuk \& Hamilton Bridge Co., 287 Ill. 246, 122 N.E. 467 (1919) . . . . 136

People v. Lots in Ashley, 122 III. 297, 13 N.E. 556 (1887) . . . . 127,136

People v. Missouri Pac. R. Co., 301 III. 541, 134 N.E. 314 (1922) 127

People v. National Box Co., 248 Il1. 141, 93 N.E. 778 (1910) . 127

People v. Noyes, 295 IIl. 355, 129 N.E. 151 (1920) . . . . 127 People v. O'Donnell, 327 Ill. 474, 158 N.E. 727 (1927) . . . 119 People v. Southwestern Bell Tel. Co., 377 Ill. 303, 36 N.E. 2d 362 (1941) . . . 139, 140, 165 
People v. Tatge, 267 Ill. 634, 108 N.E. 748 (1915) . . . . . 119

People ex rel. Carr v. Stewart, 315 III. 25,145 N.E. 600 (1924). .

136

People ex rel. Hempen v. Baltimore \& O. R. Co., 379 Ill. 543, 42 N.E. 2d 69 (1941) . . . . . 149

People ex rel. Koester v. Bd. of Review of Cook County, 351 Ill. 301, 184 N.E. 325 (1933) 137

People ex rel. Lloyd v. University of Illinois, 357 Ill. 369,192 N.E. 243 (1934) . . . . 128

People ex rel. McDonough v. Cesar, 349 Ill. 372,182 N.E. 448,

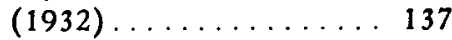

People ex rel. McDonough v. Grand Trunk Western R. Co., 357 Ill. 493, 192 N.E. 645 (1934)

$145,146,155,156,160$

People ex rel. McDonough v. Illinois Cent. R. Co., 355 Ill. 605, 190 N.E. 82 (1934) . . . . . . 145

People ex rel. McDonough v. Schmuhl, 359 Ill. 446, 194 N.E. 731 (1935) . . . . . . 138

People ex rel. Miller v. Chicago B. \& Q. R. Co., 300 Ill. 399, 133 N.E. 325 (1921) . . . . . 136

People ex rel. O'Connell v. Chicago \& W. I. R. Co., 256 Ill. 388, 100 N.E. 35 (1912) . . ...132

People ex rel. Olmstead v. University of Illinois, 328 Ill. 377,159

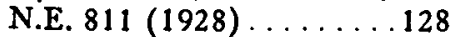

People ex rel. Prindable v. Union Elec. Power Co., 392 Ill. 271, 64 N.E. $2 d 534$ (1946) . . . . . $146,150,153$ $154,155,156,157,159,160$, $161,162,163,164,165,166$ People ex rel. Ross v. Chicago M. St. P. \& P. R. Co., 381 Ill. 58, 44 N.E. 2d 566 (1942) . . . 149 People ex rel. Schlaeger v. Allyn,
393 III. 154, 65 N.E. 2d 392 (1946) . . . . . . 139, 143

People ex rel. Smith v. Coen, 415 Iil. 73, 112 N.E. 2d 119 (1953)

People ex rel. Tedrick v. Allied Oil Corp. of Illinois, 388 Ill. 219, 67 N.E. 2d 859 (1944) . . . 141

People ex rel. Tennyson v. Texas Co., 406 Ill. 120,92 N.E. $2 \mathrm{~d}$ $142(1950) \ldots \ldots \ldots \ldots 141$

People ex rel. Toman v. Chicago Union Station Co., 383 Ill. 153, 48 N.E. 2d 524 (1943) . . 149

People ex rel. Toman v. Olympia Fields Country Club, 374 Ill. 101, 28 N.E. 2d 109 (1940) . . 139,140

People ex rel. Toman v. Pickard, 377 Ill. 610,37 N.E. $2 d 330$ (1941) . . . . . . . . 141

People ex rel. Wangelin v. Gillespie, 358 III. 40, 192 N.E. 664 (1934) . . . . . . . . 135

People ex rel. Wangelin v. St. Louis Bridge Co., 357 Ill. 245, 191 N.E. 300 (1934) . . . . . 135

People ex rel. Wangelin v. Wiggins Ferry Co., 357 Ill. 173, 191 N.E. 296 (1934) . 127, 135, 138 People's Gaslight \& Coke Co. v. Stuckart, 286 Ill. 164, 121 N.E. 629 (1919) . . . 135, 151, 155

People's Loan \& Homestead Ass'n v. Keith, 153 Ill. 609, 39 N.E. 1072 (1894) . . . . 126, 127

Porter v. Rockford, R. I., \& St. L. R. Co., 76 Ill. 561 (1875) ... . $129,149,154$ Primm v. Belleville, 59 Ill. 142 (1871) . . . . . . 126, 127 Raymond v. Hartford Fire Ins. Co., 196 I11. 329, 63 N.E. 745 (1902) . . . . . . 129 Reif v. Barrett, 355 Ill. 104, 188 N.E. 889 (1934) . . . 119, 740 
Rhinehart v. Schuyler, 7 Ill. 473 (2 Gilman) (1845) . . 126, 130 Routt v. Barrett, 396 Ill. 322, 71 N.E. 2d 660 (1947) . . . . 120

In re St. Louis Loan \& Investment Co., 194 Ill. 609,62 N.E. 810 (1902) ........... 127

In re Speed's Estate, 216 Ill. 23, 74 N.E. 809 (1905), aff'd 203 U.S. $553 \ldots \ldots \ldots \ldots 119$

Spencer \& Gardner v. People, 68 Ill. 510 (1873) . 127, 136, 137 Sterling Gas Co. v. Higby, 134 Ill. 557,25 N.E. 660 (1890) . 150 Supreme Lodge M. A. F. O. v. Board of Review, 223 IIl. 54, 79 N.E. 23 (1906) . . . . . 128 Tuttle v. Bell, 377 11l. 510, 37 N.E. 2d 180 (1941) . . . . 141 Winter v. Barrett, 352 Ill. 441, 186 N.E. 113 (1933) . 119, 121, 740 Young v. Illinois Athletic Club, 310 Ill. 75, 141 N.E. 369 (1923). . $123,212,712$

\section{Indiana}

Baldwin v. State, 194 Ind. 303, 141 N.E. 343 (1924) . . . . . 283

Barber Grocery Co. v. Fleming, 229 Ind. 140, 96 N.E. 2d 108 (1915) ........... 283

Bright v. McCullough, 27 Ind. 223 (1866) .........286, 287

Clark v. Vandalia R. Co., 172 Ind. 409, 86 N.E. 851 (1909) . 287

Cleveland, C., C. \& St. L. Ry. Co. v. Backus, 133 Ind. 513, 33 N.E. 421 (1892) . . . . . . 286

Conter v. Commercial Bank, 209 Ind. 510, 199 N.E. 567 (1936) .............. 288

Crittenberger v. State Savings and Trust Co., 189 Ind. 411,127 N.E. 552 (1920) . . 282, 283 Eavey Co. v. Department of Treasury of Indiana, 216 Ind. 255,
24 N.E. 2d 268 (1939) . . . . . 282,283

Ehle v. State, 191 Ind. 502, 133 N.E. 748 (1922) ......286 Forrey v. Board of Com'rs. of Madison County, 189 Ind. 257, 126 N.E. $673(1920) \ldots \ldots \ldots 286$ Gafill v. Bracken, 195 Ind. 551, 145 N.E. 312 (1925).282, 285 Henderson v. London \& Lancashire Ins. Co., 135 Ind. 23, N.E. 565 (1893) . . . . . . . . 283 Johnson v. Board of Park Com'rs of Ft. Wayne, 202 Ind. 282, 174 N.E. 91 (1930) . . 286, 288 Johnson v. Johnson, 173 Ind. 76, 89 N.E. 590 (1909) . . . . . . $287,288,302$ Kelly v. Finney, 207 Ind. 557, 194 N.E. 157 (1935) . . . 282, 283 Kersey v. Terre Haute, 161 Ind. 471, 68 N.E. 1027 (1903).282 Lutz v. Arnold, 208 Ind. 480, 193 N.E. 840 (1935) . . . ..282, 285, 294, 296, 299, 301, 303 Midwestern Petroleum Corp. v. State Board of Tax Com'rs, 206 Ind. 688,187 N.E. 882 (1934) 283

Miles v. Department of Treasury, 209 Ind. 172, 193 N.E. 855 (1935)

$282,283,285,304,306,739$

Richmond Baking Co. v. Department of Treasury, 215 Ind. 110 , 18 N.E. 2d 778 (1939) . . 282 Smith v. Stephens, 173 Ind. 564, 91 N.E. 167 (1910) . . . 287 Stark v. Kreyling, 207 Ind. 128, 188 N.E. 680 (1934) 288,298 State ex rel. Lewis v. Smith, 158 Ind. 543, 63 N.E. 25 (1902)

State ex rel. Morgan v. Workingmen's Bldg. \& Loan Fund \& Savings Ass'n, 152 Ind. 278 (1899) 288 
State ex rel. Tieman v. Indianapolis, 69 Ind. 375, 35 Am. Rep. 223 (1879) . . . . . . . . 288 State Board of Tax Com'rs. v. Holliday, 150 Ind. 216,49 N.E. 14 (1897) . . . . . 289, 290, $291,298,299,300,302,303$ Terre Haute v. Kersey, 159 Ind. 300,64 N. E. 469 (1902) . 283 In re Todd, 208 Ind. 168, 193 N.E. 865 (1935) . . . . . 306 Wright v. House, 199 Ind. 247, 121 N.E. 433 (1918) . . .286

\section{Iorva}

Dickinson v. Porter, 240 lowa 303, 35 N.W. 2d 66 (1949) . . . 598 Dubuque v. Illinois Cent. R. Co., 39 Iowa 56 (1874) ......599

Hawkeye Ins. Co. v. French, 109 Iowa 585, 80 N.W. 660 (1899)

Iowa Motor Vehicle Ass'n v. Board of Railroad Com'rs., 207 Iowa 461, 221 N.W. 364 (1928) 597

Leicht v. Burlington, 73 Iowa 29, 34 N.W. 494 (1887) . . . 598

Pierce v. Green, 229 lowa 22, 294 N.W. 237 (1940) . ..597, 598 Plank v. Grimes, 238 Iowa 594, 28 N.W. 2d 34 (1947) . . . . 597 Scottish Union \& National Ins. Co. v. Herriott, 109 lowa 606, 80 N.W. 665 (1899) . . ..... 598

Tolerton \& Warfield Co. v. Iowa State Board of Assessment and Review, 222 lowa 908, 270 N.W. 427 (1937) . . 597, 598 Vilas v. Iowa State Board of Assessment \& Review, 223 Iowa 604, 273 N.W. 338 (1937)... .........597, 598, 738

W. J. Sandberg Co. v. Iowa State Board of Assessment and Review, 225 Iowa 103, 278 N.W. 643 (1938) 597

\section{Kansas}

Alpha Tau Omega v. Board of Com'rs. of Douglas County, 136 Kan. 675, 18 P. 2d 573 (1933)

Associated Ry. Equipment Owners v. Wilson, $167 \mathrm{Kan}$. 608, $208 \mathrm{P}$. 2d 604 (1949)

$318,319,321,322,323,332$ Atchison T. \& S. F. Ry. Co. v. Howe, 32 Kan. 737, 5 Pac. 397 (1884) .......... 312

Chicago B. \& Q. R. Co. v. Atchison County, 54 Kan. 781, 39 Pac. 1039 (1895)..........312

Citizens' Bank v. Tax Comm. of Kansas, 132 Kan. 5, 294 Pac. 940 (1931) . . 313, 324, 329 City of Chanute v. State Comm. of Revenue \& Taxation, 156 Kan. 538, 134 P. $2 d 672$ (1943) 309 City of Harper v. Fink, 148 Kan. 278, 80 P. 2d 1080 (1938) ... .

Davis Wellcome Mfg. Co. v. Haynes, 119 Kan. 1, 237 Pac. 918 (1925) . . . . . . . . 327

First Nat. Bank v. Geary, $102 \mathrm{Kan}$. 334, 170 Pac. 33 (1918) . . 312 Francis v. Atchison T. \& S. F. R. Co., 19 Kan. 303 (1877) . . . . $313,314,316,318,320$ Graham v. Chautauqua County, 31 Kan. 473, 2 Pac. 549 (1884).. ............... 310

Gunkle v. Killingsworth, $118 \mathrm{Kan}$. 154, 233 Pac. 803 (1925)..... Hamilon wilson $61.310,311$ 59 Pac. $1069(1900) \ldots . .310$ Hartman v. State Comm. of Revenue \& Taxation, 164 Kan. 67, 187 P. 2 d 939 (1947) . 309, 738 Hines v. Leavenworth, 3 Kan. 186 (1864) ............ 312 Hunt v. Allen, 82 Kan. 824, 109 Pac. 106 (1910) . . . . . 312 
Hunt v. Eddy, 150 Kan. 1, 90 P. 2d 747 (1939)........... $\ldots \ldots \ldots 323,330,331,332$ Marion \& M. Ry. Co. v. Champlin, 37 Kan. 682, 16 Pac. 222 (1887) .......... 310 In re Martin, 62 Kan. 638, 64 Pac. 43 (1901) . ....... 309 Midland Elevator Co. v. Stewart, 50 Kan. 378, 32 Pac. 33 (1893)

312

Newton v. Atchison, 31 Kan. 151, 1 Pac. 288 (1883) ....... 309 Ottawa v. Nelson, 19 Kan. 234 (1877) ......... 313

In re Page, $60 \mathrm{Kan} .842,58 \mathrm{Pac}$. 478 (1899) . . . . . . 312

Ritchie v. Ahlstedt, 105 Kan. 739, 186 Pac. 131 (1919) ......310 Ryan v. Tax Comm. of Kansas, 132 Kan. 1, 294 Pac. 938 (1931). . 330

State v. Cumiskey, 97 Kan. 343, 155 Pac. 47 (1916) . ... 312

State v. Wilson, 101 Kan. 789, 168 Pac. 679 (1917) . . . . 308 State ex rel. Arn v. Cline, 91 Kan. 416, 137 Pac. 932 (1914). 308,309

State ex rel. Arn v. State Comm. of Revenue \& Taxation, $163 \mathrm{Kan}$. 240, 181 P. 2d 532 (1947) 308,309

State ex rel. Beck v. Board of Com'rs. of Barton County, 142 Kan. 624, 51 P. 2d 33 (1935)

State ex rel. Fatzer v. Board of Regents, 167 Kan. 587, $207 \mathrm{P}$. 2d 373 (1949) . . . . . . 310 Stevenson v. Metsker, 130 Kan. 251, 286 Pac. 673 (1930) . . . . $\ldots \ldots \ldots .318,328,329,331$

Sumner County v. Wellington, 66 Kan. 590, 72 Pac. 216 (1903) $.310,311$

Voran v. Wright, 129 Kan. 1, 281
Pac. 938 (1929), rehearing 129 Kan. 601, 284 Pac. 807 (1930) $326,327,328,329,331$ Wheeler v. Weightman, 96 Kan. 50, 149 Pac. 977 (1915) ..... $309,311,312,313,316,318$

\section{Kentucky}

Booth's Ex's v. Commonwealth, 130 Ky. 88, 113 S.W. 61 (1908) . .

City of Greenville v. Martin, 308 Ky. 247, 214 S.W. 2d 271 (1948) . . . . . . . . . 552 City of Louisville v. Sebree, 308 Ky. 420, 214 S.W. 2d 248 (1948) . . . . . . . . 552

Eminence Distillery Co. v. Henry County Board of Sup'rs, $178 \mathrm{Ky}$. 811, 200 S.W. 347 (1918) 553 Fayette County Board of Sup'rs v. O'Rear, 275 S.W. 2d (Ky.) 577 (1955) ........... 553 Great Atlantic \& Pacific Tea Co. v. Kentucky Tax Comm., $278 \mathrm{Ky}$. 367, 128 S.W. 2d 581 (1939) 551,552 Intercounty Rural Electric Co-op. Corp. v. Reeves, $294 \mathrm{Ky}$. 458, 171 S.W. 2d 978 (1943)..553 Klein v. Jefferson County Board of Tax Sup'rs, $230 \mathrm{Ky}, 182,18$ S.W. 2d 1009 (1929) .... 553 Martin v. City of Greenville, 312 Ky. 292, 227 S.W. 2d 435 (1940) . . . . . . . 552 Martin v. High Splint Coal Co., $268 \mathrm{Ky} .11,103$ S.W. 2d 711 (1937) ........... 553 Middendorf v. Goodale, $202 \mathrm{Ky}$. 118, 259 S.W. 59 (1923) . 552 Raydure v. Board of Sup'rs of Estill County, $183 \mathrm{Ky} .84,209$ S.W. 19 (1919) . . . 552, 553,554

Reeves v. Adam Hat Stores, Inc., $303 \mathrm{Ky} .633,198$ S.W. 2d 789 (1947)......... 552 
Reeves v. Island Creek Fuel \& Transp. Co., $313 \mathrm{Ky} .400,230$ S.W. 2d 924 (1950) ..... 553

Reynolds Metals Co. v. Martin, 269 Ky. 378, 108 S.W. 2d 251 (1937) ........552,738

\section{Maine}

Brewer Brick Co. v. Brewer, 62 Me. 62, 16 Am. Rep. 395 (1873) .....60, 62, 63, 64

Cumberland County Power \& Light Co. v. Hiram, $125 \mathrm{Me} .138,131$ Atl. 594 (1926) . . . . . .6 61

Dyar v. Farmington Village Corp., $70 \mathrm{Me} .515$ (1878) ... 61, 63

Hamilton v. Portland State Pier Site Dist., 120 Me. 15, 112 Atl. 836 (1921)

In re Opinion of the Justices, 97 Me. 595, 55 Atl. 827 (1903)61 In re Opinion of the Justices, 102 Me. 527, 66 Atl. 726 (1907) . 62,63

In re Opinion of the Justices, 123 Me. 573, 121 Atl. 902 (1923). . $59,61,62$

In re Opinion of the Justices, 133 Me. 525, 178 Atl. 621 (1935). . $59,60,737$

Portland v. Portland Water Co., 67 Me. 135 (1877) . . . . .662 Sandy River Plantation v. Lewis, 109 Me. 472, 84 Atl. 995 (1912) . . . . . . . . 58

Sears, Roebuck \& Co. v. Inhabitants of City of Presque Isle, $150 \mathrm{Me}$. 181, 107 Atl. 2d 475 (1954) 61 Spear v. Bath, $125 \mathrm{Me}$. 27, 130 Atl. 507 (1925).

State v. F. H. Vahlsing, Inc., 147 Me. 417, 88 Atl. 2d 144 (1952)

State v. Hamlin, 86 Me. 495, 30 Atl. 76 (1894) .........559 State v. Maine Cent. R. Co., 74 Me. 376 (1883) .......59
State v. Western Union Telegraph Co., 73 Me. 518 (1882) . . .59 Stevens v. Dixfield \& Peru Bridge Co., 115 Me. 402, 99 Atl. 94 (1916) . . . . . . . . 61

Wheeler v. County Commissioners, $88 \mathrm{Me} .174$ (1895).....61

\section{Maryland}

Anne Arundel County Com'rs v. English, $182 \mathrm{Md}$. 514, 35 A. 2d 135 (1943) .........556

Baltimore v. Starr Methodist Protestant Church, 106 Md. 281, 67 At1. 261 (1907) . .....556

Bevard v. Baughman, 167 Md. 55, 173 Atl. 40 (1934) ..... 555

Herman v. Mayor \& City Council of Baltimore, 189 Md. 191, 54 A. 2d 491 (1947) ......557 Jones v. Gordy, 169 Md. 173, 180 Atl. 272 (1935).......555

McGraw v. Merryman, $133 \mathrm{Md}$. 247, 104 Atl. 540 (1918) . 556

Oursler v. Tawes, $178 \mathrm{Md}$. 471, 13 A. 2d 763 (1940) 556, 738, 771

Rohr v. Gray, 80 Md. 274, 30 Atl. 632 (1894) ........ 555

Ruggles v. State, $120 \mathrm{Md}$. 553, 87 At]. 1080 (1913) ......555

Simpson v. Hopkins, 82 Md. 478, 33 Atl. 714 (1896) ......556

State v. Applegarth, 81 Md. 293, 31 Atl. 961 (1895) .....555

State v. Cumberland \& P. R. Co., $40 \mathrm{Md} .22$ (1873) . ......556

State v. Dalrymple, 70 Md. 294, 17 Atl. 82 (1889) . . . . . . 555

State v. Philadelphia, W. \& B. R. Co., 45 Md. 361, 24 Am. Rep. $511(1876) \ldots \ldots .555,556$

State Tax Commission v. Brandt Cabinet Works, 97 A. 2d 290 (1953) .......... 557

Tyson v. State, 28 Md. 586 (1868) 
Wells v. Hyattsville, 77 Md. 125, 26 Atl. 357 (1893) . . . . 556

\section{Massachusetts}

Alpha Portland Cement Co. v. Comm., 244 Mass. 530, 139 N.E. 158 (1923) 174, 692, 741

Assessors of Boston v. Metropolitan Life Ins. Co., 320 Mass. 559, 70 N.E. 2d 806 (1947) . . . . 176

Assessors of West Springfield v. Eastern States Exposition, 326 Mass. 167, 93 N.E. 2d 462 (1950) ..........

Board of Assessors of City of Quincy v. Cunningham Foundation, 305 Mass. 411, 26 N.E. 2d 335 (1940) .........176

Boston Fish Market Corp. v. Boston, 224 Mass. 31, 112 N.E. 616 (1916) . . . . . . 176

Cheshire v. Berkshire, 118 Mass. 386 (1875) . . . . . . 179

Connecticut Mutual Life Ins. Co. v. Comm., 133 Mass. 161 (1882) $174,179,180$

Day v. Lawrence, 167 Mass. 371, 45 N.E. 751 (1897) . 176, 177

Farr Alpaca Co. v. Comm., 212 Mass. 156, 98 N.E. 1078 (1912)

Gleason v. McKay, 134 Mass. 419 (1880)

173

Massachusetts General Hospital v. Belmont, 233 Mass. 190, 124 N.E. 21 (1919) . . . . . . 176 Minot v. Winthrop, 162 Mass. 113, 38 N.E. 512 (1894) . . . . 174 Newhall v. Assessors of Brookline, 329 Mass. 100, 106 N.E. 2d 432 (1952) . . . . . 176, 177 Northampton v. Hampshire, 145 Mass. 108, 13 N.E. 388 (1887)
O'Keefe v. Somerville, 190 Mass. 110,76 N.E. 457 (1906) . .173 Oliver v. Washington Mills, $11 \mathrm{Al}$ len (Mass.) 268 (1865)

173,179

In re Opinion of the Justices, 195 Mass. 607, 84 N.E. 499 (1907) $\ldots \ldots \ldots \ldots \ldots 175,179$

In re Opinion of the Justices, 196 Mass. 603, 85 N.E. 545 (1907) $\ldots \ldots \ldots \ldots \ldots 174,175$

In re Opinion of the Justices, 208 Mass. 616, 94 N.E. 1043 (1911) 175

In re Opinion of the Justices, 220 Mass. 613, 108 N.E. 570 (1915) $179,180,690$

In re Opinion of the Justices, 261 Mass. 523, 159 N.E. 55 (1928) 176

In re Opinion of the Justices, 266 Mass. 583, 165 N.E. 900 (1929) $\ldots \ldots \ldots 174,179,180,691$

In re Opinion of the Justices, 266 Mass. 590, 165 N.E. 904 (1929)

In re Opinion of the Justices, 270 Mass. 593, 170 N.E. 800 (1930) 181

In re Opinion of the Justices, 324 Mass. 724, 85 N.E. 2d 222 (1949) .........175, 177

Perkins v. Westwood, 226 Mass. 268, 115 N.E. 411 (1917) . . . 175, 178, 179

Portland Bank v. Apthorp, 12 Mass. 252 (1815) ...173, 174, 180 Pratt v. Dean, 246 Mass. 300,140 N.E. 924 (1923) . . . . . . 174 Tax Comm'r v. Putnam, 227 Mass. 522, 116 N.E. 904 (1917) 181 White Dental Mfg. Co. v. Comm., 212 Mass. 35, 98 N.E. 1056 (1912) .........173,174 Wilcox v. Middlesex, 103 Mass: $544(1870) \ldots \ldots \ldots 180,690$ 


\section{Michigan}

Attorney General v. Sanilac, 71 Mich. 16, 38 N.W. 639 (1888)

214

Auditor General v. MacKinnon

Boiler \& Machine Co., 199 Mich. 489, 165 N.W. 771 (1917) . . . . . . . 213

Bacon v. Board of State Tax Com'rs., 126 Mich. 22, 85 N.W. 307 (1901) ..........214

Banner Laundering Co. v. State Board of Tax Administration, 297 Mich. 419, 298 N.W. 73 (1941) . . . 200, 212, 214

Cleveland-Cliffs Iron Co. v. Department of Revenue, 329 Mich. 225, 45 N.W. 2d 46 (1950).

211

Detroit v. Kresge, 200 Mich. 668, 167 N.W. 39 (1918) ...214

First Nat. Bank v. Common Council of City of Detroit, 253 Mich. 89, 234 N.W. 151 (1931) . . . $\ldots \ldots \ldots \ldots 214,215,217$

In re Estate of Fish, 219 Mich. 369, 189 N.W. 177 (1922) ....211

Goodenough v. Dept. of Revenue, 328 Mich. 56, 43 N.W. 2d 235 (1950)

210

Jasnowski v. Board of Assessors of Detroit, 191 Mich. 287, 157 N.W. 891 (1916) .211, 213, 215

Kull v. Michigan State Apple Commission, 296 Mich. 262, 296 N.W. 250 (1941) . . . . 212

Lake Shore Coach Lines v. Sec. of State, 327 Mich. 146, 41 N.W. 2d 503 (1950) . . . 212, 215

Lucking v. People, 320 Mich. 495, 31 N.W. 2d 707 (1948) . . 213 Marquette v. Michigan Iron \& Land Co., 132 Mich. 130, 92 N.W. 934 (1903) . . . . . . 214 Miller v. Michigan State Apple Commission, 296 Mich. 248, 296 N.W. 245 (1941) . ..212, 214
Ontonagon v. Gogebic, 74 Mich. 721, 42 N.W. 170 (1889) . . 214 People ex rel. St. Mary's Falls Ship Canal Co. v. Auditor General, 7 Mich. 84 (1859) . ......213 Pingree v. Auditor General, 120 Mich. 95, 78 N.W. 1025 (1899) $\ldots \ldots \ldots \ldots \ldots 200,203$, $204,205,209,210,213,246$ Shapero v. State Department of Revenue, 322 Mich. 124, 33 N.W. 2d 729 (1948) . 198, 205, $207,208,210,212,215,216$ Shivel v. Kent County Treasurer, 295 Mich. 10, 294 N.W. 78 (1940)

205,207,208,210,212, 214 Smith Co. v. Fitzgerald, 270 Mich. 659 N.W. 352 (1935) . . . . . 200,207,212, 214, 215 Stroh v. Detroit, 131 Mich. 109, 90 N.W. 1029 (1902) .

$214,216,217$

Stumpf v. Storz, 156 Mich. 228, 120 N.W. 618 (1909) . .. 214

Thoman v. City of Lansing, 315 Mich. 566, 24 N.W. 2d 213 (1946) .........214

Thrall v. Guiney, 141 Mich. 392, 104 N.W. 646 (1905) . . . 214

Union Steam Pump Sales Co. v. Deland, 216 Mich. 261, 185 N.W. 353 (1921) .....211, 215

Union Trust Co. v. Detroit, 170 Mich. 692, 137 N.W. 122 (1912) ......205, 212, 213

Union Trust Co. v. Wayne Probate Judge, 125 Mich. 487, 84 N.W. 1101 (1901)

$199,202,203,204,211,215$ Voorhies v. Walker, 227 Mich. 291, 198 N.W. 994 (1924) .... 214

\section{Minnesota}

Almer Ry. Equipment Co. v. Commissioner of Taxation, 213, 
Minn. 62, 5 N.W. 2d 637 (1942) .............321 Apartment Operators' Ass'ns v. City of Minneapolis, 191 Minn. 365, 254 N.W. 443 (1934). $398,406,407,408$ Bidwell v. Coleman, 11 Minn. 45 (1865) .............396

City of Minneapolis v. Armson, 188 Minn. 167, 246 N.W. 660 (1933) ........4400, 415

Dohs v. Holm, 152 Minn. 529, 189 N.W. 418 (1922) . 399, 400, 407

Drew v. Tifft, 79 Minn. 175,81 N.W. 839 (1900) . . 397, 400

Faribault v. Misener, 20 Minn. 396 (1874) .............397

Hassler v. Engberg, 233 Minn. 487, 48 N.W. 2d 343 (1951).

399,408

In re Improvements of Third St., St. Paul, 185 Minn. 170, 240 N.W. 355 (1932) ...... 396

LeDuc. v. Hastings, 39 Minn. 110 , 38 N.W. 803 (1888) . . . . 395

Lyons v. Spaeth, 220 Minn. 563, 20 N.W. 2d 481 (1945) . . 399

McReavy v. Holm, 166 Minn. 22, 206 N.W. 942 (1926) . 399, 400

Mutual Benefit Life Ins. Co. v. Martin, 104 Minn. 179, 116 N.W. 472 (1908) .400, 403, 405

National Tea Co. v. State, 205 Minn. 443, 286 N.W. 360 (1939) ......... 339

National Tea Co. v. State, 208 Minn. 607, 294 N.W. 230 (1940) ..........400

Pullman Co. v. Com'r of Taxation, 223 Minn. 96, 25 N.W. 2d 838 (1947) . 403, 411, 412, 414, 415 Railway Exp. Agency v. Holm, 180 Minn. 268, 230 N.W. 815 (1930)........400, 414 Raymond v. Holm, 165 Minn. 216, 206 N.W. 166 (1925) . . . .400
Reed v. Bjornson, 191 Minn. 254, 253 N.W. 102 (1934) . 398, 399, $401,407,413,415,728,730$ Sanborn v. Rice, 9 Minn. 273 (1864) . . . . . . . 396 Sperry v. Flygare, 80 Minn. 325, 83 N.W. 177 (1900) ....396 State v. Canada Cattle Car Co., 85 Minn. 457, 89 N.W. 66 (1902) 396

State v. Duluth, M. \& N. R. Co., 207 Minn. 618, 292 N.W. 411 (1939)

$403,410,411,412,414,415$ State v. Lakeside Land Co., 71 Minn. 283, 73 N.W. 970 (1898) 396

State v. Pioneer Savings \& Loan Co., 63 Minn. 80, 65 N.W. 138 (1896) ............395

State v. Twin City Tel. Co., 104 Minn. 270, 116 N.W. 835

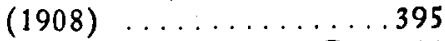

State v. Wells Fargo \& Co., 146 Minn. 444, 179 N.W. 221 (1920) . . . . . . 400, 409 State ex rel. Davidson v. Gorman, 40 Minn. 232, 41 N.W. 948 (1889) . . . . . 386, 396 State ex rel. Foote v. Bazille, 97 Minn. 11, 106 N.W. 93 (1906)

State ex rel. Frye v. Bazille, 87 Minn. 500, 92 N.W. 415 (1902) 397

State ex rel. Graff v. Probate Court, 128 Minn. 371, 150 N.W. 1094 (1913) ...... 399, 400, 407 State ex rel. Hildebrandt v. Fitzgerald, 117 Minn. 192, 134 N.W. 728 (1912) . . . . 404 State ex rel. St. Paul City Ry. Co. v. Minnesota Tax Comm., 128 Minn. 384, 150 N.W. 1087 (1915) ..........406 State ex rel. Winona Motor Co. v. Minnesota Tax Comm., 117 
Minn. 159, 134 N.W. 643 (1912) 405

Stinson v. Smith, 8 Minn. 326 (1863) ...........396

Thomas Stores Sales System v. Spaeth, 209 Minn. 504, 297 N.W. 9 (1941) . . . . 398, 399 Western Union Tel. Co. v. Spaeth, 232 Minn. 128, 44 N.W. 2d 440 (1950) .415

\section{Mississippi}

Adams v. Miss. State Bank, 75 Miss. 701, 23 So. 395 (1898) . .253

Barnes v. Jones, 139 Miss. 675, 103 So. 773 (1925) 251

Brennan v. Mississippi Home Ins. Co., 70 Miss. 531,13 So. 228 (1893) 252

Chicago, R.I. \& P.R. Co. v. Robertson, 122 Miss. 417,84 So. 499 (1920)

253

City of Jackson v. Edwards House, 145 Miss. 135, 110 So. 231 (1926) 252

Clarksdale Ins. Agency v. Cole, 87 Miss. 637, 40 So. 228 (1906) 250

Coca Cola Co. v. Skillman, 91 Miss. 677, 44 So. 985 (1908) . . 250

Dams v. Bank of Oxford, 78 Miss. 532,29 So. 402 (1900) . .253 Enochs v. State, 133 Miss. 107, 97 So. 534 (1923) ...... 252 Gulf Refining Co. v. Stone, 197 Miss. 713, 21 S. 2d 19 (1945) $\ldots \ldots \ldots \ldots \ldots \ldots 252$

Hattiesburg Grocery Co. v. Robertson, 126 Miss. 34,88 So. 4 (1921) ........252, 700

Hawkins v. Mangum, 78 Miss. 97, 28 So. 872 (1906) . . . . . 253

Jackson v. Mississippi Fire Ins. Co., 132 Miss. 415, 95 So. 845 (1923) 252
Johnson v. Long Furniture Co., 113 Miss. 373, 74 So. 283 (1917) ...............250

Miller v. Lamar Life Ins. Co., 158 Miss. 753, 131 So. 282 (1930) 252

Mississippi Power \& Light Co. v. Love, 201 Miss. 676, 27 S. 2d 850 (1946) . . . . . 252, 253 Notgrass Drug Co. v. State, 175 Miss. 358,165 So. 884 (1936) 250,739

State ex rel. Knox v. Gulf, M. \& N.R. Co., 138 Miss. 70, 104 So. 689 (1925) . . 250, 252, 700

Stone v. General Contract Purchase Corp., 193 Miss. 301, 7 S. 2d 806 (1942) . . . . . . 252

Thompson v. Kreutzer, 122 Miss. 165, 72 So. 891 (1916) $112,250,251$

Thompson v. McLeod, 112 Miss. 383, 73 So. 193 (1916) . . . . . $.90,251,277$ Vicksburg Bank v. Worrell, 67 Miss. 47,7 So. 219 (1889) . . .253

\section{Missouri}

American Express Co. v. St. Joseph, 66 Mo. 675 (1878) . . . . . 420 American Mfg. Co. v. St. Louis, 270 Mo. 40, 192 S.W. 402 (1916) ..........420

Aurora v. McGannon, 138 Mo. 38, 39 S.W. 469 (1897) . . . .420 Bacon v. Ranson, 331 Mo. 985, 56 S.W. 2d 786 (1932). $\ldots \ldots \ldots \ldots 420,421,695$

Booneville Nat. Bank v. Scholtzhauer, 317 Mo. 1298, 298 S.W. 732 (1927) . . . . . . 422

Brookfield v. Tooly, 141 Mo. 619, 43 S.W. 387 (1897) . . . . 422

City of Cape Giradeau v. Fred A. Groves Motor Co., 346 Mo. 762, 142 S.W. $2 d 1040$ (1940) . .420 
City of Washington v. Washington Oil Co., 346 Mo. 1183, 145 S.W. 2d 366 (1940) . . . .420

Copeland v. St. Joseph, 126 Mo. 417, 29 S.W. 281 (1895) . .422

General American Life Ins. Co. v. Bates, 363 Mo. 143, 249 S.W. 2d 458 (1952)

Glasgow v. Rowse, 43 Mo. 479 (1869) . . 418, 421, 692, 696

Life Ass'n of America v. Board of Assessors, 49 Mo. 512 (1872)

418

Ludlow-Saylor Wire Co. v. Wollbrinck, 275 Mo. 339, 205 S.W. 196 (1918) . . . . 4 419, 420, $421,692,695,699,711,713$

Massachusetts Bonding \& Insurance Co. v. Chorn, 274 Mo. 15, 201 S.W. 1122 (1918) 420

Mercantile Trust Co. v. Schramm, 269 Mo. 489, 190 S.W. 886 (1916) 422

St. Louis v. Spiegel, 75 Mo. 145 (1881) 420

State v. Hannibal \& St. Joseph R. Co., 75 Mo. 208 (1881) . .418

State v. Metropolitan St. Louis

Sewer District, 275 S.W. 2d 225 (1955)

State v. North \& Scott, 27 Mo. 464 (1858) 417

State ex rel. Aull v. Field, 119 Mo. 593, 24 S.W. 752 (1894) . 422

State ex rel. Fath v. Henderson, 160 Mo. 190, 60 S.W. 1093 (1900)

State ex rel. Garth v. Switzler, 143 Mo. 287, 45 S.W. 285 (1897)

$\ldots \ldots \ldots \ldots \ldots 421,422,423$

State ex rel. Johnson v. Chicago, B. \& Q. R. Co., 195 Mo. 228,93 S.W. 784 (1906) . . . . . . 422

State ex rel. McClintock v. Guinotte, 275 Mo. 298, 204 S.W. 806 (1918) .......420,422
State ex rel. McClung v. Becker, 288 Mo. 607, 233 S.W. 54 (1921) ..........420

State ex rel. Missouri Pac, R. Co. v. Danuser, 319 Mo. 799, 6 S.W. 2d 907 (1928) ...... 420

State ex rel. Missouri State Life Ins. Co. v. Gehner, 320 Mo. 691, 8 S.W. 2d 1068 (1926) . . . 422

State ex rel. Morgan v. Hemenway, 272 Mo. 187, 198 S.W. 825 (1917) .........422

State ex rel. Musser v. Birch, 186 Mo. 205, 85 S.W. 361 (1905) 422

State ex rel. Tompkins v. Shipman, 290 Mo. 65, 234 S.W. 60 (1921) . . . . .420,422, 424 State ex rel. Transport Mfg. \& Equipment Co. v. Bates, $359 \mathrm{Mo}$. 1002, 224 S.W. 2d 996 (1949) 426

Viquesney v. Kansas City, 305 Mo. 488, 266 S.W. 700 (1924) . 420 Walters v. City of St. Louis, 259 S.W. 2d 377 (1952) . . . 4426

\section{Montana}

Bank of Miles City v. Custer County, 93 Mont. 291, 19 P. 2d 885 (1933) ......... 437 Daly Bank \& Trust Co. v. Silver Bow, 33 Mont. 101, 81 Pac. 950 (1905) 433

Fruit Growers' Exp. Co. v. Brett, 94 Mont. 281, 22 P. 2d 171 (1933) ...430, 433, 438, 440 Gelsthorpe v. Furnell, 20 Mont. 299, 51 Pac. 267 (1898)... 430,431

Hale v. County Treasurer of Mineral County, 82 Mont. 98, 265 Pac. 6 (1928) . . . . . . 431 Hauser v. Miller, 37 Mont. 22, 94 Pac. 197 (1908) . . .431, 437 Hayes v. Smith, 58 Mont. 306, 192 Pac. 615 (1920) . . . . . 437 
Hilger v. Moore, 56 Mont. 147, 182 Pac. 477 (1919) . .434, 437

Mills v. State Board of Equalization, 97 Mont. 13, 33 P. 2d 563 (1934) ......431, 731, 734

New Silver Bell Mining Co. v. County of Lewis and Clark, 284 P. 2d 1012 (1955) .....437

Northwestern Mutual Life Ins. Co.

v. Lewis and Clark, 28 Mont. 484, 72 Pac. 982 (1903) ... $432,433,440$

O'Connell v. State Board of Equalization, 95 Mont. 91, 25 P. 2d 114 (1933) . . . 430, 431, 432, $714,719,730,731,732,733$ State v. Driscoll, 101 Mont. 348, 54 P. 2d 571 (1936) . . . 430 State v. Hennessy Co., 71 Mont. 301, 230 Pac. 64 (1925) . . 431 State v. North Amer. Car Corp., 118 Mont. 183, 164 P. 2d 161 (1945) ........437, 439

State ex rel. Griffin v. Greene, 104 Mont. 460, 67 P. 2d 995 (1937)

State ex rel. Lyman v. Stewart, 58 Mont. 1, 190 Pac. 129 (1920) .433

State ex rel. Sam Toi v. French, 17 Mont. 54, 411078 (1895) 430 Stoner v. Timmons, 59 Mont. 158 , 196 Pac. 519 (1921) .... 433

\section{Nebraska}

Beadle v. Sanders, 104 Neb. 427, 177 N.W. 789 (1920) . ...170 Boyd Motor Co. v. Box Butte County, 159 Neb. 514, 67 N.W. 2d 774 (1954) .........171

Burlington \& M.R.R. Co. v. Lancaster, 4 Neb. 293 (1876) . 170 Chicago, R.I. \& P.R. Co. v. State, 111 Neb. 362,197 N.W. 114 (1923) ...........170

Clother v. Maher, 15 Neb. 1, 16 N.W. 902 (1883) . . . . 170
Continental Ins. Co. v. Smrha, 131 Neb. 791, 270 N.W. 122 (1936) 168,169 Covell \& Ransome v. Young, 11 Neb. 510,9 N.W. 694 (1881)

High School Dist. No. 137 v. Lancaster, 60 Neb. 147, 82 N.W. $380(1900) \ldots \ldots \ldots \ldots 170$

Homan v. Board of Equalization, Boone County, 141 Neb. 400, 3 N.W. 2d 650 (1942) . . . 170 International Harvester Co. v. County of Douglas, 146 Neb. 555, 20 N.W. 2d 620 (1945)

In re Laub, 104 Neb. 402, 177 N.W. 749 (1920) ....... 170 Lincoln v. Lincoln Gas \& Electric Light Co., 100 Neb. 182, 158 N.W. 964 (1916) . . . . . 169 McCann v. Merriam, 11 Neb. 241, 9 N.W. 96 (1881) . . . . . 170 Magneau v. Fremont, 30 Neb. 843, 74 N.W. 280 (1890) . . . . 169

Nebraska Tel. Co. v. Lincoln, 82 Neb. 59, 117 N.W. 284 (1908)

Omaha Nat. Bank v. Heintze, 159 Neb. 520, 67 N.W. 2d 753 (1954) ...........171 Richter v. City of Lincoln, 136 Neb. 289, 289 N.W. 593 (1939) 168

Rosenbloom v. State, 64 Neb. 342, 89 N.W. 1053 (1902) . . . 169 Sommerville v. Board of Com'rs of Douglas County, 116 Neb. 282, 216 N.W. 815 (1927) . ....171 State v. Fleming, 70 Neb. 523, 97 N.W. 1063 (1903) ......170 State v. MacFarland, 104 Neb. 42, 175 N.W. 663 (1919) . . 170 State v. Osborn, 60 Neb. 415,83 N.W. 357 (1900) ......170 State v. Poynter, 59 Neb. 417, 81 N.W. 431 (1899) . . . . . 169 
State v. Savage, 65 Neb. 714, 91 N.W. 716 (1902) . . . . 170 State v. Walsh, 31 Neb. 469,48 N.W. 263 (1891) . . . . 170 State ex rel. Slabaugh v. Vinsonhaler, 74 Neb. 675, 105 N.W. 472 (1905) ............ 169

State ex rel. Spillman v. Ord State Bank, 117 Neb. 189, 220 N.W. 265 (1928) . . . . . . . 171

State Bank v. Endres, 109 Neb. 753, 192 N.W. 322 (1923). 170 Thorin v. Burke, 146 Neb. 94, 18 N.W. 2 d 664 (1945) . 168, 169 Union Pac. Ry. Co. v. Saunders, 7 Neb. 228 (1878)

Western Union Tel. Co. v. Omaha, 73 Neb. 527, 103 N.W. 84 (1905)

\section{Nevada}

Ex parte Cohn, 13 Nev. 424 (1878) $\ldots \ldots \ldots \ldots .334$

Ex parte Dixon, 43 Nev. 196, 183 Pac. 642 (1919) . . . . . 334

Ex parte Iratacable, 55 Nev. 263, 30 P. $2 d 284$ (1934) ..... 334

Ex parte Robinson, 12 Nev. 263, 28 Am. Rep. 794 (1877) . . 334 Sawyer v. Dooley, 21 Nev. 391, 32 Pac. 437 (1893) .......335 State v. Carson City Sav. Bank, 17 Nev. 146, 30 Pac. 703 (1882)

State v. Eastabrook, 3 Nev. 178 (1867) ............335

State v. Kruttschnitt, 4 Nev. 178 (1868) 335

State v. Wells Fargo \& Co., 38 Nev. 505, 150 Pac. 836 (1915) . 335

\section{New Hampshire}

Amoskeag Mfg. Co. v. Manchester, 70 N.H. 336, 46 Atl. 470 (1900) $\ldots \ldots \ldots \ldots \ldots 188$
Bemis Bro. Bag Co. v. Claremont, 98 N.H. 446, 102 A. 2d 512 (1953) .190

Bow v. Farrand, 77 N.H. 451, 92 Atl. 926 (1915) . . . . . 190

Brewster v. Hough, 10 N.H. 138 (1839) 189

Brock v. Town of Farmington, 98 N.H. 275, 98 A. 2d 162 (1953) $191,192,193$

Canaan v. Enfield Village Fire District, 74 N.H. 517,70 Atl. 250 (1908) 189

Conner v. State, 82 N.H. 126, 130 Atl. 357 (1925).

$184,191,192,195,196,705$ Curry v. Spencer, 61 N.H. 624, 60 Am. Rep. 337 (1882)

$182,183,186,190$

Eyers Woolen Co. v. Town of Gilsum, 84 N.H. 1, 146 At1. 511 (1929) . . . . . . . 189, 190

French v. Lyme, 77 N.H. 63, 86 Atl. 823 (1913) . . . . . . 190

Foster v. Farrand, 81 N.H. 448, 128 Atl. 683 (1925) . . . 193 Havens v. Atty. Gen., 91 N.H. 115, 14 A. 2 d $636(1940)$... $186,187,192$

Opinion of the Justices, 4 N.H. 565 (1828) 191 In re Opinion of the Justices, 76 N.H. 588, 78 Atl. 31 (1911) $190,191,195$ In re Opinion of the Justices, 76 N.H. 597, 79 Atl. 490 (1911)

In re Opinion of the Justices, 76 N.H. 609, 85 Atl. 757 (1913) $.190,191$

In re Opinion of the Justices, 77 N.H. 611, 93 Atl. 311 (1915) $\ldots \ldots \ldots 189,190,195,704$ In re Opinion of the Justices, 81 N.H. 552, 120 Atl. 629 (1923) 193,194 
In re Opinion of the Justices, 82 N.H. 561, 138 Atl. 284 (1927) 186, 187, 191, 192, 193, 196 In re Opinion of the Justices, 84 N.H. 559, 149 Atl. 321 (1930) 185,186 , $189,187,191,192,193,196$ Opinion of the Justices, 94 N.H. 506, 52 A. 2d 294 (1947) ... $186,187,192$

Opinion of the Justices, 95 N.H. 537,64 A. $2 \mathrm{~d} 320(1949) \ldots$ $186,193,196$ Opinion of the Justices, 95 N.H. 543, 64 A. 2d 324 (1949) ... 186,194

Opinion of the Justices, 95 N.H. 555,65 A. 2d 876 (1949)... $\ldots \ldots \ldots \ldots \ldots 187,194$ Opinion of the Justices, 95 N.H. 548,65 A. 2d 700 (1949) . . 189 Opinion of the Justices, 97 N.H. 546, 81 A. 2d 853 (1951) . . 192 In re Opinion of the Justices, 114 A. 2d 327 (1955) ........ 190 In re Opinion of the Justices, 113 A. 2d 119 (1955) ........ 192

In re Opinion of the Justices, 113 A. $2 \mathrm{~d} 547$ (1955) ........ 194 Opinion of the Justices, 112 A. $2 \mathrm{~d}$ 44 (1955)........... 193

Rollins v. City of Dover, 93 N.H. 448, 44 A. 2d 113 (1945) . 190

Rosenblum v. Griffin, 89 N.H. 314, 197 Atl. 701 (1938) . . . . 189

State v. Berlin Street Ry., 84 N.H. 313, 150 Atl. 14 (1930) . . 189 State v. United States \& Canada Express Co., 60 N.H. 219 (1880) ...183,186,190, 191

Thompson v. Kidder, 74 N.H. 89 , 65 Atl. 392 (1906) . . 186, 191 Williams v. State, 81 N.H. 341 , 125 Atl. 661 (1924). .186, 193

\section{New Jersey}

Alpha Rho Alumni Ass'n v. City of New Brunswick, 126 N.J.L. 233, 18 A. 2d 68 (1941) ..... 219 Baldwin Construction Co. v. Essex County Board of Tax., 16 N.J. 329, 108 A. 2d 598 (1954). 220

Central R. Co. of New Jersey v. State Board of Assessors, 75 N.J.L. 120, 67 Atl. 672 (1907) 219

Central R. Co. of New Jersey v. State Board of Assessors, 75 N.J.L. 771, 69 Atl. 239 (1908) 219

Eastwood v. Russell, 81 N.J.L. 672, 81 Atl. 108 (1911) . .220 Koch v. Essex County Board of Taxation, 97 N.J.L. 61, 116 Atl. 328 (1922) . . . . . 218

Royal Mfg. Co. v. Board of Equalization of Taxes, 78 N.J.L. 337, 74 Atl. 525 (1909), aff'g 76 N.J.L. 402, 70 Atl. 978 (1908) ..............220

State v. Mercer County Board of Taxation, 118 N.J.L. 408, 193 Atl. 555 (1937) . . . . . . 219 State Board of Assessors v. Central R. Co., 48 N.J.L. 146, 4 Atl. 578 (1886) ..........219

Tippett v. McGrath, 70 N.J.L. 110, 56 Atl. 134 (1903) ..218

\section{New Mexico}

Albuquerque Alumnae Ass'n of Kappa Kappa Gamma Fraternity v. Tierney, 37 N.M. 156, 20 P. 2d 267 (1933) ........ 444 Amarillo-Pecos Valley Truck Lines v. Gallegos, 44 N.M. 120, 99 P. 2d 447 (1940) . . . . 442, 443 Breece Lumber Co. v. Mirabal, 34 N.M. 643, 287 Pac. 699 (1930) 443 
Dillard v. New Mexico State Tax Comm., 53 N.M. 12, 201 P. 2d 345 (1949) .......... 444

Flynn, Welch \& Yates v. State Tax Comm., 38 N.M. 131, 28 P. 2d 889 (1934)......443, 445

Lougee v. New Mexico Bureau of Revenue Com'r., 42 N.M. 115, 76 P. 2 d 6 (1938) . . . 443, 740

Love v. Dunaway, 28 N.M. 557, 215 Pac. 822 (1923) . . . 446

Oden Buick, Inc. v. Roehl, 36 N.M. 293, 13 P. 2d 1093 (1932) . 444 Safeway Stores v. Vigil, 40 N.M. 190, 57 P. 2d 287 (1936) . 443

Sims v. Vosburg, 43 N.M. 255, 91 P. 2d 434 (1939) . . . . . 444 State v. Gomez, 34 N.M. 250, 280 Pac. 251 (1929) ... . 442, 443

State ex rel. Atty. Gen. v. State Tax Comm., 40 N.M. 299, 58 P. 2d 1204 (1936) . . . . . . 444

State ex rel. Atty. Gen. v. Tittman, 42 N.M. 76, 75 P. 2d 701 (1938) .........443

State ex rel. Taylor v. Mirabal, 33 N.M. 553, 273 Pac. 928 (1928) 442,445

Veterans of Foreign Wars v. Hull, 51 N.M. 478, 188 P. 2d 334 (1947) ........442, 443

\section{Nero York}

In re Bank of Manhattan Co., 293 N.Y. 515, 58 N.E. 2d 713 (1944), affirming 267 App. Div.

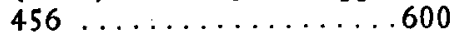

Franklin Society for Home Bldg. \& Savings v. Bennett, 282 N.Y. 79, 24 N.E. 2d 854 (1939) . . .600 In re Keeney's. Estate, 194 N.Y. 281, 87 N.E. 428 (1909) . 600 In re McPherson, 104 N.Y. 306, 10 N.E. 685 (1887) . . . .660

New York Steam Corp. v. City of New York, 268 N.Y. 137, 197 N.E. 172 (1935) . . . . .600
People v. Equitable Trust Co., 96 N.Y. 387 (1884) . . . . 600 People ex rel. Eisman v. Ronner, 185 N.Y. 285,77 N.E. 1061 (1906) ........6.600 People ex rel. Hatch v. Reardon, 184 N.Y. 431,77 N.E. 970 (1906) ..........600

People ex rel. Moskowitz v. Jenkins, 202 N.Y. 53, 94 N.E. 1065 (1911) ..........600 In re Watson's Estate, 226 N.Y. 384, 123 N.E. 758 (1919) 600 In re Wendel's Estate, 223 N.Y. 433, 119 N.E. 879 (1918) 600 Woodruff v. Oswego Starch Factory, 177 N.Y. 23, 68 N.E. 994 (1903) .........600

\section{North Carolina}

Anderson v. City of Asheville, 194 N.C. 117,138 S.E. 715 (1927) .561

Bickett v. State Tax Commission, 177 N.C. 433,99 S.E. 415 (1919) ............561

Charlotte Coca Cola Bottling Co. v. Shaw, Com'r of Revenue, 232 N.C. 307,59 S.E. 2 d 819 (1950) ............ 560

Charlotte Bldg. \& Loan Ass'n v. Mecklenburg, 115 N.C. 410, 20 S.E. $526(1894) \ldots \ldots \ldots 561$ Clark v. Maxwell, 197 N.C. 604, 150 S.E. 190 (1929) . . . . 560 Dalton v. Brown, 159 N.C. 175,75 S.E. 40 (1912) ...... 560 Drainage Commissioners v. C. A. Webb \& Co., 160 N.C. 594, 76 S.E. $552(1912) \ldots \ldots \ldots 561$ Gatlin v. Tarboro, 78 N.C. 119 (1878) .......... 560 Great Atlantic \& Pacific Tea Co. v. Doughton, 196 N.C. 145,144 S.E. 701 (1928) .......560 Great Atlantic \& Pacific Tea Co. v. 
Maxwell, 199 N.C. 433,154 S.E. $838(1930) \ldots \ldots \ldots 560$ Jamison v. City of Charlotte, 80 S.E. 2d 904 (1954) . ....562 Jones v. Com'rs., 143 N.C. 59 (1906) ............561

Kenny Co. v. Town of Brevard, 217 N.C. 269,7 S.E. 2 d 542 (1940) ..........5560

Leonard v. Maxwell, 216 N.C. 89, 3 S.E. 2d 316 (1939) . . . 560 Maxwell v. Kent-Coffey Mfg. Co., 204 N.C. 365,168 S.E. 397 (1933).......550, 737 In re Morris' Estate, 138 N.C. 259 , 50 S.E. 682 (1905) . . 560, 561

Nesbitt v. Gill, Com'r of Revenue, 227 N.C. 174,41 S.E. $2 d 646$ (1947)........550, 562

Pocomoke Guane Co. v. Biddle, 158 N.C. 212,73 S.E. 996 (1912) ............561

Redmond v. Tarboro, 106 N.C. 122, 10 S.E. 845 (1890) . . 561 Roach v. Durham, 204 N.C. 587, 169 S.E. 149 (1933) . . . . 560

Rockingham County v. Board of Trustees of Elon College, 219 N.C. 342,13 S.E. $2 d \quad 618$ (1941) ...........561

Sir Walter Lodge No. 411, I.O.O.F. v. Swain, 217 N.C. 632 , 9 S.E. 2d 365 (1940) ....5561, 562 Southern Assembly v. Palmer, 166 N.C. 75, 82 S.E. 18 (1914) 561 State v. Carter, 129 N.C. 560,40 S.E. 11 (1901) . . . . . 560 State v. Harris, 216 N.C. 746,6 S.E. 2d 854 (1940) . . . . 560 State v. Stevenson, 109 N.C. 730 , 14 S.E. 385 (1891) . . . . 559 United Brethren of Salem \& Vicinity v. Forsyth, 115 N.C. 489,20 S.E. 626 (1906) . . . . . 561 Wachovia Bank \& Trust Co. v. Maxwell, 221 N.C. 528,20 S.E. $2 \mathrm{~d}$ 840 (1942) .........560
Wayne Mercantile Co. v. Mt. O1ive, 161 N.C. 121,76 S.E. 690 (1912) .......... 560 Worth v. Wilmington \& W. R. Co., 89 N.C. 291, 45 Am. Rep. 679 (1884) .........5.560

\section{North Dakota}

Figenskau v. McCoy, 66 N.D. 290, 265 N.W. 259 (1936) ... 564 Gamble-Robinson Fruit Co. v. Thoresen, 53 N.D. 28, 204 N.W. 861 (1925) . . . . . 566 In re Lipschitz, 14 N.D. 622, 95 N.W. 157 (1902) . . . . . 564 Malin v. Lamoure, 27 N.D. 140 , 145 N.W. 582 (1914) . 385, 564 Northwestern Improvement Co. $\nabla$. County of Morton, 78 N.D. 29, 47 N.W. 2d 543 (1951) . . 565 Northwestern Improvement Co. v. State, 57 N.D. 1, 220 N.W. $436(1928) \ldots \ldots .565,566$ State v. Klectzen, 8 N.D. 286,78

N.W. 984 (1899) . . . . . 564 State ex rel. Fargo v. Wetz, 40 N.D. 299,168 N.W. 835 (1918) .....564, 565, 566 State ex rel. Haggart v. Nichols, 66 N.D. 355,265 N.W. 859

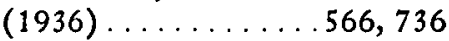

\section{Ohio}

Angell v. City of Toledo, 153 Ohio St. 179,91 N.E. 2 d 250 (1950) 226

In re Application for Exemption, 155 Ohio St. 590, 99 N.E. 2d 761 (1951) . . . . . 232 Bennett v. Evatt, 145 Ohio St. 587, 62 N.E. 2d 345 (1945) . ...230 City of Cleveland v. Board of Tax Appeals, 153 Ohio St. 97, 91 N.E. $2 d 480$ (1950) . . . . 233 
Clark v. City of Cincinnati, 163 Ohio St. 532, 127 N.E. 2d 363 (1955)

227

Columbus Metropolitan Housing Authority v. Thatcher, 140 Ohio St. 38, 42 N.E. 2d 437 (1942) 230,231

Dayton Metropolitan Housing Authority v. Evatt, 143 Ohio St. 10, 53 N.E. 2d 896 (1944) . . 231 Exchange Bank v. Hines, 3 Ohio St. 1 (1853) . . . . 227, 233

Federal Public Housing Auth, v. Guckenberger, 143 Ohio St. 251, 55 N.E. 2d 265 (1944) .. 231 Hagerty v. State, 55 Ohio St. 613, 45 N.E. 1046 (1896) . . . 225

Harvard College v. State, 106 Ohio St. 303, 140 N.E. 189 (1922)

226

Hospital Service Ass'n of Toledo v. Evatt, 144 Ohio St. 179, 57 N.E. 2d 928 (1944) .........231 Humphreys v. State, 70 Ohio St. 67, 70 N.E. 957 (1904) . . 226

New Orphans' Asylum, etc. v. Board of Tax Appeals, 150 Ohio St. 219, 80 N.E. 2d 761 (1948).

Reed v. Board of Revision of Fairfield County, 152 Ohio St. 207, 88 N.E. 2d 701 (1949) . . . 229

Roseville Pottery v. Board of Revision of Muskingum County, 149 Ohio St. 89,77 N.E. 2d 608 (1948) . . . . . . . 229

Saviers v. Smith, 101 Ohio St. 132, 128 N.E. 269 (1920) . . . 224

Sherman v. Tax Comm. of Ohio, 125 Ohio St. 367,181 N.E. 539 (1932) ..........226

Southern Gum Co. v. Laylin, 66 Ohio St. 578, 64 N.E. 564 (1902) ..........224

Standard Oil Co. v. Zangerle, 144 Ohio St. 523, 60 N.E. 2d 59 (1945) 229
State v. Hess, 113 Ohio St. 52, 148 N.E. $347(1925) \ldots \ldots \ldots 227$ State v. Jones, 51 Ohio St. 492, 37 N.E. 945 (1894) . . . 227

State ex rel. Hostetter v. Hunt, 132 Ohio St. 568, 9 N.E. 2d 676 (1937) ..........230

State ex rel. Lampson v. Cook, 44 Ohio App. 501, 185 N.E. 212 (1932) ..........229

State ex rel. Struble v. Davis, 132 Ohio St. 555, 9 N.E. 2d 684 (1937) . . 224, 229, 230, 233 State ex rel. Schwartz v. Ferris, 53 Ohio St. 314, 41 N.E. 529 (1895) . . . . . . 225, 226

State ex rel. Taylor v. Guilbert, 70 Ohio St. 229,71 N.E. 636 (1904) ..........226

State ex rel. Walls v. Wallace, 138 Ohio St. 410, 35 N.E. 2d 167 (1941) ...........224

State ex rel. Williams v. Glander, 148 Ohio St. 188, 74 N.E. 2d 82 (1947) . . . . . . 230

Treasurer v. Bank, 47 Ohio St. 503, 25 N.E. 697 (1890) . . . .227

In re University of Cincinnati, 153 Ohio St. 142,91 N.E. 2 d 502 (1950) 232

Youngstown Metropolitan Housing Auth. v. Evatt, 143 Ohio St. 268, 55 N.E. 2 d 122 (1944).. 231

Youngstown Sheet \& Tube Co. v. City of Youngstown, 108 N.E. $2 \mathrm{~d} 571$ (Court of Appeals of Ohio, 1951) ........227

Zanesville v. Richards, 5 Ohio St. 589 (1855) . . . . . . 227

Zangerle v. City of Cleveland, Division of Municipal Transp., 145 Ohio St. 347, 61 N.E. 2d 720 (1945) .........231

Zangerle v. Republic Steel Corp., 144 Ohio St. 529, 60 N.E. 2d 170 (1945) .........229 
Zangerle v. Standard Oil Co., 144 Ohio St. 506, 60 N.E. 2d 52 (1945) .229

\section{Oklahoma}

In re Assessment of Chickasha Cotton Oil Co., 80 Okla. 101, 194 Pac. 215 (1921) ...... 452

In re Assessment of Conservative Loan Co., 67 Okla. 307, 173 Pac. 654 (1918) .......451

In re Assessment of Property of Western Light \& Power Corp., 169 Okla. 53, 35 P. 2d 946 (1934) 453

In re Assessment of Sales Tax against Knapp, 185 Okla. 584, 95 P. 2d 92 (1939) . . . . . 448, 449

Bergin Oil \& Gas Co. v. Howard, 82 Okla. 176, 199 Okla. Pac. 209 (1921) 451

Comanche County v. American Nat. Bank, 122 Okla. 34, 252 Pac. 408 (1927) . . . . . . 453

County Assessor, Oklahoma County v. United Brotherhood of Carpenters \& Joiners of America, Local 329, 202 Okla. 162, 211 P. 2d 790 (1949) ......4449 Custer County Excise Board v. St. Louis-San Francisco Ry. Co., 201 OkJa, 528, 207 P. 2d 774 (1949) ...........454

Daube v. Oklahoma Tax Comm., 194 Okla. 487, 152 P. 2d 687 (1944) ........448, 449

In re Diehr, 174 Okla. 300, 50 P. 2d 725 (1935) 451, 452, 453 Gibson v. Phillips University, 195 Okla. 456, 158 P. 2d 901 (1945) ..........450

In re Gross Production Tax of Wolverine Oil Co., 53 Okla. 24, 154 Pac. 362 (1915) . . . 4 451

In re Harkness' Estate, 83 Okla. 107, 204 Pac. 911 (1922) . 449
Lowden v. Excise Board of Texas County, 185 Okla. 143, 90 P. 2d 923 (1939) 450

Love v. Silverthorn, 187 Okla. 114, 101 P. 2d 254 (1940) ... 453 McGannon v. State, 33 Okla. 145, 124 Pac. 1063 (1912) 448, 449 In re Oklahoma Nat. Life Ins. Co., 68 Okla. 219, 173 Pac. 376 (1918) .......451, 452

Ex parte Shaw, 53 Okla. 654, 157 Pac. 900 (1916) 448, 449, 451

In re Skelton Lead \& Zinc Co.'s Gross Production Tax for 1919, 81 Okla. 134, 197 Pac. 495 (1921) ........450, 452

State v. Chickasha Milling Co., 180 Okla. 611, 71 P. 2d 981 (1937) 453

State v. Pioneer Mills, 122 Okla. 6, 250 Pac. 120 (1926) . . . . 449

'Trustees, Executors \& Securities Ins. Corp. v. Hooton, 53 Okla. 530, 157 Pac. 293 (1915) . . . . $448,449,451$

Walde v. Oklahoma Tax Comm., 188 Okla. 142, 106 P. 2d 821 (1940) 449

\section{Oregon}

Corporation of Sisters of Mercy v. Lane County, 123 Ore. 144, 261 Pac. 694 (1927) .......4460 Crawford v. Linn County, 11 Ore. 482, 5 Pac. 738 (1884)..... $\ldots \ldots \ldots \ldots \ldots 456,457$ Ellis v. Frazier, 38 Ore. 462,63 Pac. 642 (1900) . . . . . 457 In re Heck's Estate, 120 Ore. 80, 250 Pac. 735 (1926) . . . . 459 Hogg v. Mackay, 23 Ore. 339, 31 Pac. 779 (1893) . . . . . . 457 Kellaher v. Portland, 57 Ore. 575, 112 Pac. 1076 (1911)... .459 Lake County v. Schroder, 47 Ore. 136, 81 Pac. 942 (1905) . . 457 
McPherson v. Fisher, 143 Ore. 615 , 23 P. 2d 913 (1933) . 460, 702 Methodist Book Concern v. State Tax Comm., 186 Ore. 585, 208 P. 2d 319 (1949) ...... .460

Portland v. Portland Ry., L. \& P. Co., 80 Ore. 271,156 Pac. 1058 (1916) . . . . . . . 457

Portland Van \& Storage Co. v. Hoss, 139 Ore. 434,9 P. 2 d 122 (1932) ........402, 459 Redfield v. Fisher, 135 Ore. 180, 292 Pac. 813 (1931) . ........ $460,702,739$

Reser v. Umatilla, 48 Ore. 326,86 Pac. 595 (1906) .......457

Safeway Stores v. City of Portland, 149 Ore. 581,42 P. 2d 162 (1935) ...........460

Smith v. Kelly, 24 Ore. 464, 33 Pac. 642 (1893) . . . . . . 457 Standard Lumber Co. v. Pierce, 112 Ore. 314, 228 Pac. 812 (1924) 402 ,

$458,459,460,701,702,730$ Wallace v. Board of Equalization, 47 Ore. 583, 86 Pac. 365 (1906) 456

\section{Pennsylvania}

Allentown v. Gross, $132 \mathrm{~Pa}$. 319, 19 At]. 269 (1890) . . 526, 527 American Stores Co. v. Boardman, $336 \mathrm{~Pa}$. 36, 6 A. 2d 174 (1939) 529,537

In re Arrott's Estate, $322 \mathrm{~Pa}$. 367, 185 Atl. 697 (1936)........ $\ldots \ldots \ldots \ldots 491,512,513$ Bangor's Appeal, $109 \mathrm{~Pa} .79$ (1885) 473, 474, 475, 479, 525, 530 Board of Christian Education v. Philadelphia School Dist., 171 Pa. Super. 610, 91 A. 2d 372 (1952), allocatur refused by the Supreme Court of Pennsylvania, $171 \mathrm{~Pa}$. Super. xxv, $172 \mathrm{~Pa}$. Super. xxvi..........528
Borough of Langhorne Manor, etc. v. Harvey, et al., Ct. of C. P., Bucks County (Feb., 1931) 469 In re Brown's Appeal, $111 \mathrm{~Pa}$. 72, 2 Atl. 77 (1885). 475

Butcher v. City of Philadelphia, 333 Pa. 497, 6 A. 2d 298 (1938). . $.530,532,533$

Christley v. Butler County, $37 \mathrm{~Pa}$. Super. 32 (1908) . . . 468, 469 Clearfield Bituminous Coal Corp. v. Thomas, $336 \mathrm{~Pa}$. 572, 9 A. 2d 727 (1940) 468, 469, 470, 471 Coal Ridge Improvement Co. v. Jennings, $127 \mathrm{~Pa}$. 397, 17 Atl. 986 (1889) . . . . . . . . 501

Commonwealth v. Alden Coal Co., 251 Pa. 134, 96 Atl. 246 (1915) $470,514,515$

Commonwealth v. American Gas Co., 352 Pa. 113, 42 A. 2d 161 (1945) ............ 513

Commonwealth v. A. Overholt \& Co., 331 Pa. 182, 200 Atl. 849 (1938) ...516, 517, 520, 537

Commonwealth v. Brush Elec. Light Co., 145 Pa. 147, 22 Atl. 844 (1891) . ..... 509, 541

Commonwealth v. Chester, $123 \mathrm{~Pa}$. 626, 16 Atl. 591 (1889) . . 501

Commonwealth v. Clark, $195 \mathrm{~Pa}$. 634, 46 Atl. 286 (1900) . .526 Commonwealth v. Columbia Gas \& Elec. Corporation, $336 \mathrm{~Pa} .209$, 8 Atl. 2d 404 (1939) . . . . 513 Commonwealth v. Dauphin County, $335 \mathrm{~Pa} .177,6$ A. 2d 870 (1939) ..........467

Commonwealth v. Delaware Div. Canal Co., 123 Pa. 594, 16 Atl. 584 (1889) 466, 467, 486, 495, $496,501,502,508,538,541$ Commonwealth v. Delaware \& Hudson Canal Co., $150 \mathrm{~Pa} .245,24$ Atl. 599 (1892) .......501 Commonwealth v. Edgerton Coal 
Co., 164 Pa. 284, 30 Atl. 125 (1894) .510

Commonwealth v. Fall Brook Coal Co., $156 \mathrm{~Pa} .488,26$ Atl. 1071 (1893) 486, 505

Commonwealth v. Ford Motor Co., $350 \mathrm{~Pa} .236,38$ A. 2d 329 (1944)

.513

Commonwealth v. Germania Brewing Co., $145 \mathrm{~Pa} .83,22$ Atl. 240 (1891)

$486,488,489,505,506,508$

Commonwealth v. Girard Life Ins. Co., 305 Pa. 558, 158 Atl. 262 (1932)

.523

Commonwealth v. Hannis Distilling Co., 265 Pa. 376, 108 Atl. 822 (1919) 508

Commonwealth v. Hudson Coal Co., 287 Pa. 64, 134 Atl. 413 (1926) Commonwealth v. Lehigh Coal \& Navigation Co., 162 Pa. 603, 29 At1. 664 (1894) ........505

Commonwealth v. Lehigh Valley $\mathrm{R}$. Co., 104 Pa. 89 (1883) ...... 494, 496, 498

Commonwealth v. Lehigh Valley R. Co., 129 Pa. 429, 18 Atl. 406 (1889) .....501, 502, 538 Commonwealth v. Lukens, $312 \mathrm{~Pa}$. 220, 167 Atl. 167 (1933) . 523

Commonwealth v. McCarthy, 332 Pa. 465, 3 A. 2d 267 (1938).. 537

Commonwealth v. Mill Creek Coal Co., 157 Pa. 524, 27 Atl. 375 (1893) 508

Commonwealth v. Monessen Amusement Co., 352 Pa. 120, 42 A. 2d 158 (1945) . . . . . . 513

Commonwealth v. Mortgage Trust Co., 227 Pa. 163, 76 Atl. 5 (1910) ............501

Commonwealth v. National Oil Co., 157 Pa. 516, 27 Atl. 374 (1893) ...........508
Commonwealth v. Pennsylvania Ins. Co., 13 Pa. 165 (1850) . . 503

Commonwealth v. Pennsylvania Threshermen \& Farmers' Mut. Casualty Ins. Co., $339 \mathrm{~Pa} .62,14$ A. 2d $295(1940) \ldots \ldots .490$ Commonwealth v. Philadelphia \& Reading Coal \& Iron Co., 278 Pa. 338, 123 Atl. 315 (1924).. 516

Commonwealth v. Quaker Oats Co., $350 \mathrm{~Pa} .253,38$ A. 2d 825 (1944) ......... 513

Commonwealth v. Randall, $225 \mathrm{~Pa}$. 197, 73 Atl. 1109 (1909) . 535 Commonwealth v. St. Clair Coal Co., 251 Pa. 159, 96 Atl. 254 (1915) .......... 514

Commonwealth v. Sharon Coal Co., 164 Pa. 284, 30 Atl. 127 (1894) $507,508,510$

Commonwealth v. Southern Pennsylvania Bus Co., $339 \mathrm{~Pa} .521$, 15 A. 2d 375 (1940) . .511, 538 Commonwealth v. Standard Oil Co., $101 \mathrm{~Pa} .119$ (1882) ...... 504 Commonwealth v. Warner Bros. Theaters, $345 \mathrm{~Pa} .270,27 \mathrm{~A}$. 2d $62(1942) \ldots \ldots \ldots \ldots .522$ In re Cope's Estate, 191 Pa. 1, 43 Atl. 79 (1899). $469,530,535,536,541$

Dick Contracting Co. v. Hazel Township School Dist., $362 \mathrm{~Pa}$. 387, 65 A. 2d 381 (1949) 520 Dole v. City of Philadelphia, 337 Pa. 375, 11 A. 2d 163 (1940) 533

Dufour v. Maize, 358 Pa. 309, 56 A. $2 \mathrm{~d} 675$ (1948) ...... 518 Dunkard Township School Tax Case, 359 Pa. 605,60 A. 2d 39 (1948) . . . . . . 517, 518 Dupuy v. Johns, $261 \mathrm{~Pa}$. 40, 104 Atl. 565 (1918) . . . . . . . $486,487,489,490,491,507$ 
In re Finnen's Estate, $196 \mathrm{~Pa}$. 72, 46 Atl. 269 (1900) . . . . . 535

Folcroft Borough v. General Outdoor Adv. Co., 72 D. \& C. (Pa.) 539, 42 Mun. 9 (1950) 516, 538

In re Fox's Appeal, 112 Pa. 337, 4 Atl. 149 (1886)

$477,478,481,483,484,485$, $487,489,492,504,505,539$

Germania Life Ins. Co. v. Commonwealth, 85 Pa. 513 (1877)

523

Girard Trust Co., Trustee's Appeal, $333 \mathrm{~Pa} .129,3$ A. 2d 252 (1937)

491

Hadtner v. Williamsport, 15 Wkly Notes Cas. (Pa.) 138 (1883)..

Hampton Township School Dist. Tax Case, 362 Pa. 395, 67 A. 2d 376 (1949) ......5 518, 519

Hawes Mfg. Co.'s Appeal, 1 Mona. 353 (Pa. Sp. Ct.) (1889) . 506 Heisler v. Thomas Colliery Co., 274 Pa. 448, 118 Atl. 394 (1922) ........470, 515

Hill School Tax Exemption Case, 370 Pa. 21, 87 A. 2d 259 (1952) 468

Jamison Coal \& Coke Co. v. Unity Township School Dist., 362 Pa. 389, 66 A. 2d 759 (1949) 518 Jermyn v. Scranton, $212 \mathrm{~Pa}$. 598, 62 Atl. 29 (1905) . . . . . 466 Jones \& Laughlin Steel Corp. Appeal, 362 Pa. 400, 67 A. 2d 378 (1949)

Kelley v. Kalodner, $320 \mathrm{~Pa} .180$, 181 Atl. 598 (1935) . 523, 529, $531,533,534,541,735,736$ Kittanning Coal Co. v. Commonwealth, $79 \mathrm{~Pa} .100$ (1875). .523

Knisely v. Cotterel, $196 \mathrm{~Pa}$. 614, 46 Atl. 861 (1900) . . 470, 527

Lawrence Township School District Tax Case, 362 Pa. 377, 67 A. 2d $372(1949) \ldots .518,519,520$
In re Miller's Estate, $330 \mathrm{~Pa}$. 477, 199 Atl. 148 (1938) 491

Moore v. Pittsburgh School Dist., 338 Pa. 466, 12 A. 2d 29 (1940) 467

Mulberger v. Indiana County, (Pa.) 71 Pitts. L.J. 964 (1923) . 476 Murray v. Philadelphia, $364 \mathrm{~Pa}$. 157,71 A. $2 \mathrm{~d} 280(1950) \ldots$ 470,534

Ogontz School Tax Exemption Case, 361 Pa. 284, 65 A. 2d 150 (1949) ..........467

In re Pennsylvania Co. for Granting Insurances on Lives \& Granting Annuities, $345 \mathrm{~Pa} .130,27$ A. 2d 57 (1942) . . . . . 491 Pennsylvania Co. for Ins. on Lives \& Granting Annuities v. Philadelphia, $346 \mathrm{~Pa}$. 406, $31 \mathrm{~A}$. 2d 137 (1943) 533

Pittsburgh v. Phelen, (Pa.) 11 Dist. Ct. 572 (1901) . ......4468 Case of Poor District, $329 \mathrm{~Pa} .390$, 197 Atl. 334 (1938) . . . .467 Provident Life \& Trust Co. v. McCaughn, $246 \mathrm{~Pa}$. 370, 91 Atl. $672(1914) \ldots .491,492,508$ Roup's Case, $81 \mathrm{I} / 2$ Pa. 211 (1874) 465

Roy Stone Transfer Corp. v. Messner, $377 \mathrm{~Pa} .234,103$ A. 2d 700 (1954) .........521, 522

Sablosky v. Messner, 372 Pa. 47, 92 A. 2d $411(1952) \ldots \ldots .520$

Thompson v. Indiana County, 83 Pa. Super. 248 (1924) $475,476,485$

Turco Paint \& Varnish Co. v. Kalodner, 320 Pa. 421, 184 Atl. 37 (1936) ...521, 522, 523, 741

White v. Smith, $189 \mathrm{~Pa} .222,42$ Atl. 125 (1899) . . . . . . 467 Williamsport v. Wenner, $172 \mathrm{~Pa}$. 173, 33 Atl. 544 (1896) $.524,525,526$ 


\section{Rhode Island}

Brown University v. Granger, 19 R.I. 704, 36 Atl. 720 (1897) . . ............592, 593 McTwiggan v. Hunter, 18 R.I. 776, 30 Atl. 962 (1895) . . 592 Manufacturers' Mut. Fire Ins. Co. v. Clarke, 41 R.I. 277, 100 Atl. 400 (1918) . . . . 592, 593

Mexican Petroleum Corp. v. Bliss, 43 R.I. 243, 100 Atl. 867 (1920) ...........593

\section{South Carolina}

Alderman v. Wells, 85 S.C. 507,67 S.E. 781 (1910) 339 Anderson v. Page, 208 S.C. 146,37 S.E. 2d 289 (1946) . . . . 340 Ex parte Bates, 127 S.C. 167,120 S.E. 717 (1923) . . ...339 Carolina Music Co. v. Query, 192 S.C. 308,6 S.E. 2d 473 (1939)

Charlotte, C. \& A. R. Co. v. Gibbes, 27 S.C. 385,4 S.E. 49 (1887)

Ellerbe v. David, 193 S.C. 332,8 S.E. 2d 518 (1940) . . . . 340 Germania Sav. Bank v. Darlington, 50 S.C. 337,27 S.E. 846 (1897) Great Atlantic \& Pacific Tea Co. v. City of Spartanburg, 170 S.C. 262, 170 S.E. 273 (1932) 339 Gregg Dyeing Co. v. Query, 166 S.C. 117,164 S.E. 588 (1932) 339,340

Hay v. Leonard, 212 S.C. 81,46 S.E. 2d 653 (1948) .... 339 Hill v. Abbeville, 59 S.C. 396, 38 S.E. 11 (1901) . . . . . 339 Marshall v. South Carolina Tax Comm., 178 S.C. 57, 182 S.E. $96(1935) \ldots \ldots \ldots \ldots 340$

Nettles v. Cantwell, 112 S.C. 24, 99 S.E. 765 (1919) . . . . 341
Smith v. Robertson, 210 S.C. 99, 41 S.E. 2d 631 (1947) . . . 341 State v. Cheraw \& D. R. Co., 54 S.C. 564,32 S.E. 691 (1898) . 341

State v. Railroad Corporations, 4 S.C. $376(1873) \ldots \ldots \ldots 341$ State v. Touchberry, 121 S.C. 5, 113 S.E. 345 (1922) . . . . 339 State ex rel. Coney v. Hicklin, 168 S.C. 440,167 S.E. 674 (1933) 339

State ex rel. Roddey v. Byrnes, 219 S.C. 485,66 S.E. 2 d 33 (1951) 339

Strong v. City of Sumter, 185 S.C. 203, 193 S.E. 649 (1937) . 340 Wofford College Trustees v. City of Spartanburg, 201 S.C. 315, 23 S.E. $2 d 9$ (1942) . . . . . 340

\section{South Dakota}

Commercial State Bank v. Wilson, 53 S.D. 82, 220 N.W. 152 (1928) ......... 571 In re Construction of Revenue Law, 2 S.D. 58,48 N.W. 813 (1891) 571

Eastern Dakota Elec. Co. v. Kirlin, 48 S.D. 462, 205 N.W. 33 (1925) ........569, 570

Great Northern R. Co. v. Whitfield, 65 S.D. 173,272 N.W. 787 (1937) ........5572 Ex parte Hoffert, 34 S.D. 271,148 N.W. 20 (1914) . . . . .. 569 In re McKennan's Estate, 27 S.D. 136, 130 N.W. 33 (1911). 569,570

Queen City Fire Ins. Co. v. Basford, 27 S.D. 164, 130 N.W. 44 (1911) .569

Schmitt v. Nord, 71 S.D. 575,27

N.W. 2d 910 (1947) . ...569 Simmons v. Ericson, 54 S.D. 429, 223 N.W. 342 (1929) 571, 572 
Standard Oil Co. v. Jones, 48 S.D. 482, 205 N.W. 72 (1925) 569

State v. Black Hills Transp. Co., 71 S.D. 28,20 N.W. 2 d 683 (1945) ........... 569

State v. Doran, 28 S.D. 486,134 N.W. 53 (1912) . . . . . 569 State ex rel. Botkin v. Welsh, 61 S.D. 593, 251 N.W. 189 (1933) 569,570

State ex rel. Bottum v. Knudtson, 65 S.D. 547,276 N.W. 150 (1937) ...........571

State ex rel. Eveland v. Johns, 43 S.D. 279,178 N.W. 945 (1920) 571

State ex rel. Roddewig v. Kutcher, 68 S.D. 366, 2 N.W. 2d 669 (1942) ........569, 570 In re Watson, 17 S.D. 486,97 N.W. 463 (1904) ......569

\section{Tennessee}

Allen v. Board of Mayor \& Aldermen of Smithville, 140 Tenn. 418, 205 S.W. 124 (1917) ... $68,69,85$

American Bemberg Corp. v. City of Elizabethton, 180 Tenn. 373, 175 S.W. 2d 535 (1943) 69, 86 Arnold v. Knoxville, 115 Tenn. 195, 90 S.W. 469 (1905) . .68

Bank of Commerce \& Trust Co. v. Senter, 149 Tenn. 569, 260 S.W. $144(1923) \ldots \ldots \ldots \ldots$ $\ldots \ldots \ldots 88,89,91,92,741$ Bell v. Town of Pulaski, 182 Tenn. 136, 184 S.W. 2d 384 (1944) 69,85

Camden Fire Ins. Ass'n v. Haston, 153 Tenn. 675, 284 S.W. 905 (1925) ........89, 90, 91

Carroll v. Alsup, 107 Tenn. 257, 64 S.W. 193 (1901) ........ $\ldots \ldots \ldots \ldots 71,86,87,88$ Chattanooga v. Nashville, C. \& St.
L. R. Co., 75 Tenn. 561 (1881) 71

City of Knoxville v. Ft. Sanders Hospital, 148 Tenn. 699, 257 S.W. 408 (1923) . . . . . .87

Corp. of Sevierville v. King, 182 Tenn. 143, 184 S.W. 2d 381 (1944) ............69 Corn v. Fort, 170 Tenn. 377, 95 S.W. 2d 620 (1935) . . .89, 91

Cumberland University v. Golladay, 152 Tenn. 82, 274 S.W. 536 (1924) ......73, 82, 83, 85

Dunn v. Dunn, 99 Tenn. 598, 42 S.W. 259 (1932) . . . . . .70 Evans v. McCabe, 164 Tenn. 672, 52 S.W. 2d 159 (1932).

91, 94, 706

Foster v. Roberts, 142 Tenn. 350, 219 S.W. 729 (1919) . .73, 75

Foster \& Creighton Co. v. Graham, 154 Tenn. 412, 285 S.W. 570 (1925) . . . . . 88, 89, 90

Hooten v. Carson, 186 Tenn. 282, 209 S.W. 2d 273 (1948) ...91

Humphries v. Carter, 172 Tenn. 392, 112 S.W. 2d 833 (1937)

Jones v. Memphis, 101 Tenn. 188, 47 S.W. 138 (1898) 68, 85, 86 Keith v. Funding Board of Tennessee, 127 Tenn. 441, 155 S.W. 142 (1912) .......72, 73

McCord v. Nashville, C. \& St. L. Ry., 187 Tenn. 277, 213 S.W. 2d 196 (1948) ... 86, 87, 88

Marion County River Transp. Co. v. Stokes, 173 Tenn. 347,117 S.W. 2d $740(1938) \ldots .89,90$

Memphis v. Ensley, 65 Tenn. 553, 32 Am. Rep. 532 (1873) . . .70 Memphis v. Home Ins. Co., 91 Tenn. 558,19 S.W. 1042 (1892) ...........70 Memphis v. Memphis City Bank, 91 Tenn. 574, 195 S.W. 1045 (1892) ..........70,85 
Nashville, C. \& St. L. Ry. v. Marshall County, 161 Tenn. 236, 30 S.W. 2d 268 (1929) . . . . . 88 Ogilvie v. Hailey, 141 Tenn. 392, 210 S.W. 645 (1918) . . .89 Phillips v. Lewis, 3 Tenn. Cas. 230 (1877) ..........86, 91

Railway Co. v. Wilson County, 89 Tenn. 597 (1891) . . . 68, 85 Reelfoot Lake Levee Dist. v. Dawson, 97 Tenn. 151,36 S.W. 1041 (1896) . . . . . 69, 86

Royal Crown Bottling Co. of Knoxville v. Stokes, 177 Tenn. 117, 146 S.W. 2 d 838 (1941) . . .99 Shields v. Williams, 159 Tenn. 349, 19 S.W. 2d 261 (1929) . . . . . $67,68,76,79$, $82,83,84,85,89,93,706,707$ Sloan v. Columbia, 144 Tenn. 197 , 232 S.W. 663 (1920) . .71, 78 State v. Alston, 94 Tenn. 674, 30 S.W. 750 (1895) . . . .89, 90 State ex rel. Hauk v. American Trust Co., 141 Tenn. 243, 208 S.W. 611 (1918) 74, 82, 83, 90 State ex rel. Stewart v. Louisville \&

N. R. Co., 139 Tenn. 406, 201 S.W. 738 (1918) .....990 State Nat. Bank v. Memphis, 116

Tenn. 641, 94 S.W. 606 (1906) $72,73,86$

Sterchi Bros. Stores, Inc. v. Wallace, 168 Tenn. 299, 77 S.W. $2 d 807$ (1934) ............ . 89

Street Railroad v. Morrow, 87 Tenn. 406, 11 S.W. 348 (1889) 70,71

Taylor McBean \& Co. v. Chandler, 56 Tenn. 349, 24 Am. Rep. 308 (1872). $68,69,86$

Tennessee Fertilizer Co. v. McFall, 128 Tenn. 645, 163 S.W. 806 (1913) 71

Union \& Planters' Bank v. Memphis, 101 Tenn. 154, 46 S.W. 557 (1898) ...........71

\section{Texas}

Austin v. Austin Gas Light \& Coal Co., 69 Tex. 180,7 S.W. 200 (1887) ...........258

Aycock v. Travis County, 255 S.W. 2d 910 (1953) .......260 City of Abilene v. State, (Tex. Civ. App.) 113 S.W. 2d 631 (1937) 258

City of Arlington v. Cannon, 271 S.W. 2d 414 (1954) . 259, 260 City of Wichita Falls v. J. J. \& M. Taxman Refining Co., (Tex. Civ. App.) 74 S.W. 2d 524 (1934) A......... 528

Dallas Gas Co. v. State, (Tex. Civ. App.) 261 S.W. 1063 (1924).. 255,256

Dickison v. Woodmen of the World Life Ins. Society, 280 S.W. 2d 315 (1955) .....258 Druesdow v. Baker, (Tex. Civ. App.) 229 S.W. 493 (1921) 260 Gaar, Scott \& Co. v. Shannon, 52 Tex. 634, 115 S.W. 361 (1909) 256

Garza Land \& Cattle Co. v. Redwine Independent School Dist., (Tex. Civ. App.) 282 S.W. 905 (1926) 260

Houston v. Baker, (Tex. Civ. App.) 178 S.W. 820 (1915) 259, 260 Hurt v. Cooper, 130 Tex. 433, 110 S.W. 2d 896 (1937) . 255, 256 Lively v. Missouri K. \& T. R. Co. of Texas, 102 Tex. 545, 120 S.W. 852 (1909) . . . 259, 260 Lockhart v. American Mutual Life Ins. Co., ('Tex. Civ. App.) 194 S.W. 2d 285 (1946) . 256, 257 Missouri, K. \& T. R. Co. of Texas v. Shannon, 100 Tex. 379, 100 S.W. 138 (1907) . . . . . 260 Producers' Oil Co. v. Stephens, 44 Tex. Civ. App. 327, 99 S.W. 157 (1906) .........257 Pullman Palace Car Co. v. State, 
64 Tex. 274, 53 Am. Rep. 758 (1885) .........256 San Jacinto Nat. Bank v. Sheppard, (Tex. Civ. App.) 125 S.W. 715 (1938)

256

State v. City of El Paso, 135 Tex. 359,143 S.W. 2d 366 (1940) . .

State v. Hogg, 123 Tex. 568, 72 S.W. 2d 593 (1934) . 256, 257

State v. Southwestern Gas \& Elec. Co., 145 Tex. 24, 193 S.W. 2d 675 (1946) . . . . . . 256

Texas Co. v. Stephens, 100 Tex. 628, 103 S.W. 481 (1907) . . . $.255,256,257$

Texas Pipe Line Co. v. Anderson, (Tex. Civ. App.) 100 S.W. $2 \mathrm{~d}$ 754 (1937) ..........260 Willis v. State, (Tex. Civ. App.) 142 S.W. $2 d 385$ (1940) . . 260

\section{Utah}

Blackrock Copper Min. \& Mill Co. v. Tingey, $34 \mathrm{Utah} 369,38$ Pac. 180 (1908) . . . . . . . 345

Commercial Bank of Utah v. State, 244 P. 2d 364 (1952) . . . . 347 Commercial Nat. Bank v. Chambers, 21 Utah 324, 61 Pac. 560 (1900) ............ 347

Continental Nat. Bank v. Naylor, 54 Utah 49, 179 Pac. 67 (1919). . 346

Davis v. Ogden City, 117 Utah 315, 215 P. 2d 616 (1950) 345 Dixon v. Ricketts, 26 Utah 215, 72 Pac. 947 (1903). 345

First Nat. Bank v. Christensen, 39

Utah 568, 118 Pac. 778 (1911)

346

Garrett Freight Lines v. State Tax Comm., 103 Utah 390, 135 P. 2d 523 (1943) ........345 Judge v. Spencer, 15 Utah 242, 48 Pac. 1097 (1897) ....344, 346 McCornick \& Co. v. Bassett, 49
Utah 444, 164 Pac. 852 (1917) 347

Ogden City v. Crossman, $17 \mathrm{Utah}$ 66, 53 Pac. 985 (1898) ... 345 Salt Lake City v. Christensen Co., 34 Utah 38, 95 Pac. 523 (1908) 345

State ex rel. Cunningham v. Thomas, 16 Utah 86, 50 Pac. 615 (1898) . . . . . . 347

State ex rel. Richards v. Armstrong,

17 Utah 166, 53 Pac. 981 (1898) ...........346

Stillman v. Lynch, 56 Utah 540 , 192 Pac. 272 (1920) . . . . 347

\section{Vermont}

Clark v. City of Burlington, 101 Vt. 391, 143 Atl. 677 (1928) . .............. 594

Colton v. Montpelier, 71 Vt. 413, 45 Atl. 1039 (1899) . . . . 594 Great Atlantic \& Pacific Tea Co. v. Harvey, 107 Vt. 215, 177 Atl. 423 (1935) . . . . . . . 594 In re Hickok's Estate, 78 Vt. 259, 62 Atl. 724 (1904) ...... 594 State v. Caplan, 100 Vt. 140, 135 Atl. 705 (1927) ........594 Village of Hardwick v. Wolcott, 98 Vt. 343, 129 Atl. 159 (1925) . .

.............. 594

\section{Virginia}

Atlantic \& Danville Ry. Co. v. Lyons, 101 Va. 1, 42 S.E. 932 (1902)

City of Fredericksburg v. Sanitary Grocery Co., 168 Va. 57, 190 S.E. 318 (1939) ........ 544 City of Richmond v. DreweyHughes Co., 122 Va. 178, 90 S.E. 635 (1918) ...... 545 Eyre v. Jacob, 14 Gratt. ( 55 Va.) 422, 73 Am. Dec. 367 (1858) 544

Pocahontas Consol. Collieries Co. v. 
Commonwealth, 113 Va. 108,73 S.E. 446 (1912) ... . . 544 Williamson v. Massey, 33 Gratt. (74 Va.) $237(1880) \ldots 544$ Woolfolk v. Driver, 186 Va. 174, 41 S.E. 2d 463 (1947) . . . 544

\section{Washington}

Aberdeen Savings \& Loan Ass'n v. Chase, 157 Wash. 351, 289 Pac. $536(1930) \ldots .581,582,583$, $584,589,590,591,719,727$ Benjamin Franklin Thrift Stores v. Henneford, 187 Wash. 472, 60 P. 2d 86 (1936) ........574 Burr, Conrad \& Broom v. Chase, 157 Wash. 393, 289 Pac. 551 (1930) 581, 582, 589, 590, 591

Culliton v. Chase, 174 Wash. 363, 25 P. 2d 81 (1933) . 583, 584, $585,586,587,588,590,591$, $715,718,720,723,725,726$, $727,728,730,731,732,740$ Dexter Horton Nat. Bank v. McKenzie, 69 Wash. 314, 124 Pac. 915 (1912) 577

Fleetwood v. Read, 21 Wash. 547, 58 Pac. 665 (1899) ...... 574 Golden Age Breweries, Inc. v. Henneford, 193 Wash. 536, 76 P. 2d 598 (1938) ......574

Gruen v. State Tax Commission, 35 Wash. 2d 1, 211 P. 2d 651 (1949) 574

Hammond Lumber Co. v. Cowlitz, 84 Wash. 462, 147 Pac. 19 (1915) .......... 577

Jensen v. Henneford, 185 Wash. 209, 53 P. 2 d 607 (1936) ... $\ldots \ldots 583,587,588,589,590$, $720,725,726,727,728,734$ Lewiston Water \& Power Co. v. Asotin, 24 Wash. 371, 64 Pac. 544 (1901) . . . . . . 577

Libby, McNeill \& Libby v. Ivarson, 19 Wash. 2d 723, 144 P. 2d 258 (1943) . . . . . . 580
MacLaren v. Ferry County, 135 Wash. 517, 238 Pac. 579 (1925) 576,577

Mahler v. Tremper, 40 Wash. $2 \mathrm{~d}$ 405, 243 P. 2 d 627 (1952) 576 Miethke v. Pierce County, 173 Wash. 381, 23 P. 2d 405 (1933)

Morrow v. Henneford, 182 Wash. 625, 47 P. 2d 1016 (1935)

574,726

Pacific Cold Storage Co. v. Pierce, 85 Wash. 625, 149 Pac. 34 (1915) 576

Pacific National Bank v. Pierce, 20 Wash. 675, 56 Pac. 936 (1899) 577

Pacific Telephone \& Telegraph Co. v. City of Seattle, 172 Wash. 649, 21 P. 2d 721 (1933) . 585 Petroleum Navigation Co. v. Henneford, 185 Wash. 495, 55 P. 2d 1056 (1936) 589, 590, 591, 728 Power, Inc. v. Huntley, 39 Wash. 2d 191, 235 P. 2d 173 (1951) 590,728

Puget Sound Power \& Light Co. v. Seattle, 117 Wash. 351, 201 Pac. 449 (1921) ...... 577 Puget Sound Power \& Light Co. v. City of Seattle, 172 Wash. 668, 21 P. $2 d 727$ (1933) 574, 585 Ridpath v. Spokane, 23 Wash. 436, 63 Pac. 261 (1900) . . ... 577

St. Paul and Tacoma Lumber Co. v. State, 40 Wash. 2d 347, 243 P. 2d 474 (1952) .......575 Spokane v. State, 198 Wash. 682, 89 P. 2d 826 (1939) .... 575 Spokane \& Eastern Trust Co. v. Spokane, 70 Wash. 48, $126 \mathrm{Pac}$.

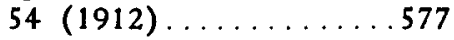
Spokane \& Eastern Trust Co. v. Spokane County, 153 Wash. 332, 280 Pac. 3 (1929) . . . . . 577 Spokane \& I. E. R. Co. v. Spokane, 
75 Wash. 72, 134 Pac. 688 (1913) ...........577

Spokane International R. Co. v. State, 162 Wash. 395, 299 Pac. 362 (1931)

State v. Clark, 30 Wash. 439, 71 Pac. 20 (1902) .....574, 575 State v. Hart, 125 Wash. 520, 217 Pac. 45 (1923) . . . . . 574 State v. Ide, 35 Wash. 576, 77 Pac. 961 (1904) . . . . . . . 574 State v. Inland Empire Refineries, 3 Wash. 2d 651, 101 P. 2d 975 (1940) 575

State ex rel. Atwood v. Wooster, 163 Wash. 659, 2 P. 2d 653 (1931) 579

State ex rel. Chamberlin v. Daniel, 17 Wash. 111, 49 Pac. 243 (1897) ......272, 576, 578 State ex rel. Egbert v. Gifford, 151 Wash. 43, 275 Pac. 74 (1929) ............... 578

State ex rel. Hansen v. Salter, 190 Wash. 703, 70 P. 2d 1056 (1937) ...........574 State ex rel. Mason County Logging Co. v. Wiley, 177 Wash. 65,31 P. 2d 539 (1934) .......580 State ex rel. Nettleton v. Case, 39 Wash. 177, 81 Pac. 554 (1905) $\ldots \ldots \ldots \ldots \ldots .575,577$

State ex rel. State Board of Tax Com'rs v. Cameron, 90 Wash. 407, 156 Pac. 537 (1916) . . 577 State ex rel. Stiner v. Yelle, 174 Wash. 402, 25 P. 91 (1933).. $\ldots \ldots \ldots \ldots .574,585,586$, $587,723,724,725,726,740$ State ex rel. Wolfe v. Parmenter, 50 Wash. 164, 96 Pac. 1047 (1908) ......... 82, 578

Stull v. DeMattos, 23 Wash. 71, 62 Pac. 451 (1900) . . . . . 574 Supply Laundry Co. v. Jenner, 178 Wash. 72, 34 P. 2d 363 (1934) $.587,726$
Tekoa v. Reilly, 47 Wash. 202, 91 Pac. 769 (1907).......5574 Texas Co. v. Cohn, 8 Wash. 2d 360, 112 P. 2d 522 (1941) 575 Thurston v. Tenino Stone Quarries, 44 Wash. 351, 87 Pac. 634 (1906) ..........5574 Vancouver Oil Co. v. Henneford, 183 Wash. 317, 49 P. 2d 14 (1935) ....5.574,575,726

\section{West Virginia}

Arslain v. Alderson, 126 W. Va. 880,30 S.E. 2d 553 (1944)... 263

Bankers Pocahontas Coal Co. v. McDowell County Court, $135 \mathrm{~W}$. Va. 174, 62 S.E. 2d 801 (1950) 269

Blue Jacket Consol. Copper Co. v. Scherr, 50 W. Va. 533, 40 S.E. 514 (1901) . ........263 Central Realty Co. v. Martin, 126 W. Va. 915,30 S.E. 2d 720 (1944) ..........268

Central Trust Co. v. State Tax Com'r, 116 W. Va. 37, 178 S.E. $520(1935) \ldots \ldots 263,264$ In re Charleston Federal Savings \& Loan Ass'n, 126 W. Va. 506, 30 S.E. 2d 513 (1944) . . . . . . . $267,268,269$ Charleston \& S. Bridge Co. v. Kanwha County Court, 41 W. Va. 658, 24 S.E. 1002 (1896) ... 265,267 Chesapeake \& O. R. Co. v. Miller, 19 W. Va. 408 (1882) ...266 Christopher v. James, $122 \mathrm{~W}$. Va. 665, 12 S.E. 2d 813 (1940).. $\ldots \ldots \ldots \ldots 265,267$

Dickinson v. James, 120 W. Va. 222, 197 S.E. 633 (1938)... $\ldots \ldots \ldots \ldots \ldots 264,265$ Douglas v. Harrisville, 9 W. Va. 162, 27 Am. Rep. 548 (1876) 
Eureka Pipe Line Co. v. Hallahan, 87 W. Va. 396, 105 S.E. 506 (1920) 263

In re Hancock County Federal Savings \& Loan Ass'n, 125 W. Va. 426, 25 S.E. 2d 543 (1943). . 268

Harvey Coal \& Coke Co. v. Tax Com'r, 59 W. Va. 605, 53 S.E. 928 (1906) . . . . . . 266

Hope Natural Gas Co. v. Hall, 102 W. Va. 272, 135 S.E. 582 (1926) .........263, 264

Laing v. Fox, 115 W. Va. 272,175 S.E. 354 (1934) 263, 264, 740 In re National Bank of West Virginia at Wheeling, 73 S.E. 2d 655 (1952) . . . . 267, 269

Powell v. Parkersburg, 28 W. Va. 698 (1886) . . . . . . 266

Prichard v. Kanwha County Court, 109 W. Va. 479, 155 S.E. 542 (1930) ..........268

Stare v. Azel Meadows Realty Co., 108 W. Va. 118,150 S.E. 378 (1929) ...........263

State v. Graybeal, 60 W. Va. 357, 55 S.E. 398 (1906) ....266 State v. McDowell Lodge, $96 \mathrm{~W}$. Va. 611, 123 S.E. 561 (1924) 266

West Penn Power Co. v. Board of Review \& Equalization; $112 \mathrm{~W}$. Va. 442, 164 S.E. 862 (1932) $\ldots \ldots \ldots \ldots 266,267$

\section{Wisconsin}

Battles v. Doll, 113 Wis. 357,89 N.W. 187 (1902) . . . . 243 Black v. State, 113 Wis. 205,89 N.W. 522 (1902) ......236 Chicago \& N. W. R. Co. v. State, 128 Wis. 553,108 N.W. 557 (1906) $235,243,244,246,247$ In re Will of Harnishfeger, 208 Wis. 317, 242 N.W. 153 (1933)
Kingsley v. Merrill, 122 Wis. 185 , 99 N.W. 1044 (1904) 243, 245 Kneeland v. Milwaukee, 15 Wis. 454 (1862) .........242

Knowlton v. Rock County, 9 Wis. 410 (1859) . . . 239, 240, 241

Lawrence University v. Outagamie, 150 Wis. 244,136 N.W. 619 (1912)

245

In re Will of Le Feber, 223 Wis. 393, 271 N.W. 95 (1937) 236 Lund v. Chippewa, 93 Wis. 640, 67 N.W. 927 (1896) .... 243 Milwaukee E. R. \& L. Co. v. Tax Comm., 207 Wis. 523, 242 N.W. 312 (1932) . .....245 Milwaukee \& M. R. Co. v. Waukesha County, 9 Wis. 431 (1855) $239,240,241,242,243$ Minneapolis, St. P. \& S. S. M. R. Co. v. Douglas, 159 Wis. 408, 150 N.W. 422 (1914) . ..247 Nash Sales v. City of Milwaukee, 198 Wis. 281,224 N.W. 126 (1929) ..........236 Nunnemacher v. State, 129 Wis. 190, 108 N.W. 627 (1906) ... $\ldots \ldots \ldots 235,236,237$ Schuster \& Co. v. Henry, 218 Wis. 506, 261 N.W. 627 (1906) ...

Slauson $v$ Racine 13 Wis 398 (1861) .........240 State v. Chicago \& N. W. R. Co., 128 Wis. 449,108 N.W. 594 (1906) ...235, 237, 238, 247 State v. Frear, 148 Wis. 456,134 N.W. 673 (1912) ........ $236,237,238,690$

State v. Mann, 76 Wis. 469, 45

N.W. $526(1890) \ldots \ldots .385$

State v. Whitcom, 122 Wis. 110,99 N.W. 468 (1904) ......235 State ex rel. Atty. Gen. v. Winnebago Lake \& Fox River Plank Road Co., 11 Wis. 35 (1860) . 241,242 
State ex rel. Atwood v. Johnson, 170 Wis. 218,175 N.W. 589 (1919) .236

State ex rel. Baker Mfg. Co. v. City of Evansville, 261 Wis. 599, 53 N.W. 2d 795 (1952) . ...248 State ex rel. Baravou v. Sauk, 70 Wis. 485, 36 N.W. 396 (1888)

243

State ex rel. Bernhard Stearn \& Sons v. Bodden, 165 Wis. 75, 160 N.W. 1077 (1917).

236,237

State ex rel. Froedtert Grain \& Malting Co. v. Tax Comm. of Wisconsin, 221 Wis. 225,267 N.W. 52 (1936) . ..... 238 State ex rel. Holt Co. v. Bellew, 86 Wis. 189,56 N.W. 782 (1893) ..........243

State ex rel. Milwaukee St. R. Co. v. Anderson, 90 Wis. 550, 63 N.W. 746 (1895) . .....243 State ex rel. Transp. Ass'n v. Zimmerman, 181 Wis. 552, 196 N.W. 848 (1923) . . . . 236 Weeks v. Milwaukee, 10 Wis. 242 (1860) .242

Welch v. Henry, 223 Wis. 319, 271 N.W. 68 (1937) . .236, 238 Wisconsin Cent. R. Co. v. Lincoln, 57 Wis. 137,15 N.W. 121 (1883) ..........243

Wisconsin Central R. Co. v. Taylor, 52 Wis. 37,8 N.W. 833 (1881) .....242, 243, 247

\section{Wyoming}

Bunten v. Rock Springs Grazing Ass'n, 29 Wyo. 461, 215 Pac. 244 (1923) . . . . . . . 2273

Continental Supply Co. v. People, 54 Wyo. 185,188 P. 2d 488 (1939) ..........271

Harkin v. Bd. of Com'rs of Niobrara County, 30 Wyo. 455, 222 Pac. 35 (1923) .......2272
Kelley v. Rhoads, 7 Wyo. 237, 51 Pac. 593 (1897) .......273 Ludwig v. Harston, 65 Wyo. 134, 197 P. 2d 252 (1948) 271, 272 Miller v. Buck Creek Oil Co., 38 Wyo. 505, 269 Pac. 43 (1928) 272

Public Service Comm. v. Grimshaw, 49 Wyo. 158, 53 P. 2d 1 (1935) 271,272

State v. Snyder, 29 Wyo. 199, 212 Pac. 771 (1922) .......272 State v. Willingham, 9 Wyo. 290, 62 Pac. 797 (1900) .....2 272 Unemployment Compensation Comm. v. Renner, 59 Wyo. 437, 143 P. 2d 181 (1943) 271, 272

\section{United States}

Bell's Gap Railroad Co. v. Pennsylvania, 134 U.S. 232 (1890) ... $.601,602,603,604$

Brown v. Board of Education, 347 U.S. 483, 74 S. Ct. 686 (1954) ............... 602

Brushaber v. Union Pacific R. Co., 240 U.S. 1, 36 S. Ct. 236 (1916) 691

Central Nat. Bank v. McFarland, 20 F. 2d 416 (1927) . 325, 329 Charleston Federal Savings \& Loan Assn. v. Alderson, 324 U.S. 182, 65 S. Ct. 624 (1945) . ...606 Coulter v. L. \& N. R. Co., 196 U.S. 599, 25 S. Ct. 342 (1905) 604 Cudahy Packing Co. v. Minn., 246 U.S. 450, 38 S. Ct. 373 (1917) 322

Davidson v. New Orleans, 96 U.S. 97 (1878) .........6.601 Dawson v. Kentucky Distilleries \& Warehouse Co., 255 U.S. 288, 41 S. Ct. 272 (1920) . 90, 112 First National Bank of Guthrie Center v. Anderson, 269 U.S. 341, 46 S. Ct. 135 (1926) 326 
First National Bank of Hartford v. City of Hartford, 273 U.S. 548, 47 S. Ct. 462 (1927) .... 326 Fox v. Standard Oil Co. of New Jersey, 294 U.S. 7, 55 S. Ct. 333 (1934) ...........263 Great Atlantic \& Pacific Tea Company v. Grosjean, 301 U.S. 412, 57 S. Ct. 772 (1937) . . . 607 Heisler v. Thomas Colliery Co., 260 U.S. 245,43 S. Ct. 83 (1922) ..........604 Hillsborough Township v. Cromwell, 326 U.S. 620,66 S. Ct. 445 (1946) . . . . . . . 605

Home Insurance Company v. New York, 134 U.S. 594, $10 \mathrm{~S}$. Ct. $593(1890) \ldots \ldots \ldots .604$

Independent Warehouses v. Scheele, 331 U.S. 70, 67 S. Ct. 1062 (1947) ..........606

Klein v. Board of Tax Supervisors, 282 U.S. 19, 51 S. Ct. 15 (1930) .........664

Knowlton v. Moore, 178 U.S. 41, 20 S. Ct. 747 (1899) . . . . 237

Lake Superior Mines v. Lord, 271 U.S. 577, 46 S. Ct. 627 (1926)

L. K. Liggett Co. v. Lee, 288 U.S. 517, 53 S. Ct. 481 (1933). $.276,607$

Louisville Gas \& Electric Company v. Coleman, 277 U.S. 32, $48 \mathrm{~S}$. Ct. 423 (1928)

Madden v. Kentucky, 309 U.S. 83, 60 S. Ct. 406 (1940) . . . . 604

Magnano Company v. Hamilton, 292 U.S. 40, 54 S. Ct. 599 (1934) ...........606

Magoun v. Illinois Trust \& Savings Bank, 170 U.S. 283, 18 S. Ct. 594 (1897) 121, 215, 237, 607 Metropolis Theater Co. v. Chicago, 228 U.S. 61, 33 S. Ct. 441 (1913) 607
New York ex rel. Cohn v. Graves, 300 U.S. 308, 57 S. Ct. 466 (1937) .........691 Nicol v. Ames, 173 U.S. 509, 19 S. Ct. 522 (1898) .......296 Pacific Express Co. v. Seibert, 142 U.S. 339, 12 S. Ct. 250 (1891) 321

Pollock v. Farmers' Loan \& Trust Co., 157 U.S. 429 (1894) . . . $691,695,699,713,735$ Quaker City Cab Co. v. Pennsylvania, 277 U.S. 389,48 S. Ct. $553(1928) \ldots \ldots \ldots \ldots 582$ Quong Wing v. Kirkendall, 223 U.S. 59, 32 S. Ct. 192 (1937) 606

Royster Guano Co. v. Virginia, 252 U.S. 412 , 40 S. Ct. 371 (1920) 604

Shaffer v. Carter, 252 U.S. 37, 40 S. Ct. 221 (1920) . . . . 607 Southwestern Oil Co. v. Texas, 217 U.S. 114, 30 S. Ct. 496 (1910) 606

State Board of Tax Com'rs of Indiana v. Jackson, 283 U.S. 527, 51 S. Ct. 540 (1931) . 283, 607 Stewart Dry Goods Co. v. Lewis, 294 U.S. 550, 55 S. Ct. 525 (1934) ...237, 238, 594, 607 Taylor v. Louisville \& N. R. Co., 88 F. 350 (6th Cir., 1898) 87 United States Express Company v. Minn., 223 U.S. 335, $32 \mathrm{~S}$. Ct. 211 (1911) . . . . . 322 Utah Power \& Light Co. v. Pfost, 52 F. 2d 226 (1931) .....386 Walters v. City of St. Louis, 347 U.S. 231, 74 S. Ct. 505 (1954) $.602,606$

Western Union Tel. Co. v. Indiana, 165 U.S. 304,17 S. Ct. 345 (1897) ............322 Wheeling Steel Corp. v. Glander, 337 U.S. 562, 69 S. Ct. 1291 (1949) ..........605 